Universidade de Brasília (UnB)

Centro de Desenvolvimento Sustentável (CDS)

Programa de Pós-Graduaçao em Desenvolvimento

Sustentável (PPGDS)

\title{
ECO-GOVERNAMENTALIDADE E GOVERNANÇA DE RECURSOS \\ ENERGÉTICOS: \\ ENTRE A PRÁTICA E O DISCURSO NA AÇÃO COLETIVA DOS POLOS GAÚCHOS DE BIODIESEL E DOS FOLHELHOS TEXANOS DE EAGLE FORD
}

Arnoldo Santos de Lima

Orientador: Fabiano Toni

Tese de Doutorado

Brasília - DF, 05 agosto de 2016 


\title{
ECO-GOVERNAMENTALIDADE E GOVERNANÇA DE RECURSOS ENERGÉTICOS: \\ ENTRE A PRÁTICA E O DISCURSO NA AÇÃO COLETIVA DOS POLOS GAÚCHOS DE BIODIESEL E DOS FOLHELHOS TEXANOS DE EAGLE FORD
}

\begin{abstract}
Arnoldo Santos de Lima
Tese de doutorado submetida ao Centro de Desenvolvimento Sustentável da Universidade de Brasília, como parte dos requisitos necessários para a obtenção do Grau de Doutor em Desenvolvimento Sustentável, área de concentração em Política e Gestão Ambiental.
\end{abstract}

Aprovado por:

Fabiano Toni, Doutor - Centro de Desenvolvimento Sustentável da Universidade de Brasília (CDS/UnB - Orientador).

Célio Bermann, Doutor - Instituto de Energia e Ambiente da Universidade de São Paulo (IEE/USP - Examinador Externo).

Camila Penna de Castro, Doutora - Instituto de Ciência Política da Universidade de Brasília (IPOL/UnB - Examinador Externo).

José Augusto Leitão Drummond, Doutor - Centro de Desenvolvimento Sustentável da Universisdade de Brasília (CDS/UnB - Examinador Interno).

Andrei Domingues Cechin, Doutor - Centro de Desenvolvimento Sustentável da Universidade de Brasília (CDS/UnB - Examinador Interno).

Brasília - DF, 05 de agosto de 2016. 
Lima, Arnoldo Santos de

Eco-governamentalidade e governança de recursos energéticos: entre a prática e o discurso na ação coletiva dos polos gaúchos de biodiesel e dos folhelhos texanos de Eagle Ford

./Arnoldo Santos de Lima.

306 f. 55 II.

Tese de doutorado. Centro de Desenvolvimento Sustentável da Universidade de Brasília, Brasília.

1. Governamentalidade. 2. Eco-governamentalidade 3. Governança dos recursos4. Recursos Energéticos 5. Biodiesel 6. Folhelhos Universidade de Brasília. CDS

II. Título.

É concedida à Universidade de Brasília permissão para reproduzir cópias desta tese e emprestar ou vender tais cópias, somente para propósitos acadêmicos ou científicos. O autor reserva outros direitos de publicação e nenhuma parte desta tese de doutorado pode ser reproduzida sem a autorização por escrito do autor.

Assinatura 


\section{AGRADECIMENTOS}

Agradeço imensamente à Coordenação de Aperfeiçoamento de Pessoal de Ensino Superior (Capes) e ao Governo Federal que me ofereceram o privilégio de uma bolsa de estudos integral e de recursos para pesquisa nos meus quatro anos de doutorado, sobretudo, pela experiência de residir e estudar nos Estados Unidos no escopo do Programa de Doutorado Sanduíche no Exterior (PDSE/Capes). Meu especial agradecimento ao professor José Augusto Drummond (CDS/UnB), o articulador e motivador de meu estágio de doutorado PDSE/Capes no exterior.

Sou igualmente agradecido à Fundação de Amparo a Pesquisa do Distrito Federal (FAP/DF), ao Decanato de Pesquisa e Pós-Graduação da Universidade de Brasília (DPP/UnB), ao Programa de Apoio à Pós-Graduação (Proap/Capes) e a Finatec pelos recursos financeiros liberados para pesquisas de campo e para a participação em congressos e conferências internacionais. Essas oportunidades ímpares me permitiram trocar experiências acadêmicas, fazer amizades, conhecer países e universidades que tanto me engrandeceram intelectualmente quanto pessoalmente.

Muito obrigado, ao Doutor Christian Brannstrom, diretor do Environmental Program in Geosciences da Texas A\&M University por sua acolhida generosa em College Station, Texas. Seus sábios conselhos literalmente salvaram minha tese. Sou igualmente grato pela camaradagem e apoio dos colegas Trey Murphy e Tom Loder do Geography Department da Texas A\&M University, que se tornaram bons amigos ao longo da pesquisa em Eagle Ford. Thank you very much guys!

Obrigado à minha tia Doracy Campana, parentes e amigos de Lagoa Vermelha, gente generosa e carinhosa, que me acolheu muito bem durante minha etapa de pesquisa nos polos gaúchos de biodiesel. Obrigado também a toda minha família materna, amigos e amigas, novos e tradicionais, que estiveram ao meu lado nessa jornada e torceram por mim. Especialmente, Antônio Carlos Guedes e sua esposa Bernadete, Bianca Sorina Racasan, Carla Leone, Caroline Loureiro, Cláudio Frate, Guinea Cardoso, Maria Amparo Basílio, Maria Cristina, Poliana Andrade, Ricardo Luís e Thana Kelly.

Agradeço, especialmente, a Deus e a minha família, sem os quais não teria conseguido produzir e finalizaressa tarefa hercúlea. Dedico essa tese ao tripé da minha vida: minha mãe, Carmem Lúcia, ao meu pai José Cícero e ao meu irmão Rodrigo que quando mais precisei não pouparam esforços, dedicação, e carinho para me ajudar a concluir a presente tese. Ahh! e sim claro! A minha Dachshund 'Vida' pelo seu amor e fidelidade incondicionais. 
"Who governs? How do they govern? And what are the results?

- Aristóteles-

"A educação é o ponto em que decidimos se amamos o mundo o bastante para assumirmos a responsabilidade por ele"

- Hannah Arendt - 


\section{RESUMO}

Os recursos energéticos são fundamentais para o desenvolvimento da humanidade. Suas formas distintas de regulação e gestão são, portanto, variáveis que pesam na geração de impactos - positivos ou negativos - durante sua exploração. Diante dessa perspectiva, essa tese foi construída com o objetivo de debater como a governança de recursos energéticos pode promover ações coletivas e o desenvolvimento de subjetividades ambientais inéditas, mas também pode abrir caminho para lógicas legitimadoras oportunistas. Uma correlação praticamente inexplorada pela literatura de governança dos recursos e estudos na área de energia. A discussão parte do conceito de governamentalidade (governmentality) de Michel Foucault, e ecogovernamentalidade (environmentality) de Timothy Luke. A partir desses referenciais teóricos são discutidos como os discursos além de moldar o conceito de meioambiente, justificar o ritmo, uso, e exploração dos recursos energéticos podem também eclipsar falhas nos sistemas de governança. Nesse contexto, duas paisagens energéticas são alvos de pesquisa: os Polos Gaúchos de biodiesel no Brasil, e Eagle Ford Shale nos Estados Unidos. Espaços caracterizados por atores sociais heterogêneos; arenas políticas particulares; regras, normas e narrativas específicas. Os'direcionadores de governança dos recursos energéticos'- e seu farol - são os instrumentos de análise propostos para organizar, discutir e avaliar as categorias de investigação. A proposta metodológica se insere nos elementos do quadro institucionalista de Elinor Ostrom, e parte dos princípios da boa governança da UNDP, além de incorporar uma análise de discursos realizada com o software Atlas.ti. Os resultados obtidos endossam a hipótese de que as estruturas e processos nos dois sistemas de governança diferem consideravelmente, mas que possuem lógicas legitimadoras semelhantes. Ambos os sistemas de governança foram classificados como 'viciososos' apresentando qualidade sofrível na descentralização, participação, cooperação, responsabilização, equidade e empoderamento. Nos dois casos se desenvolve um 'socioambientalismo tempestivo' onde policy makers e atores industriais legitimam a regulação e gestão dos seus setores a partir de discursos que interligam a exploração do biodiesel e dos folhelhos ao desenvolvimento socioeconômico e sustentável. Na prática, entretanto, a tensão entre a qualidade da governança e os padrões de eco-governamentalidades revelam quadros pouco propícios para o desenvolvimento de uma ação coletiva dos recursos energéticos nas duas paisagens energéticas pesquisadas. 


\begin{abstract}
Energy resources are critical to the development of humanity. Their different forms of regulation and management are, therefore, variables that weigh in generating impacts positive or negative - during its exploitation. Given this perspective, this thesis was built in order to discuss how the governance of energy resources can promote collective action and the development of new environmental subjectivities, but in the other hand can pave the way to opportunistic legitimating logic. A correlation virtually unexplored by the governance literature and studies in the energy sector. The analyses are connected to Foucault's governmentality and Luke's enivronmentality concecpts. From these theoretical frameworks are discussed how discourses can shape the concept of the environment and justify the pace, use, and exploitation of energy resources as well as overshadow failures in governance systems. In this context, two energy landscapes are targets of research: the biodiesel Gaucho Poles in Brazil, and Eagle Ford Shale in the United States. Both productive areas characterized by heterogeneous social actors; particular arenas, policies, rules, norms, and specific narratives. The 'energy resources drivers of governance - and its lighthouse - are proposed like analytical tools to organize, discuss and evaluate the categories of research. The methodological proposal starts from the institutionalist analysis development framework of Elinor Ostrom and the principles of good governance of UNDP, as well as an analysis of speeches held with Atlas.ti. The results endorse the hypothesis that the structures and processes in the two governance systems differ considerably, but have similar patterns. Both governance systems were classified as 'vicious' presenting poorly on decentralization, participation, cooperation, accountability, equity and empowerment. In both cases it develops a 'timely socioenvironmentalism' where policy makers and industrial actors legitimize the regulation and management of their sectors making use of discourses that undeniably interconnect the exploitation of energy resources for socio-economic and sustainable development. In practice, the tension between the quality of governance and environmentality patterns reveals inappropriate scenarios to the development of a collective action of energy resources in the two energy landscapes.
\end{abstract}




\section{RESUMEN}

Los recursos energéticos son fundamentales para el desarrollo de la humanidad. Sus diferentes formas de regulación y gestión, por tanto, son variables que pesan en la generación de impactos - positivos o negativos - durante su exploración. Ante esta perspectiva, esta tesis se construyó con el fin de discutir cómo la gobernanza de los recursos energéticos puede promover la acción colectiva y el desarrollo de nuevas subjetividades ambientales, sino que también puede allanar el camino para la lógica de legitimación oportunista. Una correlación prácticamente inexplorada por la literatura de gobernanza y estudios en el sector de la energía. La discusión comienza en los conceptos de governmentality de Michel Foucault, y environmetality de Thimoty Luke. A partir de estos marcos teóricos son discutidos, así como los discursos dan forma al concepto de medio ambiente, justifican el ritmo, el uso y la explotación de los recursos energéticos y también pueden opacar las fallas en los sistemas de gobernanza. En este contexto, dos paisajes energéticas son los objetivos de la investigación: el Polos Gauchos de biodiesel en Brasil, y Eagle Ford Shale en los Estados Unidos. Zonas productivas caracterizadas por actores sociales heterogéneos; arenas políticas particulares; reglas, normas y narrativas específicas. Los conductores de "gobernanza de los recursos energéticos'- y su semáforo - son herramientas analíticas propuestas para organizar, analizar y evaluar las categorías de investigación. La propuesta metodológica es parte de la evidencia de marco institucionalista de Elinor Ostrom, y de los principios de buena gobernanza del PNUD, así como la incorporación de un análisis de los discursos mantenidos con el software Atlas.ti. Los resultados refuerzan la hipótesis de que las estructuras y procesos difieren considerablemente, pero tienen legitimizaciones similares. Ambos sistemas de gobernanza fueron clasificadas "viciososos" ante la descentralización, la participación, la cooperación, la responsabilidad, la equidad y la potenciación. En ambos casos se desarrolla uno'socioambientalismo oportuno', donde los políticos y los actores industriales legitiman la regulación y la gestión de los sectores hacendo uso de discursos que sin lugar a dudas interconectan la explotación de los recursos energéticos para el desarrollo socioeconómico y sostenible. En la práctica, la tensión entre la calidad de los patrones de gobernanza y los discursos revela escenarios inapropriados para el desarrollo de una acción colectiva de los recursos energéticos en los dos paisajes de energía. 


\section{LISTA DE ILUSTRAÇÕES}

Figura 01 -

Figura 02 -

Figura 03 -

Figura 04 -

Figura 05 -

Figura 06 -

Figura 07 -

Figura 08 -

Figura 09 -

Figura 10 -

Figura 11 -

Figura 12 -

Figura 13 -

Figura 14 -

Figura 15 -

Figura 16 -

Figura 17 -

Figuras 18 e 19 -

Figuras 20 e 21 -

Figuras 22 e 23 -

Figura 24-

Figura 25 -

Figura 26 -

Figura 27 -

Figura 28 -

Figura 29 -

Figuras 30 e 31 -

Figuras 32 e 33 -

Figuras 34 e 35 -

Figuras 36 -

Figuras 37 e 38 -
Estrutura de relações de poder entre Estado, sociedade e

40

mercado a partir da perspectiva de governança híbrida ou soft governance.

Princípios, ou atributos elementares da boa governança.

Teorias formadoras da análise institucional de Elinor Ostrom. $\quad 67$

Modelo/Quadro de Análise Institucional de Elinor Ostrom. $\quad 72$

Etapas do processo de análise pelo software Atlas.ti $\quad 75$

$\begin{array}{ll}\text { Farol da governança dos recursos energéticos. } & 79\end{array}$

Polos gaúchos de produção de biodiesel. $\quad 81$

Folhelhos texanos de Eagle Ford Shale. 87

Delimitação das áreas dos principais hidrocarbonetos de Eagle $\quad 89$

Ford Shale.

Cadeia produtiva e distribuição do Biodiesel no Brasil. 104

Plantas autorizadas de biodiesel e evolução da soja no Brasil 105

(1990-2015).

Estrutura de relações dos Grupos de Trabalho (GT) nos Polos 113

de Biodiesel.

Logotipo da Frente Parlamentar do Biodiesel (FrenteBio). 119

Níveis estruturais de governança do biodiesel dos Polos 129

Gaúchos.

Modelo de 'participação' dos atores sociais no PNPB. 135

Fatores condicionantes ao empoderamento nos sistemas de 152

governança.

Farol da Governança do Biodiesel dos Polos Gaúchos. 158

Virtudes do biodiesel. 160

Biodiesel, sustentabilidade e compromisso com a natureza. 162

Certificações internacionais de sustentabilidade de 162

biocombustíveis.

Apresentação do Projeto Polos. 163

Processo produtivo do fraturamento hidráulico (fracking) de 170

folhelhos.

Principais áreas de exploração de hidrocarbonetos de folhelhos nos E.U.A.

American Petroleum Institute 186

Níveis estruturais de governança dos xistos americanos até $\quad 195$

Eagle Ford Shale.

Farol da Governança de Eagle Ford Shale. 219

Virtudes ambientais do fracking. 225

Folhelhos\& Sustentabilidade $\quad 226$

Certificações regionais de sustentabilidade na produção de 226 petróleo e gás

U.S. oil shale: protecting our environment. 227

Virtudes socioeconômicas dos folhelhos. 228 
Figuras 39 e 40 - Eagle Ford e o papel do Texas na independência energética americana.

Figuras 41 e 42 - Direcionador: Descentralização (PG) vs Decentralization (EFS). 235

Figuras 43 e 44 - Comparação das estruturas de governança dos PG e de EFS. 236

Figuras 45 e 46 - Direcionador da Participação (PG) vs Participation (EFS). 239

Figuras 47 e 48 - Direcionador da Cooperação (PG)vs Cooperation (EFS). 241

Figuras 49 e 50 - Direcionador de Responsabilização (PG) vs Accountability 243 (EFS).

Figuras 51 e 52 - Direcionador Transparência (PG) vs. Transparency (EFS). 245

Figuras 53 e 54 - Direcionador de Equidade (PG) vs. Equity(EFS). 248

Figuras 55 e 56 - Direcionador de Pertencimento (PG) vs. Ownweship (EFS). 250

Figuras 57 e 58 - Direcionador de Empoderamento (PG) vs. Empowerment (EFS). 252

Figuras 59 e $60 \quad$ Farois da governança dos recursos energético (PG) vs. EFS. 254

Figura 61 - $\quad$ Estrutura híbrida top-down/bottom-up de governança. 257

Figuras 62 e 63 - O socioeconômico como base legitimadora da energia. 260

Figuras 64 e 65 - Biodiesel e folhelhos- estradas e caminhos para um futuro 262 sustentável.

Figuras 66 e 67 - Recursos energéticos e nacionalismo 263

Figuras 68 e 69 - O efeito multiplicador no Texas e no Rio Grande do Sul. 265

Figura 70 - $\quad$ O recurso energético como espetáculo do desenvolvimento. $\quad 267$

\section{LISTA DE FOTOS}

\begin{tabular}{|c|c|c|}
\hline Eoto 1 - & $\begin{array}{l}\text { Aspecto do extinto conselho do grupo de trabalho dos Polos } \\
\text { Gaúchos de biodiesel. }\end{array}$ & 133 \\
\hline Foto 2 - & Farelo de Soja 46 "Energia que vem do campo". & \\
\hline Fotos 3 e 4 - & Imagens de vazamentos de efluentes de indústria de biodiesel. & \\
\hline Foto 5 - & $\begin{array}{l}\text { Reunião do grupo "Cidadãos de College Station para fracking } \\
\text { seguro" }\end{array}$ & \\
\hline Foto 6 - & $\begin{array}{l}\text { Audiência Pública (Public Hearing) para (re)definição das } \\
\text { regulações locais para a exploração de petróleo e gás na cidade } \\
\text { de College Station }\end{array}$ & \\
\hline Foto 7 - & $\begin{array}{l}\text { Placard da cidade de College Station convocando para os } \\
\text { cidadãos para a audiência pública de redefinição das } \\
\text { Ordinances para o setor de gás e petróleo. }\end{array}$ & \\
\hline & Eagle Ford Shale Flaring activity & \\
\hline & ibstone. & \\
\hline oto 11 - & O recurso energético como espetáculo do desenvolvimento. & \\
\hline
\end{tabular}




\section{LISTA DE TABELAS}

Tabela 01 - Tipologia simplificada dos graus de interação entre governança e 39 governo.

Tabela 02 - Seis abordagens/ enfoques da análise da governança ambiental $\quad 49$

Tabela 03 - Síntese dos conceitos de estruturação e gestão de poder 52

Tabela 04 - Exemplo da composição e memória de cálculo dos direcionadores: 76 participação

Tabela 05 - Exemplo da avaliação qualitativa-quantitativa dos 'direcionadores de 77 governança de recursos energéticos'.

Tabela 06 - Atores sociais e instituições envolvidas na aquisição de dados 94 primários: Polos Gaúchos.

Tabela 07 - Atores sociais e instituições envolvidas na aquisição de dados 96 primários: Eagle Ford Shale.

Tabela 08 - Síntese da avaliação qualitativa-quantitativa pelos 'direcionadores $\quad 150$ de governança dos Polos Gaúchos de produção de biodiesel'.

Tabela 09 - Síntese da avaliação qualitativa-quantitativa pelos 'direcionadores $\quad 217$ de governança dos folhelhos de Eagle Ford.

Tabela 10- Descentralização vs. Decentralization 237

$\begin{array}{ll}\text { Tabela } 11 \text { - Participação vs.Participation } & 240\end{array}$

Tabela 12 - Cooperação vs. Cooperation 242

Tabela 13 - Responsabilização vs. Accountability 244

Tabela 14 - Transparência vs. Transparency 246

$\begin{array}{lll}\text { Tabela } 15 \text { - Equidade vs. Equity } & 248\end{array}$

Tabela 16 - Pertencimento vs. Ownership 251

Tabela 17 - Empoderamento vs. Empowerment 252

LISTA DE QUADROS

Quadro 01- Características comparadas entre a governança dos PG e EFS. 255 


\section{LISTAS DE ABREVIATURAS}

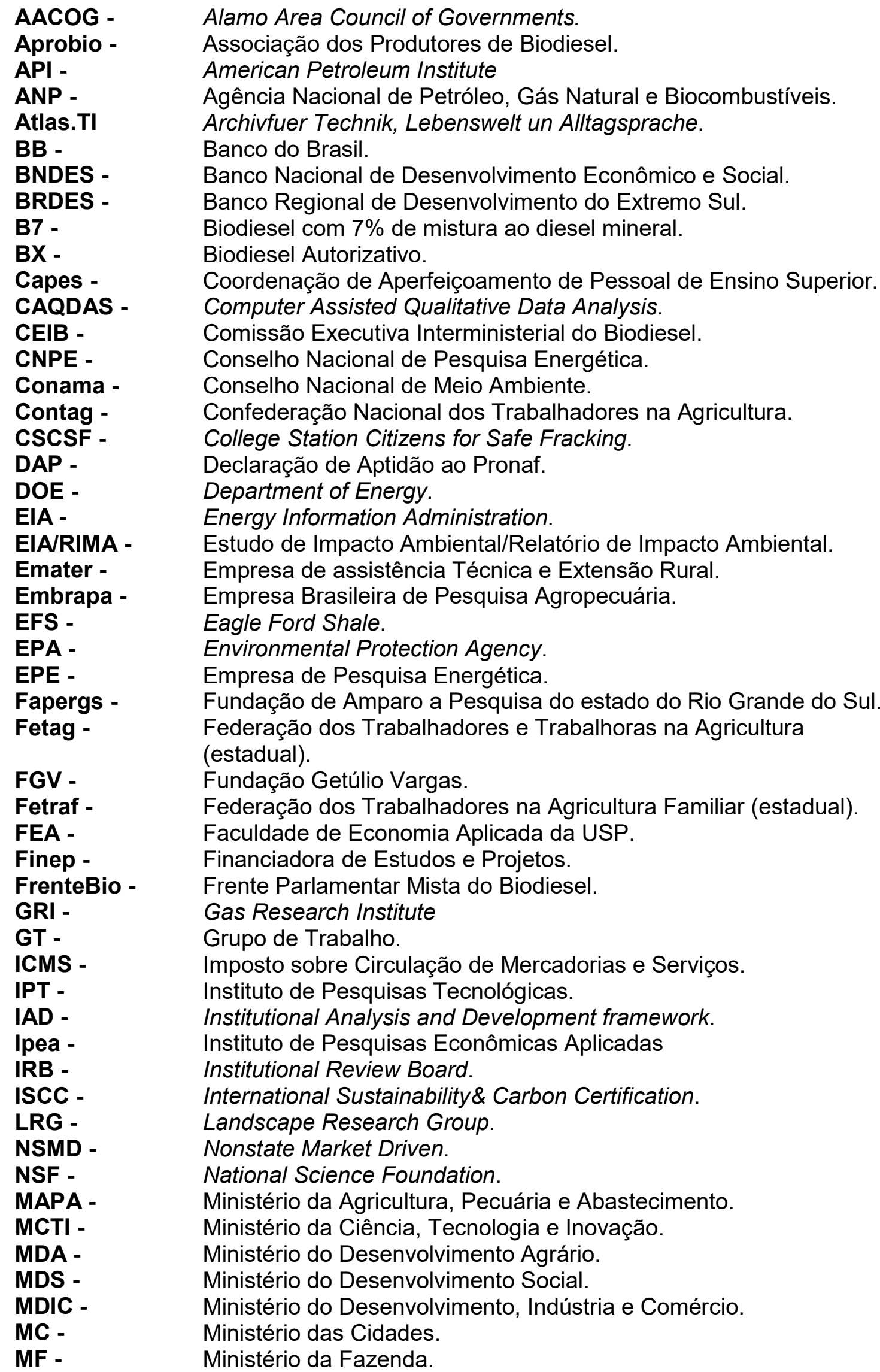




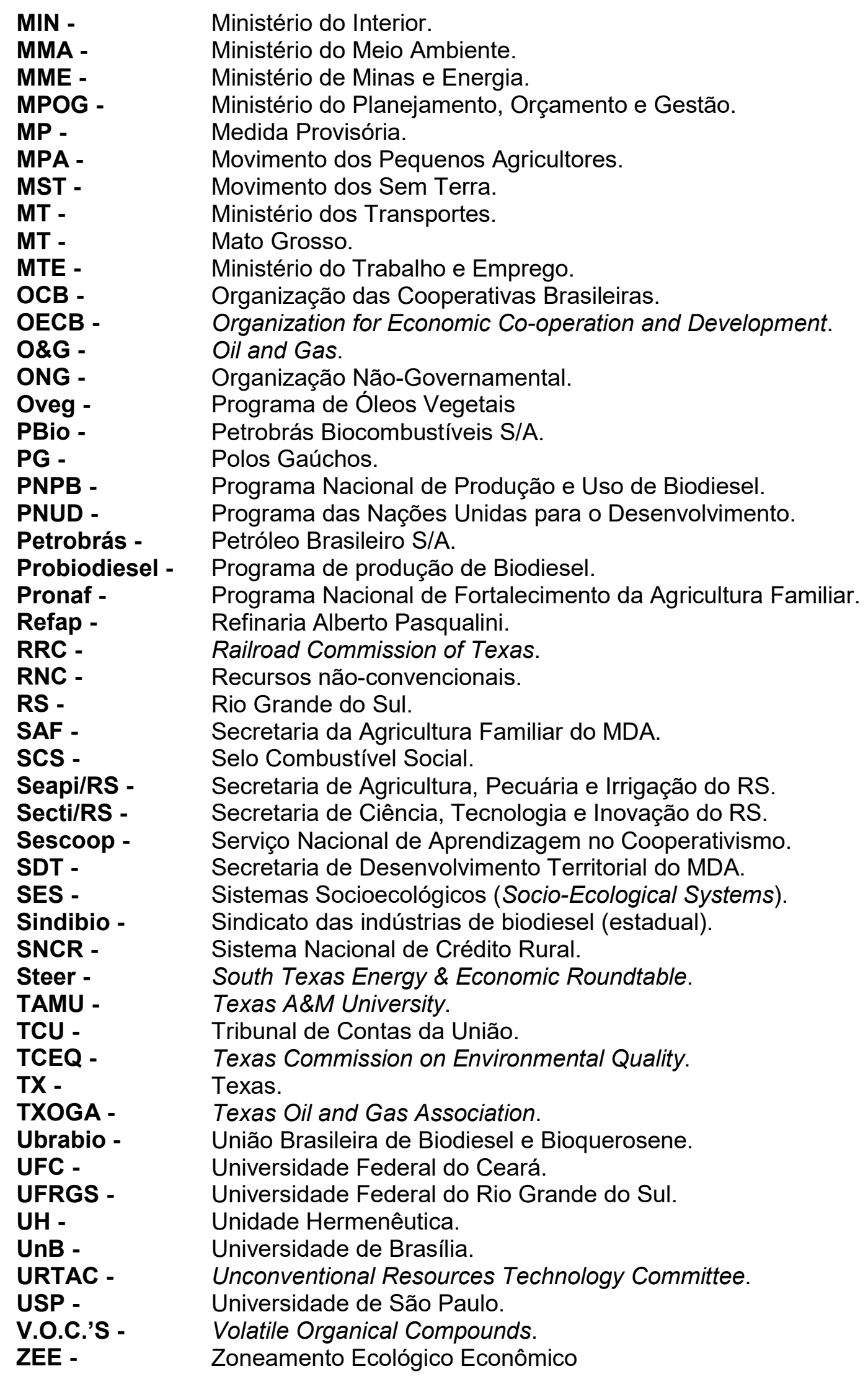




\section{SUMÁRIO}

INTRODUÇÃO

DE GOVERNAMENTALIDADE, GOVERNAMENTALIDADE E GOVERNANÇA DOS RECURSOS

Parte I - Eco-governamentalidade, relações de poder, discursos e 27 subjetividades na construção da sustentabilidade ambiental

1.1 Governamentalidade, biopoder e o panóptico social de Michel 27 Foucault

1.2 A eco-governamentalidade, geopoder e o panóptico ambiental de 29 Timothy Luke

1.3 A Eco-governamentalidade como tecnologia de governo e 31 produção de subjetividades de Arun Agrawal

1.4 Eco-governamentalidade, ambientalismo e sustentabilidade

Parte II - O conceito e qualificações de governança, conexões com ambiente, $\quad 35$ recursos naturais e eco-governamentalidade

1.5 Governança como desenho político-institucional nas relações e 35 estruturas de poder modernas

1.5.1 Governança híbrida ou soft governance: entre a força dos governos centrais e a gestão compartilhada com atores não-estatais.

1.5.2 Os princípios da boa governança

1.6 Governança ambiental ou governança dos recursos $\quad 47$

1.7 Governo, governabilidade, governamentalidade, eco- 51 governamentalidade e governança: uma síntese dos conceitos

2. PAISAGENS ENERGÉTICAS, GOVERNANÇA, ECOGOVERNAMENTALIDADE DE RECURSOS ENERGÉTICOS E A ANÁLISE INSTITUCIONALISTA DE ELINOR OSTROM

Parte I - As paisagens energéticas: um campo disciplinar emergente

2.1 Olhando para as paisagens por meio das lentes da energia 54

2.2 Transição energética: percepção, planejamento, participação e 56 poder: "os quatro P's" da governança de paisagens e recursos energéticos

Parte II - Governança sob enfoque da eco-governamentalidade nas paisagens e nos recursos energéticos

2.3 Governança dos recursos, eco-governamentalidade e o enfoque nas paisagens e recursos energéticos

2.4 Materialidade dos recursos energéticos

Parte III - O quadro de análise institucionalista de Elinor Ostrom para

avaliação de sistemas de governança 


\section{METOdOLOGIA, CONTEXTUALIZAÇÃo E DESCRIÇÃo DAS ÁREAS DE ESTUDO; PADRÕES E PROCEDIMENTOS DE PESQUISA}

Parte I - Metodologia de pesquisa: modelos, ferramentas e instrumentos propostos para análise de sistemas de governança de recursos energéticos

3.1 O Quadro de análise institucional de Elinor Ostrom como modelo norteador das categorias de investigação

3.20 emprego do software Atlas.ti como ferramenta de análise de conteúdo dos discursos dos atores sociais

3.3 Proposta dos 'direcionadores de governança dos recursos energéticos'.

Parte II - Descrição das áreas de estudo e contextualização do tema

3.4 Descrição das áreas de estudo

3.4.1 Os polos gaúchos de biodiesel (PG)

3.4.2 Desafios à governança do biodiesel no Brasil

3.4.3 Os folhelhos texanos de Eagle Ford Shale (EFS)

3.4.4 Desafios à governança dos folhelhos nos Estados 86 Unidos

Parte III - Aquisição dos dados, perfil dos respondentes, instrumentos e posicionalidade

3.5 Processo de aquisição dos dados, perfil dos respondentes, instrumentos e posicionalidade nas áreas de estudo

3.5.1 Polos gaúchos (PG)

i) Aquisição de dados e perfil dos respondentes

ii) Padrões, instrumentos e procedimentos de pesquisa

iii) Posicionalidade frente à área de pesquisa

3.5.2 Eagle Ford Shale (EFS)

96

i) Aquisição dos dados e perfil dos respondentes

96

ii) Padrões, instrumentos e procedimentos de pesquisa $\quad 97$

iii) Posicionalidade frente à área de pesquisa 99

4 GOVERNANÇA E ECO-GOVERNAMENTALIDADE NO EPICENTRO DO 100 BIODIESEL BRASILEIRO: ESTRUTURAS, PROCESSOS E DISCURSOS INTERLIGADOS AOS PÓLOS GAÚCHOS DE PRODUÇÃO (PG)

Parte I - As variáveis estruturais

4.1 Variáveis estruturais: aspectos tecnológicos, sociais, constitucionais e biofísicos ligados à regulação e exploração do biodiesel no Brasil

Parte II - As arenas de ação política e atores sociais

4.2 Arenas de ação política

i) O Conselho Nacional de Política Energética (CNPE), a 106 Política Energética Nacional e os biocombustíveis

ii) A Comissão Executiva Interministerial do Biodiesel 107 (CEIB) 
iii) Os conselhos e as câmaras setoriais dos ministérios 109 federais

iv) Câmara Temática do Programa Gaúcho de Biodiesel 110 (Probiodiesel/RS)

v) $\mathrm{O}$ projeto Polos de Biodiesel: a perspectiva de 112 governança local multi-atores

4.3 Perfil dos atores sociais

i) Indústrias energéticas 114

ii) Associações e confederações de produtores industriais 116

iii) Frente Parlamentar do Biodiesel (FrenteBio) 118

iv) Movimentos sociais e sindicatos trabalhistas 120

v) Cooperativas de produção e comercialização agrícola 122

vi) Organizações e instituições da sociedade civil 123

vii) Agência Nacional do Petróleo, Gás Natural e 124

viii) Banco Nacional de Desenvolvimento Econômico e 125

ix) Empresa Brasileira de Pesquisa Agropecuária 126 (Embrapa)

Parte III - Os direcionadores de governança a partir dos polos gaúchos de 128 Biodiesel

4.4 Os direcionadores de governança do biodiesel nos polos gaúchos 128

4.4.1 Descentralização 128

4.4.2 Participação 131

4.4.3 Cooperação 136

4.4.4 Responsabilização 139

4.4.5 Transparência 142

4.4.6 Equidade 145

$\begin{array}{lll}4.4 .7 & \text { Pertencimento } & 147\end{array}$

4.4.8 Empoderamento 148

4.4.9 Resultados da dos 'direcionadores de governança dos 150 polos gaúchos de produção de biodiesel'.

Parte IV - Governança e padrões de eco-governamentalidade no epicentro do 154 biodiesel brasileiro

4.5 Análise de resultados: estruturas e processos na governança dos polos gaúchos de produção de biodiesel

4.6 Análise dos resultados: padrões de eco-governamentalidade comuns aos polos gaúchos de produção de biodiesel

4.7 Discussão dos resultados e limitações da pesquisa

5 ECO-GOVERNAMENTALIDADE E GOVERNANÇA NO 'BOOM' DOS 169 FOLHELHOS AMERICANOS: ESTRUTURAS, PROCESSOS E DISCURSOS NA REGULAÇÃO, GESTÃO E EXPLORAÇÃO DE EAGLE FORD SHALE.

Parte I - As variáveis estruturais 
5.1 Variáveis estruturais: aspectos tecnológicos, sociais, constitucionais e biofísicos ligados à regulação e exploração dos folhelhos nos Estados Unidos

Parte II - As arenas de ação política e atores sociais

5.2 Arenas de ação política

i) Congress Committee for the Energy Policy Act

ii) Local Governments: City Council \& Public hearings

iii) Texas Legislature - The Senate of Texas and

iv) Texas Legislature - House of Representatives:

Natural Resources and Economic

Development Committee Committee on Energy Resource of Texas

5.3 Perfil dos atores sociais

i) Energy Companies

ii) Oil and Gas Industry organizations \& associations

- Texas Oil and Gas Association (TXOGA);South Texas Energy \& Economic Roundtable (STEER);

Texas Alliance of Energy Producers

iii) American Petroleum Institute $(A P I)$ e Independent

iv) Railroad Commission of Texas (RRC)

v) Texas Commission on Environmental Quality (TCEQ)

vi) Civil organizations and social movements

Parte III - Os direcionadores de governança e eco-governamentalidade a 193 partir de Eagle Ford Shale

5.4 Os direcionadores de governança de Eagle Ford Shale

5.4.1 Decentralization

5.4.2 Participation

\subsubsection{Cooperation}

5.4.4 Accountability

5.4.5 Transparency

5.4.6 Equity

5.4.7 Ownership

5.4.9 Resultados da avaliação dos 'direcionadores de governança de Eagle Ford Shale' 
Parte IV - Governança e padrões de eco-governamentalidade no boom da exploração dos folhelhos americanos

5.5 Análise de resultados: estruturas e processos na governança dos folhelhos de Eagle Ford Shale

5.6 Análise dos Resultados: padrões de eco-governamentalidade comuns em Eagle Ford Shale

5.7 Discussão dos resultados e limitações da pesquisa

6 POLOS GAÚCHOS DE BIODIESEL E EAGLE FORD SHALE: GOVERNANÇA 234 E ECO-GOVERNAMENTALIDADE DE DUAS PROMESSAS ENERGÉTICAS

6.1 Análise comparada dos Direcionadores de Governança do 235 biodiesel nos PG e dos folhelhos em EFS

6.1.1 Descentralização PG vs Decentralization EFS

6.1.2 Participação PG vs Participation EFS

6.1.3 Cooperação PG vs Cooperation EFS

6.1.4 Responsabilização PG vs Accountability EFS

6.1.5 Transparência PG vs Transparency EFS

6.1.6 Equidade PG vs Equity EFS

6.1.7 Pertencimento PG vs Ownership EFS

6.1.8 Empoderamento PG vs Empowertment EFS

6.2 Análise dos resultados - Governança e eco-governamentalidade do biodiesel e dos folhelhos: Energias propulsoras ao futuro sustentável ou reprodução de trajetórias pretéritas?

6.2.1 Estruturas e processos de governança

6.2.2 Os discursos e subjetividades: padrões comuns de governamentalidade e eco-governamentalidade

6.3 Discusão dos resultados: entre a prática e o discurso na regulação 271 do biodiesel gaúcho e dos folhelhos texanos 


\section{INTRODUÇÃO}

A energia é fundamental para o desenvolvimento da humanidade. As suas formas de regulação e gestão são, portanto, elementos decisivos quanto à qualidade de sua exploração e produção. Além da natureza e da materialidade própria das distintas fontes de energia, os processos, as estruturas e os discursos envolvidos nesses arranjos político-institucionais carregam em si o potencial de ditar impactos socioambientais (negativos e positivos) sobre o planeta e seus habitantes. Acreditando nessa perspectiva, a presente tese foi construída para refletir como as complexidades e nuances de governança potencializam, ou prejudicam o desenvolvimento e a produção racional e equilibrada de recursos energéticos. Uma tarefa considerável, frente à miríade de dimensões técnicas, socioeconômicas, políticas e culturais envolvidas; e à vasta gama de conhecimentos, informações e subjetividades abrangidas.

Vale ressaltar que, políticas públicas e sistemas de governança para o setor energético são envoltas, e definidas, prioritariamente por variáveis que obedecem, e oscilam ao balanço de forças entre os atores sociais e instituições que as compõe. Resultados proporcionados pelas relações de poder na regulação e gestão de energia têm potencial de afetar instituições, empresas e cidadãos comuns. Em alguns casos podem provocar assimetrias ao favorecer apenas os atores dotados de maiores recursos políticos e econômicos, ou beneficiar aqueles que "andam de carona" nos resultados, em detrimento daqueles que pagam, ou pagarão, pelos passivos socioambientais remanescentes nas áreas de exploração energética (SOLANA\& SAZ-CARRANZA, 2011, p.01).Vale ressaltar, que a produção de energia é talvez o mais poderoso instrumento para ação e modificação do meio humano e natural. É uma atividade produtiva que atrai volumosos investimentos e gera vultosos retornos econômicos, mas que promove transformações de elevada magnitude na paisagem e na sociedade (NADAI \& HORST, 2010).

A despeito desta complexidade e dos possíveis impactos para a relação ambiente-sociedade, análises de governança de recursos energéticos e de seus padrões de eco-governamentalidade não têm sido devidamente feitas na literatura da área de energia, nem na alçada da política ecológica. De maneira geral, quando se faz a correlação entre energia e governança, os trabalhos geralmente se concentram na discussão sobre os mecanismos legais necessários para garantir a segurança, a eficiência energética; e o enfrentamento dos desafios de concertação das políticas energéticas em escala internacional. Convencionalmente, os trabalhos versam sobre obstáculos e estímulos para o desenvolvimento de fontes energéticas 'sustentáveis', 
mecanismos de desenvolvimento limpo (MDL's) e o controle das emissões de poluentes pela produção de energia. Boa parte das análises é direcionada quanto às dificuldades de sincronia entre os países na implementação de políticas, acordos e negociações conjuntas.

Tendo em vista essa importante lacuna acadêmica, portanto, foi construída a justificativa científica da tese, que pretende chamar atenção para a tensão normativa e empírica da governança propriamente dita e dos padrões de ecogovernamentalidade atrelados. Ou seja, trata-se de ver como estruturas, processos e discursos se desenvolvem na regulação, exploração e gestão dos recursos energéticos. Ou ainda, como se materializam e interferem nos sistemas de governanças e nas políticas energéticas. Adicionalmente, a discussão remete como a relação de poder entre os atores (comunidades, empresas, instituições e grupos de interesse), seus padrões de interações e interdependências podem ser conflitantes com os discursos legitimadores dominantes.

Vale destacar que a implementação de sistemas de governança são capazes de gerar práticas coletivas inovadoras entre seus os envolvidos, mas, por outro lado, também podem promover estruturas que reforçam uma assimetria e inequidade de direitos e vantagens dos participantes. A regulação e gestão estão sujeitas tanto à geração de novas oportunidades para a reformulação e reordenamentos políticos (i.e. aumento da participação e da cooperação) quanto à ampliação de lógicas de legitimação e domínio por setores políticos e produtivos hegemônicos.

Importante ressaltar que, embora as atividades energéticas exibam uma forte dimensão local/territorial, níveis distintos de autonomia política, e normas constitucionais, muitas vezes condicionam as áreas de produção e suas comunidades à posição de meros coadjuvantes frente às decisões oriundas de escalas superiores de poder. Muitos desenhos político-institucionais promovem a marginalização, cooptação ou mesmo o tolhimento das prerrogativas políticas dos atores locais, seja pela concentração, seja por deslocamentos normativos muitas vezes legitimados pelos discursos e pela alienação dos atores locais.

Esse trade-off remete à justificativa política da tese. Uma vez que, sistemas de governança caracterizados pela assimetria de recursos políticos e econômicos, com acesso desequilibrado a informações, normas e regras, ou mesmo a formação de arenas políticas excludentes, têm o potencial de inibir processos equilibrados, posturas e práticas adequadas na produção e exploração de energia. Por esse ângulo, a discussão da qualidade de governança sob recursos energéticos 
assume grande papel e responsabilidade que governo e sociedade possuem juntos na consolidação de políticas energéticas.

Uma das características do início do século XXI é o crescimento exponencial do uso de energia, e do debate sobre formas, fontes e mecanismos de exploração. Alguns recursos energéticos, e seus respectivos arranjos políticos e produtivos, vêm aumentando a polêmica sobre a produção de energia e a sustentabilidade das fontes, seja nos países desenvolvidos, seja nos países em desenvolvimento. De igual forma, é crescente o consenso global a favor do desenvolvimento de 'energias renováveis', mas também das intituladas energias 'nãoconvencionais' defendidas por muitos líderes políticos e governos. Tecnologias de inovação em campos como energia solar, produção de biomassa, energia eólica, e a exploração dos folhelhos e areias betuminosas têm sido apontados como recursos energéticos propulsores a inovação e ao desenvolvimento, e, inclusive, como resposta à depressão econômica de países e regiões (NADAI \& HORST, 2010 p.144).

Dentro desse contexto, dois recursos energéticos se expandiram substancialmente na última década: o biodiesel de primeira geração, e os hidrocarbonetos não-convencionais obtidos dos folhelhos. Ambos tiveram um crescimento substancial na sua participação na fatia mundial de produção energética graças a lógicas, racionalidades próprias e arranjos político-institucionais específicos. Ambas os recursos, mesmo se tratando de fontes de materialidade distintas, se propagaram propulsionados como alternativas viáveis, estratégicas, e inclusive 'sustentáveis' dentro de modelos específicos de governança dos recursos energéticos.

No Brasil, por exemplo, parcerias público-privadas, incentivos econômicos, subsídios e isenções oferecidos pelo Governo Federal a segmentos do mercado e da sociedade civil conseguiram criar o segundo maior mercado mundial de biodiesel. A legitimidade das ações públicas foi pautada pela conciliação de variáveis sociais, constituicionais, tecnológicas e biofísicas disponíveis para os arranjos produtivos necessários. A produção foi justificada, entre outros argumentos, pela redução nas importações de óleo mineral combustível, pela redução das emissões de poluentes, e pelas oportunidades abertas para o setor agroindustrial, e para a sociedade civil. Os discursos ligados à produção do biodiesel emergiram, por exemplo, como um importante mecanismo de fortalecimento da agricultura familiar e demais instituições representativas de trabalhadores no campo.

Nos Estados Unidos, por sua vez, o 'shale boom' também foi consolidado a partir de parcerias entre atores estatais e não-estatais, bem como, por incentivos oficiais que colocaram o país no topo da exploração mundial dos recursos não convencionais. A tecnologia do fraturamento hidráulico (fracking) na exploração 
dos folhelhos também foi legitimada como elemento fundamental para reduzir a dependência das importações de petróleo e gás. Foi também defendida como fator propulsor do desenvolvimento social de pequenas comunidades. A tecnologia de prospecção em larga escala dos recursos não-convencionais promoveu uma verdadeira revolução energética e oportunidade ímpar para a economia norteamericana (TUNSTALL, 2015a). Uma atividade supostamente capaz de consolidar a independência energética do país tornando-o em poucos anos um potencial exportador de hidrocarbonetos líquidos (EXXON MOBIL, 2015).

Nesse contexto, duas paisagens energéticas se destacam: os polos gaúchos de produção de biodiesel (PG) e Eagle Ford Shale (EFS). A primeira se constitui na mais ativa área de produção e no espaço social mais heterogêneo envolvido na produção de biodiesel no Brasil, o segundo maior mercado mundial do biocombustível na atualidade (REN21, 2015). Os PG são paisagens energéticas que contam com uma complexa gama de atores e instituições direta e indiretamente inseridas e impactadas pela regulação e produção agroenergética. A segunda, Eagle Ford Shale, por sua vez, é igualmente a mais ativa e financeiramente vultosa área de exploração de hidrocarbonetos de folhelhos em atividade nos Estados Unidos. Uma área no sul do estado do Texas, caracterizada por uma ampla e heterogênea quantidade de atores e instituições e, significativamente impactada pelo recente shale boom no país.

Vale destacar que não são comuns estudos comparativos entre Brasil e Estados Unidos envolvendo levantamentos de natureza geográfica, etnográfica, energética e ambiental (BRANNSTROM, 2015). Diante disso, a comparação realizada pelo presente estudo tem opotencial de: i) auxiliar nos estudos de como políticas e pactos federativos nos dois países se desdobram frente à governança de recursos energéticos, ii) analisar se biodiesel e folhelhos, dois recursos energéticos de materialidades distintas, possuem estruturas e processos semelhantes, e quais elementos os distanciam, ou os aproximam da prática de boa governança; e iii) analisar como stakeholders e policy makers, distribuídos nas diferentes esferas de poder nos dois países, empregam discursos e imagens legitimadoras comuns para justificar a exploração dos recursos energéticos.

Por meio do estudo dos PG e de EFS, portanto, a presente tese busca atingir seu objetivo geral que é: avançar no arcabouço teórico, empírico e instrumental da governança ao incorporar os recursos energéticos e os padrões de ecogovernamentalidade como focos de interesse. Adicionalmente, a pesquisa tem os seguintes objetivos específicos: 
i) revisar e expôr os conceitos de governamentalidade e ecogovernamentalidade, de modo a colaborar com literatura da área de governança, correlacionando governança e energia; ii) construir uma proposta metodológica para avaliação de sistemas de governança de recursos energéticos, e dos padrões de eco-governamentalidade; iii) analisar os arranjos politico-institucionais, processuais-organizativos e discursos nos sistemas de governança do biodiesel no Brasil, a partir do estudo de caso dos Polos Gaúchos de produção; iv) de forma análoga, descrever as estruturas, processos e discursos propagados nos sistemas de governança dos folhelhos nos Estados Unidos, utilizando como estudo de caso Eagle Ford Shale; v) realizar uma análise comparativa dos padrões de eco-governamentalidade e dos sistemas de governança do biodiesel gaúcho e dos folhelhos texanos; e vi) discutir como sistemas de governança de recursos energéticos de natureza e materialidades distintas, estruturados a partir de políticas energéticas e estruturas federativas próprias, se distanciam ou se aproximam da prática da boa governança. E ainda, quais são os padrões de eco-governamentalidade preponderantes e como trazem desafios aos dois países na regulação e exploração de recursos energéticos

Diante desses objetivos, a pesquisa pretende responder simultaneamente três perguntas norteadoras:

a) Os sistemas de governança estudados ampliaram os processos de democracia participativa e ação coletiva, ou são apenas palcos de novos discursos voltados a legitimar a exploração de cadeias produtivas tradicionais?

b) Qual é o grau de cooperação e participação que sociedade civil e atores não-estatais têm na regulação e exploração do biodiesel nos PG e dos folhelhos em EFS?

c) A governança do biodiesel gaúcho e dos folhelhos texanos foi capaz de promover o deslocamento regulatório, em especial, a descentralização da regulação e gestão dos recursos energéticos?

O estudo foi desenvolvido a partir da hipótese de que a governança do biodiesel dos PG, e dos folhelhos de EFS, se desenvolve sob estruturas e processos distintos, mas utiliza de eco-governamentalidades similares que obscurecem governanças falhas na ação coletiva tanto dos recursos energéticos quanto dos recursos naturais que dão base às cadeias produtivas. A pesquisa empírica conduzida nas duas áreas de produção partiu da premissa que a regulação e a produção de 
ambos os recursos energéticos se consolidaram a partir de lógicas e discursos similares. Nos dois os casos, inovação, sustentabilidade, desenvolvimento, segurança e independência energética são fortes elementos utilizados para justificar a produção do biodiesel e exploração dos folhelhos. Elementos que reforçam, contudo, a dependência dessas áreas frente às cadeias de commodities tradicionais de significativo impacto socioambiental. A soja, no caso do biodiesel gaúcho, e do petróleo, no caso da exploração dos folhelhos texanos.

O problema central da tese diz respeito a possível tensão teórica, analítica e empírica que se estabelece nos padrões de governança e de ecogovernamentalidade dentro da análise dos recursos energéticos. Nesse contexto, se discutem a formação dos conceitos de governança e de eco-governamentalidade com o objetivo de elucidar o que são, e quais são suas relevâncias. E, especialmente, como se desenvolvem e se medem? Ou ainda, como se aplicam aos casos de estudo? A literatura das respectivas áreas, por exemplo, não aponta para metodologias capazes de responder a essas perguntas. Diante disso, a pesquisa parte do uso de modelos e de ferramentas para desenvolver uma proposta metodológica que se mostre adequada ao desafio.

A tese foi organizada em sete capítulos. O primeiro capítulo versa sobre os conceitos de governamentalidade, eco-governamentalidade e de governança ambiental, ou governança dos recursos. Nessa etapa são introduzidas as ideias de Michel Foucault sobre a governamentalidade. Um conceito que surge coligado aos novos mecanismos aplicados pelo estado no controle e gestão da população e seu território. Novas relações de poder e formação de arenas inéditas de ação política, práticas de regulação, mas, sobretudo, de procedimentos normativos de ordem social e econômica. O texto esclarece como as práticas e estratégias de comando e controle passam a ser reforçados por processos de doutrinação sócio-cultural nos quais o discurso assume o papel de propagação de lógicas dominantes e da formação de subjetividades definidas por núcleos ou campos de poder hegemônicos.

O primeiro capítulo descreve ainda o surgimento do conceito de ecogovernamentalidade, ou enviromentality. Uma forma de interpretação das relações de poder da governamentalidade, porém, interligada à concepção de códigos, aparatos institucionais, procedimentos e doutrinações sobre o controle e uso da natureza. Sob essa perspectiva, se enfatiza como a noção de 'ambiente' passa a ser sujeita a diferentes interpretações, bem como, alvo de práticas de gestão e manejo dos recursos naturais. Uma prática igualmente apoiada por discursos e subjetividades, onde o próprio conceito de natureza assume várias interpretações, contraditórias, ou 
mesmo complementares entre si, que oscilam de acordo com as retóricas e ideologias dominantes.

$\mathrm{Na}$ segunda parte do primeiro capítulo, o trabalho explora o conceito de governança e suas conexões com o ambiente, os recursos naturais e $o$ desenvolvimento de padrões de eco-governamentalidade. Nessa seção destaca-se a governança como processo inovador dos canais de regulação e gestão tradicionais, em que novos atores sociais não-estatais assumem maior participação em assuntos de domínio público. O texto destaca que a governança se apresenta sob a perspectiva de consolidar arranjos político-institucionais (e produtivos) inéditos, nos quais sociedade, Estado e mercado passam a interagir para regulação, formulação e execução de políticas públicas e gestão de setores específicos.

Nas etapas seguintes são apresentadas diferentes configurações dos mecanismos e desenhos de governança, em especial, sua forma híbrida e os princípios da 'boa governança'. Por fim, o primeiro capítulo explora a emergência da governança ambiental, ou governança dos recursos, como o fenômeno coligado, e influenciado, pelos padrões de eco-governamentalidade preponderantes.

No segundo capítulo é apresentado o conceito de paisagens energéticas como campo disciplinar emergente. Nessa etapa é enfatizada a relevância da correlação entre energia e paisagem, e como as características dessa sinergia tendem a ser decisivas no processo de transição energética. O texto destaca o papel da governança na (re)configuração das paisagens sujeitas à exploração energética e à carência de pesquisas que adotam a perspectiva da eco-governamentalidade para o estudo empírico de áreas de produção. Adicionalmente, são enfatizadas as materialidades inerentes das fontes energéticas, mas, sobretudo, a importância dos sistemas de governança frente às normas, regras e ordenamentos que regem a regulação e a exploração nas paisagens de produção.

O capítulo é encerrado com a apresentação do modelo de análise Institucionalista de Elinor Ostrom, suas categorias de investigação básicas e elementos referenciais para avaliação dos sistemas de governança dos recursos energéticos. Ou seja, os eixos basilares de investigação que incluem os papeis dos atores sociais; as interações, as interdependências e os resultados que produzem dentro das arenas de ação política, bem como, as regras que compartilham, as preferências, as crenças e os vieses cognitivos que os conduzem.

O terceiro capítulo descreve a metodologia, a contextualização e as áreas de estudo. São detalhados os padrões e procedimentos empregados na pesquisa, descritos as correlações avaliadas e o encadeamento das categorias de investigação e a incorporação da análise dos discursos realizada com apoio do 
software Atlas.ti. O capítulo propõe um método de avaliação qualitativo-quantitativa, do tipo likert, para análise dos resultados.

Em seguida é feita a contextualização histórica e econômica das duas paisagens energéticas estudadas: os PG de produção de biodiesel e EFS. Aqui são apresentadas pistas dos principais desafios à governança de ambos os recursos energéticos em seus respectivos países. Fechando o capítulo, são apresentados os detalhamentos sobre a aquisição dos dados e perfis dos respondentes, bem como, os padrões, instrumentos, procedimentos e posicionalidade do autor frente aos PG e EFS.

O quarto e o quinto capítulo são referentes à aplicação da metodologia frente aos dados coletados, e à análise de resultados das duas áreas de estudo. Divididos em quatro partes, são apresentados: i) as variáveis estruturais, ou aspectos tecnológicos, sociais, constitucionais e biofísicos da regulação e exploração de ambos os recursos energéticos em seus países; ii) as respectivas arenas de ação política e o perfil socioeconômico dos atores sociais envolvidos; iii) os dados e resultados dos oito direcionadores de governança dos recursos energéticos; e por fim iv) uma análise e discussão dos resultados na eco-governamentalidade preponderante nas duas paisagens energéticas.

No sexto capítulo é realizada uma análise comparativa entre os direcionadores de governança do biodiesel nos PG e de EFS. São discutidos os desafios a regulação e gestão de recursos energéticos nas duas áreas de estudo a partir dos critérios de descentralização, participação, cooperação, responsabilização, transparência, equidade, pertencimento e empoderamento. Também sobre os discursos e subjetividades na governança de recursos energéticos nos dois países, procurando encontrar consonâncias e dissonâncias.

A conclusão traz as principais reflexões sobre a energia como atividade propulsora de novos paradigmas de sustentabilidade. São respondidas as perguntas norteadoras e é verificada a factibilidade da hipótese sugerida. Reflete-se sobre como os discursos e subjetividades, e, portanto, padrões de eco-governamentalidade na regulação, gestão e produção de recursos energéticos se constituem como campos relevantes para a análise científica de importantes impactos e resultados na regulação e exploração de energia. 


\section{OS CONCEITOS DE GOVERNAMENTALIDADE, ECO- GOVERNAMENTALIDADE E GOVERNANÇA DOS RECURSOS}

Parte I- Eco-governamentalidade, relações de poder, discursos e subjetividades na construção dasustentabilidade ambiental

1.1 Governamentalidade, biopoder e o panóptico social de Michel Foucault

Os conceitos de governamentalidade, biopoder e biopolítica surgem das palestras 'Segurança, Território, População' e 'Nascimento da Biopolítica', proferidas por Michel Foucault, no final da década de 1970, no College de France, em Paris (FOUCAULT, 1992). As abordagens desenvolvidas pelo filósofo francês discutem as relações e estruturas de poder no processo de formação da sociedade moderna. Mesmo sem a intenção de formular uma teoria geral do fenômeno, o autor acaba por apresentar uma análise elaborada de como relações e mecanismos de poder se transformaram a partir de contextos históricos, campos e espaços específicos.

Foucault (1992) destaca que a formação do poder não se resume apenas à capacidade de proibição, dominação e coerção; mas inclui a construção de subjetividades sociais ligadas aos interesses políticos e econômicos dominantes. $O$ poder em si, seria construído sob um processo complexo e denso de relação de forças. Seria o resultado final de processos dinâmicos, conflitantes e resistentes; construído em reordenamentos políticos, rupturas e reorganização social. Processos muitas vezes, desassociados de um ponto central, e coligados a uma densa rede multifocal composta por processos múltiplos e distintos.

Segundo Foucault (1992), uma nova racionalidade política se desenvolve a partir do século XVII, com o contrato social e o surgimento do Estado moderno. Dentro desse contexto, a "biopolítica" surge como o processo pelo qual o Estado passa a se concentrar não apenas nos aspectos de soberania territorial, mas também no controle da população na qualidade de espécies biológicas, administrando e conduzindo a sociedade de acordo com suas características e padrões de longevidade, tamanho, natalidade e mortalidade. "Os traços biológicos da população passam a ser elementos pertinentes para uma gestão econômica, e necessários para organizar um dispositivo que assegure não apenas sua sujeição mas o aumento constante de sua utilidade" (FOUCAULT, 1992: 198).

É a partir, portanto, da instauração de dispositivos políticos de controle e gestão da população que Foucault (1992) sugere a emergência de uma nova mentalidade e racionalidade de governo. No qual a própria a concepção de governo passa a ser o grupo que administra a máquina estatal, aplicando a burocracia do 
Estado, controlando o patrimônio público, mas,sobretudo, uma esfera, um campo de ação que visa controlar as regras e comportamentos de indivíduos, grupos sociais específicos e a sociedade como um todo (MAIA, 1995). É a partir da 'governamentalização do Estado' que Foucault (1992) concebe a idéia de 'governamentalidade', ou da arte de governar, centrada nas interações dos homens com suas riquezas, seus recursos, suas tradições, hábitos e culturas. A lógica de governar estabelecida a partir de interações sociais aos fatores de ordem natural e biológica (SANTOS, 2010).

A partir da governamentalidade se produzem técnicas, estratégias, estruturas e incumbências para lidar com questões centrais de gestão interna e externa dos Estados. Nesse contexto emergem os mecanismos e táticas voltadas a gerir e controlar espaços de contestação e conflito, bem como, de delegar competências e atribuições. Elementos que garantem a legitimação, consolidação e a própria sobrevivência do Estado. A governamentalidade se estabelece, portanto, num processo contínuo de definição e redefinição de instâncias da ação do Estado e de práticas de governo, incluindo a separação de poderes e os papeis das esferas públicas e privadas (FOUCAULT, 1992).

$\mathrm{Na}$ análise de Foucault (1992), o elemento essencial na governamentalidade é a instauração de mecanismos de poder propagados pela formação de procedimentos normativos de ordem política e econômica, simultaneamente reforçados por processos de controle e doutrinação do meio sócio cultural. (MARTINS E PEIXOTO JUNIOR, 2009). As estruturas e os mecanismos de controle, ao contrário das medidas disciplinares físicas dos antigos regimes são substituídos por dispositivos de condicionamento moral. Foucault sugere que tais estruturas de "biopoder" estabelecem um "panóptico social", no qual a sociedade moderna e seu regime de ordenamentos ao mesmo tempo obedecem e controlam dispositivos de vigilância e autovigilância, interiorizam culpa e remorso, moldam subjetividades sociais, 'normalizam' e justificam os padrões de conduta e de pensamento.

Um dos principais mecanismos destacados por Foucault (1987) como prática de doutrinação social e formação das subjetividades é o discurso. Em suas obras Arqueologia do Saber, Vigiar e Punir, e A Ordem do Discurso, também publicadas na década de 1970, o autor destaca como as práticas discursivas, com o emprego de palavras, elementos e conceitos-chave seriam responsáveis por produzir e consolidar relações de poder, tornando-se instrumentos poderosos no processo de dominação e controle do Estado sobre a sociedade. Para o autor, haveria um mútuo 
condicionamento entre práticas discursivas, o condicionamento ideológico e a manutenção dos padrões de governamentalização do Estado.

Dentro do escopo da governamentalidade o discurso seria, portanto, um elemento condicionador da disciplina, produzindo e reproduzindo saberes e concepções dominantes. Pelos discursoselementos persuasivos se retroalimentariam mutuamente por meio de enunciados, elementos visuais, textos e pronunciamentos. Tendo o papel não apenas de referência a coisas e objetos, mas de características e regularidades próprias definidas para propagar interesses, e para atingir objetivos e finalidades específicas.

A prática discursiva seria o reflexo da mentalidade dos segmentos de maior influência e domínio sobre arenas políticas, representando a consolidação de lógicas predominantes emanadas por núcleos ou campos de poder hegemônicos (FOUCAULT, 1987, p.70). Foucault (1980) ressalta como "os efeitos da 'verdade' são produzidos com discursos que na sua essência não são verdadeiros nem falsos" (p.118), mas que funcionam como doutrinas destinadas a convencer pessoas a partir de "jogos de verdade" (FOUCAULT, 2000a p.296). Sob essa perspectiva a 'verdade' é construída de acordo com um sistema de procedimentos e uma "construção de regras [e arenas de ação], onde verdadeiro e falso são separados, e efeitos específicos de poder atrelados à noção de verdade" (p.296).

1.2 A eco-governamentalidade, geopoder e o panóptico ambiental de Timothy Luke.

A concepção de eco-governamentalidade, ou governamentalidade verde, se origina da tradução livre do inglês environmentality, um paralelo traçado por Luke (1995) frente ao conceito de governamentalidade e biopoder estabelecido por Foucault (1992). Luke (1995) lembra que environment, ou 'ambiente', é uma palavra oriunda da forma francesa e inglesa do verbo environ, que significa envolver, incorporar ou cercar. Meio-ambiente, ou ambiente, portanto, emergem com o sentido de realçar algo que estaria onipresente e dominante no espaço vivido. Na língua portuguesa, por exemplo, o termo teria a mesma etmologia, sendo ambiente, ou meioambiente, uma noção de espaço circundante, sítio, lugar específico no qual, elementos físicos, biológicos, humanos e sociais interagem e/ou prevalecem.

Para Luke (1995), a consolidação do conceito de ambiente se manifesta com o mesmo propósito no qual Foucault (1992) apresenta a lógica do biopoder. Se para Foucault a governamentalidade, ou governmentality, está ligada à governamentalização do Estado, a eco-governamentalidade, ou enviromentality, está 
ligada à governamentalização e à apropriação do conceito de natureza como mecanismo de poder. Na concepção de Luke (1995), as noções de ambiente e meioambiente criam subjetividades voltadas a justificar a apropriação de recursos naturais dentro de lógicas particulares de relações de poder. Um processo conduzido igualmente por propagações discursivas, e legitimada por elementos técnicocientíficos, conhecimentos, e saberes propagados dentro de domínios econômicos, políticos e culturais específicos (SANTOS, 2010).

$\mathrm{Na}$ leitura de Luke (1995) a eco-governamentalidade reinventa as formas de uso e exploração da natureza no seio das sociedades modernas, apoiadas num conjunto de ampliação do biopoder que articula tecnologia, conhecimento científico, necessidades da população, exploração econômica e gestão dos recursos naturais. $O$ conceito de meio-ambiente emerge nas práticas e mecanismos de governo como um "artefato histórico" (p.5) nos quais as inter-relações e retóricas de sua regulação e exploração assumem a necessidade de formação de redes de interferências técnico-científicas e mecanismos cada vez mais especializados.

Para ele o conceito de ambiente estaria, portanto, formando novas "empiricidades" (p.5) baseadas em mecanismos de controle, e resistências, esferas e campos de domínio, conhecimento e utilização. Luke (1995) intitula esse fenômeno como 'geopoder' em alusão ao 'biopoder' cunhado por Foucault. Conforme observa Santos (2010), semelhante ao caso da governamentalidade, a ecogovernamentalidade se estabelece na construção de concepções, códigos e procedimentos com o intuito de conceber verdades, ou saberes edificados, para suprir um aparato institucionalizado, e gerir o meio-ambiente e seus recursos naturais.

Para o autor, o processo de ambientalização da natureza, ou ecogovernamentalidade, semelhante ao que Foucault (1992) tece em sua análise de poder, também se estabelece a partir de múltiplos centros formadores de opinião e de saber. Luke (1995) os intitula como centros de eco-knowledges, ou núcleos de ecoconhecimento, dispostos nos espaços normalmente gerados e ocupados pelas grandes corporações e agências oficiais de Estado. É a partir deles que emanam os procedimentos de controle e uso da natureza justificados pela necessidade de manejo equilibrado e gestão racional dos recursos naturais em um processo de vigilância e autovigilância semelhante ao panóptico social.

Dentro dessa lógica é que o autor sugere a formação do panóptico ambiental, no qual o meio-ambiente passa a ser sujeito de práticas de gestão e manejo de seus recursos, apoiado no discurso de equilíbrio e racionalidade na exploração de seus mecanismos e sistemas. É sob essa perspectiva, que o autor lembra a emergência dos conceitos de 'eco-desenvolvimento' e posteriormente de 
'desenvolvimento sustentável'. Se a eco-governamentalidade propulsiona por um lado reformulações de ações voltadas a preservação da diversidade biológica e de um conjunto de novas práticas socioeconômicas, por outro lado,o processo justifica e torna legítimo, um novo regime de ordenamentos e subjetividades apropriadas para garantir a apropriação e uso dos recursos naturais dentro da lógica de acumulação capitalista (LUKE, 1995).

1.3 A eco-governamentalidade como tecnologia de governo e produção de subjetividades de Arun Agrawal

O trabalho de Agrawal (2005) é de especial importância para as análises das formações de subjetividades socioambientais dentro do escopo teórico e experimental da governamentalidade e da eco-governamentalidade. Sua obra debate como comportamentos e percepções também podem ser modificados a partir da instituição de novas arenas de participação e da ação política direta de atores sociais na regulação e uso de recursos naturais. Seu trabalho é relevante, pois é um dos primeiros a correlacionar elementos teóricos das teorias de grupos sociais a uma investigação empírica e obter resultados da observação direta de práticas de ação coletiva (HATHAWAY, 2005).

Segundo Agrawal (2005), os elementos-chave na teoria clássica de formação ideológica estariam apoiados na lógica de dominação cultural e ação política. Um processo comum, por exemplo, durante a emergência do nacionalismo, e dos choques entre dominação e resistência de classes e grupos de interesses. Por esse pressuposto, o processo de formação da consciência coletiva seria resultante da imposição da elite dominante e da resignação de grupos subjugados na aceitação dos novos parâmetros. O contrapeso de forças seria o papel das resistências culturais e das consciências autônomas no rebatimento da imposição política e ideológica. $O$ autor destaca, entretanto, a obsolescência dessa visão polarizada entre os que defendem a imposição da consciência soberana dos interesses de classe e daqueles que interpretam o processo como resultado de colonização do imaginário por grupos de interesse e/ou agentes políticos.

Para Agrawal (2005), existem processos mais complexos que determinam o tempo e as motivações para que atores sociais comecem a modificar suas subjetividades e ideologias. Para ele, as novas práticas de gestão baseadas em ações coletivas se apresentariam como alternativas inéditas na modificação de formas tradicionais de relações de poder, e do rompimento entre a dicotomia de dominação e resistência. O processo estaria ligado essencialmente ao estímulo de grupos e indivíduos em vivenciar seu espaço, organizar seus pensamentos, e correlacionar sua consciência na condução de seus atos. As condições estariam correlacionadas ao 
estímulo de novos desenhos institucionais, de uma governamentalidade capaz de estimular interesses coletivos na implementação de esferas de negociações sobre práticas ordinárias dos cidadãos (AGRAWAL, 2005).

Baseado numa série histórica de caráter etnográfico, Agrawal examina como vários níveis diferenciados de envolvimento da sociedade em regimes de regulação e exploração estimularam maneiras inéditas de compreensão, interpretação e uso do meio-ambiente. O autor defende que, embora atores sociais sejam compelidos a atender prioritariamente seus interesses e necessidades dentro de uma lógica imediatista, seria possível por meio do estímulo ao engajamento em práticas regulatóriaslocais de consolidar ambientes inovadores e comportamentos capazes de produzir uma reconfiguração das posturas e atitudes na exploração de recursos naturais comuns.

Agrawal sugere que a participação em conselhos comunitários e comitês, além de promover o rompimento da dicotomia entre dominação e resistência, seria capaz de incentivar o delineamento de objetivos comuns e promover $o$ sentimento de responsabilização e pertencimento dos atores sociais. A convicção do autor emana das suas pesquisas conduzidas nas Van Panchayats, ou conselhos comunitários de gestão de recursos florestais na India. Seus resultados apontaram que as localidades em que houve maior envolvimento direto dos aldeões no controle e regulação da exploração de madeira, lenha, manejo de animais ruminantes, queimadas e lavouras, apresentaram importantes modificações nas posturas e visões das comunidades sobre o papel das florestas, e sobre a importância das árvores no equilíbrio e manutenção do meio-ambiente.

Agrawal concorda com Luke (1995) que o objeto da ecogovernamentalidade está na inserção da natureza e do meio ambiente no centro das racionalidades políticas das nações modernas. Agrawal (2005) compreende também que a eco-governamentalidade resulta de um quadro no qual as relações de poder podem se desenvolver na criação e propagação de subjetividades para a apropriação dos recursos naturais. Entretanto, ele fornece uma visão mais otimista em relação ao panóptico ambiental ao defender a possibilidade de uma modificação das lógicas de uso e exploração dos recursos naturais a partir da experiência participatória política e do engajamento direto da sociedade em práticas regulatórias. O trabalho de Agrawal (2005) sugere que a descentralização das funções tradicionais de gestão do Estado e a formação de sistemas de governança de recursos seriam elementos fundamentais na consolidação de novas práticas, posturas e atitudes dos atores sociais em relação ao seu meio natural. 


\subsection{Eco-governamentalidade, ambientalismo e sustentabilidade}

Segundo Luke (1999a), o conceito de ambiente, ou meio-ambiente, tinha até poucas décadas atrás somente a denotação biológica e zoológica, e não fazia referência ao ambiente natural e humano. O processo histórico revelou, entretanto, que o conceito de ambiente não está restrito apenas a uma "esfera natural dos processos ecológicos", mas sim a um conceito histórico e social maior, frequentemente utilizado de forma intercambiável com os termos natureza, ecologia, conservação, mas também de outros termos e critérios como sociedade, preservação e degradação dos recursos naturais (LUKE 1999a, p.120-121).

Por esse pressuposto, Luke (1999a) afirma que o conceito de ambiente tem sido compreendido pela sociedade sob diferentes perspectivas, sendo definido desde "as condições sobre as quais uma pessoa ou coisas vivas se desenvolvem", ou ainda pela "soma total da influência que modifica e determina o desenvolvimento da vida e suas características" (p.121). O autor ressalta, porém, que somente a partir de poucas décadas atrás, em especial após 1970, é que as definições de ambiente passaram a ser associadas com o meio natural e que foram realçados a necessidade de mecanismos para sua proteção e aproveitamento. Na mesma época o adjetivo 'ambiental', e o nome 'ambientalista' passam a ser incorporados aos dicionários de língua inglesa e gradativamente alcançaram o vocabulário acadêmico e popular.

A partir de então a ideia de ambiente ficou sistematicamente associada com a proteção do ambiente natural, e o ambientalismo criou igualmente um caminho de conhecimento e procedimentos para sua proteção e controle (HAMLIN, 2011). Luke (1999a) destaca que "o ambiente se torna o resultado de uma ação sinalizada" e se forma carregado de um sentido de ação estratégica semelhante ao feito por forças militares, ou policiais, para cercar (verbo to environ) e anexar uma área. Sob essa perspectiva, numa visão ideal, ambientalistas protegem e delimitam o ambiente ao gerir um espaço geográfico (bioma, região, território) anexando-o a quadros de disciplinas, ou regulamentações, como por exemplo, adotando a gestão de recursos naturais, onde o 'ambiente' e seus recursos são protegidos, supervisionados e explorados (LUKE, 1999a, p.126-127).

Nesse contexto, a sustentabilidade ambiental estaria ligada à manutenção de longo-prazo dos recursos ambientais num contexto de evolução humana. Uma perspectiva que não impede que diferentes interpretações do conceito 'ambiente' possam produzir distintas utilizações e funções da ideia de sustentabilidade. Para economistas, engenheiros, e gestores de recursos, por exemplo, sustentabilidade ambiental caberia em "uma abordagem que leva em conta a 
manutenção dos estoques de capital". Para ambientalistas, por outro lado, estaria "na depleção dos recursos naturais e como sua utilização pode ser sustentada para um futuro distante" (ESTY ET AL, 2005 p.11). Sob essa perspectiva, a sustentabilidade se reveste de uma dinâmica mutável e variável de acordo com o qual o conceito de 'ambiente' é moldado, interpretado e adotado nas relações entre sociedade, Estado e mercado.

Para Luke (1999a), as nuances que envolvem os conceitos e controles exercidos a partir da definição e controle do ambiente ajudam a explicar como os discursos ambientais, e de sustentabilidade, se transformaram em novas formas de governamentalidade, 'eco-governamentalidade', ou 'governamentalidade verde', sendo incorporados pelos policy makerse propagados pelos discursos dos stakeholders, nos parâmentros da "arte de governar". Tal qual a governamentalidade de Foucault (1992), os elementos justificadores da eco-governamentalidade se edificam dentro de entendimentos específicos da natureza e do ambiente de forma analóga para garantir "o bem-estar da população, o melhoramento das condições, o aumento da saúde, longevidade e riqueza" (FOUCAULT, 1992 p.100).

A eco-governamentalidade se baseia, portanto, em "premissas particulares, códigos e procedimentos" ou em "verdades" sobre a sustentabilidade, a partir de discursos de eco-conhecimento que produzem condicionantes ao afirmar explícita ou implicitamente, como as indústrias devem produzir como o mercado deve comercializar e como a sociedade deve encarar formas de consumo e modos de vida. Para Hamlin (2011), eco-governamentalidade não apenas introduz as questões ambientais na arte de governar, mas também traz novas retóricas nas práticas de governança aplicadas tanto pelo Estado quanto instituições não-estatais (FOUCAULT, 2000b).

A sustentabilidade ambiental representa dentro do escopo da ecogovenamentalidade uma forma de "green power ou eco-knowledge" (poder verde ou eco-conhecimento) que gera uma base de interpretação da natureza, do ambiente, dos seus padrões e sinais significativos (LUKE, 1996). Formas de eco-conhecimento comumente utilizadas por uma miríade de atores e instituições, como governos, agentes de mercado e grupos de interesse, geralmente utilizado por universidades, orgãos de pesquisa e cientistas da área ambiental "para capturar e conter as forças da natureza pela implementação de tecnologias avançadas [...] interligando suas estruturas e processos a estratégias de racionalização da gestão ambiental" (p.2).

Segundo Hamlin (2011), portanto, a natureza por meio desses discursos de eco-conhecimento é transformada em uma base produtiva, controlada e legitimada pelas lentes de disciplinas tecno-científicas de "gerenciamento dos recursos e da 
avaliação de riscos" (LUKE, 1996 p.4). Ainda segundo Hamlin (2011), o processo faz parte de uma tentativa de despolitização da interpretação da natureza como recurso, em que os discursos tecno-científicos supostamente apolíticos, na prática favorecem a continuidade do desempenho econômico em detrimento da preservação ambiental. Práticas que prevalecem entre os gestores, produtores, e mesmo cientistas para consolidar o ambiente natural como "o sítio de recursos acumulados, que contém/detém capitais" (p.35).

Essa visão é compatilhada por autores como Li (2007) e Fletcher (2010). Eles chamam a atenção para os padrões de eco-governamentalidade empreendidos pelo Estado, em conjunto com de atores de mercado, numa tendência ampla de legitimar formas neoliberais de gestão e se apresentar sob a aparência de formas pluralistas de governança (GORDON, 1991). Uma tendência destacada por Ferguson (1990), da eco-governamentalidade como construção e legitimação de visões globais, construída a partir de organizações e setores especializados, com o objetivo de persuasão e redução do debate público. Uma "condução da conduta" (FOUCAULT, 1992), em que as "análises da eco-governamentalidade chamam a atenção para a condução de estratégias concretas de formatação das condutas" (AGRAWAL, 2005 p.223).

Parte II - O conceito de Governança, conexões com ambiente, recursos naturais e padrões de eco-governamentalidade

1.5 Governança como desenho político-institucional nas relações e estruturas de poder modernas

As primeiras citações da palavra governança remontam aos trabalhos publicados por autores da economia política (POLANYI, 1944), sociologia econômica (GRANOVETTER, 1985), relações internacionais (KRASNER, 1983; ROSENAU, 1991) e da nova economia institucional (NORTH, 1990). Sua emergência está ligada à crítica as teorias de ação política e econômica, ao ceticismo frente à economia neoclássica, às análises marxistas, e às premissas de competitividade perfeita dos mercados (BRIDGE E PERREAULT, 2009).

A governança pode ser entendida pela forma que grupos de pessoas e instituições interagem, administram seus interesses e influenciam o meio social e natural que compartilham (CÂMARA, 2011). Uma concepção baseada na perspectiva de formação de arranjos políticos específicos para negociações e acordos possíveis entre os múltiplos interesses, atores e temas em jogo na sociedade (FONSECA, 2009). Um conceito que faz com que a maior parte dos assuntos interligados as 
ciências políticas, econômicas e sociais, de uma maneira ou de outra, se enquadrem no campo da governança (KEEFER, 2004).

Para instituições e organismos supranacionais como a Organização Econômica de Cooperação e Desenvolvimento (OECD), a governança deriva do uso e delegação da autoridade política no controle e gestão de recursos sociais, naturais e econômicos. Um conceito, portanto, que se desenvolve frente ao processo de organização da sociedade e da necessidade de consolidação de ambientes adequados para que o Estado, mercado e a sociedade possam operar conjuntamente nas suas funções essenciais e construir benefícios mútuos para governantes e governados (OECD, 1995).

$\mathrm{Na}$ visão do Banco Mundial, governança seria o modo pelo qual o poder é exercido na administração de recursos socioeconômicos a partir de princípios de participação política, gestão compartilhada, informação e transparência orçamentária (WORLD BANK, 1992). Para o Programa das Nações Unidas para o Desenvolvimento (PNUD), a governança também estaria ligada ao compartilhamento da autoridade econômica, política e administrativana implementação de novos mecanismos de gestão e processos nos quais grupos e pessoas buscam a articulação de seus interesses, exercendo seus direitos e mediando suas diferenças (UNDP, 1997).

A Comissão Global de Governança das Nações Unidas, instituída em 1992, define governança como um mecanismo de formação de arenas de ação e modos de gestão, em que indivíduos e instituições interagem no escopo das esferas públicas e privadas negociando assuntos de interesse comum. Ou ainda, regimes de poder baseados em interesses múltiplos, diversos e conflitantes, caracterizados pela presença de arranjos formais, informais e espontâneos. (COMMISION ON GLOBAL GOVERNANCE, 1995).

Rosenau (1995) destaca que a emergência do conceito de governança se deve essencialmente a um processo de reconfiguração de canais de regulação e gestão para além dos mecanismos tradicionais de governo. O autor enfatiza que os mecanismos de governança teriam potencial de promover uma realocação da autoridade central dos Estados e de seus mecanismos de comando e controle tradicionais. Para ele, o fenômeno estimularia num processo irreversível de reconfiguração de estruturas e processos políticos tradicionais por meio da emergência e da evolução de mecanismos de inovação social e tecnológica.

Melo (1996) também classifica a governança como novo modus operandi das políticas de gestão, a partir da ampliação da participação política e da incorporação de outros atores sociais nas funções tradicionais de governo. A governança estaria atrelada à emergência de novos arranjos político-institucionais, ao 
compartilhamento de poderes entre entes públicos e privados; e a redistribuição de competências entre Estado e sociedade. Esses novos arranjos implicariam simultaneamente na formação de espaços de participação solidários, mas também conflituosos, erigidos para a finalidade de encontrar soluções comuns para problemas de natureza diversa (COELHO E DINIZ, 1995).

Seguindo essa mesma linha de pensamento, Bøâs (1998) destaca que governança estaria baseada na aproximação entre Estado e sociedade, com a emergência de um novo domínio para ambos os setores. Para o autor, governança se sustentaria essencialmente sobre um novo civismo capaz de propulsionar a participação de novos atores sociais em assuntos de domínio público. Para ele, o processo definiria novos modos, formas e estruturas políticas para além do instituído pelo governo. Ele destaca que o processo de transformação envolveria, sobretudo, a incorporação de instituições informais e não-governamentais na esfera de assuntos e temas de domínio de interesse público.

Baseado em estudos sobre a gestão pública na Inglaterra conduzidos no final da década de 1990, Rhodes (1996) sustenta que a governança se refere a um conjunto de "novos processos de governo, baseados em auto-organização, redes de trabalho interorganizacionais e interdependentes, que promoveria uma autonomia em relação ao Estado" (p.2). Ele sustenta que essas redes de trabalho eliminariam sistematicamente a necessidade de gestão direta pelo Estado, reduzindo as estruturas de governo, a partir de mecanismos de ajustamento mútuos, confiança e reciprocidade, estabelecidos a partir da competição equilibrada e a lógica de mercado.

Slaughter (1997), entretanto, chama atenção para a banalização e a fé excessiva no processo de "governança sem governo". Para a autora é necessário cuidado ao entoar o mantra do fim do Estado-nação, e da transferência excessiva de poder a atores e instituições supra, para, enão-estatais. Ela acredita que uma nova ordem mundial permite que os governos se beneficiem da flexibilidade dos sistemas de governança, mas questiona a intensidade com que o Estado deve ser tolhido de seu protagonismo. Para Slaughter (1997), parte da problemática estaria na incapacidade de governos estabelecerem a ordem, realizarem a infraestrutura e delegar poderes a atores sociais adequados para assumir tais responsabilidades.

Esses debates discutem o posicionamento da governança enquanto exercício teórico na formação de novos desenhos político-institucionais. De maneira geral, os trabalhos se concentram nos desafios e oportunidades das novas relações, mecanismos e reconfigurações de poder emergentes a partir da perspectiva de implementação da governança. Tais perspectivas se reproduzem nas instituições supranacionais e organismos internacionais, como OECD, PNUD e Banco Mundial. 
Nesses casos, porém, a governança, é assumida como um procedimento normativo, apresentado por comum enfoque mecanicista que destaca a governança como um processo implementável a partir de mecanismos supostamente controláveis.

Estudos da governança enquanto fenômeno empírico, entretanto, como os feitos por Agrawal (2005), ainda têm natureza incipiente, sendo poucas as pesquisas em que são avaliados casos concretos de formas, processos e subjetividades propagados em sistemas de governança dos recursos. Ou seja, situações envolvendo diferentes configurações de participação e distribuição de papéis entre os atores estatais e não-estatais e os respectivos resultados frente à implementação desses arranjos político-institucionais. Além do enfoque conceitual e normativo, portanto, os sistemas de governança carecem de pesquisas que levem em consideração estudos temporais, espaciais e setoriais capazes de identificar os desafios de transição das formas tradicionais de governo para novas formas de governança (JORDAN ET AL. 2005 p.478).

1.5.1 Governança híbrida ou soft governance: entre a força dos governos centrais e a gestão compartilhada com atores não-estatais.

Como destacado anteriormente, sistemas de governança emergem a partir da perspectiva de relações ponderadas entre sociedade e governo, em proporções variadas de interação, modos e ordenamentos. De maneira geral, o processo de emergência da governança nas sociedades modernas implica necessariamente no desafio de formação e distribuição de poderes em novos arranjos sócio-políticos e institucionais. Estruturas capazes de agregar tanto atores públicos quanto privados na resolução de problemas conjuntos, e na consolidação de ambientes favoráveis para todos participantes e instituições envolvidas (KOOIMAN, 2000 e 2003).

Para Jordan et.al. (2005), sistemas de governança estão longe de substituir por completo as funções clássicas de governo, sendo eventualmente muito mais um processo que oscila entre a coexistência, fundição e a complementação com às estruturas tradicionais. O trabalho desse grupo de pesquisadores é de essencial importância, pois introduz uma ordem lógica no debate para identificar graus diferenciados entre sistemas de governança e de governo tradicional (Tabela 1). 


\begin{tabular}{c|c|c}
\hline & $\begin{array}{c}\text { governo determina os fins } \\
\text { (objetivos sociais) }\end{array}$ & $\begin{array}{c}\text { sociedade determina os fins } \\
\text { (objetivos sociais) }\end{array}$ \\
\hline $\begin{array}{c}\text { governo seleciona os } \\
\text { meios (políticas) }\end{array}$ & $\begin{array}{c}\text { governo forte } \\
\text { "big government" } \\
\text { (hierarquia central de controle) }\end{array}$ & $\begin{array}{c}\text { governança híbrida } \\
\text { "soft governance" }\end{array}$ \\
\hline $\begin{array}{c}\text { sociedade selecionaos } \\
\text { meios (políticas) }\end{array}$ & $\begin{array}{c}\text { governança híbrida } \\
\text { "soft governance" }\end{array}$ & $\begin{array}{c}\text { governança plena } \\
\text { (sociedade é auto-gerida e } \\
\text { auto-controlada) }\end{array}$ \\
\hline
\end{tabular}

Tabela 1 - Tipologia simplificada dos graus de interação entre governança e governo.

Fonte: adaptado de Jordan et al. (2005).

Segundo os autores, a governança plena aconteceria quando a sociedade consegue determinar tanto as finalidades quanto os meios de implementação de medidas, planos, políticas e regulações. Governo forte, ou big government, por outro lado, seria caracterizado pela determinação unilateral dos meios e fins unilateralmente pelo Estado. A governança híbrida, também conhecida como soft governance, seria aquela em que o Estado e a sociedade determinam de forma equilibradaos meios e as finalidades de políticas públicas e objetivos sociais. Esse padrão de governança estaria situado, portanto, no meio-termo entre a distribuição de forças, formulação de estratégias e pontos de comum acordo entre governo e atores não-governamentais (BRANNSTROM, 2012).

Os níveis distintos entre governo forte e governança se manifestariam de acordo com as diferentes jurisdições, programas, planos e políticas setoriais analisadas. Ou seja, a governança forte de um determinado setor não implicaria necessariamente na mesma configuração em outros setores. Adicionalmente, os instrumentos de novas políticas de governança requerem graus distintos de envolvimento do Estado. Poucos arranjos político-institucionais estão totalmente descolados da ação dos mecanismos de governo. Diante dessa característica, pesquisas interessadas em sistemas de governança devem explorar a complexidade nos quais atores estatais e não estatais interagem e interferem na regulação, formulação e execução de políticas públicas e de setores específicos (JORDAN ET.AL.,2005).

Numa linha de raciocínio semelhante, Lemos e Agrawal (2009), exploramo conceito de soft governancedentro da complexidade das possíveis relações estabelecidas entre Estado, sociedade e mercado em sistemas de governança. Para os autores existem diferentes configurações entre os papeis desempenhados pelos atores sociais e suas responsabilidades nos processos e funções de regulação e gestão de recursos (Figura 1). 


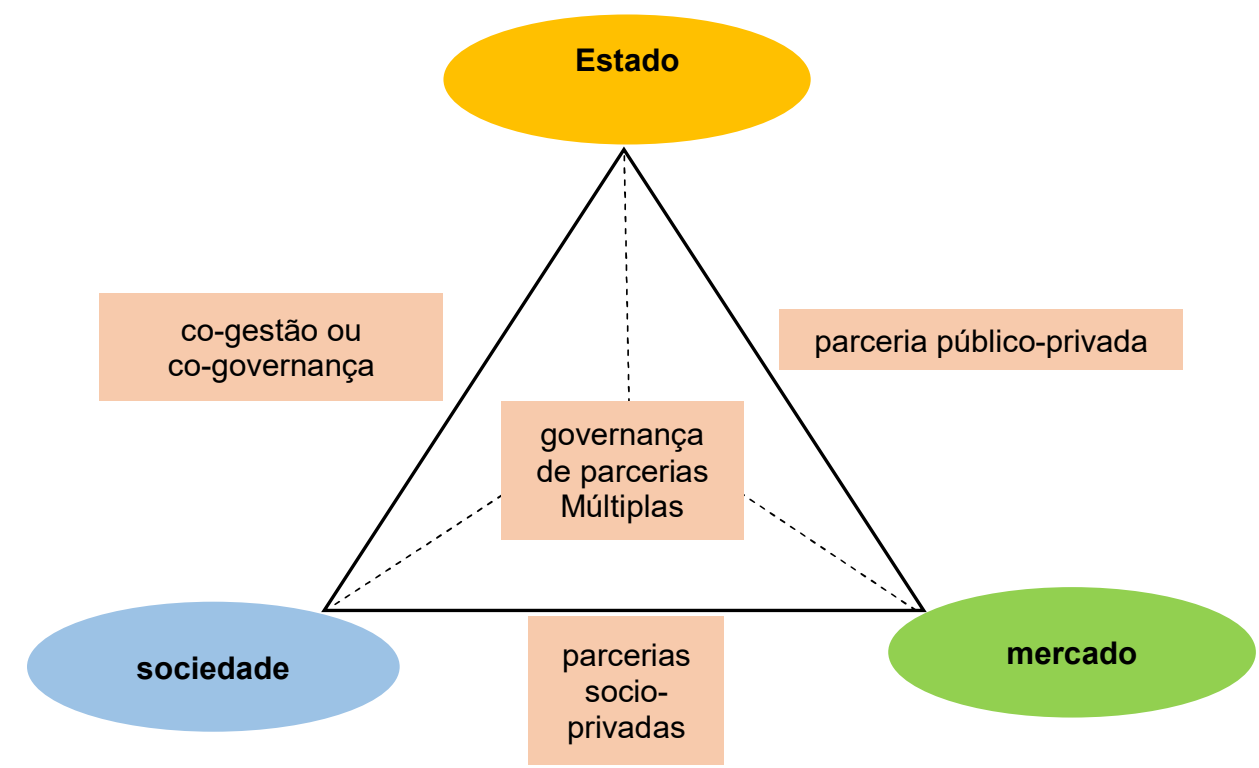

Figura 1 - Estrutura de relações de poderes entre Estado, Sociedade e Mercado a partir da perspectiva de governança híbrida ou Soft Governance.

Fonte: adaptado de Lemos \& Agrawal (2009).

Para eles, o compartilhamento de funções entre o Estado e a sociedade (i. e. comunidades locais, ONG's, associações, cooperativas) caracterizaria uma cogovernança ou cogestão. Arranjos semelhantes formados entre o Estado e o mercado (i. e. empresas, corporações, indústrias) resultariam nas parcerias público-privadas. A aproximação, por sua vez, entre sociedade e mercado seria responsável pela formação das parcerias sócio-privadas, chamadas por Cashore (2002) de nonstate market-driven (NSMD), ou governança não-estatal conduzida pelo mercado. A condição de parcerias múltiplas seria baseada na distribuição equitativa de funções e responsabilidades entre os três entes.

Esse conjunto de configurações dos mecanismos e desenhos de governança carregaria consigo perspectivas de promoção de inovações sociais nas relações de poder e gestão, especialmente, pela expansão do processo de cooperação entre atores sociais previamente excluídos do processo político, como movimentos sociais e organizações não-governamentais (HAAS, 2004). Os autores destacam, entretanto, que o sucesso dessas configurações depende essencialmente da qualidade dos sistemas de governança. Ou seja, dacapacidade dos atores sociais e instituições de superar problemas de dissonâncias no nível de participação política e coordenação de ações, bem como, de superar barreiras impostas pelas assimetrias de poder e confiança mútua (LEMOS E AGRAWAL, 2009). 


\subsubsection{Os princípios da boa governança}

O estímulo à implementação de sistemas de governança tem se tornado cada vez mais comum no processo de formulação de políticas setoriais na implementação de mecanismos de desenvolvimento. A propagação dessas estruturas trouxe, entretanto, dúvidas quanto à eficácia dos critérios e parâmetros pelos quais têm sido implementadas, tornando a avaliação dos arranjos político-institucionais correlacionados à governança fundamentais para preencher a lacuna entre a teoria e a prática da efetividade de projetos, planos e leis que envolvam tais configurações (FONSECA E BURSTYN, 2009).

A governança implica a redistribuição da tomada de decisões e de processo imparciais e neutros entre os poderes envolvidos, sem necessariamente ampliar o grau de justiça e a repartição de benefícios. A inclusão de novos atores pode conduzir a assimetrias no processo, com favorecimento de uns em detrimento de outros, beneficiando mais alguns grupos do que outros segmentos da sociedade. Diante disso, o conceito boa governança emerge e se difunde na literatura acadêmica (BURSZTYN, 2008).

A perspectiva da chamada boa governança parte do atendimento de padrões e parâmetros mínimos de formas, processos e mecanismos de implementação. Práticas de natureza humana, política, comportamentais e institucionais que em conjunto assegurem a existência de condições básicas necessárias para que sistemas de governança alcancem seus objetivos. Ou seja, de arranjos equilibrados de poderes entre a miríade de novos atores e instituições componentes (DOBSON, 2000).

De forma muito abrangente, órgãos de governo, corporações, agências internacionais e organismos supranacionais começaram a incorporar como elementos basilares da boa governança, princípios correlacionados à legitimidade, ao pluralismo político, e ao incentivo à participação da sociedade civil. A incorporação desses elementos, por sua essência, teria a capacidade de estimular a representatividade e voz ativa dos atores sociais edificando formas transparentes e equânimes nas estruturas de governança que vem sendo moldadas.

Os trabalhos intitulados de 'Sustainable Human Development and Governance', UNDP and Governance: Experiences and Lessons Learned; e 'Decentralization a sampling of definitions'do Programa das Nações Unidas para o Desenvolvimento (UNDP, 1997, 1999a, 1999b), são bons exemplos de relatórios que apresentamos atributos considerados básicos para a boa governança. Esses 
documentos sintetizam uma série de atributos entendidos na esfera internacional como princípios basilares na classificação de bons sistemas de governança:

- O princípio da descentralização

A descentralização é entendida como um atributo-chave na qualidade e eficácia dos sistemas de governança. O processo refere-se à capacidade de reestruturação ou reorganização das formas de regulação e gestão frente a autoridade tradicional de governos centrais. Pela descentralização seria possível desenvolver processos de co-responsabilidade, e delegação de poderes para as instituições, governos regionais, e locais. Na teoria, ela promoveria a maior oportunidade de participação política de atores e comunidades locais e maior legitimidade de suas decisões econômicas, sociais, e ambientais.

O atributo está interligado à ideia de devolução (devolution), ou restituição da autonomia e do desenvolvimento endógeno para governos locais, da passagem do big government para small government, e do estabelecimento de padrões híbridos de governança ou soft governance. Características compatíveis com a existência de autoridades centrais, mas que atuariam de forma conjunta na tomada de decisões sobre áreas/leis específicas, distribuindo maior competênciaaos atores locais.

Por meio da delegação de poder e autonomia as instâncias comunitárias locais por via da descentralização, tais sistemas de governança permitiriam aos cidadãos maior grau de acesso e influência junto às arenas políticas e às instituições responsáveis na deliberação de planos, projetos e serviços. Na teoria esse layout representaria o rompimento de deliberações unilaterais tradicionais, do tipo top-down, ou de cima para baixo, em que as decisões políticas são derivadas unicamente de esferas superiores de poder.

Pelo princípio de descentralização, portanto, arenas e espaços políticos de regulação e gestão seriam sujeitos igualmente às decisões do tipo bottom-up, ou de baixo para cima, em que as comunidades e governos locais estabelecidos na esfera de condados, municípios, territórios e regiões teriam maior voz ativa e participação política nas deliberações de gestão pública.

- O princípio da participação:

O quesito de'participação' é talvez um dos elementos de maior destaque para a qualidade e eficácia dos sistemas de governança. A participação de 
todos atores sociais nas arenas de ação política pressupõe uma característica democrática do processo, seja exercida diretamente pelos indivíduos, seja por meio de suas representações coletivas ou instituições oficiais. A participação carregaria em si o atributo elementar de estimular o nível de representatividade dos atores sociais e dar voz ativa aos participantes.

O critério de participação seria estimulado pela existência de escrutínios formais e espaços de tomada de decisões, sobretudo, os estabelecidos pela descentralização de poderes e atributos em favor de atores na escala local; voltados a agregar atores diretamente interessados e afetados. Frente a essa perspectiva, a participação está ligada à existência e ao acesso de atores sociais dos mais diversos setores da sociedade aos conselhos, comitês e audiências públicas em que idealmente todos possam exercer a livre associação, discurso, e capacidade de colaboração.

Para Teixeira (2002), a participação consiste na elaboração e formulação de diagnósticos conjuntos entre os principais atores envolvidos nos sistemas de governança, identificando obstáculos e potencialidades em diferentes setores da regulação pública. A participação envolve, portanto, o debate e a mobilização da sociedade civil, sobretudo, para a tomada de decisões e definições, entre outros aspectos, em torno das alternativas ao processo de desenvolvimento, da implementação de medidas específicas e da deliberação sobre políticas públicas.

- O princípio da cooperação:

A cooperação entre atores sociais e instituições é outro elemento crucial na edificação de bons sistemas de governança. Diferente da participação em escrutínios pontuais a cooperação é um processo contínuo de colaboração entre atores sociais. A cooperação seria um mecanismo social essencial para o objetivo de consolidar uma ação coletiva, em um processo continuamente construído (RING E VAN DE VEM, 1994).

Suas formas e mecanismos, bem como, a qualidade da coordenação entre os atores sociais, têm o potencial de ditar a emergência de processos de colaboração e cooperação, mas igualmente de competição e concorrência. Por esse pressuposto a cooperação vai além de conselhos e audiências. E está ligada ao desenvolvimento de parcerias contínuas, de ações conjuntas e permanentes entre as partes interessadas, como por exemplo,a gestão e exploração de recursos energéticos e de recursos naturais. A cooperação se alimentaria simultaneamente, pelo nível de qualidade, entre outros, pelo nível de concertação entre as políticas públicas federais, 
estaduais e locais; e pela qualidade das parcerias sócio-privadas,público-privadas e de co-gestão.

- O princípio da responsabilização:

O princípio da responsabilização, por sua vez, estaria ligado à qualidade e clareza dos critérios de normas e penalidades aos atores sociais e as instituições participantes nos sistemas de governança. Ou seja, a clara atribuição de códigos e responsabilidades; frente às decisões e ações tomadas no escopo desses arranjos político-institucionais. A responsabilização está ligada diretamente à qualidade dos trâmites políticos, administrativos e financeiros da governança, pois reflete a responsabilidade legal dos atores, por exemplo, na precaução durante o processo de regulação na exploração e uso dos recursos naturais; no controle e ordenamento necessário do uso do território e a responsabilidade dos atores e instituições frente à conservação do meio natural e biofísico.

- O princípio da transparência:

Um dos principais aspectos na qualidade dos sistemas de governança estaria conectado ao critério de 'transparência'. Ou seja, a disponibilidade de acesso às informações e aos dados no escopo dos arranjos político-institucionais de governança. O princípio diz respeito à capacidade de manuseio das informações pertinentes no escopo de processos e trâmites políticos em curso, bem como, de detalhes administrativos, produtivos e gerenciais. Conforme destacam Bursztyn e Bursztyn (2012), sistemas de governança considerados de boa qualidade normalmente dispõem de canais de comunicação rápidos, claros e de fácil acesso aos atores e operadores participantes. A transparência é fundamental na condução de projetos, diretrizes e estratégias; na identificação das fontes de recursos; orçamento; mobilização dos meios disponíveis e mapeamento de gargalos, desvios, mas também potencialidades e oportunidades de aprimoramento (TEIXEIRA, 2002).

- O princípio da equidade:

A 'equidade' é considerada um elemento fundamental ao desenvolvimento da boa governança. Para o PNUD, a equidade se manifesta a partir da paridade política dos atores na implementação de processos regulatórios e deliberativos. Também está refletida, por exemplo, na igualdade política frente à 
decisão quanto à aplicação das receitas e taxas derivadas na gestão e exploração de setores e atividades econômicas específicas. Está ligada à paridade nas oportunidades de ganhos e direitos, e à imparcialidade do tratamento aos diferentes gêneros, culturas ou credos envolvidos (UNDP, 1997, 1999a, 1999b).

- O princípio depertencimento:

O princípio de pertencimento é considerado um elemento de grande pertinência para a qualificação dos sistemas de governança. O princípio diz respeito ao grau de projeção, interesse e envolvimento dos atores sociais frente às estruturas $e$ processos de governança. A ausência dessas características, ou o baixo grau de ownership tem o potencialde fragilizar, ou mesmo inviabilizar ações conjuntas, parcerias e estratégias de governança.

Como destacam Bursztyn \& Bursztyn (2012), a ausência de pertencimento de atores locais pode condenar projetos, planos e programas a uma existência limitada e a vigência de seus instrumentos aos apoios externos. Em geral, o baixo nível de pertencimento estaria atrelado a medidas implementadas de cima-parabaixo (top-down) realçando a percepção dos atores locais como iniciativas contrárias, dissonantes, ou mesmo irrelevantes as suas vontades e interesses.

- O princípio do empoderamento:

O princípio do empoderamento diz respeito à capacidade dos sistemas de governança de promover mecanismos de inovação social e diversificação produtiva capazes de desencadear processos políticos e sociais que permitam a inclusão e a capacitação de grupos sociais considerados mais frágeis e vulneráveis. $O$ empoderamento está ligado à capacidade de ampliar poderes políticos de segmentos sociais mais vulneráveis e de lhes oferecer novos meios políticos e usos culturais e econômicos sobre seu território (BECKER, 1993).

É ligado à perspectiva de aumentar o poder de segmentos socias desprivilegiados aumentando sua capacidade efetiva de negociar e pleitear reivindicações. Estratégias capazes de gerar alternativas a imposição da lógica exclusiva das forças de mercado e da preponderância dos grupos de interesse hegemônicos no estabelecimento das "regras do jogo". (MOULAERT ET. AL., 2005, 2006; SWYNGEDOUW, 2005 p.1).

Vale ressaltar, dentro dos sistemas de qualificação da governança, o conceito de good enough governance, ou governança suficientemente boa (GRINDLE 
2004). A ideia surge da crítica à necessidade do alcance máximo dos princípios da boa governança como condição obrigatória para o processo de desenvolvimento. Para a autora, a edificação e capacitação das instituições responsáveis por sistemas de governança demandam tempo e amadurecimento que variam de acordo com o país, região ou território em que o processo está sendo implementado. Diante disso, ela sugere que é necessário estabelecer padrões razoáveis na definição de agendas políticas destinadas a alcançar a plenitude dos atributos de boa governança.

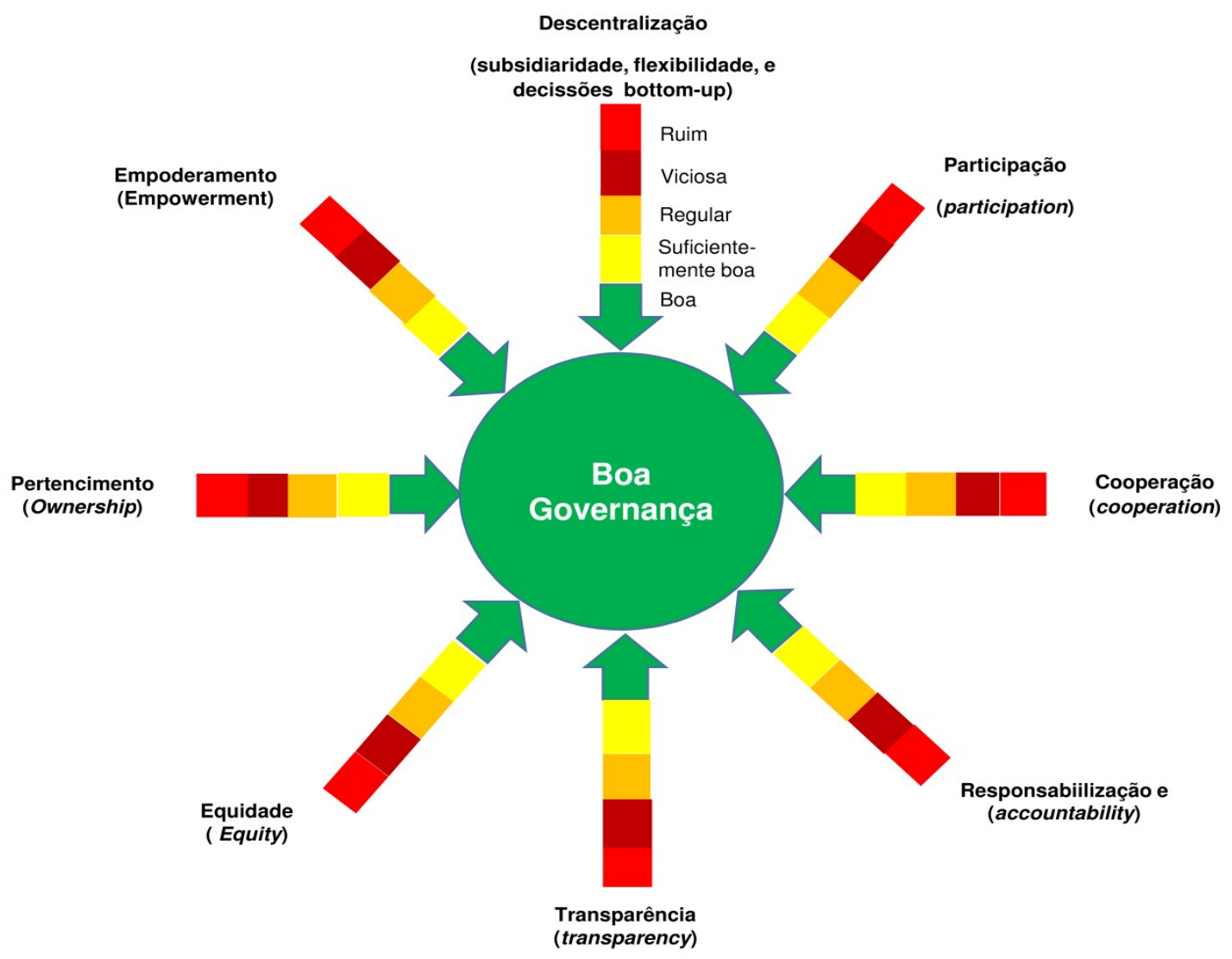

Figura 2 - Princípios, ou atributos elementares da boa governança.Fonte: elaborado pelo autor a partir dos princípios estabelecidos pela UNDP (1997, 1999a, 1999b).

A análise de variações qualitativas de governança, entre boa, suficientemente boa, ruim (má), ou viciosa, é particularmente pertinente por que a natureza dos arranjos político-institucionais de governança eventualmente apresentam aspectos contraditórios em relação aos objetivos para os quais são implementadas. Em muitos casos esses sistemas se desenvolvem como mecanismos de legitimação e ampliação espúrios da influência de determinados setores ou grupos, trazendo tensões e desvios das diretrizes originais de aumentar a democracia participativa e o empoderamento dos cidadãos. Nessas circunstâncias, se estabelecem 'más' 
governanças caracterizadas por deficiências e desvios nos processos participativos, revestidas de um caráter antidemocrático e autoritário (SWYNGEDOUW, 1996, 2000).

Não raramente, entretanto, slogans, retóricas e dicursos de participação e descentralização na regulação e gestão de atividades econômicas e produtivas têm sido utilizados por governos centrais como um dispositivo retórico para fortalecer seu poder e atender interesses de grupos econômicos dominantes (OSMANI, 2000). Nesses casos, fenômenos de personalização, e re-concentraçãode poder de grupos de interesses desvirtuam os objetivos da governança e desenvolvem um ciclo vicioso entre ação de "velhos expedientes de manipulação" e o fortalecimento do clientelismo pelas elites locais (BURSZTYN \& BURSZTYN, 2012 p.153). Sob essa condição, uma "governança viciosa" edificaria ambientes conflituosos e revelaria contradições e choques de interesses entre atores sociais participantes.

\subsection{Governança ambiental ou governança dos recursos}

Como visto nas seções anteriores, uma característica do final do século XX é a emergênciada governança como processode (des) regulação de funções tradicionais do Estado envolvendo sociedade e mercado na gestão de políticas e assuntos públicos. Um fenômeno político que surge interligado à proposta de gerir e utilizar diferentes tipos de recursos humanos, financeiros, corporativos, e naturais. Uma nova perspectiva de consolidar layouts e ações conjuntas inéditas entre organizações, instituições, e diferentes escalas degoverno (LEMOS E AGRAWAL, 2006). A governança ambiental, ou governança dos recursos, emerge a partir dessa mesma concepção, como um importante mecanismo de mediação de poderes e relações formais, informais, códigos e comportamentos entre os atores sociais no processo de regulação e uso de bens naturais (BRIDGE \& PERREAULT, 2009).

Sem sombra de dúvida, um dos principais propulsores de estudos de governança ambiental foi a obra "Tragedyof the Commons"(HARDIN, 1968), escrita pelo ecólogo Garret Hardin. Pela teoria de Hardin, o livre acesso aos bens naturais comuns os levaria inexoravelmente a uma superexploração e ao exaurimento. A teoria, entretanto foi questionada por "Governning the Commons" de Ostrom (1990), que realçou asdiferentes capacidades de atores sociais e instituições em formar "autogovernos" (p.6) capazes de romper com essa lógica predatória e estabelecer formas equilibradas e duradouras na exploraçãoe uso de recursos naturais. A partir da perspectiva de Ostrom (1990), portanto, emerge a ideia basilar da governança ambiental como arranjo propulsor para o manejo ou a ação coletiva dos recursos 
naturais, em que a participação e cooperação são elementos fundamentais (MEHTA ET. AL. 2001).

A mesma linha de raciocínio passa a conduzir uma série de outros trabalhos seminais da área, como os de Bridge \& Jones (2002) no qual a ideia central é a necessidade da re-criação de formas de coordenação política sob o controle, exploração e uso de recursos naturais. Para esses autores, por exemplo, a negligência na gestão compartilhada de recursos naturais como água, minérios, e madeira, estaria se tornando o grande desafio para o século XXI. Diante disso, consideram essencial a implementação de eixos de negociação e gestão compartilhada com as indústrias do setor primário como crucial para evitar potenciais conflitos e choques entre atores sociais inseridos nos territórios ou impactados pelas atividades de extração e produção.

A governança dos recursos emerge, portanto, como um campo de expectativa de ampliação da participação política e poderes da sociedade civil, especialmente, pela perspectiva de expansão da democracia representativa. $O$ processo traz em seu bojo o intuito de estimular audiências públicas e a perspectiva de aumentar a participação política, ao promover maior descentralização, peso e responsabilidade da população na regulação e gestão de recursos naturais. A partir da reorientação de instituições, de novas regras e normas consitucionais são desenhadas políticas para promover a garantia e o bem-estar socioambiental. Dentro de um novo layout capaz de (re)definir práticas, competências, e desenhos político-insitucionais, bem como, atenuar conflitos, promover a cooperação e estimular a açãocoletiva (YOUNG, 1994, p.15).

Como destacado por Bursztyn e Bursztyn (2012), por se tratar essencialmente da gestão de bens coletivos, especificamente de ativos ambientais, a emergência da governança dos recursos lida com a dificuldade de mediação e compatibilização entre diferentes e antagônicos interesses. Por essa razão, leis, programas e planos atrelados à consolidação da governança dos recursos passam a se consolidar como verdadeiras "pedras angulares" (p.155) na emergência de novas estruturas político-institucionais de regulação pública. Diante disso, os autores frisam a dificuldade do amadurecimento de processos equilibrados e isentos, nos quais víciosde implementação e gestão se tornam relativamente comuns. Isso ocorre por que as políticas e estruturas de regulação e exploração de recursos naturais trazem consigo o desafio de incorporar atores de interesses heterogêneos e poderes assimétricos, tendo que cumprir simultaneamente como atendimento de critérios de justiça ambiental, interesse público eo respeito aos direitos das gerações futuras (BURSZTYN, 2008). 
Vale destacar que a perspectiva da governança dos recursos emergiu sob circunstâncias políticas, econômicas e sociais bastante complexas durante a virada do século. O contexto histórico-político trouxe elementos complexos que desafiam o desenvolvimento da governança ambiental por causa da eclosão e ressurgimento de movimentos sociais e populares, do ativismo ambiental, da emergência das organizações não-governamentais, mas, sobretudo, da crescente influência do mercado sobre o vácuo deixado pelo esvaziamento da força do Estado provocado pela maré desestatizante do neoliberalismo. O desafio à governança dos recursos se estabelece, portanto, de subtraí-la da sua dimensão instrumental, e tornála factível frente à participação ampliada e envolvimento e cooperação consensual de todas as partes interessadas (JACOBI \& SINISGALLI, 2012).

A partir daí, os estudos dos desafios à implementação da governança ambiental, ou da governança dos recursos, se desenvolvem tendo por base pelo menos seis de diferentes correntes, posturas analíticas e áreas de conhecimento. (Tabela 2). Quase todas as linhas de pesquisa, seus autores e escolas consideram a governança dos recursos como um processo repleto de percalços e desvios. Para alguns, por exemplo, o principal desafio está na implementação de novas regulações e negociações políticas diante dos obstáculos criados pelas diferentes jurisdições e escalas de governo. Para outros, a dificuldade está napromoção de mecanismos de governança ambiental inter-regional ou internacional.

\begin{tabular}{|c|c|c|c|c|c|c|}
\hline & $\begin{array}{l}\text { Escala e } \\
\text { Reescala }\end{array}$ & $\begin{array}{l}\text { Coordenação } \\
\text { de cadeias de } \\
\text { commodities }\end{array}$ & $\begin{array}{c}\text { Ação } \\
\text { coletiva } \\
\text { para manejo } \\
\text { de recursos }\end{array}$ & $\begin{array}{l}\text { Participação } \\
\text { Política }\end{array}$ & $\begin{array}{l}\text { (Des)Regu- } \\
\text { lação do } \\
\text { Estado }\end{array}$ & $\begin{array}{c}\text { Regras e } \\
\text { ordenamento } \\
\text { (sócio- } \\
\text { natural) }\end{array}$ \\
\hline $\begin{array}{l}\text { Postura } \\
\text { Analítica }\end{array}$ & $\begin{array}{l}\text { Swyngedouw } \\
\text { (2000); } \\
\text { McCarthy } \\
\text { (2005), } \\
\text { Perreault } \\
\text { (2005) }\end{array}$ & $\begin{array}{l}\text { Mutersbaugh } \\
\text { et. al. (2005) } \\
\text { Taylor (2005) }\end{array}$ & $\begin{array}{l}\text { Ostrom } \\
(1990)\end{array}$ & $\begin{array}{c}\text { Keil and } \\
\text { Desfor } \\
(2003), \\
\text { Backstrand } \\
\text { (2004), } \\
\text { Swyngedou } \\
\text { w (2007) }\end{array}$ & $\begin{array}{c}\text { Bridge } \\
(2000), \\
\text { Bakker } \\
(2003), \\
\text { Whitehead } \\
\text { et.al.(2007) }\end{array}$ & $\begin{array}{l}\text { Darier (1996), } \\
\text { Watts (2003), } \\
\text { Dalby (2004) }\end{array}$ \\
\hline $\begin{array}{c}\text { Postura } \\
\text { Normativa ou } \\
\text { Descritiva }\end{array}$ & $\begin{array}{c}\text { Utto (1997), } \\
\text { Borgese (1999) }\end{array}$ & $\begin{array}{c}\text { Global } \\
\text { Witness } \\
\text { (1998), Bass } \\
\text { et.al.(2001) }\end{array}$ & $\begin{array}{c}\text { Young } \\
(1994), \\
\text { Buck (1998) }\end{array}$ & $\begin{array}{l}\text { Wapner } \\
\text { (1995), } \\
\text { Palmer } \\
(2006)\end{array}$ & $\begin{array}{c}\text { Mol and } \\
\text { Sonnenfeld } \\
(2000), \\
\text { Fischhendle } \\
r \\
(2006)\end{array}$ & Luke (1999) \\
\hline $\begin{array}{c}\text { Área de } \\
\text { conhecimento, } \\
\text { Tradição } \\
\text { intelectual e } \\
\text { antecedentes } \\
\text { históricos }\end{array}$ & $\begin{array}{c}\text { Geografia } \\
\text { Político- } \\
\text { econômica: } \\
\text { Desenvolvimen } \\
\text { to } \\
\text { desigual } \\
\end{array}$ & $\begin{array}{l}\text { Economia } \\
\text { Política: } \\
\text { Teoria da } \\
\text { Dependência }\end{array}$ & $\begin{array}{l}\text { Antropologia, } \\
\text { Relações } \\
\text { Internacionai } \\
\text { s }\end{array}$ & $\begin{array}{l}\text { Ciência } \\
\text { Política: } \\
\text { Teoria } \\
\text { Crítica } \\
\text { Social }\end{array}$ & $\begin{array}{c}\text { Economia } \\
\text { Institucional, } \\
\text { Economia e } \\
\text { Sociologia: } \\
\text { Teoria da } \\
\text { Regulação }\end{array}$ & $\begin{array}{l}\text { Governamen- } \\
\text { tabilidade, } \\
\text { Estudos Pós- } \\
\text { coloniais: } \\
\text { Teorias de } \\
\text { Império }\end{array}$ \\
\hline
\end{tabular}

Tabela 2 - Seis abordagens ou enfoques de análise da Governança Ambiental.

Fonte: Adaptado de Bridge e Perreault (2009). 
Outras pesquisas concentram-se na análise da coordenação de papéis e distribuição de poderes entre atores socias ao longo de cadeias de produção de commodities. Há também aqueles que seguem como elemento central a abordagem de Ostrom (1990) que define a governança como mecanismo de ação coletiva de recursos naturais. Uma análise focada no papel desempenhado pelas relações formais, informais, convenções, códigos e comportamentos dos atores sociais no uso de recursos naturais comuns.

Algumas correntes sugerem que estruturas e discursos em governança dos recursos estariam eventualmente subordinados ao processo de 'commodificação' da natureza e de legitimação do processo de acumulação. Características que estariam desencadeando novos desafios aos mecanismos, ações, relações de poder e regras de ordenamento, oferecendo tanto oportunidades de maior participação política eexpansão da democracia representativa, quanto ao aumento da esfera de interesse de atores do mercado e de sua influência e capacidade real de controle dos recursos naturais no contexto de esvaziamento das competências prévias do Estado (BRIDGE E PERREAULT, 2009).

Essencialmente, a regulação e gestão de recursos energéticos não se enquadram na categoria de governança dos recursos naturais, ou governança ambiental. Entrentanto, os enfoques estabelecidos por seus autores trazem as linhas basilares quanto ao desafio do estabelecimento de novas regras, da coordenação de papéis e do balanço de poderes entre atores sociais participantes. Ou seja, da abordagem e análise necessária da governança enquanto estrutura e processos de interações e interdependências, e ao mesmo tempo, palco de discursos legitimadores. Linhas basilares que norteiam a presente tese. 
1.7 Governo, governabilidade, governamentalidade, ecogovernamentalidade e governança (ambiental): uma síntese dos conceitos

Os conceitos de governo, governabilidade, governamentalidade, ecogovernamentalidade e governança embora de naturezas próximas e complementares, têm significados próprios e interpretações distintas. Diante disso, é importante diferenciá-los para esclarecer fronteiras entre suas concepções e alcances teóricos. (Tabela 03). Governo, por exemplo, é convencionalmente entendido como o aparato formal do Estado dedicado à tomada e à produção das decisões distribuídas pelas diferentes escalas nacional, estadual e municipal (LEMOS E AGRAWAL, 2009).

Governabilidade, de forma distinta, são habilidades legais que o governo lança mão para promover ações e medidas necessárias à instauração e efetividade de suas políticas e interesses. Também se dá nas "condições de autosustentação do governo no exercício de sua autoridade, nos quais atuam de forma mais incisiva fatores macroestruturais e políticos" (CAVALCANTI, 2001: p.1). Está ligada, portanto, às condições imperativas do exercício do poder, distribuídas nas relações entre executivo, legislativo e judiciário, no balanceamento de forças entre partidos políticos aliados e de oposição, e na capacidade de praticar políticas, planos e programas na esfera dos entes e agentes públicos.

Governamentalidade, por sua vez, é a governamentalização do Estado a partir da incorporação de racionalidades, técnicas e estratégias de gestão para formação da ordem política, econômica e social. Essa concepção parte da consciência, capacidade e interesse do governo em articular diferentes interesses, atores sociais e instituições ou para gerir e administrar determinados setores e políticas específicas (DINIZ, 1996). Isso se baseia na definição e redefinição de instâncias, incumbências e competências do estado. Extrapola a esfera pública por adotar novos formatos institucionais e relações de poder entre sociedade, estado e mercado na tomada de decisões e processo de gestão.

A governança, por sua vez, é um conceito que parte da incorporação de novos atores e instituições para aprimorar práticas de governo e sua governabilidade. Parte da implementação e coordenação de políticas, medidas, planos e projetos em conjunto aos mais variados setores da sociedade. Vale destacar, que a governança está essencialmente ligada à possibilidade da emergência de conflitos e choques de vários interesses, objetivos e subjetividades dos atores sociais participantes no processo de formação desse campo de ação política. 


\begin{tabular}{|c|c|}
\hline Conceito & Descrição \\
\hline Governo & $\begin{array}{l}\text {-grupo que administra a máquina estatal, que } \\
\text { administra a burocracia do estado e controla o } \\
\text { patrimônio público; } \\
\text {-Campo de ação que controla a interação dos } \\
\text { indivíduos, grupos e sociedade; }\end{array}$ \\
\hline Governabilidade & $\begin{array}{l}\text {-qualidade e fluxo da relação entre os poderes } \\
\text { (legislativo, excecutivo e judiciario); } \\
\text {-Articulação política entre aliados e adversários; } \\
\text {-capacidadede "implementação e coordenação } \\
\text { das políticas", medidas, planos e projetos; }\end{array}$ \\
\hline Governamentalidade & $\begin{array}{l}\text {-governamentalização do Estado com técnicas, } \\
\text { estratégias e estruturas de governo para } \\
\text { formação da ordem econômica e política; } \\
\text {-definição e redefinição de instâncias, } \\
\text { incumbências e competências do estado; } \\
\text {-mecanismos de regulação, segurança, } \\
\text { doutrinação e instrumentos de controle da } \\
\text { população e de meio sócio-natural; Biopoder e } \\
\text { panoptico social; }\end{array}$ \\
\hline Eco-governamentalidade & $\begin{array}{l}\text {-governamentalização e apropriação do conceito } \\
\text { de natureza como mecanismo de poder; } \\
\text {-regime de ordenamentos e subjetividades } \\
\text { apropriadas para garantir a lógica de apropriação } \\
\text { dos recursos naturais; } \\
\text {-meio-ambiente é sujeito de discursos de } \\
\text { equilíbrio e racionalidade; geopoder e panóptico } \\
\text { ambiental; }\end{array}$ \\
\hline Governança & $\begin{array}{l}\text {-capacidade de articular diferentes atores sociais } \\
\text { e instituições nas estruturas e relações de poder; } \\
\text {-nova racionalidade instrumental frente aos } \\
\text { mecanismos de coordenação de governo; } \\
\text {-incorporação de instituições informais e não- } \\
\text { governamentais à esfera de assuntos e temas de } \\
\text { domínio de interesse público; }\end{array}$ \\
\hline Governança ambiental ou dos recursos & $\begin{array}{l}\text { - mecanismo de mediação de poderes e relações } \\
\text { formais, informais, convenções, códigos e } \\
\text { comportamentos entre os atores sociais na } \\
\text { regulação, exploração e gestão de recursos } \\
\text { naturais; }\end{array}$ \\
\hline
\end{tabular}

Tabela 03- Síntese dos conceitos de estruturação e gestão de poder.

Fonte: elaborado pelo autor. 
Governamentalidade e governança, portanto, converge num layout de nova racionalidade instrumental $\mathrm{e}$, sobretudo, por meio de novos mecanismos de coordenação baseados na reconfiguração do modelo centralizador de Estado-nação, pelos desafios emergentes na agenda política e governança doméstica e internacional, alcançando no século XXI as questões ambientais (CAVALCANTI, 2001).

A ideia de governamentalidade está embasada na emergência de mecanismos de regulação, segurança, e doutrinação dotados de instrumentos de controle da população, bem como, de seu meio sócio-natural. É esse justamente o ponto de convergência com a eco-governamentalidade e governança ambiental. Ambos emergem de princípios análogos, porém, interligados cada qual a noção de governamentalização e apropriação do conceito de natureza e meio-ambiente.

A eco-governamentalidade e a governança dos recursos emergem, portanto, como novos mecanismos de relações de poder, bem como, de novos elementos para a formação de subjetividades, estratégias de disputas no processo de controle e uso dos recursos naturais. Partem de regimes de ordenamentos, discursos, lógicas e subjetividades que podem servir tanto ao desenvolvimento da ação coletiva dos recursos, quanto a racionalidades distorcidas na apropriação dos recursos naturais e acumulação capitalista. Um fenômeno atrelado a diversidade de arenas e espaços políticos específicos, atores, instituições e interesses distintos. 


\section{PAISAGENS ENERGÉTICAS, GOVERNANÇA E ECO- GOVERNAMENTALIDADE DE RECURSOS ENERGÉTICOS SOB ESCOPO DA ANÁLISE INSTITUCIONALISTA DE ELINOR OSTROM.}

Parte I - As paisagens energéticas: um campo disciplinar emergente

\subsection{Olhando para as paisagens por meio das lentes da energia}

Olhar a produção de energia por meio das lentes da paisagem é um caminho para revisitar os possíveis impactos provocados pelo uso dos recursos energéticos e compreender como suas distintas naturezas e materialidades podem se torná-las multidimensionais e correlacionais. Diante disso o estudo das paisagens energéticas é um campo emergente na análise de correlação entre o tripé energiaambiente-sociedade, e um lócus essencial para a avaliação de sistemas de governança de recursos energéticos.

Tal convicção leva pesquisadores a adotar a análise de paisagens sob o enfoque da energia, ao delimitar e estudar diferentes territórios e suas respectivas paisagens, tal como: as hidro-energéticas (MITCHELL, 2007; OWEN, 2006; UREÑA \& OLLERO, 2001), as de linhas de transmissão (NAVRUD ET AL, 2008)as petrolíferas e as paisagens de produção de energias renováveis (JANSSEN \& KNIPPENBERG, 2008). Em comum esses estudos têm o foco na tensão entre exploração dos recursos energéticos, a proteção do meio-ambiente e, sobretudo, o papel da participação da sociedade nos processos de planejamento e gestão (COLLIER \& SCOTT, 2008; JONES, 2007).

O aumento do uso dos biocombustíveis e dos hidrocarbonetos nãoconvencionais, por exemplo, não pode ser entendidos sem a consideração de como são as materialidades desses recursos energéticos, como se desenvolvem suas cadeias produtivas e os papeis de seus atores. Aspectos revelados pelos processos político-institucionais, produtivos, mas igualmente influenciados pelos discursos sobre a correlação ecologia, agricultura e desenvolvimento (NADAI \& HORST, 2010).

Vale ressaltar que embora a maior parte dos trabalhos na área foi feita há pouco tempo, a atenção para as intersecções, e conexões, entre a paisagem e o desenvolvimento energético contribui para formulação de novos debates, bem como, para propostas de ferramentas analíticas inéditas e resultados singulares. A exploração interdisciplinar da questão tem revelado novas facetas e a riqueza da correlação. Desde 2008, por exemplo, grupos de acadêmicos incluindo geógrafos, planejadores, cientistas políticos, urbanistas, antropólogos, sociólogos e ecologistas da paisagem de diferentes países vêm estudando a fertilização cruzada entre as 
políticas orientadas para a pesquisa e desenvolvimento de fontes de energias e os estudos teóricos e empíricos no processo de formação e desenvolvimento da paisagem.

Dentre eles, se destacam a equipe liderada por Alain Nadai do Centre International de Recherche sur L'Environement et le Développment (CIRED), da França, e a equipe de Dan van der Horst da University of Birmingham. De forma semelhante, acadêmicos reunidos pela Harvard University dedicaram uma edição completa do periódico New Geographies ao tema de paisagens energéticas, na qual discutem como a extração, produção e distribuição de energia têm papel fundamental na organização do espaço, sobretudo, na dinâmica territorial. No cerne da questão, está um núcleo de escritores, e pensadores, inspirados na "construção social da energia" sugerida por Ivan Ilich ([1983] 2009), que interpretam a energia como um agente e ao mesmo tempo um produto da organização socio-espacial.

Os enfoques baseiam-se, portanto, na exploração dos recursos energéticos como instrumentos poderosos de ação e modificação do meio natural e humano. Isso porque promovem a intensificação das atividades humanas e de práticas que atraem volumosos investimentos e vultosos retornos econômicos, e implicam em processos político-produtivos que normalmente são fonte de transformações sem precedentes na paisagem e na sociedade. Essa perspecitva faz com que novos enfoques sejam observados nos usos, serviços e subjetividades nas áreas de produção de energia e dos reflexos sobre a paisagem e a natureza, reflexos que não costumavam ser observados (NADAI \& HORST, 2010).

A partir desse enfoque, aspectos contraditórios, ou trade-offs, se tornaram explícitos diante das mudanças e/ou intensificações no mix de produção de energia e seus reflexos nas comunidades locais e nos seus ambientes. Energias renováveis, por exemplo, amplamente dispersas pelo planeta em extensão dependem das características específicas de certas localidades, muitas vezes promovendo a modificação significativa de territórios e suas respectivas paisagens. Esses resultados são oriundos, entre outros elementos, da descentralização da infraestrutura de produção de recursos energéticosque geram e recebem impactos e são justificadas por um leque de discursos e legitimações incluindo a segurança energética, preocupações ambientais, e o desenvolvimento rural (NADAI \& HORST, 2010).

O apoio oficial do Estado para energias renováveis, por exemplo, tem crescido substancialmente na maior parte dos países desenvolvidos e muito países em desenvolvimento. De igual forma, cresce o consenso a favor do desenvolvimento global de "energias alternativas" e "não-convencionais". Tecnologias de inovação em campos como energia solar, produção de biomassa eenergia eólica surgem em 
paralelo à crescente exploração dos folhelhos, areias betuminosas e plataformas continentais (NADAI \& HORST, 2010 p.144). A crescente preocupação da agenda global em direção a uma economia de baixo carbono igualmente induz ao desenvolvimento sem precedentes na exploração de novos recursos e políticas energéticas inéditas. Até o início dos anos 1990, por exemplo, poucos países tinham formulado políticas para promover energia renovável. Quase 20 anos depois, tomando o ano de 2009, pelo menos 73 países tinham adotado medidas e diretrizes pertinentes. (REN21, 2009).

A revolução industrial, como caso exemplar, foi propulsionada em fases distintas pelo carvão, petróleo e gás, que resultaram na modificação da paisagem de vastos territórios e das sociedades nelas instaladas. Para Nadai e Horst (2010) resta pouca dúvida de que a produção de energia continuará sendo o principal direcionador das transformações do ambiente e sociedade no século XXI, diretamente interligada aos mecanismos de extração, transporte e uso, mas também indiretamente ligada a processos de mudança de uso do solo, redução da biodiversidade, pressão sobre os recursos hídricos, emissão de poluentes e gases de efeito-estufa.

Diante disso, a compreensão das relações entre paisagem e energia e dos seus mecanismos de retroalimentação oferece um campo emergente para a observação de casos de estudo. Recursos energéticos, como a energia eólica, solar, biomassa, geotérmica, energia não-convencional e marinha são exemplos da miríade de opções existentes nem sempre pensadas por meio da descentralização participativa da sociedade e da governança territorial das paisagens. Recursos energéticos que requerem outra visão, outra prática de unificação de políticas territoriais/da paisagem eenergéticas (NADAI \& HORST, 2010).

2.2 Transição energética: percepção, planejamento, participação e poder, ou "os quatro P's"da governança de paisagens e recursos energéticos

O fenômeno intitulado 'gestão da transição energética' tem sido recentemente utilizado como um amplo campo analítico inspirado pelo novo institucionalismo, pela economia evolutiva e pelos nichos da administração pública. A 'gestão da transição' sinaliza diferentes níveis institucionais envolvidos e o papel de atores não-estatais na formulação, implementação e gestão de políticas públicas para o setor de produção de energia. Embora os recursos energéticos continuem sendo amplamente analisados com vistas às suas dimensões e instrumentos econômicos (subsídios, incentivos, retornos e taxas diferenciadas), novas inspirações, estruturas e subjetividades vêm emergindo. Entre as principais dimensões, estão sendo adicionados parâmetros de modernização ecológica, e o novo institucionalismo com a 
implementação de paradigmas inéditos de governança, sobretudo, pela perspectiva de incorporaração de segmentos da sociedade nas políticas do setor (GEELS \& SCHOTT, 2007, SMITH ET AL, 2005).

Segundo Nadai e Horst (2010), analisar a transição energética por meio da paisagem contribui, pressiona e aprofunda a agenda política para além das políticas energéticas tradicionais incorporando a paisagem como elemento material, dinâmico e socialmente inserido no âmbito local/territorial. Como tal, a paisagem ajuda entender o papel da heterogeneidade socioambiental na transição energética e a romper com o pensamento econômico hegemônico. A paisagem, dessa forma, incorpora a ideia de lugar/fenômeno e assume uma materialidade, localizada e situada. Dentro dessa perspectiva, se tornam lócus de uma situação que ajuda a compreender o caminho pelo qual tecnologias se desenvolvemem territórios e comunidades locais.

Nesse contexto, a paisagem assume um conceito geográfico básico, dentro dos territórios que a contêm, e assumem protagonismo como arenas-chave para o debate de políticas energéticas, desafiando esquemas políticos tradicionais para acessibilidade da participação da sociedade. O reverso também é verdadeiro, uma vez que, a exploração de novos recursos energéticos traz dimensões que promove novas políticas territoriais e alterações da própria paisagem, com impactos sobre a economia, sociedade e meio-ambiente. O processo se externaliza em aspectos visuais e materiais em que se torna explícito que a energia vem de algum lugar e que traz impactos e conseqüências diretas e indiretas (PASQUALETTI, 2000).

O impacto espacial, por exemplo, é apenas uma das decorrências das ligações sócio-tecnológicas entre paisagem e energia (NADAI \& HORST, 2010). Outros aspectos resultam das relações entre uma miríade de escolhas coletivas, individuais e sociais. Uma visão defendida pelo grupo de pesquisas da paisagem (LANDSCAPE RESEARCH GROUP / LRG, 2015) reunido na cidade de Dresden, Alemanha, em setembro de 2015. Por esse motivo, para esses pesquisadores, a transição energética remete a quatro aspectos principais, que intitulam de "quatro P's" da governança de paisagens energéticas: Percepção, Planejamento, Participação e Poder.

Percepção está interligada aos mecanismos pelos quais as paisagens energéticas são percebidas, determinadas e avaliadas pelas diferentes instituições e atores sociais que as compôem. Ela se baseia, por exemplo, em como as paisagens são socialmente construídas. Para o LRG (2015) essa perspectiva gera questionamentos sobre qual extensão a percepção é influenciada pelas retóricas, discursos, ideológias e normas culturais? Como tais elementos podem modificar, ou 
mesmo alterar a dinâmica na implementação dos processos de planejamento e tomada de decisão nesses espaços geográficos?

O planejamento, diz respeito à forma pela qual as paisagens energéticas são produzidas e geridas. Como agentes públicos, gestores e políticos (policy makers), e os principais atores sociais (stakeholders) conduzem disputas decisórias correlacionadas às tecnologias e regulações energéticas. Ou em qual subjetividade, visões cognitivas, ou seja, percepções são feitos provisionamentos legais, planjejamentos operacionais, exploração e gestão dos recursos. Por essa perspectiva, são estabelecidas as questões atreladas aos tipos desejáveis de planejamento e sistemas de governança para as paisagens energéticas. Ou seja, como instituições e políticas nacionais, regionais e locais são constituídas e interagem entre si? Quais as implicações de visões pluralistas (planejamento territorial e percepção ambiental) no engajamento público em novas formas deliberativas de governança?

Essas perguntas conduzem ao terceiro aspecto, correlacionado à participação, ou seja, o desafio de planejadores e gestores de adotar aspectos inclusivos nas tomadas de decisão. Políticas capazes de incorporar a população, e especialmente, grupos mais afetados pela exploração dos recursos enegéticos na escala local. Nesse caso, o interesse se dá nas causas que aumentam ou diminuem a aceitação de fontes de energia nas escalas nacional, regional e local. Quais as oportunidades e desafios de diferentes formas de participação em relação à regulação e exploração de energia e o processo participatório? Quais as formas mais adequadas de participação no contexto de manter a cooperação e evitar confitos e cooptação?

Por fim, os pesquisadores do LRG (2015) destacam que todos os aspectos estão diretamente interligados as relações de poder. Ou seja, como as práticas e processos são profundamente influenciados por estratégias de grupos de interesse, instituições ou atores específicos. As questões transitam em desvendar os papeis desempenhados nas relações de poder dentro dos sistemas de governança e, especialmente, o padrão predominante de governamentalidade e ecogovernamentalidade. Quem define o futuro e as diretrizes das paisagens energéticas? Quais as hierarquias nas escalas de governo? O que é mais poderoso: atores e seus recursos, discursos hegemônicos, ou a materialidade das paisagens e as infraestruturas energéticas? 
Parte II - Governança sob enfoque da eco-governamentalidade de recursos energéticos

2.3 Governança dos recursos e o enfoque da eco-governamentalidade nas paisagens e recursos energéticos

A análise da governança ambiental ganhou sistematicamente um significativo espaço entre pesquisadores interessados em desvendar os impactos produzidos pela reorganização de arranjos político-institucionais na regulação e exploração de recursos naturais. Isso ocorreu porqueas estruturas e processos de governança dos recursos são compostos por múltiplos atores, interesses e instituições que oferecem uma oportunidade ímpar na interpretação de novos de mecanismos inéditos de desenvolvimento. Por outro lado, essa mesma complexidade de composição pode formar desvios em direção à consolidação de clientelismos, cooptações, contradições e conflitos, numa trajetória rumo a governanças espúrias, mal conduzidas, ou a processos viciosos quanto ao uso e à exploração dos recursos e preservação do meio-ambiente (MCCARTHY 2006; BAKKER E BRIDGE 2007).

Embora trabalhos como de Agrawal (2005) destaquem que novas estratégias de governança de recursos florestais promoveram atribuições culturais inéditas ao conceito de ambiente, desencadeando modos positivos de apropriação e utilização dos bens naturais comuns, outras pesquisas na área de governança dos recursos indicam distorções no grau de participação política, cooperação e responsabilização dos atores participantes. Muitos sistemas estruturados a partir de diferentes configurações políticas e baseados em discursos da gestão equilibrada acabaram apresentando resultados questionáveis na lógica de apropriação dos bens naturais e das modificações nas subjetividades ambientais (BRIDGE E JONES, 2002).

Um estudo de governança dos recursos pesqueiros em Southland, Nova Zelândia, conduzido por Haggerty (2007) utilizou a ideia de environmentality e a ideia de implementação das novas tecnologias de governo sugeridas por Agrawal (2005). Haggerty analisou como novos espaços deliberativos participativos na gestão do pescado influenciavam a forma de pensar e agir dos atores envolvidos, sobretudo, em relação ao que estes identificavam como 'ambiente'. A autora conclui que o processo de devolução (devolution) e de participação política nas comunidades locais produziuum fenômeno casual, não espontâneo, que intitulou de "ambientalistas acidentais" (p.10). Onde, especialmente, os pescadores passaram a adotar, ainda que de forma não cognitiva, de novas posturas e conceitos em relação à exploração de seu ambiente e aos seus recursos naturais.

Numa direção oposta, Shoreman e Haenn (2009) observaram que sistemas de governança para a gestão de recursos hídricos nos Estados Unidos 
tinham mudado o perfil "ultraconservador" (p.95) de certos atores, em sua maior parte compostos por fazendeiros tradicionais do Delta do rio Mississipi. Segundo os autores, eles viraram"ambientalistas relutantes" (p.96) pois passaram a adotar discursos ambientais e modificaram algumas de suas práticas, porém, muito mais em função da ameaça de aumento da regulamentação ambiental e pela possível intervenção pelas autoridades federais.

Curiosamente, embora tenham grande impacto nas áreas de produção energética e nas comunidades envolvidas e impactadas, a correlação entre governança e eco-governamentalidade não têm sido devidamente analisadas. Pesquisas pautadas na análise de sistemas de governança e de padrões de ecogovernamentalidade com potencial de afetar territórios e suas respectivas paisagens de produção são consideravelmente escassas (Figura 3). Como consequência, pouco são os resultados e discussões sobre as novas relações de forças na regulação e gestão de energia. A dúvida paira se são oportunidades inéditas para a reformulação de posturas, reordenamentos político-participativos e procedimentos de produção equilibrados e racionais, ou são apenas novas lógicas de legitimação na exploração e produção de recursos energéticos, inclusive, que ampliam mecanismos de controle e cooptação pelos atores mais poderosos.

Nos casos em que a correlação entre energia e governança é tratada, os trabalhos se resumem a discutir os arranjos político-institucionais necessários à segurança e à eficiência energética, ou em alguns casos aos desafios de conciliação das políticas energéticas em nível internacional. Em geral, esses trabalhos versam sobre desafios e estímulos para o desenvolvimento de fontes energéticas 'sustentáveis' e sobre o controle das emissões de poluentes correlacionados a produção de energia. As análises em geral se concentram nas dificuldades de concertação dos países quanto à implementação de políticas, acordos e negociações.

Autores como Jepson et. al. (2012), em um dos raros trabalhos voltados a preencher tal lacuna, dirigiram um estudo pioneiro sobre a governança de recursos tendo como base teórica a eco-governamentalidade na regulação e gestão sobre paisagens de produção energética. Os pesquisadores trabalharam no chamado "epicentro da geração eólica nos Estados Unidos" (p.851), em Sweetwater, no oeste do Texas.O estudo revela, por exemplo, que as formas de governança não foram suficientes para superar o que intitulam de "ceticismo ambiental" (p.851) dos atores locais, mesmo diante de um quadro que a energia renovável se tornou parte significativa da economia e da paisagem. Os autores denominaram de: "ceticismo ambiental reflexivo" (p.852) as subjetividades desenvolvidas pelos atores sociais participantes. Uma visão que aceita os produtos econômicos, processos e inovações 
políticas preconizados pela modernização ecológica sem, contudo, aceitar a reivindicação de que essas inovações são necessárias frente às mudanças climáticas e ambientais.

Diante disso, análises de eco-governamentalidade e governança derecursos energéticos ganham importância devido à complexidade de estruturas, processos e discursos envolvidos. Sistemas de governança são comumente formados por atores heterogêneos, instituições e grupos de interesse distintos onde discursos nem sempre são consonantes às práticas estabelecidas. Ou seja, podem não contemplar todos atores e ainda obscurecer relações assimétricas que favorecem retóricas hegemônicas interessadas apenas na manutenção dos processos produtivos e de práticas tradicionais. Estruturas e processos de governança que condicionam as paisagens energéticas e suas comunidades, a elementos coadjuvantes frente às decisões e retóricas legitimadoras oriundas de escalas superiores de poder, ou mesmo aos interesses de elites regionais.

Dito de outra forma, a implementação de sistemas de governança de recursos energéticos se apresentam como oportunidades reais à consolidação de ações coletivas e posturas ambientais inovadoras, mas também podem induzir a subjetividades inócuas, ou mesmo desfavoráveis frente à consolidação de atores e grupos de interesse econômico e produtivo de maior poder. Isso implica que, seja pela assimetria de recursos políticos e econômicos, seja pelo acesso desequilibrado a informações e a espaços de tomadas de decisão, 'sistemas de governança espúrios' ou 'viciosos' podem inibir o desenvolvimento de processos equilibrados de práticas, posturas e atitudes socioambientais entre os atores envolvidos e a exploração sustentável de seus territórios.

A literatura sobre sistemas de governança traz parâmetros e categorias de análise aplicáveis para a governança dos recursos energéticos. Por esses princípios é possível tecer conjecturas sobre os graus decomplexidade, interesses e resultados, e inferir como a qualidade da governança pode produzir impactos e resultados diretos e indiretos nas áreas de produção.

Vale ressaltar que: a transição do século $X X$ para o século $X X I$ testemunhou dois fenômenos: a) o crescimento da pressão por participação exercida por movimentos sociais, organizações, corporações e demais membros da sociedade civil. Momento histórico em que ocorrem processos de modificação de funções clássicas de governo em direção a implementação de novos mecanismos e sistemas de governança; b) o aumento da preocupação ambiental e a exploração dos recursos naturais de forma estável, eficiente e segura para a produção de energia. Essa transição provocou tanto o aumento da produção de fontes energéticas renováveis, 
como energia hídrica, eólica, solar e biocombustíveis, mas também a expansão de novas tecnologias para exploração das chamadas fontes não-convencionais, como por exemplo, areias betuminosas e folhelhos.

As questões ligadas a esses dois fenômenos são: qual é a participação, cooperação, responsabilização e transparência que a sociedade civil e atores nãoestatais vêm exercendo na regulação e exploração de recursos energéticos? Quais os benefícios e impactos dos sistemas emergentes de governança relacionados aos recursos energéticos? Esses arranjos político-produtivos têm se demonstrado capazes de desenvolver novas subjetividades ambientais e consolidar espaços de ação coletiva, ou são apenas palcos de discursos estabelecidos em arenas de ação e espaços de poder assimétricos propagados para legitimar processos de regulação e gestão dos recursos energéticos?

Essas questões levam ao problema central da tese que é a tensão teórica, analítica e empírica entre governança e a eco-governamentalidade. Diante disso, se discutem a formação dos conceitos de governança e ecogovernamentalidade de modo a elucidar o que são? Qual sua relevância e, especialmente, como se medem? Ou ainda, como se aplicam a dois recursos energéticos de natureza, materialidades, políticas e pactos federativos distintos?Diante desse desafio, a pesquisa parte de modelos e de ferramentas específicas para desenvolver e propor uma proposta metodológica para colaborar com o debate sobre o papel da governança, da eco-governamentalidade e da análise institucionalista no estudo de recursos energéticos.

\subsection{Materialidade dos recursos energéticos}

Materialidade diz respeito às propriedades físicas de um determinado fenômeno. Levá-la em conta mostra a influência tanto material sobre o meio ambiente natural quanto física no escopo social. Diante disso, as características materiais dos recursos energéticos, sejam eles de natureza renovável ou não-renovável produzem impactos específicos. Essa seção destaca sucintamente como diferentes recursos energéticos são, portanto, portadores de características inerentes e implicam em padrões de uso e exploração com potencial para modificar paisagens, territórios de produção e, formas particulares de relações sociais. A exploração de recursos energéticos fósseis, por exemplo, imprimiu e continua a imprimir materialidades contudentes e impactantes nas relações econômicas, sociais e ambientais (PRUDHAM, 2005). Outras fontes de energia mais recentes, como os biocombustíveis 
também têm materialidades próprias que promovem intervenções biofísicas e sociais nada desprezíveis (BORRAS ET AL, 2011).

Autores como Mitchel (2011) destacam que as diferentes materialidades do carvão mineral e do petróleo causaram significativas alterações biofísicas e modificações político-produtivas. O carvão, por exemplo, enquanto recurso energético sólido, armazenado em depósitos subterrâneos, se desenvolveu tendo por base atividades mineradoras próprias, com a formação de grupos sociais característicos, e com espaços de prospecção e consumo específicos. Dito de outra forma, o carvão promoveu a materialização de atividades econômicas e sociais particulares, ligados às suas formas de exploração, beneficiamento, transporte e uso. Propriedades físicas que resultaram na modificação de paisagens, na consolidação de núcleos urbanos, indústrias energéticas, mineradoras, ferrovias e núcleos produtivos com relações de trabalho e poder dependentes da atividade.

O petróleo, por sua vez, trouxe consigo uma materialidade distinta, uma vez que é um hidrocarboneto líquido com propriedades, cooprodutos, formas de prospecção, beneficiamento, e transporte distintos. Essas particularidades consolidaram, entre outros, o desenvolvimento de oleodutos, navios-tanque e ferrovias especializadas, um apartato tecnológico de perfuração de poços e a expansão das atividades petroquímicas e de refino, que ampliou exponencialmente a quantidade de trabalhadores especializados em comparação aos grupos mineradores do carvão.

Prudham (2005) destaca que a materialidade do petróleo trouxe novos choques tanto na sua produção como recurso natural quanto mecanismo de produção social. A cadeia de produção do petróelo se ampliou para escalas mundiais como fonte de energia, mas igualmente como matéria-prima para novos produtos (resinas, tintas, tecidos, lubrificantes, plásticos, fertilizantes, etc.). Uma materialidade que imprimiu novas dimensões ao petróleo dentro e fora das áreas produtoras e consumidoras. Em ambas, as propriedades físicas e produtivas do recurso energético provocaram uma sobrecarga exponencial para a capacidade assimiladora do meioambiente, mais especificamente na sua capacidade depuradora de emissões e poluentes derivados das fases de prospecção (upstream), beneficiamento e transporte (midstream) e de utilização (downstream).

Adicionalmente, a materialidade do petróleo exerceu uma poderosa influência sobre as áreas e redes de produção estabelecendo concorrências e interdepedências entre consumidores e produtores. Além disso, conforme destaca Bridge (2008), as características comerciais do petróleo promoveram "intervenções tecnológicas constantes" (p.19) que expandiram ainda mais sua materialidade. Novas formas e áreas de prospecção, como por exemplo, a exploração oceânica nas 
plataformas continentais (off shore), bem como, o avanço de tecnologia de exploração dos hidrocarbonetos não-convencionais, como os folhelhos, rochas e areias betuminosas aumetaram ainda mais os seus impactos materiais.

No que se referem aos biocombustíveis, eles também têm materialidades próprias, sobretudo os líquidos de primeira geração, obtidosa partir de fontes agrícolas. Pesquisadores organizados por Borras et.al. (2011) destacam, por exemplo, que a materialidade da produção do biocombustível trouxe uma nova dinâmica aos padrões agroindustriais e agrícolas locais. Para os autores, os biocombustíveis intensificaram os cultivos de base, sobretudo, de monoculturas trazendo consigo substanciais impactos biológicos (desmatamento e pressão sobre a biodiversidade) e biofísicos (solo, mananciais, precipitação temperatura, umidade etc.). Para eles, a materialidade dos biocombustíveis enquanto recurso energético gerou impactos socioeconômicos negativos em termos de justiça ambiental e assimetria de oportunidades, direitos e ganhos.

Os autores frisam que as cadeias agroindustriais envolvidas na produção de biocombustíveis se estabelecem como resultado de processos políticos e pressões econômicas que além de intensificar o ritmo e intensidade de exploração das áreas de plantio ampliam significativamento o uso e exploração de recursos naturais. Além da exigência biofísica, demandam altos investimentos públicos para se consolidar e se desenvolvem sob estruturas atreladas ao mercado de commodities agrícolas e a pacotes de incentivos oficiais (BORRAS ET AL, 2011).

Autores como Ariza et.al. (2010) demostram, por exemplo, que a tentativa de implementação do biodiesel de jatropha (pinhão-manso) na Índia, formou materialidades impactantes e inadequadas tanto para os agricultores empresariais quanto para os pequenos produtores. Outros trabalhos ressaltam aspectos negativos da materialidade do biodiesel obtido a partir de culturas e setores agroindustriais específicos, entre eles, a palma/ óleo de palma na Indonésia, (MCCARTHY, 2010), a soja e o seu óleo no Brasil (WILKINSON \& HERRERA, 2011). De acordo com esses autores, essas materialidades intensificaram o ritmo em que vastas áreas têm sido transformadas e seus recursos naturais consumidos, gerando impactos preocupantes em termos de justiça socioambiental (BORRAS ET AL, 2011).

Adicionalmente, White \&Dasgupta (2010) observam que a materialidade dos biocombustíveis não se dá apenas pela ótica da expansão das culturas agrícolas de base, pois se estende aos processos industriais atrelados, que dependem do uso intensivo de recursos naturais e de insumos e componentes ambientalmente impactantes. Adicionalmente, as cadeias produtivas próprias dos biocombustíveis são 
muitas vezes sustentadas por relações espúrias de trabalho e regimes de comercialização inadequados.

Para Borras et. al. (2011),o problema maior se dá na visão de que os biocombustíveis representam um padrão produtivo inédito, ou de uma "nova agricultura" (p.6), quando na maior parte das vezes eles se inserem em cadeias agrícolas tradicionais, aproveitando-se devultosos subsídios governamentais voltados a setores econômicos consolidados. Os autores afirmam que os biocombustíveis são produzidos pela premissa de serem recursos propulsores para o desenvolvimento comunitário rural e local. Entretanto, defendem sondagens mais profundas e éticas e uma crítica sobre como a "visão tecnocrática [que] tende a mascarar os verdadeiros interesses do agronegócioe de especuladores" do setor (p.06).

Diante desse debate, entende-se que é necessário considerar a materialidade inerente das fontes energéticas, mas, sobretudo, compreender as normas, regras e ordenamentos que regem os recursos energéticos caso a caso. $O$ petróleo, carvão e gás, por exemplo, se encontram disponíveis sob forma natural em jazidas minerais sendo simultaneamente recursos naturais e energéticos. Suas formas de uso e exploração são regidas pelas normas constitucionais de cada país, região, estado em que se encontram. Em alguns países são considerados bens públicos, com sua prospecção e extração reguladas e concedidas exclusivamente pelo Estado. Em outros sistemas jurídicos, entretanto, podem ser enquadrados como bens privados. Esse é o caso da exploração dos folhelhos nos Estados Unidos, onde os direitos mineirais ou do subsolo são comercializados como propriedade privada junto ou mesmo desmembrado dos direitos de superfície.

A exploração da biomassa, por sua vez, como por exemplo, os biocombustíveis de primeira geração obviamente não envolvem a exploração de depósitos naturais. Apesar disso, esses recursos são obtidos por meio do uso intensivo de insumos animais e/ou vegetais. E como visto, devido as suas materialidade inerentes exercem grande influência e impactos nos recursos hídricos e edáficos. De forma semelhante ao caso dos hidrocarbonetos, os biocombustíveis também estão sujeitos a normas e regulações diferenciadas caso a caso, legislação a legislação, país a país. Ou seja, as variáveis constitucionais, políticas, pactos federativos e sistemas de regras que vão ditar prioritariamente o ritmo, intensidade, objetivos da exploração, além das formas de regulação, gestão e uso. 
Parte III - O quadro de desenvolvimento e Análise Institucionalista de Elinor Ostrom para avaliação de sistemas de governança

\subsection{Aanálise institucional dos sistemas de governança}

A Análise Institucionalista, ou Institutional Analysis and Development framework (IAD), foi concebida por Ostrom (2005) como um modelo para analisar elementos estruturais e processuais no escopo de formação de políticas públicas e de sistemas de governança. Seus eixos básicos de investigação concentram-se: i) nos atores sociais, ou participantes dos arranjos político-institucionais; ii) nas regras que regem os comportamentos deles, e iii) nas interações, interdependências e resultados derivados da participação, negociação e coordenação nas arenas de ação política. Semelhante aos focos abordados pela governamentalidade, e ecogovernamentalidade, o IAD lança luz sobre o papel das preferências, crenças, e vieses cognitivos dos atores sociais. A análise institucionalista procura desvendar como as assimetrias de recursos e informações, as subjetividades e discursos afetam e determinam as decisões e estruturas da governança (OSTROM, 2005).

\section{i) O papel dos atores sociais}

O IAD é centrado no entendimento das motivações e estratégias que levam atores individuais e coletivos a escolhas e tomadas de decisão distintas dentro de arenas de ação e espaços políticos. Seu escopo concentra-se na análise dos comportamentos, do grau de influência, das relações de poderes, das competências e das atribuições que levam diferentes atores sociais a desempenhar papeis distintos nas ações coletivas na esfera de políticas públicas ou nos sistemas de governança.

As categorias de análise do IAD partem da interpretação e aplicação de um seleto grupo de teorias sociais (Figura 3). Em primeiro, os pressupostos da teoria da ação racional, segundo a qual todos os atores sempre buscam tomar decisões conscientes, intencionais e racionais, aplicando os seus potenciais máximos para atingir objetivos particulares e gerar benefícios à sociedade. A crítica de Ostrom (2000) ao princípio da ação racional se dá com base na interpretação idealizada dos comportamentos dos atores. Ela questiona a concepção de funcionamento perfeito dos mercados em que patamares políticos, econômicos e sociais seriam nivelados, e que todos os atores sociais seriam bem informados, ocupando posições equilibradas dentro de uma estrutura ideal de relações socioeconômicas. 


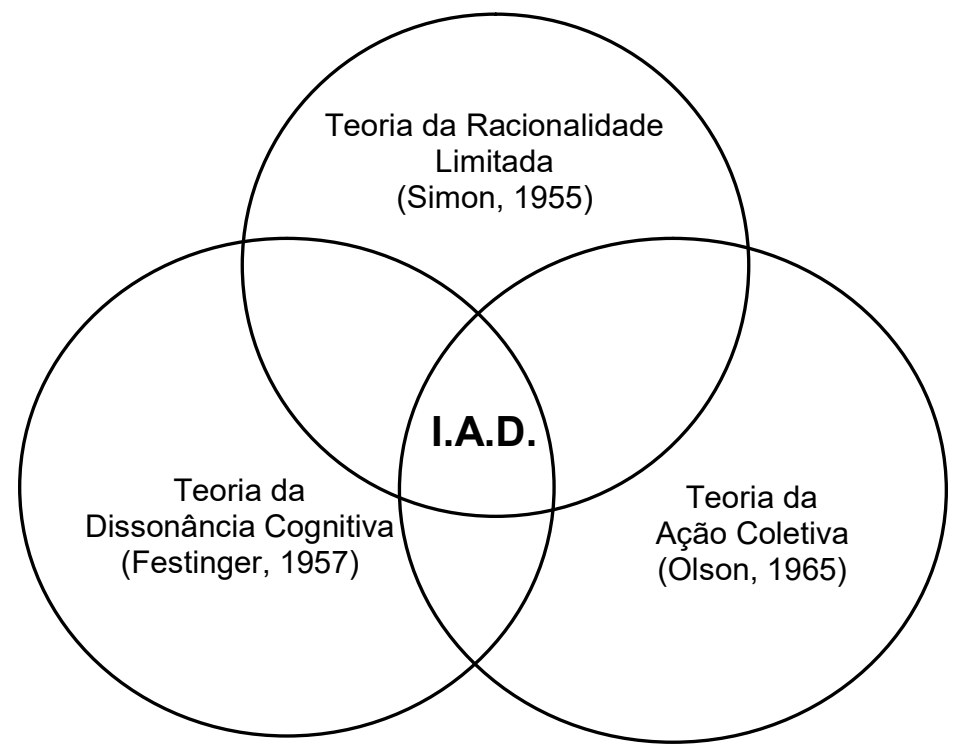

Figura 3 - Teorias formadoras da análise institucional de Elinor Ostrom. Fonte: Elaborado pelo autor.

Para Ostrom, as condutas dos atores sociais seguem um padrão muito mais complexo e dinâmico, seguindo na prática, os princípios da teoria da racionalidade limitada de Simon (1955). Nessa outra teoria os comportamentos e as interações entre os agentes estariam sujeitas a falhas de execução, a erros interpretativos, ações limitadas e mesmo tendenciosas. Para a autora, a desigualdade de recursos (políticos, econômicos, culturais) e a assimetria no acesso e no processamento de informações podem levar os atores a escolhas e decisões imprevisíveis, ou mesmo indesejáveis. Condicionantes e comportamentos irracionais, ou mesmo inconsistentes, seriam elementos presentes nas características dos atores, com a possibilidade de resultados construídos mais na obtenção de vantagens rápidas e imediatas do que em ganhos permanentes e duradouros (OSTROM, 2005).

Diante de tal perspectiva, Ostrom (1998; 2005) defende que os valores, interesses e vieses cognitivos dos atores afetam os resultados e o desempenho nas arenas de ação política. Partindo de elementos semelhantes ao da teoria da dissonância cognitiva de Festinger (1957), a autora destaca que atores são suscetíveis a contradições nas tomadas de decisão chegando a deliberações e resultados nem sempre condizentes com suas opiniões e posturas. Vícios e interpretações se manifestariam por meio de juízos de valor, interesses e comprometimentos com o uso e propagação de informações mais disponíveis e adequadas, e não necessariamente de informações mais confiáveis ou proveitosas.

Dentro do universo de possibilidades comportamentais, Ostrom (2005) incorpora também os elementos da teoria da ação coletiva de Olson (1965), com o 
debate sobre as lógicas que conduzem os atores a se reunirem sob forma de coalizões em arenas de ação política. A autora procura correlacionar quais os comportamentos conduzem atores heterogêneos a se organizarem e atuarem em torno de interesses comuns. Quais motivos e lógicas levam um participante a uma posição indiferente, ou mesmo prejudicial, na formação desses espaços?

O princípio da ação coletiva é empregado, portanto, como elemento central para debater a heterogeneidade de interesses e recursos de atores e grupos sociais durante negociações e estabelecimento de regulações nos sistemas de governança. Seguindo a lógica de Olson (1965), Ostrom procura interpretar por quais motivos se estabelecem os grupos sociais grandes, por exemplo, aqueles marcados por grande disparidade socioeconômica interna. Quais incentivos e estímulos coletivos e individuais esses grupos permanecem coesos, ou tendem a se dissolver? Como desenvolvem comportamentos oportunistas, interessados em obter vantagens sem 0 devido engajamento e envolvimento nas ações político-produtivas?

ii) As arenas de ação política e as regras

Junto com os atores, as regras ocupam uma posição central no escopo do IAD. São elas que definem, essencialmente, os padrões e ritmos de interações e, os resultados das de governança. De acordo com Ostrom (2005), as regras devem ser entendidas como meios de prescrever, proscrever e/permitir os comportamentos adotados e admitidos nas arenas de ação e espaços político-produtivos. As regras desempenham a função de: i) criar posições e funções; ii) instituir os requisitos para adquirir, ou ser destituído de, posições e funções; iii) determinar as ações requeridas, permitidas ou proibidas e; iv) selecionar e julgar os resultados obtidos. As regras são, portanto, os elementos para compreender quais mecanismos, incentivos e restrições determinam as interações e fatores de interdependência entre os atores sociais.

De acordo com Ostrom (2005), as regras são classificadas pelos cientistas sociais em quatro diferentes concepções: regulações, instruções, preceitos e princípios. Quando utilizadas no sentido de regulações, as regras se referem a algo estabelecido por uma autoridade instituída (legisladores, juízes, magistrados, diretores de uma empresa, etc.). Nesse caso, têm características formais e legais para serem instituídas, oficializadas, publicadas, revogadas ou mesmo reformadas. Quando as regras têm o sentido de instruções, entretanto, elas operam apenas como procedimentos para solucionar problemas práticos e usuais. Regras com o sentido de preceitos, por sua vez, são utilizadas como elementos condutores de comportamentos 
morais ou culturais. Por fim, regras quando consideradas como princípios são entendidas como leis físicas ou biológicas que apresentam padrões reproduzíveis.

No IAD as regras denotam regulações e são entendidas como o conjunto de mecanismos criados para gerir uma situação de ação dentro de ambientes e situações particulares. São as regras que ditam, por exemplo, os sistemas de direitos e deveres que os participantes possuem em diversas estruturas políticoinstitucionais. Para Ostrom (2005), nos sistemas de governança é essencial perguntar onde, e como, as regras são originadas. É necessário compreender como as diferentes regras são criadas e utilizadas, ou como são estabelecidas dentro de diferentes escalas de gestão como, por exemplo, o conjunto de regulações estabelecidas por um governo central, em consonância com, ou com autonomia em relação a legislações aprovadas por governos regionais ou locais.

iii) Interações, Interdependências e resultados

De crucial importância para a análise proposta pelo IAD é o questionamento sobre como se institucionalizam as interações, como se reproduzem as interdependências entre os atores sociais, e ainda, como geram diferentes resultados. Pelo quadro de análise institucional proposto por Ostrom (2005), situações de interdependências são criadas frente a um conjunto de variáveis sociais, constitucionais, tecnológicas e biofísicas, e influenciadas pelas preferências, crenças e viesses cognitivosdos atores sociais. Estariam submetidas também ao conjunto de regras ligadas aos recursos distintos dos diversos atores sociais inseridos em arenas políticas, e envolvidos em ações coletivas no seio de estruturas político-institucionais.

A abordagem das situações de interdependência na formulação de políticas públicas e na consolidação de sistemas de governança faz parte do esforço do IAD para compreender a complexidade dos processos e mecanismos de ação coletiva. Conforme destaca Ostrom (2005), as situações de interdependência seguem uma lógica semelhante à oferecida pela teoria dos Jogos e pela teoria dos paradoxos sociais do dilema do prisioneiro. Isso se dá porque, analogamente aos jogos, o conhecimento das regras, o acesso e a forma de tratamento do conjunto de informações, as escolhas das estratégias e o acesso as arenas de ação estipulam ganhadores e perdedores. Dito de outra forma, atores e grupos de atores são favorecidos em detrimento a outros e o dilema se reproduz em uma situação em que existem cooperações, mas também conflitos entre os interesses individuais e coletivos dos participantes. 
Nesse contexto, conforme destacado por Flexor (2011a), uma estrutura político-institucional caracterizada, por exemplo, por atores com acesso privilegiado às arenas políticas de decisão e às informações sobre as "regras do jogo" será consideravelmente diferente de outros arranjos nos quais os atores são tolhidos ou afastados dos espaços e arenas de decisão, ou têm níveis de conhecimento e informações assimétricos sobre os processos, e as ações permitidas.

O resultado distributivo gerado, portanto, por um sistema de governança deve ser compreendido, e analisado, como consequências da ação, inação, ou distorção dos atores sociais frente às regras que estruturam suas interações. Dessas interações podem se originar tanto processos de cooperação, mas também de conflitos, com efeitos diretos nas variáveis estruturais sociais, constitucionais, tecnológicas e biofísicas que deram origem a toda estrutura institucional. De uma forma sintética, os elementos da análise institucional de Ostrom (2005) estão embasados sobre:

- os participantes da situação: envolvendo a quantidade de atores sociais (numerosos/ poucos), suas configurações sócio-políticas e produtivas (atores individuais/ coletivos), seus recursos (significativos/ escassos) e os seus atributos específicos;

- as posições na situação: ou as funções desempenhadas pelos atores sociais, sua hierarquia (posições de membros e participantes em comissões, órgãos públicos, grupos de interesse, grupos de pressão/ lobbying, papel de organizações não-governamentais, associações, confederações e movimentos sociais, etc.);

- o conjunto de ações permitidas: o conjunto de alternativas possíveis frente às regras, regulações e demais limitações de ordem mercadológica, tecnológica e institucional;

- os resultados potenciais: as oportunidades, os efeitos, as conseqüências e os impactos possíveis das ações e interações dos atores sociais;

- o grau de controle sobre as decisões: a intensidade em que o conjunto de regras e normas influenciam e determinam as decisões tomadas;

- as informações sobre a situação: dados e particularidades a respeito dos recursos em jogo, dos ganhos potenciais e das características políticas, comerciais e produtivas dos demais "jogadores" (participantes), ou atores sociais;

- custos e benefícios: bônus e ganhos ou ônus e perdas esperados do conjunto de ações e dos resultados potenciais.

A análise institucional serve de apoio à avaliação dos sistemas de governança enquanto somatória de estruturas, processos e discursos. Suas categorias 
de análise procuram entender os desenhos específicos, formas e composições dos arranjos político-institucionais da governança e contribuem para o entendimento de formatos de regulação e gestão de políticas, e de setores específicos. Seus parâmetros lançam luz sobre a importância de identificar e avaliar as formas centralizadas, descentralizadas, ou desconcentradas de poder que se propagam em arenas e espaços de tomadas de decisão (SANCHEZ, 2000).

O IAD serve igualmente como base para a compreensão dos sistemas de governança enquanto processo, pois foca os balanços de forças, as interações e as dependências entre atores estatais e não-estatais. Concentra-se nos mecanismos e influências que iniciam, mantêm, fortalecem, ou enfraquecem as metas e diretrizes da governança. Pelas categorias de análise é possível discutir os meios, e modos de governo, ou a eco-governamentalidade pelas quais se estabelecem o domínio político e as relações de poder "exercidas e orquestradas em contextos espaciais, históricos e econômicos particulares (BULKELEY ET.AL., 2005 p.16). A análise do IAD está ligada a responder como a regulação e exploração de recursos se desdobram como "uma fonte potencial de tensões" entre grupos de interesse e os diversos atores sociais envolvidos (GIBBS E JONAS, 2000 p.306). 


\section{METOdOLOGIA, CONTEXTUALIZAÇÃO E DESCRIÇÃo DAS ÁREAS DE ESTUDO; PADRÕES E PROCEDIMENTOS DE PESQUISA}

Parte I - Metodologia de pesquisa: modelos, ferramentas e instrumentos de análise de sistemas de governança de recursos energéticos

3.1 0 quadro de análise institucional de Elinor Ostrom como modelo
norteador das categorias de investigação
O quadro de análise institucional e desenvolvimento, ou institutional analysis and development framework (IAD) proposto porOstrom (2005) é utilizado como modelo norteador para a análise das estruturas político-institucionais e processuais dos sistemas de governança de recursos energéticos. Com o uso das categorias do Quadro de Análise Institucional (Figura 4), a presente pesquisa procurou constatar como as regras, normas e regulações são estabelecidas; como se formam as arenas de ação e espaços políticos deliberativos e consultivos; e ainda, como as interações e interdependências entre os atores sociais produzem resultados e feedback's distintos que afetam a qualidade de regulação e exploração de recursos energéticos.

\begin{tabular}{|c|c|c|}
\hline Variáveis & Arenas/Atores/Regras & Resultados \\
\hline $\begin{array}{c}\text { SOCIAIS } \\
\text { CONSTITUCIONAIS }\end{array}$ & $\begin{array}{l}\text { - arenas políticas; espaços consultivos } \\
\text { e deliberativos; } \\
\text { - normas e regras legais; } \\
\text { - papeis e perfis dos atores sociais } \\
\text { (responsabilidades e funções legais); } \\
\text { - crenças; viesses cognitivos; e } \\
\text { discursos; } \\
\text {-ECO-GOVERNAMENTALIDADE - }\end{array}$ & $\begin{array}{l}\text { - Distributivos, } \\
\text { redistributivos ou } \\
\text { regulatórios } \\
\text { ( perdedores e } \\
\text { ganhadores); }\end{array}$ \\
\hline $\begin{array}{l}\text { TECNOLÓGICAS } \\
\text { BIOFÍSICAS }\end{array}$ & $\begin{array}{l}\text { INTERAÇÕES \& } \\
\text { INTERDEPENDÊNCIAS } \\
\text { - DIRECIONADORES DE GOVERNANÇA - } \\
\text {-descentralização, participaçao, cooperação, } \\
\text { responsablização; transparência, equidade, } \\
\text { pertencimento e empoderamento (*) } \\
\text { (choquesde interesse, conflitos, assimetria } \\
\text { de recursos - econômicos, informacionais, } \\
\text { políticos); }\end{array}$ & $\begin{array}{c}\text { FEEDBACK } \\
\text { - Aprendizagem das } \\
\text { falhas e potencialidades; } \\
\text { Necessidades de ajuste; } \\
\text { (revisão; } \\
\text { reforço de medidas; } \\
\text { Inação e Causação } \\
\text { Cumulativa de impactos; }\end{array}$ \\
\hline
\end{tabular}

Figura 4 - Modelo/quadro de análise institucional de Elinor Ostrom.

Fonte: Elaborado a partir de Ostrom (2005) e adaptado de Flexor (2011a).

Usando esse modelo buscou-se analisar as variáveis estruturais que condicionam a implentação das políticas e dos sistemas de governança de recursos 
energéticos. Foram exploradas as seguintes questões: i) como os condicionantes sociais, ou os critérios e justificativas socioeconômicas oficiais foram utilizados na implementação dos arranjos político-institucionais; ii) quais normas constitucionais e particularidades das leis e regras viabilizaram e ampararam a regulação e exploração dos recursos energéticos ; iii) que apectos tecnológicos foram necessários a exploração do recurso; e iv) como o conceito de meio ambiente foi incorporado, ou sob qual padrão os meios biofísicos são considerados no processo de exploração dos recursos.

As variáveis estruturais do modelo estabelecem, portanto, as bases observáveis dos sistemas de governança dos recursos energéticos. O modelo sugere que pela compreensão dos espaços de tomada de decisões é possível inferir como se desenvolvem as competências, direitos, prerrogativas, os deveres e as incumbências dos participantes. O entendimento do conjunto de regras e das arenas oferece, portanto, indicações sobre como se edificam as interações e interdependências, e consequentemente, como se desenvolvem mecanismos de cooperação e conflitos derivados do desequilíbrio das relações de poder.

As categorias do IAD destacam o papel do controle e ampliação das vantagens na exploração dos recursos por grupos privilegiados, por estratégias de lobbying, ação e pressão política de grupos de interesse frente às esferas oficiais de governo. Também contemplam o papel das preferências, crenças, e viesses cognitivos propagados pelos atores participantes (DRYZEK 2005; HAJER E VERSTEEG, 2005). Elementos que são à base da governamentalidade de Foucault, e da ecogovernamentalidade tratada por Luke (1995) e Agrawal (2005). Em especial, como discursos são utilizados para justificar e legitimar a regulação, e a exploração de recursos energéticos (LUKE, 1995; LIVERMANN, 2004, AGRAWAL, 2005).

A partir dessas categorias de análise é possível chegar a considerações sobre resultados dos arranjos político-institucionais estudados. Ou seja, o desempenho de políticas públicas e dos seus respectivos sistemas de governança, determinando o peso em que as estruturas, processos e discursos produzem possíveis beneficiados (ganhadores) ou prejudicados (perdedores). Ou ainda, como indicam feedback's (ou retornos) necessários ou o ajuste, a revisão, e medidas de reavaliações de aspectos configurativos. 
3.20 emprego do software Atlas.ti como ferramenta de análise de conteúdo dos discursos dos atores sociais

O Atlas.ti é um programa de suporte de análise de dados qualitativos do tipo computer assisted qualitative data analysis software (CAQDAS). Sua versão inicial foi concebida pela Universidade Técnica de Berlim no escopo de projetos voltados a desenvolver ferramentas de apoio a pesquisas multidisciplinares. O nome Atlas deriva da abreviação de Archivfuer Technik, Lebenswelt und Alltagssprache, ou Arquivo para Tecnologia, Mundo da vida e a Linguagem Cotidiana (BANDEIRA-DE-MELLO, 2006).

O Atlas.ti é basicamente uma ferramenta de apoio para tratamento de dados qualitativos que facilita o gerenciamento e análise de diferentes fontes documentais. Ele permite manipular e analisar textos (respostas de questionários semi-estruturados, transcrições de entrevistas, relatórios de observação, notas de campo, documentos administrativos, cartas, artigos jornalísticos, literários e acadêmicos), áudios (entrevistas de rádio, gravações de reuniões), imagens (propagandas, folders, gravuras, fotos, desenhos) e vídeos (documentários, declarações, e reportagens televisivas).

Seu emprego tem quatro funções básicas: i) rápida e fácil visualização da complexidade dos dados e do processo de análise como um todo; ii) facilidade de integração, organização e conjugação de toda a base de dados e elementos de análise dentro de um único espaço: as unidades hermenêuticas; iii) possibilidade de descobertas casuais, ou insights, ao longo do tratamento e manuseio dos dados; e iv) oferecimento de procedimentos de destaque, triangulação e interação dos materiais de pesquisa, possibilitando maior profundidade na exploração dos dados e dos resultados obtidos.

O uso do programa oferece suporte à identificação e à interpretação de fenômenos, percepções e subjetividades dos atores sociais. O processo se dá essencialmente por meio da identificação e classificação de padrões, ou códigos, revelados pelos discursos presentes na estrutura de entrevistas, depoimentos e demais materiais de divulgação em multimídia (Figura 5). No escopo do programa Atlas.ti, as unidades hermenêuticas (UH) são as bases operacionais básicas em que os projetos de pesquisa são criados e desenvolvidos. 


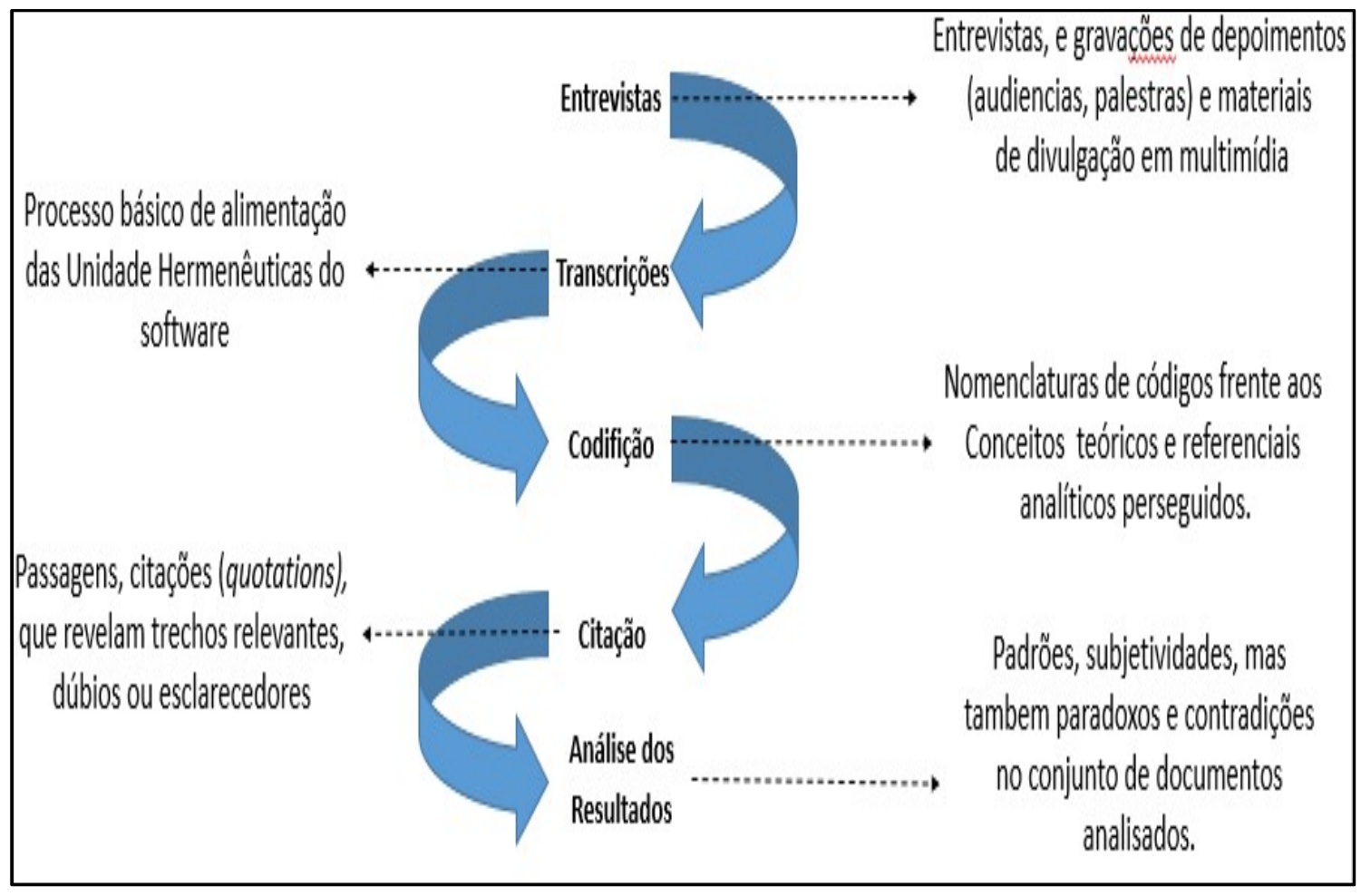

Figura 5 - Etapas do processo de análise pelo software Atlas.ti

Fonte: elaborado pelo autor.

No caso do presente estudo, duas unidades hermenêuticas distintas foram criadas para análise de conteúdo dos dados obtidos nas áreas de pesquisa: uma para os polos gaúchos de produção de biodiesel, e outra, para os territórios texanos de exploração de folhelhos de Eagle Ford Shale. Elas são a base operacional do tratamento e análise dos dados, sendo compostas essencialmente pelos materiais obtidos a partir de transcrições de entrevistas e notas de campo, mas igualmente de outros documentos e materiais obtidos, como gravações de reuniões, palestras e audiências durante as etapas de coleta de dados.

A intenção principal desse procedimento metodológico é identificar trechos, passagens, citações (quotations) que revelam raciocínios, concepções, ideologias e posturas dos atores sociais frente às características políticas e regulatórias dos sistemas de governança dos recursos energéticos. À função do software Atlas.ti, portanto, é dar suporte a análise de conteúdo dos discursos dos participantes inseridos, e interligados, a regulação e gestão da exploração de energia nos dois territórios de produção, identificando viesses cognitivos, preferências, crenças e subjetividades. 
3.3 Proposta dos 'direcionadores de governança dos recursos energéticos'.

O método dos direcionadores de governança dos recursos energéticos, proposto por essa pesquisa, parte da perspectiva de organizar, avaliar e correlacionar os resultados obtidos nas áreas de estudo frente aos atributos da boa governança. $O$ método foi elaborado de modo a qualificar os sistemas de governança de recursos energéticos baseado em oito princípios: 1) descentralização, 2) participação, 3) cooperação, 4) responsabilização, 5) transparência, 6) equidade, 7) pertencimento, e 8) empoderamento. Para atingir esse objetivo, para cada um desses princípios, ou direcionadores de governança, foi criada uma escala do tipo likert de atribuição que permitiu a atribuição de valores de desempenho.

Tomando-se, por exemplo, isoladamente apenas o direcionador: participação (Tabela 4), há três componentes, ou subfatores: i) a existência de conselhos, comitês e audiências públicas; ii) a presença da sociedade civil: movimentos sociais, organizações não-governamentais e lideranças comunitárias; e iii) a representatividade de atores sociais e instituições nos pleitos e escrutíneos. Esses subfatores são sujeitos a uma escala de avaliação psicométrica que varia assim: muito favorável $(\mathrm{MF}=+2)$; favorável $(F=+1)$; neutra $(N=0)$; desfavorável $(D=-1)$ e muito desfavorável (MD = -2).

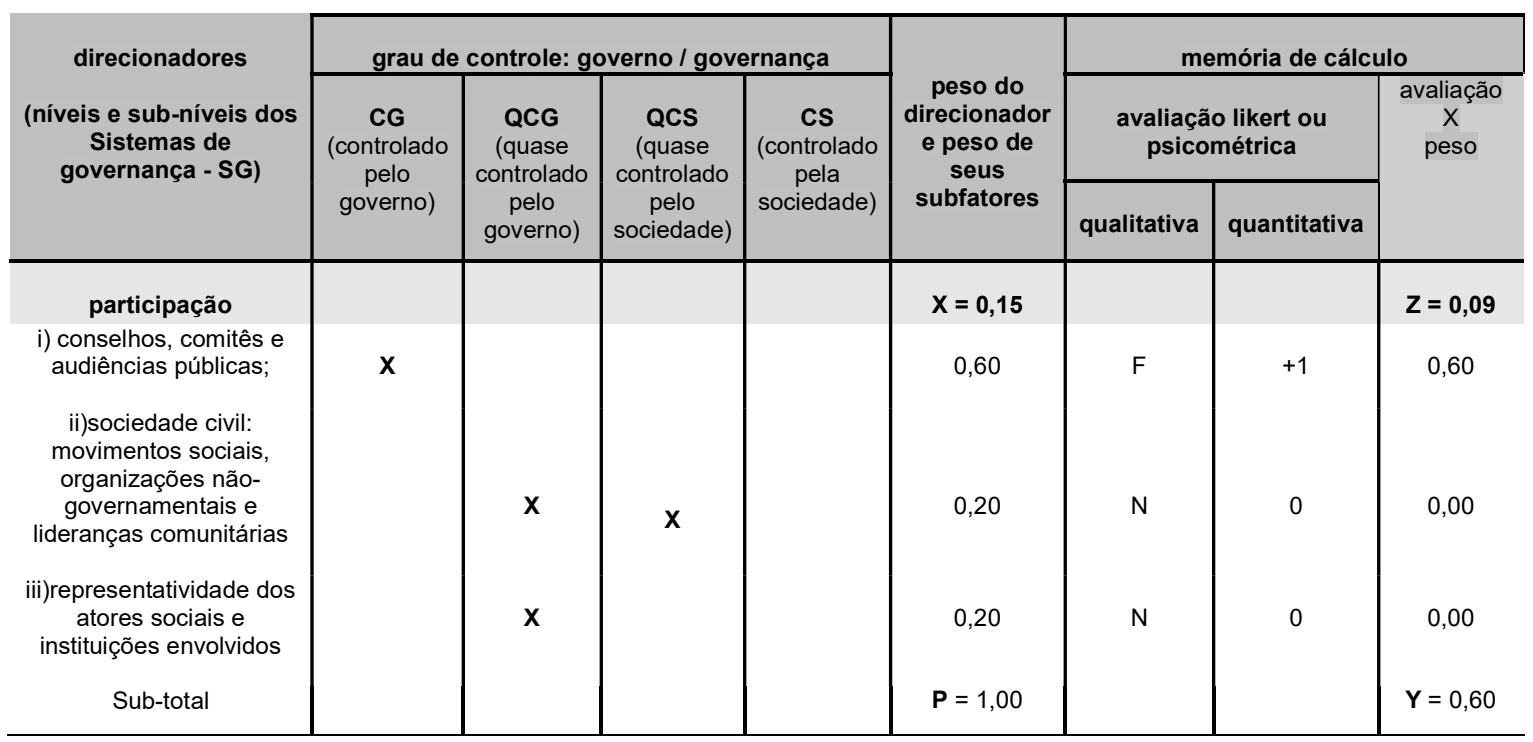

Tabela 4 - Exemplo da composição e memória de cálculo do direcionador: participação.

Fonte: elaborado pelo autor.

Nesse caso, o primeiro subfator (conselhos, comitês e audiências públicas), considerado favorável $(F=+1)$, tem seu resultado obtido pela multiplicação de sua avaliação psicométrica pelo seu peso, ou seja, $+1 \times 0,60=+0,60$. Os demais 
subfatores neutros $(\mathrm{N}=0)$ têm pesos de 0,20 ; os seus resultados são obtidos de forma idêntica, ou seja; $0 \times 0,20=0,00$. O resultado total do direcionador $(Z)$ se obtém por uma regra de três simples entre o peso do direcionador $(X)$, a soma dos seus subfatores $(Y)$, e o total dos pesos dos sub-fatores $(P)$.

$$
\text { Z . } 1,00(\mathrm{P})=0,25(\mathrm{X}) \text {. 0,60 }
$$

$$
\mathrm{Z}=0,09
$$

Com esse procedimento é possível atribuir valores de desempenho de cada um dos direcionadores e determinar um resultado agregado para o conjunto de direcionadores, estabelecendo uma avaliação geral para cada sistema analisado,

\begin{tabular}{|c|c|c|c|c|c|c|c|c|}
\hline \multirow{3}{*}{$\begin{array}{c}\text { direcionadores } \\
\text { (níveis e sub-níveis dos } \\
\text { sistemas de } \\
\text { governança - SG) }\end{array}$} & \multicolumn{4}{|c|}{ grau de controle: governo / governança } & \multirow{3}{*}{$\begin{array}{l}\text { Peso do } \\
\text { Direcionador } \\
\text { e de seus } \\
\text { subfatores }\end{array}$} & \multicolumn{3}{|c|}{ memória de cálculo } \\
\hline & \multirow{2}{*}{$\begin{array}{c}\text { CG } \\
\text { (controlado } \\
\text { pelo } \\
\text { governo) }\end{array}$} & \multirow{2}{*}{$\begin{array}{c}\text { QCG } \\
\text { (quase } \\
\text { controlado } \\
\text { pelo } \\
\text { governo) }\end{array}$} & \multirow{2}{*}{$\begin{array}{c}\text { QCS } \\
\text { (quase } \\
\text { controlado } \\
\text { pelo } \\
\text { sociedade) }\end{array}$} & \multirow{2}{*}{$\begin{array}{c}\text { CS } \\
\text { (controlado } \\
\text { pela } \\
\text { sociedade) }\end{array}$} & & \multicolumn{2}{|c|}{ avaliação } & \multirow{2}{*}{$\begin{array}{c}\text { avaliação } \\
X \\
\text { peso }\end{array}$} \\
\hline & & & & & & qualitativa & quantitativa & \\
\hline 1) descentralização & & & & & $\overline{0,15}$ & & & $\overline{0,15}$ \\
\hline $\begin{array}{l}\text { - níveis de autonomia do } \\
\text { governos locais na } \\
\text { regulação energética }\end{array}$ & $\mathbf{x}$ & & & & 0,70 & $\mathrm{~F}$ & +1 & 0,70 \\
\hline $\begin{array}{l}\text { - subsidiaridade e } \\
\text { flexibiilidade dos } \\
\text { governos centrais }\end{array}$ & $x$ & & & & 0,30 & $\mathrm{~F}$ & +1 & 0,30 \\
\hline Sub-total & & & & & 1,00 & & & 1,00 \\
\hline 2) participação & & & & & 0,15 & & & 0,09 \\
\hline $\begin{array}{l}\text {-conselhos, comitês e } \\
\text { audiências públicas; } \\
\\
\text { - movimentos sociais, } \\
\text { organizações não- } \\
\text { governamentais e } \\
\text { lideranças comunitárias }\end{array}$ & $\mathbf{x}$ & $x$ & $\mathbf{x}$ & & 0,6 & $\mathrm{~F}$ & +1 & 0,60 \\
\hline $\begin{array}{l}\text { - representatividade dos } \\
\text { atores sociais e } \\
\text { instituições envolvidos }\end{array}$ & & $\mathbf{x}$ & & & 0,2 & $\mathrm{~N}$ & 0 & 0,00 \\
\hline Sub-total & & & & & 1,00 & & & 0,60 \\
\hline 3) cooperação & & & & & 0,15 & & & 0,09 \\
\hline $\begin{array}{c}\text {-coordenação entre as } \\
\text { politicas públicas } \\
\text { federais, estaduais e } \\
\text { locais; } \\
\text { - parcerias: sócio- } \\
\text { privadas; público- } \\
\text { privadas } \\
\text { ou co-gestão }\end{array}$ & $\mathbf{x}$ & & $\mathbf{X}$ & $\mathbf{x}$ & 0,40 & $\mathrm{~N}$ & +1 & 0,60 \\
\hline Sub-total & & & & & 1,00 & & & 0,60 \\
\hline
\end{tabular}
conforme detalhado na Tabela5. 


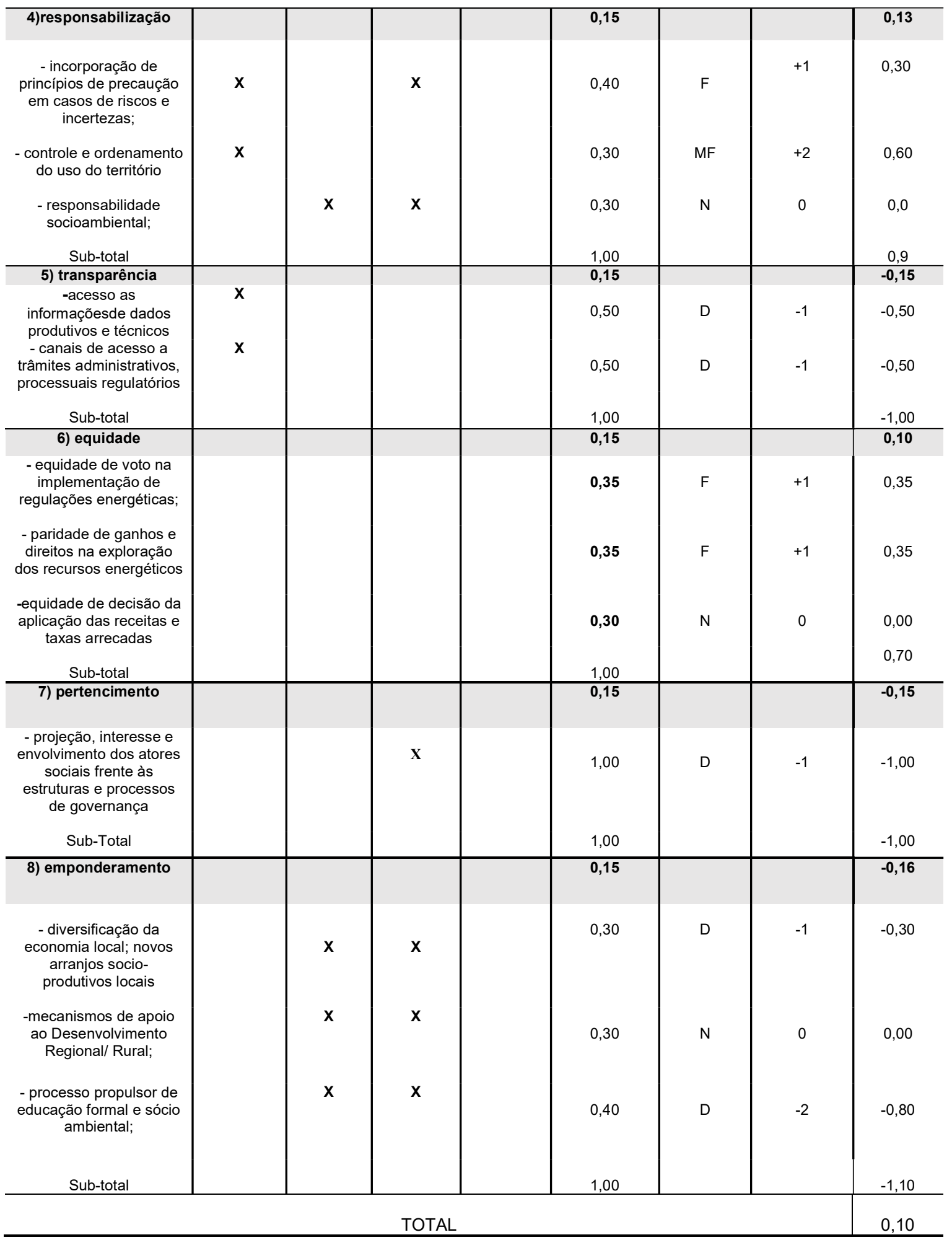

Tabela 5 - Exemplo da avaliação qualitativa-quantitativa dos 'direcionadores de governança de recursos energéticos'.

$\mathrm{MD}=$ muito desfavorável $(-2-) ; \mathrm{D}=$ desfavorável $(-1) ; \mathrm{N}=$ neutro $(0)$; Favorável= $\mathrm{F}(+1)$; $\mathrm{MF}=$ muito favorável (+2).

Fonte: elaborado pelo autor. 
Os resultados obtidos são igualmente expressos dentro de faixas likert's, que variam de -015 a 0,15 nos direcionadores; e de -2 até +2 no resultado agregado do conjuto de direcionadores. Eles permitem montar um gráfico visual de síntese de desempenho dos sistemas de governança (Figura 6). Isso permite 'ligar o farol' de governança dos recursos energéticos, e estabelecer uma ferramenta útil de leitura rápida e identificação visual de gargalos e potencialidades caso a caso.

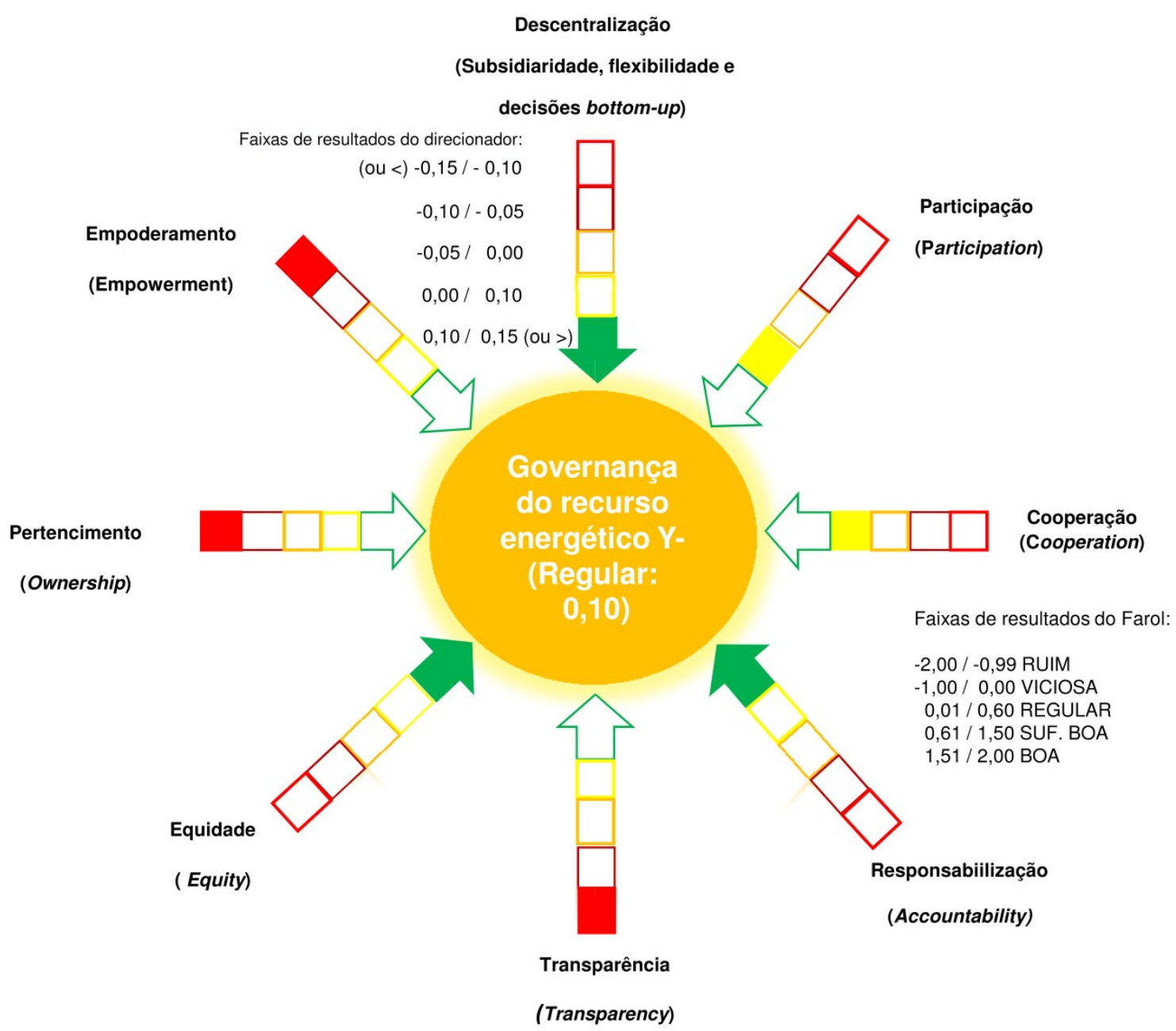

Figura 6 - Farol da governança dos recursos energéticos.

Fonte: elaborado pelo autor.

No exemplo hipotético, ilustrado pela Figura 7, a avaliação de Governança do Recurso Energético "Y", embora tenha atingido ótimas avaliações nos critérios de descentralização $(0,15)$ e responsabilização $(0,13)$; e de bons desempenhos nos atributos de participação $(0,09)$, cooperação $(0,09)$ e equidade $(0,10)$; obteve uma performance ruim nos princípios de transparência $(-0,15)$, pertencimento $(-0,15)$ e empoderamento $(-0,16)$. Essa disparidade na qualidade dos atributos de governança, ou dos índices de desempenho dos direcionadores, resultou 
no valor agregado total de 0,10 . Ficou, portanto, dentro da faixa de 0,01 a 0,60 característico de um sistema de governança regular.

Parte II - Contextualização e descrição das áreas de estudo

3.4 Descrição das áreas de estudo

\subsubsection{Os Polos Gaúchos de Biodiesel (PG)}

Os PG de biodiesel, designação criada pelo Ministério do Desenvolvimento Agrário (MDA), são um dos mais ativos terrritórios de produção de biocombustíveis no Brasil. Ao todo nove usinas de biodiesel com certificações oficiais do governo federal (Selo CombustívelSocial) operam nessas paisagens agroenergéticas (BRASIL, 2016). Três estão entre as seis maiores unidades de produção do país e as outras seis correspondem a plantas de médio e grande porte. Os PG de biodiesel teriam sido responsáveis pela geração de 1.500 empregos diretos, e 6 mil indiretos, e incorporar 38 mil produtores familiares na base produtiva de um setor que gerou desde sua chegada ao Estado, com cerca de $\mathrm{R} \$ 200$ milhões apenas em impostos (RIO GRANDE DO SUL, 2012).

Alguns fatores básicos foram responsáveis pela rápida expansão das indústrias de biodiesel nessas paisagens energéticas. O Rio Grande do Sul é o terceiro maior produtor, e exportador de soja do Brasil com uma área de aproximadamente 5,0 milhões de hectares plantados. É também o maior produtor nacional de canola, com cerca de 30 mil hectares plantados, e um dos três maiores produtores de girassol, com aproximadamente de 20 mil hectares deáreas produtivas (IBGE, 2008; BRASIL, 2014).

Adicionalmente, grandes empresas processadoras de soja e pelo menos 33 cooperativas de produção e comercialização agrícola operam nos PG, sendo expressiva a presença tanto de agricultores empresariais quanto familiares. Os dois tipos de produtores, especialmente, os de soja têm contratos ativos ou têm experiências recentes na oferta de matéria-primas para as empresas de biodiesel. Por isso os PG se estabeleceram como as áreas de maior produção de biodiesel no país sendo responsáveis por cerca de $25 \%$ de toda produção nacional, e por $21 \%$ da capacidade nominal instalada (BRASIL, 2011).

A economia dos PG de Biodiesel (Figura 7), porém, nem sempre esteve ligada ao dinamismo das modernas culturas agroenergéticas. De uma maneira geral, antes da metade do século $X X$, a pecuária era a atividade central nos diversos municípios hoje situados nos Polos Nordeste, Planalto, Alto-Uruguai e Missões. A partir da década de 1960, entretanto, com a incorporação de pacotes tecnológicos da 
revolução verde, ocorreram profundas transformações e reconfigurações socioeconômicas e produtivas nesses espaços. A pecuária tradicional cedeu espaço sistematicamente para a instalação de sistemas agroindustriais intensivos envolvendo a expansão do plantio e beneficiamento de trigo, milho, e, especialmente, a soja (FURSTENAU, 1990).

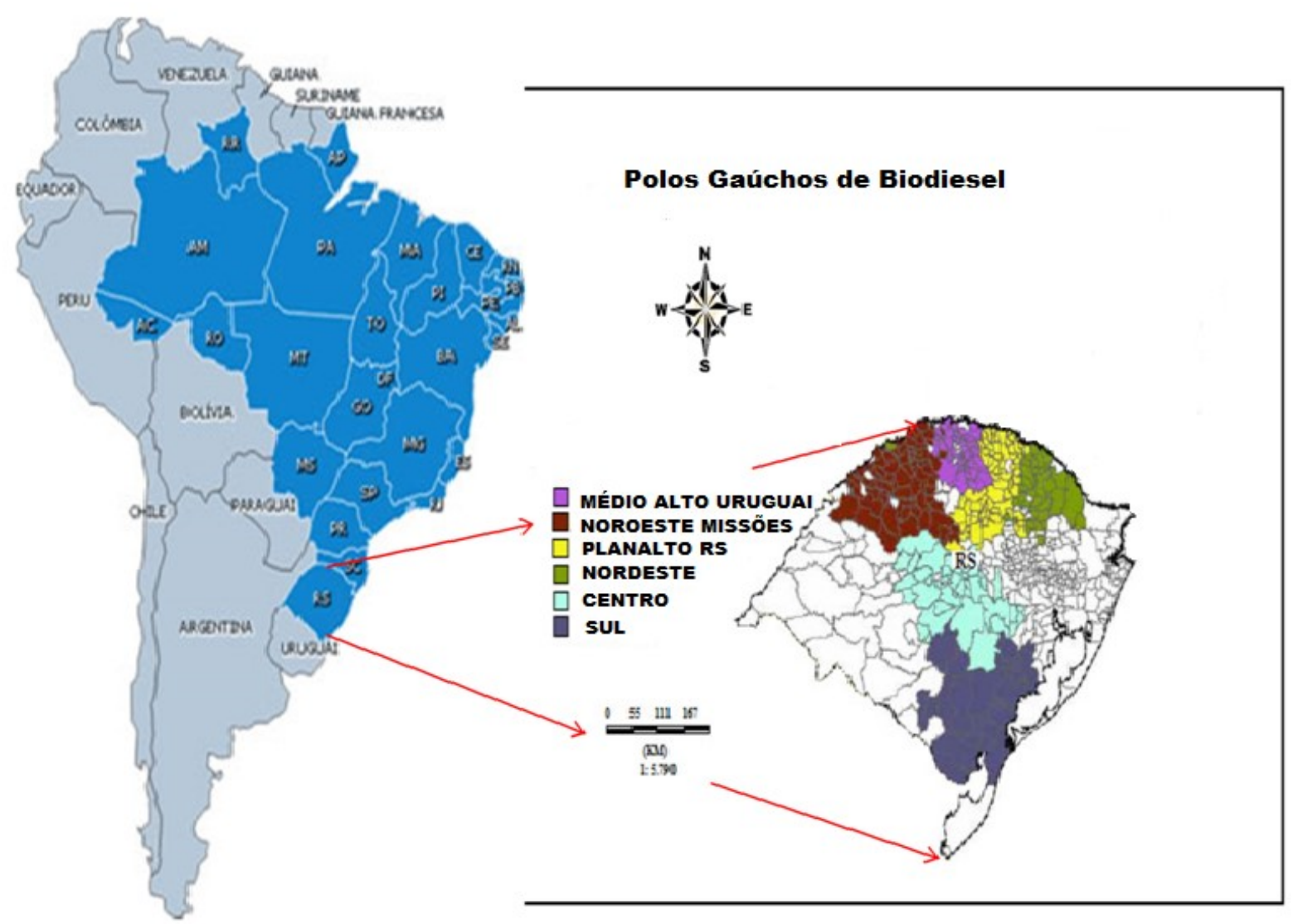

Figura 7- PolosGaúchos de produção de biodiesel. Fonte: adaptado de MDA (2011).

Com condições favoráveis para o desenvolvimento das monoculturas de exportação, e com apoio dos "bons preços internacionais, crédito abundante e barato, o Rio Grande do Sul assistiu a um verdadeiro surto de crescimento na lavoura de soja" (FURSTENAU, 1990: p.219). A produção agrícola, especificamente, da oleginosa, se intensificou adpatando-se ao modelo agroexportador promovendo o 'boom' da produção de soja nas áreas centro-norte, norte e noroeste do Estado (BRUM ET AL., 2005: 6; MOREIRA E MEDEIROS, 2014).

Vale destacar que essas transformações socioeconômicas tiveram reflexos diretos e indiretos em boa parte do país. O crescimento exponencial das atividades agrícolas, a ausência de reforma agrária, e o fracionamento de grandes propriedades, divididas por inventários familiares, promoveram a especulação e a super valorização fundiária no estado. Adicionalmente, a facilidade de acesso aos 
créditos oficiais do Sistema Nacional de Crédito Rural (SNCR), a experiência dos produtores rio-grandenses com a agricultura mecanizada, e a perspectiva de terras baratas e aptas ao plantio no centro-norte do país, conduziram à chamada 'diáspora gaúcha' pelo país (SIMOM, 2009).

Inúmeros produtores gaúchos, apostando no mercado agroexportador da soja, venderam suas propriedades no Rio Grande do Sul e adquiriram grandes parcelas de terra em áreas de expansão da fronteira agrícola brasileira. O processo promoveu a modificação de extensas áreas naturais nos grandes platôs de Cerrados nos estados do Mato Grosso Sul, Mato Grosso, Rondônia, Maranhão, Bahia, Goiás e Minas Gerais (NAVARRO, 1998).

Ao final da década de 1970, e início dos anos 1980, entretanto, houve a retração na comercialização e na intensidade das lavouras de soja. Os impactos negativos atingiram especialmente o Rio Grande do Sul, em decorrência da brusca redução de oferta dos créditos rurais, agravada pela instabilidade dos preços internacionais e a concorrência com novas áreas produtivas no Centro-Oeste. A centralidade da soja não desaparece da economia gaúcha, mas sua pujância é abalada. A retirada dos altos subsídios e empréstimos, somadas às perdas de espaço de outras culturas agrícolas reduzem a competitividade da soja e dos produtores riograndenses (BRUM ET AL., 2005).

O padrão que se estabeleceu ao longo dos anos 1980 trouxe uma realidade de preços modestos para a soja no mercado internacional. Essa condição refletiu-se em crescimentos inexpressivos da produção da soja no Estado. A área cultivada, de uma maneira geral, permaneceu estagnada. Na comparação entre regiões, os estados do Centro-Oeste que tinham $14 \%$ da participação de soja no país no início da década de 1980, passaram a ter 36\% em 1998. A região Sul, por sua vez, perde sua competitividade, caindo no mesmo período, de $77 \%$ da produção total brasileiro para 40\% (BRUM ET AL., 2005).

Um novo período de crescimento da participação da soja na economia do estado ocorre na segunda metade da década de 1990, ligada a retomada ao crescimento da demanda, e dos preços e às condições favoráveis de acesso ao mercado internacional. Desonerações fiscais na exportação de produtos primários, oferecidas pela Lei Kandir em 1996, o reestímulo às vantagens comparativas e créditos agrícolas e as demandas expressivas do mercado chinês e europeu voltaram a estimular o volume de soja produzida e exportada em grão em todo país, e para o Rio Grande do Sul (ANHOLETO E MASSUQUETI, 2014).

A emergência da política industrial do biodiesel, no início da década de 2000 , está ligada a essa retomada internacional da soja e à vasta oferta de óleo de 
soja, considerado quase um subproduto no beneficiamento da oleaginosa. O setor foi atraído pela presença da cadeia produtiva bem estruturada, de políticas públicas vantajosas, e da super oferta de insumos. Medidas legais que incluíam subsídios e linhas de créditos especiais para aquisição de terrenos e de equipamentos de produção. De fato, a entrada da indústria do biodiesel trouxe uma opção vantajosa para as empresas processadoras de soja, em especial, pela nova destinação a ser dada ao óleo vegetal.

Desde então, cresceu a influência das atividades das empresas do setor na economia local dentro dos municípios inseridos nos Polos Gaúchos. A cidade de Rosário do Sul, por exemplo, presenciou a chegada de uma planta capaz de processar 130 milhões de litros. Durante curto tempo a cidade de apenas 40 mil habitantes viu seu PIB municipal aumentar de R\$ 314 milhões para 597 milhões. Em 2008, entretanto, com a perda do Selo Combustível Social (SCS) e problemas de gestão a planta fechou gerando desemprego e desvalorização imobiliária local.

$\mathrm{Na}$ direção contrária, outras cidades continuaram com a expansão das atividades de outras indústrias concorrentes. Nos municípios de Veranopólis, Cachoeira do Sul, ljuí, Erechim e Passo Fundo, por exemplo, plantas de outras grandes empresas produzem juntas aproxidamente 1,3 bilhões de litros de biodiesel por ano. Parte desses municípios, e seus governos, destacam a responsabilidade do setor por gerar milhares de empregos diretos e indiretos, mas relatam também pressões nos serviços básicos de infraestrura (BOREKI, 2013).

A despeito de qualquer externalidade negativa, as indústrias de biodiesel e setores do Governo Federal enfatizam a produção de biodiesel nos PG como atividade promissora, seja para geração de 'energia sustentável', seja para promoção do desenvolvimento regional e rural dos territórios agrícolas. A tônica do PNPB, e dos materiais de divulgação das indústrias ligadas ao setor, é que a produção de biodiesel estaria cercada de características socioeconômicas capazes de estimular a densidade e articulação institucional, e promover a formação de arranjos socioprodutivos inéditos. Os materiais de divulgação das indústrias, e do Governo Federal, concentram-se principalmente na capacidade do setor em promover mecanismos de participação e cooperação entre agricultores, sindicatos rurais, cooperativas de produção, indústrias de óleo vegetal e de biodiesel no país (BRASIL, 2011).

\subsubsection{Desafios à governança de biodiesel no Brasil}

Desde a implemetação dos programas de biocombustíveis no Brasil, e de suas políticas públicas complementares, muitos arranjos político-institucionais se 
formaram para consolidar as respectivas cadeias produtivas. De maneira geral, até a década de 1990, os mecanismos de gestão política e mercado de biocombustíveis foram determinados quase que exclusivamente por mecanismos de comando e controle centralizados pelo Governo Federal. Muitos instrumentos, ainda utilizados, foram instituídos por meio da obrigatoriedade da mistura dos biocombustíveis aos combustíveis fósseis (álcool/ gasolina - biodiesel/diesel), estipulação de preços mínimos, subvenções para participação de atores sociais específicos e de mecanismos de incentivo econômico como subsídios, isenções e créditos especiais (HERRERA, 2014).

A experiência com o etanol, por exemplo, foi marcada durante anos por um sistema de gestão fortemente centralizado, caracterizado por uma estrutura de governo forte, e por regulação e gestão bastante centralizados e hierárquicas do tipo top-down. A governança do etanol se consolidou baseada na presença de poucos atores sociais, concentrado em orgãos do Governo Federal, agências oficiais como a Empresa Brasileira de Pesquisa Agropecuária (Embrapa), e empresários (usineiros e grandes proprietários de terra do setor canavieiro).

A partir da internacionalização dos mercados de biocombustíveis, no contexto de enxugamento das estruturas de gestão de Estado em diferentes países, incluindo o Brasil, novos atores sociais e instituições foram inseridos nos sistemas de governança de biocombustíveis (HERRERA, 2014). Houve a incorporação de participantes não-estatais oriundos da sociedade civil organizada e do mercado (JACKSON E DEEG, 2008). Uma transição significativamente influenciada pela propagação de convenções internacionais e certificações socioambientais de combustíveis justos, ou fair fuels, decisivos na definição de procedimentos produtivos domésticos e no acesso a mercados globais (MOL, 2010).

A governança do biodiesel surge nesse contexto, procurando proporcionar ambientes organizacionais e produtivos inovadores, por meio da participação e cooperação, interligando Estado, sociedade e mercado por meio das indústrias de biodiesel, óleo vegetal, cooperativas de produção agrícola, associações, sindicatos rurais e agricultores familiares na escala regional/local.

Para Favareto (2008), "a estrutura de governança dos arranjos produtivos [do biodiesel] trouxe implicações econômicas, sociais e ambientais nada desprezíveis" (p.18). A governança trouxe, entretanto, questionamentos sobre o real teor de inovação, responsabilização e equidade nesses arranjos. Ela gerou dúvidas sobre a compatibilidade entre os discursos e comportamentos dos atores, os mecanismos e incentivos criados e a incorporação de elementos de inclusão políticosocial, racionalidade e precaução ambiental. 
Ainda de acordo com Favareto (2008), levando em consideração que o mercado do biodiesel se formou sob forte influência de critérios socioambientais tornou-se fundamental considerar a eficiência dos sistemas de governança do programa. Para o autor, os dispositivos vigentes, mecanismos e certificações do PNPB se reveleram insuficientes frente aos impactos socioambientais negativos. Para ele, seria necessário reestruturar regras e estruturas de gestão, na forma de alocação dos recursos, participação e inovação social nos sistemas locais de produção e organização do segmento. E ainda, a forma como estão estabelecidos os direitos, as concepções de controle sobre o acesso e o uso aos recursos e, finalmente, as regras de troca (FAVARETO ET. AL., 2011; DINIZ \& FAVARETO, 2012).

Segundo Stattman et.al. (2013) os sistemas de governança do biodiesel no Brasil promoveram uma maior articulação entre diferentes ministérios e outros stakeholders não-estatais do mercado e da sociedade civil. Mas a despeito das estruturas criadas, na prática, as formas de regulação e gestão continuam bastante centralizadas, em especial, pela manutenção de mecanismos de subsídios na exploração das vantagens comparativas agrícolas e energéticas. Além disso, os arranjos político-institucionais do biodiesel não estariam conseguindo evitar a concentração geográfica produtiva e o domínio de grupos de interesse, restando pouca influência prática de outros setores sociais (STTATMAN ET AL., 2014).

Partindo de raciocínio semelhante, Hall et al. (2009) chegaram a traçar paralelos entre a "teoria da maldição dos recursos" e a "maldição do (bio)óleo" (p.2), afirmando que o crescimento pujante do setor estaria assentado numa distribuição desigual dos ganhos e impactos socioambientais gerados. Para os autores, os arranjos político-institucionais seriam os principais responsáveis pelas políticas inadequadas e os efeitos adversos, que entre outros impactos estariam realçando a dependência de regiões e terriórios das oscilações de commodities agrícolas internacionais e dos passivos ambientais.

A sustentabilidade do biodiesel estaria ligada, portanto, à qualidade do processo de governança, ligada às condições de implementação política e aos padrões de eco-governamentalidade nas quais essas cadeias produtivas são inseridas e reguladas, tanto no âmbito nacional quanto internacional (HERRERA, 2014). As relações assimétricas de poder e o domínio dos espaços deliberativos seriam os fatores de maior impacto na sustentabilidade desses recursos energéticos (HUMPHREYS ET AL. 2007).

A partir desse pressuposto, os sistemas de governança na regulação e produção de biodiesel se revelam como estruturas-chave para compreensão de potencialidades, mas também dos desafios e contradições na exploração de energia. 
Pesariam além de climas seguros e incentivos para as indústrias, a incorporação de da participação política e a representatividade dos atores envolvidos.

Além da lógica das certificações de venda e produção, contaria o equilíbrio entre os objetivos socioeconômicos e ambientais (SCHUT, 2013). Um problema de ordem legal que envolve esforços políticos na construção de estruturas de regulação que assegurem a transparência e a equidade dentre um universo de relações de poderes assimétrico (LIMA, 2009).

Segundo Stattman et. al. (2013), o desenvolvimento do setor de biodiesel acabou sendo dominado por grupos de interesses do setor agroindustrial sojicultor. Para os autores, outras matérias-primas não alcançaram o suporte adequado de atores estatais e instituições para obter uma resposta rápida às suas capacidades produtivas. Na prática, o PNPB seguiu a mesma lógica do Proálcool, mantendo ênfase na quantidade e velocidade da oferta de insumos. Para eles, os sistemas de regras, normas e ordenamentos não foram capazes de estabelecer uma governança autônoma para o biodiesel. De modo geral, as regulações e prioridades foram dominadas pelos grupos de interesses da agroindústria interessadas em ingressar no setor energético, excluindo sistematicamente questões socioambientais.

Tais considerações fizeram com que Pádula et. al. (2012), abrissem um debate ético sobre a manutenção do layout atual do PNPB considerando que: i) a produção de biodiesel é artificialmente rentável, baseada em uma estrutura de reduções de taxas e isenções em favor de um setor industrial dominado por grandes companhias; ii) a estrutura politico-instituicional do programa não foi capaz de diversificar as culturas agrícolas e inserir a agricultura familiar; iii) os altos níveis de demandas sociais e carências estruturais não justificam os altos recursos empregados na forma de subsídios para um setor rico e pujante. Para os autores, essas razões seriam suficientes para redesenhar as diretrizes, objetivos e sistemas de regulacão do PNPB, beneficiando diretamente a fase agrícola, e criando novas formas e oportunidades de participação da agricultura familiar.

\subsubsection{Os folhelhos texanos de Eagle Ford Shale (EFS)}

A denominação Eagle Ford Shale descreve uma das maiores e mais lucrativas áreas de exploração de hidrocarbonetos de xisto em todos Estados Unidos. Localizado no sul do estado do Texas, EFS atraiu em 2012 investimentos da ordem de US\$ 19 bilhões, e aproximadamente US\$ 28 bilhões em 2013. Investimentos realizados por companhias energéticas em projetos de infraestrutura, tais como centros de operações, tubulações, dutos, terminais de estocagem e plantas de 
processamento (TUNSTALL ET AL. 2014; TUNSTALL ET AL.2015a). Segundo Dittrick (2012) e Hughes (2015) o atual volume de capital físico e financeiro coloca EFS como a reserva de folhelho mais explorada no mundo.

Pelo menos vinte e seis condados texanos estão localizados sobre o depósito de Eagle Ford Shale (Figura 8). Atascosa, Bee, Bexar, Brazos, Burleson, DeWitt, Dimmit, Edwards, Fayette, Frio, Gonzales, Houston, Jim Wells, Karnes, La Salle, Lavaca, Lee, Leon, Live Oak, Maverick, McMullen, Milam, Nueces, San Patricio, Victoria, Webb, Wilson, Wood, Uvalde e Zavala. A maior parte dessas localidades passou por consideráveis mudanças socioeconômicas a partir da segunda metade do seculo passado.

No passado, quase todas as cidades de EFS avançaram nas atividades nas atividades agrícolas, com mecanização e pacotes tecnológicos da revolução verde que reduziram muito o número de trabalhadores braçais empregados. O subsequente êxodo rural fez com que alguns condados como DeWitt, Dimmit, Gonzales, Karnes, La Salle, e McMullen perdessem até $40 \%$ de suas populações entre 1950 e 2010 . As cidades de San Antonio, Dallas, Houston e Austin foram responsáveis pela absorção do fluxo migratório, com crescimento expressivo de suas populações. Em contrapartida, a maior parte das pequenas e médias cidades da região estagnou ou decaiu economicamente (TUSNTALL et al.2015a).

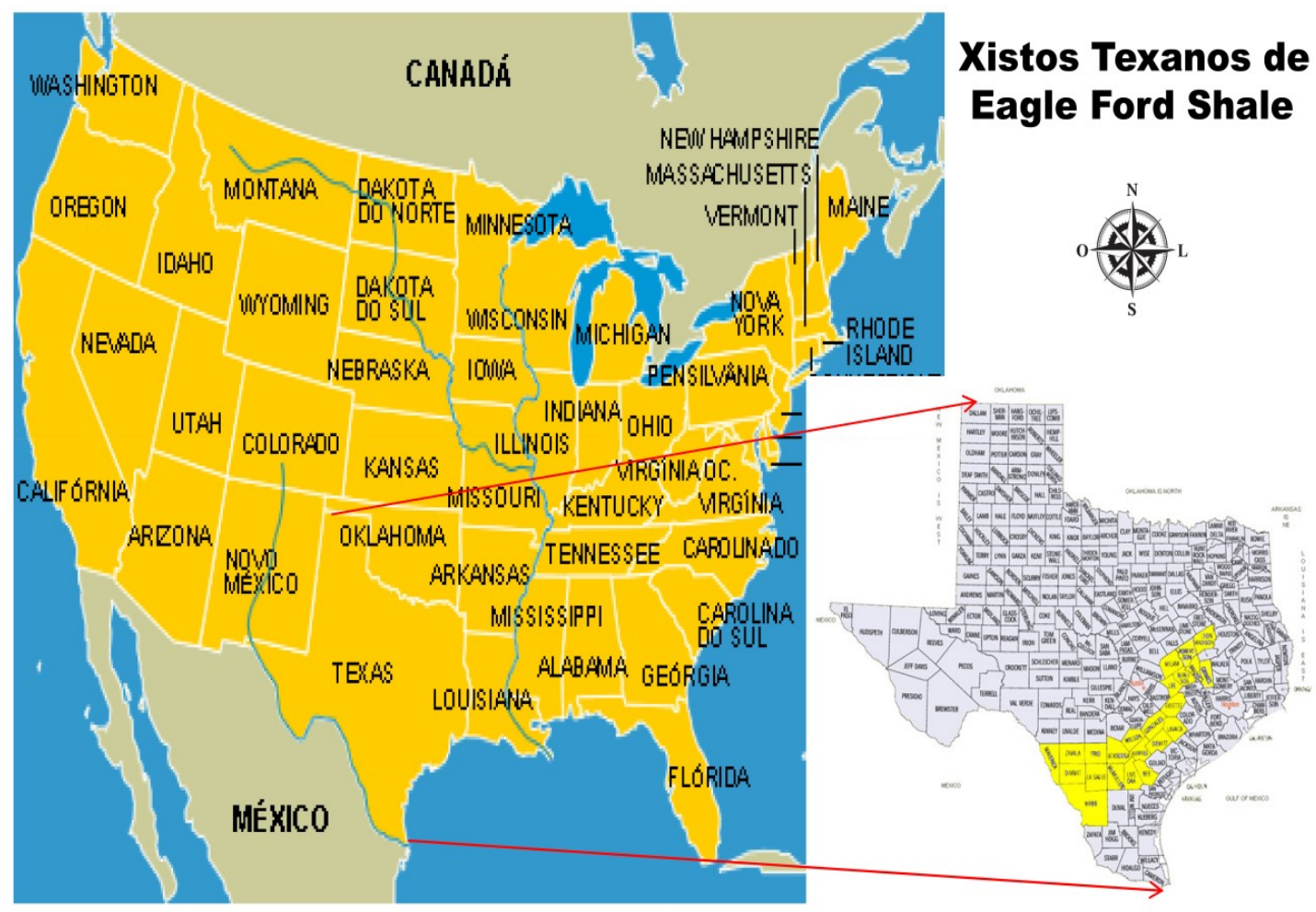

Figura 8 - Folhelhos texanos de Eagle Ford Shale.

Fonte: eaglefordshaleoiljobs.com (2015). 
Segundo Tunstallet al. (2015a), o desenvolvimento econômico desigual no sul do Texas promoveu o surgimento de cidades fantasmas. Comunidades inteiras que expandiram suas populações entre o final do século XIX e início do século XX não conseguiram se enquadrar aos novos ciclos econômicos do período do pós-guerra. Além do declínio das ocupações nas atividades agrícolas, muitas cidades pereceram por causa de sua distância em relação a novos eixos rodo/ferroviários, de secas prolongadas e da relocação de assentamentos provocados pela criação de reservatórios e lagos artificiais (BAKER, 2003).

A área da bacia permiana do Texas, onde atualmente se desenvolvem parte das atividades de EFS também testemunharam num passado não muito distante uma corrida de empresas e funcionários do setor de energia. A exploração de petróleo não é, definitivamente, uma novidade no estado do Texas, e boa parte dos municípios do sul do estado tem alguma experiência na exploração do recurso. Entre o final da década de 1970, e o início dos anos 1980, a extração de poços por métodos convencionais das camadas sedimentares dos depósitos de Austin chalk promoveu o boom do petróleo e da economia local.

Muitos condados como Lee, Burleson, Fayette, Gonzales, Washington, Brazos e Bastrop encararam a chegada das atividades como uma benção para a recuperação econômica. Em um curto intervalo de tempo, várias cidades como Giddings, no condado de Lee, presenciaram a construção de centenas de poços e o aumento exponencial das taxas de arrecadação, impostos e tarifas. Famílias de fazendeiros e rancheiros que ainda detinham seus direitos minerais incrementaram suas rendas de concessão/aluguel de terras para as companhias de petróleo. Entretanto, isso não trouxe apenas aspectos positivos (HARRY, 1981).

O boom das atividades do petróleo promoveu o desequilíbrio na oferta e na demanda de mão-de-obra, atraindo fluxos expressivos de trabalhadores. Isso promoveu o aumento repentino dos valores de produtos de primeira necessidade e provocou pressão sobre a infra-estrutura de serviços locais, sobretudo, moradia, transporte e segurança. A intensificação do fluxo de dinheiro atraiu igualmente atividades ilegais e a criminalidade. Muitos fazendeiros acusaram as companhias - e seus funcionários - de derespeitar seus limites de propriedade, derrubar cercas, danificarem estradas, poluírem córregos, corpos d'água e praticarem caça ilegal. $\mathrm{O}$ rápido declínio das reservas e a subsequentemente desaceleração das atividades de exploração indicou não apenas o fim da pujância econômica, mas de todo uma janela de oportunidades (HARRY, 1981).

A identificação das atuais reservas recuperáveis de hidrocarbonetos de xisto, e dos respectivos volumes e qualidade dos depósitos de EFS reacendeu a 
expectativados condados e seus municípios de retomar seu desenvolvimento perdido. Essa esperança se baseia grande parte, à descoberta das características geológicas dos depósitos de EFS que contêm grandes quantidades não somente de gás natural, de gás natural líquido, ou condensate, mas também de petróleo bruto (Figura 9).

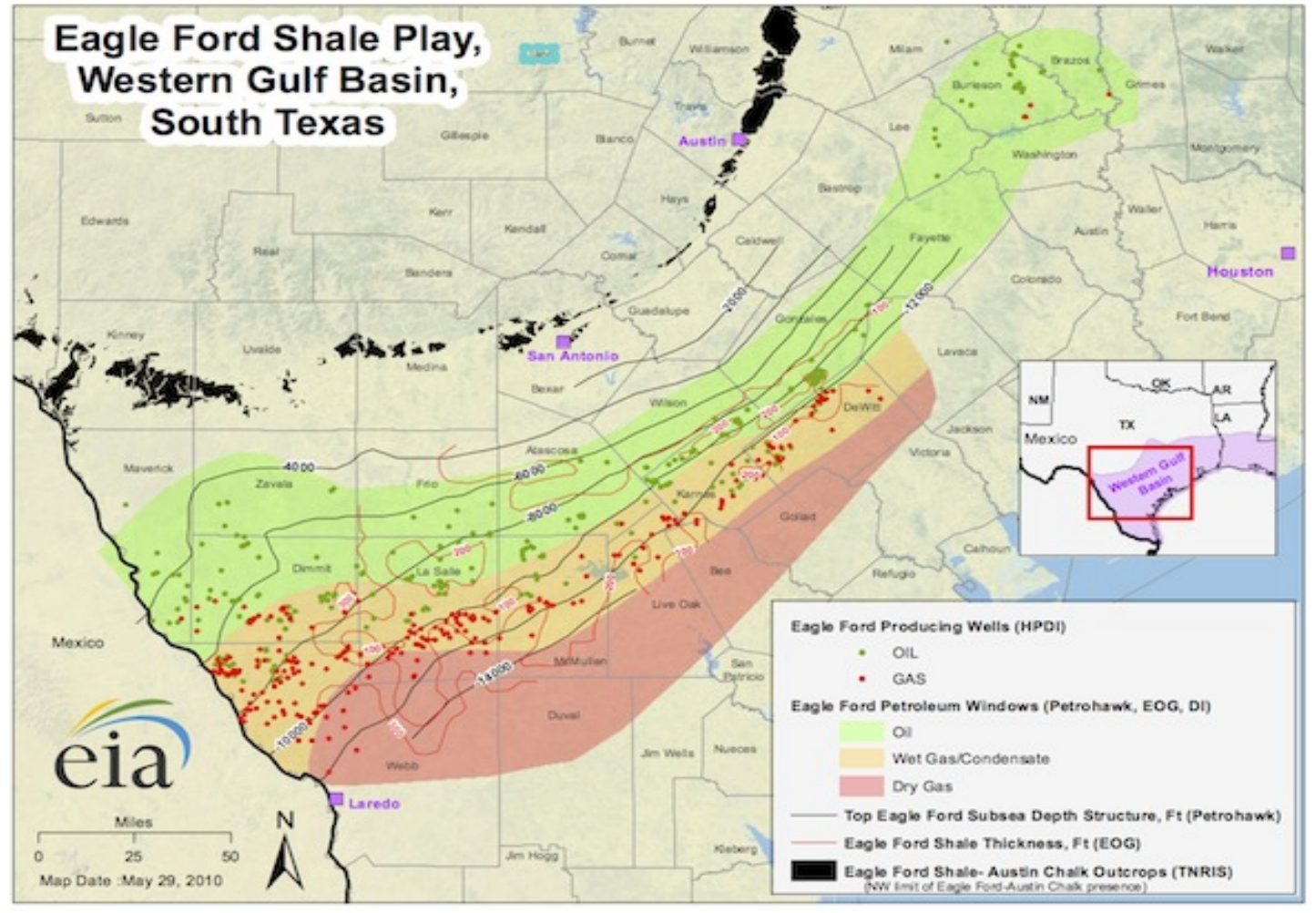

Figura 9 - Delimitação das áreas dos principais hidrocarbonetos de Eagle Ford Shale. Fonte: E.I.A (2010).

A potencialidade mineral, entretanto, trouxe novamente o desafio para as cidades inseridas em EFS quanto à definição/redefinição de normas coletivas de aproveitamento e uso desses recursos energéticos. Na implementação e definição de regulações apropriadas capazes de diversificar as economias locais e evitar a repetição dos mesmos erros cometidos no passado. As comunidades de EFS encaram o desafio de gerir a potencialidade dos shales e fugir dos efeitos indesejáveis da "maldição dos recursos", a partir do qual países, ou mesmo territórios ricos em recursos naturais não conseguem melhorar seus níveis socioeconômicos por razão do mau emprego e da má gestão da riqueza gerada durante os auges de exploração dos recursos naturais (SACHS E WARNER, 1995, 2001).

Se por um lado os prefeitos, city managers e conselheiros locais dos municípios têm novamente as vantagens de administrar um crescimento substancial no fluxo de receitas e arrecadações, por outro lado, têm a tarefa de superar os prováveis desafios socioeconômicos e ambientais atrelados ao shale boom. $\mathrm{O}$ 
principal deles é a superação dos chamados 'efeitos de exclusão' provocados pelo auge da produção energética. Um fenômeno de concentração excessiva nas atividades de prospecção e exploração dos hidrocarbonetos que acaba por marginalizar, ou invialibilizar, outros negócios e processos de desenvolvimento local/regional.

Os desafios estão correlacionados também aos impactos que o novo pico provoca nos setores de infraestrutura e serviços, como habitação, transporte, comércio, segurança e saúde pública. Muitas cidades inseridas na área de Eagle Ford apresentam descompassos entre a demanda e a oferta do setor de habitação. Valores inflacionados de imóveis e aluguéis têm causado impacto no acesso à moradia. Em algumas cidades, a resposta tem se condicionado ao aumento desproporcional do número de hotéis, motéis e acampamentos de trabalhadores, ou trailer parks.

Além disso, os salários de baixa especialização oferecidos pelo setor de energia têm criado obstáculos para contratação de mão-de-obra nas áreas de serviço e comércio local. Empresários no setor de restaurantes, lojas de varejo, e mesmo serviços públicos têm encontrado dificuldades em contratar e reter funcionários. Todos esses fenômenos criam obstáculos impactantes para o desenvolvimento de outros setores industriais não ligados direta ou indiretamente ao setor energético (TUNSTALL ET AL, 2015).

Outro fator ligado à intensificação das atividades de exploração dos hidrocarbonetos é o aumento do tráfego gerado por veículos pesados. O volume de cargas aumentou consideravelmente o trânsito de veículos pesados nas principais auto-estradas, rodovias secundárias e nas vias de acesso a áreas rurais, conhecidas como farm to market. São comuns carretas transportando água, areia, fluídos, resíduos, equipamentos, materiais de construção pesados e funcionários das empresas do setor energético. A sobrecarga tem provocado danos estruturais na pavimentação asfáltica e o aumento da periculosidade e acidentes (TUNSTALL ET AL, 2015). Todas essas questões de infraestrutura em segurança, saúde pública, transporte e moradia, de prioridade para estratégias de investimentos e recursos passam necessariamente pela estrutura, qualidade e processo de governança correlacionado à regulação e exploração dos hidrocarbonetos. 


\subsubsection{Desafios gerais à governança dos folhelhos nos Estados}

Unidos

O 'boom' da produção de hidrocarbonetos não-convencionais promoveu um intenso jogo e relações de forças entre empresas, sociedade e governo em torno da definição das regulações para o setor. As relações se dão dentro de um quadro de otimismo quanto ao novo dinamismo econômico propiciado pelas novas atividades, mas também pelas incertezas e riscos para as localidades e regiões envolvidas. Diante desses dilemas é que se estabelecem as discussões sobre as regulações da exploração de hidrocarbonetos não-convencionais nos Estados Unidos (EIA, 2011).

Uma pesquisa comportamental conduzida pela Carnegie Mellon University procurou identificar os principais dilemas e controvérsias coligadas às regulações dos shales, tendo como foco as percepções de atores sociais nas comunidades impactadas pela exploração de Marcellus Shale no Estado da Pensilvânia (PAROGI, 2014). Seis pontos principais foram revelados entre as respostas mais comuns dos entrevistados:

i) prevalece a cultura corporativa industrial nos processos deliberativos; ii) os "atalhos regulatórios", ou exceções obtidas pelas indústrias reduzem a autonomia das autoridades para regular as atividades, agravado pela falta de tempo, experiência e recursos dos governos locais; iii) São comuns a inadequação de informações e os dados imprecisos e parciais sobres os impactos das atividades de fracking. As indústrias são protegidas por mecanismos legais de não-divulgação de elementos químicos utilizados no fracking; iv) não há uma responsabilização (accountability) adequada para o setor industrial em casos de desrespeito e negligência que causem danos socioeconômicos e ambientais às comunidades; v) os critérios de justiça ambiental inexistem e vi) a participação pública é inadequada, e as opiniões são moldadas por visões polarizadas.

Apesar das críticas constatadas por Small et. al. (2014), os resultados revelaram também um ceticismo ambiental entre boa parte dos entrevistados que, de uma maneira geral, não acreditam que existam dados suficientes e razões para condenar a atividade. $O$ trabalho destaca que embora existam incertezas, falta um debate aprofundado e a incorporação de princípios de precaução ou mesmo de critérios de justiça ambiental na regulação local da exploração dos folhelhos. Para os autores, importantes questões não esclarecidas colaboram para o aumento dos riscos e incertezas na exploração dos shales, sobretudo, a escassez de conhecimento e de 
estudos de possíveis ameaças à saúde pública, de impactos sobre os ecossistemas, qualidade da água e do ar, e de impactos socioeconômicos.

De acordo com Rabe (2014), um dos principais problemas dos sistemas de governança dos folhelhos nos Estados Unidos é o federalismo sub-estatal americano, com a descentralização de poderes e pouco controle dos Governos Estaduais e Federal. Parte considerável do poder de regulação é controlado pelos governos locais e, apesar da possibilidade de intervenção e controle pela União, as leis e normas federais acabaram por beneficiar o setor energético por meio de exceções estatutárias, ou statutory exemptions, que desobrigaram o setor de fiscalizações mais rígidas. Para Rabe, as formas de regulação das atividades de exploração dos folhelhos levantam dúvidas quanto às implicações de delegar tanto poder para os sistemas de governança local. O autor conclui que a aposta é ariscada, e que dois caminhos opostos podem ser esperados: o mais comum, uma corrida competitiva de mentalidade político-econômica, sem maior critério ambiental, ou a formação - surpreendente - de mecanismos inovadores de diversificação econômica, incorporando princípios ambientais, de transparência e engajamento público.

Uma pesquisa da University of Florida enfatiza as dificuldades de aprimorar o sistema de governança de petróleo e gás não-convencional a partir da complexidade das escalas de regulação no país. Os estados norte-americanos têm múltiplas agências regulatórias, e governos locais com diferentes níveis de autonomia, atribuições e competências para a regulação do setor. A chave do problema seria uma definição de formas para que todas essas instituições consigam desenvolver mecanismos de distribuição de competências e ações conjuntas mais equilibradas e efetivas. O estudo indica que a promoção de uma governança regional envolvendo diferentes estados poderia atenuar algumas demandas, e sugere que o Governo Federal poderia estar mais presente oferecendo bases regulatórias e políticas unificadoras de taxas, permissões e procedimentos (WISEMAN, 2014).

De uma maneira geral as questões e discussões que direcionam as pesquisas recentes sobre o assunto envolvem tópicos sobre a heterogeneidade na gestão e regulação do setor. Os autores questionam a competência dos estados e governos locais para gerir, controlar e fiscalizar empresas e agentes públicos. Seguidamente são questionados o papel do Governo Federal, da mídia e da confiança entre os atores sociais na precaução dos riscos e incertezas. Os debates envolvem também os tipos de regulação necessários, oscilando entre os mecanismos de comando e controle, e mecanismos de incentivos econômicos e certificações.

As indústrias do setor energético argumentam que a uniformização permitiria um ambiente mais propício e previsível ao desenvolvimento do setor. 
Governos locais, por outro lado, contra-argumentam que uma legislação do tipo 'onesize-fits-all' é inapropriada, pois existem particularidades sociais, econômicas e geológicas nas cidades, municípios e áreas de exploração que devem ser consideradas separadamente (DAVIS, 2014).

Parte III - Aquisição dos dados, perfil dos respondentes, instrumentos e posicionalidade

3.5 Processo de aquisição dos dados, perfil dos respondentes, instrumentos e posicionalidade nas áreas de estudo

\subsubsection{Polos Gaúchos (PG)}

i) Aquisição de dados e perfil dos respondentes

Todos os dados primários do estudo de caso de produção de biodiesel foram coletados nos meses de abril, maio e junho de 2014. Foram visitadas oito cidades na área dos PG. Foram conduzidas entrevistas semi-estruturadas com atores sociais, nas áreas urbanas, e em zonas rurais, com representantes de instituições e empresas envolvidas na cadeia produtiva do biocombustível. (Tabela 6).

Foram ouvidos engenheiros agronômos da Embrapa, presidentes de cooperativas agrícolas, sócio-diretores de associações, consultorias agrícolas, diretores de sindicatos de trabalhadores rurais, gerentes de indústrias de óleo vegetal e biodiesel, além de agricultores rurais (familiares e empresariais), nas cidades de Água Santa, Erechim, Giruá, Ibiaça, ljuí, Lagoa Vermelha, Passo Fundo, Tapejara e São José do Ouro. Foram ouvidos também agentes oficiais do Ministério de Desenvolvimento Agrário (MDA), do Desenvolvimento, Indústria e Comércio (MDIC).

As questões e os temas das entrevistas se distribuíram de acordo com o perfil dos respondentes, concentrados no processo agrícola e industrial, mas tendo como núcleo comum para todos entrevistados, indagações relativas aos arranjos político-institucionais da cadeia produtiva do biodiesel (eficácia das políticas públicas, impressões e perspectivas futuras, incentivos, subsídios, tecnologia, investimentos, participação local, cooperação das instituições e inovação). 


\begin{tabular}{|c|c|c|}
\hline $\begin{array}{l}\text { Atores sociais } \\
\text { (Stakeholders) }\end{array}$ & Instituições & Respondentes/ eventos \\
\hline Agentes oficiais & $\begin{array}{l}\text { Ministérios: do Desenvolvimento } \\
\text { Agrário; do Desenvolvimento, } \\
\text { Indústria e Comércio } \\
\text { (MDA, MDIC) }\end{array}$ & 4 \\
\hline Engenheiros agronômos & $\begin{array}{c}\text { Empresa Brasileira de Pesquisa } \\
\text { Agropecuária (Embrapa) }\end{array}$ & 3 \\
\hline Gerentes/presidentes & cooperativas agrícolas & 6 \\
\hline Sócio-diretor & $\begin{array}{l}\text { associação de produtores \& } \\
\text { consultoria agrícola }\end{array}$ & 1 \\
\hline $\begin{array}{c}\text { Agricultores familiares e } \\
\text { empresariais }\end{array}$ & - & 14 \\
\hline Diretores & $\begin{array}{c}\text { sindicatos de trabalhadores } \\
\text { rurais }\end{array}$ & 2 \\
\hline Gerentes & indústrias de biodiesel & 4 \\
\hline Gerentes & indústrias de óleo vegetal & 1 \\
\hline
\end{tabular}

Tabela 6 - Atores sociais e instituições envolvidas na aquisição de dados primários (PG).

Fonte: elaborado peloautor.

Dentre os dados secundários, foram utilizados matérias das principais revistas em circulação sobre biodiesel: BiodieselBR; Biodiesel em Foco; Agroenergia em Debate; além de folders institucionais das indústrias e suas confederações; atas públicas, propostas de lei, e materiais de divulgação de ministérios e secretarias de Governo Federal/Estadual. Foram analisadas também entrevistas em jornais e revistas de circulação local/regional, além de artigos de períodicos científicos, artigos acadêmicos e livros publicados. De especial importância foi a análise de materiais relativos aos processos e órgãos do PNPB e, do projeto Polos de Biodiesel do Ministério do Desenvolvimento Agrário (MDA).

ii) Padrões, instrumentos e procedimentos de pesquisa

Os padrões e instrumentos do estudo de caso nos PG de produção de biodiesel seguiram as normas estabelecidas pela Resolução nr. 466/2012 do Ministério da Saúde e Conselho Nacional de Saúde (MS/CNS) referente à ética, à proteção e ao sigilo necessário em pesquisas científicas. A partir dos consentimentos dos respondentes para a gravação das entrevistas, foram realizadas entrevistas com o objetivo de colher as percepções, subjetividades e discursos dos atores frente ao processo de regulação e produção do biodiesel no Brasil, no Estado do Rio Grande do 
Sul e nos PG. Além das entrevistas agendadas, parte dos procedimentos seguiu a conduta de 'bola-de-neve', ou snowball, na qual alguns dos respondentes indicaram novos possíveis atores para participar das entrevistas.

As entrevistas seguiram um roteiro de perguntas-chave. Ao todo, foram entrevistados vinte e nove (24) atores sociais em conversas que oscilaram entre 45 minutos e 1 hora de duração. Todas as entrevistas foram transcritas e se transformaram em documentos primários dentro das unidades hermenêuticas do programa Atlas.ti. gerando ao final um corpo de trinta e nove (39) códigos atrelados as passagens e citações analisadas. Os códigos e as citações estão apresentados detalhadamente no apêndice da tese.

iii) Posicionalidade frente à área de pesquisa

A etapa de pesquisa de campo e obtenção de dados nos PG foi possível graças aos recursos do Programa de Apoio a Pós-Graduação da Capes (Proap). Adicionalmente, a inserção, o deslocamente, e mesmo o diálogo, dentro dos PG foi facilitada, em grande parte, pela familiaridade com o estado do Rio Grande do Sul e, em especial, com as cidades localizadas nos Polos Nordeste, Planalto e Noroeste-Missões. Apresença de familiares nesses territórios permitiu a permanência, e a realização de visitas. A familiaridade com a região permitiu também uma maior percepção das transformações ocorridas a partir do novo 'boom' da soja no final da década de 1990 e, também, pelas indústrias de biodiesel na primeira metade da década de 2000 .

Muitos produtores agrícolas nos Polos Nordeste e Planalto, incluindo pequenos e médios proprietários de terras, intensificaram os seus sistemas soja/milho de plantio, e optaram por arrendar uma parte ou a totalidade de suas terras para terceiros. A figura do 'granjeiro', regionalismo local para designar os arrendatários rurais se tornou comum; uma parcela de produtores passou a viver das rendas agrícolas e residir nas cidades próximas. Atualmente, a paisagem desses territórios é marcada por um volume expressivo de silos, instalações de armazenamento e beneficiamento de grãos pertencentes a três grandes segmentos: cooperativas agrícolas, pequenas e médias empresas cerealistas e indústrias de biodiesel. Não é difícil observar como as atuais dinâmicas produtivas e comerciais trouxeram pressões e modificações do padrão tradicional das atividades econômicas e como o ciclo traz novos desafios aos remascentes de áreas naturais na região. 


\subsubsection{Eagle Ford Shale (EFS)}

i) Aquisição dos dados e perfil dos respondentes

A aquisição dos dados do estudo de caso nos Estados Unidos foi realizada nos meses de dezembro, janeiro e fevereiro de 2015. Foram visitadas cinco cidades, em cinco diferentes condados texanos, na área de abrangência de EFS. Foram conduzidas entrevistas semi-estruturadas com diversos atores sociais, e a participação direta em eventos correlacionados à expansão das atividades e impactos na exploração dos shales (Tabela 7).

\begin{tabular}{c|c|c}
\hline $\begin{array}{c}\text { Atores Sociais } \\
\text { (Stakeholders) }\end{array}$ & Instituições & Respondentes/ Eventos \\
\hline $\begin{array}{c}\text { Gerentes municipais } \\
\text { (City Managers) }\end{array}$ & $\begin{array}{c}\text { Prefeitura } \\
\text { (City Hall) }\end{array}$ \\
\hline $\begin{array}{c}\text { Diretores Lojistas } \\
\text { (CommerceDirectors) }\end{array}$ & $\begin{array}{c}\text { Câmara de Comércio } \\
\text { (ChamberofCommerce) }\end{array}$ \\
\hline $\begin{array}{c}\text { Juíz do Condado } \\
\text { (County Judge) }\end{array}$ & $\begin{array}{c}\text { Corte do condado de Brazos } \\
\text { (BrazosCountyCourthouse) }\end{array}$ & 1 \\
\hline Juíz da cidade & Prefeitura de Caldwell \\
(City Judge) & (Caldwell City Hall) & 1 \\
\hline $\begin{array}{c}\text { Cidadãos/ Comissários } \\
\text { municipais e representantes das }\end{array}$ & $\begin{array}{c}\text { Conselho Municipal } \\
\text { indústrias de petróleo e gás } \\
\text { (Citizens/ Commisioners/ Oil } \\
\text { and Gas representatives) }\end{array}$ & $\begin{array}{c}\text { Audiência pública para } \\
\text { regulação das normas do setor } \\
\text { de petróleo e gás }\end{array}$ \\
\hline Especialistas \\
(Specialists)
\end{tabular}

Tabela 7- Atores sociais e instituições envolvidas na aquisição de dados primários em Eagle Ford.

Fonte: elaborado pelo autor.

Em EFS a pesquisa se concentrou na esfera de governo e comércio dada a escassez de recursos, tempo e consentimento específico do Institutional Review Board (IRB) para entrevistar outros atores. Valer ressaltar que as indústrias energérticas que operam em EFS são notoriamente instituições de difícil acesso e liberação de informações. Dessa forma, as entrevistas se concentraram nos gerentes municipais, ou city managers, juízes dos condados e cidades, ou county/ 
cityjudges, além de diretores de câmaras de comércio, (chamber of commerce) nas cidades de Caldwell, CollegeStation, Giddings, Karnes City e Pleasanton.

Nas entrevistas foram abordados temas relacionados à regulação e à exploração dos folhelhos de EFS, em especial, os reflexos da cadeia produtiva dos hidrocarbonetos não-convencionais no desenvolvimento regional e local. Entre outras perguntas, buscou-se de forma direta e indireta colher as percepções e subjetividades dos atores quanto às lógicas dominantes de apropriação dos recursos energéticos e naturais. Os temas orbitaram em perguntas indutoras sobre resultados esperados na força de trabalho, formação de parcerias, processo de cooperação, regulação local, participação da comunidade, conflitos e perpectivas futuras da sobre o processo na região.

Foram acompanhadas as mobilizações de um grupo cívico local intitulado de College Station Citizens for Safe Fracking (CSCSF) e os respectivos debates em torno do Fracking, ou da atividade de exploração dos folhelhos. Adicionalmente, foram coletados dados primários em uma participação direta como ouvinte e observador de uma audiência pública, ou public hearing, no Conselho Municipal (City Council) da cidade College Station, Condado de Brazos. Na ocasião, prefeita, comissários municipais, (commissioners) e 43 membros da sociedade civil e representantes do setor energético se posicionaram a respeito da (re)definição de regulações locais (Oil\&Gas Ordinances) sobre possíveis impactos da exploração e do zoneamento da prospecção de petróleo e gás, no município.

Dentre outros dados secundários utlilizados foram analisadas matérias de três revistas especializadas sobre os shalesno Texas: Shale: Oil and Gas Business Magazine; Texas Eagle Ford Shale Magazine; e The Boom. Foram analisados também jornais e revistas de circulação local/regional, sobretudo, os periódicos: The Texas Tribune e The Eagle. Adicionalmente, foram incorporados períodicos científicos, artigos acadêmicos e livros publicados sobre a temática dos folhelhos nos Estados Unidos. De especial importância foi a análise da legislação e de aspectos do federalismo norte-americano, e do subfederalismo texano no que diz respeito a políticas regulatórias energéticas.

ii) Padrões, instrumentos e procedimentos de pesquisa

Todas as incursões, padrões e procedimentos realizados por essa pesquisa foram autorizados pelo Institutional Review Board (IRB), ou Conselho de Revisão Institucional. O IRB é um comitê oficial estipulado pela esfera legal de pesquisa nos Estados Unidos, designado para aprovar, acompanhar e avaliar 
processos de investigação científica envolvendo aspectos biomédicos, sociais e comportamentais. O comitê é responsável pela análise de risco-benefícios e a ética nos processos, formas e estruturas de pesquisas envolvendo seres humanos. É o órgão responsável por julgar, aprovar, ou reprovar, os parâmetros e processos de pesquisas envolvendo a interação com representantes de instituições, bem como, quaisquer pessoas, ou grupos sociais. Os recursos necessários à execução das entrevistas foram disponibilizados por fundos da National Science Fundation (NSF) administrados pela Texas A\&M University e o Programa Ambiental em Geociências que financiou as viagens e despesas do grupo de pequisa durante os processos de entrevistas.

A partir desses procedimentos, agentes públicos, servidores e representantes de estruturas de governo local foram entrevistados sobre suas percepções do processo de regulação e exploração dos hidrocarbonetos nãoconvencionais de EFS. A abordagem adotada seguiu a concepção de 'bola-de-neve', ou snowball, em que os respondentes, indicaram outros possíveis participantes, tais como gestores e outros tomadores de decisão para participar ou co-participar das entrevistas.

O procedimento de entrevistas seguiu um roteiro semi-estruturado de perguntas-chave. Dezesseis (16) atores sociais, ou stakeholders, foram entrevistados em processos que oscilaram entre 45 minutos e 1 hora e 30 minutos de duração. Os encontros da CSCFS, e a palestra com especialistas, por sua vez, tiveram seus áudios gravados. Um vídeo de aproximadamente 3 horas de duração com todo processo da audiência pública da cidade de CollegeStationfoi concedido pela prefeitura municipal ao Departamento de Geografia da Texas A\&M University representado pelo grupo de pesquisa em questão.

Todas as entrevistas e os áudios dos eventos foram transcritos e formaram os documentos primários que perfazem as bases das unidades hermenêuticas do programa Atlas.tino projeto específico de pesquisa para EFS. Um corpo de trinta e nove (38) códigos foi gerado a partir das passagens e citações dos documentos primários. Os códigos e seus respectivos padrões foram utilizados para a análise e discussão dos dados primários que abastecem prioritariamente os Direcionadores de governança de recursos energéticos. Os códigos e as citações estão apresentados detalhadamente no apêndice da tese. 
iii) Posicionalidade frente à área de pesquisa

A experiência de pesquisa de campo em Eagle Ford Shale foi possível graças à participação no Programa de Doutorado no Exterior (PDSE) e o convite para participar no Grupo de Pesquisas em relações Ambiente-Sociedade, ou Human Environment Research Group (HERG) do Departamento de Geografia, e do Programa Ambiental em Geociências, da Texas A\&M University. Isso permitiu obter os dados primários e secundários necessários a realização do estudo, mas também possibilitou a inserção na cultura de pesquisa, métodos e procedimentos empregados por um centro socioambiental norte-americano.

Durante o período do estágio foram conduzidas as entrevistas com alguns dos atores-chave envolvidos na regulação local dos folhelhos em cidades do sul do Texas, na área de Eagle Ford Shale. As enquetes foram realizadas em conjunto com dois alunos americanos, um de mestrado, e outro de doutorado, ambos do programa de pós-graduação do departamento de geografia da Texas A\&M University. Os discentes possuiam experiência em pesquisas sobre impactos socioeconômicos e ambientais em diferentes áreas nos Estados Unidos como Bakken Shale, no Estado de Dakota do Norte, e Barnett Shale no norte do Texas.

A parceria acadêmica, além de oferecer uma grande quantidade de informações gerais comparáveis aos processos verificados em Eagle Ford, permitiu uma grande desenvoltura no colhimento dos dados, sobretudo, na precisão das perguntas, qualidade dos diálogos e interpretação das respostas dos processos de entrevistas.Coube ao autor da presente pesquisa realizar as transcrições das entrevistas, sendo um dos discentes, voluntário para consultar todos os textos gerados e corrigir os erros e lacunas existentes.

Adicionalmente, o período de residência em College Station, município pertencente ao condado de Brazos Valley, e inserido dentro da área de Eagle Ford Shale permitiu uma proximidade adequada para participação em encontros, palestras e da audiência pública deliberativa sobre regulação local do gás e petróleo na cidade. Além disso, possibilitou o acompanhamento diário dos debates sobre a exploração dos shales na midia nacional, regional e local, bem como, permitiu sentir de perto a atmosfera polêmica dos embates locais sobre o desenho necessário para as estruturas regulatórias na atividade de prospecção de hidrocarbonetos de xisto no sul do Texas. 


\section{GOVERNANÇA E ECO-GOVERNAMENTALIDADE NO EPICENTRO DO BIODIESEL BRASILEIRO: ESTRUTURAS, PROCESSOS E DISCURSOS A PARTIR DO ESTUDO DOS POLOS GAÚCHOS}

Parte I - As variáveis estruturais

4.1 Variáveis estruturais: aspectos tecnológicos, sociais, constitucionais e biofísicos ligados à regulação e exploração do biodiesel no Brasil

A política pública que introduziu oficialmente o biodiesel na matriz energética nacional completou recentemente uma década. Entretanto, as variáveis tecnológicas que deram origem ao biocombustível no país remontam a quase quatro décadas, quando o Governo Federal intencionou desenvolver um novo combustível à base de óleos vegetais. Em 1975 foram traçadas as linhas básicas do intitulado plano de produção de óleos vegetais, conhecido como Pro-óleo, um "irmão menos notório do bem-sucedido Proálcool". Um programa também delineado dentro da estratégia de segurança nacional frente ao quadro de insegurança energética criada pela primeira crise do petróleo de 1973 (RODRIGUES, 2015, p. 24).

Como resultado do aporte de recursos oficiais, o professor de engenharia química Expedito José Sá Parente da Universidade Federal do Ceará (UFC) desenvolveu em 1983 a tecnologia de transesterificação de óleos vegetais, resultando na primeira patente industrial brasileira para a produção do biocombustível. Na mesma década, o Pro-óleo ganhou um novo nome, Programa de Óleos Vegetais (Oveg). O Instituto de Pesquisas Tecnológicas (IPT) testou protótipos de veículos propulsionados com óleos vegetais modificados quimicamente por ésteres metílicos e etílicos (o que se posteriormente ganhou o nome de biodiesel) em testes rodoviários (RODRIGUES, 2015).

Mesmo com a tecnologia disponível, o projeto de produção em larga escala de biodiesel foi deixado de lado por uma questão elementar de mercado: o custo de produção do biocombustível era inviável por ser superior ao custo de importação de diesel mineral. Ao contrário da disponibilidade da cana-de-açúcar para o bioetanol, ainda não havia nas décadas de 1970 e no início de 1980 a quantidade de matéria-prima (i.e. oleaginosas) necessária para a industrialização com escala e constância para produção de biodiesel. Como decorrência, mais de duas décadas se passaram sem que o biocombustívelse desenvolvesse tal qual o etanol.

A retomada da viabilidade do biodiesel acontece justamente quando o Brasil se consolida como um dos maiores produtores e processadores mundiais de soja. Segundo Rodrigues (2015), o interesse ressurge, especialmente, a partir de um 
grupo de grandes indústrias processadoras de grãos de Mato Grosso e do Rio Grande do Sul "que já não sabiam o que fazer com todo o óleo de soja que produziam" (p.26). Um contexto histórico reforçado ainda pela emergência da "preocupação com as mudanças climáticas [que] vinha alimentando um revival no interesse global por biocombustíveis" (p.26). A partir disso, a incorporação do biodiesel na matriz energética nacional produziu debates tanto nos meios acadêmicos, quanto nos setores produtivos. No caso específico do Brasil, a experiência com a política bioenergética do Proálcool forneceu um estímulo adicional para vários setores influentes tanto no governo quanto na sociedade civil em apoiar seu desenvolvimento (FLEXOR, 2011a).

Segundo Rodrigues (2015), grande parte do processo que culminou na estrutura legal do biodiesel se deve aos debates iniciados pela Associação Brasileira de Óleos Vegetais (Abiove), em conjunto com a Agência Nacional de Petróleo, Gás Natural e Biocombustíveis (ANP) e o Ministério da Ciência, Tecnologia e Inovação (MCTI). A parceria público-privada fez surgir, por exemplo, a primeira especificação técnica do biodiesel no país, com a publicação da Portaria ANP 255/2003, que estabeleceu oficialmente o biodiesel como "combustível renovável produzido a partir de óleos de origem vegetal, animal e álcool". Seria um recurso para ser adicionado "numa etapa inicial ao óleo diesel automotivo para testes em frotas cativas ou para uso em processo industrial específico" (BRASIL, 2003). Estavam prontas, portanto, as variáveis tecnológicas e logísticas essenciais para conduzir o biocombustível a um marco legal de implementação e desenvolvimento.

Ainda na gestão do Presidente Fernando Henrique Cardoso, em 2002, a política foi lançada como 'Programa Brasileiro de Biocombustíveis' (Probiodiesel) sob coordenação do MCTI e dentro da intitulada Rede Nacional de Biocombustíveis. Uma estrutura inicial de governança composta por diversos atores estatais e não-estatais, incluindo universidades federais, agências de pesquisa, empresas públicas e privadas; associações e confederações empresariais. As principais metas do Probiodiesel eram: 1) reduzir a dependência dos derivados do petróleo; 2) criar novos mercados para oleaginosas; 3) atender a demanda global por combustíveis alternativos e; 4) reduzir as emissões de gás carbônico. Para Flexor et. al. (2011a), nessa etapa a política foi desenhada com concentração nas cadeias de cana-de-açúcar e soja, e foi voltada para estimular a viabilidade e a competitividade técnica e econômica do biodiesel produzida a partir de ésteres etílicos (RODRIGUES, 2015).

Conforme relata Rodrigues (2015), estava formado o ambiente necessário para a maturação da política, a consolidação das parcerias e a cooperação entre os setores empresariais e governamentais; a partir da conjunção de aspectos políticos, tecnológicos e produtivos. Esse cenário foi favorecido pela sinalização de 
que critérios sociais poderiam ser incorporados ao novo biocombustível oferecendo oportunidades não apenas ao setor agroindustrial, mas, igualmente, para a sociedade civil, pela perspectiva de incorporação da agricultura familiar. Flexor et. al. (2011a) destacam que essa tendência veio ao encontro das metas de inclusão social realçada a partir da posse do Presidente Luiz Inácio Lula da Silva, em 2003. Essas metas geraram uma reformulação do Probiodiesel com o fortalecimento de suas diretrizes sociais e para sua maior legitimação como política energética.

Estava criadas as bases, ou as variáveis constitucionais das futuras regras, leis e responsabilidades na estrutura de regulação, produção e uso do biodiesel. Foi determinado pela Presidência da República, com coordenação da Casa Civil, e de um grupo de trabalho insterministerial (GTI); a criação de uma equipe de estudos, composta por técnicos, analistas e executivos de doze ministérios, incumbidos de promover o debate junto à sociedade civil e criar as diretrizes do Programa Nacional de Produção e Uso do Biodiesel (PNPB).

Conforme ressalta Pedroti (2013, p.8), o PNPB se estabelece aos moldes das "políticas pró-desenvolvimento pós-2000", nas quais a legitimidade das medidas públicas é pautada pela incorporação de aspectos socioeconômicos, procurando agregar como elementos basilares, diretrizes de combate às desigualdades sociais e regionais. No caso do biodiesel, essa preocupação se manifestou pelo discurso de não reproduzir a trajetória verificada no Proálcool, no qual a monocultura intensiva da cana-de-açúcar, regionalmente concentrada, e com uma mão-de-obra precária e mal remunerada, se tornou a base da cadeia produtiva do etanol (PEDROTI, 2013; MAROUN \& LAROVERE, 2014).

Vale ressaltar que adicionalmente aos elementos legitimadores sociais dos novos arranjos político-produtivos do biodiesel, foram levadas em conta as variáveis biofísicas do espaço agrícola brasileiro, no qual se ressaltam as condições edafoclimáticas favoráveis para suportar a quantidade e a qualidade da matéria prima necessária a expansão e manutenção da produção agroenergética. Esse foi por sinal um dos principais pilares utilizados na concepção da política do biodiesel, apoiado em grande parte na ampla disponibilidade de terras agricultáveis, aliada à perspectiva de incorporação e aproveitamento de áreas degradadas por pastagens, além do desenvolvimento de sistemas agrícolas consorciáveis de alimentos e energia, e de culturas adaptáveis aos biomas e climas regionais (BECKER, 2010).

Outro pilar central da política foi erigido na perspectiva de consolidar as parcerias sócio-privadas, entre agricultores e indústrias a partir de estímulos e subvenções oferecidos pelo Estado, como estratégia suficiente para desenvolver matérias-primas básicas como a mamona no semiárido nordestino, a palma (ou 
dendê) no Norte Amazônico, o girassol no Centro-Oeste, e a canola no Sul. A ideia consistia em consolidar mecanismos inovadores de incentivos econômicos voltados a sedimentar a aproximação do setor industrial com a agricultura familiar, considerado um segmento estratégico para o desenvolvimento rural.

Não obstante,o PNPB baseou-se numa estruturação legal semelhante à da implementação do Proálcool. Leis foram igualmente editadas de forma a incentivar a produção de insumos e matérias-primas agrícolas, criando linhas de crédito e incentivos fiscais para o setor industrial; e principalmente, estabelecendo regulações de obrigatoriedade de misturas gradativas de biodiesel ao diesel mineral consumido. $\mathrm{O}$ princípio basilar foi de criar um mercado seguro para os produtores, incentivando-os a investir na produção frente à perspectiva de expansão do setor com base na garantia oficial do uso do biocombustível na matriz energética brasileira.

Para atingir tal configuração da cadeia produtiva do biodiesel (Figura10), a publicação da Lei 11.097/2005 tornou obrigatória a adição de biodiesel ao diesel mineral consumido no Brasil e definiu percentuais de aumentos regulares. Em seu texto original a lei estabelecia inicialmente um teto de 5\% (B5) de mistura para ser atingido até o ano de 2013, porém, com períodos gradativos de adição para estimular a expansão do parque industrial. Numa etapa inicial, por exemplo, a lei estipulava o prazo de três anos (2008) para que a mistura de $2 \%$ (B2) se tornasse obrigatória no país.

A lei dava também ao Governo Federal a prerrogativa de antecipar os prazos de aumento da mistura conforme a disponibilidade de oferta de matéria-prima, e a capacidade de resposta do setor industrial. Isso aconteceu em 2010, quando o teto máximo de $5 \%$ foi antecipado em razão da rápidaexpansão do setor. Ao mesmo temmpo, a lei garantiu ao setor industrial a compra da produção do biodiesel por meio de leilões públicos oficiais conduzidos pela Agência Nacional de Petróleo, Gás Natural e Biocombustíveis (ANP). A prioridade, entretanto, foi dada para as empresas produtoras capazes de processar percentuais mínimos de matérias-primas adquiridas da agricultura familiar. O Selo Combustível Social (SCS), uma certificação do Ministério do Desenvolvimento Agrário (MDA) foi instituído para identificar as indústrias parceiras dos produtores familiares e oferecer uma série de benefícios comerciais e tributários. 


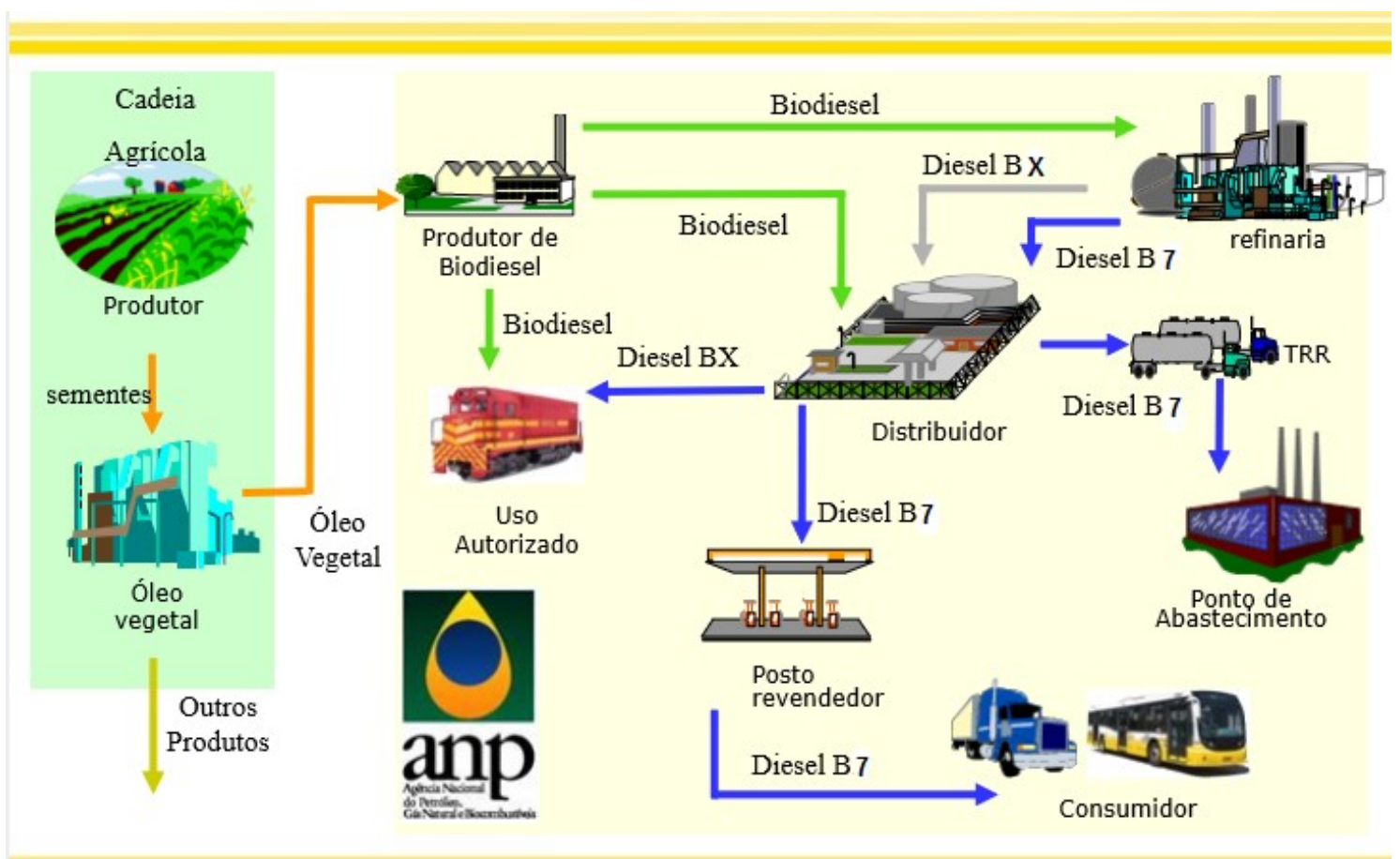

Figura 10- Cadeia produtiva e distribuição do Biodiesel no Brasil. Fonte: ANP (2011).

Pelas regras do MDA, as empresas aptas ao SCS deveriam utilizar pelo menos $15 \%$ de sua matéria-prima proveniente dos produtores familiares das Regiões Norte e Centro-Oeste; ou pelo menos 30\% das Regiões Sudeste, Nordeste e Semiárido; e40\% no caso da Região Sul. Para autores como Pedroti (2013) esse arranjo político institucional do PNPB o diferenciou do Proálcool ao incorporar variáveis sociais e ao estimular a aproximação de diferentes ministérios e de setores da sociedade civil sob a batuta do Governo Federal.

As indústrias certificadas, além de usufruirem da desoneração total e/ou parcial de impostos federais, tiveram acesso a linhas especiais de financiamentos públicos para custeio e investimento eprioridade de venda do biocombustível nos leilões públicos. Em contrapartida, porém, foram obrigadas a prestar suporte na organização e capacitação aos produtores rurais, oferecendo serviços de assistência técnica e extensão rural.

Como resultado disso tudo, o Brasil setornou o segundo maior mercado mundial de biodiesel (REN21, 2015). Apesar disso, o sistema de governança do setor não alcançou o sucesso desejado na diversificação de matérias-primas e na incorporação maciça de agricultores familiares. Na Região Nordeste, por exemplo, a mamona por uma questão de escala provou ser inviável para a produção de biodiesel (MATHEUS, 2014). Empresas localizadas na região perderam suas certificações e por produzirem biodiesel da soja adquirida de agricultores empresariais, e por venderem a mamona dos produtores familiares para a indústria ricinoquímica. O óleo de palma na 
Região Norte sequer alcançou a estrutura mínima para participar do setor de bioenergia (RODRIGUES, 2014b). Girassol, canola e crambe são culturas incipientes, sem escala,com óleos de valor inviável (RODRIGUES, 2013).

$\mathrm{O}$ argumento de parte das indústrias é que os custos de assistência técnica estipulados pelas regras do Selo Combustível Social para o gerenciamento de lavouras de culturas de baixa eficiência produtiva localizadas em áreas de grande dispersão no Norte e Nordeste superam as vantagens das isenções fiscais. Da mesma forma, a baixa incorporação de agricultores familiares na baseda cadeia produtiva do biodiesel nessas regiões estaria ligada à deficiência de infraestrutura adequada, ao baixo poder de troca dos produtores e à fragilidade de suas organizações representativas, como sindicatos, cooperativas e associações (OSAKA \& BATALHA, 2011).

As usinas de biodiesel se estabeleceram nas regiões Centro-Oeste e Sul do Brasil, como espaços capazes de oferecer grande escala de grãos, especialmente, a soja (Figura 11).

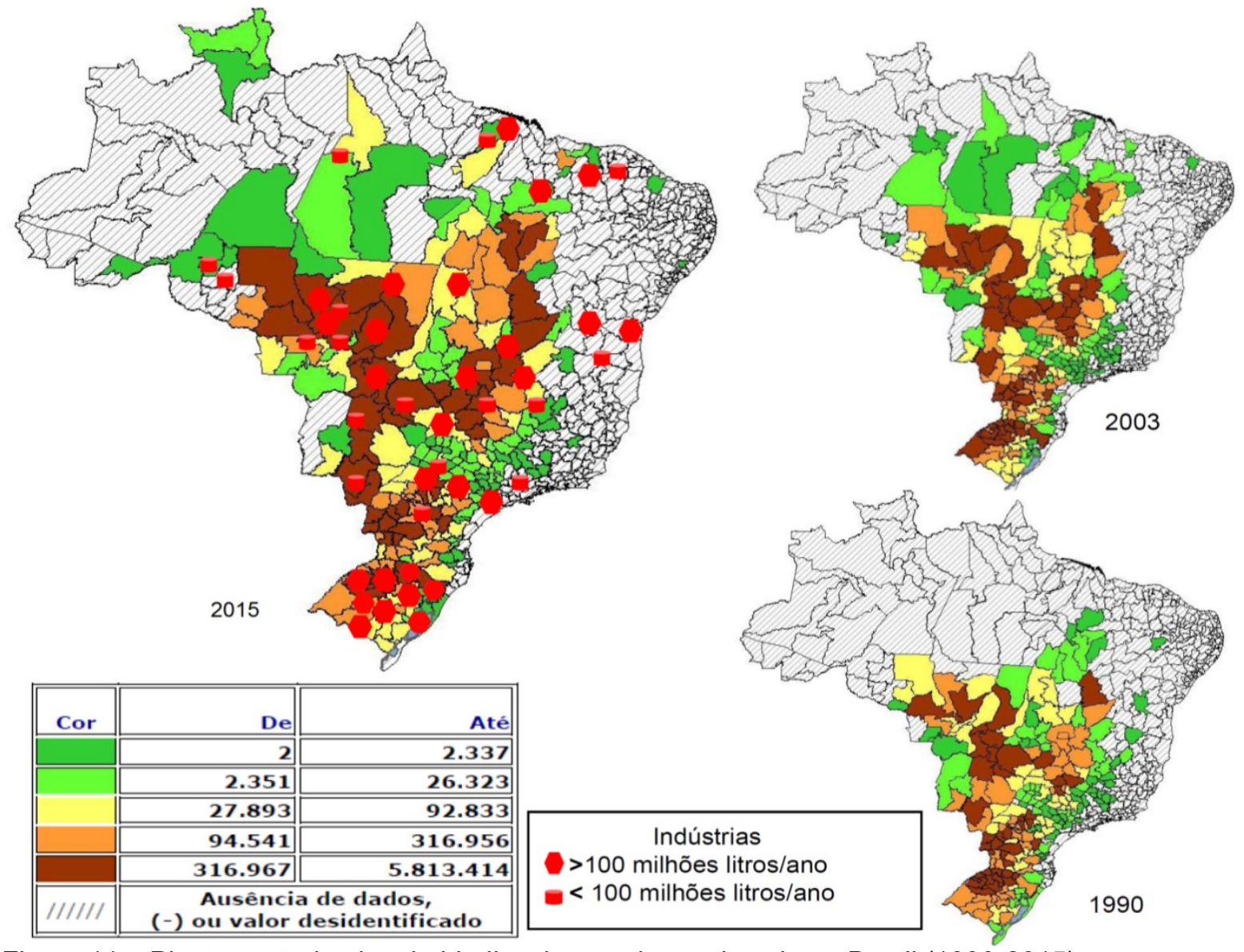

Figura 11 - Plantas autorizadas de biodiesel vs evolução da soja no Brasil (1990-2015). Fonte: Adaptado a partir de Santos (2010).

As indústrias do setor emergiram sinérgicas às áreas da expansão da oleaginosa e de todo seu amplo know-how tecnológico e mercadológico. A alta oferta 
e baixo preço de seu óleo vegetal, produzido em larga escala quase como um subproduto resultou no protagonismo da cultura no desenvolvimento do setor. Como decorrência, estados como o Mato Grosso e Rio Grande do Sul despontaram rapidamente como áreas de destaque na produção atual do biodiesel brasileiro.

Como destacado na descrição da área de estudo (item 3.4.1), somente nos PG nove indústrias certificadas (SCS) operam atualmente produzindo cerca de $25 \%$ de todo o biodiesel brasileiro. Isso ocorre dentro de um arranjo políticoinstitucional que, embora tenha alcançado inegável sucesso produtivo suscita questionamentos sobre a qualidade da governança do recurso energético e sobre seus reflexos políticos, sociais, econômicos e, sobretudo, ambientais.

Entre as questões, pairam dúvidas sobre como os elementos da atividade energética podem modificar, ou alterar processos de planejamento e tomada de decisão nesses espaços geográficos? Como instituições, políticas nacionais, regionais e locais são constituídas e interagem entre si? Quais as oportunidades e desafios aos elementos essenciais de governança do biodiesel (participação, cooperação, responsabilização, transparência, equidade, pertencimento e empoderamento)? Que padrões de eco-governamentalidade caracterizam os atores sociais estatais e não-estatais? Como essas características causam feedbacks na política pública e nas estruturas e processo de governança que determinam o ritmo de exploração dos recursos naturais basilares a atividade energética?

Para se compreender a dinâmica e o processo de governança do biodiesel nos PG é necessário entender o papel exercido pelos atores sociais, suas formas de acesso e controle de arenas políticas e as regras, funções, competências e autonomias que possuem. Uma análise de cunho institucionalista que visa entender as relações de poder, mas também os viesses cognitivos,subjetividades e discursos que ditam interações, interdependências e ritmos produtivosnas paisagens de produção.

Parte II - As arenas de ação política e os atores sociais

4.2 Arenas de ação política

i) O Conselho Nacional de Política Energética, a Política Energética Nacional e os biocombustíveis

O Conselho Nacional de Política Energética (CNPE) é o órgão máximo brasileiro no assessoramento à Presidência da República para a formulação, implementação e gestão da legislação energética brasileira. Sua principal função é definir medidas e ações oficiais para alcançar e gerir os princípios e objetivos definidos 
pela Lei 9.478, ou pela Política Energética Nacional. Dentre as principais metas destacadas no corpo da lei, é de competência do CNPE a exploração e o aproveitamento racional de recursos energéticos no Brasil, com a promoção do desenvolvimento, ampliação do mercado de trabalho, proteção dos interesses do consumidor, preço, qualidade de produtos, conservação de energia e preservação do meio ambiente (BRASIL, 1997).

Cabe ao CNPE ser uma instância de alto nível técnico e político, capaz de oferecer à Presidência da República osmeios e mecanismos de regulação de recursos energéticos de forma a garantir o suprimento necessário e estável de energia em todo território brasileiro. Entre esses recursos estão o petróleo, a energia elétrica, o gás natural, biocombustíveis e as fontes alternativas, (i. e.não-convencionais). 0 CNPE tem sua composição estabelecida pelo Decreto 6.685/2008, tendo representantes dos Ministérios de Estado de Minas e Energia (MME); Ciência e Tecnologia (MCT\&I); Planejamento, Orçamento e Gestão (MPOG); da Fazenda (MF); do Meio Ambiente (MMA); Desenvolvimento, Indústria e Comércio Exterior (MDIC); Integração Nacional (MIN); Agricultura, Pecuária e Abastecimento (MAPA) e da Casa Civil da Presidência da República (BRASIL, 2008).

Em conjunto comos ministros de Estado, há a previsão legal da participação de representantes dos Estados e do Distrito Federal; além de um especialista em matéria de energia; de um membro com notório conhecimento oriundo da universidade brasileira, e de um representante da Empresa de Pesquisa Energética (EPE). Dentre outras competências do Conselho está a incumbência de garantir e legitimar os interesses públicos e privados, para implementar as bases econômicas e socioambientais deprodução dos biocombustíveis na matriz energética nacional.

Desde a publicação da Lei 12.490/2011, o CNPE assumiu importante papel na estrutura de regulação do biodiesel, ao assumir a incumbência de garantir o fornecimento de biocombustíveis em todo o território nacional. Entre suas prerrogativas estão a concessão de linhas de investimentos necessárias para dinamizar os biocombustíveis e ações para mitigar as emissões de gases causadores de efeito estufa e poluentes atmosféricos (BRASIL, 2011).

\section{ii) A Comissão Executiva Interministerial do Biodiesel (CEIB)}

A instância máxima na estrutura de regulação e gestão do biodiesel no Brasil é a Comissão Executiva Interministerial do Biodiesel (CEIB), um órgão colegiado subordinado diretamente à Casa Civil da Presidência da República (PR). Ela é composta por representantes de treze ministérios e uma secretaria federal. São seus 
membros: o Ministério de Minas e Energia (MME); do Desenvolvimento Agrário (MDA); da Fazenda (MF); da Agricultura, Pecuária e Abastecimento (MAPA); do Desenvolvimento Social (MDS); da Ciência, Tecnologia e Inovação (MCTI); do Meio Ambiente (MMA); do Trabalho e Emprego (MTE); do Desenvolvimento, Indústria e Comércio Exterior (MDICE); do Planejamento, Orçamento e Gestão (MPOG); da Integração Nacional (MIN); dos Transportes (MT); Ministério das Cidades (MC) e a Secretaria de Governo \& Gestão da Presidência da República.

Cabe a CEIB definir as diretrizes e objetivos, implementar, monitorar o PNPB etambém discutir atos normativos e a implementação das políticas públicas coligadas ao setor no Brasil (Decreto Presidencial, s/nr., 2003, Art. $3^{\circ}$ ). Também é de sua competência da Casa Civil, por exemplo, por meio de suas prerrogativas institucionais, articular e orquestrar a participação dos ministérios, e demais instituições interessadas, conciliando diferentes interesses públicos e particulares, promovendo o alcance de objetivos socioeconômicos comuns interligados ao desenvolvimento do biodiesel no país (BRASIL, 2003).

No desenho operacional da CEIB existem dois núcleos distintos. O primeiro é o núcleo executivo, estabelecido diretamente a partir da convocação da Casa Civil, por meio da Secretaria de Governo e Gestão da Presidência da República. Esse núcleo discute marcos legais correlativos ao processo de regulação do biodiesel e debate as regras para concessão, manutenção e alterações das normas do Selo Combustível Social (SCS). O núcleo propõe também a aplicação de novos percentuais da lei de obrigatoriedade de mistura do biodiesel ao diesel mineral e define os procedimentos legais para os leilões públicos de aquisição do biodiesel.

A segunda instância, também na esfera federal, é o núcleo gestor da CEIB. Sua coordenação está por conta do Ministério das Minas e Energia (MME) e sua composição embora semelhante ao do núcleo executivo, não conta com os Ministérios do Trabalho e Emprego (MTE), dos Transportes (MT) e das Cidades (MC). Nos seus lugares estão incorporados a Agência Nacional do Petróleo, Gás Natural e Biocombustíveis (ANP), a Petrobrás, e o Banco Nacional de Desenvolvimento Econômico e Social (BNDES). Esse grupo é responsável por distribuir as competências e responsabilidades de cada uma das instituições participantes. Ele estabelece as competências, procedimentos e mecanismos, delegando para o MDA, a administração dos mecanismos do SCS e a dos projetos de participação e inclusão social; para a ANP o gerenciamento dos leilões de biodiesel; para Petrobras, a gestão de práticas sócio-produtivas; e o fornecimento de linhas especiais de financiamentos para o BNDES. 
Segundo estudo do IPEA, desde 2011, a CEIB se concentra em revisões da legislação fazendo reuniões por demanda e conveniência das instituições públicas envolvidas. Ainda de acordo com o mesmo documento, a CEIB funciona como um órgão técnico, sendo a decisão final tomada por prerrogativa exclusiva do poder Executivo, ou da Presidência da República. Entre os desafios da CEIB estão à capacidade de gerir perspectivas positivas tanto ao agronegócio, quanto para a agricultura familiar com incentivos paralelos para indústria do biodiesel, a partir da implementação, regulação e gestão do setor energético-agroindustrial. As dificuldades, portanto, se concentram na elaboração de uma regulação capaz de conciliar tanto o ponto de vista econômico e energético quanto social, promovendo desenvolvimento industrial, redução das desigualdades sociais e inclusão produtiva (PEDROTI, 2013).

Vale destacar que a CEIB recebe formalmente apenas órgãos, empresas e entidades públicas, sendo essencialmente uma instância executiva e consultiva de atores de governo. Como destacado por Flexor et al (2011) cada segmento tem seus laços próprios de cooperação e afinidade com distintos atores não-estatais, tanto na iniciativa privada, quanto com organizações da sociedade civil. A comissão difere, por exemplo, das câmaras setoriais que são fóruns, ou comitês consultivos distribuídos no Poder Executivo. De iniciativa própria e por prerrogativa dos Ministérios e secretarias estaduais, as Câmaras recebem membros e convidados, como empresas, indústrias, confederações e demais organizações pertencentes a quaisquer segmentos da sociedade civil e organizada.

iii) Os conselhos e câmaras setoriais dos ministérios

Três são as principais arenas e espaços políticos que atuam paralelamente ao CNPE e a CEIB na esfera federal: i) o Conselho de Competitividade Setorial e Comitê de Energias Renováveis, subgrupo: Biodiesel, vinculado à Secretaria de Inovação do MDIC; ii) a Câmara Setorial da Palma de Óleo, e, iii) a Câmara Setorial da Cadeia Produtiva de Oleaginosas e Biodieseis do MAPA. Essas câmaras e conselhos funcionam como grupos de trabalho formados por representantes do Governo Federal, agências públicas, órgãos e institutos de pesquisa, mas, sobretudo por representantes de associações, confederações empresariais, e executivos de indústrias.

Os Conselhos Setoriais de Competitividade foram instituídos em 2012 pelo Plano Brasil Maior sob coordenação do MDIC. Dezenove grupos foram criados 
visando reunir autoridades do governo e representantes do setor produtivo para delinear as políticas de desenvolvimento industrial e tecnológico adequadas a diversos segmentos, entre eles, os setores energéticos renováveis. No tocante ao biodiesel são discutidos os custos de produção dentro e fora da lógica do SCS, formas tributárias, participação da indústria na diversificação de matérias-primas, modelo de comercialização, logística, exportação e desafios a novas culturas. É central também nas diretrizes da câmara debater a relação do preço do biodiesel com o preço da soja, capacidade instalada, agricultura familiar, incentivos e desafios da flexibilização da legislação para que governos municipais e estaduais adotem frotas movidas a biodiesel B20 no transporte público.

A Câmara Setorial da Cadeia Produtiva de Oleaginosas e Biodiesel, por sua vez, principal arena política paralela à CEIB, promove a articulação política entre os principais atores estatais e não-estatais. Constituída para identificar oportunidades e desafios ao desenvolvimento da produção de sementes oleaginosas e da cadeia produtiva do biodiesel, esse espaço tem servido para pela definição de planos e ações de interesse no setor. Instituída pela Portaria $n^{\circ} 39$, de 31 de maio de 2006, a câmara foi formada por 45 instituições de diversos segmentos entre órgãos oficiais de governo, associações e federações. Na Reunião Ordinária $n^{\circ} .22$, realizada em março de 2015 estavam presentes treze representantes de governo (MMA, MME, MAPA, MF, Embrapa e Companhia Nacional de Abastecimento - Conab) e onze atores-não estatais, sobretudo, as associações, confederações, organizações e indústrias de biodiesel (BRASIL, 2015).

iv) Câmaras Temáticas do Programa Gaúcho de Biodiesel (Probiodiesel)

No que tange à estrutura político-institucional correlacionada ao desenvolvimento do biodiesel no Estado do Rio Grande do Sul também há muitos organismos e instituições atuantes.A Secretaria de Ciência, Inovação eDesenvolvimento Tecnológico (SCIT), subordinada à Casa Civil, coordena e estabelece as diretrizes do Programa Gaúcho de Biodiesel (Probiodiesel/RS). O programa foi lançadopelo Decreto Estadual n42.676/ 25 de novembro de 2003, em consonância ao PNPB, a suagestão executiva está a cargo da Fundação de Ciência e Tecnologia (Cientec). Porém, outras secretarias passaram a coordenar projetos de gestão das linhas de ação do programa (RIO GRANDE DO SUL, 2003). 
Entre 2008 e 2011, por exemplo, o Projeto Estruturante de Agroenergia do Estado do RS buscava inicialmente aprimorar tecnologias para o aproveitamento de coprodutos, normatização, controle de qualidade de insumos, e a qualificar recursos humanos no setor agro-energético. Almejava também a criação de um banco de dados reunindo parâmetros produtivos agroindustriais, socioeconômicos, biotecnológicos e ambientais para desenvolver competências, serviços e diretrizes ao setor. A iniciativa contou com recursos da Financiadora de Estudos e Projetos (Finep) e Fundação de Amparo a Pesquisa do Estado do Rio Grande do Sul (Fapergs). Outras entidades como a Fundação Estadual de Proteção Ambiental (Fepam), a Fundação de Pesquisa Agropecuária (Fepagro), bem como, Embrapa, Emater/RS, cooperativas agrícolas, universidades públicas e indústrias também foram nomeados membros coexecutores do projeto (FROZZA\& TATSCH, 2014).

A partir de 2011, entretanto, a Câmara Temática de Agroenergia estabelecida no âmbito da Secretaria da Agricultura, Pecuária e Agronegócio do Rio Grande do Sul (SEAPA/RS) passou a controlar e a dar continuidade ao fomento da produção de biodiesel e demais biocombustíveis no Estado. De forma semelhante, diferentes atores sociais, não somente do setor biodiesel, mas do etanol e biogás foram convidados a compor a Câmara para discutir questões relativas à bioenergia. $\mathrm{A}$ partir dessa etapa, entretanto, o enfoque deslocou-se para o fomento da agroindustrialização. O programa concentrou-se em disponibilizar linhas de financiamentos para aquisição de terrenos e instalações industriais. O Fundo de Operação de Empresas do Estado do Rio Grande do Sul (Fundopem) e o Programa de Harmonização do Desenvolvimento Industrial do Rio Grande do Sul (Integrar) passaram a ser protagonistas na nova estratégia de fomento da bioenergia (RIO GRANDE DO SUL, 2012; FROZZA, 2014).

A lógica se deslocou para a viabilização de recursos financeiros por meio de linhas de crédito especiais oferecidas por parcerias entre bancos públicos estaduais, regionais e federais e fundos disponibilizados pelo Badesul, antiga Caixa Econômica do Estadual, do Banco Regional de Desenvolvimento do Extremo Sul (BRDE) e, sobretudo, do Banco Nacional de Desenvolvimento Econômico e Social (BNDES). No tocante ao programa estadual do biodiesel as ações, portanto, se concentraram no fomento para a construção de plantas industriais, de unidades esmagadoras de grãos e estímulos para a comercialização de oleaginosas na escala estadual (FROZZA, 2014). 
v) O projeto Polos de Biodiesel: uma perspectiva de governança local multi-atores

O Projeto Polos de Biodiesel foi originalmente concebido em 2006 pelo Ministério do Desenvolvimento Agrário (MDA) com o objetivo de estimular a participação política local dos agricultores familiares e das suas organizações na gestão da cadeia produtiva e dos arranjos político-institucionais do biodiesel (BRASIL, 2010). Apesar da centralidade nos produtores agrícolas, o desenho do projeto levou em consideração os múltiplos interesses na formação de um sistema de governança para o biodiesel. A lógica básica se deu pela tentativa de articulação institucional e cooperação entre diferentes atores sociais na gestão local/territorial do recurso energético. $O$ desenho original do projeto buscou criar mecanismos de participação direta de empresas, indústrias, associações, cooperativas, sindicatos, instituições públicas, agências oficiais, e organizações não-governamentais dentro da lógica de sistemas híbridos de governança de biocombustíveis (BAILIS \& BAKA, 2011).

O principal mecanismo de implementação do projeto se deu através da implementação de conselhos, ou comitês locais incumbidos de aproximar os atoreschave e estimular a articulação político-institucional na estrutura de produção local (Figura - 12). A ideia foi consolidar a representatividade e dar voz ativa aos envolvidos na cadeia produtiva do biodiesel por meio da presença e negociação nas áreas de produção. Por meio de articuladores contratados, e representantes do MDA, membros de diversas instituições eram convidados para reuniões formais para debater estratégias de aprimoramento da logística, tecnologia, parcerias comerciais, assistência técnica, fomento à produção agrícola, diversificação de matérias-primas e desenvolvimento local/rural (BRASIL, 2010).

O desenho original do Projeto Polos de Biodiesel previa a participação de representantes da Embrapa, Banco do Brasil (BB), BNDES, BRDE, e de órgãos de representação de classe, tais como a Federação Nacional dos Trabalhadores na Agricultura Familiar (Fetraf) e as Federações Estaduais de Trabalhadores na Agricultura (Fetag). De especial importância, na composição dos grupos de trabalho (GT) era a presença de representantes municipais, agricultores empresariais e familiares, associações, cooperativas agrícolas, indústrias de óleo vegetal, indústrias certificadas de biodiesel (SCS), além de representantes de outros programas, e setores de desenvolvimento regional, territorial ou rural de diferentes escalas de governo. 


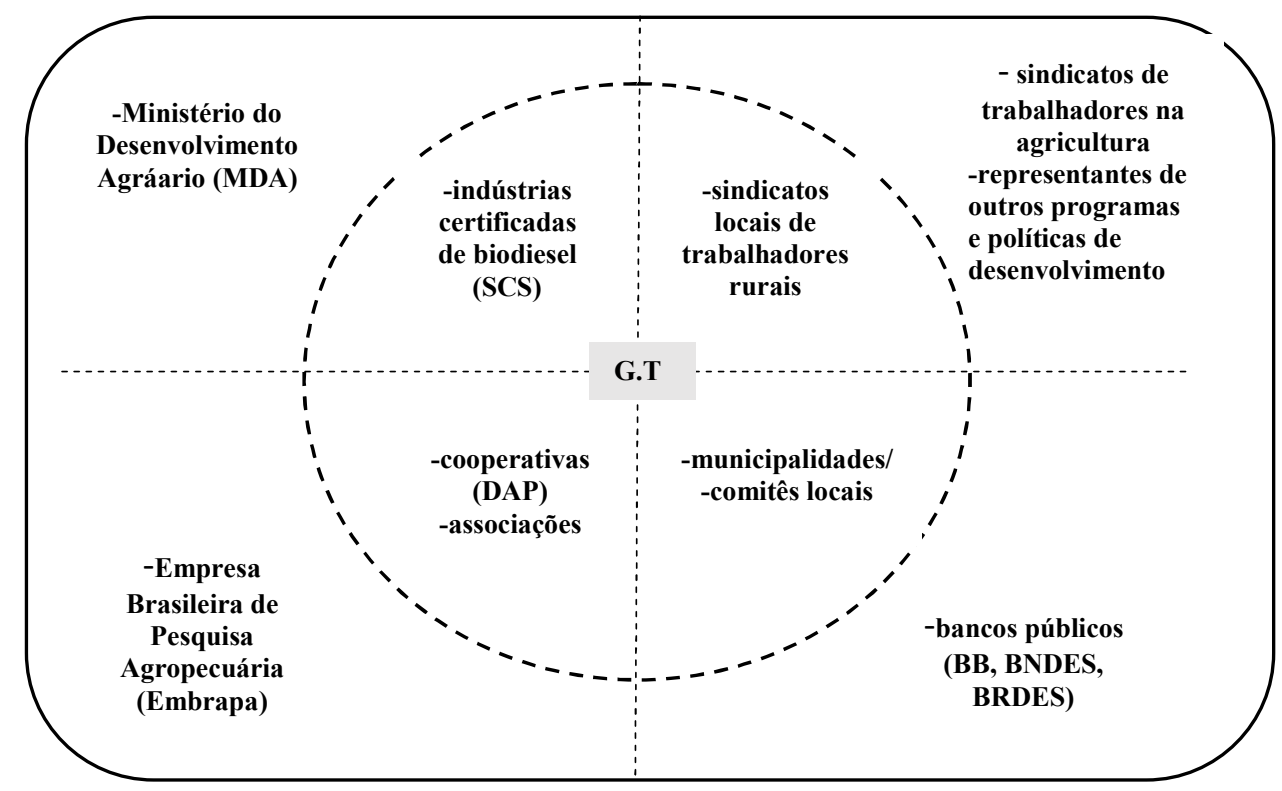

Figura 12 - Estrutura de relações dos grupos de trabalho (GT) nos polos de biodiesel. Fonte: adaptado pelo autor de Brasil (2010).

A intenção dos conselhos era consolidar ambientes sócio-produtivos inovadores capazes de gerar negócios, contratos e simultaneamente produzir biodiesel. Os conselhos intencionavam também estimular a diversificação da matriz produtiva, tecnologias agroindustriais modernas e a criação de sinergias participativas pela lógica de governança territorial. Talvez sua principal meta tenha sido a criação de um sistema duplo de ganhos, do tipo win-win, especialmente, pela aproximação das indústrias certificadas de biodiesel, detentoras do Selo Combustível Social (SCS), com as cooperativas e organizações da agricultura familiar, detentoras da Declaração de Aptidão ao Pronaf Jurídica ou DAP-Jurídica.

A DAP-jurídica e a DAP individual são certificações públicas instituídas pelo MDA com objetivos claros: i) selecionar e regularizar a situação de milhares de agricultores brasileiros com perfil enquadrável aos benefícios do Programa Nacional de Apoio a Agricultura Familiar (Pronaf - Lei 9.126/1995) e suas prerrogativas; ii) estimulara parceria entre as cooperativas e as indústrias certificadas de biodiesel (SCS); iii) garantir preços diferenciados aos credenciados,oferecendo valores adicionaisna compra de grãos. Produtores Dapianos/Pronafianos recebem valores da ordem de $\mathrm{R} \$ 1,00$ a $\mathrm{R} \$ 1,20$ a mais por saca produzida repassados pelo programa do Governo Federal. iv) facilitar o cadastro e fiscalização dos contratos firmados entre agricultores, cooperativas e indústrias por meio das entidades de classe, sindicatos de trabalhadores rurais.

No tocante àgestão do projeto, o MDA terceirizou a execução por meio da contratação da 'Obra Kolping do Brasil' e posteriormente, da auto-intitulada 
sociedade cooperativa de consultoria'Plural'. As funções dessas entidades se concentravam na marcação e organização das reuniões mensais dos GT's e do processo de seleção, contratação e treinamento dos articuladores. A escolha do articulador se baseava na seleção dos agricultores e líderes comunitários, levando em consideração sua popularidade, capacidade de articulação em suas comunidades, de comunicação e comprometimento com as linhas do projeto; Couberam igualmente às entidades contratadas, por meio dos articuladores, organizar seminários, divulgar o projeto, realizar intercâmbios com demais localidades e articular sua coordenação como outros projetos de desenvolvimento local/ rural ou territorial.

Entre o ano de implementação do projeto em 2006, até 2011, foram instituídos 63 polos em diferentes regiões brasileiras, abrangendo 1.091 municípios em um desenho voltado para incorporar áreas rurais e urbanas dentro de uma lógica de governança e desenvolvimento territorial. Os materiais de divulgação veiculados durante esse período enfatizavam a capacidade do projeto de promover a participação local entre os atores sociais, em uma estratégia de 'desenvolvimento sustentável' por meio do fortalecimento de laços institucionais e cooperativos (BRASIL, 2010).

Em 2012, porém, apenas há seis anos depois de sua criação, coordenadores ligados aos Polos de Biodiesel já assinalavam a possibilidade de mudar o seu desenhooriginal,fato que acabou se concretizando pela dissolução total do projeto na lógica de governança local multi-atores em dezembro de 2013. Após sete anos de atuação em diferentes regiões e territórios, todos os polos, incluindo os PG, foram desativados deixando margem para dúvidas sobre seus sobre seus resultados e o seu processo de aprendizado.

\subsection{Perfil dos atores sociais}

i) Indústrias energéticas

Dentre as 25 maiores indústrias de biodiesel do país, nove se encontram no Rio Grande do Sul. Grupos empresariais que se valeram de seu knowhow e capacidade de verticalização na cadeia produtiva da soja para investir e aumentar sua participação no novo segmento bioenergético. De maneira geral, companhias que têm em comum um histórico tradiconal na comercialização e beneficiamento de grãos e oleaginosas, sobretudo, farinha, farelo, leticina, óleo vegetal e casca de soja.

A Oleoplan, por exemplo, decidiu entrar no mercado de biodiesel em 2007 por meio da construção de uma planta de transesterificação em Veranopólis, no nordeste do Rio Grande do Sul. A unidade é atualmente a segunda maior do país em 
capacidade instalada. A Bianchini, outra empresa tradicional no setor agroindustrial gaúcho, entrou no mercado de biodiesel com a construção de uma planta industrial no início de 2012 no município de Canos. Usufruindo de um dos maiores parques industriais de beneficiamento de soja do Estado, sua unidade de transesterificação tem capacidade para processar de 324 milhões de litros por ano. O seu parque industrial é conectado aos terminais portuários na região metropolitana de Porto Alegre e aplanta é a quinta maior em capacidade de produção.

A Camera Agroenergia, sediada na Região Noroeste do Rio Grande do Sul,considerada por muitos como berço nacional da soja, tem 61 unidades de recebimento e armazenagem de grãos, fábricas de óleo, farelos vegetais e rações. 0 grupo agroindustrial foi atraído pelo setor energético e inaugurou sua primeira planta de transesterificação em 2010, em ljuí. Atualmente essa planta é a nona maior em capacidade produtiva do país.

A Granol, por sua vez, é um dos maiores complexos de agronegócios do país. O grupo tem seis clusters industriais, 49 regionais de compra e armazenagem de grãos, usinas de biodiesel, de lecitina de soja e glicerina, além de terminais marítimos e fluviais. As plantas de biodiesel da Granol localizadas em Anápolis, Goiás, e de Cachoeira do Sul, no Rio Grande do Sul são, respectivamente, a terceira e a quarta maiores indústrias de biodiesel em capacidade de produção. O grupo tem ainda outra unidade industrial, instalada em Porto Nacional, Tocantins que é a $30^{\mathrm{a}}$ maior planta do país.

Outras duas empresas instaladas nos PG também se destacam no cenário nacional: a Olfar tem uma planta industrial em Erechim com capacidade para produzir 216 milhões de litros/ano, sendo a $15^{\mathrm{a}}$ maior unidade do país. A Brasil Sul Biodiesel, ou BSBios, inaugurada em 2007 possui duas plantas. Uma, a 25a maior do país, é sediada na cidade de Passo Fundo, e a outra, a $16^{a}$ maior planta do Brasil é localizada em Marialva, região metropolitana de Maringá..

Desde o início das suas atividades a BSBios tem sido uma das empresas que mais se expandiu nos Polos Gaúchos. Com forte clamor pela participação da agricultura familiar e pela diversificação da matriz produtiva, a empresa surpreendeu o segmento de biodiesel no país ao anunciar a venda de $50 \%$ de seu capital para a Petrobrás Biocombustíveis (PBio). A operação envolveu metade dos ativos das usinas de Passo Fundo e de Marialva, sendo o maior investimentofinanceiro da Pbio desde sua criação. A negociação viabilizou a ampliação do parque industrial da BSbios com a construção de uma unidade de processamento de grãos, especialmente, de esmagamento de soja (CIVA, 2011). 
ii) Associações e confederações de produtores industriais.

Algumas associações e confederações nacionais e regionais se destacam na estrutura político-institucional de governança do biodiesel no Brasil. A União Brasileira do Biodiesel (Ubrabio), por exemplo, agrega diversas empresas ligadas à produção de biodiesel no país, como indústrias, produtores de insumos, equipamentos industriais, tecnologias e serviços diversos. A entidade privada se propõe a "atuar como interlocutora junto à sociedade e ao governo para mobilizar esforços, recursos e conhecimentos na busca pelo desenvolvimento do setor"(UBRABIO, 2011 p.quem somos).

Desde sua criação, em 2007, a Ubrabio é uma das lideranças mais ativas na articulação de interesses políticos e econômicos do biodiesel no país. A entidade atua como uma formadora de opinião, com websites, páginas em redes sociais e as revistas 'Biodiesel em Foco' e 'Agroenergia'. Simultaneamente, também patrocina relatórios, publica e distribui materiais de divulgação nos ministérios e financia estudos correlacionados ao setor, como: 'O Biodiesel e a Contribuição ao Desenvolvimento Brasileiro', que destaca os benefícios sociais, tecnológicos, mercadológicos e ambientais da cadeia produtiva do biodiesel (FGV, 2010).

Em 2011, um desacordo no âmbito da Ubrabio provocou a formação da Associação dos Produtores de Biodiesel no Brasil (Aprobio). Cinco vice-presidentes, diretores de grandes indústrias deixaram a união para fundar uma associação paralela limitada a indústrias produtoras de biodiesel. Apesar da cisão, que revelou desarmonias políticas e desencontro de interesses, seus respectivos presidentes afirmam que "o relacionamento é cordial. Temos alinhamento em alguns pontos e discordâncias em outros [...] nossas visões são diferentes, mas lutamos pelos mesmos objetivos" (RODRIGUES, 2012 p.8).

AAprobio utiliza estratégias semelhantes da Ubrabio, seja pela atuação direta dentre as estruturas político-institucionais, seja pela promoção de materiais e publicações de apoio ao biodiesel. A entidade também encomendou para a Fundação Instituto de Pesquisas Econômicas (Fipe)um estudo, sob coordenação da Faculdade de Economia (FEA) da Universidade de São Paulo (USP) sobre os 'Impactos socioeconômicos da indústria do biodiesel no Brasil'(IPEA, 2012).

Outra entidade com influência crescente no setor é a Associação Brasileira da Indústria de Óleo Vegetal (Abiove). Fundada em 1981, a Abiove é a maior agregadora das grandes empresas agroindustriais ligadasao setor sojicultor. A associação vem se consolidando também nos últimos três anos como outro campo de forças do setor de biodiesel. Segundo um de seus diretores, "temos vários associados 
que produzem ou estão em vias de começar a produzir biodiesel e vamos fazer o necessário para representá-los". Segundo esse mesmo representante, o biocombustível sempre esteve na pauta da entidade, desde o início do PNPB, pois "sempre tivemos uma atuação em defesa do biodiesel [...] e estivemos envolvidos em todas as negociações feitas para a promoção do biodiesel brasileiro" (RODRIGUES, 2012 p.10).

Vale igualmente ressaltar o papel de dois sindicatos estaduais de indústrias de biodiesel, considerados os principais no país seja pelo maior número de afiliados, seja pela capacidade produtiva. O Sindicato das Indústrias de Biodiesel no Estado do Mato Grosso (SindibioMT), fundado em 2009, tem cerca de 16 empresas afiliadas; e o Sindicato da Indústria de Biodiesel e Biocombustíveis do Rio Grande do Sul (SindibioRS), fundado em 2011, tem seis indústrias afiliadas, mas que juntas representam $25 \%$ da produção nacional do biocombustível no país. A principal função de ambos os sindicatos é firmar contratos coletivos de trabalho, oferecer assessoria na conciliação de dissídios, oferecer assistência jurídica às indústrias associadas, e representar interesses do setor perante os poderes públicos regional e federal e as demais associações locais (DUARTE, 2011).

Apesar de diretrizes semelhantes, os dois sindicatos têm significativas discordâncias quanto às normas de aquisição inter-regional de grãos produzidos pela agricultura familiar de acordo com as regras que determinam a obtenção e manutenção do SCS. O SindibioRS, por exemplo, protocolou formalmente junto ao MDA um pedido de alteração da Portaria $n^{\circ} 60$, que estabelece as regras do Selo Combustível Social, limitando em $50 \%$ a aquisição de grãos por planta industrial de biodiesel localizada fora da região em que está operando (BOFF, 2013). O SindibioMT, por outro lado, em manifesto também encaminhado ao MDA em 2013 rebate a proposta do SindibioRS, enfatizando que. "o objetivo do selo é fomentar e realizar a inclusão da agricultura familiar do Brasil, sem distinção de região à qual o pequeno produtor pertença" (CAMPOS, 2014 p.2).

Em paralelo às disputas dos sindicatos regionais, a Ubrabio, Aprobio e Abiove têm atuado em diferentes linhas de frente. A Abiove vem se empenhando em propagar estatísticas que realçam a importância da soja para o desenvolvimento econômico e social do Brasil. A associação divulga em seu website, e em materiais de divulgação, estatísticas que correlacionam o crescimento do IDH nas áreas agrícolas e industriais com o processamento de grãos, o refino de óleo e a produção de biodiesel. A entidade criou também uma certificação denominada de 'Soja Plus' em que frisa seu envolvimento com a sustentabilidade do setor. A associação enfatiza sua participação na moratória da soja (soy moratorium), movimento liderado pela ONG Greenpeace, 
pela qual se compromete "não comercializar nem financiar a soja produzida em áreas que foram desmatadas no Bioma Amazônia" (CAETANO, 2015 p.1).

Em relação à Ubrabio, nos últimos anos a entidade se empenha pela criação do Instituto do Biodiesel que, entre outros objetivos, pretende "acelerar a inovação tecnológica no Brasil ao criar uma sinergia dos setores de pesquisa e desenvolvimento com o setor produtivo" (RODRIGUES, 2012 p.8). A entidade esteve presente na Rio+20 para lançar uma campanha para a Plataforma Brasileira do Bioquerosene de Aviação, ou BioQAV. A própria associação passou se chamar de União Brasileira de Biodiesel e 'Bioquerosene' numa tentativa de formar novos grupos de interesse em torno da formação de uma indústria específica para o setor de biocombustíveis de aviação civil no Brasil.

A Aprobio, por sua vez, reforçou sua ação política junto às esferas federais de regulação do setor. Na última Copa do Mundo de futebol, em 2014, realizada no Brasil a associação procurou popularizar o biodiesel divulgando-o como combustível oficial do evento, fato que obteve respaldo e uma promessa que não chegou a ser concretizada pelo Ministério dos Esportes. Entretanto, a maior linha de ação e estratégia que a Aprobio foi a articulação com deputados da bancada do Rio Grande do Sul para a criação da maior coalisão política em favor do biodiesel no país: a Frente Parlamentar do Biodiesel, ou apenas FrenteBio (RODRIGUES, 2012).

iii) Frente parlamentar do biodiesel (FrenteBio)

Uma das principais forças políticas no setor de biocombustíveis é a chamada Frente Parlamentar do Biodiesel (FrenteBio). Ela funciona como lobby de interessses políticos e empresariais. Criada em 2011, com uma adesão formal de mais de 280 parlamentares, a FrenteBio (Figura 13) tem entre seus principais objetivos a formulação de um novo marco regulatório para o setor. Seus membros buscam medidas legais para estimular a competitividade do produto, aumentar o consumo interno, implementar incentivos de exportação e diminuir a carga tributária.Para tanto, a principal reivindicação da FrenteBio definição legal de patamares de aumento sistemático do percentual de mistura obrigatória biodiesel/diesel mineral no Brasil. Os membros da FrenteBio pressionam o governo para o estabelecimento de um Marco legal para acabar com os riscos e incertezas do setor e estimulador das atividades agroindustriais futuras. 


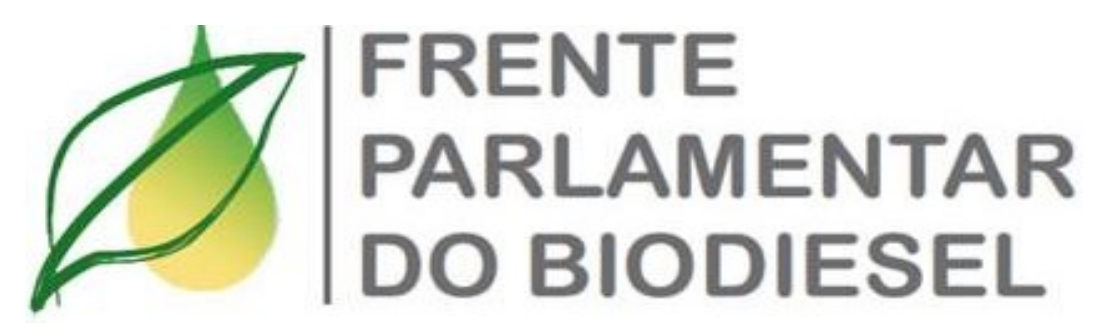

Figura 13 - Logotipo da Frente Parlamentar do Biodiesel (FrenteBio).

Fonte: www.frentebio.com.br

Desde seu lançamento os parlamentares da FrenteBio defendem um cronograma de gradativo aumento das misturas, para chegar a $20 \%$ (B20) no ano de 2020. O motivo principal é a grande capacidade instalada, e ociosa da indústria brasileira. Uma margem potencial do setor que garantiria o aumento percentual bem acima do atualmente praticado.A Frente Parlamentar do Biodiesel agrega diferentes partidos políticos, conciliando parlamentares com interesses e discursos comuns no desenvolvimento do setor.

As pressões da FrenteBio, depois de quatro anos sem que houvesse aumentos nos percentuais de adição de biodiesel, levou a Presidência da República a ceder e assinar a Medida Provisória n 647/28 de maio de 2014 de iniciativa da Câmara dos Deputados. A MP foi composta por 47 emendas de senadores e deputados propondo aumento gradativo da adição de biodiesel ao diesel mineral. A Presidência da República deferiu apenas novas misturas de $6 \%$ (B6) a partir de $1^{\circ}$ de julho de 2014, e de 7\% (B7), a partir de novembro de 2014.Não foi definido, porém, o Marco Legal reivindicado pelos parlamentares e o setor industrial.

Em 2015,um ato simbólico com a presença da Abiove, Ubrabrio, Aprobio, Senadores e Deputados relançou o movimento reintitulando-o de Frente Parlamentar Mista do Biodiesel. Entre as novas demandas, somadas à do Marco Legal pretendido, estão a aprovação do uso imediato de $20 \%$ (B20) de biodiesel no transporte coletivo nas regiões metropolitanas, de 30\% (B30) em maquinários agrícolas e termoelétricas, além de um instrumento normativo regionalmente diferenciado para a mistura obrigatória. Essa última pauta tem sido uma das principais reivindicações da FrenteBio, que pretende flexibilizar as misturas pela criação do 'BX autorizativo' pelo qual os Estados passariam a ter competência para determinar as quantidades de adição de biodiesel ao diesel mineral. Essa visão surgiu atrelada a incentivos para maior produção e utilização do biocombustível, especialmente em Estados como Goiás, Mato Grosso e Rio Grande do Sul onde o custo do biodiesel é inferior ao diesel produzido de petróleo. 


\section{iv) Movimentos sociais e sindicatos trabalhistas}

Algumas organizações e movimentos sociais atuaram muito durante as primeiras discussões dos grupos de trabalho interministeriais que originaram a estrutura político-institucional do PNPB (PEDROTI, 2013). Sob estímulo e coordenação do MDA, muitas entidades ligadas aos movimentos sociais e aos sindicatos trabalhistas foram decisivas na definição das linhas e diretrizes aprovadas. Para Flexor et. al (2011a), entretanto, embora a presença dos movimentos sociais tenha sido importante na formação da política do biodiesel não há consenso atual entre essas entidades sobre a eficácia dos resultados sociais do PNPB. Membros de entidades como o Movimento dos Sem Terra (MST), Movimento dos Pequenos Agricultores (MPA) e Via Campensina se queixam da baixa capacidade, ou interesse do Governo Federal, de inserir e beneficiar os produtores familiares e suas organizações (BARROS, 2014).

Um exemplo da frustração dos movimentos sociais pode ser sintetizado pelo fracasso da implementação de um projeto para produção de biodiesel pretendido por duas cooperativas vinculadas ao MPA e ao MST nos Polos Gaúchos. A Cooperativa Mista de Produção, Agroindustrialização e Comercialização de Biocombustíveis do Brasil (Cooperbio), e a Cooperativa de Biocombustíveis da Região do Pampa Gaúcho (Biopampa) foram concebidas a partir da expectativa de implementar um arranjo produtivo local e formar um complexo industrial para a produção de biodiesel e etanol no noroeste do Rio Grande do Sul.

Em parceria com a Petrobras, o projeto pretendia erigir uma planta de transesterificação e incorporar em sua base produtiva 50 mil famílias de pequenos agricultores e assentados, distribuídos em 106 municípios. Um estudo técnico e um acordo de intenções chegaram a ser assinados entre as cooperativas e o Governo Federal, com apoio do MDA, Eletrosul, Embrapa Clima Temperado e Emater. O projeto tramitou por anos sem, contudo ter sido viabilizado. O presidente da Biopampa enfatizava sua perspectiva quanto à produção de bioenergia como estratégica para a "soberania dos povos, e a consolidação da participação dos agricultores no desenvolvimento econômico, social, preservação do meio ambiente, trabalho, geração e distribuição de renda" (BRASILDEFATO, 2007 p.1).

Os sindicatos tiveram importância seminal na gestação da política do biodiesel no Brasil e nos Polos Gaúchos de produção. Seu papel, entretanto, diferente dos movimentos sociais, tem sido fundamental para o desenho de relações políticoprodutivas do PNPB. De acordo com a Portaria $n^{\circ} 60$ do MDA para receber, manter e usufruir das prerrogativas do Selo Combustível Social, as indústrias de biodiesel são 
obrigadas a celebrar contratos de assistência técnica e de aquisição de percentuais mínimos da produção agrícola familiare das suas cooperativas, com a anuência dos sindicatos. Por isso os sindicatos assumiram o papel de agentes fiscalizadores das relações comerciais dentro das regras do SCS.

Cabe a eles, portanto, fiscalizar se as indústrias estão cumprindo os percentuais mínimos de aquisição da agricultura familiar, ou seja, pelo menos $15 \%$ para matérias-primas provenientes das regiões Norte e Centro-Oeste; 30\% para as aquisições provenientes das regiões Sudeste, Nordeste e Semiárido; e 40\% para as matérias-primas provenientes da região Sul. Não há restrições, entretanto, para compras inter-regionais de grãos (BRASIL, 2012).

De acordo com esse modelo, as entidades filiadas à Federação dos Trabalhadores da Agricultura Familiar (Fetraf) e à Confederação Nacional dos Trabalhadores na Agricultura (Contag) se tornaram elementos centrais na negociação entre agricultores, indústrias de biodiesel e as cooperativas de produção. Centrais sindicais menores, como a Associação Nacional dos Pequenos Agricultores (ANPA) também têm essa função, que inclui a identificação das partes integrantes, as quantidades contratadas, à especificação de matéria-prima, a área contratada e o prazo de entrega dos grãos.

Os sindicatos assumiram, portanto, o papel de assessorar os produtores e cooperativas no tocante a parcerias comerciais com indústrias de biodiesel. Uma função aos moldes do re-governing markets tratados por Vorley et. al (2006), onde os gestores do PNPB apostaram que num desenho inédito de intervenção indireta do Estado por meio das entidades representativas de classe, no intuito de obter ganhos para agricultura familiar. Autores como Dias e Abramovay (2007), logo no início do programa acreditavam que essas interações representavam uma inovação social, em que a: "estrutura de monitoramento no próprio desempenho dos contratos diminuiriam as fontes potenciais de conflito em torno deles" (p.20).

De fato, a centralidade do papel fiscalizador dos sindicatos e entidades representativas de classe fez com que muitas indústrias de biodiesel se aproximassem delas. De uma maneira geral, empresas e unidades industriais do Rio Grande do Sul, Santa Catarina, Paraná, Goiás e Mato Grosso buscaram uma maior aproximação e articulação regional e inter-regional, com unidades sindicais para estabelecer e manter seus acordos comerciais com os produtores familiares. Esse layout, entretanto, parece não ter sido suficiente para evitar tensões motivadas, sobretudo, pela disputa da produção agrícola familiar concentrada na região Sul. 
v) Cooperativas de produção e comercialização agrícola

Duas perspectivas e estratégias antagônicas marcaram a perspectiva de participação das cooperativas no desenho produtivo, político e institucional da política do biodiesel no Brasil. Num primeiro momento,sob liderança da Organização das Cooperativas Brasileiras (OCB), o segmento enxergava a produção do biodiesel como uma nova oportunidade para as entidades. Segundo a visão do Serviço Nacional de Aprendizagem do Cooperativismo (Sescoop), em estudo encomendado pela sua Gerência de Apoio ao Desenvolvimento de Mercados (Germec), entendia-se que a produção industrial de biodiesel poderia ser realizada diretamente pelas cooperativas de produção e comercialização (SESCOOP, 2008).

O estudo realizado por essas entidades destacava as potencialidades e oportunidades do biodiesel, enfatizando os critérios fiscais e tributários positivos para a sua consolidação. Na prática, porém, essa perspectiva tal qual o exemplo da Biopampa, foi marcada por tentativas infrutíferas de acessar recursos financeiros e viabilizar projetos executivos para construção de plantas de transesterificação, ou unidades de esmagamento de grãos e produção de óleos vegetais. Os projetos de verticalização agroindustrial geridos pelas cooperativas, por uma questão de economia de escala agrícola e industrial, ou mesmo por opção política dos agentes financeiros envolvidos não chegaram a sair do papel (LIMA, 2011).

A segunda perspectiva, de caráter mais recente, depositou grande credibilidade nas cooperativas para reinventar seu papel dentro das linhas do PNPB. Por essa concepção, aproveitando a necessidade de melhoria logística das empresas para a obtenção de grãos e para a manutenção do SCS, as cooperativas com DAPjurídica, formadas majoritariamente por agricultores familiares seriam a solução natural para o fornecimento de matéria-prima para as indústrias de biodiesel. Essa foi a lógica dos idealizadores do Projeto Polos de Biodiesel e dos coordenadores políticos do MDA. 
vi) Organizações e instituições da sociedade civil

Obras Kolping do Brasil e a Plural Cooperativa de Consultoria são instituições da sociedade civil organizada que tiveram protagonismo no projeto piloto do PNPB, atuando sob convênio e coordenação do MDA no Projeto Polos de Biodiesel. Ambas atuaram na propagação das normas do Selo Combustível Social e na articulação entre indústrias de biodiesel, produtores e cooperativas para a formação de arranjos produtivos e políticos locais. Equipes técnicas das duas instituições atuavam em diferentes regiões do país, sob supervisão da Coordenação de Biocombustíveis, e do Departamento de Agregação de Valor e Renda, da Secretaria de Agricultura Familiar (SAF/MDA).

Durante a vigência do projeto, as duas organizações atuaram na formação do incipiente mercado do biodiesel e promoveram a participação social, política e econômica dos agricultores familiares, bem como, sua responsividade Lunardi (2011), em pesquisa realizada durante cinco anos, acompanhou as ações da Plural e dos coordenadores do MDA. Embora o autor afirme que inicialmente as ações tenham num momento inicial estimulado acordos comerciais entre cooperativas dapistas e indústrias certificadas houve uma inversão da cooperação inicial e a lógica migrou para uma disputa pelos melhores produtores de grãos. Ele conclui que a integração dos produtores rurais familiares se converteu, de fato, numa "integração [produtiva] subordinada ao complexo soja, deixando inócua a relação de equivalência entre inclusão social e o Selo Combustível Social" (p.138).

Com relação às organizações não-governamentais, de maneira geral não há participação direta delas nas estruturas e processos de governança do biodiesel brasileiro. Durante a pesquisa não foram identificadas ONGs atuantes nos Polos Gaúchos de produção. Uma ONG, entretanto, a Repórter Brasil, é bastante ativa no questionamento da sustentabilidade e da lógica de governança dos biocombustíveis. A organização mantém o Centro de Monitoramento de Agrocombustíveis, em que afirma seu empenho em pesquisar e publicar reportagens e relatórios sobre os impactos trabalhistas, ambientais e fundiários dos cultivos usados para a produção de agrocombustíveis, especialmente, cana-de-açúcar, soja, e palma.

$\mathrm{Na}$ visão dessa ONG os biocombustíveis não são uma panacéia e as modificações do espaço agrícola e agrário podem promover sérios impactos negativos como mudança direta e indireta de uso do solo, pressão sobre os recursos hídricos, concentração setorial das indústrias, intensificação de uso de insumos químicos e pressão sobre a biodiversidade. A organização destaca também os entraves trabalhistas e fundiários das cadeias agroenergéticas, inclusive denunciando casos de 
trabalho análogo ao escravo, impactos sobre a segurança alimentar, conflitos de terra e violações de direitos de populações indígenas e tradicionais.

A Repórter Brasil enfatiza que é necessário criar mecanismos que fortaleçam o papel do governo incorporando maiores mecanismos de controle por parte da sociedade civil. A estratégia empregada em parceria com outras ONG's como Doen, Cordaid e Solidariedad é exercer pressão sobre governo, empresas e associações, por meio da divulgação de relatórios e estudos na mídia digital e internacional, como o livro "Biofuel Partnerships: from battleground to common ground?" (QUIÑÓNEZ ET AL, 2012). A Repórter Brasil faz também articulação política junto a membros do executivo e a legisladores, para buscar o aperfeiçoamento dos marcos legais pertinentes das empresas no Brasil e de seus parceiros no exterior.

vii) Agência Nacional do Petróleo, Gás Natural e Biocombustíveis e a Petrobrás

A comercialização de todo biodiesel no Brasil é de competência da Agência Nacional do Petróleo, Gás Natural e Biocombustíveis (ANP). Cabe a ela administrar os leilões públicos de aquisição do biocombustível a partir das diretrizes estabelecidas pelo CNPE e do Ministério de Minas e Energia (MME). Os leilões de biodiesel foram estipulados dentro da estrutura político-institucional do PNPB para manter e estimular a formação de mercado seguro e estável para as indústrias do setor. Atrelada aos parâmetros da legislação que rege as misturas de biodiesel ao diesel mineral no país, a agência reguladora é encarregada de realizar os arremates oficiais do biocombustível e distribuí-lo pelas refinarias da Petrobrás por todo país. Adicionalmente, a ANP estabelece as especificações técnicas de qualidade para o biocombustível, a regulamentação e a realização dos leilões.

Quarenta e quatro leilões foram realizados pela ANP desde o início do PNPB. Oleilão 44 (L44) arrematou 696,8 milhões de litros de biodiesel, em que praticamentetodo o volume foi adquirido de indústrias portadoras do Selo Combustível Social. Os arremates operaram de acordo com a nova Lei $n^{\circ} 13.033 / 2014$, que aumentou de 5\% (B5) para 7\% (B7) o percentual obrigatório de mistura de biodiesel ao óleo diesel consumido no Brasil (BRASIL, 2014b).

$\mathrm{Na}$ outra ponta dessa engenharia produtiva-comercial a Petrobras é um dos atores principais da cadeia do biodiesel, uma vez que, na prática é a companhia que compra todo o biodiesel produzido no país. Ela teve também papel crucial na concepção do PNPB, contribuindo significativamente para as discussões nos grupos de trabalho interministeriais. A posição da empresa creditava ao biodiesel a capacidade de reduzir a dependência do diesel importado, aprimorar a qualidade do 
diesel consumido no país, reduzir as emissões de CO2, e estimular uma produção descentralizada do biocombustível gerando renda e empregos (FLEXOR ET AL, 2011a).

Em 2008, por motivações estratégicas e políticas foi lançada uma nova divisão da companhia energética,a Petrobrás Biocombustíveis (Pbio). Desde a sua criação, a Pbio atua em diferentes fases da cadeia produtiva do biodiesel, começando com o fomento da agricultura familiar e das suas organizações, o beneficiamento de grãos, até a produção industrial. Em uma primeira etapa, a empresa construiu plantas de transesterificação em Candeias (BA), Montes Claros (MG) e Quixadá (CE).

Após uma fase inicial marcada por relações comerciais frágeis e por dificuldades em alcançar escalas de produção necessárias para o abastecimento de matérias-primas às indústrias, a Pbio adotou parcerias formadas com as cooperativas agrícolas familiares. A cooperação envolveu o repasse de recursos da Pbio diretamente para que cooperativas atuassem no fomento, assistência técnica e aquisição de matéria-prima dos agricultores familiares. A estratégia de verticalização foi também adotada pela empresa, que passou a adquirir unidades de esmagamento de oleaginosas em diferentes Estados.

Nos PG a empresa atuou junto aos movimentos sociais e as cooperativas familiares, especialmente no fomento de projetos de produção de soja, girassol e a canola. A empresa, no entanto, não adotou a mesma estratégia empregada em outras regiões brasileiras. Ao invés disso, optou por formar sociedade diretamente com indústrias de biodiesel do Rio Grande do Sul, como ficou claro com a aquisição de $50 \%$ da Brasil Sul Biocombustíveis (BSBios). A aquisição de duas plantas industriais da empresa, uma em Passo Fundo (RS) ea outra em Marialva (PR) por R\$ 200 milhões, é objeto de auditoria pelo Tribunal de Contas da União (TCU) que suspeita se houve sobrevalorização de preços.

viii) Banco Nacional de Desenvolvimento Econômico e Social (BNDES)

É de competência do Banco Nacional de Desenvolvimento Econômico e Social (BNDES) fornecer linhas especiais de financiamento diretamente por meio de suas agências regionais ou de outras instituições financeiras credenciadas, como o Banco da Amazônia S.A. (Basa), o Banco do Nordeste do Brasil (BNB) e o Banco do Brasil (BB). A Resolução n 1.135, do BNDES, de 3 de dezembro de 2004 estabeleceu as diretrizes de financiamento de todas as fases da produção do biodiesel.

Em 2007, três anos após a implementação do PNPB, o BNDES já oferecia uma carteira de financiamento da ordem de $\mathrm{R} \$ 700$ milhões. Esses recursos 
viabilizaram a construção de plantas industriais em Mato Grosso, Goiás e Rio Grande do Sul, (CLICRBS, 2007; ELETROSUL, 2007). Para o gerente da área de infraestrutura do banco, o foco caiu sobre projetos de grande porte, sem contemplar produtores da agricultura familiar ou suas entidades, uma vez que:

\begin{abstract}
A maioria que nós temos aqui é de projetos consorciados de soja com algodão, soja com girassol e soja com sebo bovino. 0 BNDES financia mais a parte industrial. Nessa parte de agricultura familiar, os recursos vêm do Programa Nacional de Fortalecimento da Agricultura Familiar e a parte agrícola é financiada por outro agente, no caso o Banco do Brasil (GANDRA, 2007, grifos do autor).
\end{abstract}

O BNDES financia até $90 \%$ a aquisição de itens para indústrias certificadas com o selo combustível social (SCS) com taxas de juros de longo prazo (TJLP) de $1 \%$ ao ano para pequenas e médias empresas, e de $2 \%$ para as empresas de grande porte. Entre os itens financiáveis estão a produção de óleo bruto, coprodutos e subprodutos do biodiesel, armazenamento, equipamentos para logística e máquinas homologados para uso de biodiesel ou de óleo vegetal bruto (CAVALCANTI, 2006).

ix) Empresa Brasileira de Pesquisa Agropecuária (Embrapa)

A Embrapa é uma empresa pública que atua dentro da cadeia do biodiesel como uma instituição engajada em estudos, processos, tecnologias e matérias-primas voltadas para o desenvolvimento da agricultura e também da produção de agroenergia no Brasil. A Embrapa Agronenergia, com sede em Brasília, é uma das mais recentes subdivisões da empresa, criada em 2006, dentro do Plano Nacional de Agroenergia (PNA) do MAPA. A unidade atua especificamente na pesquisa, desenvolvimento e inovação na área de biologia energética, processamento de novas matérias-primas, aproveitamento de resíduos e co-produtos e gestão do conhecimento no campo bioenergético.

Pesquisa, desenvolvimento e inovação têm sido, portanto, as funções básicas da empresa na política do biodiesel. A empresa operatambém em parceria com a Petrobras para resolver questões relativas ao incremento da produção de óleos vegetais, zoneamento agroclimático e aproveitamento de co-produtos a partir de resíduos como farelo e tortas. Suas atividades estão alinhadas com as diretrizes de tecnologias acessíveis à agricultura familiar, mas, sobretudo, com as demandas de grupos empresariais do setor bioenergético com o qual celebra contratos e convênios de pesquisa. 
Outras unidades da Embrapa atuam em projetos de PD\&I na cadeia produtiva do biodiesel. Unidades como a Embrapa Semi-Árido, por exemplo, desenvolvem linhas de pesquisa, parcerias público-privadas e projetos de co-gestão com associações e cooperativas da Região Nordeste, voltados para o aprimoramento de técnicas produtivas de sementes alternativas como a mamona, o girassol e o amendoim. De maneira geral, as unidades regionais da Embrapa atuam no desenvolvimento da agricultura como base produtiva eficaz para o suprimento de alimento e energia.

Nos PG, experiências com culturas alternativas também foram desenvolvidas pela Embrapa Clima Temperado de Pelotas. Entretanto, a Embrapa Trigo, em Passo Fundo, no Polo Nordeste/RS, sediada dentro de um dos principais territórios agroenergéticos no Estado, foi responsável pela formação de projetos de alguns projetos pilotos com indústrias de biodiesel, produtores, associações e cooperativas.

A Embrapa Trigo, junto com asindústrias dos PG, a Empresa Estadual de Assistência Técnica do Rio Grande do Sul (Emater/RS) e o programa Desenvolvimento Regional Sustentável para Biocombustíveis do Banco do Brasil (DRS Biocombustíveis/ BB), tem um histórico de articulações institucionais com centros universitários locais e associações de produtores rurais para realização de projetos e dias de campo voltados para o desenvolvimento do cultivo de novas matérias-primas para adiversificação da matriz do biodiesel.

Durante o 'Seminário B20 Metropolitano' realizado em parceria da Ubrabio com a Embrapa Agroenergia, a instituição debateu o tema 'Mobilidade Sustentável para as Cidades Brasileiras'. O diretor da da Embrapa Agroenergia destacou "o biodiesel é um produto nacional e sustentável e garantido pelas principais montadoras e fabricantes de motores a diesel. E, com os aumentos sucessivos no preço dos combustíveis fósseis, é uma ótima oportunidade para a adoção de um combustível mais limpo e mais barato" (EMBRAPA, 2015 p.1, grifos do autor). Durante o seminário foi destacada a capacidade do aumento do biodiesel contribuir para a redução da pegada de carbono brasileira e tornar um país um exemplo no alcance de reduções de emissões de GEE. 
Parte III - Os direcionadores de governança e eco-governamentalidade a partir dos Polos Gaúchos de Biodiesel

4.4 Os direcionadores de governança do biodiesel nos Polos Gaúchos

Após conhecer as variáveis estruturais que caracterizaram a implementação das regulações, leis, normas e regras, os papeis e perfis dos atores e instituições e os elementos legitimadores que instuíram as arenas de ação política, espaços deliberativos e consultivos do PNPB, é possível refletir sobre como as competências, direitos, prerrogativas, e, igualmente, deveres e incumbências se desenvolvem na governança do biodiesel nos PG. É possível também refletir sobre as atuais interações e interdependências, e consequentemente os impactos - positivos ou negativos - derivados desse conjunto complexo de relações de poder.

Esta seção procura correlacionar as categorias de análise oferecidas pelo modelo IAD de Ostrom (2005) frente aos princípios da 'boa governança' e analisá-los dentro da proposta dos 'direcionadores de governança dos recursos energéticos'. Uma análise conjunta das estruturas e processos que regem os atores, as instituições envolvidas e que remetem a uma discussão das configurações sóciopolíticas e produtivas dos atores individuais/coletivos. Uma análise, portanto, de seus recursos (políticos e econômicos), seus atributos específicos, funções e hierarquias, além do conjunto de ações permitidas frente às regras, regulações e limitações de ordem mercadológica, tecnológica e institucional. São apresentadas igualmente algumas das racionalidades e discursos presentes na regulação, gestão e exploração do biodiesel no PG.

\subsubsection{Descentralização}

A despeito de o regime federalista brasileiro delegar competências comuns e concorrentes às unidades federativas e aos municípios, em matéria de regulação e exploração do biodiesel esta prerrogativa é exercida exclusivamente pelo Governo Federal. No Brasil, o setor obedece a uma disposição hierárquica concentrada nas deliberações da Casa Civil, referendadas pelo Conselho Nacional de Política Energética, e pela gestão executiva da Agência Nacional de Petróleo, Gás Natural e Biocombustíveis (ANP). A CEIB e a Câmara de Oleaginosas e do Biodiesel do MAPA, por sua vez, são as principais arenas consultivas e loci de ação política que compreendem os atores estatais, mas também grupos de atores não-estatais com maior capacidade de articulação e recursos para exercer influência no âmbito do Governo Federal. 
$\mathrm{Na}$ prática, a atual estrutura político-institucional da governança do biodiesel no Brasil não incorpora qualquer mecanismo de descentralização ou princípio de subsidiaridade, flexibilidade, ou decisões bottom-up em favor dos governos regionais e locais. Isso quer dizer que não há autonomia dos governos dos estados e dos municípios na definição de critérios e parâmetros legais para regulação do biocombustível. As comunidades rurais, zonas urbanas e periurbanas de cidades e as localidades inseridas nos territórios de produção, como os PG, obedecem a ordenamentos e regulações determinados unicamente por atores de governo em um fluxo de decisões top-down, ou de cima-para-baixo (Figura 14).

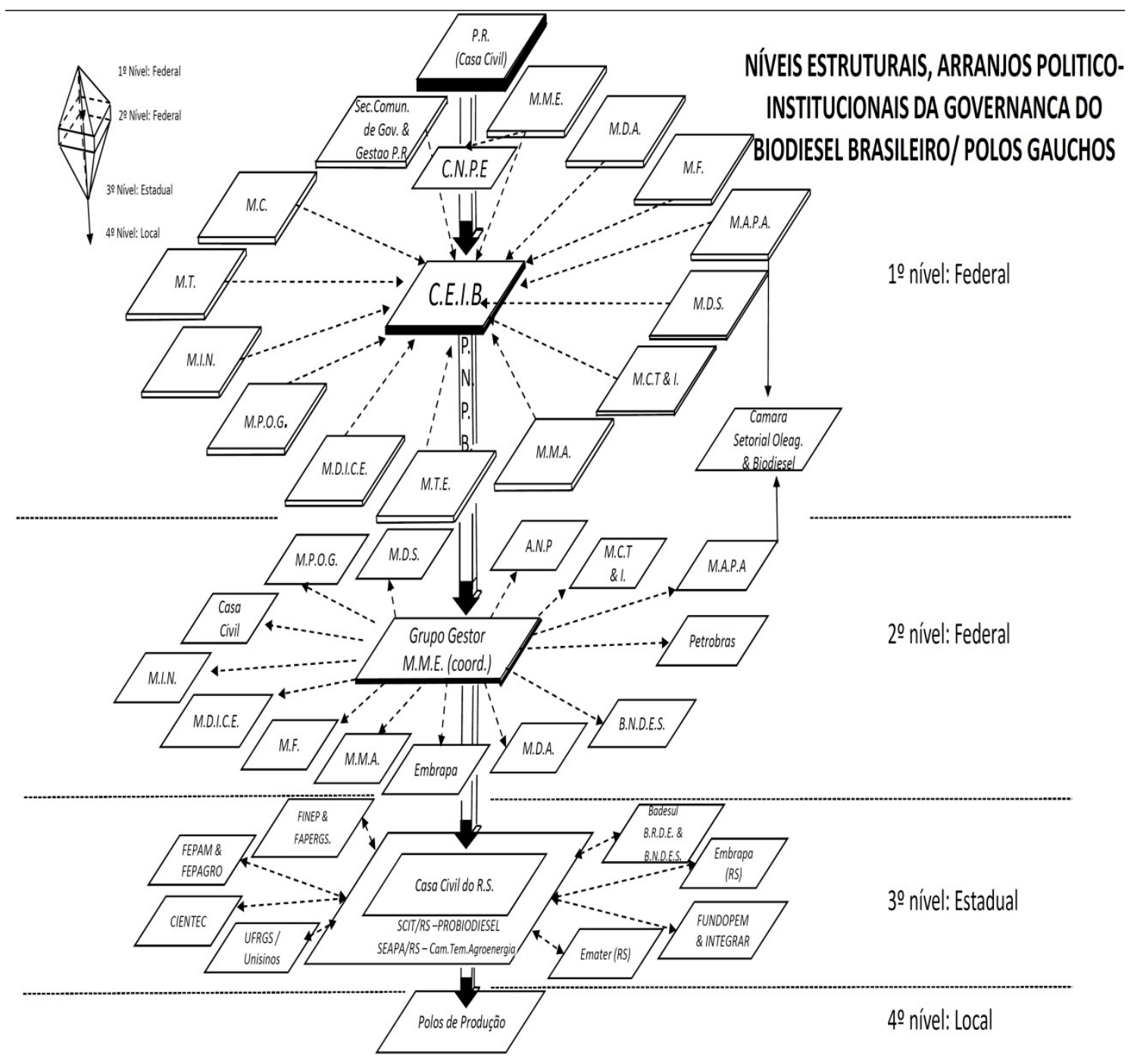

Figura 14- Níveis estruturais de governança do biodiesel no Brasil. Fonte: elaborada pelo autor.

Essa característica não implica que iniciativas sejam tomadas pelas Casas Civis estaduais, como a Câmara Estruturante de Agroenergia do Rio Grande do Sul. Entretanto, como expresso na própria designação da política estadual, trata-se apenas de medidas para estimular a estruturação e a consolidação do setor 
agroenergético, sem maiores poderes ou prerrogativas autônomas para implementação de regulações produtivas. De forma geral, as ações resumem-se a organizar e estimular o setor de bioenergia, sobretudo pela atração de investimentos privados e políticas tributárias diferenciadas (RIO GRANDE DO SUL, 2012).

Essas considerações condizem com o observado por Azevedo (2010 e 2013) para quem os governos estaduais estabelecem programas e planos conexos às diretrizes do PNPB para incentivar redes de instituições públicas e privadas regionais, porém, eles fazem mais interessados nas oportunidades de acessar recursos federais para estimular os setores agroindustriais e energéticos. Ainda de acordo com o autor, boa parte dos investimentos e incentivos têm sido direcionados para projetos de curta duração oferecidos por institutos como a Finep, para "financiar projetos de pesquisa em temas isolados sem alcance suficiente para criar políticas públicas duradouras e impactantes" (AZEVEDO, 2010 p.33).

Os estados, como o RS, não têm o direito de definir o nível de mistura obrigatória de biodiesel ao óleo diesel mineral consumido em sua jurisdição. Eles não podem estabelecer diretrizes independentes para a exportação de biocombustíveis, uma atribuição exclusiva da CNPE. Não têm a prerrogativa de determinar o volume de compras das refinarias instaladas no estado, como, por exemplo, as quantidades adquiridas pela Refinaria Alberto Pasqualini (REAP), em Canoas, Rio Grande do Sul. Essas competências são exercidas exclusivamente pelo Governo Federal, por meio dos leilões e regras da Agência Nacional do Petróleo, Gás Natural e Biocombustíveis (ANP).

Dito de outra forma é competência exclusiva dos ministérios, agências e empresas públicas do Governo Federal estabelecer o regime de produção, distribuição e consumo de biodiesel. Quando muito, as políticas estaduais se restringem a normas e leis complementares editadas para estimular a produção do biocombustível dentro dos parâmetros, normas e leis federais. Nos Polos Gaúchos, por exemplo, o Probiodiesel/RS foi lançado para estimular parcerias com outros atores sociais, como universidades, órgãos e fundações de pesquisa. Mas, como outras unidades federativas interessadas em desenvolver o setor, acabou atuando muito mais na criação de políticas tributárias diferenciadas e mecanismos de aprimoramento da infraestrutura logística, agroindustrial e comercial.

No caso dos governos locais o nível de autonomia é praticamente inexistente em matéria de regulação do biocombustível. As responsabilidades e competências atribuídas no art. 30 da Constituição Federal de 1988, e da própria Política Energética Nacional não prevêem qualquer grau de participação dos municípios na regulação e gestão de recursos energéticos. Os municípios se 
restringem ao ordenamento territorial das atividades agrícolas e industriais, e atuam de forma complementar às autoridades estaduais no estabelecimento de critérios para o licenciamento ambiental.

$\mathrm{Na}$ prática, os municípios se restringem a criar ambientes atraentes para atividades agroindustriais, uma vez que são considerados investimentos economicamente vantajosos em termos de arrecadação de impostos, em especial, o de circulação de mercadorias ICMS, e de ganhos indiretos na geração de empregos, renda e dinamização da economia local. Os governos locais costumam oferecer, em consonância com o governo estadual, condições favoráveis para a aquisição de terrenos e a implementação da infraestrutura necessária para as instalações agrícolas e industriais.

\subsubsection{Participação}

Autores como Pedroti (2013) destacam que a conjuntura estrutural que deu origem à política do biodiesel no Brasilteve influência de diferentes segmentos da sociedade civil. Isso teria resultado num equilíbrio das condições sociais, econômicas e políticas na formulação do PNPB. Mas, na prática, a estrutura funcional de regulação e gestão do biodiesel, tendo por base os Polos Gaúchos, é caracterizada por uma participação desfavorável.

Essa característica começa pela própria deficiência da principal arena de regulação de energia do país em promover a participação da sociedade. Um exemplo é o protesto de 41 organizações da sociedade civil enviado à Presidência da República em 2013 que classifica a CNPE como um espaço político desequilibrado e concentrador. Para os autores do documento, que incluem ONG's nacionais e internacionais como a Conservantion International, Greenpeace, o Instituto Sociambiental (ISA) e o Instituto Brasileiro de Análise Social e Econômica (Ibase), o conselho é uma arena "chapa branca, onde decisões tomadas ad referendum carimbam a vontade de seu Presidente, o Ministro de Minas e Energia" (YAMAOKA, 2013 p.2). Para o grupo, a ausência de membros da sociedade civil, previstos na legislação, demonstra o perfil produtivista do órgão que por vezes é negligente com quesitos sociais e ambientais.

Simultaneamente, a disposição concentrada dos principais órgãos reguladores na esfera pública federal favorece apenas aos atores com maiores recursos econômicos e políticos. No amplo universo de atores sociais envolvidos na governança do biodiesel, esses espaços são ocupados pelos setores agroindustriais, especialmente, pelas associações e confederações industriais, como a Aprobio, 
Ubravio e Abiove. Essas entidades atuam como centrais de inteligência setorial, propagando seu eco-knowledge e suas estratégias de lobby em conjunto com a Frente Parlamentar Mista do Biodiesel. Como resultado, essas entidades estabelecem um alto patamar de influência sobre os arranjos político-institucionais e os processos que caracterizam a regulação e a gestão do biodiesel no país.

Ainda assim, eventualmente, parte do próprio setor industrial por vezes demonstra sua insatisfação com a participação na política de regulação e gestão do setor. Isso tem acontecidoespecialmente após o fim da vigência da Lei 11.097/ 13 de janeiro de 2005, em virtude do baixo interesse do Governo Federal em estabelecer um novo marco legal definitivo para o biodiesel. Na prática, a Presidência da República tem controlado o setor por meio de Medidas Provisórias, como a MP 647/ 28 de maior de 2014, convertida na Lei 13.033/24 de setembro de 2014 que determinou o último aumento de $7 \%$ (B7) no índice de mistura de biodiesel/diesel mineral, dentro do padrão e prazos que a Casa Civil considerou adequado, sem sinalizar um novo marco regulatório para os próximos anos, conforme as demandas do setor empresarial (BRASIL, 2014).

De acordo com um dos diretores da Aprobio, os textos oriundos da CEIB não estão sendo aproveitados, e embora acredite que a comissão seja um fórum de participação política importante para o programa de biodiesel, "com um corpo técnico muito qualificado", o representante industrial pergunta: "se o governo continua considerando o órgão como sendo um consultor final?" (FRANCO, 2014 p.24). Para um representante do MDIC e membro da CEIB, parte da resposta reside no fato de que "houve um deslocamento das discussõesda CEIB para a Câmara de Oleaginosas e do Biodiesel do Ministério da Agricultura, de maior influência da Ubrabio" (PG022, grifos do autor). Nesse "deslocamento" grupos de interesse industrial têm se articulado com atores estatais e parlamentares e segundo o mesmo entrevistado as "decisõesigualmente se deslocaram para o escopo do Ministério das Minas e Energia, sob comando direto da Casa Civil" (PG022, grifos do autor).

Ainda de acordo com o representante do MDIC, esse arranjo políticoinstitucional reflete o caráter atual de uma política energética que embora tenha um desenho institucional que legitima a participação de diversos setores da sociedade, está presa a "uma estrutura federativa concentrada que controla critérios e processos de regulação e gestão do setor" (PG022, grifos meus).

No tocante à participação na escala estadual, no âmbito do Programa Gaúcho de Biodiesel e do Projeto Estruturante de Agroenergia e, posteriormente da Câmara Estruturante de Agroenergia, as ações também são voltadas para facilitar a inserção produtiva de agricultores. A partir de deliberações tomadas na esfera do 
Poder Executivo Estadual, representantes dos programas estaduais promovem e atuam como interlocutores em seminários e fóruns correlacionados. Em geral, o fazem no sentido de realçar os aspectos socioeconômicos positivos do desenvolvimento não só do biodiesel, mas também do bioetanol. Entretanto, iniciativas estaduais para a consolidação de arenas participativas locais, abertas e permanentes nos territórios agroenergéticos gaúchos não fazem parte das ações estruturantes.

$\mathrm{Na}$ escala local, por sua vez, a dissolução dos conselhos participativos dentro da esfera do projeto Polos de Biodiesel eliminou por completo mecanismos de participação política local na estrutura institucional de biodiesel no Brasil. A dissolução ocorreu a despeito da importância da participação no âmbito do Projeto Polos exaltada pelo ex-coordenador regional do projeto para a região Sul, e por um dos exarticuladores do Polo Nordeste/RS:

A participação foi fundamental... nós tivemos uma participação muito boa aqui... Muitas parcerias... que nós fizemos... e que até hoje nós temos...os sindicatos participavam, as indústrias participavam, a Embrapa, as cooperativas da agricultura familiar... A gente fazia muito encontro com as regionais sindicais, mobilizava, participava!" (PG019, grifos meus).

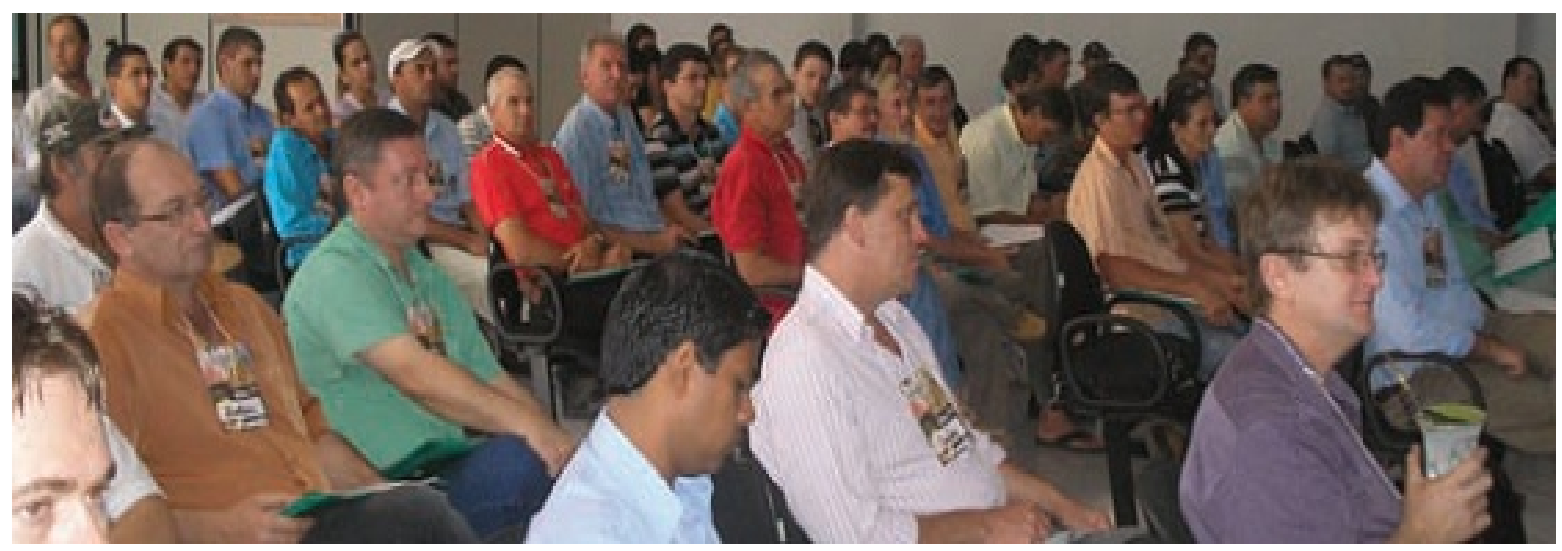

Foto 1 - Aspecto do extinto conselho grupo de trabalho dos Polos Gaúchos de biodiesel. Fonte: Brasil (2010).

A despeito disso, a iniciativa do MDA de acabar com o projeto significou a ruptura de um processo de amadurecimento do único espaço de governança multi-atores destinado a dar voz e representatividade não somente aos atores do setor agroindustrial e às cooperativas, mas também aos demais membros da sociedade civil como produtores rurais, associações, comunidades rurais, entre outros atores diretamente interessados e/ou impactados pela exploração do recurso energético. Como herança,o projeto deixou a percepção da produção do biodiesel como importante elemento da reestruturação do cooperativismo no Rio Grande do Sul, uma característicadestacada nos entrevistados. 
Outro legado da dissolução do Projeto Polos parece ter sido a propagação dos termos e expressões: "cooperação, participação, inclusão social e formação de parcerias"como elementos legitimadores, utilizados principalmente pelas indústrias de biodiesel. Ele surge, de forma recorrente entre os representantes empresariais para justificar o interesse e a lógica comum para o segmento empresarial.

\begin{abstract}
A formação de parcerias é necessária para obter a soja produzida por cooperativas da agricultura familiar, de agricultores maiores e também de cerealistas!" (PG 19, grifos do autor).
\end{abstract}

Inicialmente trabalhamos em parcerias com as cooperativas...esse é o arranjo produtivo... vamos dizer assim necessário... pra se ter o volume necessário para o Selo Combustível Social (PG 19, grifos do autor).

A importância de parcerias comerciais e a participação da agricultura familiar seguem as mesmas lógicas que conduziram os argumentos para a compra da metade do capital e dos ativos da BSBios adquiridos pela Petrobrás Biocombustíveis. Para os representantes das duas empresas, respectivamente:

A parceria com a Petrobrás permitiu pensar em novos conceitos e investimentos futuros à frente da matriz energética no país" (TONATTO, $2011 \mathrm{~s} / \mathrm{p}$. grifos do autor).

...e a atuação [da Pbio] na região Sul é estratégica pela grande produção de oleaginosas, e a presença significativa da agricultura familiar (TONATTO, $2011 \mathrm{~s} / \mathrm{p}$. grifos do autor).

Vale destacar, entretanto, que o que muitos autores denominaram e a própria política pública convencionou chamar de modelo de'participação' (Figura 15) dos atores da sociedade civilresume-se a um modelo de inserção produtiva. Um arranjo político-produtivo que na prática subordina os produtores familiares no país ao setor sojicultor, sobretudo, aqueles concentrados nas cerca de 40 mil unidades familiares que produzem grãos nos PG.

Seguindo o roteiro das perguntas norteadoras do IAD de Ostrom (2005), os atores 'participam' na cadeia produtiva do 'biodiesel' somente estimuladospelos mecanismos artificiais de mercado, pelas subvenções e prerrogativas comerciais oferecidas às indústrias detentoras do Selo Combustível Social e, sobretudo pelos incentivos econômicos materializados pelos pagamentos adicionais nas sacas de soja comercializados dentro do âmbito da certificação DAP/Pronaf. 


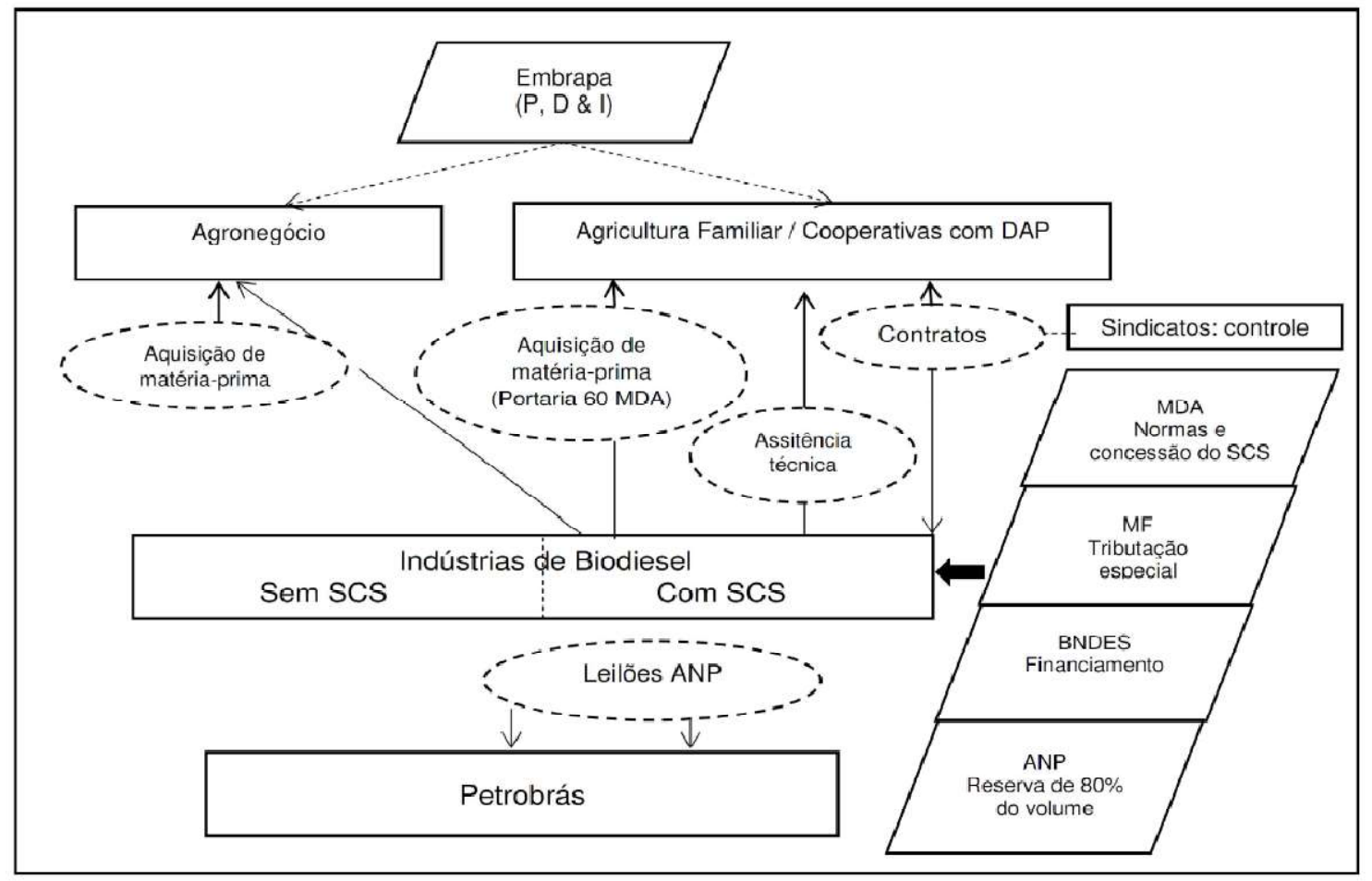

Figura 15 - Modelo de 'participação' dos atores sociais no PNPB.

Fonte: Pedroti (2013).

Essa configuração mantém um elevado grau de alienação dos agricultores da oleaginosa, uma vez que, eles não fazem distinção quanto à destinação de seus grãos, sendo a racionalidade direcionada pela lógica de preços e de mercado. Uma mentalidade que se propaga entre os produtores rurais nos PG, e mesmo em suas organizações, bem resumida por um dos presidentes das cooperativas de produção agrícola: "a [atual] participação dos produtores se resume ao fornecimento de soja, mas para eles não faz diferença qual a destinação dos grãos e sim a rentabilidade!" (PG09, grifos do autor).

Para um dos principais representantes da Embrapa de Passo Fundo, há uma retórica demasida nas políticas de governo correlacionadas a participação e benefícios sociais do PNPB e do Projeto Polos de Biodiesel. Para ele:

\footnotetext{
...programa de governo...essas questões que você coloca...Polos do MDA... não sei o quê.... nós temos conversado de montão aqui com pessoal.... dei palestra de montão... e vai procurar onde mudou a realidade de alguém? entende? (PG07, grifos do autor).

O que prevalece é a lógica da viabilidade econômica...Então o quê acontece...na prática,o programa de produção de biodiesel, nas empresas de biodiesel? Como que funciona? Elas (indústrias de biodiesel) ajudam a fomentar por que é uma exigência de governo pra reduzir PIS e COFINS! É responsabilidade dela! Fundamental pra viabilizar! (PG07, grifos do autor).
} 
Essas consideraçãoes vão ao encontro das considerações tecidas por Diniz e Favaretto (2012), para quem o formato que se convencionou chamar de 'participação' dos agricultores e de suas associações no PNPB e no SCS ao invés de trazer segurança aos produtores revelou a fragilidade desses incentivos, uma vez que, além de não garantir a fidelidade dos vínculos comerciais, erigiu uma estabilização artificial dos arranjos produtivos locais.

\subsubsection{Cooperação}

Nos territórios energéticos compreendidos pelos PG há um considerável número de atores sociais ligados direta e indiretamente à cadeia produtiva do biodiesel. Além das indústrias propriamente ditas, associações de produtores rurais, cooperativas agrícolas, órgãos de representação de classe, agências de pesquisa e empresas públicas mantêm relações socioeconômicas e produtivas que oscilam entre o discurso da cooperação e a consolidação de concorrências cada vez mais acirradas.

O mesmo é ressaltado por líderes de associações de produtores rurais que destacam a incorporação do novo nicho industrial e das suas respectivas atividades produtivas e comerciais, como atos inéditos de cooperação entre empresas e demais setores da sociedade envolvidos nas atividades agrícolas e industriais. Para o presidente de uma das principais associações de agricultores do Polo Nordeste/RS, ouvido na cidade de Passo Fundo, "as parcerias [promovidos] do setor gerou a formação de empregos, de... novas rendas! [e] hoje [a indústria $\mathrm{X}$ ] é a número 'um' em termos de geração de ICMS pro município!" (PG08, grifos do autor).

Mesmo os sindicatos de trabalhadores rurais, entidades que têm conflitos com setores empresariais, destacam que os processos de cooperação e as parcerias com as indústrias de biodiesel criaram impactos positivos para os produtores da região. Os representantes entrevistados acreditam que as ações conjuntas com a indústria vieram em prol da agricultura familiar e da geração de rendas agrícolas. Segundo o dirigente de um dos mais ativos sindicatos da região:

...nossas empresas aqui em Passo Fundo sempre foramparceiros nessa questão aí...é uma questão de incremento a mais na propriedade né! Pra gerar uma renda pro produtor, a gente é parceiro!(PG12, grifos do autor). 
Eles vieram procurar a gente...justamente por isso! Estamos mais próximos do produtor né... nas lavouras...As parcerias foram feitas pra questão de insumos, assistência...eles colocavam uma parte do insumo também! (PG12, grifos do autor).

Para o representante de uma das maiores indústrias de biodiesel dos PG, o nível de cooperação em prol da cadeia produtiva é tão expressivo que apesar de atuarem na mesma linha de produtos, e fornecedores:

[Nós] não somos concorrentes porque a gente acaba vendendo óleo e farelo na mesma linha... um vende pro outro! Um compra do outro! Ou a soja mesmo, acontece isso, não somos concorrentes, somos agentes do mercado! (PG14, grifos do autor).

Segundo o gerente industrial existe "uma interação e dez [empresas], que compram da agricultura familiar", num mercado disponível que possui apenas na região de Passo Fundo de "um número próximo ao de 25 mil agricultores com DAP habilitados para vender!" (PG14).

A efetividade e qualidade das parcerias e dos processos de cooperação estão, entretanto, longe de serem unanimidades entre os atores entrevistados. Para outros representantes de indústria de biodiesel, há um quadro de concorrência acirrada entre as empresas agroenergéticas. Segundo o gerente de uma das principais indústrias de biodiesel, que atua também no beneficiamento de grãos e soja, localizada no Polos Noroeste-Missões, a disputa vem acontecendo dentro e fora das divisas dos Polos Gaúchos e do estado, conforme frisa:

\footnotetext{
Lá no Mato Grosso é muito concorrido! Então as companhias de lá pra ter Selo Social, elas vêm até o RS pra comprar soja! (PG16, grifos do autor).
}

Vem comprar das cooperativas [pois elas]não precisam provar se fazem assistência técnica pro produtor! Não precisa comprovar nada! Não precisa, por exemplo, ir lá no sindicato pra eles carimbarem!(PG16, grifos do autor).

Nós [indústria] somos obrigados a fazer! Tem que ter um carimbo...! $\mathrm{E}$ o sindicato às vezes dificulta pra fazer isso aí né! (PG16, grifos do autor).

$\mathrm{Na}$ visão do representante industrial, as atuais regras do Selo Combustível Social estariam criando uma situação de disputa pelos produtores de soja dentro e fora das divisas do estado. As indústrias dos PG estariam sendo prejudicadas em parte pela ação das cooperativas e dos sindicatos locais que estariam favorecendo 
a ação logística de um ou outro grupo empresarial, conforme seus interesses comerciais.

A conversa com diretores de cooperativas agrícolas também confirma a crescente insatisfação que as entidades possuem com as indústrias. Dessa vez, porém, o argumento é a mudança de postura dos grupos empresariais, que estariam ampliando sua atuação e acirrando a concorrência direta pela aquisição dos grãos (soja), especialmente, juntoaos agricultores vinculados as cooperativas, conforme destaca o presidente de uma das entidades acessadas do Polo PlanaltoRS:

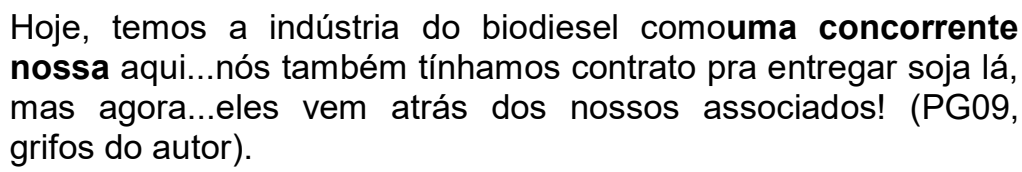

Para ele, a conduta comercial agressiva das indústrias de biodiesel afeta $\circ$ rendimento financeiro $e$, conseqüentemente, $\mathrm{o}$ volume de ações de desenvolvimento rural que pode ser oferecido pelas cooperativas. A lógica se repete nos depoimentos de diretores de outras duas cooperativas questionados sobre 0 processo de cooperação com as indústrias de biodiesel, em que:

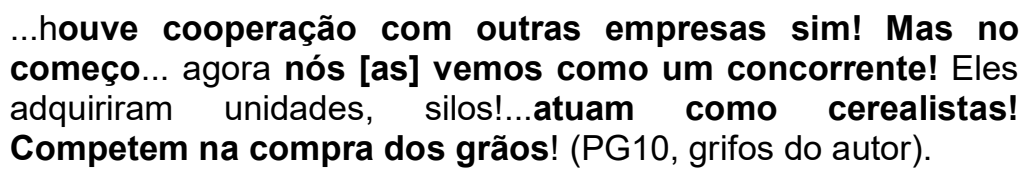

O presidente de uma das mais ativas cooperativas do Polo Nordeste/RS declarou o seguinte:

As cooperativas fizeram parcerias com a indústria de biodiesel! Nós e eles! Estávamos dispostos a ser o guarda-chuva! Trabalhamos todos os outros anos sempre em parceria (PG11, grifos do autor).

No início havia cooperação, hoje o processo só beneficia as indústrias... que estão indo direto nos produtores, enfraquecendo as instituições, as organizações da agricultura familiar... (PG11, grifos do autor).

$\mathrm{Na}$ visão das cooperativassão as indústrias que se valem da retórica da cooperação e das parcerias sociais para manter suas vantagens e benefícios fiscais, num quadro que lhes dá condições ainda mais favoráveisde competição. Para as entidades associativas, as empresas atuam sem preocupação com a assistência técnica com outras culturas fundamentais, ou com linhas de apoio agrícola. Características que são questionadas pelos diretores das entidades: 


\begin{abstract}
Foi para isso que o programa veio? Não! Foi pra ajudar na inserção da agricultura familiar [...] e suas organizações!Essa é a grande crítica das cooperativas com o Programa de Biodiesel. (PG11, grifos do autor).
Por que elas [empresas] vêm com um patamar de indústria querendo os melhores produtores. Alguns pequenos ela faz pra temática né! Pra manter os subsídios do Ministério né! (PG11, grifos do autor).

Ela [indústria] quer volume! Ela não quer quantidade de produtor assistido! Ela quer volume de produção! Ela quer produção!Foca muito mais nos melhores produtores com DAP! (PG11, grifos do autor).
\end{abstract}

Tal configuração conflituosase reflete igualmente no desfavorável grau de concertação entre as políticas públicas no escopo dos PG. Um dos exemplos se dá dentro do próprio escopo do MDA, principal instituição responsável pelo desenvolvimento social no PNPB. Nesse caso, o depoimento dos representantes entrevistados revelou um importante descompasso das ações públicas voltadas à implementação de sistemas de governança local/territorial e o desenvolvimento rural. Articuladores do antigo Projeto Polos, ligados à Secretaria da Agricultura Familiar (SAF), e coordenadores dos Territórios Rurais, da Secretaria de Desenvolvimento Territorial (SDT), têm um histórico de baixo intercâmbio, ou mesmo conflito, na interpretação dos atuais processos concorrenciais.

De acordo com um dos ex-articuladores dos PG, a questão da concorrência entre empresas e cooperativas na aquisição dos grãos da agricultura familiar se tornou um campo de discórdia entre representantes do próprio ministério. $\mathrm{O}$ entrevistado relata que um coordenador do Território Rural da região Nordeste, sob o escopo da SDT, teria acusado o Projeto Polos e o respectivo desenho operacional do programa do biodiesel como mecanismos que estariam estimulando as empresas agroindustriais do setor biodiesel e destruindo a viabilidade econômica das cooperativas.

\title{
4.4.4 Responsabilização
}

A produção do biodiesel está sujeita ao regime de licenciamento (e responsabilizaçao) ambiental, sob o enquadramento de "Indústria química de fabricação de combustíveis não derivados de petróleo" (Resolução CONAMA 237/97). Diante disso, as empresas são obrigadas a passar por todas as fases de licenciamento, incluindo o impacto das atividades das obras de implementação, e potenciais efeitos poluidores e/ou degradantes do empreendimento. De acordo com o Conselho Nacional de Meio Ambiente, cabe aos Órgãos Estaduais Ambientais (OEA), no caso dos PG cabe à Federação Estadual de Proteção Ambiental (Fepam), definir 
os critérios do Estudo e Relatório de Impacto Ambiental (EIA/RIMA) e os condicionantes para obtenção das licenças de instalação e operação.

Para o MMA (2015), no entanto, a principal questão envolvendo a responsabilização do biodiesel passa pela regularidade ambiental das propriedades produtoras de matéria-prima. Para o MMA os principais gargalos estão nas emissões no ciclo de vida do biodiesel e no impacto da mudança do uso da terra em conexão com o cultivo da soja. Segundo o ministério, isso realça a necessidade de um zoneamento agroecológico das atividades agrícolas da soja ligado a atividade do biodiesel, a exemplo do zoneamento da cana-de-açúcar estabelecido pelo Decreto $\mathrm{nr}$. 6.961/ 17 de setembro de 2009(BRASIL/2009).

Vale destacar que o Rio Grande do Sul é o Estado que menos avançou no Cadastro Ambiental Rural (CAR). De acordo com o último levantamento do Serviço Florestal Brasileiro, apenas 3\% das 480 mil propriedades rurais gaúchas cadastradas já se adequaram às exigências do novo Código Florestal (PANKE, 2015). Paralelamente à inadequação das propriedades, o estado assiste ao segundo boom da monocultura da soja. A Secretaria Estadual de Meio Ambiente se preocupa em esclarecer aos produtores rurais que existem limites legais de obrigatoriedade de recuperar, ou preservar, $20 \%$ das propriedades com o bioma nativo em cada propriedade de acordo com as previsões de reserva legal da Lei 12.651/ 25 de maio de 2012.

A Associação Brasileira da Indústria de Óleo Vegetal (Abiove) e as demais associações industriais ressaltam que não há ligação direta do biodiesel com a expansão da cadeia soja, uma vez que o setor teria margem para crescer aproveitando a super oferta do óleo vegetal. Mas as empresas que operam com o biocombustível nos PG, são prioritariamente agroindústrias processadoras de soja, interessadas também na compra dos grãos, beneficiamento e comercialização de seus coprodutos, sobretudo, o rentável farelo protéico. $\mathrm{Na}$ prática, as indústrias de biodiesel são agroindústrias processadoras de soja que estimulam não apenas o aumento da produtividade, mas também da área plantada de soja.

Segundo o gerente operacional de uma das maiores indústrias de biodiesel dos PG, a racionalidade comercial no setor é definida pela soja e pelos seus derivados. O biocombustível é um investimento de médio e longo prazo para as empresas, potencializado em grande parte pelos estímulos fiscais. Para ele, a atividade é benéfica, pois representa um nicho a mais para o óleo vegetal de soja, mas na realidade a atratividade e rentabilidade do farelo é que regem grande parte do interesse e comportamento dos grupos agroindustriais envolvidos: 
O que interessa mesmo é o farelo! O que dita o preço de mercado é o farelo! Não é o óleo! Pode ver que o preço do farelo está cada vez subindo! Mais o óleo se mantém nesse custo de patamar, não variou muito na bolsa de Chicago! (PG 20 , grifos do autor).

Outros depoimentos reforçam a centralidade da soja e de seus subprodutos, em especial o farelo proteico, conforme a declaração dada a um periódico especializado do setor pelo diretor de uma das maiores empresas gaúchas:

\begin{abstract}
...éramos os maiores fornecedores de óleo de soja para o biodiesel no Rio Grande do Sul [...] entramos no segmento, pois conhecíamos as regras e macetes do mercado... [mas] o biodiesel não é vital para a empresa, pois somos uma grande exportadora de farelo de soja, e podemos vender parte do óleo que não usarmos no biodiesel" (RODRIGUES, 2014 p.10, grifos do autor).
\end{abstract}

Essa percepção é reforçada pelas declarações do presidente de outra das principais indústrias de biodiesel dos Polos Gaúchos, indicando que o principal filão comercial da empresa deriva de um faturamento interligado a "mais de 4 mil caminhões e 1.200 vagões carregados de farelo para exportação para a Europa" (TONATTO, 2011 s/p. grifos meus). Vendido sob a designação de 'Farelo de Soja 46' (Foto 2), o produto também é comercializado em suas auto-intituladas: "unidades de originação", sob o slogan: "energia que vem do campo".

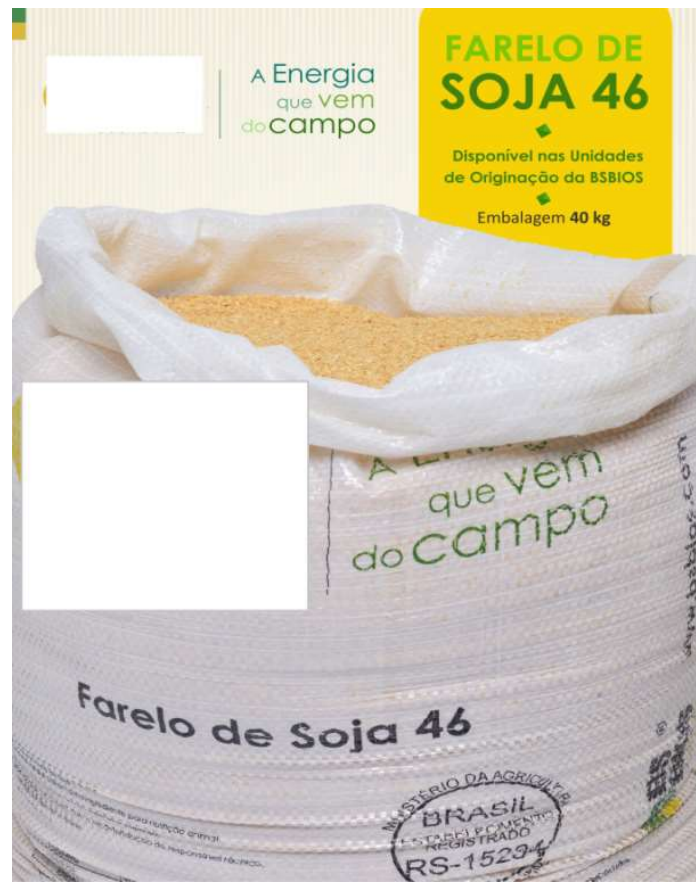

Foto 2: Farelo de Soja 46 "Energia que vem do campo". Fonte: google images. 
Para outra empresa, esse comportamento é natural, uma vez que a alta ociosidade, aliada à falta de perspectiva provocada pela ausência de um novo marco regulatório para o setor, fez com que as empresas centralizassem cada vez mais suas atividades e negócios no comércio da soja e de seus co-produtos. Na ocasião da pesquisa, antes da Medida Provisória que aumentou a mistura obrigatória de biodiesel de $5 \%$ para $7 \%$ (MP 647/2014) as operações com o biocombustível estavam praticamente paradas na empresa, conforme relata seu engenheiro de produção:

O biodiesel, esse semestre, a gente não vendeu nada!" $\mathrm{Na}$ realidade o grande nicho da empresa se concentrou "no comércio e beneficiamento de grãos, sobretudo, a soja e seus derivados (PG13, grifos do autor).

Os atores entrevistados nos PG enxergam como uma resposta natural de mercado que a soja ocupe áreas de outras atividades agropecuárias tradicionais do Estado e modifique as paisagens de produção. Para o diretor de associação de produtores rurais entrevistado em Passo Fundo existe a estimativa de abertura para novas áreas de plantio de soja sobre mais de 2 milhões de hectares de pastagens de gado, onde:

\begin{abstract}
A tendência é ter esse incremento da área de soja nas pastagens degradadas, [de] onde o gado já saiu.., uma profissionalização!Ao invés de trabalhar toda área com pasto, concentra, lota melhor essa área, e o resto fica disponível pra soja! (PG 08, grifos do autor).
\end{abstract}

Para o gerente de operações comerciais de um grupo agroindustrial produtora de biodiesel o novo boom da soja estaria inclusive avançando sobre a rizicultura gaúcha Para ele:

\footnotetext{
...até Cruz Alta que era uma das maiores produtoras de Soja do Estado está perdendo [a posição] hojepra Cachoeira do Sul né! Que antes era tradicional no Arroz! O Arroz tá perdendo espaço justamente por causa do mercado do biodiesel... do mercado da Soja! (PG 20, grifos do autor).
}

\title{
4.4.5 Transparência
}

A Transparência nas informações administrativas e produtivas na governança do biodiesel brasileiro, a partir do observado nos PG foi considerado de qualidade suficientemente boa, ainda que com ressalvas. Isso porque existem canais favoráveis de acesso às informações pertinentes. No sistema de governança do biodiesel brasileiro existem canais de comunicação dos órgãos oficiais envolvidos, 
embora ainda falhem na rapidez, clareza e acessibilidade. Em contrapartida, porém, há pouca divulgação sobre seus procedimentos químico-industriais técnicos e operacionais.

Críticas levantadas por autores como Schaffel (2010), sobre a baixa transparência no escopo do PNPB levaram à construção de canais oficiais de informação do MDA para divulgar a quantidade de agricultores familiares incluídos e de contratos celebrados por região, especificando tipo de oleaginosas contratadas. É possível, por exemplo, obter informações sobre os números de famílias, cooperativas fornecedoras por unidade federativa e região, além de volumes e valores de matéria prima no âmbito do Selo Combustível Social, entre 2008 e 2014.

Dentre as 73.479 famílias cadastradas, por exemplo, 61.815 (89,3\%) estão na Região Sul, e somente nos PG encontram-se 44.906 famílias, ou seja, mais $60 \%$ dos contratos. Os mesmos números deixam claro que apesar da evolução do número de cooperativas participantes (78 no Brasil; e 39 no Rio Grande do Sul), bem como, no volume de matéria-prima (3 bilhões de toneladas em 2014), o volume e o valor dos negócios estão significativamente concentrados na produção de soja pelos produtores familiares gaúchos (BRASIL, 2016).

Em contrapartida, existem pouquíssimos detalhes dos contratos, especificando quais cooperativas, e produtores individuais vêm firmando acordos comerciais com as indústrias de biodiesel dentro e fora de seus respectivos estados de origem. Muitas empresasdas Regiões Centro-Oeste e Norte, por não possuírem a quantidade necessária de produtores familiares com o volume necessário para obter 0 SCS, recorrem aos grãos produzidos na Região Sul para justificar a manutenção de suas certificações. Essas informações poderiam igualmente oferecer dados sobre os órgãos e entidades de classe (sindicatos) responsáveis pela fiscalização dos contratos.

Relatórios de qualidade e quantidade de ATER também continuam sendo um desafio de transparência para o MDA. Tentativas de consultas ao intitulado Sistema de Gerenciamento das Ações do Biodiesel (Sabido) do MDA resultaram em reiteradas falhas de acesso. De maneira semelhante os portais de transparência do BNDES não informam com precisão os critérios utilizados e a quantidade de recursos liberados e contratos firmados com as agroindústrias contempladas.

No tocanteàs indústrias, embora não haja a obrigatoriedade de divulgação de dados produtivos e riscos inerentes as atividades agroindustriais, além dos exigidos pelo processo de licenciamento ambiental,falta a divulgação de dados produtivos e técnicos. Embora o biodiesel seja classificado como um combustível de origem orgânica (vegetal e animal) biodegradável, seu processo de produção ou 
transesterficação implica na utilização de quantidades significativas de água e produtos químicos como hexano. Em especial, as águas resultantes do processo de lavagem do biodiesel são quimicamente inadequadas para serem lançadas em qualquer corpo hídrico(RODRIGUES, 2014).

A falha na transparência das indústrias e a desinformação sobre procedimentos dos órgãos ambientais e/ou das comunidades locais podem causar consequências ambientais danosas. Não são raros os casos de vazamentos de efluentes no setor (Fotos 3 e 4).

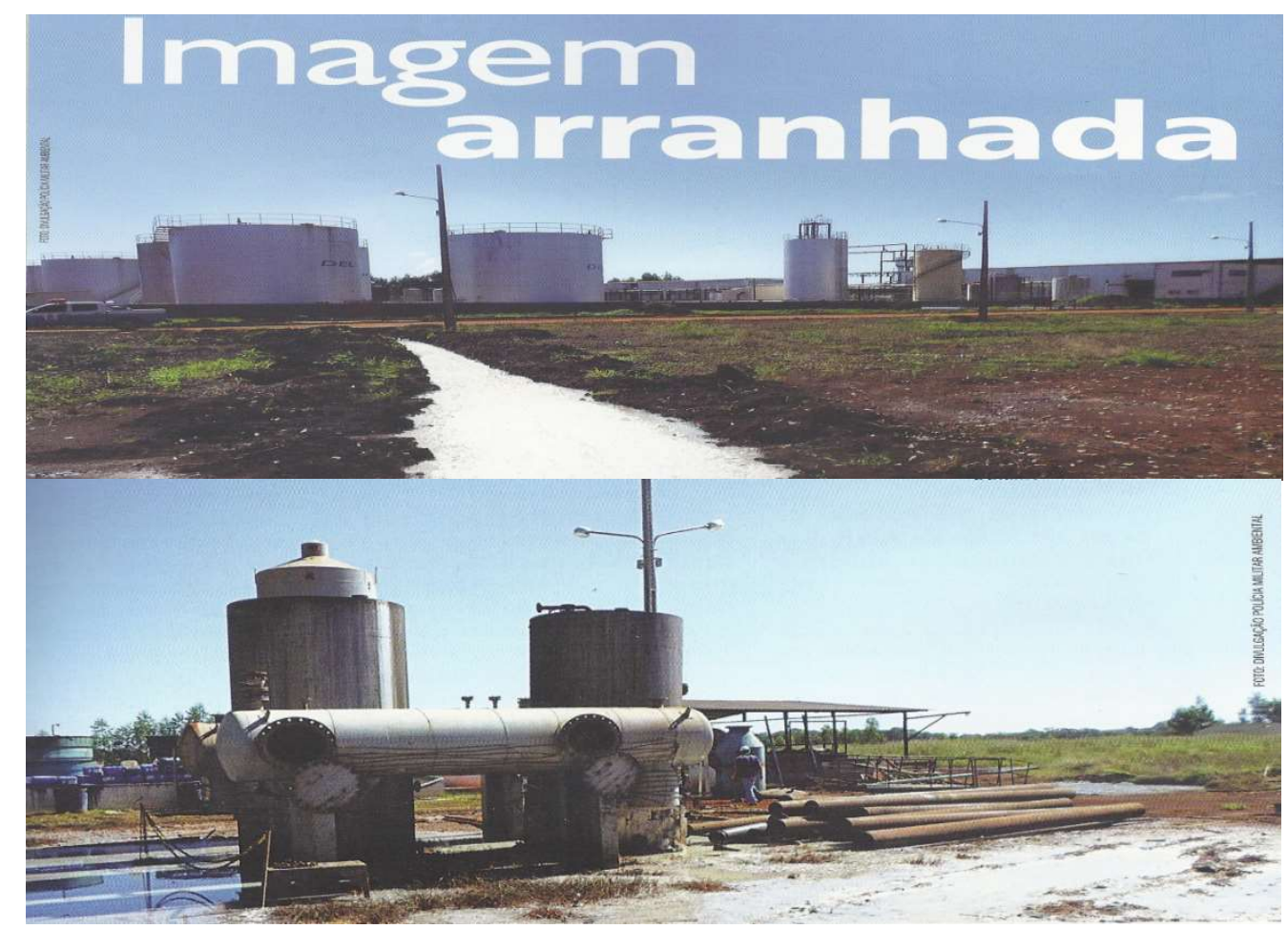

Fotos 3 e 4 - Imagens de vazamentos de efluentes de indústria de biodiesel.

Fonte: Rodrigues (2014).

Em 2014, por exemplo, duas plantas gaúchas geraram vazamentos que mataram pelo menos cinco toneladas de peixes de um lago na cidade de Erechim-RS. A empresa teria recebido uma multa de $\mathrm{R} \$ 224$ mil por danos ambientais (TAVARES, 2014). Houve outro vazamento no Arroio Jabuticaba, nas imediações da cidade de Veranópolis-RS, comprometendo a micro-bacia do rio das Antas (RODRIGUES, 2014).

Incêndios e explosões também estão no histórico das usinas brasileiras. Os casos envolveram não apenas prejuízos materiais, mas também de vidas humanas. De acordo com Juarez (2011) o segmento é perigoso em relação a outros setores industriais. Mas para o professor "o efeito dessas notícias junto à opinião pública pode, em médio ou longo prazo, macular a imagem que o biodiesel tem de ser uma solução energética limpa e ambientalmente correta" (p.01, grifos do autor). Uma lacuna, entretanto, que demanda mais transparência por parte 
agroindústrias quanto aos seus procedimentos de produção e manuseio de produtos e insumos, e uma maior transparência.

Juarez (2011) explica que invariavelmente, a causa dos acidentes nas indústrias de biodiesel é o uso de metanol. Uma substância incolor suscetível a explosões e de altíssima inflamabilidade. O seu ponto de inflamação éde apenas $11^{\circ}$ $C$ em que seus vapores podem inflamar ecomconcentração de apenas 5,5\%, no ar atmosférico é suscetível a explosões. O pesquisador frisa que é necessário o composto não está presente só nos reservatórios específicos do composto, mas também dissolvido no biodiesel, na glicerina e mesmo na água de lavagem, ampliando os riscos de contaminação, incêndio ou explosão.

\subsubsection{Equidade}

A assimetria de poderes entre os atores sociais é uma característica bastante comumdentro de numa estrutura de governança do biodiesel no Brasil, seja nos PG, seja nas demais áreas de produção do biocombustível. Devido à concentração das arenas políticas e das tomadas de decisoesna esfera federal ea uma participação política debilitada, não há uma equidade. Tal configuração faz com que inexista uma equidade de direitos e ganhos quanto a critérios como prerrogativa de voto e decisões na implementação de regulações, ou mesmo, na decisao sobre a aplicação de receitas e taxas na esfera estadual e, especialmente, municipal.

Os diferentes grupos, associações, empresas e entidades têm uma considerável assimetria de poderes, prerrogativas e benefícios dentro da estrutura política e produtiva do setor. Enquanto grupos como a Ubrabio, Aprobio, Abiove, entre outros, têm estratégias claras e proativas de divulgação de materiais, revistas e estudos, além de uma articulaçãoeficiente frente aos poderes públicos, outros participantes exercem muito mais a função de legitimadores do PNPB. Majoritariamente, são os atores providos de maiores recursos financeiros e estratégias políticas que conseguem acessar e influenciar de forma efetiva arenas e espaços políticos de regulação e gestão, efazer valer sua lógica nas escalas locais, como os $P G$.

Xavier e Vianna (2009), logo nos primeiros anos de formação do PNPB, chamavam atenção para a lógica contraditória e assimétrica de interações e relações de poder entre os atores sociais. Para os autores, o programa apesar de constituído como uma política pluralista estaria na prática se consolidando pelo fortalecimento da lógica produtivista e dos atores no setor privado. Os arranjos produtivos e os processos políticos estariam de fato fortalecendo um "neo-corporativismo" e as 
interações envolviam "conflitos de atores com interesses socioeconômicos distintos que se enfrentavam de forma assimétrica na arena decisória da política nacional" (XAVIER \& VIANNA, 2009 p.701, grifos do autor).

Uma visão semelhante é proposta por Flexor et. al. (2011a; 2011b e 2011c). Para esse grupo de pesquisa, as estruturas de grande complexidade dentro do PNPB refletiam um elevado número de interesses, recursos e valores distintos, tendo em comum uma significativa assimetria de poder. Os autores dividem em três grupos os principais atores sociais envolvidos: os atores energéticos, os atores do agronegócio e os atores do desenvolvimento agrário.

Os atores energéticos, de grande poder, inclusive com capacidade de veto nas arenas do CNPE e da CEIB, estariam concentrados dentro das instituições de governo, representados pelo MME, ANP e Petrobrás. Os atores do agronegócio estariam entrelaçados nas estruturas de governo, especialmente pela presença em câmaras privilegiadas para discutir e estabelecer os critérios técnicos, pressionar o formato do mercado, ditar preferências, converter valores em parâmetros da política. $O$ terceiro grupo, denominado de atores do desenvolvimento agrário, embora com participação no desenho político-institucional basilar do PNPB ocupariam uma posição periférica e legitimadora da política pública.

Partindo desse enquadramento, as associações, sindicatos empresariais e confederações industriais seriam o segmento da sociedade civil com maior volume de recursos, organização e capacidade de influenciar e interagir com os atores energéticos que ocupam posições-chave na regulação federal da política. Suas redes de negócios, contatos políticos e interpessoais permitem o acesso direto ao governo (FLEXOR, 2011a).

De fato, quando se leva em consideração as agendas políticas e práticas das associações de empresas e produtores de biodiesel é bastante visível a ação dessas entidades no Poder Legislativo e nas pautas de reuniões no Palácio do Planalto e nas demais arenas distribuídas na Esplanada dos Ministérios. Elas "existem para ter uma negociação mais qualificada com o governo, especialmente o federal aumentando sua capacidade de barganha" (GROS APUD RODRIGUES, 2012). Dito de outra forma elas atuam regularmente na prática de lobby para aumentar seu poder de negociação. Atuam como verdadeiras "centrais de inteligência setorial", encomendando e financiando estudos e estatísticas para orientar as lógicas discursivas de seus associados e dar cientificidade e legitimidade aos seus argumentos e interesses (RODRIGUES, 2012p. 01). 


\subsubsection{Pertencimento}

De forma geral é fraco, ou mesmo inexistente, o sentimento de pertencimento dos atores sociais envolvidos na cadeia produtiva do biodiesel nos PG, sobretudona estrutura de produção rural e frente aos arranjos políticos de governança do setor. Isso ocorre porque o papel dos produtores rurais, como destacado no item sobre participação, se resume ao fornecimento de grãos de soja para as agroindústrias dentro do quadro concorrencial que envolve as cooperativas locais e as muitas empresas cerealistas que operam na região.

$\mathrm{Na}$ visão de um diretor de cooperativa, a ausência de condições e estímulos para que parte do setor pudesse ser apropriado e conduzido diretamente pela agricultura familiar e suas associações contribuíram para a baixa sensação de pertencimento que o biodiesel desperta nas comunidades locais. Na opinião do entrevistado, os principais órgãos públicos e bancos oficiais não apostaram na verticalização agroindustrial de cooperativas da agricultura familiar em direção à produção de óleo vegetal e/ou biodiesel. Segundo o entrevistado, sua cooperativa apresentou pioneiramente um projeto para uma planta de biodiesel com a função "de ser uma indústria, uma planta conduzida pelos produtores" (PG11).

\footnotetext{
Fomos lá 'no' BNDES do Rio de Janeiro negociar financiamento [...] não faríamos esmagamento de soja..., íamos fazer uma parceria com duas indústrias que iriam esmagar pra nós, tinha até contrato com essas indústrias pra esmagamento... (PG11).
}

... íamos pegar o óleo, comercializar o farelo no mercado, e fazer o biodiesel!...a gente tinha tudo... (PG11, grifos do autor).

Para ele, entretanto, as esperanças foram encerradas quando "saiu a notícia da [indústria X] em Passo Fundo, com capacidade de processamento de 300 mil toneladas por dia!" (PG11). Isso demonstra, na avaliação do entrevistado, que o programa do biodiesel foi delineado desde seu início para, no máximo, inserir os produtores como fornecedores de matéria-prima ao setor agroindustrial.

Vale ressaltar que a ausência de comitês, fóruns e audiências locais mina a questão do pertencimento das comunidades inseridas nosPG, sobretudo, dosprodutores rurais. A configuração top-downdasregulações, mecanismos de gestão e formas de exploração do biodiesel não colabora para o amadurecimento de um sentimento de condução conjunta, ou em comum, das diretrizes e benefícios do PNPB. A ausência dessas características, ou o baixo grau de ownership,como destacado por Bursztyn \& Bursztyn (2012), tem fragilizado, ou mesmo inviabilizado as ações conjuntas, parcerias e estratégias de governança no seio do PNPB. 


\subsubsection{Empoderamento}

Embora o engajamento frente aos aspectos socioeconômicos seja um forte elemento legitimador de governo e do setor agroenergético para o fortalecimento da agricultura familiar e da melhora da qualidade de vida de pequenas cidades, comunidades rurais e periurbanas envolvidas na produção do biodiesel, o que se observa nos PG são configuraçõespolítico-produtivas desfavoráveis ao empoderamento dos atores locais. Isso ocorre, porque não se desenvolveram medidas e ações de desenvolvimento endógeno capazes de promover o fortalecimento político, produtivo e econômico dos atores locais sobre seus territórios (BECKER, 1993). O processo resultou numa coesão social incapaz de consolidar direitos e desenvolver percepções políticas, sociais e ambientais entre os atores inseridos e interligados aos polos.

De maneira geral, prevalece a lógica do desenho operacional da política pública,na qual, o aumento de renda produzido pela certificação DAP é entendida como suficiente para o empoderamento. Essa percepção esconde o "pobre alinhamento" e a superficialidade doslaços sociais na gestão do recurso energético nas áreas produtivas (VACCARO, 2010 p.1267). Na prática, o desenho políticoinstitucional é pouco propenso para reforçar mecanismos de governança local, formação de capital social, formação de projetos de inovação e consolidação de práticas socioeconômicas e ambientais produtoras de empoderamento.

O tolhimento de espaços de ação coletiva ou de dispositivos coletivos, como do Projeto Polos de biodiesel, dificultou o crescimento de um maior protagonismo de agricultores e suas comunidades tanto na produção, manuseio e utilização do recurso energético (uso do biodiesel em máquinas, frotas comunitárias, implementos), quanto no manuseio dos recursos naturais que dão base à cadeia produtiva (uso da água, tratamento do solo, conservação/recuperação de APP e RL's). Elementos esses, capazes de produzir o aperfeiçoamento comunitário e individual dos atores sociais (RAMBO \&COSTA, 2010).

Concretamente, os elos 'sociais' se resumem aos incentivos econômicos criados em torno do PNPB e à ligação do setor agroindustrial aos produtores rurais dentro da estrutura de produção de soja. Um arranjo produtivo que compromete tanto adiversificação da economia quanto a pluriatividade das atividades rurais, diminuindo assim as chances de empoderamento real dos atores inseridos e interligados na base da cadeia produtiva do biodiesel. As relações e articulações se restringem assim ao contrato e comércio dos grãos, onde as empresas nutrem o sentimento comum de que oaumento do 'poder de troca' e 'renda' dos produtores 
familiares são sinônimos plenos de empoderamento dos atores locais, como bem exemplifica um dos gerentes de agroindústria:

\begin{abstract}
Hoje o produtor familiar é jóia rara! Ele pode ter a tranquilidade de investir na sua pequena propriedade, que por muitos anos ele vai ter pra quem vender e vai ser muito assediado! Hoje ele é tão ou mais assediado pela indústria do que $o$ grande produtor! Isso se reverte em renda, no seu poder de troca! (PG15, grifos do autor).
\end{abstract}

Diante desse quadro interpretativo é possível compreender que, apesar de ser uma atividade inédita no rol de produtos e atividades, o biodiesel se expande incorporado dentro da cadeia agroindustrial de empresas sojicultoras, não representando uma ruptura frente aos padrões da economia ou de mecanismos de empoderamento, uma vez que não é capaz de modificar as atividades que the dão base. Aocontrário,parece reforçar o comportamento produtivo dos agricultores familiares dentro de uma super dependência da soja em detrimento de outras atividades e produtos agrícolas, como destaca o presidente de uma importante cooperativa agrícola:

Estão fazendo isso [as indústrias de biodiesel]esquecendo que - agricultor familiar não produz só soja né! $O$ agricultor familiar produz trigo, produz milho, produz leite...leite também né! Outras atividades que ajudam a fortalecer o produtor... Tem tudo isso aí que nós apoiamos e elesnão! Eles tão priorizando... só o Filet Mignon! (PG09, grifos do autor).

A passagem reflete como importantes atividades socioeconômicas vêm sendo eclipsadas dentro da estrutura atual de concorrência entre indústrias, cooperativas e cerealistas, cujo contexto de supervalorização da soja no mercado internacional resultou, na última safra, recorde da oleaginosa no estado, que atingiu 5 milhões de hectares plantados e injetou cerca de 19,3 bilhões de reais na economia gaúcha (COLUSSI, 2015).

A jupança econômica esconde o fato de que não se criam condições alternativas ao desenvolvimento paralelo de mecanismos de empoderamento aos atores locais, mas sim do reforço de prerrogativas para repetir os mesmos erros de um passado não muito distante, no qual toda região concentrou suas atividades e apostouno futuro atrelado a uma commidity agrícola que tem seus preços e demanda atrelados ao comportamento do mercado internacional. Uma miopia que eclipsou importantes aspectos sociais na geração de empregos rurais não agrícolas e da pluriatividade dos membros inseridos em áreas de produção agroenergética (SACHS, 
2008). Uma lógica refém da racionalidade econômica e das fragilidades associativas que as caracterizam (DINIZ \& FAVARETTO, 2012).

4.4.9 Resultados da avaliação pelos 'Direcionadores de Governança dos Polos Gaúchos de produção de biodiesel'

Os resultados obtidos pelos'Direcionadores de Governança dos Polos Gaúchos de produção de biodiesel (detalhados na Tabela 8) revelaram um arranjo político-institucional com características que colocam em xeque a qualidade de regulação e gestão do recurso energético na região e no país. Por meio das categorias de análise selecionadas é possível afirmar que as estruturas e processos do atual sistema de governança interligado aos Polos Gaúchos é consideralvemente falho e inadequado.

\begin{tabular}{|c|c|c|c|c|c|c|c|c|}
\hline \multirow{3}{*}{$\begin{array}{c}\text { Direcionadores } \\
\text { (níveis e sub-níveis dos } \\
\text { sistemas de } \\
\text { sovernança - SG) }\end{array}$} & \multicolumn{4}{|c|}{ grau de controle: governo / governança } & \multirow{3}{*}{$\begin{array}{l}\text { peso do } \\
\text { direcionador } \\
\text { e de seus } \\
\text { subfatores }\end{array}$} & \multicolumn{3}{|c|}{ memória de cálculo } \\
\hline & \multirow{2}{*}{$\begin{array}{c}\text { CG } \\
\text { (controlado } \\
\text { pelo } \\
\text { governo) }\end{array}$} & \multirow{2}{*}{$\begin{array}{c}\text { QCG } \\
\text { (quase } \\
\text { controlado } \\
\text { pelo } \\
\text { governo) }\end{array}$} & \multirow{2}{*}{$\begin{array}{c}\text { QCS } \\
\text { (quase } \\
\text { controlado } \\
\text { pelo } \\
\text { sociedade) }\end{array}$} & \multirow{2}{*}{$\begin{array}{c}\text { CS } \\
\text { (controlado } \\
\text { pela } \\
\text { sociedade) }\end{array}$} & & \multicolumn{2}{|c|}{ avaliação } & \multirow{2}{*}{$\begin{array}{c}\text { avaliação } \\
X \text { peso }\end{array}$} \\
\hline & & & & & & qualitativa & quantitativa & \\
\hline 1) descentralização & & & & & $\overline{0,15}$ & & & $-0,15$ \\
\hline $\begin{array}{l}\text { - níveis de autonomia } \\
\text { dos governos locais na } \\
\text { regulação energética; }\end{array}$ & $\mathbf{x}$ & & & & 0,60 & D & -1 & $-0,60$ \\
\hline $\begin{array}{l}\text { - subsidiaridade e } \\
\text { Flexibilidade dos } \\
\text { governos centrais. }\end{array}$ & $\mathbf{x}$ & & & & 0,40 & D & -1 & $-0,40$ \\
\hline Sub-total & & & & & 1,00 & & & $-1,00$ \\
\hline 2) participação & & & & & 0,15 & & & $-0,12$ \\
\hline $\begin{array}{l}\text {-conselhos, comitês e } \\
\text { audiências públicas; } \\
\text { - movimentos sociais, } \\
\text { organizações não- } \\
\text { governamentais e } \\
\text { lideranças comunitárias; }\end{array}$ & $\mathbf{x}$ & $\mathbf{x}$ & $\mathrm{x}$ & & 0,6 & D & -1 & $-0,60$ \\
\hline $\begin{array}{l}\text { - representatividade dos } \\
\text { atores sociais e } \\
\text { instituições envolvidos. }\end{array}$ & & $\mathbf{x}$ & & & 0,2 & $\mathrm{~N}$ & 0 & 0,00 \\
\hline Sub-total & & & & & 1,00 & & & $-0,80$ \\
\hline 3) cooperação & & & & & 0,15 & & & $-0,06$ \\
\hline $\begin{array}{l}\text {-coordenação entre as } \\
\text { politicas públicas } \\
\text { federais, estaduais e } \\
\text { locais; } \\
\text { - parcerias: sócio- } \\
\text { privadas; público- } \\
\text { privadas } \\
\text { ou co-gestão. }\end{array}$ & $x$ & & $x$ & $x$ & 0,60 & D & -1 & $-0,60$ \\
\hline Sub-total & & & & & 1,00 & & & $-0,60$ \\
\hline
\end{tabular}




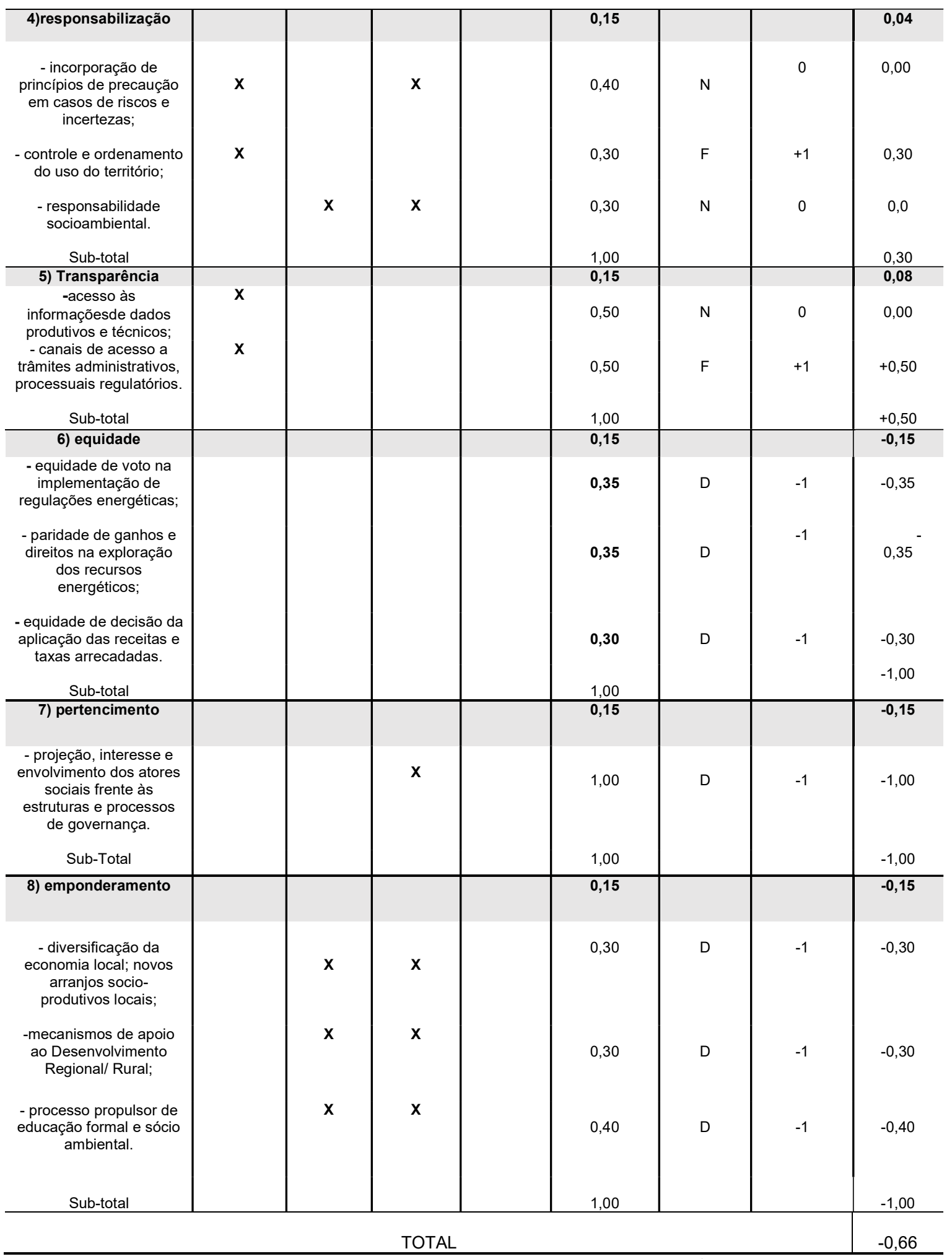

Tabela 8 - Resultados da avaliação qualitativa-quantitativa pelos 'direcionadores de governança dos Polos Gaúchos de produção de biodiesel'.Fonte: elaborada pelo autor.

Isso porque os direcionadores como descentralização, participação, equidade, pertencimento e empoderamento obtiveram baixíssimas avaliações. Mas também pelo baixo desempenho do princípio de cooperação e a performance regular no quesito de responsabilização. Somente o princípio de transparência, ainda que com 
ressalvas, foi considerado suficientemente bom. Em virtude desses desempenhos a soma total dos Direcionadores alcançou o resultado negativo de $-0,66$ acionando o 'farol' na faixa de: 'governança viciosa', e revelando consideráveis fragilidades, desvios e falhas (Figura 16).

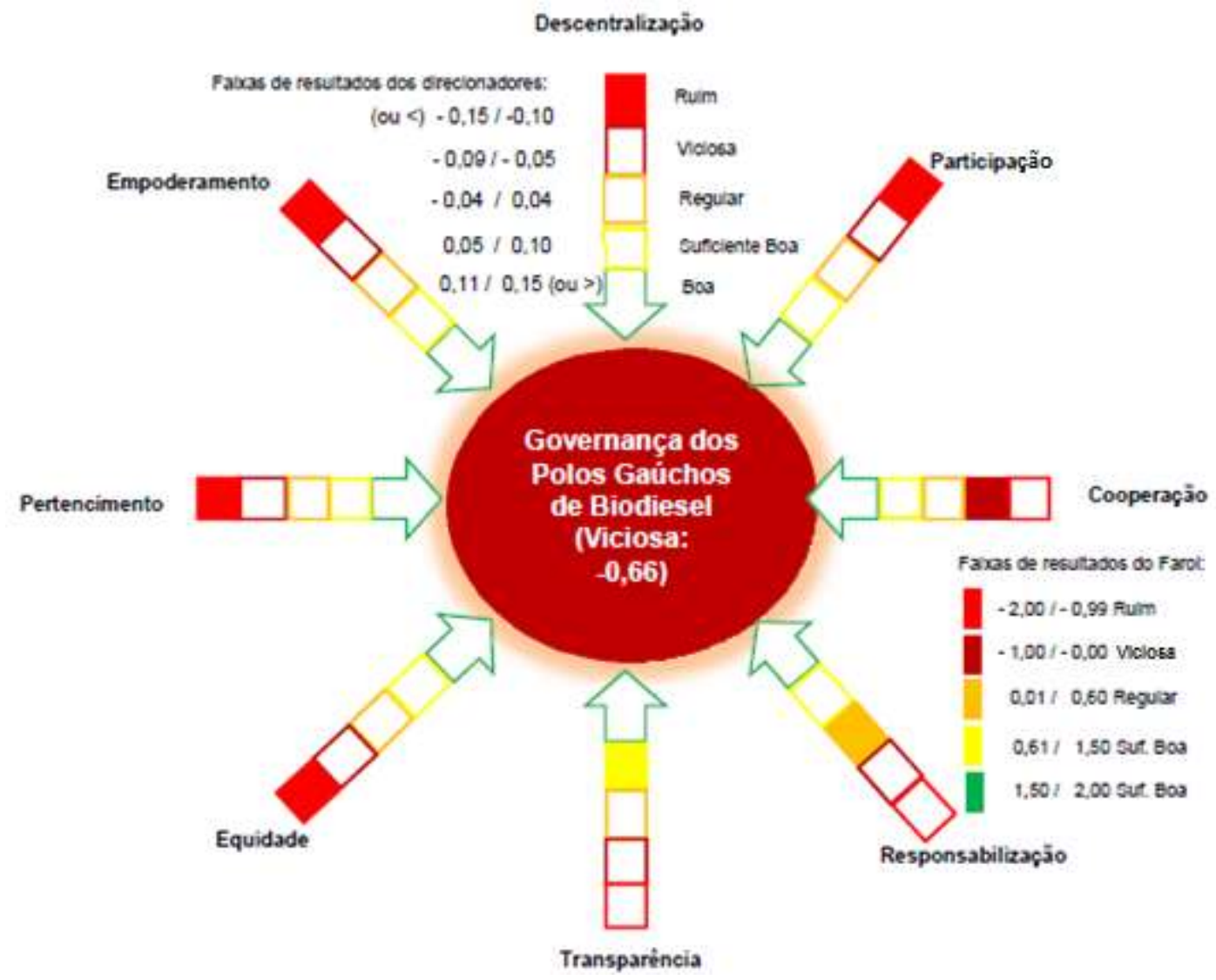

Figura 16 - Farol da governança do biodiesel dos Polos Gaúchos.

Fonte: elaborada pelo autor.

O baixo rendimento do direcionador descentralização $(-0,16)$, por exemplo, está diretamente ligado à inexistência de autonomia dos governos locais na regulação de biocombustíveis no Brasil. Embora o PNPB, dentro de suas diretrizes tenha sido criado com a ideia de descentralização da produção, não houve a mesma descentralização das autonomias regulatórias ou mesmo gestoriais. No caso dos PG, coube ao governo estadual apenas a implementação de políticas complementares (Probiodiesel) e, aos governos locais, o papel de eventualmente atuar no zoneamento e licenciamento das atividades agroenergéticas. O baixíssimo desempenho também está coligado às prerrogativas da Política Energética Nacional e das próprias características constitucionais do federalismo brasileiro. Em ambos os caos não existem previsão de mecanismos de subsidiaridade, devolução e flexibilidade aos poderes e atores locais. Medidas do padrão top-down, portanto, são impetradas de 
cima para baixo dentro de um padrão big government que prevalece na governança do biodiesel gaúcho.

De forma interligada a esse desenho político-insitucional, deu-se o fraco desempenho do direcionador participação $(-0,12)$, uma vez que não existem conselhos municipais, comitês e audiências públicas voltadas a consolidar critérios participativos de governança local do biodiesel nos PG. Embora seja forte a presença de movimentos sociais, cooperativas, organizações e associações, esse critério (subfator) foi considerado desfavorável, uma vez que fóruns e grupos de trabalho que ainda davam voz e representatividade aos atores locais, como o Projeto Polos de Biodiesel, foram desativados em seu formato original.

Quanto ao desempenho do direcionador cooperação $(-0,08)$, embora os discursos sejam bastante concentrados nas parcerias, julgou-se como desfavorável o atual nível de cooperação entre os atores sociais. A razão se configura, especialmente, pela concorrência e desconfiança mútua que vem emergindo das relações entre cooperativas, indústrias e empresas cerealistas. Algo semelhante ao que acontece ao nível de coordenação entre as políticas públicas federais, estaduais e locais que, apesar da indicação de dissonâncias, pulverização e mesmo sobreposições de ações públicas, optou-se pela prudência e imparcialidade avaliativa em atribur um valor neutro ao subfator.

Os mesmos cuidados foram tomados na avaliação do direcionador responsabilização, que pela mesma razão, obteve uma avaliação considerada regular $(0,04)$. O resultado deriva do julgamento favorável quanto ao aspecto de controle e ordenamento territorial, uma vez que existem zoneamentos agrícolas, climáticos e licenciamentos ambientaisdas atividades industriais. Por outro lado, em razão da falta de indicadores ambientais mais consolidados frente aos impactos da cadeia produtiva do biodiesel, julgaram-se neutros os aspectos de responsabilidade socioambiental e da incorporação de princípios de precaução.

O direcionador transparência foi o que obteve maior desempenho entre os critérios de governança avaliados $(0,08)$. Isso porque foram avaliados como favoráveis os meios de acesso às informações pertinentes aos trâmites administrativos, processuais e regulatórios em curso no âmbito do PNPB. Embora a pesquisa acredite que existam falhas na transparência das indústrias, quanto ao maior comprometimento na divulgação de insumos químicos, recursos naturais e procedimentos produtivos utilizadosaos órgãos ambientais competentes e comunidades locais, optou-se por atribuir um valor neutro ao subfator em virtude da necessidade de maior profundidade necessária ao debate do tema. 
Vale destacar que, entre os direcionadores de pior desempenho, está a equidade $(-0,15)$. Seu desempenho está diretamente correlacionado às fragilidades de seus três subfatores componentes. Todos considerados como desfavoráveis, uma vez que resultam de um desenho político-insitucional que não promove nem a equidade de votos na implementação de regulações energéticas, na paridade de ganhos e direitos na exploração e uso do recurso energético, nem a equidade de decisão quanto a aplicação das receitas obtidas e das taxas aplicadas ao setor.

Por fim, os direcionadores pertencimento e empoderamento, ambos com péssimas avaliações $(-0,15)$, também refletem uma estrutura e processos de governança desfavoráveis. Arranjos pouquíssimos eficazes no sentido de promover um sentimento de interesse, envolvimento e responsividade efetiva dos atores sociais,visto que não carregam em si elementos de empoderamento dos participantes mais vulneráveis dentro da cadeia produtiva. Especialmente os inseridos nas cadeias agrícolas que não são contemplados com nenhuma alteração de diversificação da economia local, dos novos arranjos produtivos e dos projetos sociais e comunitários que possam conduzir a um desenvolvimento local de base endógena.

Parte IV - Governança e padrões de eco-governamentalidadeno epicentro do biodiesel brasileiro

4.5 Análise de resultados: estruturas e processos na governança dos Polos Gaúchos de produção de biodiesel

A despeito dos PG estarem, sob o ponto de vista produtivo, comercial e associativo (número de indústrias, produtores e cooperativas), entre as mais bem sucedidas áreas de produção de biodiesel do país, essas novas paisagens energéticas não foram capazes de gerar deslocamentos normativos como a descentralização de arenas e espaços efetivos de regulação e gestão energética. $O$ que se observa concretamante é um padrão big government em que estão subordinadas, com a manutenção de poderes e funções na escala federal, e a participação dos ministérios exercendo mais fortemente uma função legitimadora da representação de interesses da sociedade na produção do recurso energético.

A inovação energética não foi, portanto, capaz de estimular a inovação regulatória, e promover consigo uma maior autonomia e prerrogativa aos governos estaduais, sobretudo, aos governos locais. Municípios e comunidades inseridos nas cadeias de produção do biodiesel nos PG, na prática, se tornaram espaços 
dependentes de uma lógicade gestão top-down, em que as decisões são tomadas a milhares de quilômetros de suas áreas de produção.

Apesar da ênfase dada ao ineditismo do desenho de construção da política do biodiesel no Brasil (PNPB), a sua estrutura regulatória, e de gestão, continuam concentradas e engessadas na esfera federal. Seus processos deliberativos e consultivos não contemplam, nem estimulam um dos critérios mais importantes da governança dos recursos que é a efetiva participação política e a equidade dos atores sociais, sobretudo, daqueles diretamente inseridos nos territórios de produção.O que se converncionou chamar, por exemplo, de participação dos produtores rurais, nada mais é do que uma inserção produtiva mantida por mecanismos artificiais. Coube assim, aos grupos de interesse munidos de práticas de lobby, de estratégias claras e proativas de articulação, organização e pressão a participação proativa e reativa em que exercem pressão e obtêm vantagens, enquanto outros segmentos ocupam muito mais a função de elementos de legitimadores.

Conforme destaca Ostrom (2005), as regras têm o potencial de criar e instituirposições e funções; determinar as ações requeridas, permitidas ou proibidas. Entre elas, os mecanismos, incentivos e restrições que passam a ditar as interações e as interdependências entre os atores sociais. Na política pública e na governança do biodiesel elas edificaram um caminho em que as arenas e os espaços políticos se consolidaram de forma excludente, concentrados na esfera federal, onde normas e procedimentos de interações e interdependências são estabelecidos frente aos interesses dos atores de maior poder e influência, e dentro de uma estrutura deamarras puramente econômicas e comerciais, como subvenções, e incentivos fiscais e tributários.

Indústrias de biodiesel, suas associações e entidades (Abiove, Aprobio, Ubrabio e Sindibio/RS) são, nesse sentido, segmentos de maior poder na sociedade civil com maior volume de recursos, organização e capacidade de influenciar e interagir (lobbying) com os atores estatais na capital federal e, inclusive, ocupar posições-chave em câmaras e comissões em Brasília (FrenteBio). Prevalece, portanto, uma assimetria de poderes e equidade de direitos, mas também de ganhos que poderiam ser obtidos a partir da incorporação de critérios e prerrogativas aos atores locais. Ou seja, uma maior delegação e peso das comunidades inseridas frente àimplementação de regulações, uso do recurso energético, ou até mesmo, de decisão frente à aplicação de receitas e taxas oriundas das atividades agroindustriais, especialmente, na escala municipal.

Diante dessa configuração, os mecanismos e processos não são capazes de estabelecer laços sociais fortes entre os atores e instituições ou, 
consolidar um capital social que permita o desenvolvimento de uma sensação de pertencimento ou de processos de empoderamento nas áreas produtivas. Os comportamentos são atrelados a uma corrida aos ganhos e às vantagens econômicas imediatas. Reduzindo significativamente as probabilidades de retroalimentação entre governança local e formação de subjetividades socioeconômicas e ambientais positivas. Um arranjo que relega aos produtores rurais uma função marginal no manuseio e utilização do recurso energético (biodiesel) e reduz mais ainda mudanças desejáveis nas subjetividades ambientais e, portanto, nas ações coletivas dos recursos naturais (água, solo, manejo dos biomas).

As parcerias e a cooperação são mantidas única e exclusivamente pelos mecanismos de incentivos políticos e econômicos criados articialmente para a manutenção dos acordos entre os atores heterogêneos que compõem a governança do biodiesel nos PG. Algo que sistematicamente tem sido minado frente ao crescente ambiente competitivo que se estabeleceu entre indústrias, cooperativas e cerealistas pelos grãos de soja. Uma pista de que apenas estes dispositivos utilizados nas parcerias sócio-privadas (i.e. cooperativas e indústrias), ou mesmo nas públicoprivadas (caso da Petrobrás com as cooperativas, Pbio com agroindústria energética) não foram, e não têm sido suficientes para dirimir, ou atenuar conflitos e dissonâncias.

Em grande medida, tal configuração acontece porque a estrutura e o processo de gestão do biodiesel fortemente apoiado nos mecanismos do Selo Combustível Social, não rompem ou atenuam comas fortes assimetrias de poder e concentração de forças na regulação e gestão do setor. Tampouco consegue edificar ambientes favoráveis ao desenvovlimento local/rural nas áreas de produção. Pelo contrário, promove, na prática, uma subordinação de pequenos e médios produtores frente à dinâmica dos grandes grupos agroindustriais e induz a uma nova intensificação de dependênciada soja, utilizando elementos legitimadores da produção 'de um combustível limpo e sustentável'.

O dispositivo de certificação oficial (SCS), por exemplo, não possui critérios e exigências ambientais com o atrelamento de mecanismos de monitoramento socioambiental. Não envolve a responsabilização do biodiesel frente à intensificação da cultura da soja e do seu necessário zoneamento ecológico-econômico (ZEE), ou levam em consideração os passivos ambientais (contaminação por herbicidas e pesticidas, eutrofização de corpos hídricos e pressões a biodiversidade) e a modificação direta e/ou indireta do uso da terra. Não atrela seus procedimentos para preservação e manutenção de Áreas de Preservação Permanente (APPs), e de averbação das Reservas Legais que poderiam reforçar os aspectos socioambientais da produção do biodiesel (CASTENALLANELLI \& CUNHA, 2015). 
Como resultado da 'função social do biocombustível', a materialidade produtiva do biodiesel marcha atrelada à intensificação dos sistemas agrícolas monocultores e à conseqüente manutenção de altíssimos percentuais das aquisições de matérias-primas oriundas da soja e do seu óleo. Dentro de uma lógica economicista de relações e incentivos (DAP - SCS) que, concretamente, não faz menor diferença aos produtores rurais o para quem, ou para quê, os seus grãos estão sendo destinados. Uma lógica em que agroindústrias beneficiam-se da commodificação dos recursos naturais, comprando a soja dos produtores num ritmo cada vez mais intenso, e, lucrando com a comercialização dos grãos e dos derivados da oleaginosa.

De forma agravante, ao contrário do esperado, o número de produtores incorporados à base produtiva do PNPB não aumentam no país, mas sim reduzem- se sistematicamente desde 2008, passando de 104.295, para 72.382 famílias cadastradas (BRASIL, 2016). Concentrando-se cada vez mais nos sojicultores da região Sul, responsáveis por cercade $90 \%$ dos contratos no país. Onde, se por um lado, aumenta a renda dos produtores nos PG, por outro lado, os torna presos e subordinados a um processo de dependência no qual vem aumentando sua média dedicada à oleaginosa de 8,5 hectares para 14,1 hectares em média(VEDANA, 2014).

Vale ressaltar que muitas das indústrias que operam nos PG também possuem unidades e parceiros comerciais em demais unidades federativas e em outras regiões do país. Mesmo diante das novas regras do SCS, que criam fatores multiplicadores nos pagamentos de grãos oriundos das mesmas regiões em que estão instaladas as plantas industriais, na prática, as maiores empresas recorrem a contratos com produtores e cooperativas rio-grandenses, ou na área de influência geoeconômica do PG, aumentando ainda mais essa característica (Figura 17).

Um comportamento que vai à contramão da diversificação da base de produção do biocombustível e traz consigo as consequências, e impactos inerentes do avanço da monocultura, mesmo quando consideradas propriedades de pequeno e médio porte (VEDANA, 2014). Uma configuração que adicionalmente traz impactos diretos e indiretos para os PG, mas igualmente dentro e fora do Rio Grande dos Sul, determinando trocas comerciais e comportamentos produtivos nas demais áreas de produção debiodiesel do país.

Essa prática suscita dúvidas quanto aos efeitos e implicações socioeconômicas e ambientais do PNPB, uma vez que a integralidade dessas empresas que operam com o biocombustível éde agroindústrias processadoras de soja, igualmente interessadas na compra dos grãos, beneficiamento e comercialização de seus coprodutos, sobretudo, o rentável farelo protéico. Na prática, as indústrias de 
biodiesel estimulam não apenas o aumento da produtividade, mas também da área de soja produzida dentro e fora dos limites dos PG no Rio Grande do Sul.

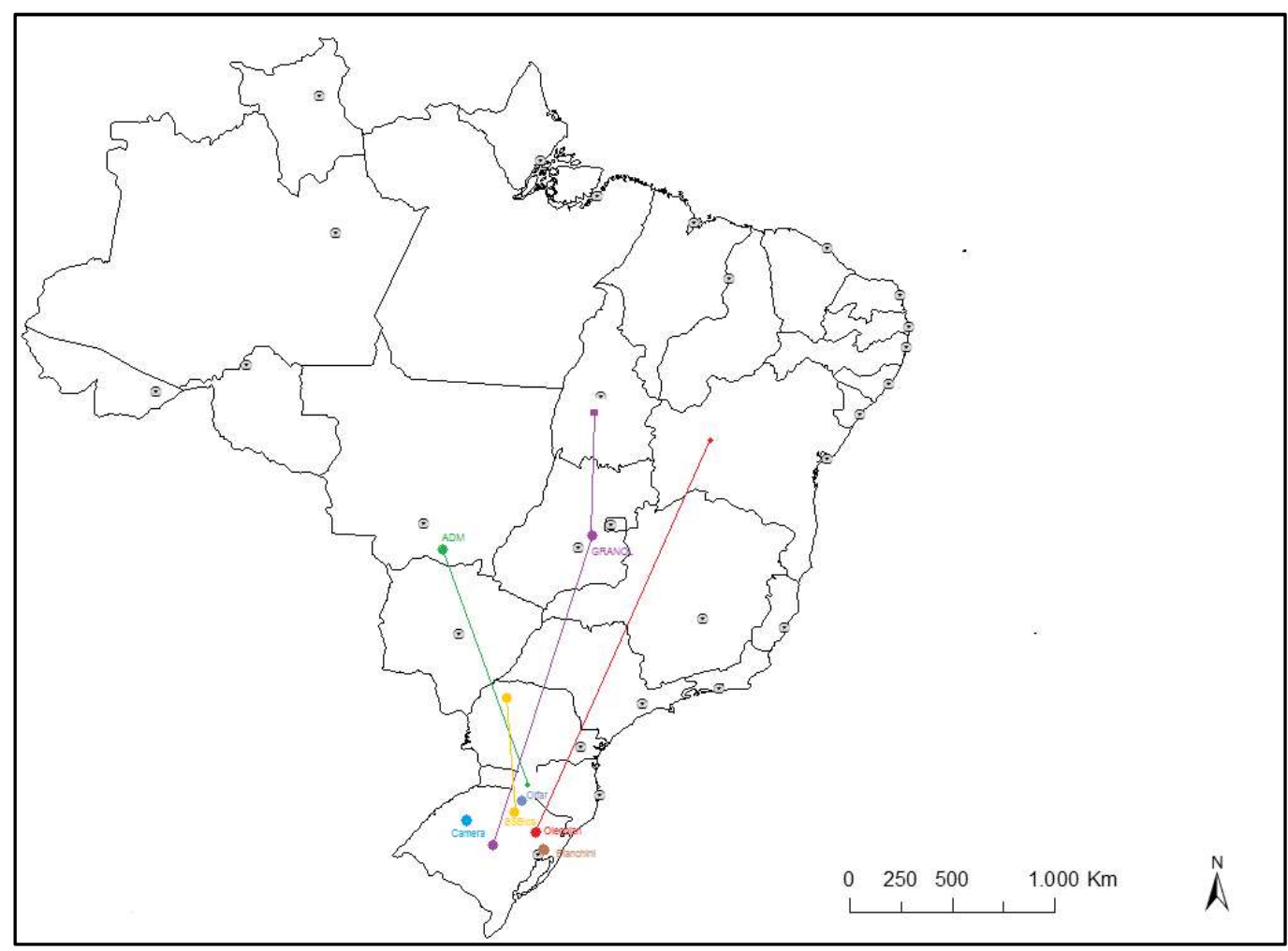

Figura17- Indústrias portadoras do SCS presentes e próximas aos Polos Gaúchos e suas plantas e ligações nas regiões Centro-Oeste, Nordeste e Norte do Brasil.

Fonte: elaborado pelo autor a partir da base cartográfica do IBGE.

Resumindo, a governança que atinge os PG, insere-se dentro da mesma lógica que caracteriza a política energética brasileira em que se prevalecem posturas visando garantir a "governabilidade" e a estabilidade do governo. Barganhas sustentadas em "alianças" sob a definição de postos de comando e ministérios que não envolvem o devido conhecimento técnico ou a devida incorporação de critérios ambientais. Questões destacadas por Bermann (2002), que pergunta: "Energia no Brasil: [é] Para quê? [e] Para quem? Indagações do autor queafimaquea política energética brasileira "é uma caixa preta, onde "a população não participado processo de decisões... e inexiste a adoção de "energia descentralizada [...] mais bem controlada pela população. Isso não passa pela cabeça porque define inclusive outra relação social" (BRUM, 2011 p.02, grifos meus). 
4.6 Análise dos Resultados: padrões de eco-governamentalidade comuns aos Polos Gaúchos de produção de biodiesel

Que padrão de eco-governamentalidade se manifesta nos discursos empregados pelos atores e instituições interligados e inseridos nos Polos Gaúchos de biodiesel? Diferente dos "ambientalistas relutantes" (SHOREMAN \& HAENN, 2009), ou "acidentais" (HAGGERTY, 2007), um padrão bastante notório se desenvolve entre os atores sociais interligados e inseridos nos Polos Gaúchos, sobretudo, o que parte das indústrias e suas entidades representativas, mas também de órgãos do Governo Federal e seus representantes. Nele, se configura um 'ambientalismo tempestivo', onde a tempestividade se reveste do sentido de apropriado, propício ou favorável.

Num padrão similar ao discurso desenvolvimentista utilizado como elemento legitimador pelo setor sucro-alcooleiro e instituições oficiais durante as etapas de consolidação do Proálcool, o discurso socioambiental tempestivo é empregado recorrentemente ao padrão de eco-governamentalidade no escopo do PNPB,e é utilizado como justificativa irrefutável para o crescimento e expansão das atividades agroindustriais do biodiesel nos PG. Tanto os"atores energéticos" (Flexor, 2011a), representados pelas agroindústrias processadoras óleo vegetal, farelo e biodiesel de soja, quanto suas associações, confederações e sindicatos, se apoiam fortemente na produção do biocombustível como recurso energético propulsor ao desenvolvimento, à sustentabilidade e à preservação do ambiente.

De forma bastante contundente a iconografia que cerca o setor (Figuras 19 e 20) reflete o clamor e as subjetividades propagadas como elementos legitimadores da produção bioenergética nos PG e no país. Imagens de panfletos digitais, folders, informativos e capas de revistas em que são reproduzidos slogans e conceitos consonantes ao conteúdo de declarações dos representantes entrevistados configuram-se em apelos visuais e textuais que caracterizam as vantagens do uso e exploração do biodiesel como recurso energético.

Nas matérias divulgadas é recorrente identificar a correlação do setor ao termo 'sustentável', como por exemplo, "Biodiesel: combustível sustentável que cuida do futuro", (Figura 18) em um cenário realçado por gotas de óleo vegetal e sobreposto a uma lavoura mecanizada de soja. Um padrão que ressalta a produção do principal insumo energético do biodiesel brasileiro, a soja, atrelada a força da agricultura e ao trabalho do produtor rural. Ou ainda, realçada na capa de uma das edições da revista Biodiesel em Foco (Figura 19) no qual a placa verde, ao centro, com a inscrição "Biodiesel" indica com setas apontadas para o horizonte indica a direção ou caminho da "Estrada Sustentável" advertindo o "Perigo" de desvios para a 
energia nuclear e do petróleo, representados, pelo trifólio da radiação e pela bombade-vareta de petróleo (UBRABIO, 2011, grifos do autor).

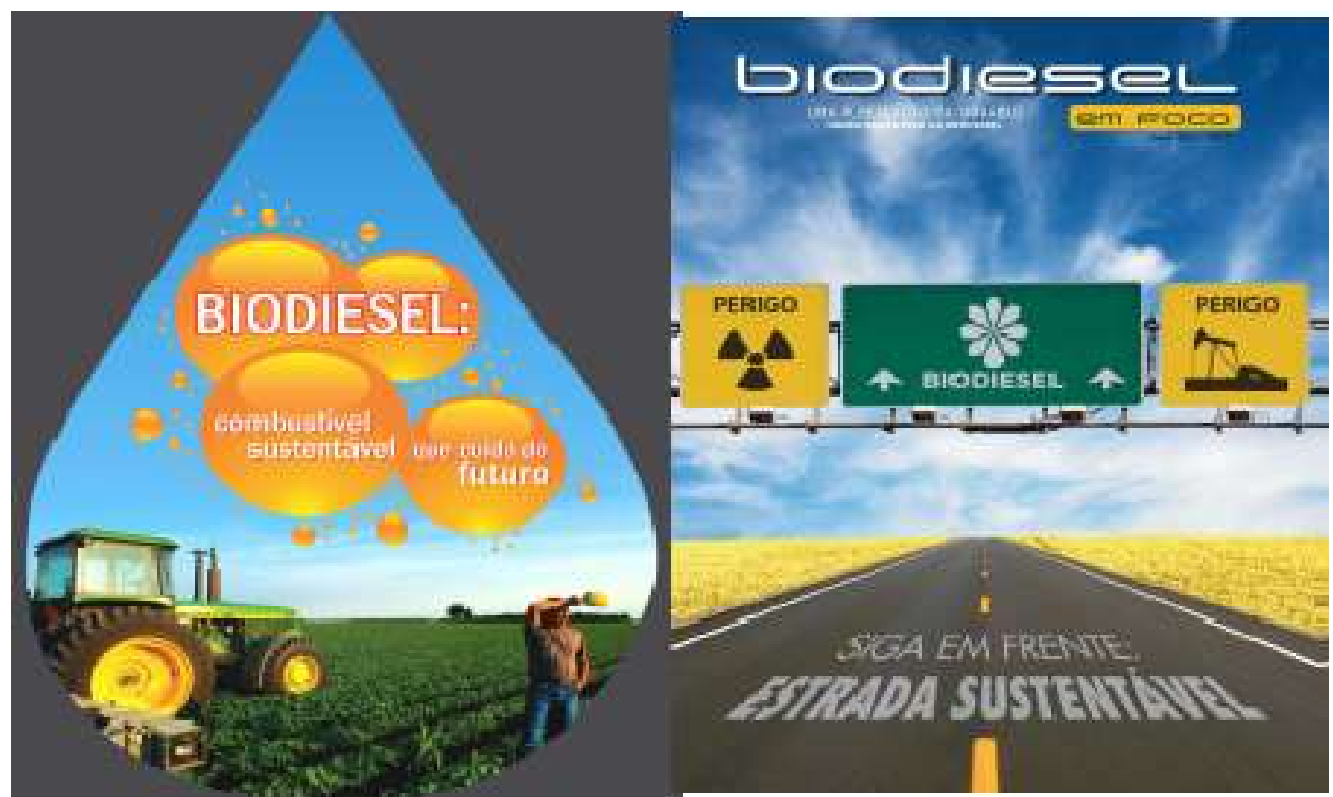

Figuras 18 e 19: Virtudes do biodiesel.Fontes: Ubrabio [s.d.] \&Ubrabio (2011)

No editorial da revista, o presidente da Ubrabio utiliza o exemplo dessas duas fontes energéticas (nuclear e petróleo) para realçar a sustentabilidade do biodiesel. No primeiro caso, pela explosão e vazamento da plataforma de petróleo Deepwater Horizon da Bristih Petroleum na Costa do Golfo; e no segundo, pela explosão da termonuclear de Fukushima e a contaminação radioativa acontecida no Japão. Para ele, o Biodiesel é:

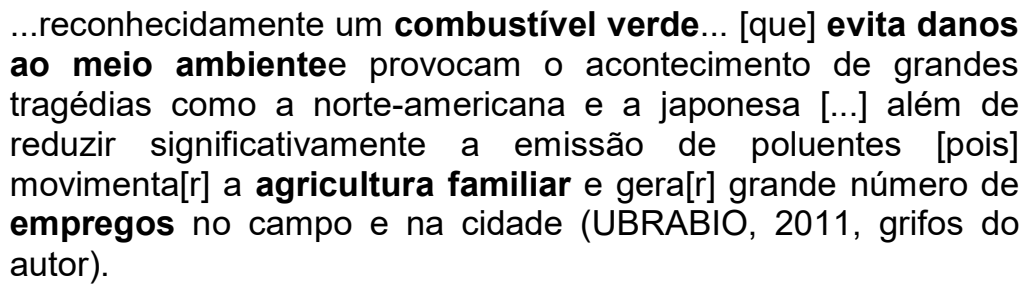

A Aprobio utiliza-se da mesma lógica discursiva nos seus canais de informação divulgando resultados obtidos pelo estudo da Fundação Instituto de Pesquisas Econômicas (Fipe) em que "o aumento do teor do biodiesel no óleo diesel provoca impactos positivos e importantes sobre a economia nacional, superando substancialmente os efeitos negativos". O estudo ratifica que a modificação do biodiesel na matriz energética do país "pode contribuir com as políticas de emprego, distribuição de renda, meio ambiente, desenvolvimento regional e tecnológico" (FIPE, 2012, grifos do autor). 
Padrões discursivos que se repetem quase que mecanicamente nas entrevistas dos representantes das indústrias de biodiesel, quando perguntados sobre o que pensam sobre o futuro da atividade no Brasil e nos Polos Gaúchos de produção. Quando questionados sobre a correlação do biodiesel com o desenvolvimento, as respostas dadas por gerentes operacionais de indústrias de biodiesel se apoiam nas justificativas econômicas e sociais propagados pelas entidades do setor:

\begin{abstract}
O biodiesel é um propulsor de desenvolvimento regional... não é que nem o Proálcool que acabou sendo conduzido pelo agronegócio, e a matéria-prima produzida, por grandes empresas, por mega investimentos, né!... ele tá estruturado, e não vai sair, na mão daagricultura familiar...(PG011, grifos do autor).
\end{abstract}

Se tu olhar... minha esposa trabalha com banco! Banco para produtor né! Então os produtores hoje estão investindo e comprando casa, comprando apartamento, comprando carro! Então isso vai girando a economia...o desenvolvimento! (PG020, grifos do autor).

Esses padrões confirmam o que Borras et al. (2010) ressaltam sobre os discursos predominantes na apresentação da agroenergia como recurso energético apto a se firmar pela preserção do meio ambiente, estímulo ao crescimento econômico e promoção de um modelo de desenvolvimento cuja narrativa seria traduzida no modelo win-win.

Em material colhido durante a fase de pesquisas em uma das principais indústrias do setor, é utilizada a imagem de um Becker que correlaciona às três grandes bases de comprometimento da indústria na produção do biodiesel (Figura 20 e 21). Na base do recipiente, semelhante à estrutura de um solo estão pequenos grãos de oleaginosas, provavelmente de canola que equivalem ao 'desenvolvimento da agricultura familiar'. No centro, os grãos de soja lembram que o biocombustível tem origem em uma 'matéria-prima $100 \%$ vegetal'oriunda da produção agrícola familiar. No estrato superior, o óleo vegetal é colocado como elemento propulsor, ou base do 'compromisso com a natureza', e com o 'meio-ambiente'.

A identificação e correlações do setor com o compromisso social, com a agricultura, o desenvolvimento e o meio ambiente são fios condutores das lógicas argumentativas comuns de grande parte dos atores sociais envolvidos. A mensagem está apoiada na produção agrícola familiar, que produz um combustível limpo e renovável, logo, é uma atividade compromissada com a natureza e a sociedade. $\mathrm{Na}$ prática o discurso propaga lógicas estabelecidas pela própria política pública, em especial, aquela estabelecida pelas regras e pelo Selo Combustível Social. 
As empresas, no entanto, tem ido além da certificação pública nacional buscando mais elementos legitimadores em certificações internacionais como a International Biofuels \& Carbon Certificatione 2BSvs (Figura 22 e 23).Em 2014, quatro das nove indústrias de biodiesel nos PG se aproximou das chamadas Roundtables ou Mesas Redondas e de suas certificações para demonstrar comprometimento, por exemplo, com a produção sinérgica entre alimentos e biocombustíveis, e de cadeias produtivas com balanços de carbono favoráveis. O expediente das certificações tem sido uma tendência das indústrias agroenergéticas para legitimar suas práticas comopositivas à sociedade e ao meio ambiente.
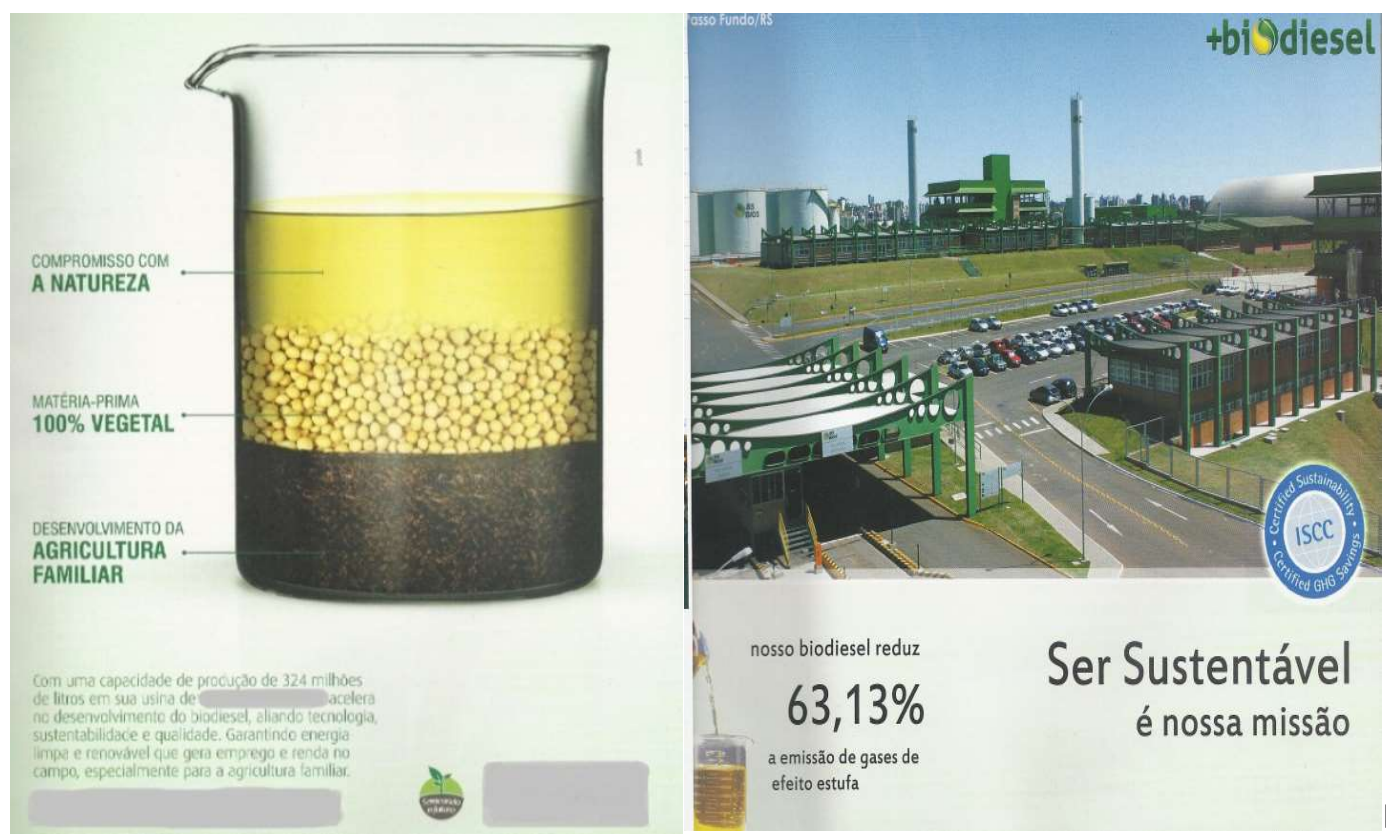

20e 21- Biodiesel, sustentabilidade e compromisso com a natureza.

Figura Fonte: BiodieselBR (2013 e 2014).

A ideia está correlacionada a comprovar padrões produtivos que promovem a inovação tecnológica, social e a preservação ambiental. Procedimentos que muitas companhias brasileiras dentro e fora do estado tem se esforçado parareferendar a 'sustentabilidade' de suas operações. Reforçando o discurso que:“Ser Sustentável é nossa missão”(BIODIESELBR, 2014, grifos do autor).
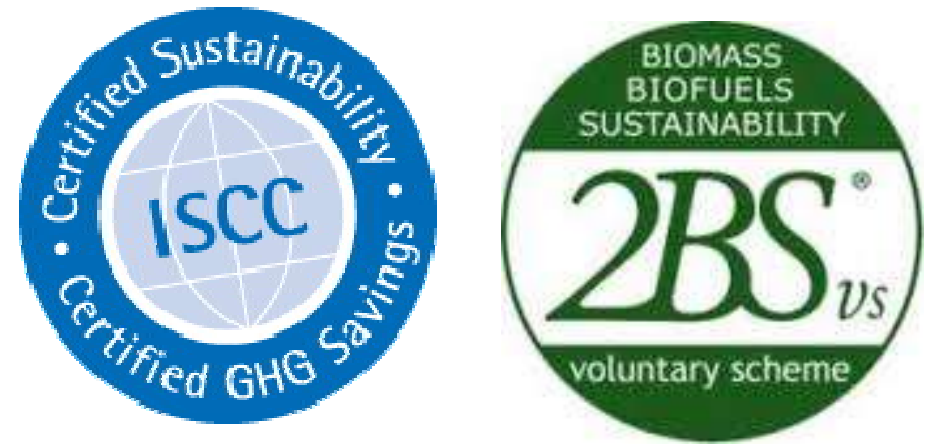

Figura 22 e 23 - Certificações Internacionais de sustentabilidade de biocombustíveis. Fonte: www.iscc-system.org 
As certificações possuem adicionalmente o potencial de credenciar e garantir o acesso a regimes e mercados futuros. Um quesito particularmente importante no controverso mercado mundial dos biocombustíveis. Tais certificações internacionais servem para reforçar o compromisso que os certificados possuem com a 'sustentabilidade' e buscam reforçar a imagem de seus portadores como provedores de sistemas produtivos e produtos isentos de impactos e alinhados às demandas ambientalistas de ONGs e, mesmo, de mercados consumidores finais (LIN, 2012).

De forma consonante, as lógicas legitimadoras das indústrias se coadunam e se reproduzem nos argumentos dos atores de governo em diferentes escalas e setores. Os discursos se reproduzem nos atores e nas propostas das agências e ministérios, consoantes com os clamores das agroindústrias, na qual o setor é uma cadeia produtiva erigida tendo por base "os agricultores familiares [que] plantam o combustível do futuro" (Figura 24).

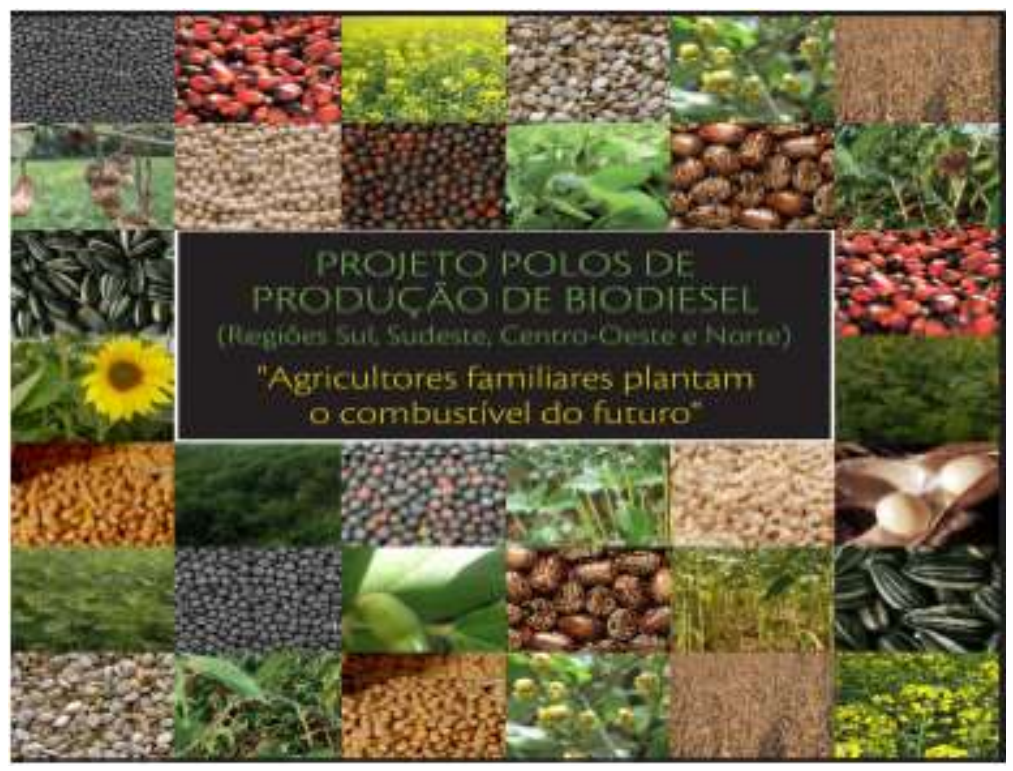

Figura 24 - Apresentação do Projeto Polos de Biodiesel do MDA. Fonte: Brasil (2010).

Nesse intuito, especialmente, os parlamentares da FrenteBio reforçam os elementos legitimadores adicionando elementos da defesa da balança comercial, estímulo à produção agrícola, fomento da atividade industrial, geração de emprego e renda; além de critérios interligados às mudanças climáticas e à preservação do meio ambiente. Aqui o elemento central é destacar o papel do biodiesel na redução do uso do diesel fóssil, importações e gastos desnecessários e, consequentemente a redução das emissões de gases de efeito estufa e benefícios à saúde humana: 
O biodiesel, como combustível disponível no mercado brasileiro, é uma grande vitória [...] Até o ano 2005,nenhuma usina de biodiesel existia entre nós. Hoje [...] biodiesel substituindo parte do diesel importado, permite àPetrobras economizar divisas, havendo melhoria no meio ambiente e mobilização expressiva de mão de obra (Parlamentar participante MP647/2014, grifos do autor).

Programa de Produção e Uso do Biodiesel possui entre as suas características a diversificação da matriz energética brasileira, com o aumento no uso de energias renováveis [...] e dentre outros objetivos importantes, [como[ o desenvolvimento regional (Parlamentar participante MP647/2014, grifos do autor).

A eco-governamentalidade expressa pelo setor industrial e parte significativa dos atores de governo é que:

O aumento da mistura de biodiesel ao diesel fóssil traz diversos benefícios sociais, ambientais e econômicos, dinamizando a economia e levando desenvolvimento para as regiões agrícolas (Parlamentar participante - MP647/2014, grifos do autor).

Em 2013, o Brasil importou 10,3 bilhões de litros de óleo diesel convencional, com dispêndio de 8,3 bilhões de dólares. Com as novas medidas, teremos uma redução da ordem de 1,2 bilhão de litros de diesel importando, com uma economia de 1 bilhão de dólares [...] criação de 132.632 novos postos de trabalho e um aumento do PIB (Parlamentar participante MP647/2014, grifos do autor).

O PNPB beneficia agricultores familiares no fornecimentode matérias-primas para a produção desse combustível sustentável (Parlamentar participante - MP647/2014, grifos do autor)".

Ou seja, se a produção de biodiesel promove o desenvolvimento em bases sustentáveis, gerando empregos, renda, impulsionando a arrecadação de impostos, e uma energia 'limpa e renovável', não há porque se questionar seus padrões produtivos. Nessas mesmas bases, quem está contra sua produção está, consequentemente, contrário ao próprio desenvolvimento sustentável, ainda que, 'desenvolvimento, sustentabilidade e ambiente' se revistam de significações próprias para os atores do setor produtivo.

Vale destacar, entretanto, que esse padrão não ser reproduz nos atores locais, como produtores rurais, associações, sindicatos patronais, e inclusive de membros oficiais de governo envolvidos nas áreas oficiais de desenvolvimento tecnológico. Ao contrário do 'ambientalismo tempestivo' das indústrias, e do governo, ocorre um sentimento, e um discurso, que vai da crítica aguda ao 'ceticismo ambiental' 
quando questionados sobre os parâmetros de justiça ambiental, modernização ecológica, mudanças climáticas e impactos ambientais.

Para representantes locais de entidades do governo federal, por exemplo, "do ponto de vista ambiental, [basta] se mistura[r] os 5\%" (PG18). Ou seja, os critérios ambientais se resumem na adição do biodiesel ao combustível fóssil, onde os $5 \%$ de adição (B5) seria na concepção do respondente, um membro-chave na governança do biodiesel. Resposta suficiente frente à responsabilidade do biocombustível nos recursos naturais e ecossistemas atrelados. De forma bastante contundente, sentimentos e discursos céticos se reproduzem nas passagens e depoimentos de produtores e especialistas diretamente envolvidos com 0 desenvolvimento de insumos para da cadeia produtiva do biodiesel:

\section{Sabe que isso aí é uma falácia! Isso aí do aquecimento global! [...] O que prevalece é a lógica da viabilidade econômica (PG07, grifos do autor).}

Eu não acho que seja mudança climática, olha...digamos assim ô, tem ano que dá seca! Estiagem!! depois chove bem... Pelo histórico é algo normal ter né! $O$ agricultor sabe que a cada quatro, cinco anos ele tem que preparar mas não acho que seja nenhuma mudança(PG03, grifos do autor).

Essa coisa de crédito de carbono e meio-ambiente é tudo muito bonito quando é nos olhos dos outros sabe! Quando deu a crise econômica mundial [...]em parte porque o petróleo ficou barato... todo tipo de energia renovável perde a força...(PG02, grifos do autor).

Para um dos especialistas entrevistados a polêmica ambiental, adicionalmente, se constrói com base na polarização ideológica e política que afeta o discernimento, por exemplo, no uso dos defensivos. Produtos que, na sua visão, são como um mal necessário:

Nós tinhamos um governador aqui... 'eles' mandaram fazer uma cerca, um biombo, e todos os livros sobre defensivos foram confinados [...] eu quero conhecer melhor os defensivos...vou procurar evitar o máximo! Mas o quê que acontece, eu não vou perder uma lavoura...uma lavoura maravilhos aqui... (PG07, grifos do autor)

O mesmo entrevistado defende uma concepção que não são os procedimentos agrícolas, defensivos e insumos, ou a própria agricultura que afeta o meio ambiente, pelo contrário são procedimentos e atividades capazes de gerar riqueza. Na sua visão:

O maior problema ambiental é uma pessoa pobre [...] Veja só o seguinte, a pessoa que causa mais problema ambiental por que não tem dinheiro para tratar esgoto, para ter água limpa... (PG07, grifos do autor). 
Semelhante ao revelado por Jepson et.al., (2012), se reproduzem de formasemelhante no 'epicentro' da produção de biodiesel no Brasil, ou seja, nos Polos Gaúchos, um "ceticismo ambiental" semelhante ao de Sweetwater. Curiosamente, ao lado do ceticismo e das críticas, é comum, entretantoque produtores e gerentes industriais demonstrem o que consideram como procedimentos ambientais quando demonstram sua confiança nas técnicas de plantio, insumos e fertilizantes como procedimentos e respostas suficientes para dar cabo de eventuais desequilíbrios na oferta de recursos naturais (água e solo especialmente).

\footnotetext{
Olha! Com plantio direto melhorei os'trabalho de curva' e acabei com a erosão, metade larga, metade média, quase uma barroca... melhorando a qualidade e saúde do solo...do ambiente...(PG01, grifos do autor).

...hoje no RS nós temos as áreas muito mecanizadas, mas ahh....nós temos um pacotinho tecnológico que a gente entende que é fator de inclusão social[renda] e melhoria da qualidade ambiental... (PG15, grifos do autor).
}

...[a] parceria na questão de insumos, assistência, plantio direto...eles [indústria de biodiesel] colocavam uma parte do insumo também! Além de dar uma incentivada na produção melhora as condições do solo...ambiente...tudo... ! (PG12, grifos do autor).

$\mathrm{Na}$ lógica predominante dos atores entrevistados técnicas como o plantio direto e o uso de fertilizantes se demonstram como procedimentos plenamente adequados à conservação das potencialidades produtivas do solo. Discursos, portanto, que revelam uma fé 'tecnocêntrica', na medida em que, de forma bastante generalizada os atores acreditam que os gargalos e obstáculos são perfeitamente equilibráveis somente por meio da aplicação de tecnologia.

\subsection{Discussão dos resultados da pesquisa}

As regras e as arenas políticas do sistema de governança do biodiesel brasileiro, verificadas a partir do observado nos PG, pouco favorecem a consolidação de ambientes positivos de ação coletiva, seja para gestão do recurso energético, o biodiesel, seja para manutenção dos recursos naturais que the dão base. Embora os parâmetros operativos e normas legais tenham sido constituídos inicialmente a partir de uma base pluralista, procurando incorporar uma grande quantidade de atores heterogêneos e diferentes interesses na organização e produção agroindustrial do biodiesel, as próprias regras acabaram por consolidar posições e 
funções hierárquicas engessadas no escopo de arenas políticas e espaços deliberativos/ consultivos concentrados na esfera federal.

Tal configuração reforça a grande disparidade socioeconômica e política; bem como, a assimetria informacional e de recursos, dentre os diferentes e ecléticos grupos de interesse inseridos nas estruturas e processos de governança. $\mathrm{Na}$ prática, respondendo à pergunta estabelecida pelo modelo de Ostrom (2005), os atores 'participam', e se mantêm coesos, mesmo diante da grande e heterogênea composição tão somente pela lógica economicista das subvenções e prerrogativas comerciais, estabelecida pelo Selo Combustível Social concedido às indústrias, e dos valores adicionais pagos aos produtores rurais familiares portadores da DAP/Pronaf.

Os agricultores familiares ou empresariais, possuindo os direitos de propriedade e livre escolha produtiva, ampliam o cultivo da soja sem se importar na realidade para quem, ou para quê, os seus grãos estão sendo destinados: biocombustível, exportação in natura, processamento ou comercialização dos rentáveis coprodutos (farelo, farinha, leticina, entre outros). O que importa é quem paga mais: cooperativas, indústrias ou cerealistas. Na prática, o setor de bioenergia, representado pelos grandes grupos processadores de soja, propulsiona a materialidade do biodiesel de primeira geração colaborando tanto para a expansão das áreas de produção quanto para a intensificação da produtividade nas áreas já consolidadas. Impacta, portanto, significativamente no elo agrícola, o comportamento e o ritmo dos produtores no uso, exploração e pressão de recursos naturais comuns (água, solo, áreas de proteção) que dão base à produção do recurso energético.

Apesar disso, atores de governo e de mercado justificam esses parâmetros baseados numa eco-governamentalidade que qualifica o biodiesel como recurso energético sustentável e de sua suposta vantagem social, ainda que os ganhos e vantagens sejam de caráter imediato e estritamente econômico para os atores de maior poder e influência. A lógica também se propaga pelos discursos de colaboração, cooperação, participação e desenvolvimento rural empregados dentro e fora dos PG. Eles perfazem a imagem do recurso energético e justificam o ritmo de transformação das paisagens e dos territórios de produção agroenergéticos e o uso dos bens naturais comuns, reduzindo assim críticas e questionamentos da sociedade.

Dentro da lógica do IAD de Ostrom(2005), os "ganhadores" se apresentam pelo grupo de agroindústrias do setor sojicultor que reforçam seus interesses e subvenções e criam uma superdependência produtiva, logística e comercial da oleaginosa. Situação na qual, produtores rurais, e suas comunidades rurais, urbanas e periurbanas, se tornam reféns da força econômica da soja, mas não percebem o potencial de tornarem-se os "perdedores" potenciais frente ao passivo 
socioambiental deixado pela intensificação de uma commodity caracterizada por práticas ambientais impactantes e históricos econômicos oscilantes. Considerações que vão ao encontro das suspeições apontados por Favaretto et. al.(2008) sobre as necessárias reformulações nas regras e estruturas de gestão do PNPB, sobretudo, na alocação dos recursos, participação e inovação social.

De fato, a presente pesquisa endossa as considerações realizadas por Stattman et.al. (2013), nas quais,supostamente, os sistemas de governança criados pelo biodiesel no Brasil, a despeito das estruturas implementadas, continuam bastante centralizadas e politicamente desiguais, sobretudo, pela manutenção de mecanismos de subsídios na exploração das vantagens comparativas agrícolas e energéticas. Processos baseados nos amplos recursos ofertados aos atores de maior poder $\mathrm{e}$ procedimentos que não conseguem evitar a concentração geográfica produtiva e o domínio de grupos de interesse agroindustrial, restando pouca, ou mesmo nenhuma, influência prática de outros setores socioambientais (STTATMAN\& MOL, 2014).

Vale destacar que as presentes considerações não objetivam condenar o biodiesel como recurso energético, sobretudo, negar sua importância e necessária utilização na transição energética, mas lembrar que sua 'sustentabilidade' está, antes de tudo, interligada à qualidade do processo de governança e, consequentemente, das condições em que os aspectos político-produtivos são implementados, com especial atenção aos padrões preponderantes de eco-governamentalidade aos quais essas cadeias de produção agroindustrias são inseridas e legitimadas, tanto no âmbito local, regional e nacional quanto no âmbito internacional.

Características que, conforme destacado por Hall et al. (2009), podem estabelecer o lado da fronteiraque se quer posiocionar a produção do biodiesel:entre um quadro de "maldição dos recursos do (bio)óleo" (p.2), gerador de uma distribuição desigual dos ganhos obtidos e externalidades socioambientais negativas, oupara novos arranjos político-institucionais capazesde atenuar relações assimétricas de poder,sedimentar espaços deliberativos democráticos e dispositivos coletivos na regulação e produção de biocombustíveis. Conforme destacado por Humphreys et. al. (2007), quesitos que podemdeterminar o rumo da sustentabilidade no desenvolvimento de qualquer recurso energético.

As considerações endossam a necessidade de um debate ético sobre a reformulação dos sistemas de regulacão e gestão do PNPB, tornando-o mais apto a beneficiar diretamente a fase agrícola, criando e estimulando simultaneamente formas e oportunidades de participação política, inovação tecnológica e de ambientes capazes de gerar reformulações das subjetividades dos atores sociais frente aos recursos naturais e procedimentos produtivos que dão base ao recurso energético. 


\section{GOVERNANÇA E ECO-GOVERNAMENTALIDADE NO 'BOOM’ DOS SHALES AMERICANOS: ESTRUTURAS, PROCESSOS E DISCURSOS NA REGULAÇÃO, GESTÃO E EXPLORAÇÃO DE EAGLE FORD.}

Parte I - Contextualização dos folhelhos americanos: a expectativa da revolução energética a partir da exploração dos Shales nos Estados Unidos

\subsection{Variáveis estruturais}

O crescimento expressivo da produção de hidrocarbonetos a partir da extração de gás e petróleo das camadas geológicas denominadas de folhelhos ou shalesé vista por grande parte da sociedade norte-americana como uma verdadeira revolução energética e oportunidade ímpar para a economia do país. O recente 'Shale Boom' norte-americano trouxe impactos imediatos na estrutura e mercado global de energia e movimentou o eixo econômico e geopolítico do gás e do petróleo mundial (TUNSTALL, 2015a).

O conhecimento de reservas não-convencionais de hidrocarbonetos nas camadas de folhelhos não é recente, porém, as técnicas necessárias para a devida prospecção são relativamente novas. As primeiras tentativas remontam à década de 1950, mas somente em meados da década de 1970 é que parcerias público-privadas entre empresas, U.S Department of Energy (DOE) e o Gas Researchlnstitute (GRI) tornaram possível adotar procedimentos mais efetivos para explorar os depósitos de hidrocarbonetos nos folhelhos. Nesse período, ainda se aprimoravam os primeiros procedimentos tecnológicos voltados a 'recuperação' de depósitos de hidrocarbonetos de baixa permeabilidade, considerados, até então, como inacessíveis (EIA, 2011).

Para autores como Valle (2014), a revolução dos recursos nãoconvencionais nos EUA teve como substrato a interferência governamental direta, e persistente, baseada no estímulo das atividades econômicas e fomento das inovações tecnológicas. As parcerias entre empresas, órgãos de pesquisa e governos impulsionou o desenvolvimento das técnicas e promoveu a expansão na exploração do gás natural e petróleo de folhelho no país. Os procedimentos do que se convencionou chamar de fracking, uma contração de fraturamento hidráulico (hydraulic fracturing) deriva de sinergias, interesses e justificativas comuns entre governo e mercado. Um desenvolvimento tecnológico aliado à vontade política que permitiu o avanço da tecnologia de perfuração vertical convencional (drilling) para novas técnicas de abertura de canais de fraturamento horizontais (fracking) ao longo das camadas sedimentares dos shales com o uso de um coquetel de água pressurizada, compostos químicos e areia (Figura 25). 


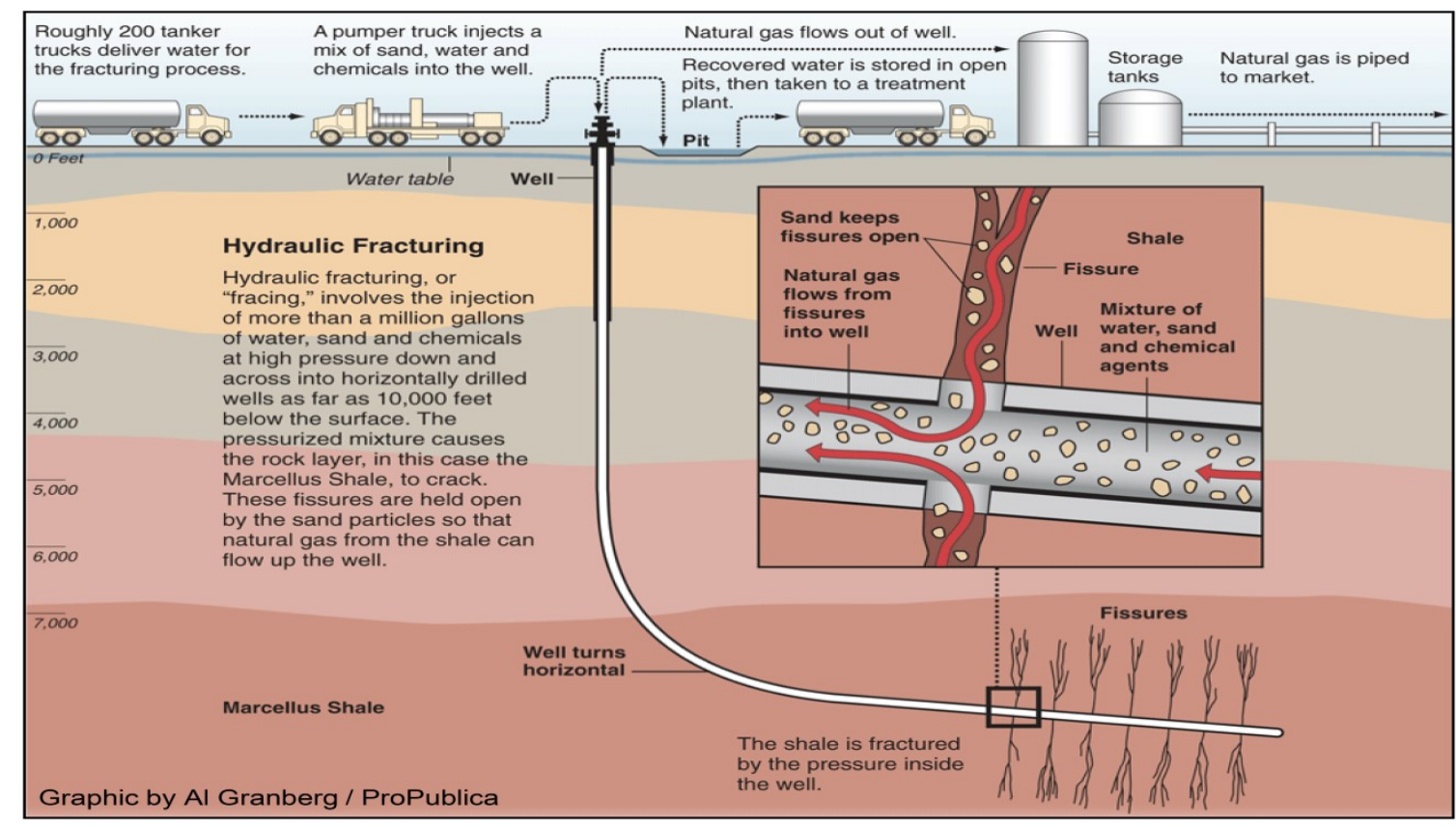

Figura 25 - Processo produtivo do fraturamento hidráulico (fracking) de folhelhos.

Fonte: Environmental Protection Agency (EPA, 2011).

À disseminação das novas técnicas de produção por fraturamento hidráulico e a subsequente produção de recursos não-convencionais em larga escala, entretanto, somente tomaram maior vulto ao final da década de 1990. A principal responsável foi a companhia Mitchell Energy que obteve grande sucesso na exploração das camadas profundas do xisto de Barnett Shale na região centro-norte do Texas, próximo as cidades de Fort Worth e Dallas. A experiência bem sucedida de obtenção de altíssimas quantidades de gás natural pelo método estabeleceu as variáveis tecnológicas necessárias para que demais empresas do setor energético entrassem agressivamente na exploração de hidrocarbonetos não-convencionais. Apenas nos depósitos de Barnett Shale, desde 2005, se atingiram em pouco tempo marcas de 0,5 trilhões de pés cúbicos de gás natural produzidos ao ano (EIA, 2011).

A propagação do know-how e a confiança na rentabilidade da exploração dos folhelhos provocaram um efeito bola-de-neve na prospecção de novos depósitos de recursos energéticos não-convencionais por todo país. Como resultado, autoridades públicas e empresas identificaram vastos depósitos geológicos em boa parte das unidades Federativas (Figura 26). Nos últimos cinco anos, por exemplo, a exploração de shales como Fayetteville, em Arkansas, e Marcellus, na Pensilvânia, foram os responsáveis pela 'virada de mesa' da energia produzida no país. Os padrões geofísicos também revelaram quantidades expressivas de petróleo em depósitos como Bakken Shale, no estado da Dakota do Norte, e, especialmente, em Eagle Ford Shale no sul do Texas. Uma característica geológica que contribuiu para 
uma verdadeira reviravolta no mercado mundial de hidrocarbonetos, impactando significativamente a economia dos EUA (E.I.A, 2011).

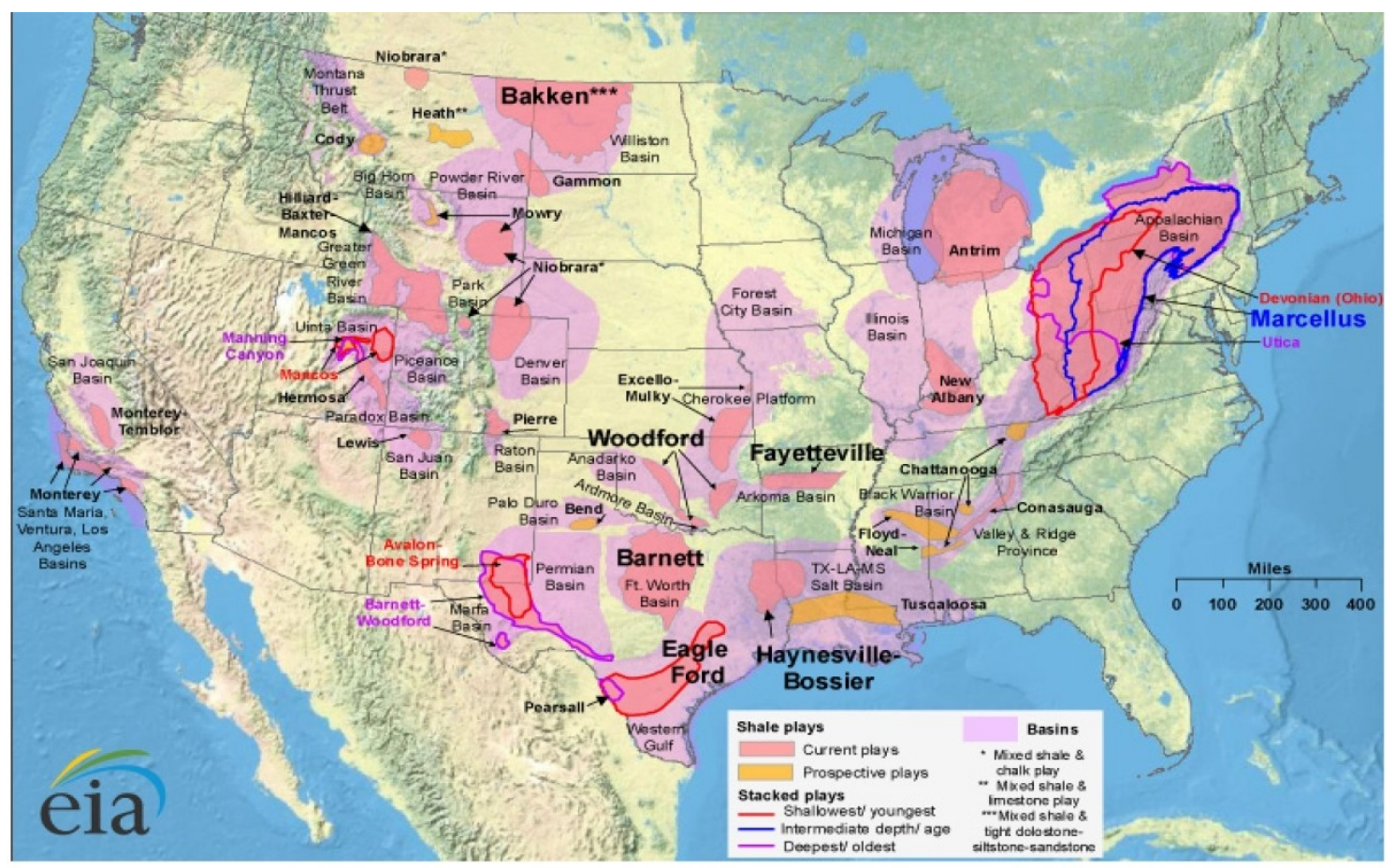

Figura 26- Principais áreas de exploração de hidrocarbonetos de shales nos E.U.A Fonte: E.I.A.(2011).

A exploração de hidrocarbonetos não-convencionais significou, entretanto, novos desafios quanto ao estabelecimento de normas para o setor, ou da implementação das variáveis constitucionais necessárias para regulação e exploração dos folhelhos por fracking. Na área de Marcellus Shale, por exemplo, o maior depósito em extensão do país, que abrange boa parte do nordeste americano, o debate aconteceu sobre as normas legais e regras de exploração, provocando intensos embates e a consolidação de diferentes resultados normativos nos estados de Nova Iorque, Pensilvânia, Ohio e Virgínia Ocidental.

Segundo Jackson et. al. (2014), a expectativa gerada pelos recursos não-convencionais trouxe, de fato, uma desejável atmosfera de recuperação econômica ao país, mas com consequências incertas entre a consolidação de uma atividade "revolucionária", ou "desastrosa", para a sociedade americana (p.327). Para esses autores, a exploração do gás natural proveniente dos folhelhos, trouxe consigo a expectativa de estabelecer um alto potencial de geração de emprego e renda, e, inclusive, ganhos ambientais pela substituição gradativa do carvão mineral utilizado nas termoelétricas. Entretanto, destacam também que, a propagação da atividade sob condições inadequadas, poderia acarretar riscos à saúde humana e impactos 
socioambientais interligados à poluição atmosférica, hídrica e à redução de investimentos em energias renováveis.

Diante de tamanha incerteza e polêmica, os estados têm enfrentado discussões sobre a (re)formulação de normas e leis, apresentando resoluções distintas quanto à regulação e exploração dos hidrocarbonetos dos shales. A questão tem despertado a atenção de todo o país, envolvendo meio acadêmico, mídia, grupos de interesse, associações civis e organizações não-governamentais. Campanhas contra a atividade, alimentadas por conferências, filmes e documentários como Gasland (2010) e Promised Land (2013), se propagaram por todos os Estados Unidos. Em contrapartida, produções como Truthland (2012) e movimentos de sociedades civis foram lançadas para desmentir os riscos associados aos folhelhos.

A controvérsia se estabeleceu em torno dos riscos de contaminação ressaltados pelos ativistas ambientais e os contra-argumentos das indústrias sobre a lacuna de dados científicos definitivos confiáveis para justificar o banimento das atividades de exploração de hidrocarbonetos por fracking (MATZ \& RENFREW, 2014). O estado de Nova lorque, por exemplo, diante de forte pressão de dezenas de comunidades e setores 'liberais' da sociedade civil conseguiram que o governador democrata George Cuomo e a mais alta corte do estado,a corte de apelações (Court of Appeals), aprovassem a total autonomia dos governos locais em estabelecer regulações (Ordinances) restritivas ao fraturamento hidráulico. Um ato que, na prática, acabou por banir as atividades no estado (KAPLAN, 2014).

$\mathrm{Na}$ direção contrária, a Pensilvânia, com apoio do governador republicano Tom Wolf e do forte lobby da indústria energética, incentivou a atividade em toda a jurisdição do estado. Somente nos primeiros meses de 2015, setenta e três Permissões (Permits) de prospecção por fracking foram emitidas, num total de mais de 6 mil poços em operação desde 2007 (PENNSYLVANIA, 2015). A posição antagônica, entre estados, ou mesmo entre municípios, reflete os variados níveis de argumentação em torno da atividade, bem como, diferentes níveis de estratégias e recursos de grupos de interesse, setores da sociedade e de governo perante a legitimação, ou oposição na exploração dos depósitos de shales (MATZ E RENFREW, 2014).

De forma bastante recorrente, diferentes escalas legislativas (federal, estadual e local) alinham as justificativas do setor energético quanto à segurança tecnológica dos procedimentos de exploração e as vantagens econômicas atreladas. Os aspectos, ou variáveis sociais correlatos ao boom das atividades econômicas se tornaram, sistematicamente, fortes elementos legitimadores da atividade. Por essa lógica, a atividade significa a chegada de uma "nova era de prosperidade", e os folhelhos como um novo "economic game changer" na promoção do 
"desenvolvimento", sobretudo, pelo potencial de criação de milhares de empregos diretos e indiretos, geração de renda e atividades econômicas (DESROSIER, 2012a p.01 e 2012b p.01).

Em áreas como Eagle Ford Shale, no sul do estado do Texas (área de estudo item 3.4.3) - considerado como "The Nation's Top Tight Oil Play", apenas durante seu auge de produção (boom) em março de 2015, foram produzidos espantosos 1.61 milhões de barris por dia. Toda essa pujança atrelada e controlada por um arranjo político-insitucional particular que, se por um lado proporcionou o inegável sucesso sob o ponto de vista produtivo, por outro, abriu margem para considerações quanto à qualidade da governança dos hidrocarbonetos nãoconvencionais nessa importante paisagem energética. Ou seja, além dos aspectos produtivos positivos, quais os critérios políticos, sociais, econômicos e ambientais que caracterizam a governança dos shales em EFS?

Entre as perguntas, se encontram as seguintes indagações. Como a exploração dos folhelhos no estado do Texas, um tradicional produtor de hidrocarbonetos, tem sido conduzida frente aos processos de planejamento e gestão dos recursos? Órgãos públicos, agências reguladoras, instituições de governo em suas diferentes escalas têm interagido entre si na construção de uma política de exploração equilibrada e duradoura, ou trata-se de uma reprise de episódios já vistos no passado do estado? Perguntas que estão ligadas diretamente às oportunidades e desafios da boa governança (descentralização, participação, cooperação, responsabilização, transparência, equidade, pertencimento e empoderamento). Resultados que estão ligados a padrões de eco-governamentalidade preponderantes, promovetores de feedbacks específicos no ritmo e exploração dos recursos naturais e energéticos.

Para se compreender a dinâmica e a qualidade de governançados folhelhos no Texas é necessário compreender o papel exercido pelos atores sociais dentro e fora do estado, e de EFS, bem como, as formas de acesso e controle dearenas políticas referentes à regulação de energia nos Estados Unidos. Analisando simultaneamente como as regras, competências e autonomias que instituições e atores compartilham, estabelecem e delimitam as relações de poder. E ainda, analisar como vieses cognitivos, subjetividades e discursos predominantes acabam por ditar as interações, interdependências e ritmos produtivosnas paisagens de produção. 
Parte II - Arenas de ação política e atores sociais

5.2 Arenas de ação política

i) Congress Committee for the Energy Policy Act: Energy Policy Act (EPACT)

O Comitê para o Ato de Política Energética do Congresso Americano (Congress Committee for the Energy Policy Act) se estabeleceu, por anos, como a principal arena de ação política para a definição de linhas estratégicas para exploração de recursos energéticos no país. Esse espaço e suas medidas deliberativas produziram importantes reflexos quanto ao desenvolvimento de fontes energéticas e seus respectivos sistemas de governança nos Estados Unidos.

O Ato de Política Energética' ou Energy Policy Act (EPACT) sancionado sob a coordenação do comitê na administração do Ex-presidente George W. Bush em 2005, por exemplo, trouxe novos mecanismos legais para o fomento, produção e inovação de energia no país. A lei, por exemplo, foi editada tendo por base uma série de incentivos fiscais e econômicos, incluindo subsídios e linhas especiais de crédito para incentivar a exploração, produção, transmissão e transporte de energia elétrica, calor e combustíveis por todo país.

Entre os dispositivos criados, foram estabelecidos loans guarantees (empréstimos garantidos), espécie de financiamentos especiais com seguro do governo para o caso de inadimplência dos tomadores dos recursos. Também foram criados incentivos financeiros e fiscais para progressão das misturas de biocombustíveis aos combustíveis fósseis, sobretudo, bioetanol na gasolina. Adicionalmente, as chamadas energias alternativas, e renováveis, como energia eólica, solar, maremotriz e geotermal ganharam provisões especiais para aumentarem sua participação na produção de eletricidade.

A produção de hidrocarbonetos de xisto, por sua vez, especialmente o gás natural, recebeu fortes incentivos federais. O Energy Policy Act estabeleceu uma série de exceções (exempts) de medidas restritivas quanto às atividades de exploração de recursos energéticos não-convencionais por fraturamento hidráulico (fracking). Entre as principais resoluções, o EPACT isentou as companhias energéticas de cumprirem medidas e controles de leis ambientais como o Clean Air Act; Clean Water Act; Safe Drinking Water Act, e do Superfund for Comprehensive Environmental Response, Compensation, and Liability Act.

Com tal prerrogativa as empresas se tornaram desobrigadas, por exemplo, de divulgar seus procedimentos e produtos utilizados nas operações de 
prospecção e extração. O processo ficou conhecido nos Estados Unidos como "Halliburton Loophole", ou uma brecha regulatória que teria sido obtida por influência do Ex-Vice Presidente americano Dick Cheney, antigo chefe executivo (CEO) da Halliburton, uma das maiores companhias energéticas do setor de petróleo e gás dos Estados Unidos(HOWARTH, 2011).

Como resultado direto do EPACT, também foi criado o Comitê Consultivo de Tecnologias para Recursos Não-convencionais ou Unconventional Resources Technology Advisory Committee (URTAC). Subordinado ao Departament of Energy (DOE), e a Secretária de Energia, o comitê foi estabelecido na seção 999 da política energética nacional, ficando responsável pelo acompanhamento das tecnologias de produção de gás natural produzido por fraturamento hidráulico, mas também de exploração de hidrocarbonetos em águas profundas (off shore). Entre as incumbências do comitê se encontram o levantamento de dados, investigação, desenvolvimento e demonstração da aplicação comercial das novas tecnologias, bem como, a missão de debater os desafios para garantir operações seguras e a mitigação de impactos ambientais (UNITED STATES, 2013).

O URTAC é composto por funcionários de agências de governo federal, universidades, representantes da indústria e da sociedade civil. Seus funcionários são nomeados pelo Secretário de Energia (Department of Energy)para participar, tendo por base os seus conhecimentos na área energética, enquanto os demais participantes são membros proeminentes de grupos de interesse ou membros de organizações não-governamentais. Na gestão 2012-2014 havia 17 membros, sendo 09 chefes-executivos e presidentes de companhias energéticas; 02 representantes de universidades (University of Texas at Austin e University of North Dakota), 01 membro de órgão de pesquisa privado (Berkeley National Laboratory) e especialistas do Departamento de Energia (UNITED STATES, 2013).

Concretamente, o URTAC dispõe de recursos da ordem de U\$50 milhões por ano, durante um período de oito anos, oriundos do Departamento do Interior (Department of the Interior - DOI) e obtidos pela arrecadação federal de leases, royalties, rendimentos e bônus obtidos da exploração energética em terras públicas federais. As prerrogativas legais do URTAC, entretanto, dizem respeito somente a recomendações de políticas, sendo um órgão consultivo com funções especiais de incentivar os debates e articulações institucionais necessárias para transferência aos estados de tecnologia, mecanismos de P\&D (Research \& Development) e práticas de segurança e controle ambiental.

Outra comissão federal encarregada, atuante na regulação e gestão de recursos energéticos, é a Comissão Federal Reguladora de Energia, ou Federal 
Energy Regulatory Commission (FERC). A comissão regula especificamente a transmissão interestadual de eletricidade, gás natural e petróleo. A FERC também analisa propostas para construção de terminais interestaduais de gás natural liquefeito (GNL) de licenciamento para construção de hidrelétricas. A comissão tem suas competências referendadas e delimitadas pelo EPACT, no qual a comissão assumiu parte das responsabilidades na supervisão de questões ambientais relacionadas com projetos de exploração e transporte de gás e construção de hidrelétricas. Está fora de sua alçada jurídica, porém, a regulação sobre a prospecção e produção no escopo dos governos estaduais e/ou locais, seja de gás e petróleo convencional, seja de recursos não-convencionais (UNITED STATES, 2016).

\section{ii) Local Governments: City Council\&Public hearings}

Nos Estados Unidos, municípios e condados são tradicionalmente esferas basilares e possuem arenas de ação política independentes do estado e da União para a regulação e gestão de serviços e infraestrutura. Nessas localidades, os governos locais legislam sobre a segurança pública (i.e. polícia, bombeiros, ordenamento territorial de atividades energéticas, químicas e industriais), transporte (pavimentação, manutenção de ruas e estradas), saneamento (tratamento de água, esgoto, fornecimento de água potável) fornecimento de eletricidade, coleta e tratamento de lixo (amplamente designados cityutilities). Algumas cidades oferecem inclusive políticas sociais, como assistência aos cidadãos de baixa renda por meio de abrigos e alimentação, bem como, hospitais, parques \& recreação e, inclusive, aeroportos (TUCKER \& LUTTBEG, 2010).

A forma mais antiga de governos locais nos Estados Unidos são os condados, e quase todos os estados os possuem, com exceção de Connecticut e Rhode Island (U.S.; 2007). Os condados fornecem um número limitado de serviços e possuem poucas competências legais, atuando basicamente na manutenção de documentos e taxas de propriedade, na saúde pública, e preservação de rodovias nas áreas rurais. O County Commission, ou Board of Supervisors, são designações comuns dadas a esses espaços políticos nos condados americanos. No Texas essas arenas de ação política são chamadas de County Commissioners Court (TUCKER \& LUTTBEG, 2010).

Os municípios, por sua vez, possuem as maiores competências na escala de governos locais. Essas prerrogativas são postas em prática especificamente por dois sistemas: Mayor /Council of government (prefeito e conselho de governo) ou 
pelo sistema Municipal Government Council/ Manager Form. Na primeira forma, semelhante ao Brasil, o prefeito é o chefe do executivo e o conselho funciona como instância legislativa. A segunda forma se dá pela contratação de um gerente profissional (city manager), escolhido pelo conselho, para administrar a cidade. A ideia é eliminar vieses partidários e profissionalizar o gerenciamento dos interesses e recursos públicos. Os prefeitos também existem nesse sistema, mas tem um papel apenas formal, exercendo funções simbólicas. Essa forma de governo local é majoritária em cidades, cuja população esteja cotada entre 25.000 e 250.000 habitantes. Utilizada, portanto, em $58 \%$ dos municípios americanos (TUCKER E LUTTBEG, 2010).

As cidades americanas, bem como, as do estado do Texas, seguem critérios atrelados ao número de seus habitantes, seguindo, portanto, duas formas distintas de governo local. A primeira, designada de general law é própria das cidades com populações abaixo de 5.000 habitantes. Nessas comunidades a autoridade é concedida e limitada pelo governo estadual, não havendo, praticamente, autonomia política. Se não possuírem autorizações expressas dos seus congressos estaduais (i.e. Texas Legislature) não têm competência para iniciar ações e medidas regulatórias. A segunda forma, home rule (ou regras da casa) diz respeito a cidades com mais de 5.000 habitantes. Esses municípios têm a prerrogativa de estabelecer regulações locais (Ordinances) e escolher, por exemplo, entre Mayor/Council Form ou Municipal Government Council/ Manager Form.

Além disso, cidades home rule têm a prerrogativa de convocar suas comunidades para conselhos (City Councils), especialmente, quando as deliberações em pauta são consideradas polêmicas e devem ser tomadas levando em consideração a posição da sociedade.Entre elas, por exemplo, as Oil \& Gas Ordinances, com as regulações locais para estabelecimento de normas de instalação e segurança, bem como, imposição de restrições e distâncias da prospecção mineral para residências, escolas e locais públicos; assim como a exigência de procedimentos especiais de operação, manutenção e desativação de poços convencionais e não-convencionais dentro da jurisdição das cidades. As audiências públicas (Public Hearings) funcionam nesses casos, conforme destacam autores da ciência política americana, como os mais difundidos mecanismos de participação política pública nos Estados Unidos (KARPOWITZ, 2005).

Parte considerável dos municípios e condados dispostos sobre a área compreendida por Eagle Ford Shale são localidades com menos de 5.000 habitantes, e, portanto, geridas pelo sistema General Law,não possuindo, portanto, autonomia. Muitas cidades, como destacado por Tunstall (2015a), lutavam antes do boom dos 
shalespara não se tornarem as próximas ghost towns. Uma situação não muito distinta das cidades Home Rule que, na prática, possuem apenas um status simbólico diferenciado. Isso porque se tornaram tão carentes de recursos financeiros que mal conseguiam oferecer serviços fundamentais, tornado-se dependentes de fundos e recursos estaduais, uma vez que não dispunham de atividades econômicas contundentes para taxar e arrecadar fundos (TUCKER \& LUTTBEG, 2010; TUNSTALL, 2015).

iii) Texas Legislature - The Senate of Texas: Natural Resources and Economic Development Committee

Uma peculiaridade do estado do Texas é possuir um poder legislativo bicameral, no qual The Senate of Texase House of Representatives são equivalentes a Senado e Câmara estaduais e possuem grande influência e prerrogativas na regulação de recursos naturais, e energéticos no estado. O Senado e, em especial, seu Comitê para Recursos Naturais e Desenvolvimento Econômico (Natural Resources and Economic Development Senate Committee) exerceram recentemente papel central na (re)divisão de poderes e reformulação da regulação estadual das atividades de exploração de hidrocarbonetos no estado.

O Natural Resources Senate Committee, ou Comitê do Senado para Recursos Naturais, por exemplo,surgiu inicialmente com a função de analisar e identificar os desafios das agências estaduais (i.e. Railroad Commission of Texas e Texas Commissionn on Environmental Quality) e normatizá-las frente aos procedimentos e normas estabelecidas pela Agência de Proteção Ambiental federal (Environmental Protection Agency). Dentro da alçada, por exemplo, do chamado Texas Emissions Reduction Plan (TERC), as incumbências do comitê incluíam o debate para implementação de planos de incentivo para produção de "fontes de energia limpa", programas de controle de emissões de GEE, além da manutenção de mananciais, programas de combate à seca e preservação de bacias hídricas. Suas competências também se estendiam para o estabelecimento de medidas de controle da qualidade do ar, com planos para a redução de compostos orgânicos voláteis (VOCs), ozônio, metano e outros efluentes da indústria química e petrolífera (TEXAS, 2015).

Rebatizada de Natural Resources and Economic Development Senate Committee em 2015, o comitê passou a ter poderes para propôr modificações de barreiras administrativas ou de regulações consideradas ineficazes ao 
desenvolvimento econômico. Seus membros, por exemplo, passaram a deliberar sobre a necessidade de dinamização de permissões ambientais para empreendimentos comerciais e industriais, valendo-se da lógica de que a morosidade de licenciamento teria potencial de promover "delays on economic development" e desafiar negócios e a própria velocidade da criação de empregos compatíveis com a proteção ambiental no estado. Na sessão regular nr. 84 do Senado Texano, o comitê concentrou-se, por exemplo, na recente expansão de negócios na produção de petróleo e gás no sul do estado. As preocupações giraram em torno de gerir as oportunidades e desafios ao crescimento econômico na exploração dos recursos de Eagle Ford Shale (TEXAS, 2015 p.01).

Nos últimos quatro anos, dezenas de propostas de Lei relacionadas ao setor de petróleo e gás tramitaram no Congresso Texano (Texas Legislature), incluindo medidas elaboradas pelo Comitê para Recursos Naturais e Desenvolvimento Econômico (OPENSTATESPROJECT, 2015). As propostas cobriram tópicos nas áreas de impostos compensatórios (Severance Taxes), Fundos especiais de arrecadação de taxas das companhias de petróleo e gás para "dias chuvosos" (Rainy Days Fund) e normas para permissões de operação (Permits), procedimentos e obrigações na exploração dos poços. A maior parte das peças legislativas, entretanto, diziam respeito à autonomia legal das cidades e municípios na regulamentação das atividades energéticas.

Como resultado, em março de 2015, um dos senadores e presidente do comitê, foi diretamente responsável pela introdução de uma proposta de Lei, ou Senate Bill 1165 (SB1165) que previa a retirada da autonomia histórica dos governos locais sob a regulamentação e exploração de recursos energéticos (OPENSTATESPROJECT, 2015). De acordo com o texto original, a proposta ressaltava que qualquer:

\footnotetext{
...municipality or other political subdivision may not enact or enforce an ordinance or other measure, or an amendment or revision of an existing ordinance or other measure, that bans, limits, or otherwise regulates an oil and gas operation within its boundaries or extraterritorial jurisdiction (TEXAS, 2015).
}

Uma proposta de Lei que elimina a competência dos municípios quanto à autonomia de reformulação ou implementação de regulações locais (Ordinances) relativas à exploração de petróleo e gás natural. Ou seja, tolhendo o direito ao zoneamento territorial e demais controles urbanos e ambientais às atividades de prospecção de hidrocarbonetos. 
$\mathrm{Na}$ ocasião da audiência promovida pelo comitê, pelo menos setenta representantes ligados ao setor energético, em especial, membros de grandes associações de produtores, se posicionaram a favor do novo marco legal, contrariando poucos cidadãos presentes e alguns representantes de entidades civis que se posicionaram contra a medida no plenário em Austin (TEXAS, 2015). Antes que houvesse a tramitação no congresso texano que exige a aprovação de três quartos dos parlamentares das duas casas (Senado e Câmara), a SB1165 teve, porém, seu processo legislativo encerrado em virtude da aprovação de outra proposta de Lei com objetivo semelhante, oriunda da House of Representatives.

\section{iv) Texas Legislature - House of Representatives:} Committee on Energy Resource of Texas

A Câmara dos Deputados texana, ou House of Representatives semelhante ao senado estadual possui vários comitês que funcionam com o objetivo de debater a legislação ou regulamentação de assuntos estratégicos. Os comitês da Câmara dos Deputados seguem regras de composição do Senado texano e são formados historicamente para debater, entre outros, assuntos correlatos a agricultura e pecuária, defesa, economia, educação, comércio internacional, transporte, fronteiras, regulação ambiental, recursos naturais e recursos energéticos. O Comitê de Recursos Energéticos, por exemplo, é uma comissão permanente da Câmara dos Deputados do Texas que, como as outras, é composta por ordem de antiguidade e indicação do presidente da Câmara (TEXAS, 2015).

Treze membros compõem a House Committee on Energy Resource of Texas, sendo quatro do Partido Democrata, e nove do Partido Republicano. Eles dividem a competência de: i) zelar pela conservação dos recursos energéticos doTexas; ii) atuar na regulação, transporte e desenvolvimento de petróleo, gás e outras fontes de energia; e iii) regular a mineração e o desenvolvimento de depósitos minerais no interior do Estado. Além disso, a comissão tem prerrogativa para editar e publicar normas de direitos de exploração mineral e leasing sobre terras públicas estaduais, instalação de oleodutos e gasodutos por empresas atuantes no estado. Também estão subordinadas à comissão, órgãos estaduais como Railroad Commission of Texas (RRC); Office of Interstate Oil Compact Commissioner; Office of Interstate Mining Compact Commissioner; StateEnergy Conservation Office; e Office of Southern States Energy Board Member for Texas (TEXAS, 2015).

Antecipando a tramitação da SB1165, os parlamentares do Comitê de Recursos Energéticos foram responsáveis pela aprovação de um projeto de Lei com 
objetivos semelhantes designado de House of Representative Bill 40, ou HB40. O projeto também tinha como proposta retirar a autonomia das cidades texanas para banir ou restringir a exploração de petróleo e gás. Em uma votação de 122 votos a favor e apenas 18 contra, a HB40 avançou para o Senado onde, em sinergia com os parlamentares da casa, foi aprovado em 04 de maio de 2015 e teve seu texto final endossado pelo Governador Greg Abbott no dia 18 maio de 2015 (OPEN STATES PROJECT, 2015).

A votação na Câmara dos Deputados, em conjunto com os senadores, constituiu-se no processo político que culminou na retirada dos poderes dos governos locais e restringiu a autonomia legislativa das cidades quanto à regulação da indústria de O\&G. Para muitos analistas, um processo decorrido em função do episódio de Denton, uma pequena cidade do centro norte do estado, localizada dentro da área de exploração de outro folhelho texano, Barnett Shale, surpreendeu a mídia e empresas do setor energético ao aprovar o banimento das atividades energéticas envolvendoo fraturamento hidráulico em toda a sua jurisdição. Denton foi a primeira, única, e a última comunidade do Texas a proibir a prática, uma vez que, a nova legislação encerrou as prerrogativas do município e acabou com as ações judiciais que a cidade sofria em decorrência da insatisfação da indústria energética e de suas associações (STAPLETON, 2015).

\subsection{Perfil dos atores sociais}

\section{i) Energy companies}

Grandes companhias energéticas multinacionais que lideram a exploração de petróleo e gás nos Estados Unidos, e ao redor do mundo, possuem operações em Eagle Ford Shale. Empresas com grande know-how e recursos para fechar contratos de leasing e/ou adquirir os direitos minerais de vastas áreas com alto potencial para produção de hidrocarbonetos não-convencionais. De maneira geral, são empresas que compartilham estratégias comerciais, produtivas e possuem um histórico comum na exploração, transporte e beneficiamento de gás natural, petróleo e seus derivados.

O Grupo Lewis de Energia (Lewis Energy Group and Properties), por exemplo, é uma empresa que atua na engenharia de produção e na aquisição de áreas de prospeção mineral (Engineering \& Procurement). O grupo está sediado na cidade de Encinal, Texas, o que facilitou sua atuação pioneira em Eagle Ford Shale. A empresa foia primeira a perfurar os shales na região, em 2002, quando passou a 
analisar, prospectar e adquirir sistematicamente mais áreas. A empresa é integrada verticalmente, o que the ajuda a controlar seus custos de produção ao longo de oscilações dos ciclos de preços de petróleo e gás. A Lewis é uma das líderes na exploração de recursos não-convencionais em EFS, possuindo mais de 400.000 acres de direitos minerais próprios. A empresa se orgulha em declarar que "We control our own destiny-by owning our own rigs, completions, and continually expanding our operations". Atualmente a empresa é parceira da British Petroleum (BP) em uma joint venture que explora e controla grandes áreas nos condados de Dimmit County, La Salle e Webb County (eaglefordshale.com, 2016).

A Anadarko Petroleum Corporation, por sua vez, é uma companhia energética com sede na cidade Woodlands, Texas. Uma comunidade desenvolvida pelo falecido mega empresário texano George Mitchell, fundador da antiga Mitchell Energy, vendida em 2002 para a Devon Energy por U\$ 3,5 bilhões. A Anadarko possui operações nas principais áreas de prospecção de petróleo e gás nos Estados Unidos, e outros países, como Brasil, China, Ghana, Indonésia e Nova Zelândia. Domesticamente, além de atuar e investir em todos shales do sul dos Estados Unidos, opera nos estados do Colorado, Wyoming, Utah e Pensilvânia. Em Eagle Ford Shale a empresa controla 388.000 acres igualmente concentrados nos condados de Dimmit, LaSalle e Webb. A empresa possui parceria com a Korean National Oil Corporation (KNOC) onde a estatal asiática possui $33 \%$ dos direitos de exploração de bases estabelecidas no condado de Maverick, em uma área de cerca de 88.000 acres.

A companhia Conoco Phillips também é uma corporação internacional de energia que tem foco especial na exploração dos ricos shales em petróleo de BakkenShale (no estado da Dakota do Norte) e Eagle Ford Shale. A empresa também de capital texano possui seu escritório principal em Houston onde comanda operaçoes em mais de 30 países. No sul do Texas a empresa atua sob a designação de Burlington Resources, onde possui direito de produção sobre aproximadamente 220.000 acres, dentro do coração da área de EFS.

A também texana Apache Corporation é uma multinacional, sediada em Houston, onde a empresa controla operações nos Estados Unidos, Canadá, Egito e Argentina. Em Eagle Ford possui mais de 450 milacres, na qual a maior parte (400.000 acres) é explorada por meio de uma joint-venture com Enervest (EV Energy Partners). A Apache vem obtendo resultados mistos na exploração de EagleFord, uma vez que, as características geológicas de suas áreas de produção na porção norte do shale nos condados de Brazos, Burleson, Grimes e Lee, são mais ricas em gás natural, comprometendo os lucros da empresa, mais interessada nos preços, ainda que atualmente módicos, dos barris de petróleo negociados no internacional. 
A Marathon Oil, por exemplo, é a unidade operacional upstream de um conglomerado de exploração interessado quase que exclusivamente no petróleo. A Marathon Petroleum tem interesse específico em vários shales ricos em recursos nãoconvencionais líquidos, sobretudo, o petróleo de Bakken Shale, Woodford Shale (Oklahoma), e de Niobrara Shale (Colorado). O conglomerado pertence a mais uma empresa energética texana com sede em Houston, de onde comanda suas operações em Eagle Ford Shale e dirige seus escritórios de campo em Pleasanton e SanAntonio. A empresa possui 180.000 acres em Eagle Ford, onde desde 2011 adquiriu os direitos da Hilcorp Energy Company. A área de exploração está localizada principalmente dentro dos condados de Atascosa, DeWitt, Frio, Gonzales e Karnes.

A gigante Exxon Mobil, sob a bandeira da XTO Energy, também atua ativamente em Eagle Ford Shale. A empresa possui, por exemplo, sua sede americana em Irving, e, adicionalmente, escritório em Houston e Victoria, todas as três cidades no estado do Texas. Além de EFS, a companhia fez grandes aquisições em outros shales, como Marcellus (Pensilvânia) e Fayeteviile, (Arkansas). A ExxonMobil divulga muito pouco sobre suas atividades em Eagle Ford, mas a XTOEnergy tem aumentado sua posição em contratos de exploração e aquisição de direitos minerais nas áreas ricas em gás natural, condensate e petróleo.

ii) Oil and Gas industry organizations \& associations

Importantes associações e confederações regionais se destacam nos arranjos político-institucionais de governança deEFS. Uma delas é a Texas Oil \& Gas Association (TXOGA), uma associação comercial que possui grande influência nos governos locais e no poder Legislativo texano. Fundada em 1919 a TXOGA funciona como um forte grupo de interesse, que atua na defesa do setor energético, possuindo como missão:

\footnotetext{
...to promote a robust oil and natural gas industry and to advocate for sound, science-based policies and free-market principles.(TXOGA, 2015 p.01, grifos do autor).
}

Atualmente seu quadro de associados oscila por volta de 5.000 membros oriundos dos mais variados segmentos da indústria de petróleo e gás. Seu Conselho de Administração é composto por 45 líderes da indústria que se reúnem em sua sede localizada estrategicamente na capital do Estado, Austin. Juntos, seus associados detêm mais de $90 \%$ de toda atividade que envolve petróleo e gás natural convencional e não-convencional produzidos no Texas, englobando empresas de prospecção, transporte, tubulações, processamento e refino (TXOGA, 2015). 
Seus membros e representantes são figuras comuns nos debates envolvendo a legislação e a regulação indústria do petróleo e gás no Texas, mas também de outras unidades federativas do país. A entidade alinha-se com a American Petroleum Association e a Independent Petroleum Association of America no sentido de repudiar qualquer tipo de implementação de leis e/ou medidas que considerem restritivas ou abusivas para o desenvolvimento do setor.

O trabalho da TXOGA se concentra em questões de regulamentação governamental e tributação, mas igualmente de outras demandas que considerem sensíveis aos interesses da indústria petrolífera, seja na esfera do Governo Federal, seja na esfera dos governos estaduais ou locais. $\mathrm{Na}$ questão envolvendo o deslocamento regulatório das competências relativas à regulamentação do setor energético para o estado, em detrimento das autonomias dos governos locais, a associação declarou que:

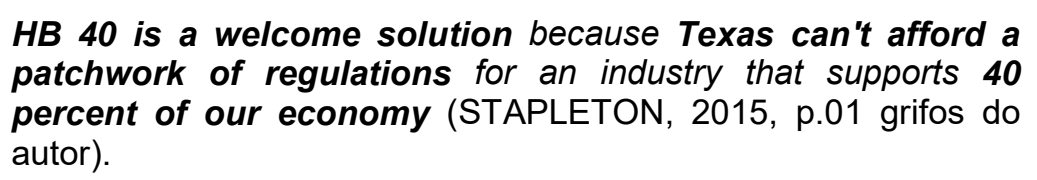

Outras estratégias da associação, por exemplo, consistem em trabalhar como formadora de opinião junto à mídia regional, elaborando e divulgando estudos, reportagens e pesquisas que refletem os pontos de vista da indústria e que consideram relevantes sobre as políticas públicas correlatas ao setor. Em seu website são facilmente encontrados artigos e materiais de divulgação que destacam os: "benefits of Oil and Gas" e matérias de cunho informativo em que se explica o que é "fact or myth" nas atividades de perfuração e fraturamento hidráulico (TOXGA, 2015 página principal, grifos do autor).

Outra importante associação de cunho bastante pontual é a South Texas Energy \& Economic Roundtable (STEER). Uma entidade formada por onze das maiores operadoras estabelecidas emEagle Ford Shale. A associação se descreve como uma entidade coordenadora da comunicação e defesa pública de boas práticas em torno da produção de recursos energéticos no sul do Texas. Entre seus objetivos, divulgados em seusítio digital e também nas páginas de rede sociais que mantém, a associação destaca seu papel de ser uma "bridge connecting the oil and natural gas industry to South Texas communities”, ou seja, atuar na articulação institucional entre a indústria, governos locais, autoridades regionais, universidades, entidades sociais e membros das comunidades de EFS(STEER, 2015 p.about us). Segundo as palavras de seu presidente, a entidade: 
...provides both oil and gas companies and their contractors an opportunity to be acknowledged for their efforts in preserving the environment, contributing to the communities in which they work and promoting safety in and around the workplace (STEER, 2015 p.about us, grifos do autor).

Para destacar seu envolvimento com suas diretrizes, a associação lançou uma espécie de certificação, designada de Eagle Ford Excellence Awards, aberta às suas empresas associadas e demais indústrias do setor energéticointeressadas em promover e divulgar seusesforços na preservação do meio ambiente, colaboração e educação mútua dos atores sociais inseridos nas comunidades de EFSS (STEER, 2015).

...we understand that growth and prosperity in South Texas depend on active dialogue, collaboration and education among the various stakeholders (STEER, 2015 p.about us, grifos do autor).

A Texas Alliance of Energy Producers, por sua vez, apesar da designação é uma associação de caráter nacional que possui mais de 3.300 membros distribuídos em 34 Estados americanos. A Aliança se auto-classifica como a maior associação de comércio de petróleo e gás natural nos Estados Unidos. A missão da associação destacada em seu website é: "garantir que a política energética do futuro será aquela em que nossos membros possam crescer e prosperar." (TEXASALLIANCE.ORG, 2015).

A entidade divulga um periódico digital intitulado de "Eyes on Texas and Washington" (Olhos no Texas e em Washington), no qual publica artigos sobre gargalos e desafios a atividades de exploração de hidrocarbonetos no estado. A principal preocupação, destacada pelo seu editorial é: "olhar atentamente para os entraves ao desenvolvimento do setor no Texas e, igualmente, fiscalizar as medidas e ações do Governo Federal" (TEXASALLIANCE.ORG, 2014 p. about us).

iii) American Petroleum Institute (API), America's Natural Gas Alliance (ANGA) e Independent Petroleum Association of America (IPAA)

American Petroleum Institute ( $A P I)$, America's Natural Gas Alliance (ANGA) e Independent Petroleum Association of America (IPAA) são as maiores organizações e os mais poderosos lobbies interligados à indústria de petróleo e gás dos Estados Unidos. Todas possuem grande influência nas maiores áreas de produção do país, incluindo Eagle Ford Shale. Essas instituições historicamente se 
fazem presentes nas muitas arenas de ação política, e espaços deliberativos de governos locais e estaduais, alinhando-se especialmente às agências de desenvolvimento, órgãos de meio-ambiente e câmaras de comércio para assegurar que as estruturas regulatórias do setor se mantenham longe do controle do Governo Federal (DAVIS, 2012).

A American Petroleum Institute $(A P I)$, por exemplo, é a organização mais antiga e consolidada do setor energético americano, tendo sido criada após a primeira guerra mundial, em 1919 (Figura 27). A API atua como porta-voz política e entidade representativa do setor industrial, sendo engajada no que chama de livre defesa da exploração de hidrocarbonetos nos Estados Unidos. Recentemente, a API teve papel central no processo legislativo que acabou por revogar quarenta anos de proibição federal de exportação de petróleo bruto (crude oil). Uma medida em vigor desde as grandes crises do petróleo na década de 1970. Adicionalmente, o instituto atua na divulgação de dados e informações com o objetivo de unificar os discursos do setor industrial, de movimentos e organizações da sociedade civil, favoráveis à exploração do petróleo e gás natural dos folhelhos.

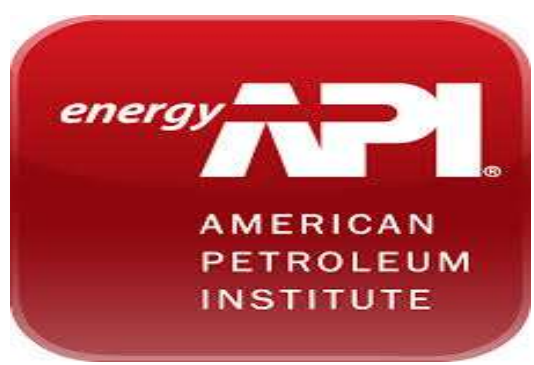

Figura 27 - Logo da American Petroleum Institute (API).

Fonte:api.org

Como parte de suas formas de ação política, a APl apóia, e está interligada, a entidades e plataformas digitais de divulgação como a 'Energy Citizens'; 'We are energynation'; 'Energy from Shale.org'; e 'Energy Tomorrow'. Organizações que utilizam slogans como: "Keep Washington out of my Gas Tank" e propagam campanhas de repúdio ao Ato de Combustíveis Renováveis (Renewable Fuel Standard-RFS) do Governo Federal, alegando que "Renewables fuels Standard can cause engine damage, cost American consumers and harms the environment" (ENERGYCITIZENS.ORG, 2016 p.01). Adicionalmente, a API também patrocina portais como o 'Oil and Gas Workforce' desenhados para estimular o desenvolvimento de carreiras profissionais e oferecer "links" entre trabalhadores e a demanda das indústrias por mão-de-obra.

Recentemente, a API reagiu às pressões públicas dirigidas ao Congresso Americano para instituir um marco de regulação nacional. As demandas orbitaram na maior transparência e rigidez para o setor energético, obrigando as 
companhias energéticas do país a divulgarem poço-por-poço seus dados de produtivos, e elementos químicos utilizados. Uma iniciativa conhecida nos Estados Unidos como disclosure, ou divulgação, em resposta à insatisfação de segmentos da sociedade as exempts obtidas pelas empresas no processo de fraturamento hidráulico. A resposta da $A P I$ tem sido divulgar seu comprometimento frente ao processo de disclosure segundo qual estaria seguindo:

... four basic principles of the disclosure policy ... 'no federal regulation', maintaining state control over regulation of fracturing, 'confidentiality of proprietary information,' and transparency.(DAVIS, 2012b p.233, grifos do autor).

A ação da associação é interpretada por analistas políticos como uma estratégia oportunista do instituto, no sentido de se colocar à frente da questão, ou "get out ahead of the issue" (DAVIS, 2012b, p.233), e evitar dessa maneira a possibilidade de encarar regulações mais restritivas e contundentes por parte do Governo Federal.

No final de 2015 a $A P I$ anunciou em Houston seus planos de se fundir à ANGA em uma estratégia de promover uma "single voice promoting the industry" (GRATTAN, 2015 p. 01). Embora a ANG tenha sido criada somente em 2009, exclusivamente por produtores e processadores de gás natural, as duas entidades possuem agendas semelhantes, preocupadas em pressionar legisladores e promover regulações favoráveis à exploração dos folhelhos. Segundo Grattan (2015), a fusão se deve em boa medida à fragilidade da $A N G A$ em resistir às apertadas determinações federais de emissões de metano durante a produção, bem como, o sucesso limitado das empresas do segmento em destacar o gás natural como combustível mais barato e limpo, com propriedades de queima e baixas emissões de carbono.

Paralelamente ao API, o Independent Petroleum Association of America (IPAA), atua como uma entidade representativa de 'produtores independentes', descritos pela entidade, como aqueles que não detêm mais do que U\$ 5 milhões nas vendas de varejo (retail sales) e não produzem mais do que 75 mil barris/dia. A partir dessa classificação, a associação se diz representante de mais de 9 mil produtores nos Estados Unidos. Curiosamente, entre seus fundadores, estão as mais poderosas companhias energéticas mundiais como a Bristih Petroleum, Marathon, Chevron, Shell, e Halliburton (MATZ \& RENFREW, 2014).

Os objetivos da IPAA estão em consonância com as metas da $A P I$, especialmente no que diz respeito a combater a disseminação de regulações restritivas quanto à exploração dos shales, a criação de barreiras e impostos 
ambientais e, inclusive, trabalhar como formadores de opinião no combate ao que chamam de mitos sobre o fraturamento hidráulico.

Para essa tarefa, a IPAA financia equipes de profissionais qualificados (jornalistas, engenheiros, químicos) que conduzem um blog spot que tem por missão: "fazer com que novas ferramentas de comunicação se tornem uma via de influência e escolha no seio de campanhas políticas afetas ao setor".Para isso, a IPAA presta especial atenção ao processo de cooperação com agências de notícias, bem como, formuladores de políticas federais (RUSSELL, 2009 p.01). O instituto foi responsável pelo lançamento da campanha de relações públicas "Energy in Depth (EID)", ou Energia em Profundidade, em que uma plataforma digital de notícias trata de questões referentes ao setor energético e sobre o fraturamento hidráulico e a prospecção de petróleo e gás natural nos shales americanos(MATZ \& RENFREW, 2014).

Para autores com Faber (2008), Energy in Depth articula redes de trabalho compostos por "think tanks", firmas de relações públicas, campanhas, grupos de interesse, comitês de ação política, empresas e estratégias de lobby que trabalham em retratar positivamente as atividades das indústrias energéticas e químicas, mesmo se tratando de "um complexo industrial-poluidor, que nega qualquer clamor de procedimentos ambientais nocivos" (p.01). Matz e Renfrew (2014) observam que os materiais divulgados no EID representam e caracterizam a exploração dos folhelhos como atividade patriótica, cercadas de imagens de apelo ambiental e argumentos de um setor comprometido e referendado pela razão científica.

\section{iv) Railroad Commission of Texas (RRC)}

A intitulada Railroad Commission foi fundada em 1891 para regular as atividades logísticas, produtivas e comerciais do setor de ferroviário no Texas. Ao longo de sua história, entretanto, a comissão passou a incorporar uma função de agência reguladora de muitas outras atividades industriais e energéticas, incluindo o setor de regulação e fiscalização das atividades da indústria do gás e petróleo.

A Divisão de Petróleo e Gás da RRC, com sede em Austin, capital do Texas, é um dos principais órgãos oficiais incumbidos pela regulação, exploração, produção e transporte de petróleo e gás natural no Estado. O papel estatutário da divisão garante sua atuação em: i) evitar o desperdício dos recursos naturais do estado; ii) proteger os distintos direitos de propriedade, sobretudo, os minerais; iii) evitar a poluição e; iv) fornecer segurança para controle de materiais tóxicos como o sulfeto de hidrogênio(RRC, 2015). 
Para atingir esses objetivos, a agência é responsável por emitir as importantes permissões e licenças de operação (Permits) e produzir relatórios de inspeções de campo, testes e monitoramento de atividades das companhias energéticas. A comissão também é responsável por controlar programas de remediação de poços abandonados que realiza com fundos obtidos da arrecadação de taxas e impostos das empresas fiscalizadas. Segundo o website institucional da $R R C$ esses serviços são prestados de acordo com a missão institucional de:

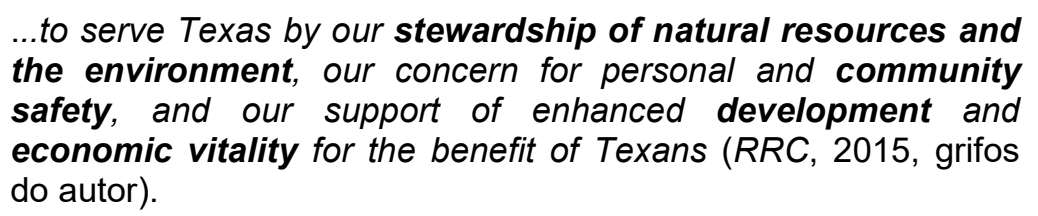

É a $R R C$, portanto, o órgão estadual que possui competência primária para fiscalizar e controlar os procedimentos de perfuração convencional (drilling), fraturamento hidráulico (fracking), construção de gasodutos e tubulações de líquidos perigosos, beneficiamento do gás e demais operações de mineração. Suas responsabilidades legais, apesar das exempts no fraturamento hidráulico, são de zelar pelo enquadramento de Leis federais como: Safe Drinking Water Act, Clean Water Act, Resource Conservation Recovery Act e Pipeline Safety Act, exercendo a mediação dereclamações e conflitos, estabelecendo punições e, eventualmente, revogando licenças comerciais e produtivas. A comissão tem a obrigação de observar: "Water used in the exploration, development, and extraction of oil and gas, including hydraulic fracturing" (RRC,2013 p.43, grifos do autor).

A designação de 'comissão' deriva do fato de a agência ser composta por três comissários, ou delegados eleitos periodicamente que são responsáveis, entre outras tarefas, por realizar audiências com consumidores de energia, donos de terras e de direitos minerais, além de membros da imprensa e da mídia no Estado. Vale ressaltar que, apesar de sua designação, a $R R C$ não possui competências para regular e fiscalizar ferrovias, estradas e o tráfego de cargas e pessoas. Essas atribuições são atualmente responsabilidades da Administração Federal de Ferrovias e da divisão de estradas de ferro do Departamento de Transportes do Texas (TXDOT).

Também não é incumbência legal da $R R C$, pelas normas constitucionais do Estado, os assuntos correlacionados a contratos de leasing, acordos comerciais e royalties interligados à exploração de gás e petróleo. A agência, igualmente, não possui competência de normas e controle sobre a poluição sonora, um aspecto controlado pelos governos locais (leis municipais, ou ordinances), e sobre 
a poluição atmosférica, uma questão controlada pela Texas Commission on Environmental Quality (TCEQ).

v) Texas Commission on Environmental Quality(TCEQ)

A Comissão de Qualidade Ambiental do Texas, ou Texas Commission on Environmental Quality (TCEQ) é a agência reguladora responsável pelo monitoramento da qualidade do ar, da água e da gestão de resíduos sólidos e líquidos no Estado. Concebida originalmente pelo Congresso Texano, em 1991, como Comissão de Conservação de Recursos Naturais do Texas, ou Texas Natural Resource Conservation Commission (TNRCC), a agência foi renomeada pelo Congresso Texano em 2002, quando incorporou três subcomissões estaduais: Texas Water Commission, a Texas Air ControlBoard, e o programa ambiental do departamento de saúde do Estado, ou Texas Department of Health. Segundo seu website institucional, o órgão público estadual passou a: "Proteger a saúde pública e dos recursos naturais no Estado do Texas de forma compatível com o desenvolvimento econômico sustentável" (TCEQ, 2015 p.about us).

Dirigida por três comissários nomeados diretamente pelo governador do Texas, as competências da TCEQ se distribuem em emitir licenças ambientais, e oferecer esclarecimento ao público quanto aos potenciais impactos de atividades econômicas e produtivas frente à exploração de recursos naturais. No seu "Plano Estratégico 2013-2017", por exemplo, a agência ressalta seu papel nas avaliações de atividades com efeitos nocivos à saúde pública, no monitoramento e análise da qualidade do ar, da água e do solo, assim como seu comprometimento com a divulgação e transparência de dados, por meio da divulgação de relatórios anuais identificando atividades, reclamações, mediações e soluções de conflitos (TCEQ, 2013).

Um estudo preparado, por exemplo, em parceria da TCEQ e o Conselho de Governos da Região de Alamo, Alamo Area Council of Governments (AACOG), entre os anos de 2013 e 2014, produziu um inventário de emissões de gases e um cenário das condições de poluentes esperado para Eagle Ford Shale nos próximos seis anos. As conclusões são que o número de poços de EFS podem quadruplicar dos atuais 8 mil para aproximadamente 32 mil, cujo salto na produção passaria de 363 milhões de barris anuais, para mais de 760 milhões, produzindo o aumento de $281 \%$ dos chamados componentes orgânicos voláteis, ou Volatile Organic Compounds (VOC's), elementos gasosos tóxicos como benzeno e tolueno (AACOG, 2014). Boa parte desses compostos é emitida no armazenamento, transporte dos 
hidrocarbonetos, mas, também, como resultado da queima de gases pelos chamados 'flares'.

A despeito dessas conclusões, os procedimentos para emissões de licenças ambientais da TCEQ não têm caminhado num sentido mais restritivo para as indústrias do setor de petróleo e gás, ou qualquer outro setor industrial no Texas. Em 2015, por exemplo, os procedimentos que regem o licenciamento ambiental e a emissão e controle de permissões de operação industrial foram flexibilizados em favor do setor industrial. Considerados inapropriados pela bancada do partido republicano estadual, seus mecanismos e processos foram alterados pela Senate Bill 709, que aprovada somente três meses após sua proposição, passou a permitir que licenças e permissões sejam aprovadas de maneira mais rápida, com menos influência de protestos e bloqueios legais.

Segundo o senador autor da nova Lei: "We're losing a lot of jobs to surrounding states. [and] This [Bill] is clearly for economic development" (MALEWITZ, 2015b, grifos do autor). A Lei reduziu prazos e prerrogativas dos governos locais, e audiências públicas, restringindo o engajamentodas comunidades locaisem escrutinar e desafiar procedimentos industriais, tais como descargas de águas residuais em corpos hídricos ou emissões de contaminantes atmosféricos.

vi) Civil organizations, associations, social \& media movements

Um número considerável de organizações não-governamentais, associações, ligas e movimentos sociais coexistem no Texas, com reflexos diretos e indiretos na governança dos recursos energéticos. Organizações como a Local Control Texas Organization, e a Texas Municipal League, seguem a mesma linha ideológica de proteção das autonomias e poderes das cidades e municípios, mas destoam, entretanto, quanto aos meios empregados para "protect local sovereignty and to limit the size and scope of state government" (LOCALCONTROLTEXAS.ORG, 2015 p.01).

Para a organização não-governamental Local Control Texas, por exemplo, a autonomia política dos governos locais faz parte da cultura da sociedade texana, mesmo antes da formação da República do Texas (1836-1846) e da consolidação do seu atual território como um estado americano. Para a entidade o espírito de independência está consagrado na constituição texana e surgiu do nascimento de comunidades autônomas como San Antonio, El Paso e Nacogdoches, onde se consolidaram direitos de independência e auto-governos (self-governments) longe da interferência estadual ou federal (LOCALCONTROLTEXAS.ORG, 2015 p.01).. 
A Liga Municipal do Texas (Texas Municipal League), por sua vez, também é uma organização não-governamental, porém de maior porte e sediada em Austin. A associação possui uma postura mais branda em relação ao esvaziamento de prerrogativas dos poderes locais no caso das Oil and Gas Ordinances. A Lei HB40, por exemplo, teve sua versão final aprovada com a negociação ativa da entidade nas rodadas que culminaram na sua publicação. Embora admita que "The Bill isn't perfect", uma vez que as autonomias locais ficaram desprovidas da regulação do uso do subsolo, a organização justifica sua postura ao frisar que os municípios continuaram a reter $80 \%$ da responsabilidade sobre atividades superficiais, incluindo legislação de combate a incêndios, tráfico, luzes, poluição sonora, advertências e limites territoriais e comerciais "razoáveis" (TML, 2016 p.01).

Diante da polêmica semelhante ao debate nacional estabelecida pelo fracking boom, outros grupos de interesse heterogêneos se engajaram nos aspectos políticos, mas igualmente nos critérios interligados a saúde pública, segurança, meioambiente e desenvolvimento econômico. Entre os grupos opositores, comumente designados pelos conservadores como "greenies" (verdes), se encontram ONG's como a Earthworks Organization e The Centre of Public Integrity que utilizam dados estatísticos de relatórios dos órgãos reguladores estaduais (RRC e TECQ) e dados obtidos de estudos acadêmicos que conduzem investigações próprias voltadas a revelar falhas e lacunas nas estruturas político-institucionais de regulação e exploração dos folhelhos no Texas.

Associações civis como a State Impact: Energy and Environment Reporting for Texas denunciam impactos socioeconômicos geradas pelo boom. Para a entidade os movimentos de alta e baixa das atividades exploratórias, atreladas à oscilação mundial do preço do petróleo, comprometem o desenvolvimento de EFS. Eles chamam a atenção para como um quadro onde "thousands of men rushing in to work in the Oil Fields" passou rapidamente para um ambiente de incerteza provocado pela queda brusca nos barris do petróleo em 2015 e 2016. Um quadro onde muitas cidades se perguntam: "what comes next? Cotulla, por exemplo, um município de apenas 4 mil habitantes se tornou o "Hotel Capital" de EFS, e testemunhou a construção de vinte e cinco hotéis que, de um movimento frenético há dois anos atrás, passou a conviver com altas taxas de desocupação, lembrando, aos moradores mais antigos, os erros e as falhas do passado, na ausência de planejamento na diversificação das atividades econômicas (BUCHELE, 2015 p.01).

Numa visão diametralmente oposta, entretanto, várias entidades texanas vêm apostando suas fichas na retomada dos preços e atividades e possuem uma visão extremamente positiva à expansão das atividades de exploração dos 
shales.Uma quantidade significativa de Websites e Blogspots como Eagle Ford Shale News, Market Place and Jobs e Eagle Ford Shale Jobs: Job Research, Jobs and Carreers, mas também organizações como a The Texas Land \& Mineral Owners Association e a Texas Consumer Energy Alliance,mantêm fóruns e blogspots onde alinham-se em posições políticas favoráveis à exploração dos folhelhos e ao livre direito de explorar seus direitos minerais de subsolo. Esses grupos e entidades exploram, especialmente, aspectos de desenvolvimento econômico correlacionado ao novo boom, sobretudo, os interligados a oportunidades de trabalho, empregos diretos e indiretos.

Adicionalmente, revistas digitais e impressas circulam como peças de divulgação e formação da cultura do setor de petróleo e gás no estado. Revistas como Shale: Oil and Gas Business Magazine,Texas Eagle Ford Shale Magazine, e The Boom,trabalham de forma simultânea às plataformas digitais para propagarem o debate sobre políticas de governo necessárias a proteção da exploração energética, garantia de direitos minerais, oferta de serviços públicos (segurança, transporte, treinamento e recreação), além de base para campanhas publicitárias na construção civil, aviação, equipamentos industriais, serviços de alimentação, hotelaria, moradia e alojamento.

No meio do fogo cruzado entre contrários e favoráveis ao frackinge a exploração dos folhelhos, existem algumas organizações civis voltadas a democratizar o debate e ampliar a participação política da sociedade civil no processo regulatório e controle dos impactos. Entidades como Denton Drilling Awareness Group (DAG), por exemplo, foram decisivas no processo,inédito no Texas,que culminou no banimento do fraturamento hidráulico das áreas do Barnnet Shale dispostas dentro da jurisdição da cidade.A ação do grupo certamente influenciou a mobilização de outros grupos como $o$ College Station Citizens for Safe Fracking nas cidades gêmeas de Bryan/College Station. Essas cidades foram as únicas dentro da área de EFS em que organizações civis se manifestaram receosas frente aos possíveisimpactos socioeconômicos e ambientais causados pelo boom.

Parte III - Os Direcionadores de Governança e Eco-governamentalidade a partir de Eagle Ford Shale

5.4 Os direcionadores de governança dos folhelhos de EFS como análise das interações, interdepedências e viesses cognitivos dos atores sociais

\subsubsection{Decentralization}


Historicamente o sistema federalista americano delega amplas competências comuns e concorrentes às unidades federativas. De forma análoga, os governos estaduais também possuem uma forte tradição em respeitar e manter a autonomia dos governos locais (condados e municípios). Como destacam Tucker \& Luttbeg (2010), os Estados Unidos é composto pela união indissolúvel dos seus cinqüenta estados, sobretudo, pela alta representatividade e autonomia de seus "noventa mil governos locais" (p.01). A solidez desse quadro político-institucional e de seu histórico arranjo descentralizado, entretanto, se demonstrou instável e desfavorável quando confrontado com a regulação e gestão de recursos energéticos não-convencionais. No Texas, por exemplo, a exploração dos shales foi capaz de promover,de modo inédito, o rompimento de competências e prerrogativas históricas.

Como visto anteriormente, nos Estados Unidos, todo setor energético está diretamente subordinado às linhas diretrizes e medidas estabelecidas pelo Energy Policy Act(2005). Vale destacar, entretanto, que embora o marco regulatório (EPACT) tenha sido estabelecido pela comissão especial do congresso americano para viger em todo país, suas normas não interferem nas prerrogativas dos estados quanto à regulamentação energética. As diretrizes da EPACT dizem respeito muito mais a implementação de mecanismos de apoio, incentivos e subsídios para a pesquisa, desenvolvimento e inovação de fontes convencionais e não-convencionais.

A EPACT não estabelece, portanto, nenhuma imposição federal no que diz respeito à forma pela qual os estados devem editar regulações e gerir a produção e exploração de recursos energéticos em suas jurisdições. Não existe, nesse sentido, uma política nacional de uso e produção, ou de legislação obrigatória quanto ao uso e exploração de recursos não-convencionais com parâmetros e diretrizes obrigatórias. As agências federais URTAC e a FERC se restringem a atuar como órgãos consultivos, ou deliberativospara funções específicas. Enquanto a URTACtem o papelde incentivar debates e articulações institucionais entre sociedade, estado e mercado, para o desenvolvimento tecnológico, segurança e controle ambiental de recursos não-convencionais, a FERC se limita a transmissão de energia interestadual como linhas elétricas, gasodutos e oleodutos.

Concretamente, a estrutura político-institucional da governança dos folhelhos nos Estados Unidos (Figura 28) se caracteriza por uma forma descentralizada das atribuições normativas na exploração e produção definida separadamente por cada um dos cinquenta estados e seus governos locais. Um arranjo político-institucional que deriva historicamente dos critérios de subsidiaridade, 
flexibilidade e devolução em favor dos governos locais. Um sistema que envolve delegação de autonomias e prerrogativas que a princípio trazem grande responsabilidade e voz para as comunidades inseridas nas áreas de produção energética. Processos onde decisões bottom-up, ou de baixo-para-cima, possuem força significativa, e são respeitados diante às medidas top-down, dentro da lógica ideal de boa governança.

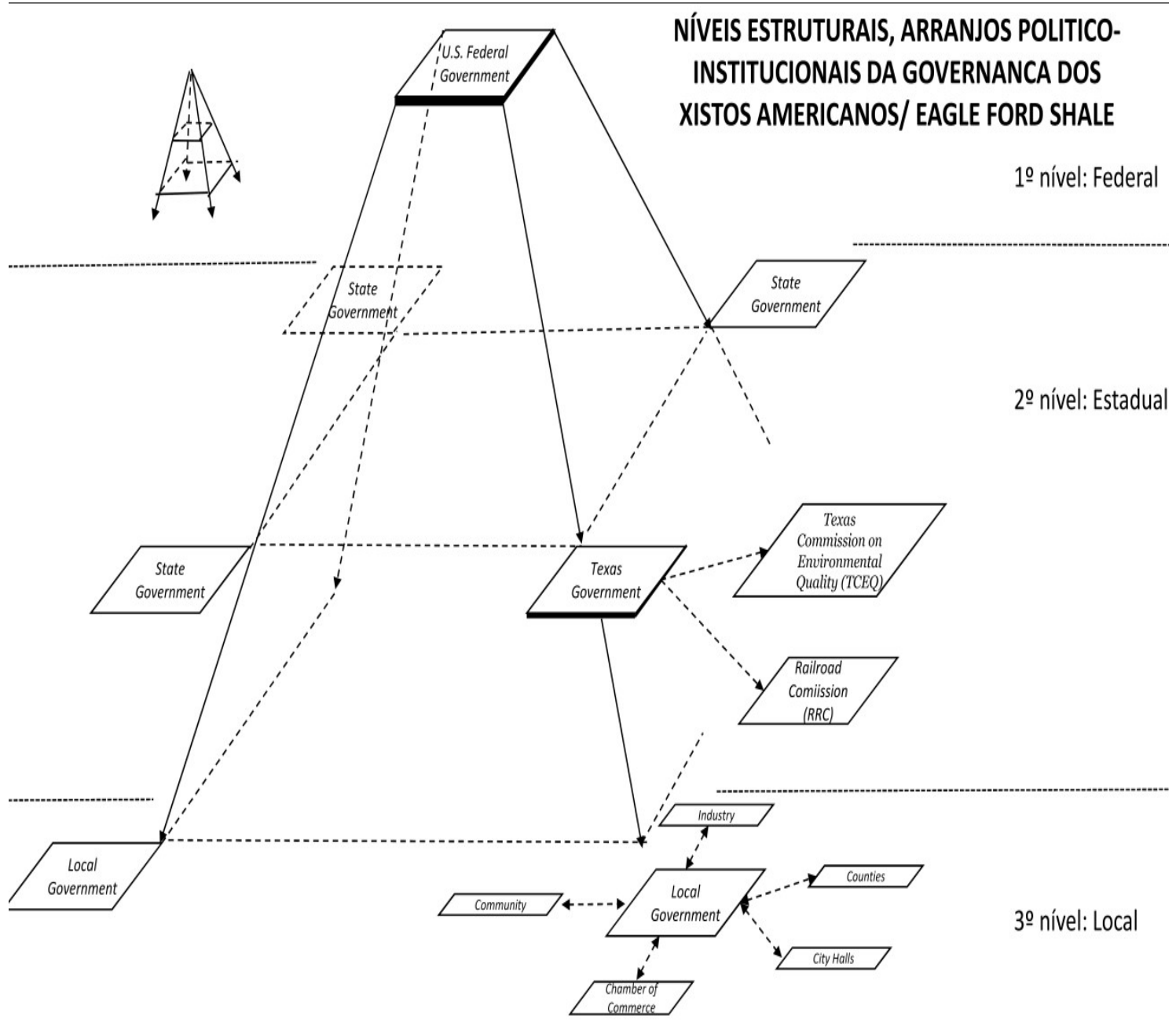

Figura 28 - Hierarquia estrutural nos processos de governança dos folhelhos americanos da escala federal até Eagle Ford Shale.Fonte: elaborado pelo autor.

Vale destacar, entretanto, que a hierarquia estrutural descentralizada, não quer dizer que os estados e seus municípios não estejam submetidos às legislações federais. A Agência de Proteção Ambiental americana Agency (EPA) e suas diretrizes federais de controle da qualidade atmosférica e hídrica, por exemplo, determinadas pelo Governo Federal, têm força legal para balizar procedimentos exploratórios nas escalas estaduais e locais.

Não obstante, ao contrário de um maior controle nacional a partir da publicação do marco regulatório EPACT, as exceções (Exempts) concedidas às atividades de exploração dos recursos não-convencionais criaram brechas que 
deixaram as companhias energéticas livres de procedimentos rígidos de fiscalização,ou mesmo da obrigatoriedade da divulgação de produtos químicos utilizados no fraturamento hidráulico por todo o país. Em decorrência do chamado Halliburton Loophole, as companhias energéticas do setor ficaram desatreladas do atendimento de normas do Clean Air Act;Clean Water Act; Safe Drinking Water Act; e do Superfund of Comprehensive Environmental Response, Compensation, and Liability Act.

Como destacado por Gurule (2013) a manobra "efetivamente alejou a autoridade regulatória da Agência de Proteção Ambiental" (EPA), suprimindo ainda maisações e medidas de comando e controle do Governo Federal sob a gestão e fiscalização de áreas de produção como Eagle Ford Shale(p.04). Concretamente, a 'manobra' retirou a competência fiscalizatória federal sobre normas e leis correlativas aos procedimentos de exploração dos shales, repassando-as às constituições dos governos estaduais e de suas respectivas formas de substate federalism(CHANDHOKE, 2010 p. 01; DAVIS, 2014). Ou seja, sujeita às diferentes formas e relações de poder encontradas no seio dos estados e aberta tanto a procedimentos de aumento, quanto a diminuição da autonomia dos governos locais e das comunidades inseridas nas áreas produtivas.

No caso específico do estado do Texas, o quesito de descentralização da governança foi considerado desfavorável, pois as autonomias locais foram diretamente afetadas pelas assimetrias de forças durante os processos de (re)formulações dasOil \& Gas Ordinances. Um processo que acabou por tolher parte considerável da responsabilidade das cidades home rule, suas arenas de ação política (City Council) e a voz das comunidades (Public Hearings) relativas à regulação do fracking. Toda a prerrogativa de controle da atividade energética subterrânea foi retirada da competência das cidades e incorporada à alçada do governo estadual pelas medidas do poder legislativo texano. Ao que tudo indica um movimento resultante do banimento ocorrido em Denton, frente à possibilidade da replicação de movimentos restritivos em outras cidades do estado. Na prática, a House Bill40, em consonância com o projeto de Lei SB1165, representou uma concretização de poderes políticos e industriais que tolheram a maior parte da competência regulatória dos governos locais.

O forte lobby das companhias energéticas, TXOGA, API, IPAA, entre outras, e de parlamentares interligados ao setor energético nas duas casas legislativas, comissões do Senado, e comissões da Câmara estadual, conduziram a modificação das normas processuais que mudaram as regras do jogo e, sistematicamente, retiraram a histórica autonomia dos municípios quanto à regulação 
e gestão de recursos energéticos. Uma ação típica aos moldes de uma racionalidade big government(JORDAN ET AL, 2005).

O cerceamento das prerrogativas dos governos locais, porém, não chegou a ser uma surpresa ou um ato mal visto de ingerência do estado, inclusive por ser considerado por muitos atores locais, bem antes da publicação da HB40, como um procedimento necessário. Um deslocamento normativo defendido por parte considerável de autoridades políticas e entidades comerciais em EFS. A declaração de autoridades locais das cidades de Cotula e Caldwell, por exemplo, refletem bem essa visão, na qual:

\begin{abstract}
...it presents problems for say like oil companies, because they [cities] have so many different regulation...l mean so many different local things[rules] that can happen to them in really a pretty small geographic area (EFS015, grifos do autor).
\end{abstract}

The no drill thing[...] when city governments have the tendency to overreact, [...] brings the ire other people who are being affected[...] when you're enacting ordinances and other things... it can't be an overreaction that you're doing a complete prohibition...(EFS007, grifos do autor).

Para os respondentes, o padrão excessivo de autonomias regulatórias, em favor dos governos locais, gerava no seu entendimento de possíveis "reações exageradas" e entraves para o desenvolvimento econômico e para o ritmo das atividades energéticas, visto que a complexidade de pleitos locais, e controvérsias, provocavam incertezas para investidores, e dificultava "uma comunicação aberta" e segura para as companhias energéticas.

\footnotetext{
If you go up to Leon County, Robertson County, some of their local rules are different than they are here. And so, that's...the only way they can make that work is through an open communication. (EFS015, grifos do autor).
}

Para o juiz da cidade (City Judge) de Caldwell e outras autoridades locais como o gerente municipal (City Manager) de Cotulla o banimento das atividades exploratórias - como ocorridas em Denton - deveriam ser evitados nas tomadas de decisões locais. Eo melhor processo seria aquele controlado e definido na alçada das autoridades estaduais, onde se admite, num tom sarcástico que: "dictatorships are much easier to run than democracies", ou seja,"ditaduras são muito mais fáceis para conduzir democracias" (EFS015, grifos do autor). 


\subsubsection{Participation}

Apesar de autores como Tucker \& Luttbeg (2010) e Karpovitz (2010), destacarem o papel das audiências públicas (Public Hearings) como importantes arenas políticas de consideração das demandas e solicitações da sociedade americana, na prática, a disponibilização desses espaços democráticos de ação política para debater regulações e normas de exploração emEagle Ford Shale foi caracterizada por uma participação política desfavorável.

Como visto, a participação é um princípio importante no equilíbrio de poder e distribuição de responsabilidades entre governo e sociedade nos Estados Unidos. Os dispositivos de participação funcionam como instrumentos legitimadores das decisões tomadas na esfera pública, sobretudo, daquelas consideradas controversas e importantes para o planejamento e gestão. Apesar disso, muitas autoridades competentes pelo estabelecimento de arenas participativas nos governos locais, como prefeitos, gerentes municipais e conselheiros "are not obliged to act on them or, typically, even to respond publicly" (WILLIAMSON \& ARCHON, 2004, p.08, grifos do autor).

A não obrigatoriedade foi exatamente o padrão preponderante que se seguiu nas cidades inseridas em Eagle Ford Shale, onde pouquíssimos municípios utilizaram de suas prerrogativaspara convocar e inserir a sociedade no processo de regulação e zoneamento das atividades energéticas em suas jurisdições. Praticamente todos os governos locais de EFS reproduziram em seus rulebooks (livros de normas), Oil \& Gas Ordinances de outras cidades texanas com históricos anteriores na exploração dos folhelhos. Em um fenômeno de copy and paste de reprodução das políticas em um 'efeito dominó' sem a devida participação pública.

Não houve, portanto, audiências, na maioria esmagadora das cidades que compõe a região, e como resultado, as atividades de fracking e o uso de flares se expandiram rapidamente em conjunto com o aumento exponencial do trânsito de veículos pesados e fluxo de trabalhadores do setor. Atividades que sobrecarregaram os serviços públicos e que passaram a conviver e produzir lado a lado com áreas residenciais, hospitalares e escolares. De forma concreta, em quase todos os municípios, general Law, ou home rule, as companhias energéticas foram recebidas de braços abertos pelas autoridades e comerciantes locais como uma benção divina. Um sentimento externalizado pela gerente da Câmara de Comércio de Dimmit: "It is the answer to a prayer, the answer to a dream" (RRC, 2013 p.73, grifos do autor). 
O único núcleo urbano em que a participação pública tomou corpo, ocorreu nas cidades gêmeas de Bryan/College Station, no condado de Brazos, porção norte de Eagle Ford Shale. Nesses municípios, a exemplo do ocorrido em Denton, o movimento intitulado de College Station Citizens for Safe Fracking (CSCSF, Foto 5) gerou uma demanda participativa e crítica frente ao processo de reformulação das regulações. A associação se formou: "to ensuring that oil and gas in our city is regulated in a way that protects the health and welfare of our community" (EFS 016). As ações da associação civil acabaram por desencadear um debate local sobre a necessidade de atuação da sociedade frente às novas atividades de exploração de petróleo e gás de folhelho pelo fraturamento hidráulico.

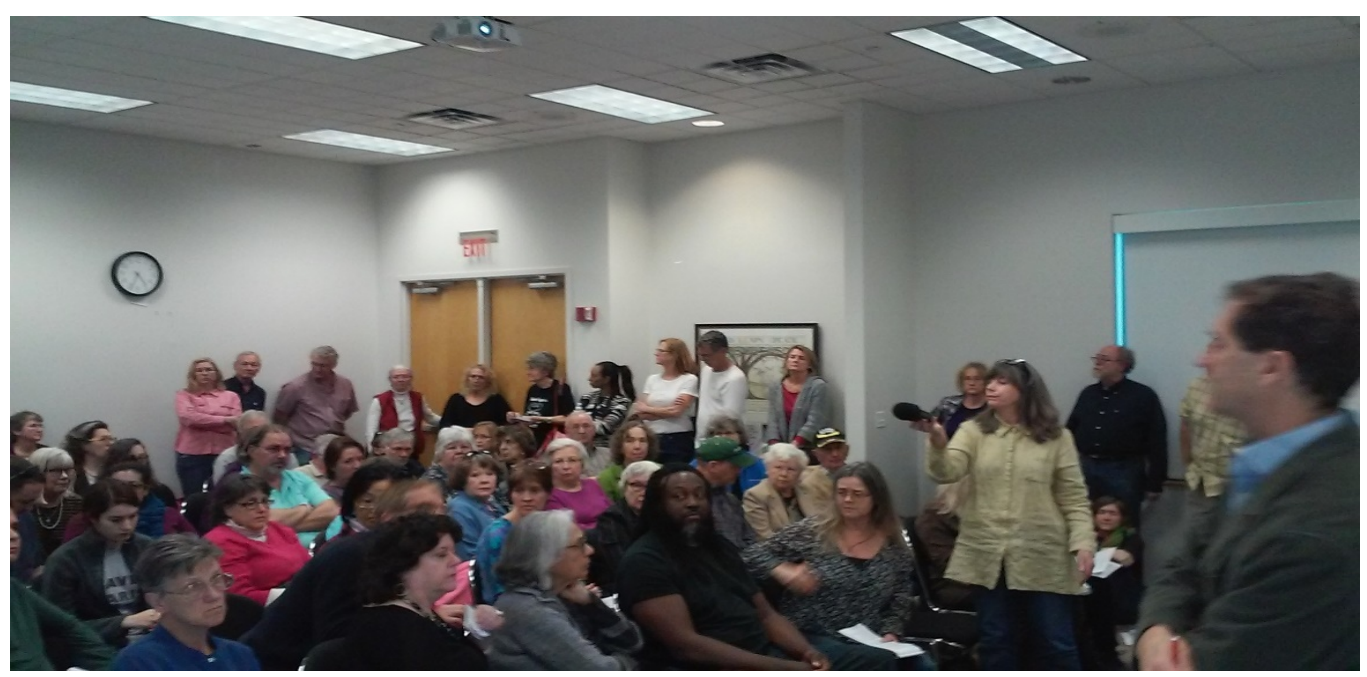

Foto 5 - Reunião do grupo "Cidadãos de College Station para fracking seguro" Fonte: do autor (2015).

Vale ressaltar que College Station é uma cidade diferenciada na região, uma vez que é a sede da Texas A\&M University, uma das mais importantes universidades americanas e do sul do país. Por essa razão, o município possui volumosos investimentos tecnológicos, comerciais e de infraestrutura atrelados ao intenso fluxo de estudantes nacionais e internacionais, e de toda sua comunidade acadêmica. No município cerca de cem mil habitantes entre alunos, professores, técnicos e funcionários convivem interligados ao campus universitário formando um núcleo diferenciado tanto em nível de instrução quanto decomposição social. Fatores que contaram para a absorção da polêmica nacionalenvolvendo a regulação e exploração dos shales.

Tal configuração acirrou o pré-debate que culminou na audiência pública do City Council de College Station onde os articuladores da CSCSF convocavam a participação da sociedade, baseado na argumentação de que: 
The O\&G industry has been lobbying for weeks and will do so at the public hearing to get terms most favorable to it [...] meaning our concerns get pushed aside. State law is in their favor, so only by city ordinance can we have any control of this truly industrial scale operation (EFS016, grifos do autor).

As principais reivindicações levantadas pela associação foram expostas durante a audiência pública (Public Hearing) que se realizou em 22 de janeiro de 2015 (Fotos 6 e 7). Na ocasião os debates orbitaram principalmente sobre o zoneamento territorial energético e a necessidade de aumento da distância de segurança das atividades de fraturamento hidráulico. Durante o escrutínio foi colocado em pauta a possibilidade de emendas reformuladoras dos procedimentos de exploração de petróleo e gás não-convencional na cidade.

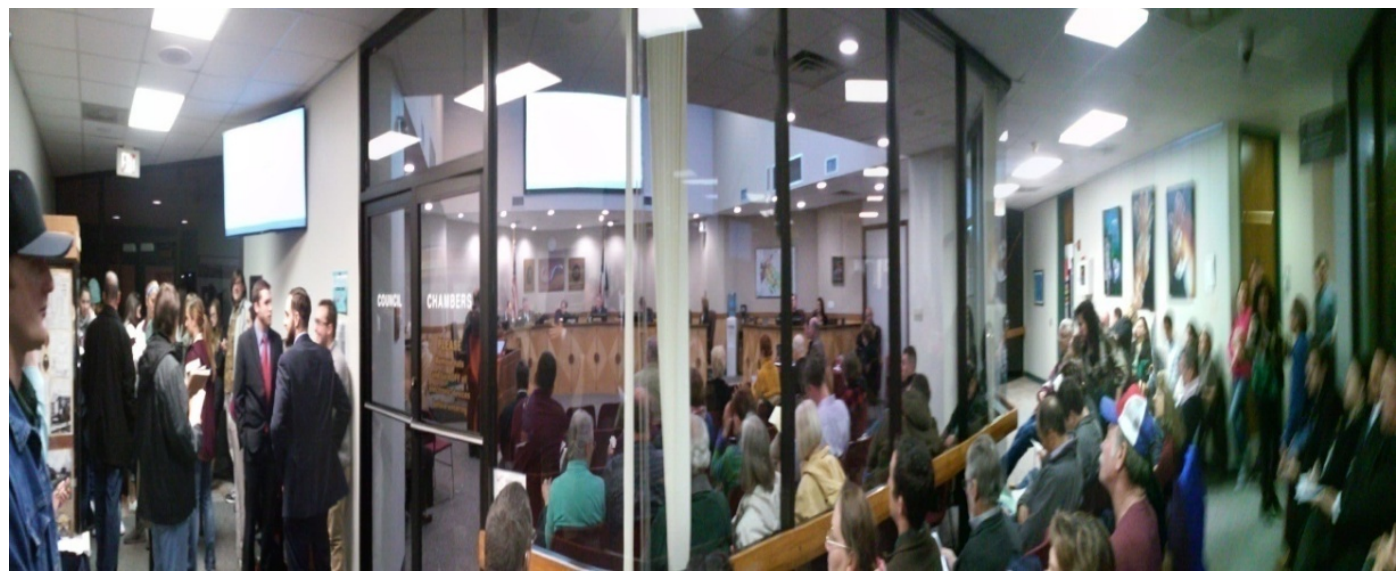

Foto 6 - Audiência Pública (Public Hearing) para (re)definição das regulações locais para a exploração de petróleo e gás na cidade de College Station. Fonte: do autor (2015).

Foram discutidas, especialmente, a possibilidade de alteração das margens de segurança estabelecidas pelas Oil \& Gas Regulations (Foto 6), com a proposta de modificar os 183 metros (600 feet)obrigatóriospara 450 metros (1500 feet) de distância de operação dos poços para as áreas residenciais.

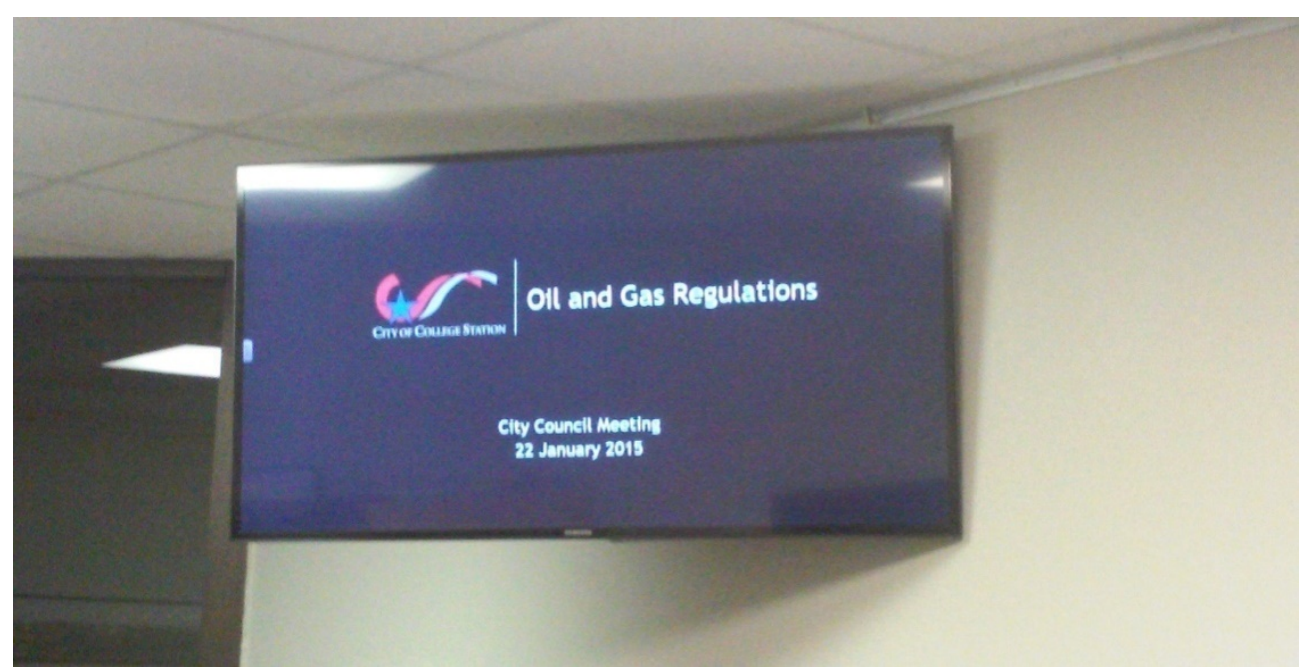

Foto 7 -Placard da cidade de College Stationconvocando paraos cidadãos para a audiência pública de redefinição das Ordinances para o setor de gás e petróleo.

Fonte: do autor (2015). 
Um tema polêmico diante da transição da perfuração convencional (drilling) preponderante no passado, para as técnicas atuais de fracking. A partir dessa pauta, a comunidade foi chamada para declarar-se a favor ou contra à manutenção das leis locais e se manifestar sobre o controle e segurança de V.O.C's, o monitoramento de qualidade do ar, poluição sonora, infraestrutura, qualidade de vida, bem como, quaisquer outros impactos positivos ou negativos que julgassem correlatos às atividades energéticas.

Entre os quarenta e dois cidadãos ouvidos, divididos entre membros da comunidade local, especialistas da área, representantes de companhias e associações do setor de O\&G, houve divisão entre os contrários à manutenção das normas vigentes (17 declarações), os favoráveis à permanência dos setbackse exigências legais (15 declarações) e os que se posicionaram como indecisos (10 declarações). Entre as declarações favoráveis à manutenção das normas de 1991 e a não ampliação das restrições, as lógicas realçavam a ligação da energia como fator propulsor ao desenvolvimento econômico local, sobretudo, pelo estímulo as áreas de produção e serviços, criação de empregos e o aumento de arrecadação de impostos:

I believe that affordable and reliable energy are good to the
American consumer [...] to agricultural transportation,
manufacturing, restaurants, hotels...good to businesses as to
individuals...Energy development helps every single aspect of our
economy (EFS017/\#4 PUBLIC HEARING, grifos do autor).

Texas criated more jobs than the others $\mathbf{5 0}$ states combined during the recent recession and a O\&G industry has a large part in that..it provide in Brazos Valley more than 45 million dollars in 2014 and more than 2300 jobs.(EFS017/\#12 PUBLIC HEARING, grifos do autor).

Ordinances are vital to protect our community of anti-growth economy[...] the discussion of this ordinances it's not just of O\&G production it's about good government and science based policy (EFS017/\#13 PUBLIC HEARING, grifos do autor).

A manutenção das normas de regulação e exploração de gás e petróleo também foi defendida conclamando a lógica da ciência, da“verdade", e do respeito à liberdade de comercialização, aluguel do subsolo (leasing) daqueles que possuem o direito de propriedade mineral (mineral rights). Princípios entendidos como elementos básicos dos atores pro-fracking diante das regulações e zoneamento das atividades de fraturamento hidráulico:

The truth is, the science is there... 600 feet setbacks is the answer to belting developing with people concerns about health (EFS017/\#2 PUBLIC HEARING, grifos do autor). 
We know from researches that 600 'foot' setbacks protect public health and allow for responsible production. Setbacks that exceeds it will be unreasonable, make production very difficult or impossible...this kind of proposals will have impact on property rights...great distances will significantly impact the mineral owners (EFS017/\#7 PUBLIC HEARING, grifos do autor).

Argumentos que ressaltavam a credibilidade científica e política da exploração dos hidrocarbonetos também foram utilizados frente à tradição do estado na produção petrolífera e da ausência nessa trajetória de danos causados pela atividade energética à saúde humana ou mesmo para a ecologia:

We have many wells and it produces for decades with no harm to our health or ecology"(EFS017/\#12 PUBLIC HEARING, grifos do autor).

Studies does show that responsible O\&G production does not harm public health...but you don't need to take my word for it..."...President Obama former Secretary of Energy said: fracking is something you can do in a safe way" Obama's former Secretary of Interior said[...] we know that isn't that any single case that hydraulic fracking has created problem to anyone (EFS017\#12 PUBLIC HEARING, grifos do autor).

Por outro lado, os palestrantes contrários à manutenção das normas ressaltavam a discrepância na tecnológica e procedimentos das perfurações convencionais do passado (drilling) em relação ao fraturamento hidráulico (fracking) e a consequente necessidade de equipamentos específicos, como unidades de recuperação e gasodutos, além da proibição do uso de flarings e do monitoramento das emissões de V.O.C's:

I also strongly endorse to council to consider an addition to abandon on flaring... andall O\&G operators must be required to have pipelines in facilities to mitigate any possible reasons for safety flares. (EFS017/\#21 PUBLIC HEARING, grifos do autor).

Recover units and Pipelines should be put in...because that is part of expensive of doing business with oil wells, that is not something that is unfairly put (EFS017/\#22 PUBLIC HEARING, grifos do autor).

We lived by oil wells but fracking that they are doingt's a high pressure hydraulic fracturing its not oil wells that were here when we were children and you can talk about wells in your backyard (EFS017/\#22 PUBLIC HEARING, grifos do autor).

As considerações dos atores locais a favor de normas mais rígidas lembravam ao conselho a necessidade prioritária de incorporação de princípios de precaução e ponderamento na reformulação das O\&G Ordinances. As declarações ressaltavam que, na prática, nenhuma distância poderia ser considerada plenamente 
segura e que a comunidade deveria abandonar os falsos dilemas envolvendo o tolhimento do direito dos mineral owners e o uso de junk science para eclipsar os reais riscos e incertezas que envolvem as novas técnicas de produção:

Black and with statements like $600 \mathrm{ft}$ setbacks are safe...are very unscientific statements [once] science never going to make such statements, [and[ nobody can guarantee that any specific distances are safe (EFS017/\#11 PUBLIC HEARING, grifos autor).

[...] the only responsible action I believe the City Council can take is to make all efforts to help the safety of our citizen. It's a false debate between people who don't understand and mineral state owners (EFS017/\#21 PUBLIC HEARING, grifos do autor).

The science involving hydraulic fracturing is not junk. It's evolving...it's towards an understanding of the environmental and public health impacts of shale gas development. We need to make reasonable decisions. A protective and precautionary ordinance is prudent (EFS017/\#1 PUBLIC HEARING, grifos do autor).

A decisão final dos conselheiros e da prefeita de College Station referendou o desejo daqueles preocupados com os direitos minerais e manutenção dos critérios de localização e setback requeriments. A ata de deliberação do City Council manteve em (600 feet) 183 metros a distância de poços de exploração de hidrocarbonetos em relação a parques, cemitérios, áreas comerciais, prédios públicos, templos religiosos, consultórios médicos, odontológicos e condomínios residenciais. Somente escolas públicas e privadas, hospitais e centros de cuidados para adultos e crianças (asilos e crechês) obtiveram a prerrogativa da distância para 1000 pés, cerca de 300 metros. (COLLEGE STATION, 2015).

A audiência pública conseguiu, entretanto, que os legisladores locais aumentassem as exigências de segurança de localização de tanques de armazenagem, unidades de recuperação de vapores, remoção de efluentes e medidas de controle de poluição sonora. Também estabeleceu regras para planos de controle e monitoramento atmosféricos, determinando que "all salable gas will be directed to the sales lineas soon as practicable or shut in" e "all Wells that have a sale pipeline will employ reduced emission completion techniques and methods" para o controle de V.O.C's exigidos pelas normas da EPA, RRC e TCEQ (p.25).

Finalmente estabeleceu padrões preliminares de instalação e operação para utilização dos recursos hídricos na jurisdição da cidade, incluindo análises sazonais e regulares da quantidade e qualidade da água utilizada, descarga, controle de efluentes e reciclagem. Além do estabelecimento de critérios de manutenção de 
estradas e ruas dentro do perímetro do município, normas de segurança relativas a horas de trabalho, evacuação, vazamentos, explosões e cercamento das atividades de produção. Todos os requisitos sujeitos a fiscalização e taxação pelas autoridades públicas municipais (COLLEGE STATION, 2015).

\subsubsection{Cooperation}

$\mathrm{Na}$ área de Eagle Ford Shale, bem como, no estado do Texas, existeuma quantidade considerável de atores sociais interligados direta e indiretamente à cadeia produtiva dos hidrocarbonetos não-convencionais. Como visto no perfil dos atores sociais, órgãos reguladores estaduais, autoridades locais, companhias energéticas, associações, confederações de produtores e consumidores de energia estão correlacionados com empresas de prestação de serviços que interagem entre si dentro de uma estrutura socioeconômica e produtiva que se caracteriza pelo discurso de parcerias e cooperação, mas que na prática estão atrelados a uma lógica do voluntariado, patrocínios e doações financeiras oferecidas pelo setor energético.

Dentro desse contexto, a formação de parcerias público-privadas, projetos contínuos e duradouros entre órgãos públicos, companhias energéticas e comunidades locais se resumeem grande parte ao benefício sazonal no fluxo de produção, aumento da arrecadação tributária, mas, especialmente, aos aportes eventuais de recursos financeiros ofertados pelas companhias para os governos e instituições locais. Nas pequenas cidades visitadas, por exemplo, questionamentos feitos às autoridades e representantes públicos correlacionados a "partnerships" normalmente despertaram respostas correlacionadas a "sponsorships" obtidos para o município, entidades comunitárias e eventos locais:

They're great, they're big hope, they're sponsor. Some of them are sponsors like in many of our main events (EFS005, grifos do autor).

They are large supporters...they have been a good business partners with the Chamber [of Commerce] supporting us, sponsorhips...if we need something...they do anything they can do...(EFS008 -009, grifos do autor).

Generally a lot of companies have piece meal donationsto different groups, nonprofit groups within the community. [Company $X]$ has been very strong in partnering with volunteer (EFS007, grifos do autor).

Muitos dos entrevistados dos governos locais relatam que as companhias energéticas costumam se sentar à mesa de negociações com fatias 
generosas de doações e contribuições sob forma de prestação de serviços, equipamentos, ou mesmo em dinheiro em espécie, como expressado por um dos entrevistados:

Usually at the table will see representatives from varies cities and civic organizations along with their [O\&G] representatives...[...] most of companies in the area have been generous with contributions either...either...cash" (EFS006, grifos do autor).

Os entrevistados destacam que, embora, de maneira geral, não ocorra a formação oficial de parcerias formais, eles entendem que a postura das companhias demonstra que as empresas estão engajadas para inserirem-se nas comunidades, fazendo serviços voluntários e oferecendo recursos para vários projetos sociais ligados a atividades juvenis, mutirões de limpeza, combate ao fogo, estruturas de parques e recreação comunitária:

[there is] no any formal partnerships but [...] you know... for example... litter abatement, cleanup activities [...] persons to assist with various projects most related, or directed towards youth activities, parks and recreation activities, volunteers organizations, fire department (EFS006, grifos do autor).

They've been involved in the in the stock show... with people supporting... I think they've tried to become partners in the community as an official positionto what they do (EFS007, grifos do autor).

De forma geral, esse layout manteve coligados, nos anos iniciais de exploração de EFS, muitos dos governos locais e as companhias energéticas inseridas emsua área. Autoridades e empresas conectadas a um processo de "comformidade" ou compliance sustentado nos interesses comerciais comuns, no qual:

Everybody wants to be compliant. We've not had any issues from any company[...] and this is how we work with the oil companies to try and make this a... business-friendly climate"(EFS015grifos do autor).

The partnerships or the good relationships that we have are the oil field companies that have been here for a long time. We have a really relationship with [companies] that just joined the Chamber [of Commerce]. They wanted to get involved (EFS010, grifos do autor).

Apesar da sinergia e boa vontade frisada pelos entrevistados e o desejo das empresas em operar em conformidade com a lei e contribuírem para clima amigável para os negócios e boas relações comerciais, muitos representantes admitem a fragilidade dos processos de parcerias e cooperações atuais, lembrando que "They do their jobs and then they leave. They stay in the hotel and then they're gone" (EFS011, grifos meus), ou ainda: 
"In the first [oil] boom there was more...the companies took more interest in the community[...] but now they don't have much interest. They would say: well, how much money do you need?" (EFS013, grifos do autor).

Ou seja, tudo se baseia no: "quanto dinheiro você quer?" e no comportamento de "fazer o trabalho e depois partir" sem maior interesse nas comunidades que frequentam. $\mathrm{Na}$ concepção de parte dos entrevistados, esses comportamentos estão conectados a origem e tamanho da organização, uma vez que, empresas locais teriam maior potencialidade de cooperação, com projetos contínuos e empregando pessoas locais, sendo mais ativos nas parcerias com a comunidade. "Empresas pequenas e locais têm filhos jovens, estão inseridos na comunidade, as multinacionais com a maioria de seu quadro de fora daqui, não" (EFS011).

Não obstante, a fragilidade do desenho político-institucional das relações de cooperação e das parcerias sustentadas pela lógica das doações e patrocínios, revelou, durante a ocasião da pesquisa, ainda que de forma focal, a existência de pequenos conflitos correlacionados a autonomia e prerrogativa dos governos locais frente ao comportamento das companhias energéticas, conforme revela de forma metafórica um dos entrevistados:

\footnotetext{
...they [O\&G] try to hang their hat over here... while I hang my hat over here... and nobody wants to go to court. Well, they didn't want to go, because we were doingeverything complies completely with statute (EFS015, grifos do autor).
}

Ou seja, demonstrando um comportamento em que empresas,muitas vezes, estabeleciam procedimentos e padrões inapropriados para as normas locais, try[ing] to hang their hat over here, algo como: "tentando pendurar o chapéu por aqui", ou determinar uma situação, mas esbarravam nas autoridades locais que: while I hang my hat over here, ou quando eu penduro o meu chapéu aqui, demonstro autoridade, e força de lei para enquadrar o setor dentro dos procedimentos estatutários locais.

\subsubsection{Accountability}

Como destacado nas funções dos atores sociais e instituições envolvidas na exploração dos folhelhos no Texas, e em EFS,a $R R C$ é responsável pela fiscalização dos procedimentos de controle de qualidade ambiental na prospecção dos hidrocarbonetos convencionais e não-convencionais. A agência reguladora possui a competência de fiscalizar as operações e emitir permissões de operação (Permits) para perfurações e fraturamento hidráulico. A TECQ, por sua vez, 
possui a função de monitoramento da qualidade do ar, água e gestão de resíduos sólidos e líquidos interligados as atividades industriais e energéticas. As duas agências têm, portanto, a responsabilidade legal de zelarem pelas normas federais determinadas pelo EPA.

Para muitas entidades e atores, entretanto, esses órgãos públicos estaduais têm se demonstrado bastante flexíveis, coniventes ou mesmo ineficientes frente aos interesses e atividades produtivas das indústrias de $O \& G$ no estado do Texas. Para a ONG EarthWorks (2012), a "RRC falha em fiscalizar as companhias energéticas e fazê-las cumprirem as $O \& G$ Ordinances aumentando os danos a saúde pública, segurança e meio-ambiente"(p.01). Segundo dados da própria $R R C$, divulgados no documento publicado pela ONG, o inadequado número de inspeções, poucos agentes de fiscalização, baixo valor de penalidades e notificações estariam compelindo o não comprometimento e conformidade das empresas dentro das normas estaduais e federais.

Ainda de acordo com a entidade, pouquíssimos casos em que ocorrem violações frente aos procedimentos de extração de hidrocarbonetos pela $R R C$, os inspetores não costumam encaminhar os processos para os departamentos internos de "enforcement", algo semelhante a medidas cautelares de força pública que obrigam o devido enquadramento mediante um termo de compromisso pelos infratores. Segundo a Earthworks (2012), em apenas $2 \%$ dos casos, essas medidas são levadas a cabo pelos fiscais, uma média excepcionalmente baixa quando comparada com estados como a Pensilvânia onde as 'enforcements' atingem um a cada três casos de infrações registradas.

De forma similar, a Earthworks também crítica falhas de responsabilização da $T E C Q$ enquanto órgão público que deveria zelar pela saúde de comunidades inseridas nas áreas de produção como EFS. Segundo a organização: "Government fails, public health suffers and industry profits from the shale oil boom" (SEPTOFF, 2013 p.01), ou seja, o governo falha na defesa da saúde pública diante dos lucros crescentes das indústrias no pico de produção petrolífera. Para a entidade a TECQ sistematicamente divulga relatórios vagos, omissos ou mesmo coniventes com os interesses do setor energético.

The Centre of Public Integrity'tambémdestaca as falhas da TECQ em EFS.Baseado numa investigação em Karnes City, uma pequena comunidade de imigrantes poloneses, a entidade denuncia que a emissão de centenas de milhares toneladas de V.O.C'.s vem sendo negligenciada pela agência reguladora texana. Segundo conclusões do documento intitulado: Big Oil Bad Air, as permissões e fiscalizações do TECQse caracterizam por procedimentos vagos e inadequados no 
controle do volume de componentes tóxicos e carbono emitidos na região (MORRIS ET.AL.. 2014a e b). A área é considerada um epicentro dentro de EFSe assistiu nos últimos anos à proliferação das chaminés-incineradoras de gás (flares) numa escala observável do espaço (Foto 8 e 9).

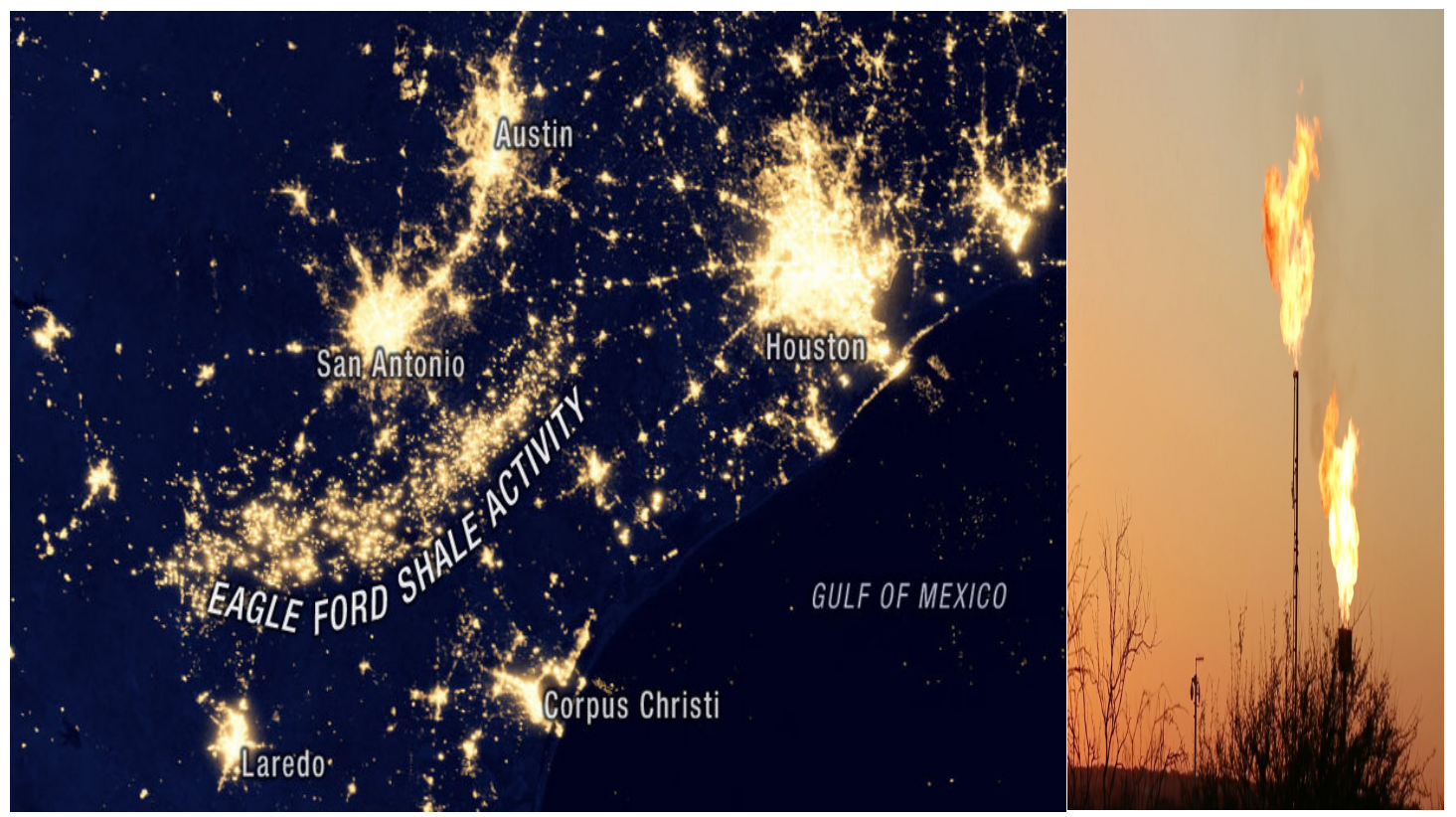

Foto 8 e 9 - Eagle Ford Shale Flaring activity. Fontes: Wogan (2012) e Morris et. al. (2014).

Um fenômeno de proliferação do número de queimadores que ocupam uma área maior que Houston e San Antonio. Uma consequência interligada diretamente ao baixíssimo valor do gás que leva as companhias energéticas simplesmente a queimar o metano liberado no processo de fracking e direcionar toda sua atenção ao produto que realmente lhes interessa: o petróleo. "The problem is that the shale wells, none of them are hooked up to pipelines! And they're flaring all over' (EFS011, grifos do autor).

As denúncias das duas entidades chamaram a atenção de oficiais da Agência de Proteção Ambiental americana (EPA) que demonstrou, em mais de uma ocasião, preocupação com os procedimentos flexíveis ou mesmo inadequados das agências reguladoras texanas quanto aos seus respectivos processos de fiscalização, controle, licenciamento e permissão das atividades energéticas e industriais como a SB709 (MALEWITZ, 2016). Autores como Morris et.al. (2014) destacam que as regulações e formas de gestão do petróleo e gás no Texas colocaram as agências reguladoras do estado e EPA em pelo menos dezoito ocasiões de litígios judiciais.

Em consonância com esse quadro de falhas na escala estadual, somam-se as fragilidades de responsabilidades e de responsabilizações de atores e instituições que se deram inicialmente na escala dos governos locais. Uma situação pela replicação sem critérios das $O \& G$ Ordinances e sem o devido debate sobre as 
possíveis externalidades, controles e competências comuns e diferenciadas. Processos que muitas vezes foram influenciados pelo peso dos investimentos e doações das companhias energéticas e que promoveram, inclusive, conflitos de interesses no domínio de assuntos públicos supostamente neutros, como revelado por um dos city managers entrevistados:

[we] also...fortunate that our city council included...ah...one person who was...actively... in oil and gas business. He is familiar with all these various of practices... Encourage mineral production, we can toss that out, because it was going to take place (EFS06, grifos do autor).

Mesmo na situação ímpar de College Station, onde as Ordinances foram decididas com a prévia consulta pública e a participação política dos atores locais, as autoridades não adotaram, deram prioridade ao direito de propriedade dos mineral owners e tangenciou importantes quesitos fundamentais de responsabilização socioambiental frente à comunidade, deixando, por exemplo, de adotar o princípio da precaução frente às incertezas e riscos na extração de hidrocarbonetos por fracking. Prefeita e conselheiros mantiveram as distâncias vigentes desde a década de 1990 (setbacks), mesmo se tratando de atividades polêmicas e controversas sob o ponto de vista da saúde pública.

\subsubsection{Transparency}

A transparência de dados e informações sobre trâmites administrativos e produtivos interligados à governança dos folhelhos de EFS é caracterizada por uma configuração de qualidade regular e incipiente. Isso porque, se por um lado as instituições públicas envolvidas, como órgãos, agências estaduais e autoridades locais têm atualmente a obrigação legal de fornecer canais de fácil acesso à sociedade sobre informações pertinentes às atividades energéticas, como licenças, permissões e localização das atividades de extração, por outro, o setor tem episódios e configuração interligados a conflitos de interesse, onde os dados nem sempre foram divulgados de forma clara e isenta diante das comunidades inseridas em EFS.

Apesar do recente aparato legal que determina a transparência de dados, muitas informações relevantes foram minimizadas, distorcidas ou mesmo não foram devidamente apresentadas durante a rápida expansão das atividades de exploração dos folhelhos. Um fator agravado diante das prerrogativas das companhias energéticas em não divulgar (disclosure) seus procedimentos e produtos utilizados no fracking. 
Desde o início do boom de EFS, a agência reguladora responsável pelo setor de O\&G no Texas, a Railroad Commission of Texas (RRC) buscou destacar a importância da transparência na gestão das atividades energéticas, enfatizando que:

...citizens are extra eyes to help RRC identify problems...and [the commission] strategically positioned itself to continually improve public access to is data repositories (TEXAS, 2009, p.10, grifos do autor).

O discurso oficial do órgão estadual foi, desde o princípio, de oferecer abertura para todos os atores sociais, instituições e demais membros da sociedade interessados nos dados de campos de exploração (field rules), projetos secundários de recuperação (secondary recovery projects), eficiências de taxas produtivas (efficient rates of production), abandono de poços (abandoned wells), solicitações do uso e manejo de injeções hídricas (applications to inject water), prevenção e controle de poluição por petróleo e gás natural (TEXAS, 2009).

Ainda assim a agência admitia que mais progressos eram necessários frente aos mecanismos de transparência para oferecer de forma permanente e adequada mais dados e informações de uma indústria de tamanho dinamismo. A autocrítica avaliativa, contudo, não foi o bastante para que a $R R C$ deixasse de ser enquadrada pelo chamado General Approtiations Act for 2012-2013 biennium que determinou que o órgão público fosse obrigado a incluir em seu website informações demandadas pela sociedade, como:violações, quantidade de penalidades e multas emitidas aos operadores, bem como, relatório bimestral de empresas envolvidas em violações e ajustes de conduta (TEXAS, 2011 Rider 17).

Vale ressaltar que o acompanhamento de notificações de violações (Notices Of Violation - NOV) com a quantidade de incidências e frequências de casos de falhas e vazamentos são uma importante ferramenta tanto de transparência como responsabilização (accountability). Essas informações podem revelar, por exemplo, padrões de falhas nos equipamentos, erros de contratos (terceirizados), inconsistências de relatórios, e episódios de contaminação ambiental (LIOFF ET AL, 2013).

Para entidades como a Earthworks (2012), entretanto, a letargia da $R R C$ para promover um fácil rastreamento das atividades, penalidades e infrações das companhias energéticas derivou da conivência de seus conselheiros e ligação com o setor energético. Segundo Malewitz (2015a), o papel duplo da RRC de regular as mesmas empresas que ao mesmo tempo tem que incentivar, faz com que não sejam estranhos conflitos de interesse no qual o presidente da agência seja formalmente dono de uma empresa de contabilidade que presta serviço às empresas de petróleo e 
gás. Um membro ativo da comunidade pro-fracking, pessoalmente engajado em participar de audiências públicas dos governos locais para defender as atividades energéticas e controle do Estado na regulação e gestão da energia, como expresso durante sua posse no cargo:

\begin{abstract}
As railroad commissioners, it is our job to make sure industry produces efficiently and economically, and does so in the safest, most responsible manner possible [...]. We must continue to challenge federal overreach because Texans know how to oversee Texas oil and gas production better than Washington does (MALEWITZ, 2015a, grifos meus).
\end{abstract}

Em 2012, outro conflito de interesse colocou em cheque a credibilidade do Energy Institute da University of Texas (UT). Um estudo conduzido pelo instituto concluiu que as atividades de fraturamento hidráulico produziam riscos ambientais mínimos. A validade da pesquisa foi questionada por uma associação civil de New York que revelou que o principal investigator era membro remunerado de uma empresa de exploração e produção de gás natural de Houston (MARSHALL, 2012).

De forma agravante as companhias energéticas que atuam em EFS, semelhante ao quadro nacional de outras áreas de produção, não possuem histórico de divulgação de seus dados de produção quanto à quantidade do uso, reciclagem e descarte de água, em especial, dos elementos químicos utilizados nos coquetéis de alta pressão para executar o fraturamento hidráulico. Essa é, por sinal, uma das maiores polêmicas envolvendo a regulação e exploração dos recursos nãoconvencionais nos Estados Unidos, onde grupos de pressão de ambos os lados profracking ou anti-fracking debatem com o governo federal e suas agências (EPA) normas para a divulgação (disclosure).

De acordo com Lioff et. al. (2013) as companhias que se dizem mais comprometidas, por exemplo, com a divulgação de indicadores de uso da água e descarte de efluentes, o fazem de forma limitada, geralmente restringindo-se aos dados de a uma área específica de exploração, quando na prática possuem dezenas de outras áreas com performances distintas. O mesmo vale para caso de divulgação do volume de emissão de metano, óxido nitroso e compostos orgânicos voláteis.

\title{
5.4.6 Equity
}

A relação de poderes entre os atores sociais na governança dos shalesem EFS é caracterizada por um quadro assimétrico e desfavorável. De maneira contundente, não há um balanço equilibrado e harmonioso de poderes entre os atores distribuídos na sociedade, mercado e estado sob a regulação e gestão dos hidrocarbonetos não-convencionais. O próprio deslocamento normativo, e a tomada de 
prerrogativas e poderes pelo governo estadual, em detrimento da autonomia dos governos locais exemplificam claramente o desequilíbrio de forças que caracteriza o arranjo político-insitucional no estado.

Concretamente, as companhias energéticas organizadas sob forma de associações e organizações, e em conjunto com práticas regulares de lobby exercem grande influência e poder no Congresso Texano (Texas Legislature) e acabam ditando sistematicamente o rumo das políticas estaduais correlatas à exploração energética. Sua influência se estende para órgãos e agências reguladoras como a $R R C$, onde os comissários eleitos, ou nomeados, geralmente possuem um histórico em comum com as empresas, ou mesmo dividem interesses convergentes ao setor de O\&G.

Simultaneamente, entidades como a API, IPAA, TXOGA e STEER alinham-se com associações como The Texas Land \& Mineral Owners Association e a Texas Consumer Energy Alliance para estabelecer discursos próprios de defesa do setor e estabelecer redes que se empenhem na divulgação de campanhas, mobilização de grupos de interesse e comitês de ação política. Segmentos empenhados em retratar positivamente os impactos socioeconômicos das indústrias energéticas e químicas. Em EFS revistas especializadas como Shale: Oil and Gas Business Magazine; Texas Eagle Ford Shale Magazine; e The Boom, dão o tom da força do setor onde num movimento semelhante da iniciativa Energy in Depth, promovem a cultura, identidade e organização da revolução energética dos folhelhos.

Como resultado da iniquidade, é comum a inadequação e assimetria de informações com a divulgação de dados de forma tendenciosa, mas também a assimetria de poderes que permitem atalhos para as companhias, sistemas e regimes legais flexíveis e complacentes quanto à responsabilização das empresas do setor energético. Somados as fragilidades de uma participação pública que de um quadro inicialmente inadequado tornou-se cerceada de suas prerrogativas e ajuda a edificar quadros futuros de agravamento de justiça e passivos ambientais, onde:

\section{...justice in the distribution of risks and benefits [in shale exploration] and in decision-making processesaffects individuals, communities, nations, and future generations (PAROGI 2014, p. 1664, grifos do autor).}

Ao que tudo indica o sistema de governança que se edificou no Texas, e, portanto, em EFS, tem seguido o ciclo desarmonioso indicado por Rabe (2014), no qual: os "estados entram numa disputa de apertar o botão e começar uma política econômica agressiva de perseguição aos recursos - naturais e energéticos regateando (trumping) com a proteção ambiental e criando regulações reféns" aos interesses do setor de O\&G (p.1666). 


\title{
5.4.7 Ownership
}

De forma contundente, o sentimento de pertencimento na estrutura de governança de EFS é desfavorável. Isso porque o layout políticoinsitucional, caracterizado pela reconcentração dos poderes na escala estadual, a fraca participação política, a baixa responsabilização e assimetria de poderes entre atores e instituições, não foi capaz de promover uma maior amplitude no protagonismo e responsividade das comunidades de EFS. Embora alguns gestores e autoridades locais tenham externalizado suas funções e papéis políticos frentes aos processos regulatórios, o sentimento não é comum entre todos os segmentos sociais, especialmente aqueles que se sentiram cerceados frente aos novos marcos regulatórios impostos pela capital do estado.

$\mathrm{Na}$ visão de gerentes municipais e diretores executivos comerciais ouvidos nas cidades visitadas, existe uma sensação comum e compartilhada de centralidade, protagonismo e euforia de comunidades no desenvolvimento de EFS:

\begin{abstract}
...we haven't had a big role...it just came to town...for some reason they picked [city name] to be a kind of a hub or a focal point [...] it's definitely helped us drag more business" (EFS008-9, grifos do autor).
\end{abstract}

They [O\&G] have just recently bought a 170 acres of nondeveloped business park out on the east side the town!...between 290 and 226 (routes)...we have roads, we have water and electrical access...it will be our business park! (EFS010, grifos do autor).

If you do a backward look at how the EFS has developed and how the communities have been impacted, you will see areas that have more capabilities and more capacities to be able to absorb growth [...] like our community [where] all of the entities, the county and the city, are vertically aligned in the same trajectory (EFS007, grifos do autor).

A percepção comum dos respondentes é que seus municípios são a mais central e mais ativa parte das atividades (hub or a local point) ou epicentro dos investimentos das companhias de O\&G e que suas localizações Ihes garantem protagonismo de longo prazo frente às benesses do desenvolvimento provocado pela exploração de gás e petróleo dos folhelhos de EFS. Para muitos dos atores, a expressão 'ownership' é atribuída aos critérios de 'owner,' ou seja, titularidade das propriedades minerais que incluem no estado do Texas o petróleo e gás, mas também o direito de exploração da água subterrânea. Em nenhum caso o princípio de ownership é correlacionado pelos entrevistados como um conceito de boa governança.

De forma complementar ao quadro desfavorável se encontram as manifestações de algumas das associações civis defensoras do que consideram um 
direito originário dos munícipios. Para eles, o cerceamento das prerrogativas legais dos governos locais levados a cabo pela Lei HB40 trouxe um grave dano à autonomia das comunidades e seus cidadãos. Para a organização Local Control a virada de mesa em favor das companhias energéticas se dá no conluio entre o Congresso Texano, Texas Legislature e a Texas Oil and Gas Association (TXOGA) que na prática significou o enterro das prerrogativas e autonomia dos governos locais (Foto 10).

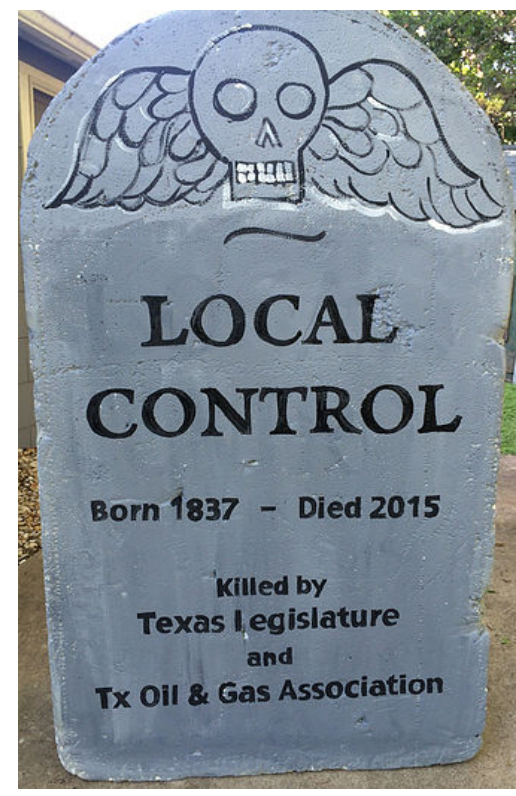

Foto 10 - Local Control tombstone. Fonte: localcontroltexas.org (2015).

O tolhimento dos poderes gera um sentimento de exclusão no estabelecimento de normas e procedimentos ao setor de O\&G. Nas palavras dos representantes da entidade, num processo politico que rompe com o processo histórico dos governos locais que: "began in 1837 when the state of Texas granted a home rule charter to the city of San Augustine" encerrados em função de um "powergrab - tomada de poder - que põe fim a esse prerrogativa em 2015!". Para o grupo de ativistas, "This loss of autonomy at the local level and the threat this poses to our health, environment and quality of life are causes for mourning, hence the funeral today" Ou seja,o tolhimento de poderes produzido em conivência ao poder público estadualque põe em risco aqualidade de vida dos cidadãos, com ameaças à saúde pública e ao equilíbrio do ambiente natural das comunidades texanas (LOCALCONTROLTEXAS.ORG, 2015, p.03, grifos do autor).

\subsubsection{Empowerment}

Ao contrário da visão otimista oferecida por Tunstall (2015a), os sistemas de governança que regem EFS, não tem se demonstrado capazes de oferecer o devido empoderamento de comunidades locais e segmentos sociais mais 
vulneráveis. A exploração dos recursos energéticos não vem promovendo processos de diversificação da economia e coesão social, ou mesmo a consolidação de novas subjetividades ambientais. Ao contrário, a configuração preponderante indica um quadro desfavorável do aperfeiçoamento de práticas e condições comunitárias inovadoras ou da geração de oportunidades sócio-produtivas inovadoras.

Concretamente, a lógica que se estabeleceu fixou-se em torno dos royalties, revenues e sale taxes, que acabaram por ditar o ritmo da corrida aos recursos financeiros do setor energético. Um processo que não abriu margens a novos mecanismos de empoderamento dos atores locais, mas concentrou-se no atendimento do interesse financeiro dos municípios e dos proprietários minerais (mineral owners) que retinham os direitos do subsolo. Um desenho político institucional que provocou inclusive a redução de poderes e direitos dos governos e comunidades locais e, consequentemente, prejudicou seriamente a formação de capital e coesão social voltados a projetos de inovação e consolidação de novas práticas socioeconômicas.

A despeito disso, os indicadores de empregos, renda e arrecadação normalmente são destacados como elementos de empoderamento das comunidades de EFS e critérios legitimadores utilizados pelas companhias energéticas e parte das autoridades texanas. Tunstall (2015b) destaca que de fato aumentos de renda aconteceram em pelo menos 14 condados, sugerindo um movimento contrário a uma possível maldição dos recursos (resource curse) atrelados à exploração de "unconventional O\&G" na região. O próprio autor, entretanto, reconhece, nas suas conclusões, que pesquisas mais detalhadas quanto aos critérios de qualidade de governança local, qualidade de vida e gestão ambiental traz novas perspectivas e dilemas a serem considerados.

Vale ressaltar que o atual caminho da regulação e gestão, sobretudo, o preponderante até a imposição da $H B 40$, parece reproduzir comportamentos e resultados semelhantes ao boom acontecido no final da década de 1970. Uma lógica igualmente baseada na corrida desenfreada pelos ganhos e vantagens imediatas que eclipsou quaisquer tipos de ações coletivas sobre os recursos. Um comportamento que se reproduz atualmente sobre o uso e exploração dos recursos energéticos nãoconvencionais, com o agravante dos possíveis impactos negativos do fraturamento hidráulico frente ao uso da água, solo e contaminação atmosférica.

Essa observação está ligada ao padrão verificado nas declarações de administradores locais, e de suas interpretações quanto aos procedimentos necessários em relação aoaproveitamento do atual boom. Surpreendentemente, as estratégias pouco ou nada seguem da potencial diversificação sugerida por Tunstall et al. (2015a) e o conseqüente empoderamento dos atores, mas sim da reprodução de 
padrões semelhantes, e ampliação dos incentivos e facilidades para a exploração energética, como exalta um dos diretores-executivos entrevistados na cidade de Giddings:

what do we need to do to make sure these companies...if they all gonna be here... What can we do to make they stay longer?"What can we do to offer them...ah...incentives or benefits packages especially like...I think the county and the city on work on...ah...tax abatement or incentive program...(EFS010, grifos do autor).

Ou seja, a manutenção de uma superdependência frente a companhias energéticas e suas atividades e, inclusivecom a abertura de novas prerrogativas especiais para'mantê-las por mais tempo', e garantir sua permanência a partir de estímulos fiscais, estruturais, abatimentos de taxas e programas de incentivo. A passagem reflete como atividades socioeconômicas alternativas, que poderiam ser criadas com o fluxo das arrecadações acabam sendo eclipsadas pelos efeitos de exclusão provocados pelo boom energético em detrimento de outros mecanismos de desenvolvimento.

O vigor econômico provocado pelos hidrocarbonetos mascara o fato de quê pouquíssimas condições alternativas foram criadas paralelamente para o empoderamento dos atores inseridos nas comunidades de EFS. Ao contrário, novas prerrogativas e ações legitimadoras na exploração dosshalesreforçam procedimentos semelhantes de um passado não muito distante nas quais áreas de produção e suas comunidades concentraram suas atividades e colocaram todas suas fichas atreladas ao futuro e oscilações do mercado de commodities energéticas, sobretudo, dos valores dos barris de petróleo. Uma miopia que obscureceu importantes aspectos sociais na geração de empregos em outras áreas de investimento, mantendo as comunidades refém da 'saúde' e 'benevolência' do setor energético. 
5.4.9 Resultados da avaliação pelos 'direcionadores de governança dos folhelhos de Eagle Ford Shale'

A análise dos 'direcionadores de governança de EFS (detalhados na Tabela 9) demonstraram um arranjo político-institucional que trazem sérios questionamentos quanto à qualidade de regulação e gestão dos hidrocarbonetos nãoconvencionais na região. Por meio das categorias de análise e do referencial teórico adotado é possível dizer que as estruturas e processos são consideravelmente falhos.

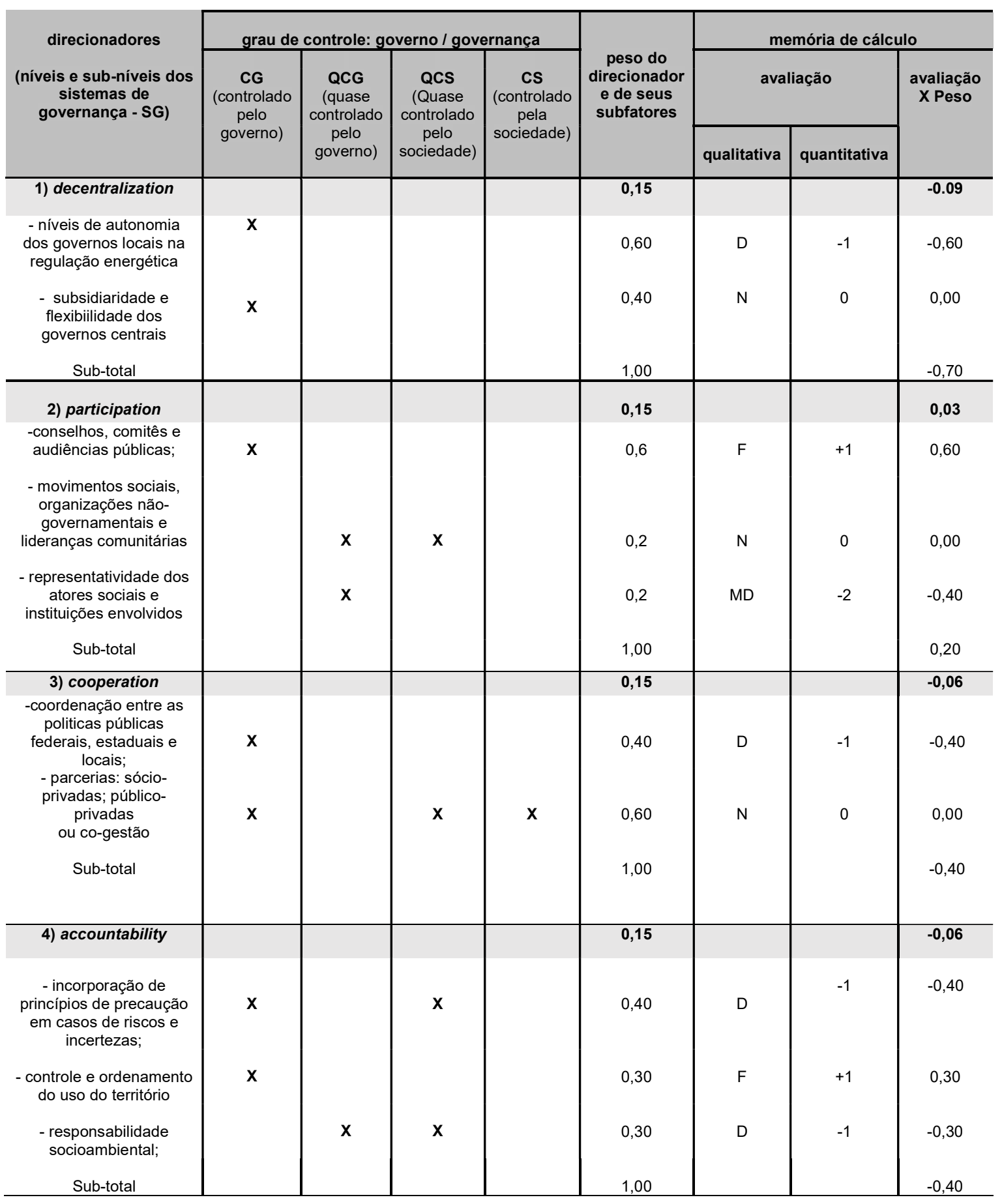




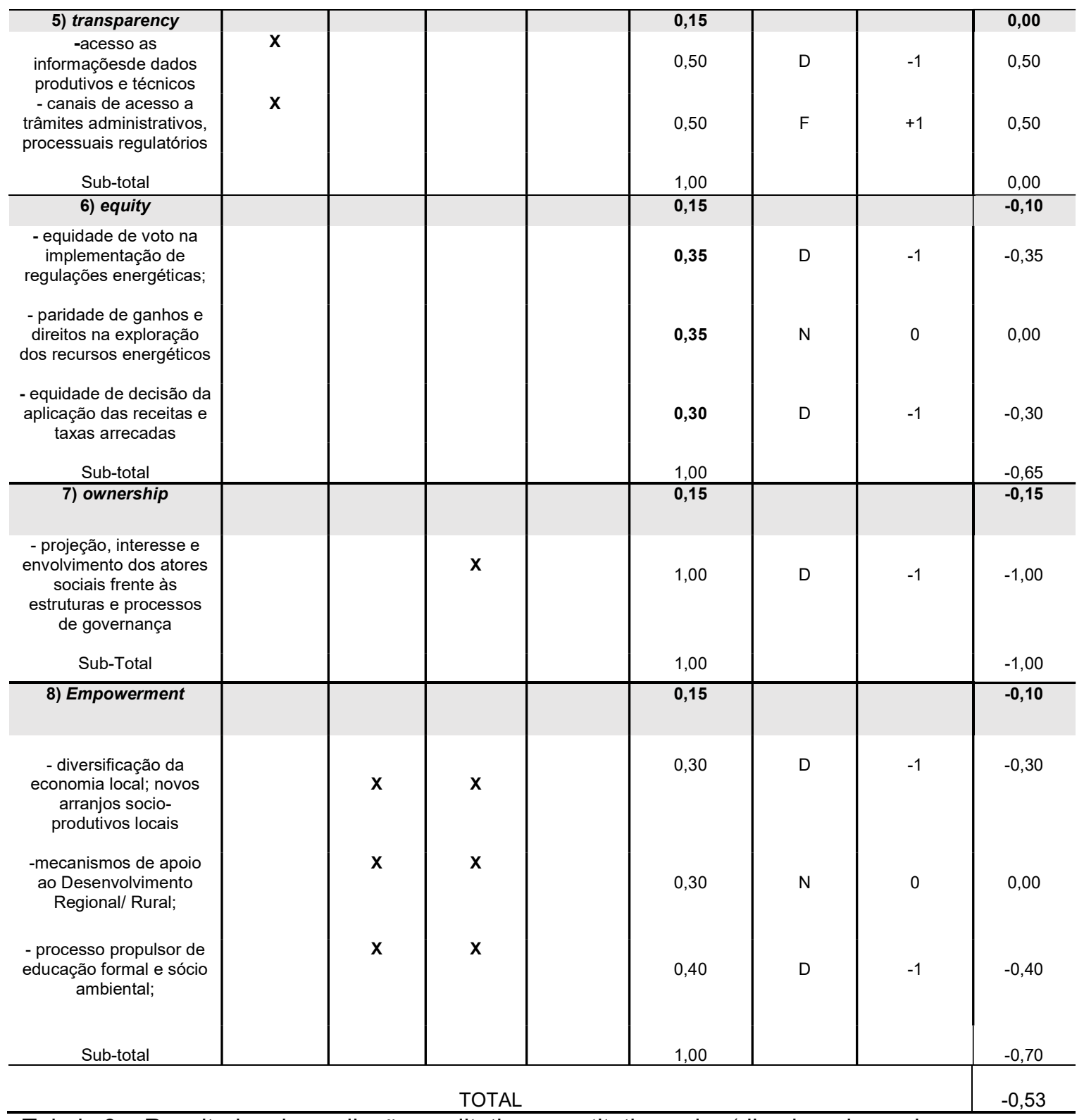

Tabela 9 - Resultados da avaliação qualitativa-quantitativa pelos 'direcionadores de governança de EFS.Fonte: elaborada pelo autor.

Isso porque os direcionadores de: ownership $(-0,16)$; empowerment e equity obtiveram baixíssimos desempenhos. Mas igualmente pela fraca performance dos princípios de decentralization (-0,09); cooperation e accountability $(-0,08)$. Somente os critérios de participation e transparency foram considerados regulares, ainda que com ressalvas. Em virtude do fraco desempenho de cada um dos drivers, o resultado agregado total alcançou a marca negativa de $-0,54$ pontos, acendendo o 'farol' da governança dos folhelhos de Eagle Ford Shale na categoria de 'governança 
viciosa', e revelando consideráveis fragilidades, desvios e falhas (Figura 29).

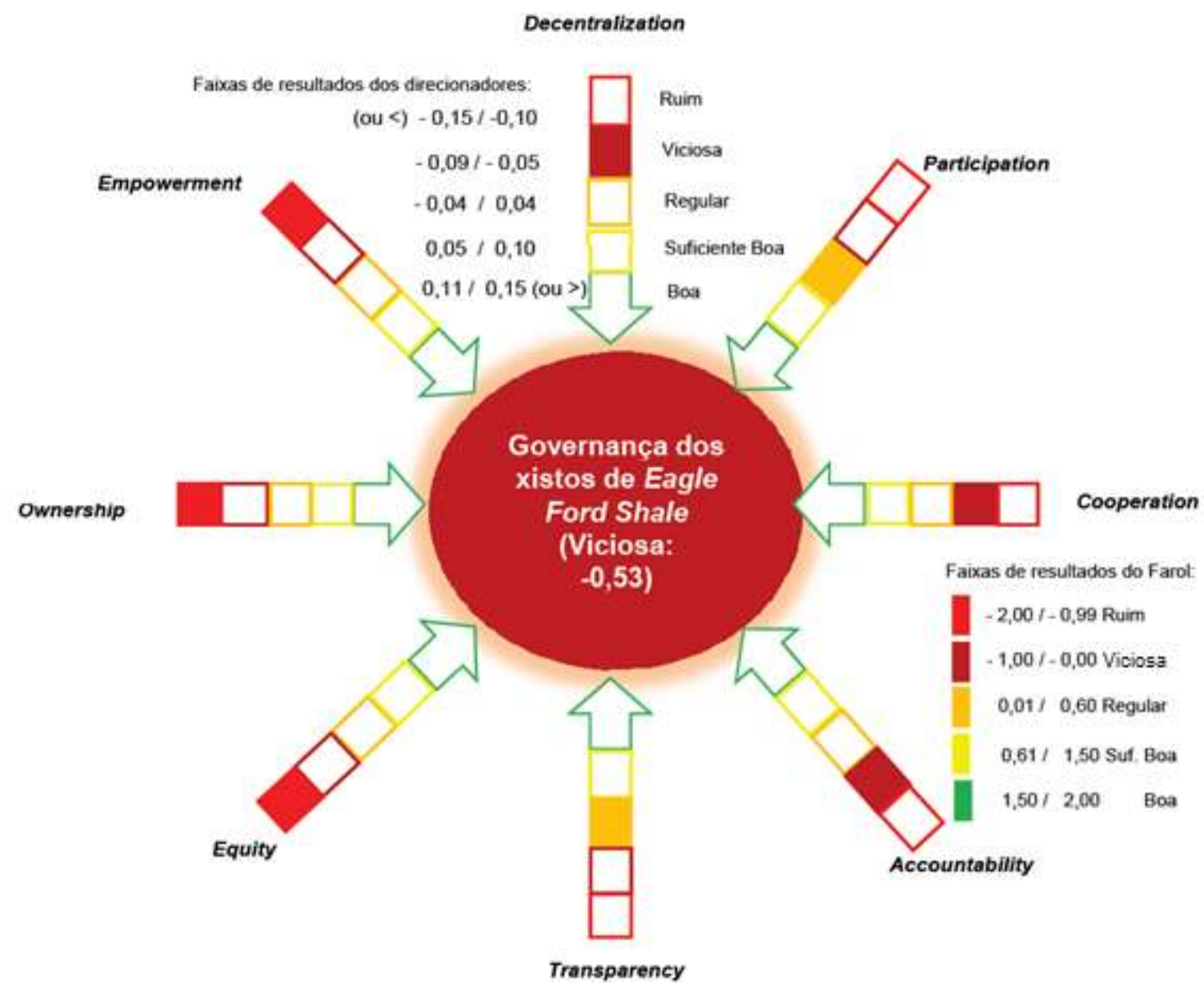

Figura 29 - Farol da Governança dos folhelhos texanos de Eagle Ford Shale.

Fonte: elaborada pelo autor.

No tocante ao direcionador decentralization, embora a política energética nacional (EPACT) seja essencialmente descentralizada e, para quenão ocorra a imposição de parâmetros fixos de regulação pela União, a avaliação geral do critério foi desfavorável $(-0,10)$. Apesar da grande distribuição de competências repassada do Governo Federal americano em relação aos estados, e seus respectivos governos locais, a prerrogativa de estabelecer normas, regras de exploração e gestão de recursos energéticos no caso específico de EFS representou um caminho contrário a descentralização.

Medidas top-down impetradas pelo Congresso Texano cercearam as autonomias e prerrogativas das cidades e suas comunidades, comprometendo a avaliação do parâmetro. Embora o ato legislativo HB40, na sua essência, tenha sido igualmente desfavorável a subsidiaridade, devolução e flexibilidade aos poderes e atores locais, esses critérios foram avaliados como neutros, uma vez que, mesmo com a redução das destes aspectos de descentralização, os municípios mantiveram parte 
de suas prerrogativas de zoneamento territorial de superfície das atividades energéticas.

Está característica está diretamente ligada ao desempenho regular do direcionador participation (0,08); uma vez que, os conselhos municipais, comitês e audiências públicas continuam a existir na escala municipal, ainda que tenham sido esvaziados de poderes e autonomias. Embora a participação de movimentos sociais, organizações e associações civis tenham sido consideradas incipientes e pouco notórias em EFS optou-se pela neutralidade na avaliação desse subfator. A representatividade dos atores sociais foi considerada, entretanto, como um subfator muito desfavorável, pois o deslocamento das decisões para a alçada exclusiva de Austin, longe das áreas de produção, compromete a qualidade de participação.

Quanto à cooperação político-institucional (cooperation) considerou-se um quadro muito desfavorável em EFS. Isso por que o nível de coordenação entre as políticas federais e estaduais é bastante sofrível. Sobretudo, frente a dissonância entre os padrões da EPA e dos critérios aplicados pelas agências reguladoras do estado. $\mathrm{A}$ concertação entre políticas públicas federais, estaduais e locais é um aspecto desfavorável no Texas, onde muitas vezes as próprias autoridades não conhecem seus limites jurisdicionais. Em relação à qualidade de ações conjuntas e colaboração, embora seja comum a interpretação errônea de parcerias (partnerships) enquanto doações, patrocínios (sponsorships) e voluntariado das companhias energéticas, optou-se pela avaliação neutra do subfator. Ainda assim, o driver cooperation obteve a fraca performance de $-0,08$ pontos.

Igualmente fraco foi o resultado do direcionador accountability $(-0,08)$ pontos. Isso por que foi o grau de incorporação de princípios de precaução na regulação e gestão dos folhelhos de EFS é consideravelmente negligenciado, e, portanto, desfavorável. Embora exista um controle oficial favorável realizado pelas autoridades locais no ordenamento e uso do território nas competências municipais remanescentes, a incorporação de critérios e responsabilizações socioambientais no controle de emissões, efluentes, contaminantes hídricos e edáficos são aspectos tangenciais e desfavoráveis.

O direcionador transparency, por sua vez, apresenta um valor neutro $(0,00)$ em razão do padrão contraditório de seus subfatores. Se por um lado é favorável $o$ acesso dos atores sociais a informações administrativas, trâmites burocráticos, processuais e regulatórios, aspectos garantidos por força de lei estadual, por outro lado, a transparência frente aos processos produtivos, e mesmo de dados das agências fiscalizadoras sobre os padrões exploratórios das companhias energéticas foram considerados desfavoráveis. 
No direcionador equityo fraquíssimo desempenho $(-0,10)$ está ligado, sobretudo, a atual iniqüidade entre o governo estadual e os governos locais na implementação de regulações energéticas, principalmente em relação aos aspectos desfavoráveis à paridade de ganhos e direitos na exploração dos recursos energéticos. A assimetria de poderes na decisão quanto à aplicação das receitas e taxas obtidas com a exploração dos hidrocarbonetos também colaborou para o mau resultado do driver.

Por fim, tanto o driver ownership quanto o empowerment foram considerados de fraco desempenho, com respectivas avaliaçõesde - $-0,15$ e $-0,10$ pontos. De forma contundente, o sentimento de pertencimento na estrutura de governança de EFS é desfavorável, bem como o Empoderamento dos atores e instituições locais. A avaliação baseou-se na observação de que a atual forma de regulação e exploração dos folhelhos não vem promovendo processos de diversificação da economia e mecanismos de coesão social, além disso, estão fortemente embasados no critério da renda como indicador suficiente de fortalecimento e aperfeiçoamento das comunidades inseridas na região.

Parte IV - Governança e padrões de eco-governamentalidade no boom da exploração dos folhelhos americanos

5.5 Análise de resultados: estruturas e processos na governança dos hidrocarbonetos de Eagle Ford Shale

Apesar das estruturas e processos de governança energética nos Estados Unidos serem constitucionalmente estruturadas na descentralização regulatória em favor dos governos locais, no caso específico de EFS, o processo promoveu ineditamente um deslocamento normativo da esfera de regulação e gestão energética para o estado. Um padrão tipicamente big government que esvaziou consideravelmente os poderes e prerrogativas dos governos locais, indo na contramão dos processos de devolution, subsidiarity e flexibility. Ou seja, a governança no Texas provocou uma modificação das regras políticas vigentes e a respectiva (re)centralização em favor do governo estadual, esvaziando as autonomias políticas históricas dos governos locais.

A inovação energética, portanto, modificou os procedimentos regulatórios e gerenciais, indo numa direção contrária ao que se espera de uma boa governança dos recursos energéticos. Municípios e comunidades inseridos nas cadeias de exploração em EFS passaram de uma posição independente e 
autônoma,para espaços dependentes dos processos e mecanismos de gestão decididos por Austin, num fluxo top-down de comando e controle em que as principais decisões passaram a ser tomadas longe das áreas de produção e distante dos atores diretamente envolvidos e impactados.

A manobra do poder legislativo texano (Texas Legislature HB40 \& SB1165) confirmou a modificação da agenda política pública correlativa ao fraturamento hidráulico dentro de uma "policy expansion" que acabou ocorrendoalheia às forças "bottom-up"na redefinição de questões político-regulatórias, produtivas ede coalizão (DAVIS, 2010 p.238). O processo cerceou concretamente a possibilidade de amadurecimento da participação política local na governança dos recursos energéticos, que apesar das fragilidades apresentadas na maior parte das cidades de EFS, se demonstrou contundente nas comunidades de Bryan/College Station. Cidades no qual o engajamento,ainda que pontual dentro da vasta paisagem energética, demonstrou o desejo de parte da população em participar ativamente nos debates sobre as regulações necessárias.

Novamente, as regras deram o tom das medidas de posição e funções sociais possíveis aos participantes, estabelecendo a criação, instituição e atribuição de responsabilidades e ações requeridas (OSTROM, 2005). Esses atributos das regras na política e governança de EFS, entretanto, foram modificados no 'meio do jogo', distorcendo o caminho histórico e tradicional e as prerrogativas políticas que arenas e espaços deliberativos locais costumavam possuir. Um processo que tolheu a maior parte das competências e atribuições legais das cidades quanto a decisões independentes. Uma imposição derivada diretamente da força política de grupos de interesses e da pressão de atores com maior poder e influência, que fizeram prevalecer a lógica amarrada aos aspectos econômicos e comerciais advindos da exploração energética.

Companhias energéticas e suas associações (Txoga,Texas Alliance e Steer) além de entidades como Texas Land \& Mineral Owners Association e a Texas Consumer Energy Alliance foram, nesse sentido, os segmentos dentro da sociedade civil com maior volume de recursos financeiros, capacidade organizacional e informacional que impôs seus critérios e interesses, influenciando e interagindo com os atores estatais (lobbying), na aprovação da HB40 em Austin. Uma estratégia que se alinhada aos esforços tradicionais desses grupos em emplacar representantes políticos e executivos estaduais, em agências reguladoras e no poder legislativo. Um quadro que reflete a significativa assimetria de poderes e equidade de direitos e remetem ao descompasso entre ganhos e direitos, critérios e prerrogativas na exploração dos shales. 
De forma mais agravante para a qualidade dos sistemas de governança, revela-se um layout que se demonstra pouco provável para promover laços sociais, sentimentos de pertencimento (ownership) e empoderamento (empowerment) dos atores locais e das instituições participantes. Pelo contrário, contribuiu dentro e fora das áreas de produção para a sedimentação de uma corrida aos ganhos e às vantagens imediatas na exploração dos hidrocarbonetos não-convencionais. Restringindo os atores e autoridades locais a festejarem a arrecadação de taxas (revenues, tax sales), a obtenção de leasings e royalties pelos mineral owners, sem que houvesse contudo a edificação de mecanismos de ação coletiva para gerir tanto os recursos energéticos quanto os recursos naturais comuns interligados à cadeia de exploração (água, solo, e qualidade atmosférica).

De forma complementar e agravante, as ações de voluntariado, doações e patrocínios realizadas pelas companhias energéticas nas cidades de EFS são entendidas e realçadas, por parte considerável das autoridades locais entrevistadas, como atitudes que comprovam a boa vontade do setor energético em estabelecer parcerias e cooperação. Outra vez, revelam comportamentos ofuscados e percepções restritas frente a lógica das vantagens econômicas rápidas e dos ganhos expressivos imediatos na exploração dos recursos energéticos, sem que haja contudo a formação de projetos sociais, ligações duradouras e oficiais entre os entes envolvidos.

A corrida em torno dos interesses das empresas energéticas reforça novamente os efeitos de exclusão provocados pelo boom energético, especialmente nos momentos de auge dos preços internacionais. Reforça uma condição, nessas situações, que reduz as possibilidades de edificação de novos cenários de diversificação das atividades econômicas, remetendo as comunidades de EFS a uma nova trajetória de dependência do petróleo, tornando-as novamente reféns dos ciclos de alta e baixa dos valores das commodities energéticas, sobretudo do petróleo nos mercados internacionais. Restando às comunidades, rezarem pela saúde e generosidade das companhias energéticas.

Como resultado das 'benesses econômicas dos folhelhos' a materialidade produtiva dos hidrocarbonetos não-convencionais se faz cada vez mais presente, seja pelo tráfego de carretas e a proliferação das unidades de infraestrutura e logística das empresas, seja pelo número de pump jacks, flares e depósitos de águas residuais para fracking que dividem espaço lado-a-lado com ranchos, casas e escolas das comunidades de EFS.Um ritmo de intensificação das atividades produtivas na prospecção, fraturamento e produção de gás e petróleo que traz consigotodos os impactossocioambientais de uma cadeia de produção energética. 
5.6 Análise dos resultados: padrões de eco-governamentalidade comuns em Eagle Ford Shale

Que padrão de eco-governamentalidade ocorre nas lógicas dos stakeholders, instituições e policy makers interligados e inseridos em EFS? Longe do "ambientalismo relutante" destacado por Shoreman \& Haenn (2009), ou do ambientalismo de caráter acidental de Haggerty (2007), o padrão comum dos discursos revelado nas companhias energéticas, mas, igualmente, de parte significativa dos representantes e instituições de governo, revela o que se condicionou chamar de 'ambientalismo tempestivo'. Onde a tempestividade se reveste de um sentido de ação, retórica apropriada, propícia e favorável.

Um padrão que não esconde a lógica desenvolvimentista e nacionalista como elementos legitimadores centrais da exploração dos folhelhos, mas que recorrentemente se vale de elementos e justificativas socioambientais na exploração dos hidrocarbonetos não-convencionais. Tanto os atores do setor energético (companhias produtoras, empresas de transporte, logística e infraestrutura de distribuição), quanto associações e confederações interligadas ao setor valem-se da ligação entre a produção dos recursos energéticos como fatores propulsores ao desenvolvimento, mas não raramente do compromisso com a preservação do ambiente e dos recursos naturais.

Nos materiais divulgados nas revistas, e na iconografia empregada, é comum identificar slogans como: "Hydraulic Fracturing: bridge to a clean energy future" numa alusão a declaração da ex-diretora da EPA no qual o gás natural de xisto poderia ser um "combustível ponte", ou de transição, "bridge fuel" para as energias renováveis necessárias (HIGGINS, 2013 p.01). Não são raros os posicionamentos de seus autores sobre as virtudes socioambientais do fracking como em: "Going Green: The Virtues of Fracking" e "Taking the bad with the good" (Figura 30 e 31).

No primeiro, o fracking é apresentado como um caminho plausível a uma trajetória verde, "Going Green", uma vez que o uso do gás natural de xisto "reduz as emissões de combustão" em comparação aquelas emitidas pelas termoelétricas alimentadas a carvão mineral, e utiliza menos água do que as termonucleares, além de "não matar pássaros como as turbinas eólicas e, nunca contaminou a água subterrânea" (DUPPER, 2014 p.62); 


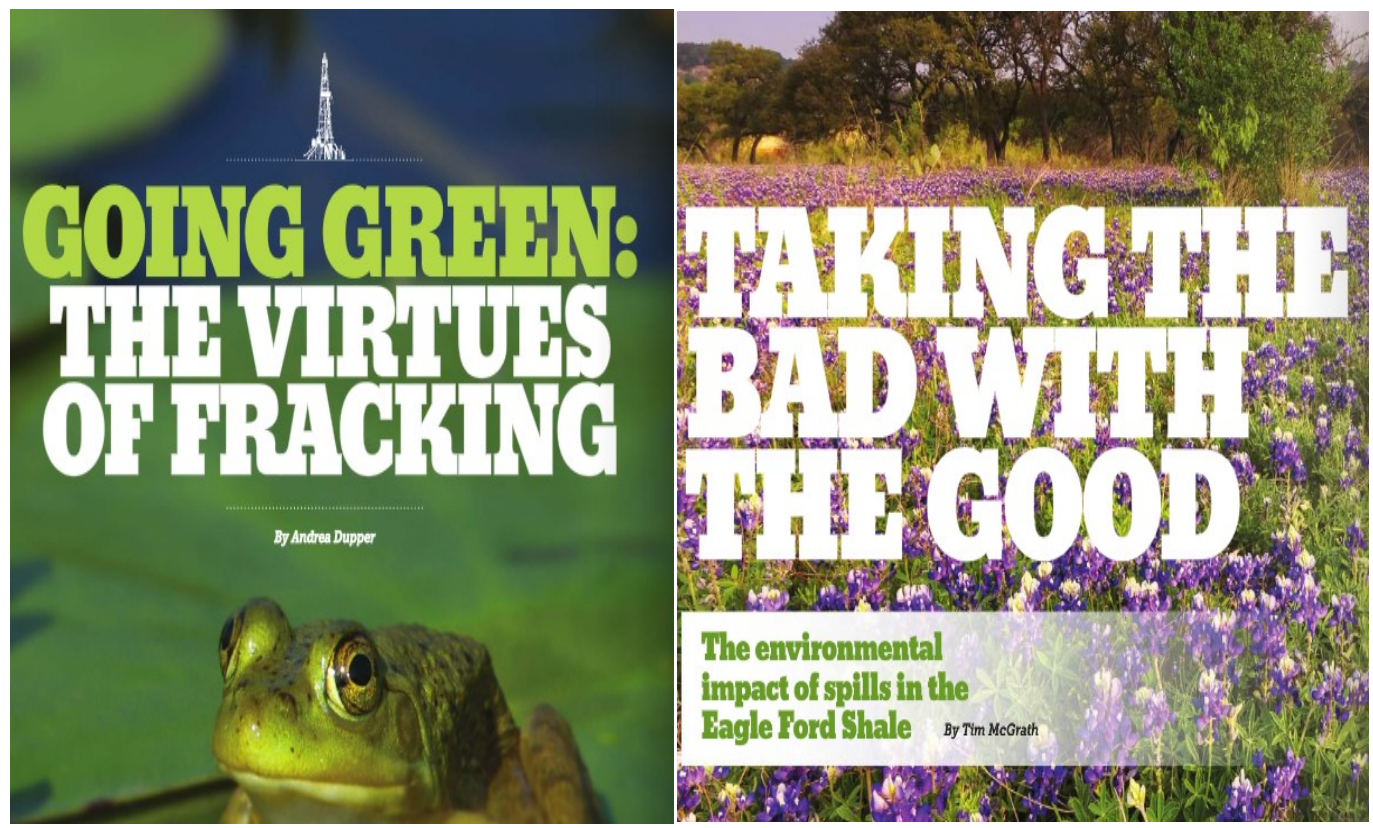

Figura 30 e $31-$ As virtudes ambientais do fracking.

Fonte: Dupper (2014).

No segundo caso, o artigo de McGrath (2014) sugere uma espécie de 'veja o lado bom do fenômeno', onde "good" remete a valorização dos impactos sociais positivos (emprego, renda, arrecadação e inclusão) e minimiza a questão ambiental interligando-a às supostas conspirações da esquerda política (BRANNSTROM, 2015). Embora seu autor admita, ao contrário do posicionamento nacional do setor, que existem certos riscos associados, ele acredita que “...with proper precautionary measures, we can minimize the impact and keep it all good" tornando a exploração dosshales uma atividade tão comum e harmoniosa na paisagem local quanto as flores "Blue Bonnets" símbolos do Texas (MCGRATH, 2014 p. 23, grifos meus).

Padrões que se repetem nas publicações anuais de relatórios de sustentabilidade das companhias energética em que as empresas endossam suas motivações frente ao comprometimento com um "futuro energético sustentável" ou de parâmetros de "sustentabilidade corporativa" que os coloca na vanguarda na produção de energia (Figura 32 e 33).

De acordo com os CEO's (Chief Executive Officer) de grupos energéticos, as companhias operantes em EFS possuem um "strong commitment to sustainability. Protecting the environments and communitiese garantindo aos "employees and properties [...] constant vigilance in day-to-day operations and new ideas to change and improve the future" (EFS018 p.02 grifos do autor). Ou ainda, alcançar a "sustainabilityby living core values of integrity and trust,servant leadership, open communication, people, passion, and commercial focus, all of which guide our activities and decisions." (EFS019 p.01, grifos do autor). 

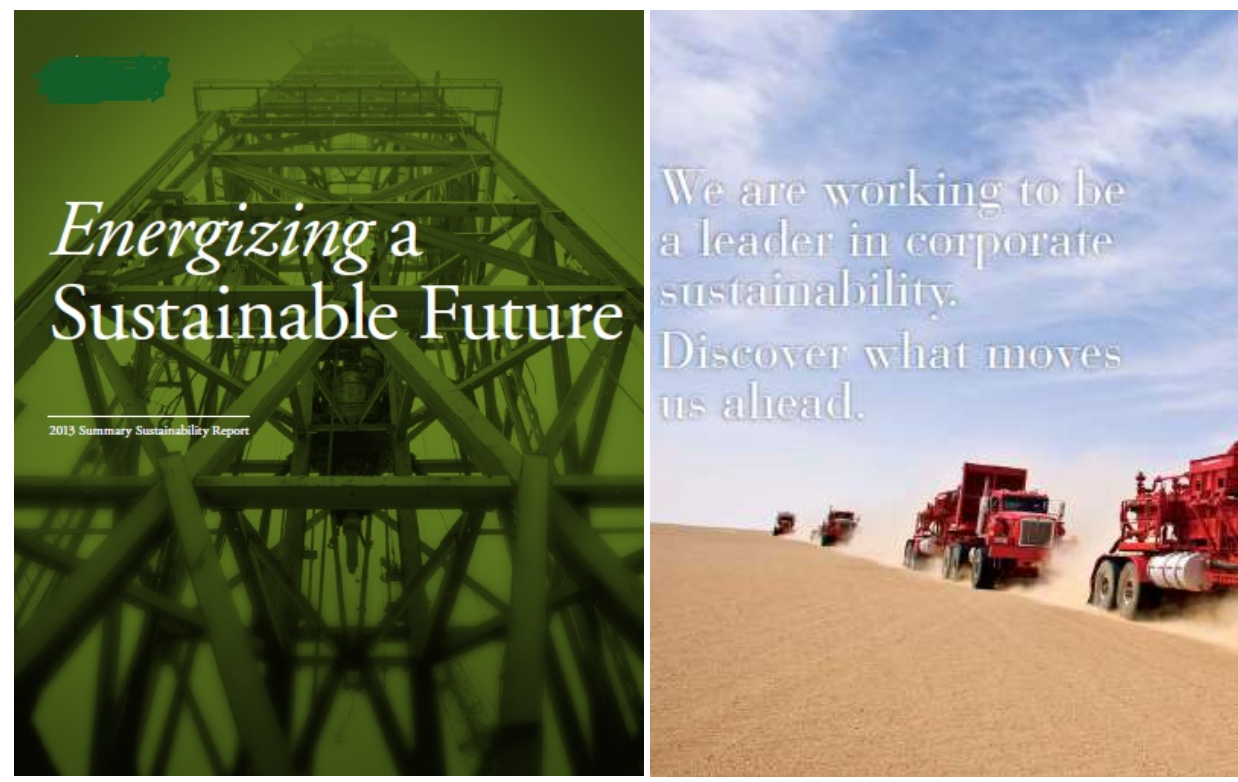

Figuras 32 e 33 - Folhelhos e sustentabilidade. Fonte: Apache (2013); Halliburton (2013).

De forma simultânea, algumas empresas buscam comprovar suas intenções inserindo-se ainda que de forma incipiente em certificações regionais como a Eagle Ford Excelence Awards da STEER, e State Review of Oil and Natural Gas Environmental Regulation da STRONGER(Figura 34e 35).
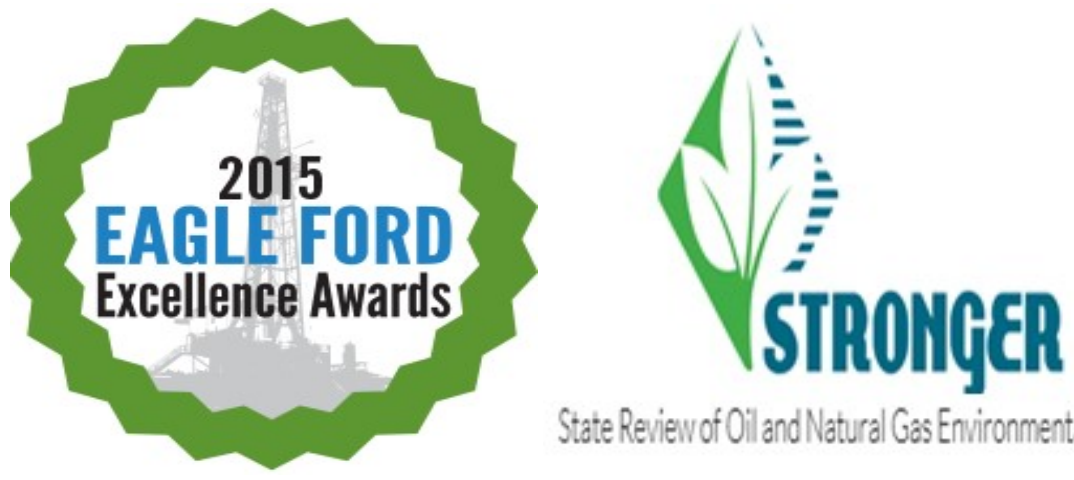

State Review of Oil and Natural Gas Environmental Regulations

Figuras 34 e 35 - Certificações regionais de sustentabilidade na produção de petróleo e gás não-convencionais. Fonte: www.steer.com\&http://www.strongerinc.org/

No primeiro caso, a "South Texas Energy \& Economic Roundtable STEER" trata-se na realidade de uma premiação dada as companhias energéticas que se destacam em: " [make] efforts in the areas of community and social investment, environmental stewardship, and safety performance" na região de Eagle Ford Shale (STEER, 2014 p. about us, grifos do autor). Apesar disso, a premiação revestese do caráter de uma certificação das empresas que produzem a partir de boas práticas de investimento nas áreas sociais e comunitárias, gerenciamento ambiental e atendimento a padrões máximos de segurança. 
No segundo caso, trata-se de uma organização não-governamental que oferece seus serviços a agências regulatórias estaduais (como a RRC e a TECQ), mas também empresas, no sentido de apontar questões pertinentes e, quando necessário, montar equipes de consultoria para ajustamento de procedimentos. Se um estado qualquer, por exemplo, se submete a uma avaliação da STRONGER e recebe o selo de aprovado, o efeito em rede é equivalente ao de receber uma certificação dando credibilidade a seus critérios de fiscalização ambiental. Vale destacar, entretanto que tais certificações, assim como a STEER, acontecem à margem do conhecimento, atenção e participação pública. E muitas vezes tratam-se apenas de dispositivos para, artificialmente, dar consistência à imagem que as empresas querem passar ao público (DAVIS, 2012).

As companhias de EFS, dessa forma, alinham-se às estratégias de propagação dos discursos de entidades nacionais como da API e Energy in Depth que afirmam que o fracking só traz benefícios, uma vez que uma atividade limpa, que promove o crescimento econômico e empregos sob bases científicas confiáveis e técnicas controláveis que não produzem impactos ao meio ambiente. Simultaneamente, campanhas da API conduzem trabalhos voltados a 'educar atores sociais', como por exemplo, "Best Practices for Talking Fracking", ou melhores maneiras para se conversar sobre fraturamento hidráulico. Um manual destinado às indústrias energéticas e ativistas pro-fracking para a devida interlocução com os governos locais e "minimizar a interrupção" nas atividades de exploração enfatizando seu "compromisso com a comunidade" (NEUHAUSER, 2014).

O maior lobby nacional da indústria do petróleo destaca, por exemplo, a responsabilidade do setor frente à exploração dos shales petrolíferos americanos com a proteção do meio-ambiente: "U.S. Oil Shale:[is] Protecting our environment" (API, 2013, p.about us, grifos do autor - Figura 36).

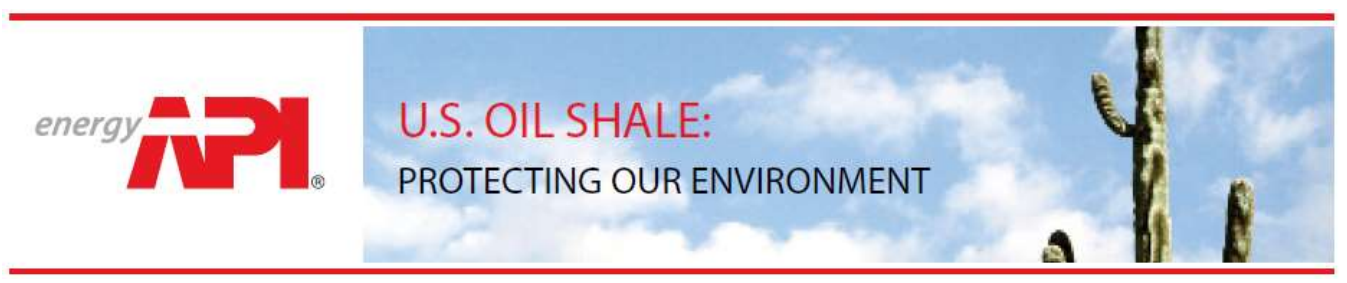

Figura 36 - U.S. Oil Shale: Protecting our environment.

Fonte: API (2013).

$O$ instituto se diz "committed to environmentally responsible oil shale development" e enfatiza seu comprometimento com a proteção, conservação da água, paisagens naturais e vida selvagem, ressaltando que: "Oil and gas operations in western oil shale areas have coexisted with wildlife resources for many years (API, 2013 p.about us, grifos do autor).Para o instituto, entretanto, com 
atenção aos números do desenvolvimento de EFS, a API propaga a criação em 2011 de 47 mil empregos, 257 milhões de dólares em arrecadações de taxas para os municípios, e 358 milhões para o estado. Os dados enfatizam a duplicação da produção de gás natural e do aumento em seis vezes na produção de petróleo, comemorando que o "shale revolution is providing a clear path foward for increased energy security and economic growth" (API, 2013 p.our mission, grifos do autor).

Diante das mesmas justificativas, periódicos como a EFS Magazine, por exemplo, dão o tom dos discursos propagados pelo setor realçando os empregos, ocupações e trabalho gerados como a commodity mais importante e preciosa na exploração dos folhelhos no Texas (Figura 37 e 38).
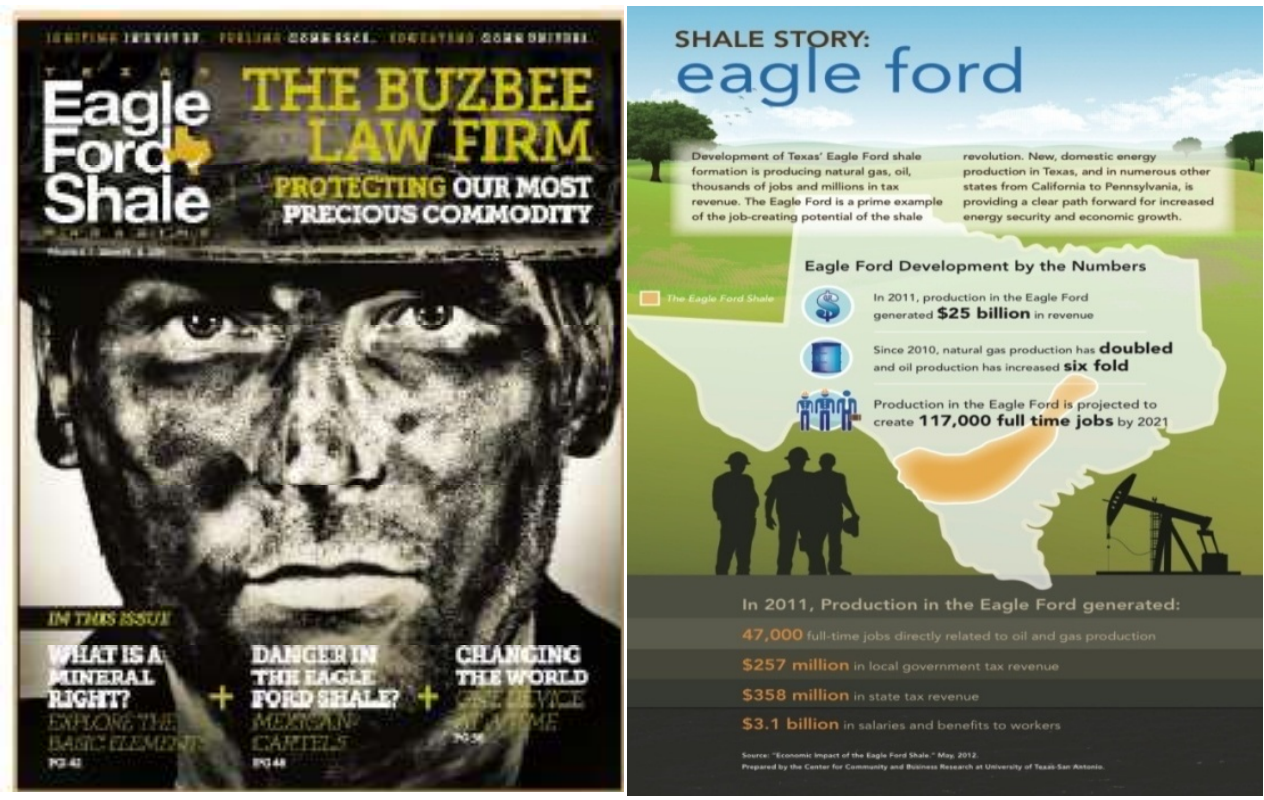

Figuras 37 e 38: Virtudes socioeconômicas dos folhelhos.

Fontes: Stralow (2014); API (2013).

Editoriais que junto com associações como a Txoga e Texas Alliance recorrem ao nacionalismo e orgulho regional como elementos inquestionáveis sobre 0 papel do setor no desenvolvimento local. Elementos utilizados, por exemplo, para convocar as comunidades de EFS em resistir à atual desaceleração da exploração energética causada pelo: "grip and sheer envy" (aperto e pura inveja) da Organização dos Países Exportadores de Petróleo (API, 2015 p.08). . Conclamando empresas e trabalhadores a se unirem e se manterem firmes no caminho daindependência energética americana, “Texas: keeping the U.S. energy independent"(API, 2015 p.08, grifos do autor -Figura 39 e 40). 


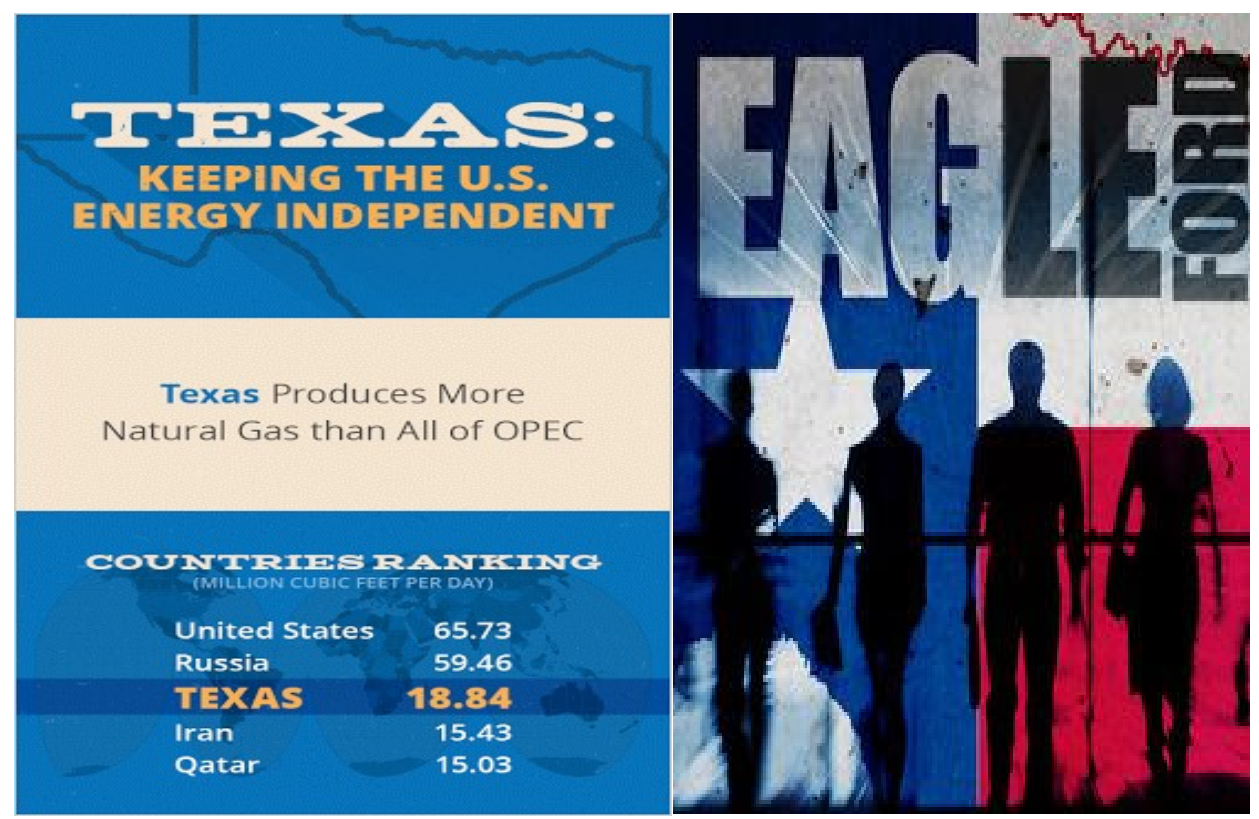

Figura39 e 40: Eagle Ford e o papel do Texas na independência energética americana. Fonte: EAGLEFORDSHALE (2015).

Representantes de governo estadual, como o deputado autor da HB40, são igualmente enfáticos em preservar o "most valuable natural resource" do Texas (RAUF, 2015 p. 01, grifos do autor). Declarando seu empenho em resgatar e manter o ritmo econômico para da exploração dos "mais valiosos recursos naturais do estado" para as futuras gerações, como frisaram senadores diretamente envolvidos no desenrolar do processo de regulação, gestão e controle deEFS: "I am committed to continuing to work with theagenciesand all my constituents to make certain that this economic surge continues for many generations safely and effectively."(ZAFFIRINI, 2014, grifos do autor). Onde: "our Oil and Gas industry is very environmentaly concerned" (HASEMYER ET AL 2014, p01, grifos do autor). Quem está, portanto, contra a exploração de EFS, nesse sentido, assume a postura de ignorante, "cabeça-dura", radical e está, portanto, contra o próprio desenvolvimento da região e do país (BRANNSTROM, 2015 p.97).

Essa lógica, entretanto, parece ser contraditória no discurso que se reproduz nos atores e autoridades estaduais e locais, sobretudo, quando diz respeito à continuidade nas regulações ambientais necessárias. Nessas ocasiões as subjetividades dos parlamentares revelam uma racionalidade oposta às exigências de associações civis por normas ambientais mais severas: "Do we want to put further burdens on an already struggling industry? [...] We need to do no harm."(MALEWITZ, 2015b p.01, grifos do autor). Uma governamentalidade disposta em poupar o setor já abalado pelos preços baixos do petróleo. Não causando, portanto, "danos" ao impor normas mais rígidas no controle de injeções, coquetéis 
líquidos de fracking, relatórios de uso, re-uso e controle da água, e restrições dos flarings. Ou seja, uma direção contrária ao "ambientalismo tempestivo" das indústrias, onde se mascara a posição expressa por outro senador: "I believe if you're anti-oiland-gas, you're anti-Texas" (MORRIS ET AL, 2014 p.03, grifos do autor).

Para algumas das autoridades locais como city managers, grupos ambientalistas são elementos exógenos as comunidades, e quando se opõem a atividade de exploração de gás e petróleo em Eagle Ford Shalepromovem uma visão ideológica, distorcida ouexagerada, interferindo no grau de independência das comunidades, conforme revelado pela declaração do gerente municipal da cidade de Cotulla, condado de La Salle:

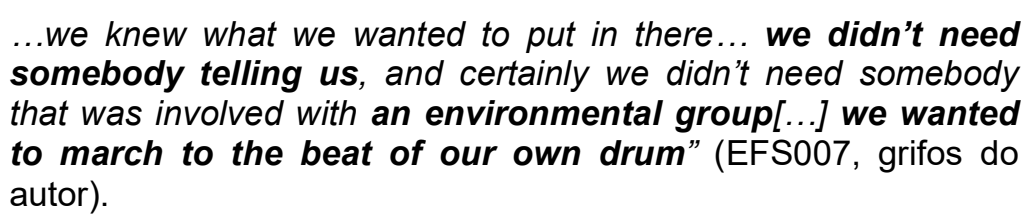

$\mathrm{Na}$ prática as subjetividades e sentimentos que prevalecem estão intimamente atreladas ao desejo de que: "everybody wants an Oil Well in their backyard and if they could attract that, then they would" (EFS011, grifos do autor).Ou ainda como questionado por um morador de Karnes City, no coração de EFS:

...are we going to prevent people from having jobs? Are we
going to relegate an entire section of the state to continued
poverty or are we going to move forward with economic
development? (MORRIS ET AL 2014 p.10, grifos do autor).

Um fenômeno de reprodução de racionalidades e comportamentos do primeiro boom da década de 1980 descrito por Mealer (2013), no qual o forte odor da fuga de componentes orgânicos voláteis (V.O.C's) resultante do processo de extração e queima dos flarings lembram seu primeiro contato com o petróleo e da pergunta de seu pai: "Y'all smell that?That's the smell of Money!" (p.03, grifos do autor), ou, "todos podem sentir o cheiro? Esse é o cheiro de dinheiro! Uma lógica que conquistou mentes e corações, mas no final apenas deixou um considerável passivo socioambiental as cidades do Texas.

\subsection{Discussão dos resultados e limitações da pesquisa}

As regras e as arenas políticas do sistema de governança dos folhelhos americanos, verificadas a partir do estudo de caso de Eagle Ford Shale, pouco favorecem a consolidação de ambientes positivos de ação coletiva, seja na gestão dos recursos energéticos, petróleo e gás, seja na gestão dos recursos naturais que lhe dão base. Em EFS, o parâmetro legal que constitucionalmente foi desenhado para garantir 
uma base pluralista voltado a garantir a autonomia deliberativa local nas regulações energéticas foi tolhido. De uma etapa inicial onde os direitos foram negligenciados em razão da fé excessiva depositada no novo boom dos recursos energéticos, uma virada de mesa política histórica cerceou quase que por completo as prerrogativas da população na regulação e gestão energética. Levando as decisões, arenas políticas e espaços deliberativos para a capital do estado, Austin, longe das áreas de produção diretamente impactadas.

Tal configuração aumentou ainda mais a desigualdade socioeconômica e política; sobretudo, a assimetria informacional, de direitos e ganhos entre os segmentos mais vulneráveis da população, distribuídos nas áreas rurais, periurbanas e urbanas de EFS e dos grupos de interesse articulados em prol do setor energético. $\mathrm{Na}$ prática, dentro do roll de perguntas norteadoras do modelo de análise institucionalista de Ostrom (2005), a participação acabou se resumindo a lógica economicista das revenues, sales taxes, mas, especialmente, dos royalties daqueles que ainda detém os direitos de propriedade (mineral owners). Um resultado interligado a própria constituição nos Estados Unidos que diferencia a propriedade imobiliária em duas partes: a propriedade da superfície, e a do subsolo, que podem ser desmembradas, negociadas e 'alugadas' (leasing) para terceiros.

No Texas, como destacado por Brannstrom (2015) os 'mineral owners' tem direitos que ultrapassam inclusive os direitos do dono da superfície, conhecido pejorativamente como 'donos da poeira, 'dust owner'. A disparidade de interesses é tão discrepante que se, por exemplo, o dono de superfície, seja ele uma empresa, cidadão, ou entidade pública, tentar impedir o acesso aos hidrocarbonetos, o proprietário mineral tem a prerrogativa legal de processá-los judicialmente. Ainda de acordo com o mesmo autor, nestes termos, as comunidades locais e, às vezes, o próprio estado (terras públicas) coloca-se a mercê de pressões que resultam em perfurações que convivem lado a lado com habitações e outras infraestruturas, resultando num aumento substancial dos impactos da materialidade e da singularidade legal da exploração dos folhelhos no estado.

Dito de outra forma, o regime jurídico, conjunto de políticas e sistema de governança dos hidrocarbonetos não-convencionais propulsiona a expansão da materialidade inerente da exploração dos shales e que bate de frente com o uso racional equilibrado dos recursos energéticos (petróleo e gás natural) e menos ainda dos recursos naturais comuns (água, solo e ar). Indo, portanto, na direção oposta de ações coletivas sob os recursos energéticos e naturais, e consolidando uma visão utilitarista que dá peso ao que pode ser visto facilmente em detrimento da consideração dos riscos ao meio natural e humano. 
Apesar disso, atores de governo e de mercado justificam seus parâmetros baseados numa eco-governamentalidade que qualifica osfolhelhos como oportunidade ímpar de desenvolvimento sustentável. Lançam mão de discursos que ressaltam as vantagens sociais e econômicas dos recursos energéticos, ainda que os ganhos e vantagens sejam de caráter imediato e alcancem apenas uma parcela dos atores, sobretudo, daqueles investidos de maior poder e recursos. Mascara ainda o fato, de quê, as atividades exploratórias não têm promovido processos legítimos de cooperação, participação, pertencimento e empoderamento das comunidades. Pior, constroem uma imagem positiva sustentada na lógica economicista do fluxo de doações, patrocínios, rendas e royalties que legitimam a transformação das paisagens e dos territórios de produção energética e o uso dos bens naturais comuns.

Seguindo a lógica do IAD de Ostrom, os "ganhadores" se apresentam pelo grupo das companhias energéticas que reforçam seus interesses e privilégios, criando novamente uma dependênciaprodutiva, logística e comercial de suas atividades. Uma trajetória onde pequenas e médias comunidades rurais, periurbanas e urbanas se tornam reféns da saúde econômica dos recursos energéticos, não percebendo seu status de "perdedores" frente a essa dependência e relação de poder, ou ainda, sendo incapazes de levar em conta os possíveis prejuízos futuro em frente aos potenciais passivos ambientais deixados pela intensificação de commodities impactantes e oscilantes como o petróleo.

Considerações que vão ao encontro das colocações realizadas por autores que tratam da 'maldição dos recursos', onde comunidades inseridas nas áreas de produção acabam por não usufruir das riquezas geradas que migram para longe das áreas de produção e são incapazes de gerar processos independentes de diversificação da economia e do desenvolvimento local, produzindo ao final dos ciclos produtivos resultados socioeconômicos e ambientais danosos. Como destacado por Hasemyer et. al. (2014), os riscos ambientais, a sociedade, e à saúde humana não são contabilizados, ou mesmo percebidos como elementos importantes na equação de custos-benefícios e demonstrando uma conta desequilibrada e perversa.

De fato, a pesquisa em EFS endossa as considerações realizadas por outros autores em diferentes shales americanos, como por exemplo, Parogi (2014) que chama a atenção para o intenso jogo e relações de forças entre empresas, sociedade e governo que acaba sendo ditado pelo dinamismo econômico, sem a devida atenção aos demais riscos e incertezas incorporados. Processos e estruturas que privilegiam a cultura corporativa das companhias nos processos deliberativos, e diminuem a autonomia regulatória dos governos locais e a participação pública. De forma ainda mais grave, não promovem uma responsabilização (accountability) 
adequada e avançam as atividades exploratórias sem considerar possíveis danos socioeconômicos, ou de critérios de justiça ambiental.

Elementos que muitas vezes são distorcidos pelas companhias e atores de governo, tendo por base argumentos da 'ciência e da tecnologia' como elementos justificadores. Retóricas que influenciam percepções e subjetividades e resultam, conforme destacado por Small et al (2014), numa polarização entre favoráveis e contras, que acaba desviando e distorcendo a devida atenção para importantes princípios de precaução frente a atividades tão impactantes.

Finalmente, as considerações aqui feitas convergem quanto às dúvidas levantadas por autores como Davis (2012) e Rabe (2014) sobre o federalismo subestatal americano e o processo de descentralização de poderes. Ou seja, a delegação de poderes aos governos locais e estaduais nem sempre se reveste de características positivas na qualidade de governança. Elementos que levam os autores a conjecturar sobre a necessidade de federalização da energia nos Estados Unidos e, portanto, a (re)centralização das competências deliberativas para Washington. Na visão dos pesquisadores um processo que poderia oferecer um padrão de bases regulatórias e políticas unificadoras em nível nacional. Equilibrando procedimentos de taxas, permissões e procedimentos sob a égide do Governo Federal.

Como se observa, as questões e discussões de pesquisas recentes orbitam no desafio da governança dos folhelhos nos Estados Unidos. Um desafio que envolve a competência regulatória dos estados e seus governos locais em gerir, controlar e fiscalizar empresas e agentes públicos. Novamente, não se trata de condenar sumariamente a exploração dos folhelhos e negar veementemente sua exploração no roll de recursos energéticos. Entretanto, vale lembrar que a 'sustentabilidade do recurso está em grande parte ligada a qualidade do processo de governança e aos padrões preponderantes de eco-governamentalidade na qual suas cadeias produtivas são inseridas e legitimadas. 


\section{POLOS GAÚCHOS DE BIODIESEL E EAGLE FORD SHALE: GOVERNANÇA E ECO-GOVERNAMENTALIDADE DE DUAS PROMESSAS ENERGÉTICAS}

Como visto nos capítulos IV e $\mathrm{V}$, as variáveis institucionais que estabeleceram a produção de biodiesel gaúcho e a exploração dos folhelhos texanos têm uma configuração e uma temporalidade semelhante. Em pouco mais de uma década, os dois recursostiveram um crescimento substancial na sua participação mundial. No Brasil, a produção de biodiesel cresceu incentivada pela formação de parcerias público-privadas, incentivos econômicos, subsídios e isenções fiscais oferecidos pelo Governo Federal. O conjunto de incentivos paraestimular segmentos específicos do mercado conseguiu criar o segundo maior mercado mundial de biodiesel (REN21, 2015).Nos Estados Unidos, por sua vez, o ‘shale boom' também foi consolidado a partir de parcerias entre atores estatais e não-estatais, bem como, por incentivos oficiais que colocaram o país no topo da exploração mundial dos intitulados'recursos não convencionais' (EXXON, 2015)

A despeito dessas características, por que comparar os dois recursos energéticos? Qual a razão para comparar especificamenteo biodiesel gaúcho e os folhelhos texanos? Não obstante ao crescimento em escala mundial de ambos, a justificativa centralse dá pela oportunidade ímpar de aplicar as mesmas perguntas teóricas, normativas e analíticas para doisrecursos energéticos de natureza e de materialidades completamente diferentes entre si. Mais ainda, fazer a comparação frente à luz do mesmo referencial teórico e metodológico focando na tensão entre os padrões de governança e de eco-governamentalidade nas duas paisagens energéticas e nos dois países envolvidos. Isso implica considerar, entre outros fatores, a comparação das respectivas políticas energéticas e dos seus pactos federativos, bem como, a disposição de seus respectivos níveis estruturais e padrões de governança.

Ainda nesse sentido, a comparação permite explorar os padrões comuns ou dissonantes nas lógicas, racionalidades, subjetividades e discursos propagados dentro dos respectivos sistemas de governança pesquisados. Vale ressaltar que tanto a produção de biodiesel quanto a exploração dos shales foram justificadas desde o início das suas trajetórias produtivas e tecnológicas como promessas energéticas. Diante disso, as seções do presente capítulo buscam analisar e comparar as estruturas e processos de governança dos $P G$ e de EFS, e simultaneamente identificar parâmetros comuns de eco-governamentalidade nos dois casos de estudo. 
6.1 Análise comparada dos Direcionadores de Governança do biodiesel nos $P G$ e dos folhelhos deEFS

\subsubsection{Descentralização (PG) / Decentralization (EFS)}

Embora por razões distintas, seja o sistema de governança dos Polos Gaúchos de Biodiesel,seja o sistema de governança dos folhelhos de EFS, o princípio dedescentralização/decentralization se apresenta como um aspecto desfavorável à regulação e gestão dos recursos energéticos. Sendo o princípio, ou direcionador considerado 'ruim' nos PG e 'vicioso' em EFS (Figura 41 e 42).

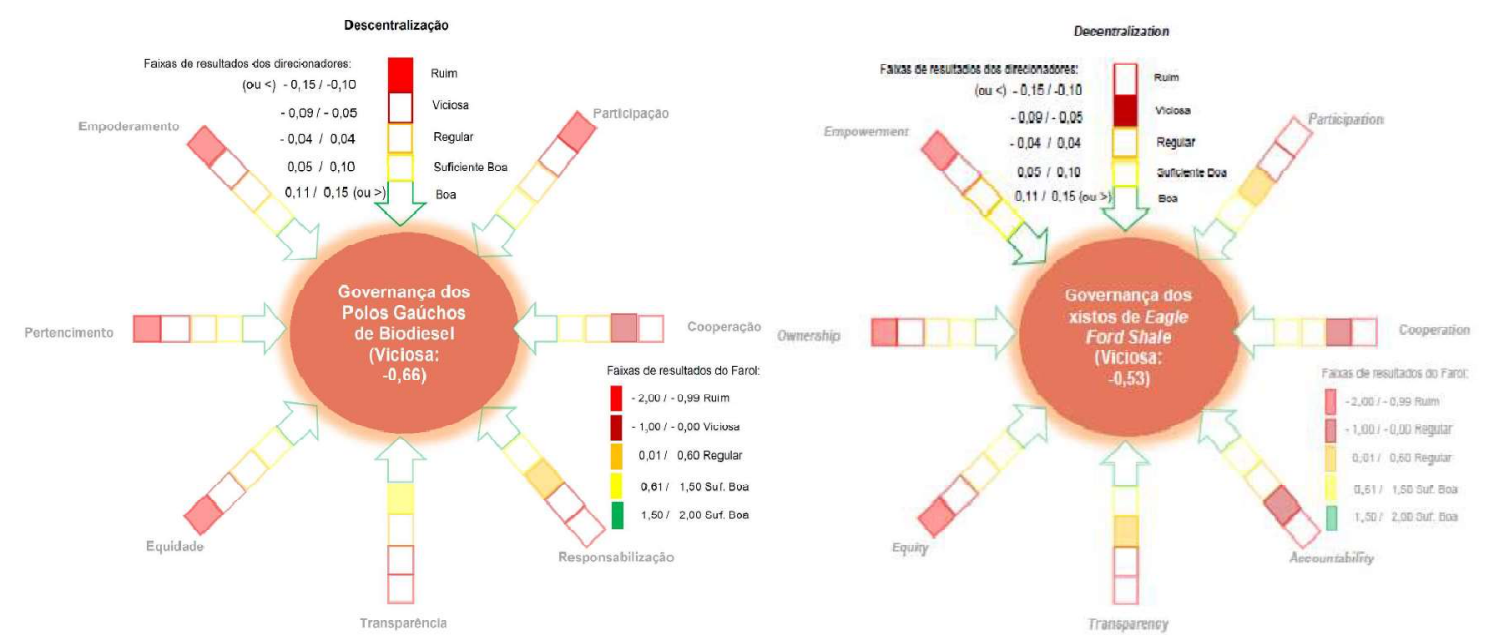

Figura 41 e 42 - direcionador: descentralização (PG) / decentralization (EFS).

Fonte: Elaborado pelo autor.

Apesardos PG e EFS caracterizarem-se por estruturas distintas e diferentes fluxos políticos (Figuras 43 e 44) ambas as paisagens energéticas são caracterizadas por procedimentos desfavoráveis na incorporação e/ou manutenção de critérios de descentralização de competências e delegação de prerrogativas em favor dos governos locais (Tabela 11).

No Brasil, como visto no capítulo IV, os níveis estruturais dos arranjos político-institucionais da governança do Biodiesel nos Polos são dispostos de forma bastante hierárquica e unidirecional. A política pública nacional do biodiesel (PNPB), embora tenha sido desenhada para legitimar uma produção e gestão descentralizada, na prática sedimentou processos bastante centralizados e subordinados a um fluxo de regulação e gestão top-dow, ou de cima-para-baixo emanado exclusivamente a partir de arenas, órgãos públicos e entidades concentrados no Governo Federal.

Tal configuração faz com que as áreas de produção, por exemplo, não possuam nenhum tipo de prerrogativa legal na regulação energética, e as localidades nelas inseridas tenham pouquíssima influência prática na gestão do recurso energético. De forma concreta, todas as deliberações originam-se de processos iniciados e/ou controlados pela Casa Civil (Presidência da República), nos quais 
propostas e processos acabam por tramitar no escopo do Ministério de Minas e Energia, que é tanto responsável por hospedar e administrar o CNPE, quanto gerir o núcleo executivo e gestor da CEIB.

De forma concreta a governança do biodiesel brasileiro concentra todas as arenas e espaços deliberativos na capital federal longe das áreas de produção diretamente envolvidas e impactadas. Essa estrutura, portanto, elimina quaisquer tipos delegação de poderes aos entes locais, seja por subsidiaridade, devolução, seja por flexibilidade em prol das comunidades rurais, periurbanas e urbanas inseridas nos PG. Um arranjo político-insitucional rígido no qual inexistem dispositivos constitucionais, ou mesmo parâmetros legais na Polítca Energética Nacional que preveja maior distribuição de competências e autonomias regulatórias para cidades e municípios.

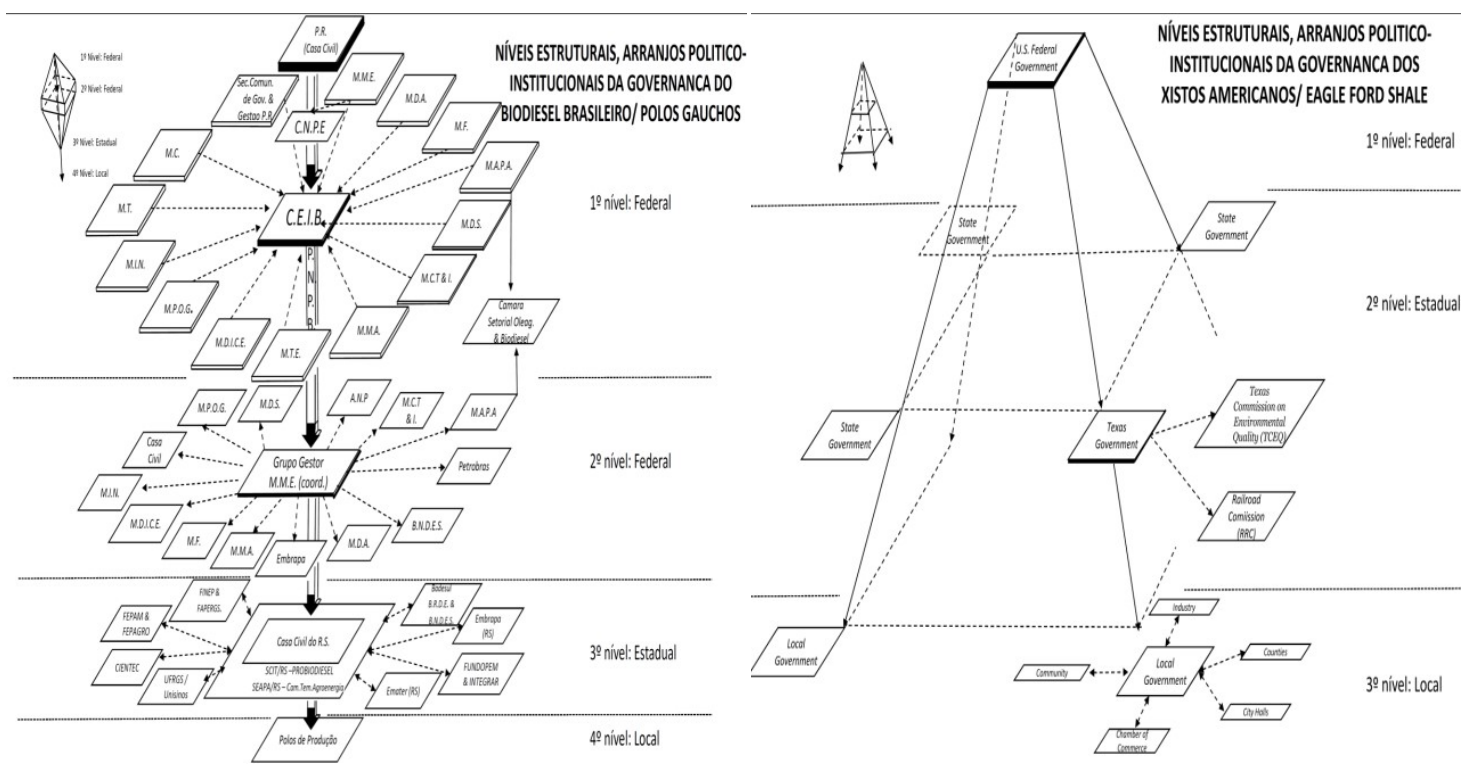

Figura 43 e 44 - Comparação das estruturasda governança dos PG e de EFS. Fonte: elaborada pelo autor.

No caso americano, conforme discutido no capítulo $\mathrm{V}$, o layout é totalmente distinto. Nele há uma ampla descentralização e delegação de poderes de regulação e gestão dos hidrocarbonetos não-convencionais no país. A disposição estrutural dos arranjos político-institucionais da governança dos folhelhos americanos remete a um fluxo de competência que, embora também seja hierárquico a partir do Governo Federal, na prática, funciona de forma bastante descentralizada, delegando amplos poderes aos estados e seus respectivos sistemas subfederalistas. Cada unidade federativa e suas cidades definem separadamente como decidir e determinar regras e distribuir competências deliberativas, consultivas e fiscalizatórias nas suas jurisdições. 
A constiuição americana concede historicamente essa grande autonomia e dentro dessa mesma lógica, a política energética nacional, ou Energy Policy Act (EPACT), foi reformulada no ano de 2005, e manteve um padrão de não interferência de normas federais aos estados, aos governos estaduais e locais. No máximo estabeleceu parâmetros balizadores, ou quesitos que não podem ser negligenciados, e desobedecidos, como, por exemplo, os critérios ambientaisda Environmental Protection Agency (EPA).

Vale ressaltar que, tamanha independência regulatória não quer dizer necessariamente que o princípio de descentralização é sempre favorável nos Estados Unidos e em seus estados. No caso específico do Texas, incluindo EFS, houve pelo contrário um efeito reverso, no qual as prerrogativas do poder estadual, concedidas pela União, serviram de base legal para cercear, tomar o poder (powergrab) e as prerrogativas regulatórias historicamente dos governos locais.

\begin{tabular}{c|c|c}
\hline $\begin{array}{c}\text { Direcionadores/ Paisagem } \\
\text { Energética }\end{array}$ & $\begin{array}{c}\text { Polos Gaúchos/Brasil } \\
\text { (Biodiesel) }\end{array}$ & $\begin{array}{c}\text { Eagle Ford Shale/ U.S. } \\
\text { (Hidrocarbonetos de Xisto) }\end{array}$ \\
\hline Descentralização vs. & $\begin{array}{c}\text {-Implementação aos moldes de uma } \\
\text { governança híbrida, mas gestão e } \\
\text { exploração do tipo 'big government'. } \\
\text { Decisões 'top-down' oriundas } \\
\text { essencialmentedo Governo Federal. }\end{array}$ & $\begin{array}{c}\text {-Implementação nacional aos moldes do } \\
\text { Federalismo Americano (small } \\
\text { government e decisões bottom-up), } \\
\text { porém; }\end{array}$ \\
$\begin{array}{c}\text {-Conforme o federalismo e Constituição } \\
\text { Brasileira não há autonomia ( e/ou } \\
\text { devolução) dos governos locais no no } \\
\text { tocante a regulação energética. }\end{array}$ & $\begin{array}{c}\text {-O desenvolvimento da produção e da } \\
\text { polêmica do 'fracking' alterou os marcos } \\
\text { regulatórios texanos - levando a uma } \\
\text { transição das decisões dos governos } \\
\text { locais para o Estadual - em uma tomada } \\
\text { de poder do tipo 'Big Government'. }\end{array}$ \\
\hline
\end{tabular}

Tabela 10 - descentralização vs.decentralization

Fonte: elaborada pelo autor.

O desenvolvimento das atividades produtivas e a polêmica que se projetou ao redor do 'fracking' ameançando dificultar, ou tornar complexa a rede de ordenamentos (Ordinances) para a exploração do petróleo e do gás de folhelho no estado provocou a modificação dos marcos regulatórios (re)centralizando as decisões na esfera estadual em detrimento dos poderes locais. Um padrão típico de 'big government', onde as atuais deliberações sobre uso e exploração de recursos energéticos, também se tornaram de fluxo top-down, ou de cima-para-baixo, a partir dos interesses impostos por Austin.

De forma curiosa, as estruturas de governança nos dois países favorecem, ou são frutos dos interesses dos stakeholders, atores de maior poder, sua capacidade de organização e influência política. Nos dois casos, atendem as demandas das agroindustriais e companhias energéticas, suas associações, confederações e lobbies. Nas duas situações, tanto os policy makers texanos, quanto os principais tomadores de decisões do em Brasília são muito mais suscetíveis aos 
seus interesses do que de outros grupos de atores sociais. Nesse sentido, as articulações de TXOGA, TEXAS ALLIANCE, STEER e API, no Congresso Texano e no governo do estado, em muito se equivalem àquelas desempenhadas pela UBRABIO, APROBIO, SINDIBIO/RS e FrenteBio no Congresso Nacional e no Governo Federal brasileiros.

Dito de outra forma, ambas as estruturas apesar de possuírem desenhos próprios, nos dois casos de estudo, PG e EFS se configuraram de forma mais favorável a atender as demandas de parte de elites regionais. Atores que fizeram, e fazem prevalecer seus interesses e ganhos por lobbies e representantes inseridos no parlamento, mas também em agências reguladoras e demais entidades oficiais nas esferas de gestão energética pública. No caso brasileiro a quantidade de entes oficiais envolvidos como empresas agências ministérios e órgãos de governo revestem o sistema de uma legitimação necessária, mas na prática favorecem os atores com maiores recursos financeiros, políticos e informacionais. Exatamente a mesma lógica configuracional que acabou prevalecendo no Texas.

\subsubsection{Participação PG / Participation EFS}

Processos de participação política dos atores sociais nos PG e em EFS possuem históricos distintos coligados as variáveis constitucionais diferenciada de cada um de seus países e, em parte, derivado de seus respectivos estados e territórios. Enquanto no Brasil inexistem constitucionalmente e legalmente (Política Energética) mecanismos de participação pública para deliberação de regulamentações em energia na escala local, nos Estados Unidos as comunidades historicamente as possuem.

Embora, tanto o Rio Grande do Sul, quanto o Texas tenham um forte apelo aos laços comunitários, como por exemplo, a forte tradição associativista e cooperativista gaúcha e comunitária texana, esses aspectos não foram suficientes para reverter o atual cenário nas duas áreas de produção. $\mathrm{Na}$ prática, nos dois estados e áreas de produção, a participação política foi considerada 'ruim' nos PG e 'regular' em EFS (Figuras 45 e 46). 


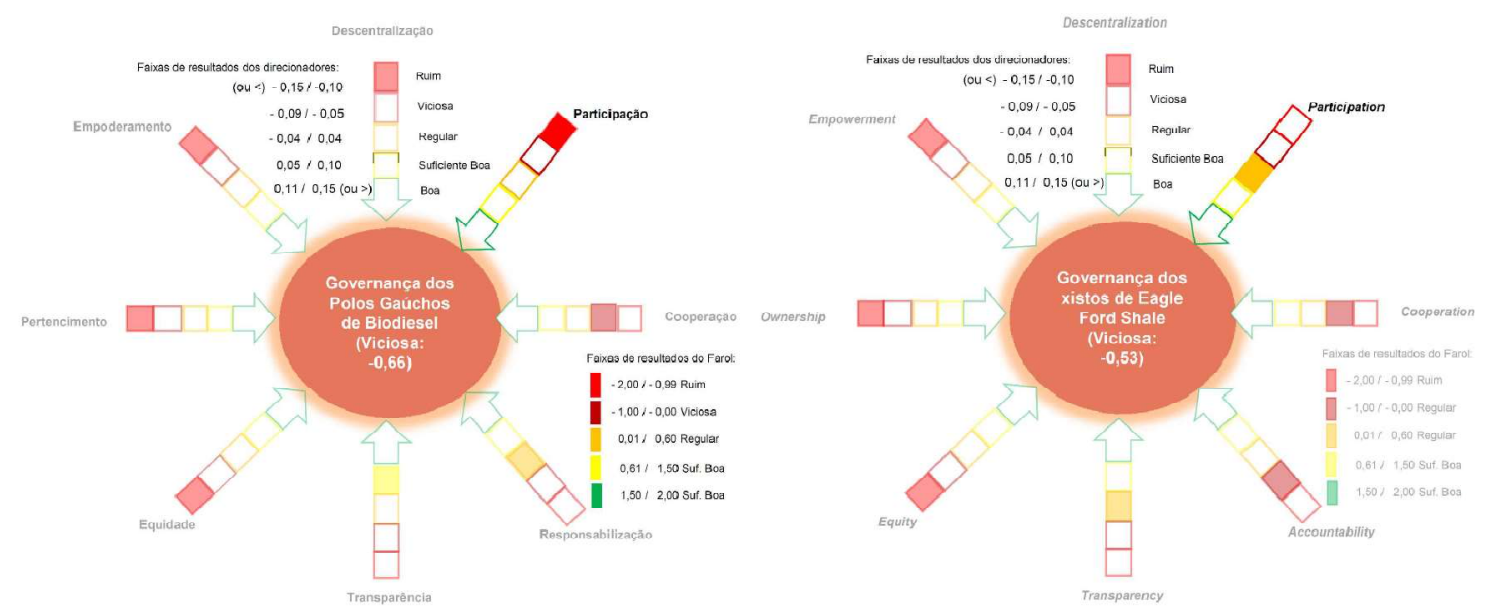

Figura 45 e 46 - direcionador da participação (PG) / participation (EFS).

Fonte: elaborado pelo autor.

Isso porque na comparação entre esses critérios (Tabela 12), inexistem conselhos, comitês, fóruns ou audiências públicas nos PG voltados a discutir os rumos, normas e regras de produção de biodiesel, enquanto no caso do Texas, a autonomia das comunidades de EFS em as arenas políticas locais desenhadas para decidir sobre os padrões e rumos das Oil and Gas Ordinances foram inicialmente negligenciadas e, posteriormente, cerceadas de grande parte de suas prerrogativas e incumbências.

Nos PG, o único projeto desenhado pelo MDA (também de concepção top-down) com intuito de fomentar a participação, o Projeto Polos, foi dissolvido no final de 2013. A ruptura eliminou a formação de quaisquer elementos condutores ou formadores de uma lógica de ação coletiva, seja para o recurso energético, seja para o manejo dos recursos naturais que dão base a produção do biocombustível. Vale destacar que os Polos não possuíam prerrogativas legais de deliberação, mas apenas da intenção de articular os participantes da cadeia produtiva nas áreas de produção.

Dentro dessa configuração fecharam-se acordos comerciais entre produtores familiares, suas cooperativas e as indústrias de biodiesel, sobretudo, dentro da lógica das certificações DAP-sindicatos-SCS. Não houve, entretanto,a experiência emancipatória de amadurecimento de dispositivos coletivos independentes ou deliberativos capazes de modificar o rumo da política na escala local, ou mesmo, contribuir para a modificação das subjetividades e percepções dos atores.

De forma geral, como destacado no capítulo IV, o que se convencionou chamar de 'participação' da agricultura familiar, por exemplo, funcionou muito mais como uma 'inserção produtiva' amarrada por estímulos financeiros. Um processo mantido na realidade pelas subvenções e incentivos econômicos das certificações do MDA, que de forma concreta subordinou os produtores rurais ainda mais aos interesses e oscilações do setor agroindustrial sojicultor. 


\begin{tabular}{c|c|c}
\hline $\begin{array}{c}\text { Direcionadores/ Paisagem } \\
\text { Energética }\end{array}$ & $\begin{array}{c}\text { Polos Gaúchos/Brasil } \\
\text { (Biodiesel) }\end{array}$ & $\begin{array}{c}\text { Eagle Ford Shale/ U.S. } \\
\text { (Hidrocarbonetos de Xisto) }\end{array}$ \\
\hline Participação vs. & $\begin{array}{c}\text { Destituição de elementos condutores e } \\
\text { formadores de ação coletiva dos } \\
\text { recursos energéticos e/ou naturais } \\
\text { (Dissolução das iniciativas de incentivos } \\
\text { à participação política local: Polos de } \\
\text { Biodiesel/MDA); }\end{array}$ & $\begin{array}{c}\text {-Destituição de elementos condutores e } \\
\text { formadores de ação coletiva dos } \\
\text { recursos energéticos e/ou naturais } \\
\text { (Reprodução das 'Ordinances'sem o } \\
\text { debate público); }\end{array}$ \\
$\begin{array}{c}\text { - Inexistência de espaços/arenas de } \\
\text { participação política pública conforme } \\
\text { legislação da Política Energética } \\
\text { Nacional; }\end{array}$ & $\begin{array}{c}\text {-Tolhimento dos espaços/arenas de } \\
\text { locais de participação pela HB40 do } \\
\text { Legislativo Texano; }\end{array}$ \\
\hline
\end{tabular}

Tabela 11 - participação (PG) vs.participation (EFS).

Fonte: Elaborado pelo autor.

Em EFS, por sua vez, no início do boom o processo de participação política foi atropelado pelas próprias autoridades locais no seu desejo, afã, de atrair o mais rápido possível as atividades e recursos financeiros do setor energético. De maneira geral, as pequenas e médias cidades reproduziram ou mantiveram ordinances de forma favorável a instalação das companhias energéticas e aos seus processos de produção utilizando fracking e flarings. Isso não impediu, entretanto, que focos de oposição e crítica emergissem seguindo o exemplo do acontecido na cidade de Denton, pelos movimentos de associações e entidades civis de College Station, cidade inserida nos territórios de produção energética, mas que representa um dos maiores núcleos universitários do país.

Diante desse quadro, as pressões e interesses das elites regionais, bem como, de parte dos interesses locais, sobretudo, dos mineral owners, ganharam força no Congresso Texano e conseguiram prevalecer sua lógica (HB40) e 'mudar as regras do jogo'de modo a fazer valer seus interesses e vantagens imediatas. Uma manobra que, na prática, cerceou a maior parte da capacidade de participação política e autonomias históricas dos governos locais de EFS sob a regulação e gestão, não apenas do petróleo e do gás, mas também sobre o uso de recursos naturais atrelados a produção dos hidrocarbonetos não-convencionais. A participação política continua sendo um dispositivo legal, porém de efetividade regular nas cidades de EFS, uma vez que é limitada a alguns aspectos das atividades de 'superfície' do setor energético.

\subsubsection{Cooperação PG / Cooperation EFS}

Considerado como um dos elementos de importância central na qualidade de sistemas de governança, o princípio de cooperação e seus respectivos Direcionadores nos PG e em EFS obtiveram desempenhos sofríveis, em ambos os casos considerados como 'viciosos' (Figuras 47 e 48). 


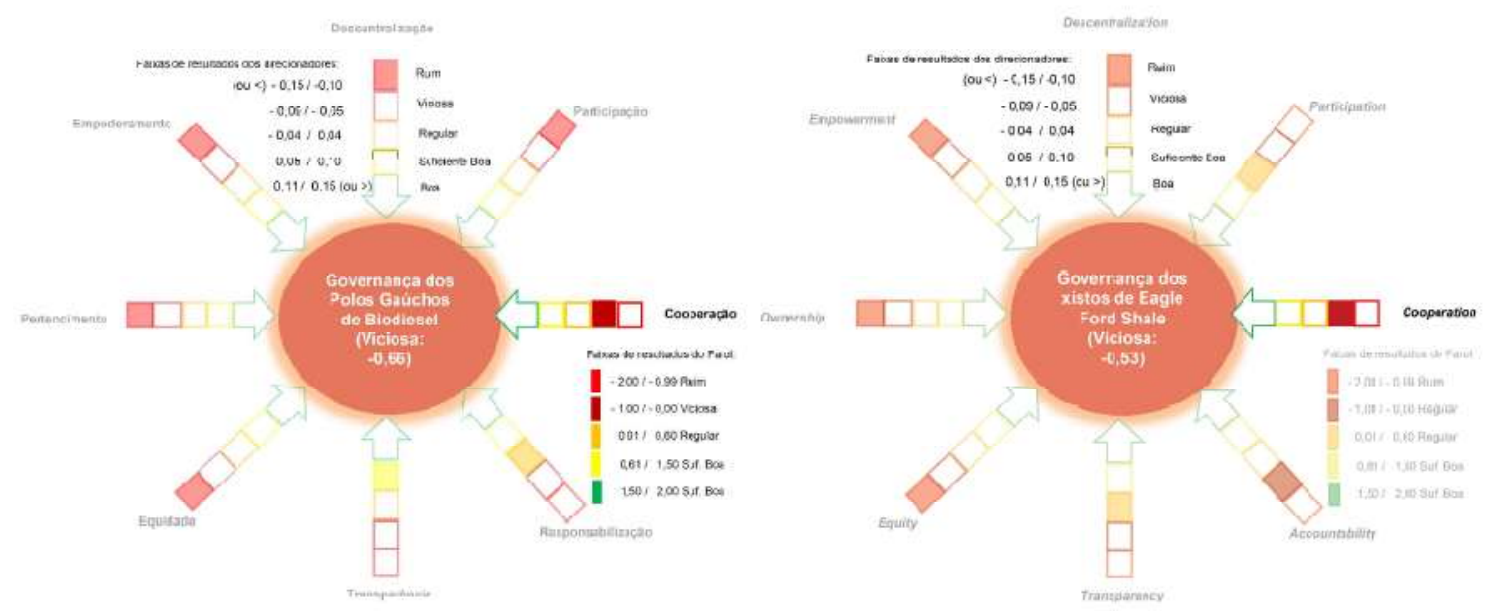

Figuras 47 e 48 - direcionador da cooperação (PG) vs. cooperation (EFS). Fonte: elaborado pelo autor.

$\mathrm{Na}$ comparação entre o critério entre as duas paisagens energéticas, tanto nos PG quanto emEFS (Tabela 13) existem falhas de condução ou mesmo de interpretação quanto aos mecanismos de cooperação, colaboração e parcerias entre os atores e instituições participantes. Elementos que revelam em ambos os caso a fragilidade dos quesitos de cooperação perante a avaliação proposta.

No caso dos PG, a razão se deve em virtude de fatores claros. Em primeiro lugar as parcerias público-privadas são mantidas de forma artificial entre os atores e instituições envolvidas. A lógica segue o mesmo raciocínio de subvenções, estímulos financeiros e tributários para manter a coesão e a inserção produtiva dos agricultores junto ao setor empresarial, ou seja, incentivos econômicos para promover ações conjuntas e projetos contínuos de colaboração entre produtores rurais, cooperativas e as indústrias de óleo/farelo/biodiesel.

Essa configuração, entretanto, demonstrou-se insuficiente para conter o aumento do ambiente concorrencial e de desconfiança mútua entre esses mesmos atores, em especial, do desconforto das cooperativas em relação ao aumento da área de influência das agroindústrias energéticas em relação aos espaços de atuação consolidadas das cooperativas. Uma mostra da fragilidade de cooperação dentro dos atuais dispositivos DAP-sindicatos-SCS.

Nos PG também é nítido um problema bastante comum no Brasil em relação à gestão de políticas públicas onde ocorre comumente a sobreposição, pulverização ou mesmo os conflitos de coordenação entre planos, programas e projetos conduzidos por diferentes escalas e instâncias de governos. Casos como os observáveis diretamente na área de pesquisa, onde existem dissonâncias entre atores que conduzem projetos, por exemplo, no escopo da Secretaria de Desenvolvimento 
Territorial e a Secretaria de Agricultura Familiar que apesar de estarem abrigados no mesmo ministério 'falam línguas e tem ações completamente diferentes'.

\begin{tabular}{|c|c|c|}
\hline $\begin{array}{c}\text { Direcionadores/ Paisagem } \\
\text { Energética }\end{array}$ & $\begin{array}{l}\text { PG /Brasil } \\
\text { (Biodiesel) }\end{array}$ & $\begin{array}{c}\text { EFS/ U.S. } \\
\text { (Hidrocarbonetos de folhelho) }\end{array}$ \\
\hline $\begin{array}{c}\text { Cooperação vs. } \\
\text { Cooperation }\end{array}$ & $\begin{array}{c}\text { - Caracterizada por parcerias público- } \\
\text { privadas artificiais entre os atores das } \\
\text { cadeias produtiva implementada pela } \\
\text { política pública (PNPB); } \\
\text {-Caracterizada atualmente pela } \\
\text { concorrência acirrada entre } \\
\text { cooperativas, agroindústrias e } \\
\text { cerealistas pelos contratos com os } \\
\text { produtores rurais; } \\
\text {-Nível sofrível de coordenação entre as } \\
\text { políticas públicas federais, estaduais e } \\
\text { locais; } \\
\text { - Lógica Economicista: apoiada em } \\
\text { mecanismos artificiais de mercado como } \\
\text { subsídios e incentivos econômicos (SCS } \\
\text { \& DAP); }\end{array}$ & $\begin{array}{c}\text { - Entendida pelas autoridades locais } \\
\text { comopatrocínios, doações e } \\
\text { voluntariado das companhias } \\
\text { energéticas; } \\
\text { - Caracterizada recentemente pelos } \\
\text { conflitos de autonomia regulatória entre } \\
\text { os municípios (Municipal League) e o } \\
\text { Governo Estadual; } \\
\text {-Baixo nível de coordenação entre as } \\
\text { políticas públicas federais, estaduais e } \\
\text { locais; } \\
\text {-Lógica Economicista: baseada na } \\
\text { arrecadação (revenues), royaltiese nas } \\
\text { taxas sobre vendas (sales taxes); }\end{array}$ \\
\hline
\end{tabular}

Tabela 12 -cooperação vs. cooperation.

Fonte: Elaborada pelo autor.

Em EFS, os problemas de cooperação estão mais correlacionados as distorções feitas por grande parte das autoridades locais na interpretação do significado de partnerships ou parcerias. É comum que representantes de governos locais e suas agências de desenvolvimento, como as Câmaras de Comércio, de grande influência nos Estados Unidos, e no Texas, assumam discursos que resumem as parcerias as sponsorships \& donations, bem como as ações de volunteer feitas pelas companhias energéticas.

Apesar disso, ainda que pontualmente, foi possível relatar a crítica de agentes de desenvolvimento local que manifestaram seu desapontamento com o comportamento atual das companhias e seu baixo envolvimento com as cidades e comunidades. Um sentimento que reflete o baixo comprometimento das empresas com as comunidades locais, e que se resume a lógica do: quanto de dinheiro você precisa.

Exatamente nesse ponto se dá a convergência entre a racionalidade comum entre os PG e EFS. Prevalece uma lógica economicista comum que está atrelada no Brasil aos incentivos econômicos e tributários oferecidos pelo Governo Federal, enquanto de outro lado, nos Estados Unidos, dentro da lógica liberal, é exercido de forma livre e sem questionamentos éticos pelas empresas que garantem fluxos generosos de doações às comunidades locais. 


\subsubsection{Responsabilização PG/ Accountability EFS}

Os quesitos de responsabilização dos PG e de EFS revelaram uma leve discrepância de desempenho das duas paisagens energéticas. Enquanto no caso texano existe uma configuração 'viciosa' na avaliação de accountability correlativas as atividades energéticas dos folhelhhos, nas áreas de produção de biodiesel gaúchas, ainda que com ressalvas, obtiveram uma performance 'regular' (Figuras49 e 50).

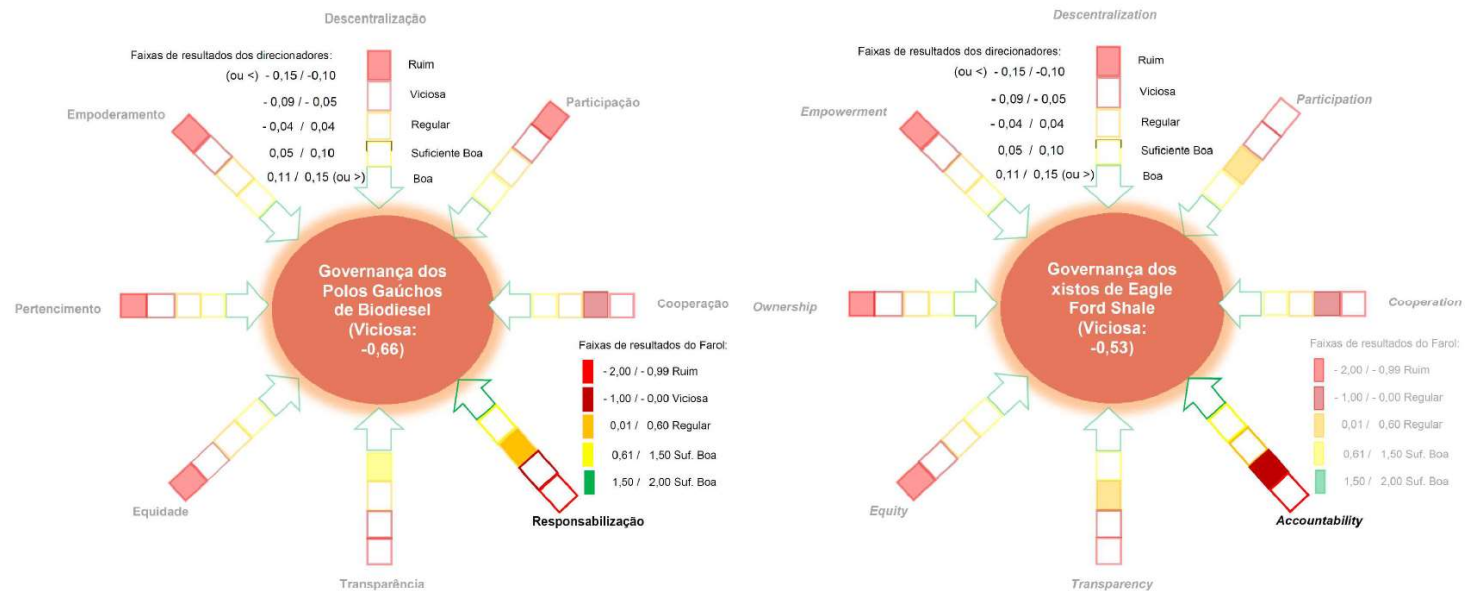

Figura 49 e 50 - direcionador de responsabilização vs. accountability.

Fonte: Elaborada pelo autor.

Na comparação entre a qualidade de responsabilização nas duas áreas de produção (Tabela 14) o controle federal do governo brasileiro no estabelecimento de normas de ordenamento e uso do território, juntamente com as regras conjuntas entre união, governo estadual e municipal em relação às normas de licenciamento ambiental das atividades produtivas, foi considerado superior ao posto em prática pelas autoridades texanas. No Brasil, estão postos os mecanismos de comando, controle e penalidades de responsabilização, embora persistam questionamentos contundentes sobre a eficácia desses dispositivos na fislcalizaçao e controle, entre outras, de atividades industriais e mineradoras.

O que se quer dizer é que as atividades do elo agrícola, apesar de falhas, estão submetidas a critérios de responsabilização e conduta das atividades produtivas rurais, sobretudo, pelo novo Código Florestal que estabelece zoneamentos e critérios de manutenção de áreas de preservação. Assim como, as atividades industriais estão sujeitas aos procedimentos legais de emissões e manutenção de licenças ambientais. No caso americano, entretanto, caracterizado por um padrão bastante heterogêneo entre os estados, o Texas e suas agências reguladoras não são casos exemplares de accountability para o setor energético. 


\begin{tabular}{c|c|c}
\hline $\begin{array}{c}\text { Direcionadores/ Paisagem } \\
\text { Energética }\end{array}$ & $\begin{array}{c}\text { Polos Gaúchos/Brasil } \\
\text { (Biodiesel) }\end{array}$ & $\begin{array}{c}\text { Eagle Ford Shale/ U.S. } \\
\text { (Hidrocarbonetos de Xisto) }\end{array}$ \\
\hline Responsabilização vs. & $\begin{array}{c}\text { - Controlefederal/estadual do } \\
\text { ordenamento e uso do território } \\
\text { (Zoneamento agrícola) e de } \\
\text { licenciamentoambiental das } \\
\text { accountandústrias; }\end{array}$ & $\begin{array}{c}\text { - Controle estadual no uso e } \\
\text { ordenamento do uso do território } \\
\text { (Flexibilidade nasPermissões e } \\
\text { delimitações de uso da superfície\& } \\
\text { lacunas derivadas do 'Halliburton } \\
\text { Loophole'); }\end{array}$ \\
$\begin{array}{c}\text { - Baixa incorporação de princípios de } \\
\text { precaução em casos de risco e } \\
\text { incertezas socioambientais; } \\
\text { (APP e RL's vs. SCS e Inexistência de } \\
\text { um Zoneamento Ecológico Econômico } \\
\text { da Soja) }\end{array}$ & $\begin{array}{c}\text {-Baixa incorporação de princípios de } \\
\text { precaução em casos de risco e } \\
\text { incertezas socioambientais } \\
\text { (contaminação hídrica, atmosférica, } \\
\text { segurança residencial); }\end{array}$ \\
\hline
\end{tabular}

Tabela 13 - responsabilização vs accountability.

Fonte: Elaborada pelo autor.

Ao que tudo indica em EFS, bem como em todo o estado, a responsabilização sob os procedimentos a cargo da $R R C$ e a TECQ, tem se demonstrado bastante flexíveis com as companhias energéticas, coniventes com falhas reincidentes, ou mesmo ineficientes frente aos interesses $e$ atividades produtivas das indústrias de $O \& G$. Raramente, os oficiais da $R R C$, responsáveis pelas emissões de Permits, equivalente a uma licença de operação, encaminham medidas cautelares às companhias infratoras ou levam a cabo processos de encaminhamento de "enforcement" ou cancelamento das atividades de empresas.

Os procedimentos da TECQ também são vagos e inadequados frente ao controle e responsabilização das companhias com relação ao volume de componentes tóxicos e carbono emitidos na região. Situações, como destacadas no capítulo $V$, que levaram a conflitos judiciais entre o estado do Texas e a Agência de Proteção Ambiental americana (EPA),em que em mais de uma ocasião, estado e Uniãose enfretaram na justiça tendo por basea alegação de interferência ilegal da agência federal nas questões estaduais, no qual o objeto dos conflitos judiciais era a eficácia das agências reguladoras texanas frente aos processos de controle, licenciamento e responsabilização das atividades energéticas e industriais.

Nos dois casos, entretanto, seja nos PG, seja em EFS é muito baixa a incorporação do princípio da precaução frente aos riscos e incertezas causados pela produção energética. No caso brasileiro, por exemplo, não existe um Zoneamento Ecológico Econômico (ZEE) da soja, ou qualquer procedimento de dimensionamento e responsabilização socioambiental da sojicultura e as agroindústrias envolvidas na produção de grãos, farelo, óleo e biodiesel.

De forma complementar, o Selo Combustível Social não traz em seu escopo nenhum tipo de incorporação de responsabilidade ou responsabilização ambiental. Não há, por exemplo, nenhuma ligação entre a certificação SCS e o 
Cadastro Rural Ambiental (CAR) enquadrando a produçao de oleaginosas frente à obrigatoriedade de preservar ou recompor as áreas de proteção permanente (APP) ou as reservas legais $(R L)$. Especialmente, no estado do Rio Grande do Sul onde o índice de ajustamento aos novos patamares estabelecidos pelo Código Florestal é o menor do país.

De forma complementar em Eagle Ford, as execuções falhas de $R R C \mathrm{e}$ $T E C Q$, as autoridades públicas, sejam elas estaduais, sejam elas locais, também não levam em conta a devida precaução e prudência no estabelecimento das regulações das atividades energéticas. Em College Station, antes da publicação da $H B 40$, por exemplo, prefeito e conselheiros municipais, mesmo com a expressão tácita dos cidadãos na audiência pública demonstrando sua preocupação frente os possíveis impactos do fracking, não obtiveram uma resposta cautelosa de seus representantes. Pelo contrário, os legisladores locais mantiveram uma postura conservadora e pouco prudente no zoneamento e responsabilização das atividades energéticas.

\subsubsection{Transparência PG / Transparency EFS}

A análise do Direcionadorde Transparência nos processos políticoprodutivos nos $P G$ e em EFS novamente revelou uma pequena diferença de desempenho do princípio nas duas paisagens energéticas. Enquanto no caso brasileiro existe, ainda que com ressalvas, uma configuração 'suficientemente boa', a transparência dos sistemas de governançade EFS obteve uma performance'regular' (Figuras 51 e 52).

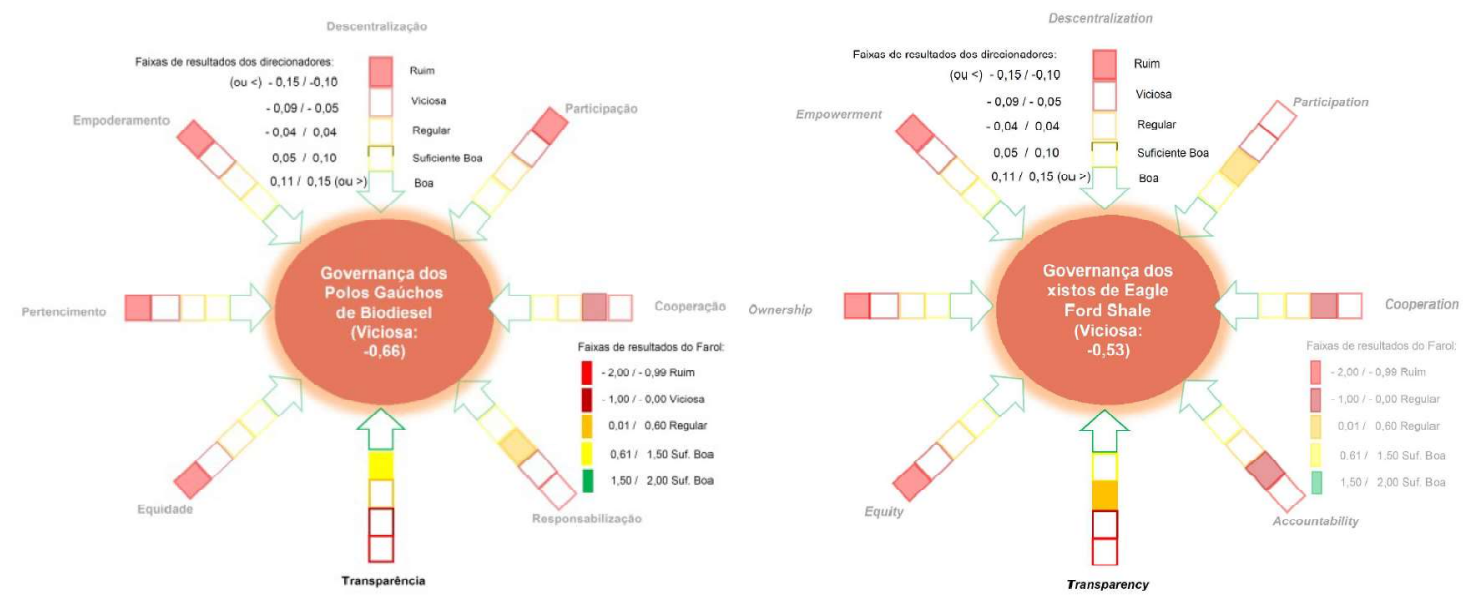

Figuras51 e 52 - direcionador transparência vs. transparency.

Fonte: Elaborada pelo autor. 
Na comparação do Direcionador entre os PG e EFS (Tabela 15), o que contou foram os elementos de obrigatoriedade, superficialidade e incipiência de canais e mecanismos de transparência. Um quesito observado tanto nos órgãos fiscalizadores oficiais como no grau de comprometimento das agroindústrias e companhias energéticas em divulgar seus procedimentos e produtos.

\begin{tabular}{c|c|c}
\hline $\begin{array}{c}\text { Direcionadores/ Paisagem } \\
\text { Energética }\end{array}$ & $\begin{array}{c}\text { PG /Brasil } \\
\text { (Biodiesel) }\end{array}$ & $\begin{array}{c}\text { EFS/ U.S. } \\
\text { (Hidrocarbonetos de Xisto) }\end{array}$ \\
\hline Transparência vs. & $\begin{array}{c}\text { - Boa disponibiidade de acesso aos } \\
\text { processos e trâmites regulatórios, } \\
\text { concentrados na esfera federal e } \\
\text { estadual; }\end{array}$ & $\begin{array}{c}\text { - Disponibilidade incipiente e ainda frágil } \\
\text { quanto ao acesso aos trâmites } \\
\text { administrativos, processuais } \\
\text { regulatórios, }\end{array}$ \\
& $\begin{array}{c}\text { - Disponibilidade de dados técnicos e } \\
\text { produtivos, mas baixo esclarecimento da } \\
\text { periculosidade dos elementos químicos; }\end{array}$ & $\begin{array}{c}\text { - Elevada desinformação e divulgação } \\
\text { dosdados produtivos e compostos } \\
\text { químicos utilizados no "fracking"; }\end{array}$ \\
\hline
\end{tabular}

Tabela 14 - transparência vs.transparency.

Fonte: Elaborada pelo autor.

No caso dos PG, por exemplo, existem canais favoráveis de divulgação de atividades administrativas dos órgãos oficiais envolvidos, embora ainda sejam mecanismos que falham na rapidez, clareza e acessibilidade. É possível acessar informações de trâmites processuais e regulatórios em curso e obter informações sobre número de famílias, cooperativas fornecedoras, volumes e valores de matéria prima negociados no âmbito do Selo Combustível Social. Ainda são frágeis, entretanto, informações mais detalhadas sobre contratos, firmados entre cooperativas, e produtores individuais, ou dos contratos entre indústrias dentro e fora de seus respectivos estados de origem. Igualmente são superficiais as informações prestadas por órgãos como BNDES e Petrobrás em contratos de investimentos, parcerias e financiamentos concedidos.

As indústrias não guardam segredo dos processos químicos e industriais utilizados na fabricação do biodiesel. Elas não são obrigadas por lei a fazêlo, porém, conforme destacado por Juarez (2011), ampliam, com esse comportamento, a periculosidade do uso de compostos como o metanol utilizado na transesterificação do óleo vegetal. Além disso, a ausência de divulgação de dados de procedimentos relativos a descarte de produtos químico-industriais e uso de recursos naturais, como a água empregada na hidratação do biocombustível, inibe um maior controle e/ou a ação de órgãos ambientais e de defesa civl em casos de falhas de segurança, sinistros e contaminação do ambiente.

A transparência de dados e informações sobre trâmites administrativos, fiscalizatórios e processuaisna governança dos folhelhos de EFS, por sua vez, foi considerada regularporque os canais de acesso impostos às agências regulatórias pela General Approtiations Act são relativamente recentes e ainda frágeis quanto ao 
nível de detalhamento e conteúdos. Entidades e associações civis reclamam da falta de informações mais detalhadas sobre violações, quantidade de penalidades e multas emitidas aos operadores. A apresentação de relatórios bimestrais de empresas envolvidas em violações e ajustes de conduta ainda são alvos críticos das fragilidades das agências no critério (TEXAS, 2011 Rider 17).

Vale destacar, entretanto, que o que compromete o quesito em EFS é a insistência de não-divulgação dos elementos químicos empregados no fraturamento hidráulico. Uma prerrogativa derivada das exempts conquistadas no texto final da EPACT (2005) que garantiu ao setor em todo país, a desobrigatoriedade de divulgarem seus segredos industriais. Na prática o enclosure dos procedimentos e produtos utilizados no fracking, além de constituir uma falha na transparência dos procedimentos industriais, é um potencializador de riscos e incertezas associados ao controle da atividade de exploração dos hidrocarbonetos não-convencionais. Adicionalmente, como destacado no capítulo IV, conflitos de interesse entre os diretores das agências reguladoras em relação às companhias energéticas põem em xeque a forma clara e isenta da divulgação dos dados.

O baixo comprometimento com uma maior abertura na transparência de procedimentos químicos e industriais, bem como, de compartilhamento de informações sobre procedimentos de segurança e também os planos de ação para uso, reutilização, manejo e descarte de água são pontos em comum nas falhas de transparência na atividade industrial de ambos as áreas de produção energética.

\subsubsection{Equidade PG / Equity EFS}

O Direcionador de Equidade foi considerado como 'ruim' tanto na análise dos PG quanto de EFS (Figuras 53 e 54). Nos dois arranjos políticoinsititucionais o princípio configura-se como característica que mais compromete a avaliação de governança dos recursos energéticos nos dois estudos de caso. De maneira bastante clara, em ambos os casos, é considerável a assimetria de poderes e recursos (informacionais, políticos e econômicos) entre os atores sociais e instituições, assim comoé bastante desigual a distribuição de direitos, ganhos, vantagens, mas, sobretudo no provável desequilíbrio socioambiental gerado. 


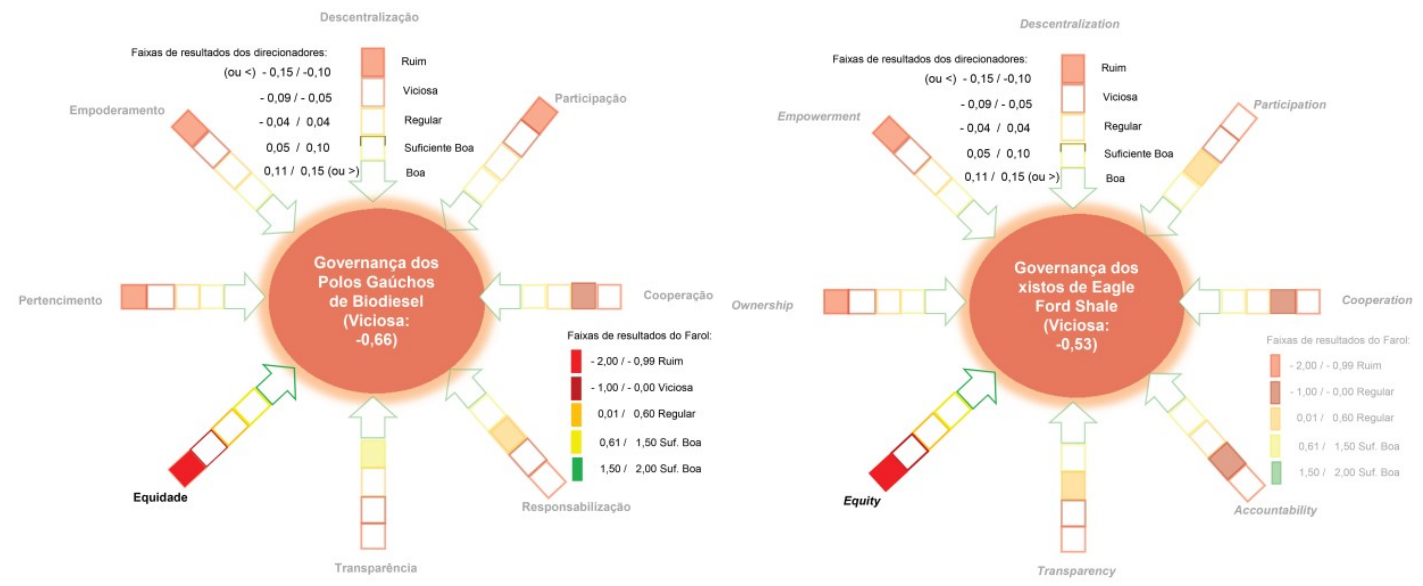

Figura 53 e 54 - Direcionador de Equidade vs. Equity.

Fonte: Elaborada pelo autor.

Entre todos os Direcionadoresa comparação das duas paisagens energéticos, a partir da análise do princípio de Equidade foi o que apresentou o maior número de características negativas comuns (Tabela 15).

\begin{tabular}{c|c|c}
\hline $\begin{array}{c}\text { Direcionadores/ Paisagem } \\
\text { Energética }\end{array}$ & $\begin{array}{c}\text { PG /Brasil } \\
\text { (Biodiesel) }\end{array}$ & $\begin{array}{c}\text { EFS / U.S. } \\
\text { (Hidrocarbonetos de Xisto) }\end{array}$ \\
\hline \multirow{2}{*}{ Equidade vs. } & $\begin{array}{c}\text {-Inequidade nas decisões de } \\
\text { regulações; }\end{array}$ & $\begin{array}{c}\text {-Inequidade nas decisões de } \\
\text { regulações; }\end{array}$ \\
& $\begin{array}{c}\text {-Disparidades de ganhos e direitos na } \\
\text { exploração dos recursos; }\end{array}$ & $\begin{array}{c}\text {-Disparidades de ganhos e direitos na } \\
\text { exploração dos recursos; }\end{array}$ \\
& $\begin{array}{c}\text {-Inequidade na decisão sobre a } \\
\text { aplicação das receitas e taxas; } \\
\text {-Desigualdades socioambientais } \\
\text { geradas; }\end{array}$ & $\begin{array}{c}\text {-Inequidade na decisão sobre a } \\
\text { aplicação das receitas e taxas; }\end{array}$ \\
& - Desiguladades socioambientais \\
& geradas;
\end{tabular}

Tabela 15 - equidade vs.equity.

Fonte: Elaborada pelo autor.

Nos Polos Gaúchos a inequidade é resultado, em primeiro lugar, da concentração das arenas políticas e das tomadas de decisões na esfera federal resumindo a participação política a uma inserção produtiva. $O$ fato de não haver nenhuma prerrogativa de voto e decisões na implementação de regulações, elimina-se qualquer chance de protagonismo dos atores locais no tocante ao desenvolvimento de projetos inovadores com o biodiesel, ou mesmo, de exercer maior direito de opinião na aplicação de receitas e taxas oriundas das atividades agroindustriais.

De forma concreta, enquanto grupos como a Ubrabio, Aprobio, Abiove, entre outros, têm estratégias claras e proativas de divulgação de materiais, revistas e estudos, além de uma eficiente articulação, organização e pressão frente aos poderes públicos, outros segmentos participantes, como produtores rurais, cooperativas e 
sindicatos exercem muito mais um papel de atores legitimadores das linhas de ação, ou das normas e regras do PNPB.

$\mathrm{Na}$ atual configuração de governança do biodiesel gaúcho que se reproduz também em escala nacional, inexistem, portanto, equidade de direitos e autonomias para que os atores locais, como comunidades rurais, periurbanas e urbanas desenvolvam novas percepções e subjetividades no uso do recurso energético e, simultaneamente, no uso e exploração dos recursos naturais (água, solo, áreas de preservação) que são utilizados, ou que oferecem aos serviços ecossitêmicos para a estabilidade necessária ao elo agrícola, base da cadeia produtiva do biocombustível.

Ao serem postos às margens das decisões, os atores locais, especialmente os agricultores, perdem oportunidades e ganhos possíveis na exploração do novo recurso energético e se resumem apenas ao papel de vendedores de grãos, interessados somente nos maiores retornos de seus trabalhos e derivadodas riquezas naturais de suas propriedades. Adicionalmente, e de forma mais grave, a inequidade se reforça quando levado em consideração a distribuição dos impactos sociais e dos passivos ambientais que são gerados normalmente pela intensificação de quaisquer monoculturas. No caso dos PG, esse quadro amplifica uma superdependência da sojafrente às demandas crescentes do trinômio óleo/farelo/biodiesel, trazendo consigo uma distribuição injusta dos riscos e incertezas futuras às comunidades atreladas à intensificação agrícola e industrial, ambos dependentes de uma commodity de histórico impactante e oscilante.

De forma bastante similar se dá a relação de poderes e direitos entre os atores sociais inseridos e interligados na governança em EFS, ou seja, de forma assimétrica e desfavorável. Concretamente, as companhias energéticas organizadas sob forma de associações e organizações, em conjunto com práticas regulares de lobby, exercem grande influência e poder no Congresso Texano (Texas Legislature). Entidades como a API, IPAA, TXOGA e STEERalinham-se com associações como The Texas Land \& Mineral Owners Association e a Texas Consumer Energy Alliance estendendo sua influência e poder para órgãos e agências reguladoras onde os comissários eleitos, ou nomeados, geralmente possuem um histórico em comum ou dividem interesses convergentes ao setor de O\&G.

Como destacado no capítulo $\mathrm{V}$, esse layout favorece a inadequação e assimetria de poderes e decisões, inclusive, de atalhos legais para as companhias, sistemas e regimes legais mais flexíveis e complacentes para o interesse das empresas do setor energético. O próprio deslocamento normativo, e a tomada de prerrogativas e poderes pelo governo estadual, em detrimento da autonomia dos 
governos locais, exemplificam claramente o descompasso de forças que caracteriza o arranjo político-insitucional no estado.

O padrão também marginaliza grande parte dos cidadãos e comunidades de EFS, uma vez que restringe as oportunidades de ganhos, direitos e vantagens na exploração dos recursos energéticos. Benesses concentradas para as empresas e para os poucos mineral owners interessados somente em obter bons valores de leasing por acre no aluguel de seu subsolo para as companhias do setor. Um quadro que se agrava frente à desigual distribuição dos riscos socioambientais negativos que normalmente são gerados pela intensificação da exploração de hidrocarbonetos. Adicionalmente, amplificam uma nova superdependênciado petróleo e a distribuição injusta dos riscos e incertezas socioeconômicas e ambientais futuras frente aos ciclos de alta e baixa da commodity no cenário mundial.

\subsubsection{Pertencimento PG / Ownership EFS}

Outro quesito desfavorável na estrutura de governança dos PG e de EFS é o critério, ou princípio de pertencimento. Isso porque o layout políticoinsitucional, nos dois casos em estudo, favorece fatores como a concentração de poderes, a fraca participação política, a baixa responsabilização e a inequidade entre atores e instituições. $O$ desenho de ambos não foi capaz de promover uma amplitude no sentimento de protagonismo e condução das políticas e dos recursos energéticos. Tanto nos PG quanto em EFS o Direcionador foi, portanto, considerado 'ruim' (Figuras 55 e 56$)$.

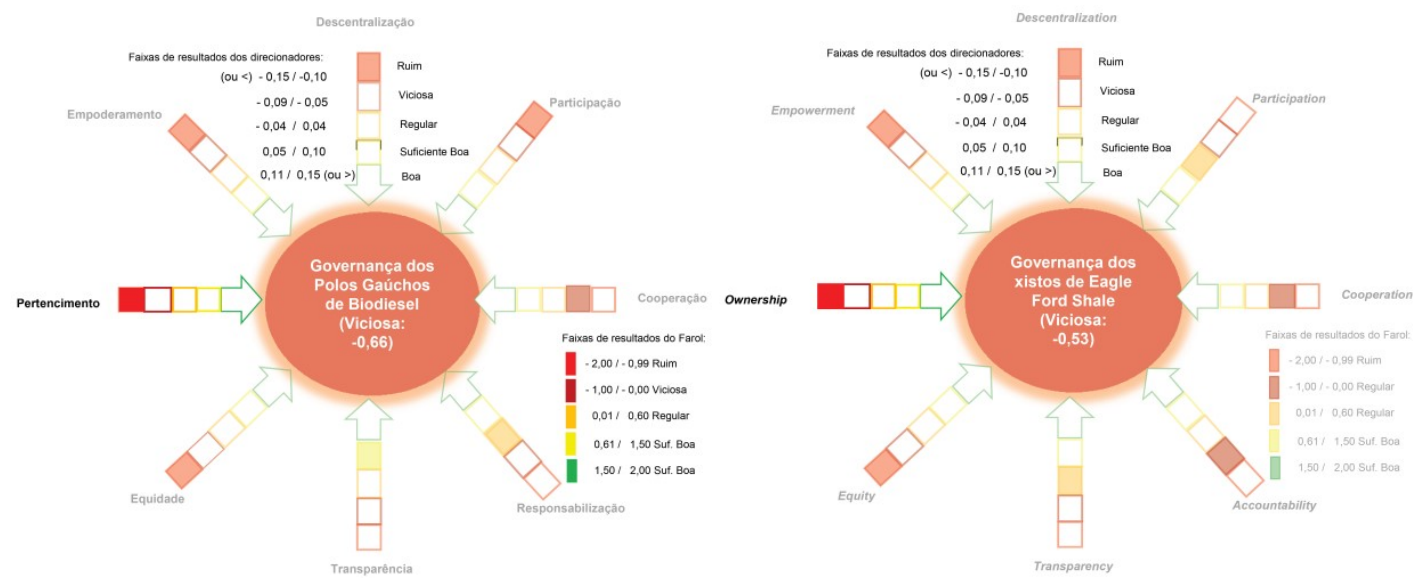

Figuras 55 e 56 - direcionador de pertencimento vs. ownweship.

Fonte: Elaborada pelo autor.

$\mathrm{Na}$ comparação das características dos dois Direcionadores (Tabela 17), foi avaliado como baixíssimo o nível, ou sensação geral de pertencimento, que as comunidades desenvolveram frente à produção energética. Uma consequência direta 
de um arranjo político que não promove o interesse e o envolvimento dos atores locais, cerceando o desenvolvimento e incorporação desses sentimentos e aspectos políticos de suma importância na governança de recursos.

\begin{tabular}{c|c|c}
\hline $\begin{array}{c}\text { Direcionadores/ Paisagem } \\
\text { Energética }\end{array}$ & $\begin{array}{c}\text { PG /Brasil } \\
\text { (Biodiesel) }\end{array}$ & $\begin{array}{c}\text { EFS / U.S. } \\
\text { (Hidrocarbonetos de Xisto) }\end{array}$ \\
\hline Pertencimento vs. & $\begin{array}{c}\text {-Baixíssimo nível de pertencimento dos } \\
\text { produtores rurais e população frente à } \\
\text { produção energética; }\end{array}$ & $\begin{array}{c}\text {-Baixíssimo nível de pertencimento da } \\
\text { população frente às polítcas de } \\
\text { exploração energética; }\end{array}$ \\
Ownership & $\begin{array}{c}\text { - Baixo interesse, envolvimento e } \\
\text { cerceamento dos atores sociais frente } \\
\text { às estruturas e processos de } \\
\text { governança; }\end{array}$ & $\begin{array}{c}\text { - Baixo interesse, envolvimento e } \\
\text { cerceamento dos atores sociais frente } \\
\text { às estruturas e processos de } \\
\text { governança; }\end{array}$ \\
\hline
\end{tabular}

Tabela 16 -pertencimento vs.ownership

Fonte: Elaborada pelo autor.

No caso brasileiro, a ausência de comitês, fóruns e audiências locais minam a questão do pertencimento das comunidades inseridas nos Polos Gaúchos, sobretudo, dos produtores rurais e de sua relação frente aos desafios e oportunidades da política de desenvolvimento do biodiesel. Uma configuração amarrada a deliberações Top-Down que não colaboram para o amadurecimento de um sentimento de condução conjunta, ou em comum, das diretrizes e benefícios do biocombustível.

No caso americano a sensação de ownership, é eclipsada pelo sentido de propriedade que reveste o próprio sentido da palavra na língua inglesa, agravada ainda pelo histórico de tolhimento de participação da população nas decisões tomadas inicialmente tomadas pelos mayors, city managers e counselors de EFS. Um processo que se agravou no momento do cerceamento das prerrogativas e autonomias das cidades e município provocado pela HB40 que obstruiu ainda mais a incorporação de centralidade e da sensação de serem sujeitos ativos no desenvolvimento da política e exploração energética.

\subsubsection{Empoderamento PG / Empowerment EFS}

O empoderamento dos atores sociais, último aspecto, porém, não menos importante quesito de avaliação e comparação dos sistemas de governança dos PG e de EFS, também revelou uma configuração desfavorável. Nas duas paisagens energéticas e seus respectivos territórios, o indicador defendido tanto pelas agroindústrias brasileiras quanto pelas companhias energéticas nas suas análises de desenvolvimento e empoderamento dos atores locaisé polêmico. Pelos critérios adotados na presente pesquisa, os PG e EFS têm um processo de empoderamento de qualidade 'ruim' (Figuras 57 e 58). 




Figuras 57 e 58 - direcionador: empoderamento vs empowerment. Fonte: Elaboradas pelo autor.

$\mathrm{Na}$ comparação entre as estruturas e os processos preponderantes nos dois estudos de caso (Tabela 18), não há indícios de que houve, ou esteja havendo, um processo efetivo de empoderamento dos atores sociais, sobretudo, dos mais vulneráveis. Pelo contrário, as estruturas e processos incentivam o desenvolvimento de racionalidades econômicas limitadas que muito pouco contribui para a edificação de mecanismos e dispositivos de coesão social ou da formação de um capital social necessário para empoderar as comunidades inseridas nas áreas de produção.

\begin{tabular}{|c|c|c|}
\hline $\begin{array}{c}\text { Direcionadores/ Paisagem } \\
\text { Energética }\end{array}$ & $\begin{array}{l}\text { PG /Brasil } \\
\text { (Biodiesel) }\end{array}$ & $\begin{array}{c}\text { EFS / U.S. } \\
\text { (Hidrocarbonetos de Xisto) }\end{array}$ \\
\hline $\begin{array}{l}\text { Empoderamento vs. } \\
\text { Empowerment }\end{array}$ & $\begin{array}{c}\text { - } \\
\text { Baixa diversificação da economia local } \\
\text { e/ou de novos arranjos sócio-produtivos } \\
\text { - Mecanismos inadequados ou fracos de } \\
\text { desenvolvimento local e/ ou rural, ou } \\
\text { pluriatividade das funções e ocupações } \\
\text { rurais; } \\
\text { - Concentrado na lógica economicista do } \\
\text { aumento de renda }\end{array}$ & $\begin{array}{c}\text { - Baixa diversificação da economia local } \\
\text { e/ou de novos arranjos sócio-produtivos; } \\
\text { - Mecanismos duvidosos de } \\
\text { desenvolvimento local e/ ou } \\
\text { 'subsequente'; } \\
\text { - Concentrado na lógiaca economicista } \\
\text { do aumento de renda }\end{array}$ \\
\hline
\end{tabular}

Tabela 17 - empoderamento vs.empowerment.

Fonte: Elaborada pelo autor.

Em ambos os casos, a lógica do aumento da renda derivada da exploração/produção das cadeias produtivas dos recursos energéticos obscurece raciocínios voltados à consolidação de dispositivos de ação coletiva destinados, por exemplo, a sedimentarem espaços de governança local capazes de criar de forma independente e endógena, mecanismos de diversificação da economia e projetos inovadores de natureza socioeconômica e ambiental.

Nos PG a entrada do setor agroenergético per si não significou o fortalecimento da agricultura familiar e aumento da qualidade de vida dascomunidades rurais e periurbanas envolvidas na produção do biodiesel. Na realidade uma pujança 
econômica derivada do novo ciclo de valorização e comercialização da soja. As configurações político-produtivas do biocombustível, entretanto, pelos critérios adotados na presente avaliação, pouco colaboraram ao empoderamento dos atores locais.

Como frisado por Becker (1993), os processos não estimularam medidas autônomas ou ações efetivas de desenvolvimento endógeno. Processos capazes de promover o aperfeiçoamentocoletivo e individual dos atores locais e ampliar suas potencialidades sobre seus próprios territórios. O processo, de fato, resultou numa coesão social artificial e incapaz de consolidar direitos e desenvolver percepções políticas, sociais e ambientais entre os atores inseridos e interligados aos polos.

Concretamente, no caso de EFS, a lógica que se estabeleceuao redor da pujança dos royalties, revenues e sale taxes, acabou por criar uma corrida aos recursose interesses do setor energético, obstruindo a diversificação dos investimentos para outras áreas sociais, econômicas e de infraestrutura, mantendo novamente no recente boom,as comunidades de EFS reféns da 'saúde' e 'benevolência' do setor energético. Processos próprios dos efeitos de exclusão do petróleo que criam de forma prática, pouquíssimas condições alternativas à lógica de manter as companhias por mais tempo, estimulando sua permanência na base de incentivos fiscais, abatimentos de taxas e incentivos que nada melhoram o aperfeiçoamento das comunidades envolvidas.

6.2 Análise dos Resultados - Governança e Eco-governamentalidade do biodiesel do PG e dos folhelhos de EFS: Energias propulsoras ao futuro sustentável ou reprodução de trajetórias pretéritas?

O que se pode deduzir do processo comparativo entre a governança do biodiesel nos PG e dos folhelhos emEFS? O que nos diz a estrutura e os processos envolvidos? A partir dessas perguntas norteadoras básicas é apresentada uma análise final dos resultados, na qual são discutidas algumas características identificadas a partir do estudo de caso dessas duas importantes áreas de produção energética. Elementos que oferecem a oportunidade de tecer algumas considerações sobre a governança e a eco-governamentalidade, sobretudo, de pontos consoantes e dissonantes entre a regulação e gestão em energia nos países. 


\subsubsection{Estruturas e processos de governança}

Alimentado pelos dados e pelas discussões realizadas nos direcionadores, oacionamento do farol permite observar que, tanto o desempenho da governança do biodesel nos Polos Gaúchos, quanto da performance da governança nos folhelhos de Eagle Ford Shale resultaram em avaliações de estruturas e processos 'viciosos' (Figuras 59 e 60). Embora os dois sistemas apresentem configurações e mecanismos político-institucionais distintos, ambos apresentaram aspectos prejudiciais em muitas das categorias de análise utilizadas por esse estudo.

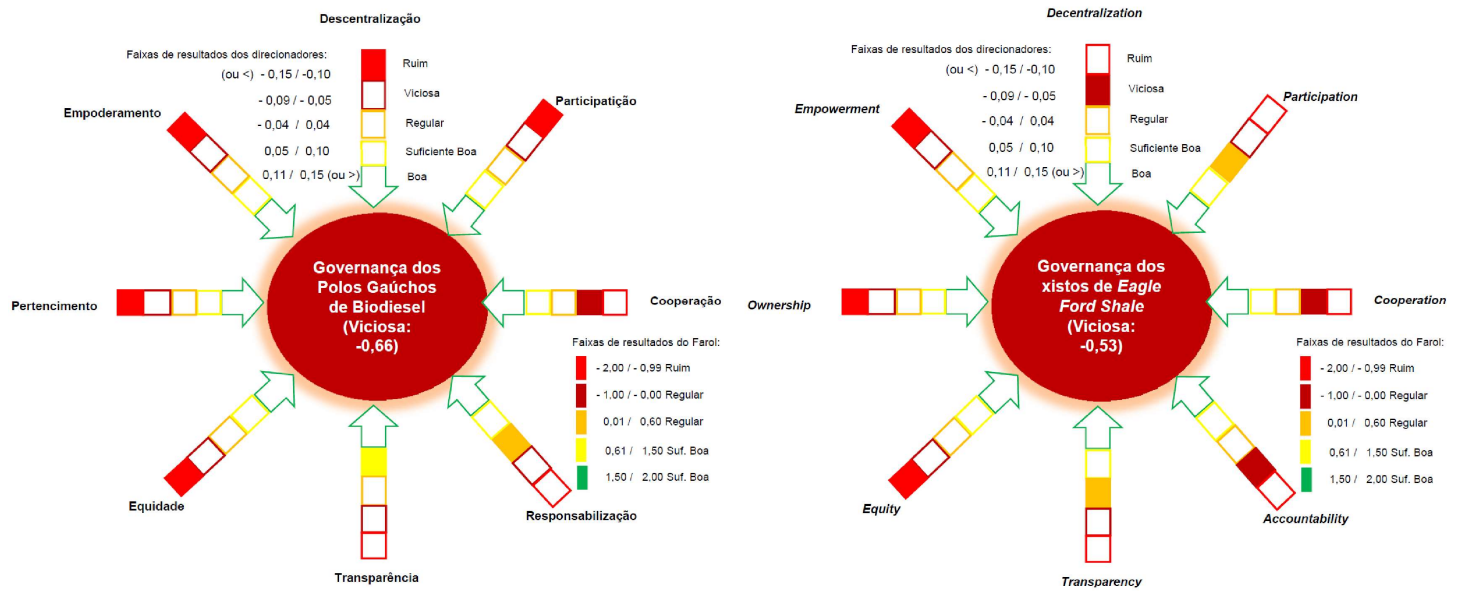

Figura 59 e 60 - farois da governança dos recursos energético PG vs. EFS. Fonte: Elaboradas pelo autor.

Tomando por base os dois casos de estudo analisados pela pesquisa (Quadro 01) é possível conjecturar que ambos os sistemas de governança são prejudicados por configurações que apesar de diametralmente distintas, guardam em comum aspectos negativos. Um primeiro exemplo se dá pelas políticas energéticas de ambos os países. A Política Energética Nacional brasileira, por exemplo, peca pela sua excessiva centralização de poderes, ao passo que a Energy Policy Act americana peca por sua excessiva descentralização. Curiosamente, em ambos os casos as duas políticas acabam sendo falhas e viciosas em promover uma participação política adequada e equilibrada.

No Brasil, por exemplo, os arranjos político-insituticionais do biodiesel estão amarrados a um sistema federativo rígido no qual as normas constitucionais e o conjunto de dispositivos legais delegam pouca autonomia aos estados e em nenhum grau aos governos locais. Muncípios e suas comunidades não possuem prerrogativas e autonomias frente aos processos de regulação e gestão de recursos energéticos. $A$ presença de quatorze ministérios na formação e gestão da política do biodiesel, materializada pela CEIB, não garantiu a perenidade de participação no programa, mas 
apenas desconcentrou na escala federal competências administrativas. Não há concretamente nenhum mecanismo que promove um rompimento dessa lógica e a maior descentralização de poderes. De forma prática todas as deliberações e as principais decisões são tomadas pela Presidência da República (PR), em conjunto com o ministro do MME, e no escopo restrito da arena política do CNPE.

\begin{tabular}{|c|c|}
\hline do & 5 \\
\hline $\begin{array}{l}\text { - Fortemente vinculada a Política Energética } \\
\text { Nacional, e aos padrões do sistema federativo } \\
\text { Brasileiro que existe uma autonomia limitada dos } \\
\text { estados e nenhuma competência aos municípios } \\
\text { para legislar e regular sobre aspectos } \\
\text { correlacionados ao biodiesel no país. Na prática, a } \\
\text { competência é exclusiva do Ministério das Minas e } \\
\text { Energia e da Casa Civil da Presidência da } \\
\text { República; } \\
\text { - As diretrizes da Política do Biodiesel (PNPB) no } \\
\text { Brasil foram estabelecidas com a presença e } \\
\text { debate de vários setores da sociedade civil,porém, } \\
\text { os meios de implementação, regras e } \\
\text { ordenamentos correlativos ao programa têm sido } \\
\text { de competência exclusiva do Governo Federal } \\
\text { - Nos P.G. não existem arenas deliberativas e } \\
\text { consultivas no tocante a regulação do biodiesel, e } \\
\text { todos os espaços políticos de tomada de decisão, } \\
\text { com efeitos diretos e indiretos nos territórios de } \\
\text { produção, estão alojados e concentrados no } \\
\text { Governo Federal; } \\
\text { - Segue um formato centralizado, (ou big } \\
\text { government), assentado em um sistema de gestão } \\
\text { notoriamente de cima-para-baixo, (top-down)ea } \\
\text { notória ausência da participação política e }\end{array}$ & $\begin{array}{l}\text {-Em EFS a autonomia dos governos e das } \\
\text { comunidades locais foi comprometida pela } \\
\text { aprovação da proposta de Lei } H B 40 \text { que retirou a } \\
\text { maior parte da prerrogativa das cidades na } \\
\text { regulação e gestão dosshales em favor do governo } \\
\text { estadual; }\end{array}$ \\
\hline
\end{tabular}

Quadro 01 - Características comparadas entre a governança dos PG e EFS. Elaborado pelo autor.

Dito de outra forma, as diretrizes da política do biodiesel (PNPB) que regem a governança dos $P G$, embora tenham sido estabelecidas de forma inovadora com a presença de outros atores sociais, além do governo e representantes do setor agroindustrial, na prática,consagraram regras e práticas que acabaram por engessar comandos e processos em Brasília. Uma configuração que como visto, potencializa uma governança desequilibrada no tocante a gestão compartilhada e a participação política efetiva de atores diretamente inseridos e impactados nas áreas de produção.

Um modelo que se consolidou, a partir de um sistema de gestão nitidamente controlado de cima-para-baixo, ou top-down, onde arenas deliberativas e decisões finais emanam de plenários a milhares de quilômetros, estabelecendo unilateralmente a tônica e direções políticas da produção e exploração energética. Um processo sem autonomia e delegação de prerrogativas aos governos locais ou das comunidades inseridas nos territórios energéticos. De forma concreta, o ritmo de 
modificação das paisagens ligadas à produção de energia é ditado somente a partir dos interesses e demandas dos atores-chave na capital federal.

Nos Estados Unidos, por sua vez, num padrão diametralmente oposto, estabelecido pelas normas constitucionais que regem historicamente a estrutura federativa do país, e em conjunto com o marco jurídico energético nacional (EPACT 2005), há uma ampla autonomia aos estados e municípios no 'jogo da regulação e gestão energética'. Ou seja, não há a federalização energética, como acontece no Brasil, e na prática cada unidade federativa possui a prerrogativa independente de explorar seus recursos energéticos - e naturais - contanto que não infrinjam nenhuma lei federal, como por exemplo, as estabelecidas pela EPA.

No tocante a exploração dos folhelhos, entretanto, essa liberdade regulatória surtiu efeitos reversos na regulação e gestão equilibrada dos hidrocarbonetos não-convencionais. Como visto não há uma política nacional de exploração dos shales e como consequência direta da ausência de um quadro legal quepropulsionou a formação de quadros heterogêneos nos estados. Apesar das exceções, como do estado de New York, o padrão que se seguiu foi de uma participação política frágil e uma baixa influência pública da população no estabelecimento das Oil and Gas ordinances. De forma bastante comum, os processos legislativos têm sido fortemente cooptados pelo poder das companhias energéticas que acabam ditando padrões das deliberações Estados Unidos afora.

Esse é o caso específico do estado do Texas e de EFS, onde de forma exemplar,a força da indústria petrolífera promoveu ineditamente um processo de powergrab, ou de tomada de poder das prerrogativas legais dos governos locais, deslocando grande parte de suas competências sobre os rumos dos recursos energéticos para a esfera estadual. Um processo resultante diretamente dos interesses das companhias e demandas de mineral owners, e em detrimento da automia e salvaguardas das comunidades inseridas nas áreas de produção.

Como destacado no capítulo $\mathrm{V}$, a partir da publicação da proposta de Lei HB40, de iniciativa da Câmara dos deputados do Congresso Texano, o estado rompeu com o princípio de descentralização, re-centralizando para si os limites das deliberações. Impondo, portanto, um sistema de gestão tradicional top-downe uma postura big government, atropelando quaisquer outros enfoquesque não os critérios financeiros e econômicos. Um processo que suscita questionamentos como feitos por Davis (2012) e Rabe (2014) sobre a necessidade ou não de aumentar a centralização da regulamentação energética em direção a Washington, no qual os autores propoem que, sob gestão federal, poderia haver um nivelamento dos padrões socioambientais obrigatórios atodas as unidades federativas. 
Tais diferenças antagônicas entre Brasil e Estados Unidos em suas políticas energéticas, uma excessivamente centralizada e outra excessivamente descentralizada, remetem ao questionamento sobre qual arranjo político-insitucional seria mais adequado para conciliar parâmetros balizadores e quadrosmais harmoniosos de responsabilidades comuns e compartilhadas no uso e exploração de recursos energéticos e naturais. Sistemas mistos que levassem em conta, simultaneamente, as estipulações federais e estaduais, mas capazes de incorporar as demandas e interesses das comunidades e demais entes locais. Ou seja,estruturas híbridas (Figura 61) onde deliberações top-down não suprimam decisões bottom-upe, consequentemente respeitem as vontades expressas dos governos locais, sendo sinérgicas na lógica de regulação e gestão em energia.

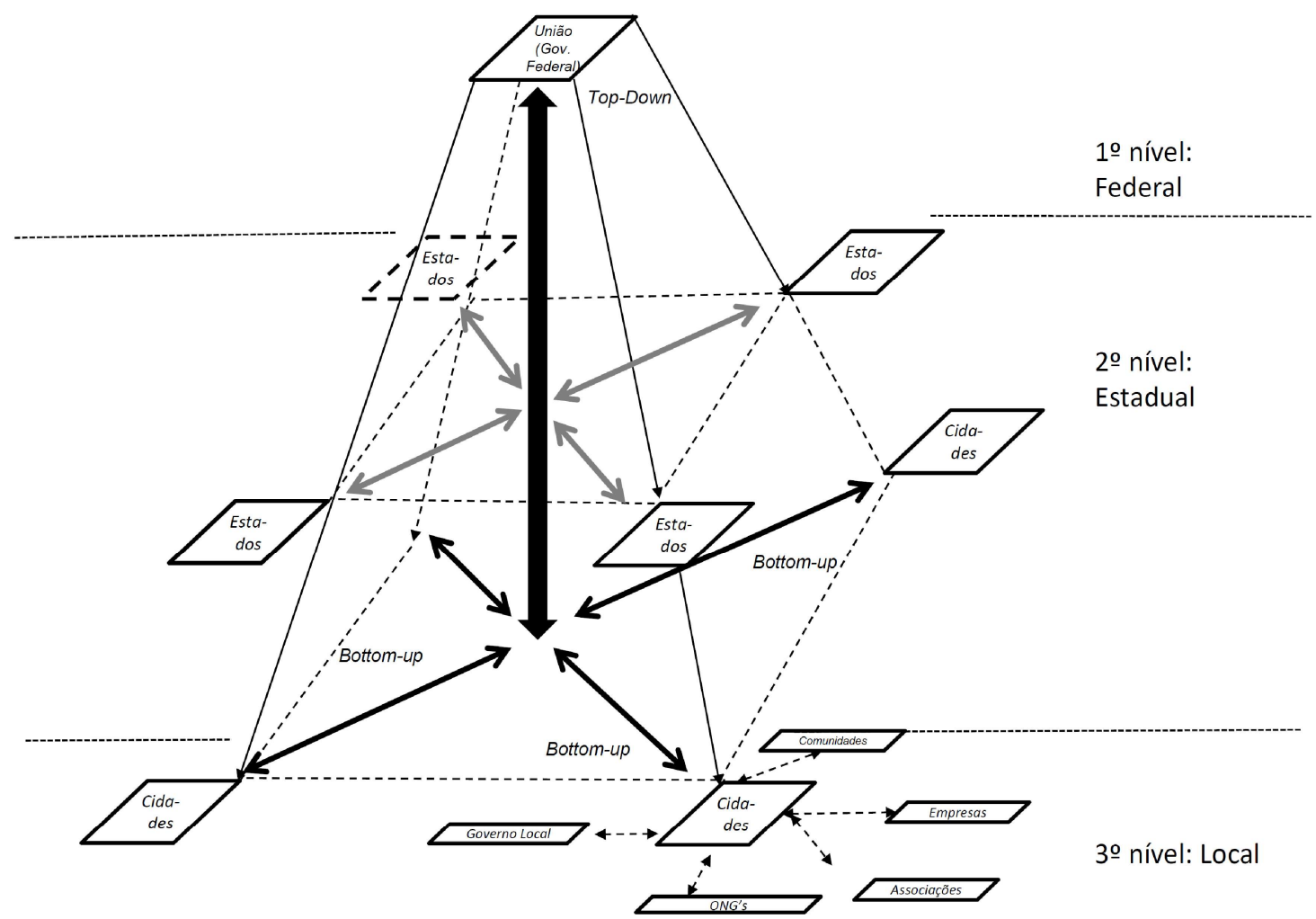

Figura 61 - Estrutura híbrida Top-Down/Bottom-up de governança.

Fonte: Elaborada pelo autor.

Vale destacar que, ainda assim, sem a devida atenção ao princípio da equidade entre os atores, não existe efetividade nas práticas de boa governança independentemente de estruturas centralizadas ou descentralizadas. Essa é justamente a análise que se faz das estruturas de governança estudadas, onde mesmo diante de configurações completamente distintas o prejuízo ocorre devido à grande assimetria de poderes e recursos (políticos, informacionais e econômicos). Disparidades em que somente as estruturas e fluxos de deliberações não são garantia de maior participação, uma vez que,não impedem, por exemplo, a cooptação feita por 
elites regionais/locais, ouo domínio por participantes mais poderosos e articulados. Uma reflexão que suscita o papel de políticas de estado e ações de governo capazes de estimular sistemas de governança com maior equidade.

Nos dois casos em estudo, entretanto, seja nos PG, seja em EFS, nenhuma das configurações possibilitou, ou permitiu um maior envolvimento e participação política das comunidades inseridas nas áreas de produção, muito menos conseguiram reduzir a inequidade entre os atores sociais envolvidos. De forma agravante nos dois sistemas de governança, tanto o brasileiro, quanto o americano, a balança pendeu para o lado e favoreceu as agroindústrias e companhias energéticas que, com sua articulação e disponibilidade material, exerceram grande influência, pressionando e influenciando seus respectivos governos quanto aos rumos da política de produção e exploração dos recursos energéticos.

O desequilíbrio também se propaga nas assimetrias de direitos, vantangens e ganhos na exploração/produção de recursos energéticos, bem como, nos resultados socioambientais. Uma questão agravada nos dois casos, pela baixa, ou mesmo inexistente, incorporação de critérios de precaução frente aos riscos e incertezas causados pela produção energética. Em ambos os casos estudados, a soma de transparências opacas, responsabilizações frouxas, somadas a características normativas nos direitos de propriedade, produzem a formação de cenários preocupantes de justiça ambiental.

Nos PG, por exemplo, apesar da existência de critérios legais de responsabilização e conduta nas atividades produtivas ruraiseindustriais, a falta de maiortransparência nos procedimentos e produtos empregados nas usinas, mas, sobretudo, de um efetivo zoneamento ecológico da soja, e a imposição de atrelamentos do Selo Combustível Social na manutenção e recuperação de APP's e RL's colaboram para a formação de quadros preocupantes na materialidade do biocombustível. De forma concreta, o segmento traz um novo ambiente concorrencial formado entre agroindústrias, cooperativas e cerealistas que promove a intensificação e expansão da cultura de base. Intensificando, portanto, o uso e a utilização de bens naturais comuns como os recursos hídricos e edáficos atrelados a produção da soja.

Em EFS os critérios de responsabilização e transparência também estão estabelecidos, porém, como visto, sob um grande conflito de interesses entre os gestores das agências reguladoras e seu papel duplo de incentivar as atividades de exploração energética e ao mesmo tempo emitir permissões, fiscalizar e punir companhias infratoras. De forma agravante somam-se as particularidades dos direitos de propriedade nos Estados Unidos, em que se a propriedade de superfície e do subsolo é desmembrável e negociável a parte. Os mineral owners tem inclusive o 
direito à exploração de depósitos hídricos subterrâneos tornando ainda mais complexo o controle da exploração. Em muitos casos, por exemplo, os proprietários dos direitos de superfície são obrigados a aceitar a interferência das atividades de prospecção, impostas pelos mineral owners, ficando apenas com as possíveis externalidades ambientais geradas.

Não obstante a essas dificuldades, como pano de fundo comum aos PG e a EFS, a lógica das vantangens imediatas como aumento da arrecadação de impostos e taxas, mas especialmente do incremento da renda inibem a formação de ações e dispositivos coletivos na regulação e gestão dos recursos energéticos e naturais. Nas duas paisagens energéticas, e seus respectivos territórios, adicionalmente discursos próprios de base legitimadora, incorporando elementos como o fomento à tecnologia, inovação e segurança energética são empregados, inclusive, como propulsores ao futuro sustentável tanto pelas agroindústrias brasileiras quanto pelas companhias energéticas americanas na lógica do recurso energético enquanto um espetáculo de desenvolvimento (BRANNSTROM, 2015).

6.2.2 Os discursos e subjetividades: padrões comuns de governamentalidade e eco-governamentalidade

Embora de natureza e materialidades diferentes, realçados por políticas, estruturas e processos de governança distintos, tanto a produção do biodiesel quanto a exploração dos folhelhos possuem elementos similares nos seus padrões de ecogovernamentalidade. Ambos os recursos energéticosse propagaram e continuam a se expandir baseados em lógicas, racionalidades e discursos comuns. Mesmo o biodiesel sendo um recurso renovável e os folhelhos recursos não-renováveis, ambos se apropiam delógicas que ressaltam suas vantagens como recursos alternativos viáveis, estratégicos e, 'sustentáveis', frente aos modelos e recursos energéticos convencionais. Os itens a seguir descrevemos principais pontos convergentes de governamentalidade e, especialmente, de eco-governamentalidade empregados tanto nos PG quanto emEFS:

i) O socioeconômico como base legitimadora

Tanto nos PG quanto em EFS existe uma forte correlação feita pelos atores de governo, mas, sobretudo, pelas agroindústrias, companhias energéticas e suas associações no tocante à ligação da produção/exploração dos recursos energéticos como base segura para a melhoria das condições socioeconômicas. Um 
aspecto ressaltado, especialmente no 'ciclo virtuoso da produção-trabalho-renda' e nos reflexos positivos ao quadro social. No caso brasileiro esse padrão está coligado ao apoio à agricultura familiar, trabalhadores rurais, mas também de mecanismo de estímulo à agricultura empresarial e posto de ocupação nas unidades processadoras de grãos e óleo vegetal. Uma lógica igualmente explorada na legitimação socioeconômica da exploração dos shales americanos como atividade propulsora da geração de empregos e renda.

A ocupação do homem do campo, por exemplo, dentro da cadeia produtiva do biodiesel, e das atividades industriais de exploração dos hidrocarbonetos de folhelhos ganha dimensões da 'moral do trabalho árduo e edificante', como retratado na iconografia utilizado por ambos os setores (Figura 62 e 63). Imagens que reforçam uma visão de nobreza das atividades que sobrepujam quaisquer argumentos contrários ao maior ritmo e intensidade da exploração dos recursos energéticos. Uma vez que quanto mais produção, mais trabalho e mais benefícios sociais gerados melhor é para a sociedade. Como realçado no capítulo IV, quem está contra a expansão das respectivas cadeias produtivas está contra o próprio sentido do desenvolvimento.
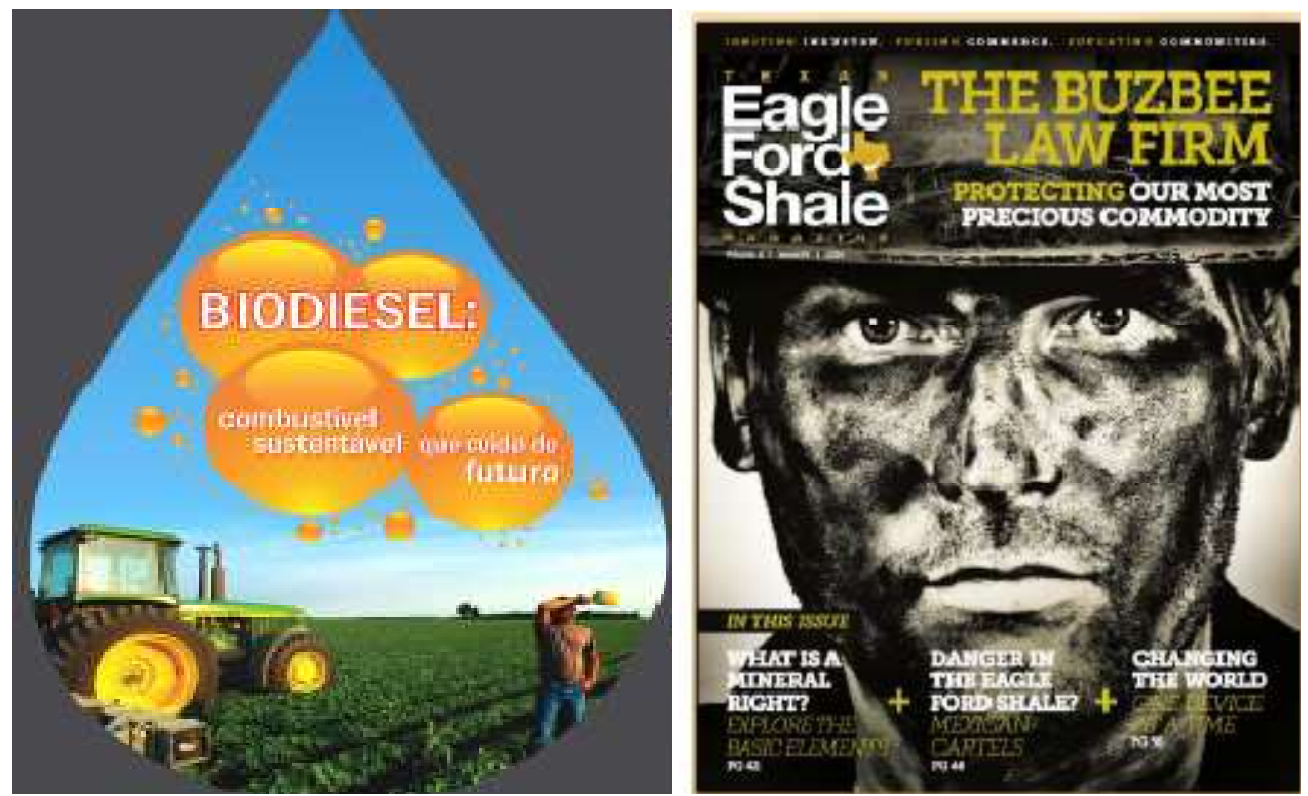

Figuras 62 e 63- O socioeconômico como base legitimadora da energia.

Fonte: Ubrabio [s.d.]\&Stralow (2014);

Como cunhado por Luke (1995), a lógica se propaga pelo apoio dos núcleos, ou "centros de eco-conhecimento", ou eco-knowledge, na divulgação de dados incontestáveis sobre os benefícios na produção/exploração dos recursos. No caso brasileiro, por exemplo, por trabalhos como os 'Impactos socioeconômicos da indústria do biodiesel no Brasil(APROBIO/IPEA, 2012), e, simultaneamente, por 
relatórios e estudos distribuídos em campanhas de divulgação nos ministérios, e outros entes públicos envolvidos na governança do biocombustível, reforçam-se narrativas e argumentos favoráveis. Projetos como: 'O Biodiesel e a Contribuição ao Desenvolvimento Brasileiro', realizado pela Fundação Getúlio Vargas (FGV), e publicado com patrocínio da Ubrabio, já no seu títtulo enfatizam os impactos positivos do biodiesel na saúde macroeconômica do país.

Nos Estados Unidos o mesmo padrão se reproduz pelos esforços das associações e confederações industriais. Seja na escala regional, seja na escala nacional, conceitos e linguagens socioeconômicos são utilizados para reforçar a importância da exploração. No Texas, por exemplo, é extremamente comum e contundente a ligação que autoridades públicas e o setor energético fazem entre a geração de empregos na exploração dos recursos não-convencionais e o bem-estarsocial promovido. Onde o trabalho é tratado como "our most precious commoditiy" (STRALOW, 2014 p.12) e logo, a exploração dos folhelhos é alçada a um importante mecanismo de desenvolvimento que deve ser preservado.

Núcleos ou centros de eco-knowledge, também assinam trabalhos que reforçam essa lógica, como em: Economic Impact of Eagle Ford Shale: County Level Detail appendix assinados por Tunstall (2014), um pesquisador do Instituto para Desenvolvimento Econômico da University of Texas at San Antonio, patrocinado e financiadode forma conflituosa pela STEER, ANGA e uma revista especializada do setor -Shale Oil \& Gas Business Magazine. Estudos que igualmente trazem dados e argumentos poderosos para ressaltar as externalidades positivas da exploração dos shales. Considerações em que,segundo o mesmo autor, Tunstall (2015b), utiliza para ressaltar que indicadores do incremento de trabalho e renda vêm rompendo com a expectativa de uma nova maldição dos recursos.

Não obstante, entretanto aos fortes argumentos de base socioeconomica, outros critérios como a ciência, a tecnologia e a capacidade de inovação também são empregados como padrões de governamentalidade e ecogovernamentalidade que envolvem e caracterizam a produção do biodiesel no caso de estudo brasileiro e na exploração dosfolhelhos no caso de estudo americano, como destacados a seguir:

ii) Tecnologia e inovação como garantias ao futuro e desenvolvimento sustentável

Seja no biodiesel, seja nos shales, o papel da ciência,tecnologia e da inovação são fortes elementos utilizados para enfatizar ambas as cadeias produtivas e seus respectivos produtos como propulsores de uma transição rumo às economias de 
baixo carbono. Aqui,curiosamente, embora se tratando de um recurso energético renovável e de outro não-renovável, os dois setores lançam mão de critérios e de argumentos científicos semelhantes para edificar seus argumentos econstruir pontos favoráveis na lógica de defesa de ambos os recursos. Tecnologia e inovação são, portanto, elementos bastante centrais nas campanhas e discursos oferecidos tanto pelas agroindústrias de biodiesel gaúchas quanto pelas companhias energéticas texanas, onde o biocombustível e os hidrocarbonetos não-convencionais são tratados como trajetórias, caminhos e processos garantidos para se chegar a um futuro energético 'sustentável' (Figuras 64 e 65).

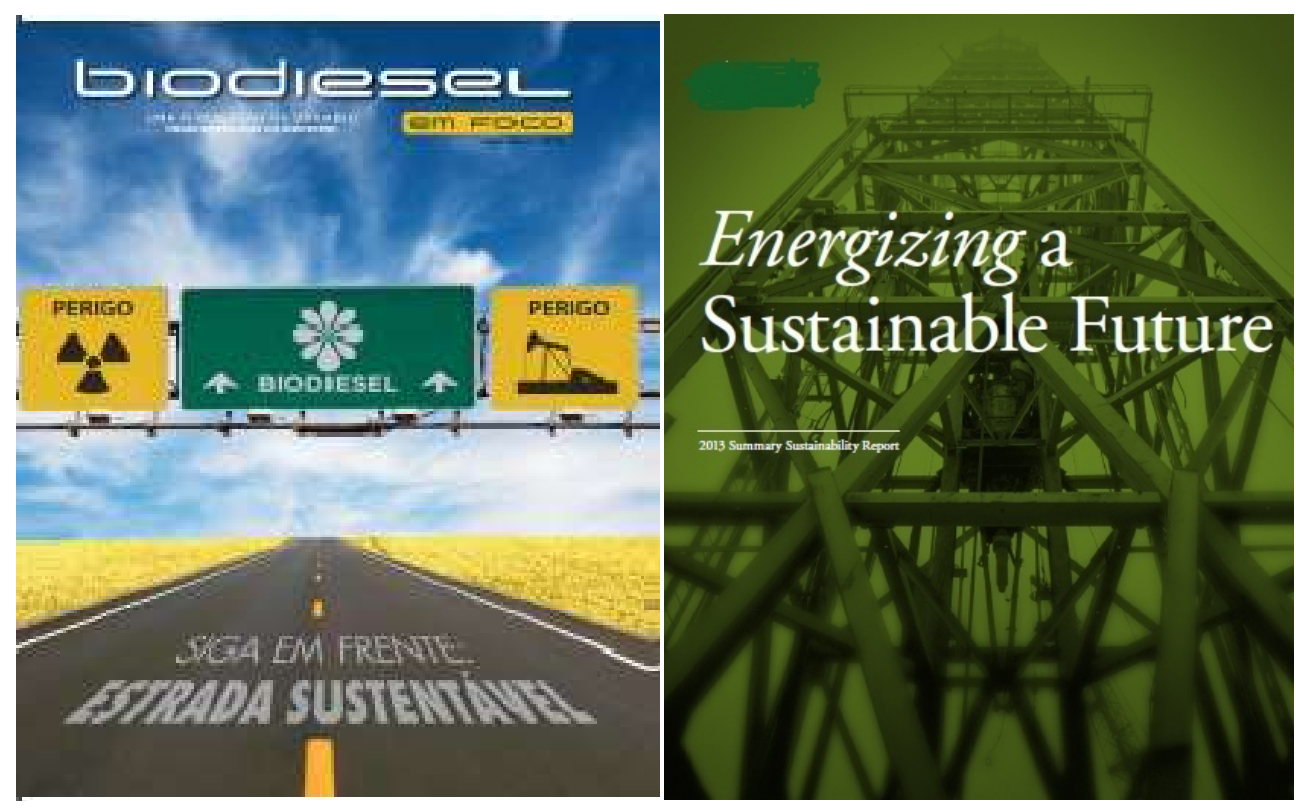

Figuras 64 e 65: Biodiesel e Shales - estradas e caminhos para um futuro sustentável. Fonte: Ubrabio (2011) \& Apache (2013).

No Brasil, por exemplo, a base argumentativa empregada pelo setor se concentra nas vantanges em promover o aumento sistemático das misturas de biodiesel ao diesel mineral. Isso porque para o setor empresarial o maior uso do biocombustível promove inquestionavelmente uma melhoria da saúde humana e qualidade ambiental. Na capa da edição da Ubrabio (2011), o biodiesel, nesse sentido, é alçado à categoria decaminho segurofrente aos 'desvios indesejáveis' para outras fontes e recursos energéticos. A ótica propulsora se dá na expansão do recurso energético como uma opção incontestável frente ao processo de transição energética, sendo a opção mais lógica para o alcance de uma economia de baixo-carbono e eficiênciana substituição do petróleo e energia nuclear.

A exploração dos folhelhos nos Estados Unidos, por sua vez, lança mão da mesma estratégia discursiva, destacando estrategicamente a importância do gás natural. Um elemento elevado à categoria de recurso inovador na produção de energia elétrica, calor, processos industriais e combustível veicular. $\mathrm{O}$ argumento é reforçado 
pela possibilidade de substituição do carvão nas termoelétricas e da redução substancial do uso de combustíveis como gasolina e diesel na motorização veicular. Estratégias reforçadas pelos preços extremamente baixos do gás natural nos Estados Unidos e no Texas (TUNSTALL, 2015a). propagado em Eagle Ford shale, onde autoridades locais, regionais, companhias energéticas ressaltam esse aspecto, para demonstrar que o fracking só traz benefícios,além de ser limpo e se basear na ciência pura (BRANNSTROM, 2015).

Tamanho escopo das vantagens socioeconômicas, tecnológicas e cientificas, ainda ganham fôlego a partir de mais elementos, como os que remetem a exploração dos recursos energéticos como fatores de orgulho nacional e prestígio regional, onde a lógica discursiva e osentimento de segurança e independencia energética são empregados por ambos os atores $e$ instituições ligados ao desenvolvimento dos recursos energéticos.

iii) Nacionalismo, segurança energética e prestígio regional

Entre os discursos utilizados, seja para produção de biodiesel, seja para exploração dos shales se encontram, de forma bastante contundente, a lógica de independência, a soberania ea consolidação da segurança energética. O raciocínio segue um padrão que remete não somente ao uso desses recursos como estratégias limpas, eficientes e viáveis, mas de cadeias produtivas capazes, simultaneamente, de garantir prestígio e autonomia aos países, dando maior visibilidade e desenvolvimento as regiões produtivas (Figura 66 e 67 ).
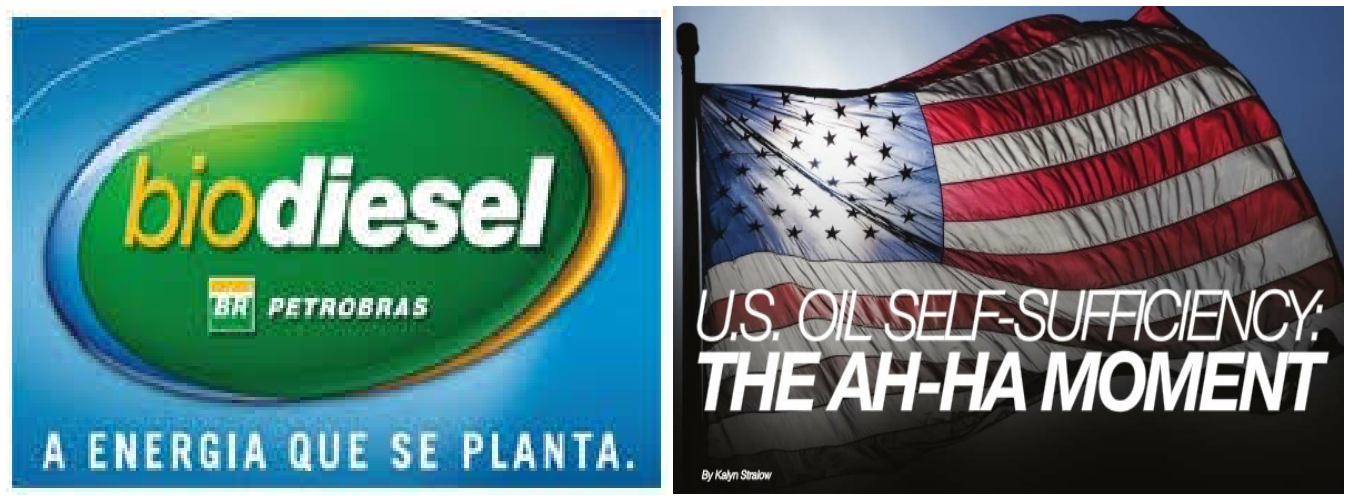

Figuras 66 e 67 - Recursos energéticos e nacionalismo Fontes: www.biodiesel.ar (domínio público) \& Stralow (2013).

No Brasil, a política do biodiesel, por exemplo, foi desenhada levando em consideração a questão da segurança energéticae discursos de ênfase ao seu uso como meio de ampliar a segurança energética e reduzir a dependência de produtos e mercados exteriores. Embora esse não tenha sido o aspecto principal, ou diretriz mais contundente na governamentalidade que foi utilizada na implementação do PNPB, a 
força do biocombustível como um produtor de divisas e substituto de combustíveis líquidos derivados do petróleo se demonstrou um forte argumento na expansão do setor. Um discurso que se propagou nas agroindústrias fabricantes, empresas públicas como a Petrobrás (PBio), associações industriais, representantes de governo, eespecialmente empregadopelos parlamentares da FrenteBioemque: "é um orgulho nacional o processo científico que o Brasil possui na produção do biocombustível" (PG018, grifos do autor).

Dentro dessa lógica o biodiesel além de ser um orgulho da capacidade científica do país e um "combustível ambientalmente correto", segundo o presidente da Aprobio, é um recurso energético capaz de gerar um mercado de mais de $R \$ 10$ bilhões de reais apenas na comercialização, prestando um serviço ao país na economia de milhões de dólares na balança comercial e agregando bilhões ao PIB brasilerio (FREIRE, 2015 p.01).

Novamente, essa é a mesma lógica que se faz presente nos discursos de defesa do uso intensivo dos recursos não-convencionais ofererecidos pelos folhelhos. No caso de Eagle Ford Shale, os argumentos também se concentram no pacote de argumentos socioeconômicos, 'ambientais', científicos e tecnológicos do fracking como elementos-chave para garantir as divisas e a segurança energética ao país. Os folhelhos são, nesse sentido, eleitos como protagonistas para reduzir drasticamente as importações de petróleo e de gás estrangeirossendo apontados como recursos capazes de consolidar a própria independência energética dos Estados Unidos tornando-o um potencial exportador de hidrocarbonetos líquidos até o ano de 2025 (EXXON MOBIL, 2015).

Essa mesma perspectiva patriótica de "superpotência energética" é realçada pelos discursos nacionalistas daAmerican Petroleum Institute (2014), que ressalta anova "revolução energética americana" e seu papel na recuperação da economia nacional e da sua importância para devolver ao país a posição natural de líder mundial na produção de petróleo e gás natural. Onde haverá "mais dinheiro no seu bolso", empregos, maior volume de arrecadação, menos déficit no câmbio internacional, e um maior produto bruto interno (BRANNSTROM, 2015).

Não é incomum, coligado a essa mentalidade, a associação da bandeira norte-americana, mas também do estado do Texas, como uma assimilação do caráter patriótico de apoiar a indústria energética em direção a auto-suficiência americana, ou a “U.S. oil self-sufficiency"(STRALOW, 2013). A lógica se propaga onde o efeito multiplicador das atividades energéticas gera desenvolvimento das regiões produtivas. Ainda que em quadros distintos, e guardada as devidas proporções, se reproduz no Rio Grande do Sul e no Texas (Figura 68 e 69). Os estados também absorvem a 
ligação e a importância das respectivas cadeias produtivas energéticas como elemento de orgulho regional. Elementos representados pelos barris verdes de biodiesel gaúcho e pelos barris vermelhos de petróleo texano - símbolos materiais de riqueza e pujança produtiva.

Nos dois estados, o histórico econômico, político e cultural colabora para a correlação do biodiesel e dos shales como critérios de desenvolvimento e prestígio regional.

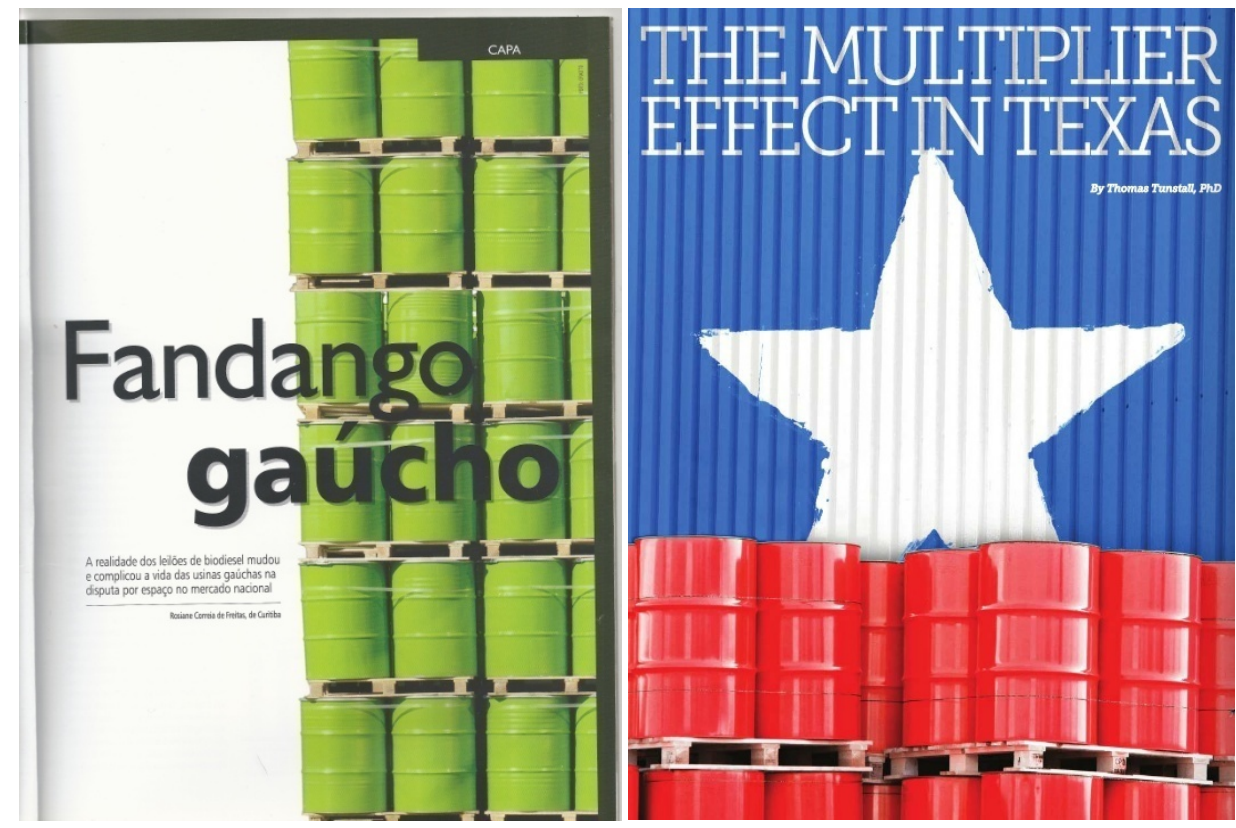

Figuras 68 e 69 - o efeito multiplicador no Texas e no Rio Grande do Sul. Fonte: Freitas (2013) \& Tunstall (2014).

No Texas, por exemplo, explorar o petróleo e o gás é visto "como uma parte natural da vida", associado à topografia, à rede rodoviária e à "cultura texana" que aceita e celebra o retorno das companhias energéticas com gratidão e regozijo de colher novos frutos de outro boom (STRALOW, 2013 p. 11). Um pensamento similar se desenvolve entre a sinergia de produção entre farelo-óleo-biodiesel frente à 'cultura gaúcha' da soja, afeita a produção agrícola e agroindustrial. Um pensamento refletido, por exemplo, por um diretor-presidente de uma das maiores usinas do Rio Grande do Sul. Para ele, o sucesso do biodiesel no estado se deve ao ambiente propício "em razão da vinculação com a produção da soja, a principal matéria-prima [do biodiesel], mas também porque [as agroindústrias] já tinham uma raíz no local" (BOREKI, 2013 p.35).

De fato os PG, há anos, ocupam a posição de liderança na entrega de biodiesel nos leilões públicos da ANP, mesmo sofrendo dificuldades antes do aumento da demanda obrigatória para o B7 (7\% de mistura) que reaqueceu o mercado 
domético oficial para todos os estados produtores. Antes disso, as usinas gaúchas passavam por momentos difíceis em decorrência da baixa demanda e da modificação dos mecanismos de entrega do biodiesel diretamente para as distribuidoras, que representou um golpe nos custos de logística para as empresas do estado. Um processo que afetou seriamente a competitividade das indústrias gaúchas e deixaram Freitas (2013) perplexas, como era possível,diante desse quadro que um número ainda crescente de novas usinas/plantas de biodiesel estivesseem abertura no estado. Assunto destacado na matéria "Fandango Gaúcho" e da "Crise Inevitável" explorados pela revista BiodieselBR de novembro de 2013.

$\mathrm{Na}$ análise, entretanto, não há uma correlação de que os investimentos no biodiesel estariam na realidade, muito mais ligados a apostas em legislações e mercados futuros, onde de forma concreta o biocombustível está dentro de uma estratégia de ampliação do mix de produtos e política de diversificação de um setor que na realidade se mantém pela rentabilidade na comercialização e beneficiamento da soja. Uma vitalidade industrial atrelada à própria saúde econômica doméstica e internacional da oleaginosa e seus cooprodutos. Vale ressaltar que, no momento da matéria, por exemplo, o mercado do biodiesel encontrava-se inadequado para as indústrias gaúchas, mas a comercialização da sojain natura, entretanto, passava por um período glorioso, em um segundo pico de valorização internacional entre 2006 e 2016, que atingiu em 2013 a marca recorde de U\$ 18/Bushel, com valores superiores a U\$ 600 por tonelada do grão (www.tradingeconomics.com).

No Texas, por sua vez, o efeito multiplicador também é explorado como elemento de orgulho e desenvolvimento regional. Tunstall (2014), por exemplo, realça a importância que o shaleboom, traz ao ritmo e intensidade das atividades de exploração energética com conseqüentes oportunidades favoráveis para o estado despontar na liderança da produção de hidrocarbonetos não-convencionais e ao mesmo tempo propulsionar e diversificar toda sua economia e desenvolver suas comunidades. Vale ressaltar que, no momento da matéria publicada pelo autor, no início de 2014, opetróleo também se encontrava com cotações internacionais bastante atrativas ao redor de U\$100 o barril.

Ou seja, tanto nos PG quanto em EFS,ambos os recursos energéticos se tornam centros das atenções em fenômeno similar a um espetáculo e perspectiva de desenvolvimento explorada por ambos os setores empresariais em seus repectivos países. 
Converter a produção do biodiesel e a exploração dos folhelhoscomo um espetáculoé outro padrão comum empregado e propagado tanto pelos atores energéticos quanto governamentais inseridos e interligados a governança do PG e de EFS. Nesse aspecto, todos os argumentos e subjetividades convergem na legitimação da expansão das respectivas cadeias de produção energética como mecanismos soberbos de prosperidade e desenvolvimento (Figura 70 e Foto 11).

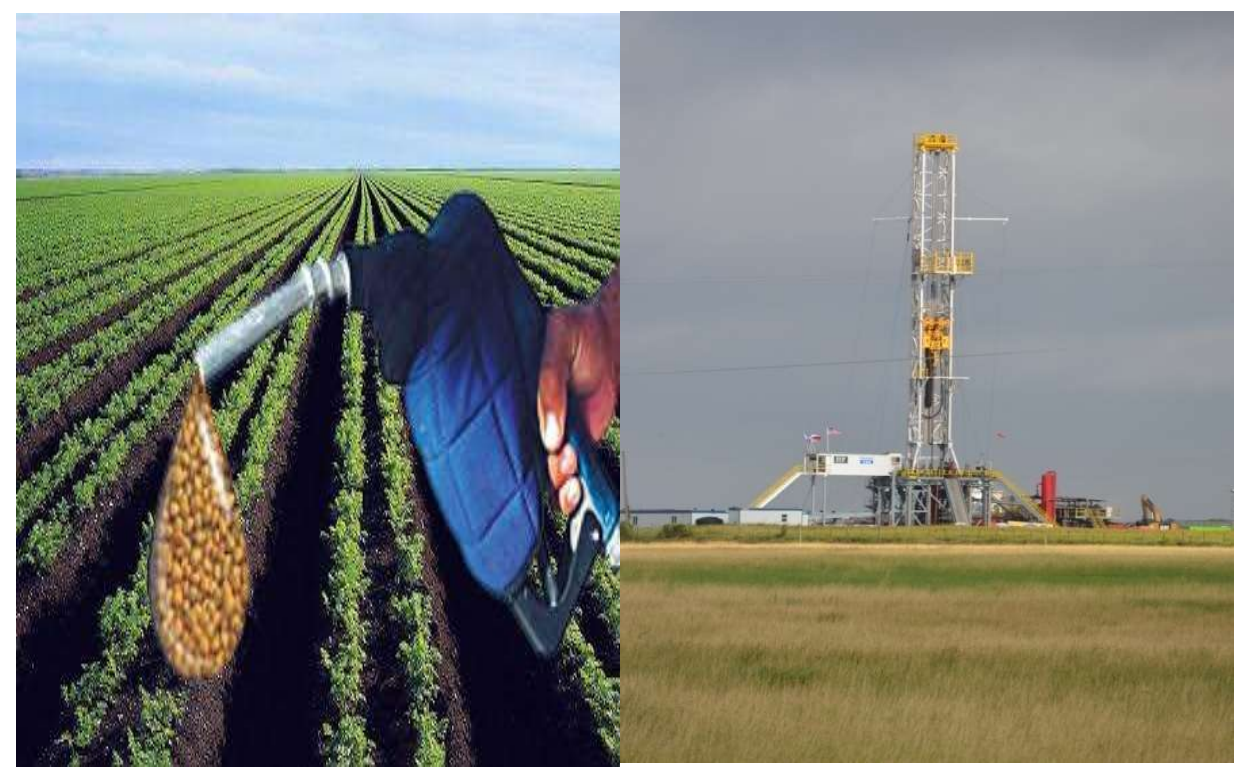

Figura 70 e Foto 11- O recurso energéticocomo espetáculo do desenvolvimento. Fontes: www.camera.com (domínio público); Brannstrom (2015).

A exploração de ambos os recursos energéticos passam inclusive a recorrer a analogias da grandiosidade de suas atividades de exploração e das vantagens e atributos gloriosos na produção de energia. Visão exemplificada pelo presidente da Ubrabio, na qual "o Brasil precisa explorar o seu pré-sal verde; [como] um combustível que capta as pontencialidades regionais para transformá-las em desenvolvimento econômico sustentável" (FERRES, 2014 p.34 grifos meus). Uma visão antagônica aos "desertos verdes" descritos por Altieri (2009), na qual a perspectiva de uso do recurso transforma o padrãomonocultor da soja-biodiesel como um grandiosoespetáculo equiparável às próprias reservas de petróleo na plataforma continental do país.

O espetáculo se propaga igualmente em EFS interligado a uma nova riqueza capaz de fazer frente aos árabes, ainda que dentro de um quadro de desvalorização do petróelo, conforme ressaltado pela matéria Sheiks vs Shaledo editorial da revista The Economist (2014). No qual o jogo de forças no desenvolvimento dos shales frente ao cartel da Organização dos Países Exportadores 
de Petróleo (OPEP) também impulsiona a lógica do espetáculo. Nos territórios compreendidos em Eagle Ford a paisagem se confunde e se transforma sob essa tônica, onde o ritmo e intensidade depump jacks e propagação de torres de frackingseguem a lógica doY'll smell it? It's smell like Money! (MEALER, 2013), ou: sente o cheiro disso? E o cheiro do dinheiro daamerican energy revolution.

Nos dois casos, entretanto, o espetáculo está fragilmente assentado sobre lógicas econômicas e insumos oscilantes que os coloca a mercê do balanço mundial entre a oferta e a demanda mundial das matérias-primas e produz reflexos no mínimo preocupantes no uso e intesificação dos recursos naturais atrelados a produção energética. Um padrão refém de custos, e retornos, que se refletem na intensidade de uso da água, modicação do uso da terra, solos, sub-solos e dos sistemas ecológicos que os suportam.

No caso do biodiesel a lógica dos custos de produção, como destacado no capítulo IV, fez com que a produção do biocombustível naturalmente se concentrasse nas mãos de grandes empresas detentoras da capacidade de esmagamento e beneficiamento dos grãos de soja. Ou seja, de agroindústrias tradicionalmente processadoras da oleaginosa que verticalizaram suas atividades para frente no sentido de construírem unidades de transesterificação, ou daquelas que investiram se verticalizaram para trás, incorporando o esmagamento dos grãos e produção de óleo e farelo, características de todas as maiores empresas de 'bioenergia' nos Polos Gaúchos.

Vale lembrar que na implementação do PNPB havia uma previsão incial de expansão do uso de matérias-primas diversificadas, e igualmente dos materiais que eram abundantes ou mesmo descartáveis. Imaginava-se que os óleos vegetais, a exemplo do óleo de soja, mantivessem seus preços módicos e viabilizassem a produção de biodiesel de forma perene. De forma concreta, entretanto, isso não aconteceu, pelo contrário, houve uma supervalorização dos preços dos óleos vegetais de grãos alternativos em todo mundo, (mamona, canola, girassol, crambe, palma), inclusive, do até então desvalorizado óleo vegetal de soja.

Esse movimento de valorização favoreceu, portanto, os grandes grupos agroindustriais brasileiros negociadores de grãos e processadores de óleo vegetalque não sofreram com maiores custos para incorporar a produção do biodiesel ao seu rollde produtos. Um movimento, inclusive, custeado pelo Governo Federal, por meio das linhas de financiamento especiais do BNDES para construção de novas plantas de biodiesel.

Nesse ínterim, os grãos in natura e o farelo protéico percorreram uma trajetória de valorização constante, resultante da soma da demanda internacional e do 
mercado interno brasileiro que se tornaram peças-chave na manutenção das agroindústrias energéticas. Somente em 2014, foram produzidos 28 milhoes de toneladas de farelopara rações animais no Brasil, (avicultura e suinocultura), no qual a metade saiu direto das unidades de esmagamento vendidas para o mercado exterior (TAVARES, 2014).

O padrão de biodiesel no Brasil, sobretudo nos Polos Gaúchos, se desenvolveu, portanto, nos últimos dez anos, intimamente interligado àverticalização de empresas agroindustriais que passaram a disputar entre si, com as cooperativas e empresas cerealista gaúchas, a matéria-prima predominante do recurso energético, a soja. Numa direção que criou a sinergia no trinômio óleo-farelo-biodiesel e resultou numa nova e poderosa dependência frente à uma monocultura intensiva de conhecido impacto socioambiental.

De forma semelhante, a questão dos custos de produção influenciou e determina o ritmo dos processos produtivos de EFS. Em primeiro lugar, porque, de modo geral, o Texas, em relação ao restante do país, oferece uma infraestrutura mais flexível e adequada aos interesses e atividades do setor energético, reduzindo, portanto, os custos de produção. Uma característica realçada pelo histórico da exploração de hidrocarbonetos convencionais no estado. Em segundo lugar, pelos preços praticados no gás natural que não compensam os custos de transportá-lo, ou sequer investir em gasodutos. Isso faz com que as companhias propaguem o uso de flarings queimando o hidrocarboneto gasoso e demonstrando que o seu real interesse está no petróleo.

A corrida, portanto, está concentrada na lucratividade do óleo cru, crude oil, onde o argumento do gás como "ponte para a transição energética" é na prática totalmente eclipsado no Texas, onde as margens inibem o seu desenvolvimento, e colaboram para um quadro de emissões de V.O.C's e monóxido de carbono em altíssimas quantidades. Mesmo as próprias margens do petróleo tendo entrado em declínio sendo sistematicamente menores os retornos, as grandes empresas do setor, com várias áreas de exploração em todo o mundo, têm mantido o ritmo de exploração de EFS.

Resumindo, os folhelhos de EFS, embora, sejam explorados sob a bandeira da utilização do gás natural como elemento inovador, na prática,promovem a intensificação das atividades produtivas do setor petrolífero, aumentando a pressão sobre os recursos naturais, especialmente a água envolvida no processo do fraturamento hidráulico, submetendo as comunidades de EFS a uma novadependência, com todos os riscos e vulnerabilidades envolvidos na intensificação e dependência de uma commodity energética internacional. 
Nos dois casos, portanto, há em comum uma retomada da trajetória de superdependência, sendo no primeiro caso em relação à soja, e no segundo caso, em relação ao petróleo. Ambos propulsionados, entretanto sob novos pretextos, ou seja, da produção de novos recursos energéticos: o biodiesel e os folhelhos. Um fenômeno que coloca novamente as comunidades inseridas nas áreas de produção a mercê da gangorra das commodities internacionais (Gráfico 01), e coloca de lado os riscos e incertezas inerentes aos critérios de justiça ambiental e precaução frente aos impactos nos bens naturais interligados à intensificação dessas cadeias produtivas.

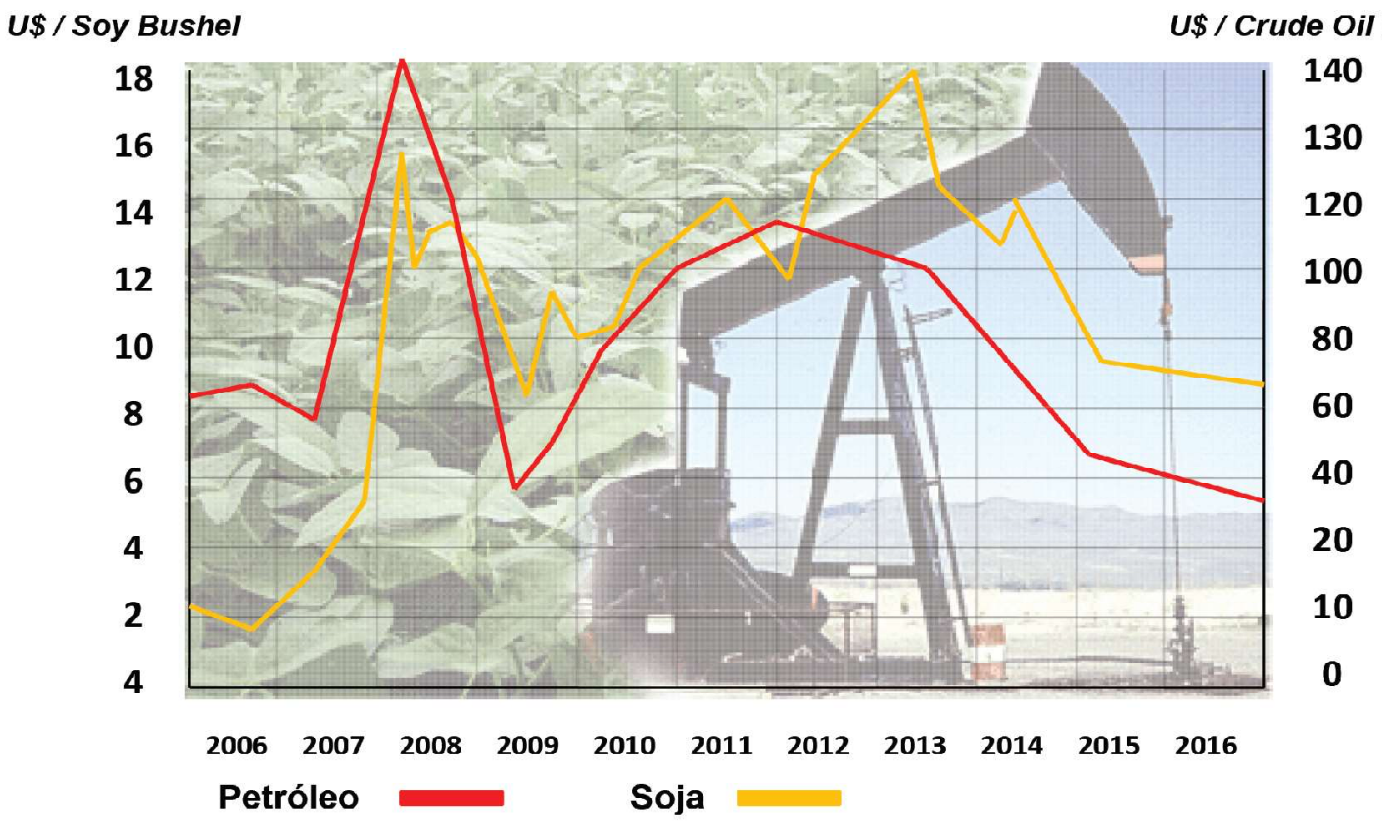

Gráfico 01 - Gangorra da soja e do petróleo como commodities internacionais.

Fonte: Elaborado pelo autor a partir dos dados do Chigago Board of Trade (CBOT) e de www.tradingeconomics.com

Nesse contexto, quando soja e petróleo estão valorizados, ambos os setores energéticos ganham, uma vez que o setor das agroindústrias brasileiras direciona suas operações na comercialização dos grãos in natura para exportação e venda deseus cooprodutos (óleo, farelo, farinha, leticina de soja) para os mercados domésticos e internacionais. A margem do biodiesel fica comprometida, mas se segura nos subsídios e incentivos fiscais.

Quando ambas as commodities desvalorizam, como vem acontecendo nos dois últimos anos, as agroindústrias brasileiras, por exemplo, ganham no custo de produção do biodiesel, mas perdem na competitividade frente aos combustíveis fósseis (gasolina e diesel) e igualmente na lucratividade dos cooprodutos. Nesse caso, pressionam por mais leis de apoio à demanda doméstica (mistura obrigatória) e de maiores subsídios e incentivos econômicos federais. Um comportamento novamente semelhante às companhias energéticas americanas que nos momentos de queda do 
petróleo também pressionam por mais subsídios federais e incentivos para manter um setor comprometido pelo bem-estar socioeconômico do país.

6.3 Discusão dos resultados: entre a prática e o discurso na regulação do biodiesel gaúcho e dos folhelhos texanos

O que dizer dos padrões de governança e eco-governamentalidade do biodiesel gaúcho e dos folhelhos texanos? Esses novos recursos energéticos trouxeram consigo novos paradigmas de regulação e gestão e a formação de critérios favoráveis para a consolidação de ambientes sustentáveis de exploração, ou tratam-se apenas de novas retóricas e discursos apropriados para dar guarida à continuidade deantigos padrões?

Uma primeira consideração, para dar cabo dessa resposta reside na discrepância entre os padrões de governança aferidos e a eco-governamentalidade identificada em ambos os casos estudados. Ou seja, há uma nítida diferença entre a prática e os discursos envolvidos na regulação e gestão desses recursos energéticos. Uma diferença entre o que se diz e o que se realmente faz na consolidação de ambientes de ação coletiva inovadores tanto em relação à produção do biodiesel gaúcho quanto em relação à exploração dos shales texanos.

$O$ que se quer dizer é que os arranjos político-institucionais analisados em ambos os casos, com suas normas próprias e regras diferenciadas, demonstraram-se pouquíssimos propensos a modificaras tradicionais interações e interdependências entre os atores envolvidos. Ao contrário, as estruturas verificadas sedimentam a formação de espaços e arenas políticas de forma assimétrica e desigual. Onde as relações e articulações consolidaram níveis hierarquicos e administrativos com pouca efetividade para inovar na articulação e formação de novas configurações produtivas e sociais ou na melhor articulação de participantes dentro dos sistemas de governança estudados.

Como visto, em ambos os casos, a lógica que os mantém relativamente coesos é envolta num padrão mantido nos ganhos e vantagens imediatas na exploração de ambas as cadeias produtivas. No caso brasileiro, aliada aos incentivos fiscais, tributários e econômicos para a produção do biodiesel, mas, sobretudo, apoiada no pujante comércio e beneficiamento da soja e seus cooprodutos. No caso americano, na corrida pelos royalties, revenues e wages (direitos minerais, taxas de arrecadação e renda), na lógica das doações e patrocínios interligados, por sua vez, ao pujante comércio e beneficiamento do petróleo. Nas duas situações, portanto, ocorrre uma mentalidade predatória, imediatista, de corrida aos benefícios econômicosque inibe a incorporação de riscos e impactos futuros frente a uma nova 
superdependência em relação ao balanço valorativos das commodities soja e petróleo, e frente à negligência com a precaução dos possíveis passivos socioambientais futuros.

Num sentido dissonante, entretanto, desenvolvem-se os discursos, narrativas e iconografias utilizadas na legitimação de ambos os recursos energéticos. Em ambos os casos, as eco-governamentalidades empregadas, ressaltam quadros em que ambos os recursos e seus processos produtivos são geradores inquestionáveis de benefícios socioeconômicos, ambientais, tecnológicos, de elementos propulsores ao desenvolvimento, à segurança e à indepedência energética nacional.

Elementos que como destacado nos capítulos IV e V, e realizados na comparação do capítulo VI, são incorporados não somente na narrativa e discursos dos representantes industriais, mas igualmente pelos demais participantes dos setores produtivos envolvidos na governança do biodiesel gaúcho e dos folhelhos texanos. Lógicas que se propagampelos atores do setor de gestão pública, e os posicionados nas mais diferentes escalas de governo, empresas públicas, órgãos e agências oficiais. Tônicas e ideias que trabalham em sinergia com os argumentos utilizados na defesa que parlamentares fazem do biodiesel e dos folhelhos em seus respectivos espaços legislativos no Brasil e nos Estados Unidos.

Uma eco-governamentalidade comum que o presente estudo intitula de 'socioambientalismo tempestivo' onde a tempestividade se reveste do sentido de apropriado, do caráter propício ou favorável. Um discurso social e econômico que utiliza igualmente de critérios sociais e da incorporação de critérios e conceitos para legitimar o crescimento e expansão das atividades agroindustriais tanto nos PG de produção de biodiesel quanto na exploração de EFS. Padrões que retratam e propagam a produção de ambos os recursos energéticos como elementos propulsores não só do desenvolvimento em suas mais variadas adjetivações, mas inclusive, como fomentadores do desenvolvimento sustentável.

A análise realizada nos dois casos de estudo leva a crêr que o padrão comum revela que as retóricas e os discursos são apropriados e utlizados para legitimar velhos expedientes de apropriação dos recursos oficiais, de acumulação de capital e de domínio das estruturas de governança. Onde a distribuição de ganhos, vantagens e direitos se demonstraram bastante desiguais e assimétricos. $\mathrm{Na}$ qual, de forma concreta, sistemas de 'governança viciosos' parecem destoar com uma ecogovernamentalidade baseada em um 'socioambientalismo tempestivo'.

Vale ressaltar que as formas e percepções preponderantes em que brasileiros e americanos, no caso específico, gaúchos e texanos, se correlacionam 
com seu meio-natural e seus recursos naturais também são fatores que devem ser considerados nos padrões de eco-governamentalidade encontrados. No caso particular dessas duas unidades federativas, prevalece nas áreas rurais e nos pequenos municípios visitados uma cultura fisiocrática expressiva, na qual a terra é uma fonte quase cornucorpiana de riqueza e bem-estar.

Dentro desse contexto, a agricultura e demais atividades de exploração das potencialidades produtivas da terra como a pecuária, plantio e lavoura no Rio Grande do Sul, bem como, das atividades agroindustriais correlatas, são percebidas como mecanismos condutores de prosperidade ad infinitum. No caso americano, e em especial no Texas, a forte cultura fisiocrática também se propaga na esperança perene e centrada nas riquezas e potencialidades da terra e do subsolo. Para boa parte dos texanos, gado e petróleo são sinônimos indiscutíveis de prosperidade e desenvolvimento. Nos dois casos, entretanto, tal mentalidade eclipsa a percepção do papel dos sistemas socioecológicos como base na exploração da cadeia produtiva de ambos os recursos energéticos, negligenciando a importância de limites e da conservação no uso dos bens naturais empregados.

Os fortes laços comunitários nas pequenas cidades que abrigamtanto as áreas de produção dos PG quanto de EFS não se refletem em modificações consistentes de suas subjetividades ambientais. Sejam nos municípios visitados no Rio Grande do Sul, sejam nas cidades visitadas no Texas, prevalecem discursos que enaltecem as qualidades locais de coesão social, laços de pertencimento e orgulho que possuem de suas comunidades, mas, ironicamente o comportamento não se reproduz no desejo de maior participação frente à regulação, gestão e exploração dos recursos energéticos. 


\section{CONCLUSÃO}

A despeito da complexidade da temática abordada é possível afirmar que o desenvolvimento da tese contribui, ainda que timidamente, com o arcabouço teórico, normativo e instrumental da governança. O referencial teórico adotado, a metodologia desenvolvida, os dados e os resultados obtidos parecem evidenciar a tensão entre a governança no seu sentido institucionalista e a ecogovernamentalidade. Uma tensão pouco explorada no escopo das análises de governança, ou mesmo na literatura especializada de governança ambiental e de governança dos recursos energéticos.

Nesse sentido, se estabelece de um lado uma visão relativamente otimista que elenca a governança como uma nova configuração entre Estado, sociedade e mercado, um arranjo supostamente capaz de harmonizar funções públicas e privadas, e construir benefícios mútuos. Ou ainda, como um novo desenho político-institucional com potencial de promover novos modos, formas e estruturas políticas para além do instituído pelos mecanismos tradicionais de governo. A governança é apresentada como instrumento hábil para aproximar indivíduos e instituições no escopo das esferas públicas e privadas, de ser dotada de mecanismos para viabilizar a negociação de assuntos de interesse comum. A visão institucionalista, por exemplo, leva a crer que seu funciomento está atrelado à qualidade das interações e interdependências entre os atores sociais, sobretudo, na qualidade de acesso às arenas de ação política, onde parece ser possível mudar e negociar as regras estabelecidas.

Numa direção contrária, entretanto, se apresenta uma visão mais pessimista das relações de poder e domínio de arenas políticas pelas práticas do panóptico social de Foucault (1980) absorvida pela figura do panóptico ambiental de Luke (1995). Nessa concepção, meios persuasivos são construídos para se atingir fins, sedimentar verdades e empregar expedientes desejáveis. A análise da ecogovernamentalidade traz em seu bojo uma crítica à própria emergência das questões ambientais na gestão pública, indicando-as, inclusive, como parte de novas retóricas aplicadas tanto pelo Estado quanto por instituições não-estatais para legitimar interesses e atividades produtivas.

Nos dois estudos de caso, os arranjos político-institucionais de governança seriam supostamente capazes de promover a participação, cooperação, responsabilização e equidade na regulação e gestão de recursos energéticos. No Brasil, como visto, a política pública ao setor - PNPB - foi gerida intencionalmente para incorporar de forma pluralista diversos atores na governança do biodiesel. Nos 
Estados Unidos, por sua vez, a exploração dos folhelhos seguiu a lógica da história, cultura e política do país e de suas unidades federativas, no qual as instituições e governos locais voltam-se comumente a perseguir a good governance.

Os resultados, entretanto, demonstraram que ambos os sistemas de governança, independente de seus históricos de implementação, a despeito da materialidade dos recursos envolvidos, da significativa diferença das políticas e, especialmente, dos pactos federativos que estão envoltas, evoluíram igualmente para sistemas viciosos. Nos dois casos as práticas envolvidas e mesmo as relações de poder que supostamente seriam controláveis e negociáveis pelos mecanismos de governança, demonstraram-se super arraigados e regidos pelos valores profundos de atores sociais hegemônicos, aqueles de maior poder, representados pelas indústrias (agro) energéticas.

A pesquisa evidenciou que a despeito das diferenças antagônicas das políticas energéticas dos dois países, uma excessivamente centralizada e outra bastante descentralizada, sem a devida atenção ao princípio da equidade, os sistemas de governança tanto nos PG quanto em EFS se configuraram inapropriados para promover mecanismos inéditos de ação coletiva, independentemente de serem descentralizadas ou não. Nos dois estudos de caso, a grande assimetria de poderes e de recursos (políticos, informacionais e econômicos) não impediu a consolidação de expedientes de cooptação feita por elites regionais/locais, ou mesmo do domínio dos arranjos político-institucionais pelos participantes mais poderosos e articulados.

A análise realizada nos dois casos de estudo revelou que o padrão de eco-governamentalidade comum aos dois casos evidencia que as retóricas e discursos são na realidade instrumentos apropriados e utlizados para legitimar velhos expedientes de apropriação dos recursos oficiais e de domínio das estruturas políticoprodutivas. Essa condição se revelou nas duas paisagens energéticas e seus respectivos sistemas de governança onde os discursos se materializam e justificam as estruturas produtivas de acordo com o interesse dos atores do setor industrial.

Entre as práticas de governança aferidas e os padrões de ecogovernamentalidade revelados acredita-se, entretanto, que não há necessariamente uma contradição, apesar de a análise revelar um quadro bastante distinto de uma em relação à outra. Isso porque os discursos, retóricas e eco-knowledges propagados pelos policy makers e stakeholders distribuídos nas associações, confederações industriais e seus respectivos lobbies justificam as estruturas políticas e a exploração de suas cadeias produtivas. São eles que dão guarida aos processos e diretrizes de governança dos recursos energéticos. Na prática, portanto, não existe nos dois casos uma contradição, mas muito mais uma coabitação ou coadunação adequada, propícia 
entre a eco-governamentalidade e a governança, ou seja, entre o 'socioambientalismo tempestivo' e os 'sistemas de governança viciosos'.

No afã de lançar luz a essa correlação, o trabalho gerou o desenvolvimento de uma proposta metodológica que se mostrou suficientemente adequada para avaliação de sistemas de governança e da eco-governamentalidade dos recursos energéticos. Isso porque a análise qualitativa-quantitativa abrangeu as principais categorias de investigação e incorporou parâmetros, fatores e subfatores qualificáveis. A utilização da ferramenta Atlas.ti para a análise de conteúdo dos discursos se demonstrou, por sua vez, suficientemente eficaz para auxiliar na compreensão das percepções dos atores e identificar trechos, citações e padrões representativos de seus vieses cognitivos e ideológicos. A metodologia atendeu, portanto, ao terceiro e quarto objetivos da pesquisa voltados a analisar as estruturas, processos e os discursos tanto nos PG de biodiesel quanto em EFS.

Ainda nesse sentido, a análise comparativa entre os sistemas de governança do biodiesel gaúcho e dos folhelhos texanos foi eficaz para debater a gama considerável de elementos teóricos e de estabelecer uma base para identificação e visualização rápida de pontos fracos e gargalos nos dois casos investigados. A partir dessas caracteríticas foi possível tecer considerações sobre potencialidades e fragilidades na governança dos recursos energéticos, mesmo se tratando de fontes de energia e sistemas políticos bastante distintos. Em ambos os casos foi possível, portanto, identificar os gargalos e vícios de governança do biodiesel e dos folhelhos, mas também apontar para padrões similares de ecogovernamentalidade.

A partir dos resultados obtidos foi possível responder também as perguntas norteadoras que acompanharam a execução da tese. A primeira, sobre a capacidade dos sistemas de governança de recursos energéticos serem capazes de promover dispositivos inéditos de ação coletiva. A resposta comum encontrada aponta que nem os Polos Gaúchos nem Eagle Ford foram capazes de promover ou estimular novas lógicas de regulação e gestão na regulação e exploração de energia. Numa direção oposta, nos dois casos se edificaram concretamente ambientes que promoveram uma corrida aos ganhos e vantagens imeditatos sem a devida incorporação de critérios sociais e precauções ambientais.

A respeito da interação, cooperação e participação que ambos os sistemas de governança promoveram, a resposta é que o processo foi de uma expressiva superficialidade e de baixa qualidade. Nos dois casos estudados, os direcionadores demonstraram que, ao contrário da maior conjugação de interesses, cooperação interinstitucional e de participação política, se desenvolveram ambientes 
concorrenciais acirrados, focos de conflitos comerciais, jurisdicionais e mesmo processos de cooptação, como exemplificado pelo caso das doações financeiras das companhias energéticas aos governos locais no Texas.

No tocante a capacidade da governança de recursos energéticos promover o deslocamento regulatório de funções tradicionais de gestão do Estado terceira pergunta norteadora - a pesquisa determinou que sim, houve o deslocamento, mas não necessariamente de forma positiva a boa governança. Isso porque nem sempre o processo aconteceu na direção, sentido e formas consideradas benéficas. No sistema de governança do biodiesel gaúcho não houve uma descentralização das funções, mas uma desconcentração das funções administrativas na escala federal. Não houve, entretanto, nenhuma ruptura no desenho tradicional e do fluxo top-down característicos da política energética nacional. Na prática as deliberações do biodiesel brasileiro continuaram centralizadas. No caso dos folhelhos texanos, por sua vez, houve um deslocamento regulatório, mas numa direção que cerceou a autonomia histórica e a liberdade dos governos locais, indo no sentido da re-centralização das competências e prerrogativas para o estado.

O conjunto de dados e resultados obtidos por meio da metodologia serviu como base para referendar a hipótese tecida incialmente pelo presente estudo, na qual, as estruturas e processos que regem os sistemas de governança dos $P G$ e de EFS são particulares e diferentes entre si. De fato, cada sistema possui suas particularidades constitutivas, arranjos político-institucionais, regras e normas. Elementos que ditam tanto as interdependências, interações e relações de poder quanto determinam os fluxos e processos produtivos e administrativos de maneiras distintas.

Apesar disso, de forma igualmente levantada pela hipótese, os discursos propagados pelos atores de governo e do setor (agro) industrial-energético envolvidos nos dois casos é bastante semelhante. Ou seja, em ambos os sistemas, os atores empregam amplamente o conceito de sustentabilidade, propagam aspectos tecnológicos e cientificos de modo a ressaltar seus comprometimentos com os ambientes humanos e naturais envolvidos, de forma a justificar seus padrões produtivos frente ao estímulo socioeconômico que seus setores representam. Um padrão de eco-governamentalidade, voltado nos dois casos, para legitimar as ações e interesses das empresas, companhias e seus representantes políticos no uso e exploração das fontes de energia e dos recursos naturais atrelados. 


\section{CONSIDERAÇÕES FINAIS (limitações e potencialidades da pesquisa)}

Toda pesquisa está sujeita a limitações e restrições. O presente estudo obviamente não está livre de fragilidades e de lacunas avaliativas. Mais ainda, por se tratarde uma pesquisa de vasto caráter multidisciplinar e etnocêntrico, está naturalmente sujeita as subjetividades e aos vieses cognitivos de seu condutor. Adicionalmente, suas limitações interligam-se às restrições legais, orçamentárias e temporais que não pemitiram um maior volume de captação de dados primários, e a respectiva compilação e tratamento pela metodologia proposta.

Essas limitações naturalmente conduziram a uma superficialidade indesejável em aspectos pontuais da pesquisa e emoutros aspectos políticos, econômicos, culturais, sociais e ambientais abordados. Deve se considerar que o maior aprofundamento de temáticas pontuais também foi prejudicado pela incipiência de dados científicos consolidados, tanto dos impactos ambientais do biodiesel (i.e.mudança de uso da terra, pressão direta e indireta na modificação de ambientes naturais), quanto dos folhelhos (i.e. impactos causados aos recursos hídricos e contaminação atmosférica). Recursos energéticos que, dado as suas temporalidades e as suas práticas intensivas iniciadas há pouco mais de uma década, têm boa parte das pesquisas ainda em andamento.

Ainda assim, considerando a dimensão e a complexidade das duas áreas de produção investigadas, bem como, o universo de instituições e a miríade de atores envolvidos, e ainda, a complexidade de arenas, de regras, de variáveis estruturais, de informações e de dados obtidos, os resultados se demonstraram suficientemente sólidos para validar a discussão que se propôs inicialmente. Ou seja, da importância de se incorporar, debater e qualificar a governança dos recursos energéticos sob o escopo da eco-governamentalidade.

Vale ressaltar, entretanto, que os direcionadores de governança dos recursos energéticos e o farol da governança, apesar do seu funcionamento satisfatório, podem ser aprimorados para pesquisas futuras, reavaliando o número de componentes - direcionadores e subfatores - envolvidos. Isso porque algumas variáveis demonstraram-se bastante interligadas, redundantes, ou mesmo dependentes de outras. O princípio de empoderamento, por exemplo, demonstrou-se diretamente dependente dos critérios de participação e cooperação, de análise mais tangível e mensurável. Essas modificações implicariam no enxugamento dos direcionadores, dos seus componentes e, portanto, da escala likert adotada.

Ainda assim, acredita-se que os procedimentos aqui descritos demonstraram sua validade como base para novas pesquisas e possibilitaram a 
abertura de aspectos polêmicos para novas discussões que pemeiam o corpo teórico da governança quando considerados a regulação e agestão de políticas energéticas. A pesquisa e o seu enfoque jogam luz, portanto, na complexidade político-insitucional e cultural que acompanham a produção e a exploração de fontes de energia.

O enfoque na governança demonstra que, independente das características materiais dos recursos, análises de base institucionalista incluindo os padrões de eco-governamentaliade são de grande importância para avaliação de novos e tradicionais arranjos políticos-produtivos na exploração e produção de energia. Sejam eles na produção de hidroeletricidade (Belo Monte, Santo Antônio, Girau), de energia eólica (Campos Neutrais, Sweetwater, Alto Sertão, Praia Formosa, Osório), de energia solar; sejam eles nas futuras áreas de exploração de recursos não-convencionais de folhelhos no Brasil. 


\section{BIBLIOGRAFIA}

AACOG. Alamo Area Council of Governments. Natural Resources/ Transportation Department. Oil and Gas Emission Inventory, Eagle Ford Shale. Thecnical Report. November 30 2013.

AGRAWAL, A. Environmentality: Technologies of government and the making of subjects. I. Durham (NC) and London: Duke University Press, 2005. xvi, 325 p. paper. ISBN 0-8223- 3492-5.

ALTIERI, M. A. Green Deserts: Monocultures and their impacts on biodiversity. In: EMANUELLI, M. S.; JONSÉN, J.; SUÁREZ, S. M.;(Eds).Red Sugar Green Deserts: Latin American report on monocultures and violations of the humam rights to adequate food and housing, to water, to land and to territory. Oslo, Sweden,FIAN International, 2009, p.67-77.

ANDERSON, benedict.Imagined communities: Reflections on the origins and spread of nationalism.1991 (1983). New York: Verso.

ANHOLETO, C. D. MASSUQUETTI, A. A soja brasileira e gaúcha no período 19942010: Uma análise da produção, exportação, renda e emprego.Anais do $7^{\circ}$ encontro de economia gaúcha Sessão Temática: K. Agricultura Familiar e Desenvolvimento Rural. Disponível em:http://www.fee.rs.gov.br/wpcontent/uploads/2014/05/201405267eeg-mesa26-sojabrasileiragauchaperiodo19942010.pdf Acesso em: 01/01/15.

APACHE. Energizing a Sustainable Future.2013 Summary Sustainability Report. Disponível em: http://www.apachecorp.com/Resources/Upload/file/sustainability/APACHESustainability Report 2013.pdf Acesso em: 22/02/2016.

API. AMERICAN PETROLEUM INSTITUTE. America's energy revolution: How "fracking" has transformed the U.S. into an energy superpower. 2014. Disponível em: www.api.org. Acesso em:04/03/2016.

API. AMERICAN PETROLEUM INSTITUTE. Shale Story.2011. Infographic.http://www.api.org/News-and-Media/Infographics/Shale-Story-EagleFord Acesso em: 22/02/2016.

API. AMERICAN PETROLEUM INSTITUTE. U.S. Oil Shale: Protecting our environment.[2013]. Disponível em: http://www.api.org/ /media/Files/Oil-and-NaturalGas/Oil Shale/Oil Shale Factsheet 2.pdf Acesso em: 22/02/2016.

ARIZA, P.M.; LELE, S.; KALLIS, G.; MARTINEZ-ALIER, J. The political ecology of Jatropha plantations for biodiesel in Tamil Nadu, India. The Journal of Peasant StudiesSpecial Issue: Biofuels, Land and Agrarian Change, v.37, nr.04,pp.875-897, 2010

AZEVEDO, A. M. M. Análise top-down e bottom-up de um programa de inovação tecnológica na área de energia: o programa nacional de produção e uso de biodiesel (PNPB). $331 \mathrm{f}$. Tese de Doutorado. Departamento de Política Científica e Tecnológica, Universidade Estadual deCampinas, Campinas, 2010. 
AZEVEDO, A. M. M. Análise top-down e bottom-up de um programa de inovação tecnológica na área de energia:o programa nacional de produção e uso de biodiesel (PNPB).Revista Gestão \& Conexões - Management and Connections Journal, v. 2, nr. 2, pp.33-51, 2013.

BAILIS, R.; BAKA, J. Constructing Sustainable Biofuels: Governance of Emerging Biofuel Economy. 2011. Annals of the Association of American Geographers, v. 101 , nr. 04, p.827-838.

BANDEIRA-DE-MELLO, R. Softwares em pesquisa qualitativa. In: GODOI, Christiane K, BANDEIRA-DE-MELLO, Rodrigo; SILVA, Anielson B. (Org.). Pesquisa Qualitativa em Estudos Organizacionais: paradigmas, estratégias e métodos. São Paulo: Editora Saraiva, 2006.

BARROS, C. J. Parceria entre PBio e Embrapa é a última chance para o biodiesel de mamona do Semiárido? 2014. Reporte Brasil. Disponível em: http://reporterbrasil.org.br/2014/06/parceria-entre-pbio-e-embrapa-e-a-ultima-chancepara-o-biodiesel-de-mamona-do-semiarido/. Acesso em: 15/08/2015.

BAKER, T.L. More Ghost Towns of Texas.Normam: University of Oklahoma Press 2003, 210pp.

BAKKER, K. A political ecology of water privatization.Studies in Political Economy, V. 70, NR.[S.I.] pp. 35-58, 2003.

BAKKER, K. An uncooperative commodity: privatizing water in England and Wales. Oxford, 2003, Oxford University Press.

BAKKER, K; BRIDGE, G. Resource regulation.In Handbook of political geography, ed. K. Cox, M. Low, and J. Robinson, 2007. pp. 269-88. London: Sage.

BARRY, A. Visible Invisibility. pp. 67-75. In: New Geographies 2: Landscapes of Energy. Harvard University Press, 2009.

BECK, U. Risk Society: Towards a New Modernity. 1992. Sage: London and Newbury, CA.

BECKER, Berta K. O Uso Político do Território: questões a partir de uma visão do terceiro mundo. In: BECKER, Berta K.; COSTA, Rogério K.; SILVEIRA, Carmem B.; (orgs.) Abordagens Políticas da Espacialidade. Rio de Janeiro: UFRJ, 1993.

BECKER, Berta. Recuperação de áreas desflorestadas da Amazônia: será pertinente o cultivo da palma de óleo (Dendê)? Confins, v.10, nr.10, pp. [s/d], 2010.

BERMANN, C. Energia no Brasil: Para quê? Para quem? Crise e alternativas para um país sustentável, São Paulo: Ed. Livraria da Física/FASE, 2002;

BERMANN, C. As novas energias no Brasil: Dilemas da inclusão social e programas de Governo". Rio de Janeiro: FASE, 2007.

BIODIESELBR. A Inevitável Crise. Edição de outubro/novembro de 2013. Disponível em: $\quad$ http://loja.biodieselbr.com/revista-anteriores/revista-37.html Acesso em:01//01/2014. 
BIODIESELBR. A Chegada do B7. Edição de junho/julho de 2014, nr.41. Disponível em: http://loja.biodieselbr.com/revista-anteriores/revista-37.html Acesso em:01//01/2014.

BIRKENHOLTZ, T. Groundwater governmentality: hegemony and Technologies of resistance in Rajasthan's (India) groundwater governance. The Geographical Journal nr.175, p. 208-220, 2009.

BØÂS, Morten.Governance as multilateral bank policy: the cases of the African Development Bank and the Asian Development Bank', European Journal of Development Research, v.10, nr.02, pp. 117-134, 1998.

BOFF, I. Portaria MDA n $\mathbf{6 0}$, de 06/09/12 - alteração. Proposta de Alteração na Minuta da Consulta Pública. Ofício encaminhado pelo Sindibio/RS ao Ministério do Desenvolvimento Agrário, Coordenação Geral de Biocombustíveis. Disponível em: http://www.mda.gov.br/sitemda/sites/sitemda/files/user arquivos 64/SINDIBIO-RS.pdf. Acesso em: 30/07/2015.

BORRAS, S. J.R. et al. The politics of biofuels, land and agrarian change: editors' introduction. Journal of Peasant Studies, London, GB: Frank Cass, v.37, n.4, pp.575592, 2010.

BORRAS, S. J.R; MCMICHAEL, P.; SCOONES, I. (Orgs) The Politics of Biofuels, Land and Agrarian Change. Critical Agrarian Studies. Routledge, pp.01-19,2011.

BOREKI, Vinicius. Distribuindo riqueza. BiodieselBR, v.6, nr.36, p.32-35, 2013.

BRANNSTROM, C. A sustentabilidade em função do uso não sustentável dos recursos naturais no Oeste Baiano e Eagle Ford Shale texano. Mercator, Fortaleza, v. 14, n. 1, p. 89-104, jan/abr. 2015.

BRANNSTROM, C. Compliance and market exclusion in Brazilian agriculture: Analysis and implications for "soft" governance. Land Use Policy, v. 29, pp. 357- 366, 2012.

BRANNSTROM, C., CLARKE, J. and NEWPORT, M. Civil society participation in the decentralisation of Brazil's water resources: assessing participation in three states. Singapore Journal of Tropical Geography, v. 25, nr.03, pp. 304-21, 2004.

BRASIL. Agência Nacional do Petróleo, gás natural e biocombustíveis (ANP). Anuário estatístico brasileiro do petróleo, gás natural e biocombustíveis. 2011. Rio de Janeiro.

BRASIL. Companhia Nacional de Abastecimento (Conab). 2014. Séries agrícolas históricas das safrasde 1976 a 2014/15. Disponível em: http://www.conab.gov.br/conteudos.php?a=1252\&\&Pagina objcmsconteudos=3\#A obj cmsconteudos. Acesso em: 23/02/2014.

BRASIL. Decreto [s/n] de 23 de dezembro de 2003. Comissão Executiva Interministerial encarregada da implantação das ações direcionadas à produção e uso de óleo vegetal-biodiesel como fonte alternativa de energia. Presidência da República. Disponível em: https://www.planalto.gov.br/ccivil 03/DNN/2003/Dnn10093.htm. Acesso em: 15/06/2015. 
BRASIL. Decreto 6.685 de 10 de dezembro de 2008. Estrutura de funcionamento do Conselho Nacional de Política Energética (CNPE). Presidência da República. Disponível em: http://www.planalto.gov.br/ccivil 03/ Ato20072010/2008/Decreto/D6685.htm. Acesso em: 01/07/2015.

BRASIL. Lei 9.478 de 6 de agosto de 1997. Política Energética Nacional. Presidência da República. Disponível em: http://www.planalto.gov.br/ccivil 03/leis/L9478.htm. Acesso em: 01/07/2015.

BRASIL. Lei 12.490 de 16 de setembro de 2011. Política e fiscalização das atividades relativas ao abastecimento nacional de combustíveis. Presidência da República. Disponível em: http://www.planalto.gov.br/ccivil 03/ Ato20112014/2011/Lei/L12490.htm. Acesso em: 01/07/2015.

BRASIL. Lei $n^{0}$ 13.033, de 24 setembro de 2014. Dispõe sobre a adição obrigatória de biodiesel ao óleo diesel comercializado com o consumidor final; altera as Leis nos 9.478, de 6 de agosto de 1997, e 8.723, de 28 de outubro de 1993; revoga dispositivos da Lei no 11.097, de 13 de janeiro de 2005; e dá outras providências. Disponível em: http://www2.camara.leg.br/legin/fed/lei/2014/lei-13033-24-setembro-2014-779372norma-pl.html. Acesso em: 01/02/2015.

BRASIL. Ministério da Agricultura, Pecuária e Abastecimento. Câmaras Setoriais e Temáticas de. Oleaginosas e Biodiesel.Sistema de Gestão de Câmaras Setoriais e Temáticas. Coordenação Geral de Apoio às Câmaras Setoriais e Temáticas. Ata de Reunião. Reunião Ordinária $\mathrm{n}^{0} .22$ 24/03/2015. Disponível em: http://www.agricultura.gov.br/camaras-setoriais-e-tematicas. Acesso em: 20/08/2015.

BRASIL. Ministério do Desenvolvimento Agrário. Balanço do Selo Combustível Social. $2016 \quad$ Disponível em: http://www.mda.gov.br/sitemda/sites/sitemda/files/user img 873/SCS\%20\%20Balan\%C3\%A70\%202014\%20Graficos\%20ajustados.pdf. Acesso em: 14/01/2016.

BRASIL. Presidência da República. Casa Civil. Subchefia para assuntos jurídicos. Decreto 6961/2009. Zoneamento Agroecológico da cana-de-açúcar. Disponível em: http://www.planalto.gov.br/ccivil 03/ Ato2007-2010/2009/Decreto/D6961.htm. Acesso em: 12/10/2015.

BRASIL. Projeto Polos de Produção de Biodiesel: Agricultores familiares plantam o combustível do futuro. Secretaria da Agricultura Familiar do Ministério do Desenvolvimento Agrário (SAF/MDA) e Plural Cooperativa - Consultoria, pesquisa e serviços. $2010 . \quad$ Disponível em: http://www.pluralcooperativa.com.br/publicacoes/Projeto Polos de Producao de Bio diesel.pdf. Acesso em:01/01/2015.

BRASILDEFATO. Camponeses vão produzir biodiesel. 2010. Disponível em: https://www.google.com.br/webhp?sourceid=chrome-instant\&ion=1\&espv=2\&ie=UTF$8 \# q=$ cooperativa+biopampa. Acesso em: 15/08/2015.

BRIDGE, G. and JONES, A. Governing nature: the reregulation of resource access, production and consumption. Environment and Planning A, v.34, nr.[s.i.] pp. 759-66, 2002.

BRIDGE, G. Global production networks and the extractive sector: governing resourcebased development. Journal of Economic Geography, v.08, nr.[s.i] pp.389-419, 2008. 
BRIDGE, G; PERREAULT, T. Environmental Governance. In: Noel Castree, David Demeritt, Diana Liverman and Bruce Rhoads (Eds.) A Companion for environmental geography. Wiley-Blackwell, 2009, pp. 475-97. ISBN 978-1-405156226.

BRUM, A. L.; HECK, C. R.; LEMES, C. L.; MÜLLER, P. K.:A economia mundial da soja: impactos na cadeia produtiva da oleaginosa no Rio Grande do Sul 19702000.Anais dos Congressos. XLIII Congresso da Sober em Ribeirão Preto. São Paulo, 2005.

BRUM, E. Belo Monte, nosso dinheiro e o bigode do Sarney. Revista Época. Sociedade, outubro de 2011. Disponível em: http://revistaepoca.globo.com/Sociedade/noticia/2011/10/belo-monte-nosso-dinheiro-eo-bigode-do-sarney.htm|\#header comentarios Acesso em: 24/02/2016.

BUCHELE, M. Hard Times come to the 'Hotel Capitol”. stateimpacnpr.org, july 21, 2015. Disponível em: https://stateimpact.npr.org/texas/2015/07/21/hard-times-come-tothe-hotel-capital/ Acesso em: 01/02/2106.

BULKELEY, H.;WATSON, R; WEAVER, P. Governing municipal waste: Toward a new analytical framework. Journal of Environmental Policy \& Planning, v.7, nr.01, pp.126, 2005.

BURSZTYN, M. A.Think Locally, Act Globally: New Challenges to Environmental Governance. Sustainability Science Program Kennedy School of Government Harvard University.Working Paper No. 33, Harvard Press.2008Disponível em: http://www.hks.harvard.edu/centers/cid/publications/fellow-graduate-student-workingpapersAcesso em: 23/02/2016.

BURSZTYN, M. A.; BURSZTYN, M. Fundamentos de Política e Gestão Ambiental: Caminhos para a sustentabilidade. Ed.Garamond, Rio de Janeiro, 2012.

CAETANO, M. Abiove e Aprosoja discutem critérios de sustentabilidade com europeu. Valor Econômico. Agronegócios. 2015. Disponível em: http://www.valor.com.br/agro/4000028/abiove-e-aprosoja-discutem-criterios-desustentabilidade-com-europeus. Acesso em: 31/07/2015.

CÂMARA, J. B. G. Governabilidade e governança ambiental e estado do meio ambiente no Distrito Federal. 2011. Tese (Doutorado em Desenvolvimento Sustentável) Centro de Desenvolvimento Sustentável, Universidade de Brasília, Brasília.

CAMPOS, A. Agronegócio da soja domina a produção de biodiesel no Mato Grosso. Repórter Brasil. 2014. Disponível em: http://reporterbrasil.org.br/2014/10/agronegociodasojadominaproducaodebiodieselnom atogrossol. Acesso em:28/07/15.

CASHORE, B. Legitimacy and the privatization of environmental governance: How non-state market-driven (NSMD) governance systems gain rule-making authority. Governance, v. 15, nr.04, pp.503-529, 2002.

CASHORE, B., AULD, G. and NEWSOM, D. (eds) Governing Through Markets: Regulating Forestry Through Non-State Environmental Governance.2004 New Haven: Yale University Press. 
CASTELLANELLI, A.; CUNHA, L.M. Land grabbing: uma abordagem inicial nos aspectos sociais do programa nacional de produção e uso de biodiesel no Brasil. Contribuciones a las Ciencias Sociales. Agosto de 2015.v[s.d.], ISSN: 1988-7833. Disponível em: $\quad$ https://scholar.google.com.br/scholar?um=1\&ie=UTF8\&Ir\&q=related:jvUJU55k 5fnVM:scholar.google.com/ Acesso em: 02/02/16.

CASTREE, N. Commentary: from neoliberalism to neoliberalisation: consolations, confusions, and necessary illusions. Environment and PlanningA, v. 38, nr.[s.i.] pp. 1-6, 2006.

CAVALCANTI, B. S.; PECI, A. Reflexões sobre a autonomia do órgão regulador: análise das agências reguladoras estaduais. Rio de Janeiro: FGV/ Ebap,2001.

CAVALCANTI, J.C. Seminários: Investimento em biodisel. Banco Nacional de Desenvolvimento Econômico e Social (BNDES). Março de 2006. Disponível em: http://www.bndes.gov.br/SiteBNDES/bndes/bndes pt/Institucional/Publicacoes/Pagina s/s biodiesel.html Acesso em: 13/08/2016,

COELHO, M; DINIZ, E. Governabilidade, governança local e pobrezano Brasil. Rio de Janeiro, IUPERJ, 1995.

CHANDHOKE, N. When Is Secession Justified? The Context of Kashmir. Economic and Political Weekly, v. 45, nr. 46, pp. 59-66, 2010. Disponível em: Stable URL: http://www.jstor.org/stable/25764126 Acesso em: 08/02/2016.

CIVA, G. Petrobrás adquire $\mathbf{5 0} \%$ da BSBios. Baguete Jornalismo Digital. Disponível em: $\quad$ http://www.baguete.com.br/noticias/negocios-e-gestao/04/07/2011/petrobrasadquire-50-da-bsbios. Acesso em: 27/07/2015.

CLICRBS. Ambiente: Metasa é a primeira usina de biodiesel com financiamento do BNDES. 2007. Disponíveis em: http://www.clicrbs.com.br/especiais/jsp/default.jsp?newsID=a1448247.htm\&template=3 847.dwt\&section=Not\%EDcias\&espid=21. Acesso em: 15/08/2015.

COLLEGE STATION.College Station City Council Meeting Agenda - Final. January 22, 2015. Disponível em: www.cstx.gov. Acesso em: 01/02/2015.

COLLIER, M. J. \& SCOTT, M. Industrially harvested peatlands and after-use potential: understanding local stakeholder narratives and landscape preferences, Landscape Research, 33(4), pp. 439-460, 2008.

COLUSSI, J. Emater projeta collheita recorde de 16 milhões de toneladas de soja neste ano no RS. Zero Hora Campo e Lavoura. Disponível em: http://zh.clicrbs.com.br/rs/noticias/campo-e-lavoura/noticia/2016/03/emater-projetacolheita-recorde-de-16-milhoes-de-toneladas-de-soja-neste-ano-no-rs-4992729.html\# Acesso em 10/03/2016.

COMMISSION ON GLOBAL GOVERNANCE. Our Global Neighbourhood. 1995. Disponível em: www./cgg.ch/ Acesso em: 01/01/2015.

CRAWFORD, S. E. S; OSTROM, E. A Grammar of Institutions. The American Political Science Review, v.89, nr.03, pp.582-600, 1995. 
DAVIS, C. The Politics of "Fracking": Regulating Natural Gas Drilling Practice in Colorado and Texas. Review of Policy Research, Volume 29, Number 2 p.177-191, 2012a.

DAVIS, C. Substate Federalism and Fracking Policies: Does State Regulatory Authority Trump Local Land Use Autonomy? In: STERN, Paul C. Risks and Risk Governance in Shale Gas Development. Summary of two workshops. The National Academy Press, Whasington, DC, 2014, p.1874-1925.

DAVIS, C.; HOFFER,K. Federalizing energy? Agenda change and the politics of fracking.Policy Sci, v.[s.i.], nr. 45, pp.221-241, 2012 b.

DESROSIER, B. Marcellus Shale Parallel Universe. Energy in Depth Blog Spot. Disponível em: http://energyindepth.org/marcellus/marcellus-shale-parallel-universe/ Acesso em: 21/01/2016.

DESROSIER, B. Serfdom, Coming to a Town Near You. Energy in Depth Blog Spot. Disponível em: http://energyindepth.org/marcellus/serfdom-coming-to-a-town-near-you/ Acesso em: 21/01/2016.

DIARIO CATARINENSE.Energia Limpa: Única usina de biodiesel de SC opera em Joaçaba, no Meio-Oeste.Disponível em: http://diariocatarinense.clicrbs.com.br/sc/noticia/2014/05/unica-usina-de-biodiesel-desc-opera-em-joacaba-no-meio-oeste-4493221.html. Acesso em: 24/07/2015.

DIAS, G.; ABRAMOVAY, R.A Política do BiodieselEm: Agronegócio: Desenvolvimento, meio ambiente e sociedade. SiLVA, V.; MELLO, N.T.C. (Org.) Ciclo de Debates IEA 65 Anos. 2007, p.75-97. Instituto de Economia Agrícola. Disponível em: ftp://ftp.sp.gov.br/ftpiea/publicacoes/65anos/65anos.pdf. Acesso em: 14/08/2015.

DINIZ, M. Governabilidade, governance e reforma do Estado: considerações sobre o novo paradigma. Revista do Serviço Público, Brasília, v.120, nr. 02, 1996.

DINIZ, J.B.; FAVARETTO, A. Os desafios da inclusão da agricultura familiar no mercado de matéria-prima para o biodiesel no Brasil. Estud. Soc. e Agric., Rio de Janeiro, vol. 20, nR. 1, pp. 139-187, 2012.

DITTRICK, P. WoodMac: Eagle Ford 2013 spending to reach U\$ 28 billion. 2012, Oil Gas Journal, v. 110, p.12.

DOBSON, K. Is physics debatable? Phys. Educ. Volume 35, número 1. 2000.

DOWLING, R. Geographies of identity: climate change, governmentality and activism.Progress in Human Geography, nr. 34, v.04, pp.488-495, 2010.

DRAKE, Elisabeth et. Al. Good governance and the World Bank. University of Oxford, 2002. Dispponivel em: http://www.ucl.ac.uk/dpuprojects/drivers urb change/urb economy/pdf glob SAP/BWP Governance World\% 20Bank.pdf. Acesso em: 22/05/2015.

DRYZEK, J. S. The Politics of the Earth: Environmental Discourses. 2nd Ed. Oxford University Press, New York, 2005. 
DUARTE, A. Sindicatos: Força Regional. BiodieselBR, 2011, v. 3, nr. [s/nº, p. [s/d]. Disponível em: http://www.biodieselbr.com/revista/023/forca-regional-1.htm. Acesso em: 03/08/15.

DUPPER, A. Going Green: The Virtues of Fracking, Eagle Ford Shale Magazine, v.02, nr.03, p. 62-3, 2014.

EARTHWORKS. Enforcement Report RRC. Texas Railroad Commission: Inadequatre enforcement means irresponsible oil and gas development. September 2012. Disponível em: https://www.earthworksaction.org/issues/detail/texas oil gas enforcement the publics role\#.VhKfRDZdHIU. Acesso em: 05/10/2015.

EARTHWORKS. Texas Oil \& Gas Enforcement - Public Participation. Citizen
Complaints help uncover violations. Disponível em:
https://www.earthworksaction.org/issues/detail/texas oil gas enforcement the publics
role\#.VhKfRDZdHIU. Acesso em: 05/10/2015.

ENERGY CITIZENS. JoinAmerica's Energy Revolution. energycitizens.org. Disponível em: http://energycitizens.org/ Acesso em: 02/02/2016.

ELETROSUL. Agência Digital de Informações. 2007. BNDES financia fábrica de biodiesel da Granol. Disponivel em: http://www2.eletrosul.gov.br/gdi/gdi/cl pesquisa.php?pg=cl abre\&cd=geobbe09BObeg . Acesso em: 15/08/2015.

EMBRAPA. Empresa Brasileira de Pesquisa Agropecuária. Portal Embrapa Notícias. Agroenergia. Biodiesel reduz 70\% a emissão de Gases de Efeito Estufa. 2015. Disponível em: https://www.embrapa.br/busca-de-noticias/-/noticia/2723697/biodieselreduz-em-70-a-emissao-de-gases-do-efeito-estufa. Acesso em: 05/08/15.

E.I.A. United StatesEnergy Information Agency. Review of Emerging Resources: U.S. Shale Gas and Shale Oil Plays, Energy Information Administration. July 2011. Disponível em: https://www.eia.gov/analysis/studies/usshalegas/pdf/usshaleplays.pdf Acesso em: 08/10/2014.

E.P.A. United States Environmental Protection Agency. Draft Plan to Study the Potential Impacts of Hydraulic Fracturing on Drinking Water Resources. 2011. Office of Research and Development. Disponivel em: http://www.epa.gov/hydraulicfracturing. Acesso em: 01/02/15.

ESTY, D. C., LEVY, M., SREBOTNJAK, T. \& de SHERBININ, A. 2005 environmental sustainability index: Benchmarking environmental stewardship. New Haven, CT: Yale Center for Environmental Law and Policy.

EVANS, J.P. Environmental Governance. Routledge.2012. Park Square, Milton Park, Abingdon, Oxon, England.272 p. ISBN 978-0-415-58982-6.

EXXON MOBIL. The Outlook for Energy: A view to 2040. 2015. Disponível em : http://cdn.exxonmobil.com/ /media/Global/Files/Outlook-for-Energy/2015-Outlook-forEnergy print-resolution.pdf. Acesso em: 30/09/2015.

FABER, D. Nature's meaning: Capitalizing on environmental injustice: The polluter-industrial complex in the age of globalization. 1. ed. Lanham, MD: Rowman \& Littlefield, 2008. 
FAVARETO, A.; KAWAMURA, Y.; DINIZ, J.B. Controvérsias científicas e sociais na produção de biocombustíveis - uma avaliação do programa nacional de produção e uso do biodiesel. Contemporâneos Revista de Artes e Humanidades, v. [s/d], nr.09, pp.02-28, 2011.

FAVARETO, A.; MAGALHÃES, R.; SCHRODER, M. Dilemas da inovação institucional e governança nos arranjos produtivos de biodiesel. Anais do XLVI Congresso da Sociedade Brasileira de Economia, Administração e Sociologia Rural (SOBER). Rio Branco, Acre, pp. [s/d], 2008.

FESTINGER, L. A Theory of Cognitive Dissonance. Stanford, CA: Stanford University Press, 1957.

FERGUSON, J. The anti-politics machine: “development," depoliticisation, and bureaucratic power in Lesotho. 1990. Cambridge: Cambridge University Press.

FERRES, J.D. Prontos para uma nova fase. BiodieselBR, v.08, nr.47, p.34-35, 2015.

FGV. Fundação Getúlio Vargas. 0 biodiesel e sua contribuição ao desenvolvimento Brasileiro. Estudo encomendado pela União Brasileira do Biodiesel. Disponível em: http://www.ubrabio.com.br/sites/1700/1729/00000201.pdf. Acesso em: 01/07/2015.

FIPE. Fundação Instituto de Pesquisas Econômica. Impacto Socioeconômicos da Indústria de biodiesel no Brasil. Estudo encomendado pela Associação dos Produtores de Biodiesel no Brasil. Relatório Final. São Paulo, 2012. Disponível em: http://www.aprobio.com.br/AprobioFIPERelatorioFinalsetembro2012.pdf. Acesso em: 01/07/2015.

FLETCHER, R., Neoliberal environmentality: towards a poststructuralist political ecology of the conservation debate. Conservation and Society, nr. 8, v.03, p.171$181,2010$.

FLEXOR, G. G. A Economia Política da Construção Institucional do Mercado de Biodiesel no Brasil. In: Philippe Bonnal, Sergio Pereira Leite (Org.). Análise Comparada de Políticas Agrícolas. Rio de Janeiro: Mauad, 2011, v. [n.d.] p. 363-387.

FLEXOR, G. G; KATO, K.; LIMA, M. S.; ROCHA, B. N. Dilemas institucionais na promoção dos biocombustíveis. 2011. Cadernos do Desenvolvimento, v.8, p. 329354.

FLEXOR, G. G; KATO, K.; LIMA, M. S.; ROCHA, B. N. Poíticas Públicas, Dinâmica Institucional de Interesses: Análise do Programa Nacional de Produção e Uso de Biodiesel. Fundação de Amparo a Pesquisa do Rio de Janeiro. 2011. Disponível em: http://oppa.net.br/acervo/publicacoes/Relat\%C3\%B3rio final-pesquisa PNPB.PDF.

Acesso em: 22/07/2015.

FONSECA. I. F. Entre o discurso e a prática: Boa governança e Agendas 21 locais na Amazônia. Dissertação (Mestrado em Desenvolvimento Sustentável). Centro de Desenvolvimento Sustentável, Universidade de Brasília, Brasília.

FONSECA, I. F.; BURSZTYN, M. A banalização da sustentabilidade:reflexões sobre governança ambiental em escalalocal. Sociedade e Estado, Brasília, v. 24, n. 1, p. 17-46, 2009. 
FOUCAULT, M. A Arqueologia do Saber. Ed. Forense-Universitária, 1987, $3^{\mathrm{a}}$ edição, pp.125.

FOUCAULT, M. Govenmentality. In: G. Burchall, C.Gordon, and P.Miller (Eds.) The Foucault Effect: Studies in Governmentality, Chicago University Press. 1992.

FOUCAULT, M. Subjectivity and truth. In P. Rabinow (Ed.). 2000a. Michel Foucault: Ethics: Subjectivity and truth/translated by Robert Hurley and others, pp. 87-92. London, England: Penguin.

FOUCAULT, M. The ethics of the concern for self as a practice of freedom. In $\mathrm{P}$. Rabinow (Ed.). 2000b Michel Foucault: Ethics: Subjectivity and truth/translated by Robert Hurley and others. pp. 281-301. London, England: Penguin.

FURSTENAU, Vivian. A economia gaúcha e os anos 80: uma trajetória regional no context da crise brasileira. Aspectos setoriais do desenvolvimento do Rio Grande do Sul. 1990. pp. 207-240. FEE, Porto Alegre.

FRANCO, C. Em busca de um (novo) norte. Comissão Interministerial continua tendo um papel relevante. BiodieselBR, v. 07, nr. 41, p.22-25.

FREIRE, L. Soja: Imbatível na produção do biodiesel brasileiro. Óleos e Gorduras: Grãos e Derivados, v.01, nr.04, p.01-03, 2015.

FREITAS, R. C. Fandango Gaúcho. BiodieselBR, v.06, nr.37, p.24-29, 2013.

FROZZA, M. S.; TATSCH, A. L. Sistema setorial do biodiesel no Rio Grande do Sul: caracterização e oportunidades para a consolidação de um sistema inovativo em agroenergia. 2014. Ciência Rural, v. 44, nr. 12, p. 2286-2292.

GORDON, C. Governmental rationality: an introduction. In: The Foucault effect: studies in governmentality(eds. Burchell, G., C. Gordon, and P. Miller), pp. 01- 48, 1991. Chicago, IL: University of Chicago Press.

GEELS, F. W. \& SCHOTT, J.Typology of sociotechnical transition pathways, ResearchPolicy, nr.36, v.03, pp. 399-417, 2007.

GIBBS, D; JONAS A. E. G.Governance and regulation in local environmental policy: The utility of a regime approach. Geoforum.nr. 31, pp.299-313, 2000.

GRANOVETTER, M. Economic action and social structure: the problem of embeddedness.American Journal of Sociology.Number 91, pp.481-510, 1985.

GRATTAN, R. Oil and natural gas boosters to merge into energy lobbying behemoth. Fuel Fix, November 18, 2015. Disponível em: http://fuelfix.com/blog/2015/11/18/oiland-natural-gas-boosters-to-merge-into-energy-lobbying-behemoth/ Acesso em: 27/01/2016.

GRINDLE, Merilee. Good enough governance: poverty reduction and reform in developing countries. Governance: Na International Journal of Policy, Administration, and Institutions, v.17, nr. 04, pp.525-548, 2004.

GURULE, K. Wath is the Halliburton Loophole? Frackwire. June 5, 2013. Disponível em: http://frackwire.com/halliburtonloophole/. Acesso em: 23/12/2015. 
HALL, J.;MATOS, S.;SEVERINO, L.;BELTRÃO, N. Brazilian biofuels and social exclusion: established and concentrated ethanol versus emerging and dispersed biodiesel. Journal of Cleaner Production, v. 17 S77-S85, 2009.

HAAS, P. Global environmental governance in terms of vertical linkages. In: $N$. Kanie and P. Hass Emerging Forces in Environmental Governance, United Nations University Press, Tokyo, 2004.

HAGGERTY, Julia. H."I'm not a greenie but.": environmentality, eco-populism and governance in New Zealand experiences from the Southland whitebait fishery. Journal of Rural Studies, nr.23, v.02, pp.222-237, 2007.

HAJER, M.; VERSTEEG, W.Adecade of discourse analysis of environmental policy: The utility or a regime approach. Geoforum, v.31, pp.299-313, 2005.

HAMLIN, M. J. Governing Sustainable Subjects: Environmentality in Polity, Economy and Civil Society. Tese de Doutorado. Victoria University of Wellington, New Zealand. Victoria, 2011. Disponível em: http://researcharchive.vuw.ac.nz/xmlui/bitstream/handle/10063/1661/thesis.pdf?sequen ce=1. Acesso em: 12/12/2015.

HARDIN, G. The tragedy of the commons.Science, v.162, pp. 1243-48, 1968.

HARRY, New Oil: The Giddings Gamble. Texas Monthly.Austin, fevereiro de 1981, p. 1-31 Disponível em: http://www.texasmonthly.com/story/new -oil-giddingsgamble?fullpage=1. Acesso em: 01/03/2015.

HASEMEYER, D.; WIEDER, B.; SUDERMAN, A. Satured with oil money, Texas Legislature saved industry from pollution rule. Big Oil, Bad Air. The Center for Public Integrity. Disponível em: http://www.publicintegrity.org/2014/02/18/14240/saturated-oilmoney-texas-legislature-saved-industry-pollution-rule Acesso em: 23/02/2016.

HATHAWAY, M. Comment on Environmentality. Current Anthropology, v.46, nr.02, pp. 182, 2005.

HERRERA, Selena. Análise da governança global da sustentabilidade dos biocombustíveis e proposta para o etanol brasileiro. Tese (doutorado) - UFRJ/ COPPE/ Programa de Planejamento Energético. Rio de Janeiro, 2014.

HESS, C. ; OSTROM, E. Ideas, Artifacts, and Facilities: Information as a CommonPool Resource. Law and Contemporary Problems, v. 66, nr. 1/2, pp. 111-145, 2003.

HIERRO, S. DEL.; LEGGET, G. Plane Violence: A Sectional Landscape of Oil in Amazonia. pp. 59-67. In: New Geographies 2: Landscapes of Energy. Harvard University Press, 2009.

HIGGINS, S. Will Obama go down in history as the 'fracking president'. Washington Examiner, June 6, 2013. Disponível em: http://www.washingtonexaminer.com/willobama-go-down-in-history-as-the-fracking-president/article/2532321. Acesso em: 07/01/2015.

HOWARTH, R.W; INGRAFFEA, A.; ENGELDER, T. Natural gas: Should fracking stop?Nature, v. [s.i.], nr.477, pp.271-275, 2011. 
HUDSON, R. Producing Places. New York, 2001.GuilfordPress.

HUGHES, J.D. Eagle Ford Reality Check: The Nation's top tight oil play after more than a year of low oil prices.Post Carbon Institute, 2015. Santa Rosa, California. Disponível em: http://www.postcarbon.org/publications/eagle-ford-realitycheck/ Acesso em: 14/02/2016.

HUMPHREY, J. and SCHMITZ, H. Governance in global value chains. 2001. IDS Bulletin, Volume 32, number 3, pp.19-29.

HUMPHREYS, M. SACHS, J. STIGLITZ, J. Escaping the resource curse.Columbia Press University. 2007. 432p. ISBN 9780231141963.

IBGE. Instituto Brasileiro de Geografia e Estatística. Levantamento sistemático da produção agrícola (LSPA). Fascículo indicadores do IBGE. Disponível em: ftp://ftp.ibge.gov.br/Producao Agricola/Fasciculo Indicadores IBGE/2008. Acessoem: 01/01/2013.

ILICH, Ivan. The Social Construction of Energy, pp. 11-23. In: New Geographies 2: Landscapes of Energy. Harvard University Press, 2009.

IPEA. Instituto de Pesquisas Econômicas Aplicadas. Impactos socioeconômicos da indústria de biodiesel no Brasil: Estudo encomendado pela aAssociação dos Produtores deBiodiesel do Brasil - Aprobio. Relatório Final. São Paulo, setembro, 2012. Disponível em: http://aprobio.com.br/wp-content/uploads/2014/10/Aprobio-FIPERelatorioFinal-setembro-2012.pdfAcesso em: 01/01/2015.

JACOBI, P.R.; SINISGALLI, P.A.de A. Governança Ambiental e Economia Verde. Ciência e Saúde Coletiva 17(6), 1469-1478, 2012.

JACKSON, G.; DEEG, R.From comparing capitalisms to the politics of institutional change.Review of International Political Economy, v. 15, n. 4, p. 680-709, 2008.

JACKSON, Robert B; VENGOSH, Avner, CAREY, J. W., DAVIES, R. J., DARRAH, T. H., O'SULLIVAN, F., P'ETRON, Gabrielle.The Environmental Costs and Benefits of Fracking.Annu. Rev. Environ. Resour. 2014. pp - 39:327-62.

JANSSEN, J. \& KNIPPENBERG, L. The heritage of the productive landscape: landscape design for rural areas in the Netherlands, 1954 - 1985, Landscape Research, 33(1), pp. 1-28, 2008.

JEPSON, W.; BRANNSTROM, C.;PERSONS, N. "We Don't Take the Pledge": Environmentality and environmental skepticism at the epicenter of US windy energy development.Geoforum, nr. 43, pp. 851-863, 2012.

JESSOP, B. Regulation Theory, Post-Fordism and the State: more than a reply to Werner Bonefeld. In: BONEFELD, W. e HOLLOWAY, J. (Eds.). PostFordism and Social Form: a Marxist debate on post-fordist state. London: Macmillan, 1991.

JESSOP, B. Liberalism, neoliberalism, and urban governance: A state-theoretical perspective. Antipode, Number 34, pp.452-72,2002.

JOHN, D.Civic Environmentalism: Alternatives to Regulation in States and Communities. CQ Press, 1993.Washington, DC:: 
JONAS, A; GIBBS, D.A tale of two areas: Governance and regulation in local environmental policy making in the East of England. Social Science Quarterly,v.84, nr.04, pp. 1018-37, 2002.

JORDAN, A., WURZEL, R. K. W., ZITO, A.The rise of 'new' policy instruments in comparative perspective: Has governance eclipsed government?Political Studies 53, p.477-96, 2005.

JUAREZ, P. Explosões em usinas de biodiesel: O que fazer? BiodieselBR, edição digital, junho de 2011. Disponível em: http://www.biodieselbr.com/revista/023/colunapaulo-suarez.htm Acesso em: 28/02/2016.

KAIKA,M. Landscapes of energy: Hydropower from Techno-Natures to Retro-Natures, pp. In: New Geographies 2: Landscapes of Energy. Harvard University Press, 2009.

KAPLAN, T. Citing Health Risks, Cuomo Bans Fracking in New York State. The New York Times.Disponível em: http://www.nytimes.com/2014/12/18/nyregion/cuomo-toban-fracking-in-new-york-state-citing-health-risks.html? $r=0$ Acesso em: 23/01/2016.

KARPOWITZ, C. F.Context Matters: A Theory of Local Public Talk and Deliberative Reform. In: Annual meeting of the American Political Science Association, 2005. Disponível em:http://citation.allacademic.com/meta/p39980 index.html. Acesso em: 27/01/2016.

KEIL, R. and DESFOR, G. Ecological modernization in Los Angeles and Toronto.Local Environment, Volume 8, pp. 27-44. 2003.

KEEFER, P. A review of the political economy of governance: From property rights to voice. World Bank Policy Research Working Paper 3315, 2004.

KOOIMAN, J. "Societal governance: Levels, models and orders of social-political interaction". In: Debating governance: Authority, steering and democracy. (Ed.) J. Pierre. Oxford: Oxford University Press. 2000. pp. 138-164.

KOOIMAN, J. Governing as governance. 2003. London. Sage.

KOOIMAN, J. Societal Governance: levels, models and orders os social political interaction. In: J.Pierre (Ed.) Debating Governance: Authority, Steering and Democracy, Oxford University Press, Oxford 2000, pp.138-166.

KRASNER, Stephen D., (Org.). International Regimes. Cornell, NY: Cornell UniversityPress, 1983.

YAMAOKA, M. CNPE? O quê? Dezembro de 2013. Blogspot Greenpeace Brasil. Disponível em: http://www.greenpeace.org/brasil/pt/Blog/cnpe-o-qu/blog/47758/. Acesso em: 04/01/2015.

YOUNG, O. R. International Governance: protecting the environment in a stateless society. Ithaca and London, Cornell University Press, 1994.

LAND RESEARCH GROUP, LRG. European Conference of the Landscape Research GroupEnergy Landscapes: Perception, Planning, Participation and Power. Disponível em: http:///rg2015.ioer.infol. Acesso em: 28/11/2015. 
LEMOS, M. and AGRAWAL, A. Environmental governance.Annual Review of Environment and Resources.Number 31, pp. 297-325, 2009.

$\mathrm{LI}, \mathrm{T}$. Practices of assemblage and community forest management. Economy and Society, nr.36, v.02 pp. 263-293, 2007.

LIN, J. Governing Biofuels: A Principal-Agent Analysis of the European Union Biofuels Certification Regime and Clean Development Mechanism. Journal of Environmental Law, v.24, nr.01. pp.43-73, 2012.

LIMA, A. S. Desafios a verticalização agroindustrial familiar de oleaginosas no Semiárido Baiano. Direcionadores de competitividade das usinas de Lapão e Olindina. Dissertação de Mestrado. Programa de Pós-Graduação em Desenvolvimento Sustentável. Universidade de Brasília, Brasília, 2011.

LIMA, M.G.B. Biofuel governance and international legal principles: is it equitable and sustainable? Melbourne Journal of International Law,v. 10, pp.1-23, 2009.

LIVERMAN, D.Who governs, at what scale, and at what price? Geography, environmental governance, and the commodification of nature.Annals of the Association of American Geographers,v.94, nr.04, pp.734-738, 2004.

LIOF, R.; FUGERE, D.; REUSNER, L.V.; HEIM, S.; SAMUELRICH, L. Disclosing the Facts: Transparency and risk in hydraulic fractruring operations. 2013.As You Sow, Boston Common Asset Management, LLC; Green Century Management, Inc; and Investor Environmental Health Network. Falls Church, Vancouver. Disponível em: http://pt.slideshare.net/MarcellusDN/disclosing-the-facts-transparency-and-risk-inhydraulic-fracturing-operations Acesso em: 13/02/2016.

LOCALCONTROLTEXAS.ORG. Funeral for Local Control. May 4, 2015. Disponível em: http://www.localcontroltexas.org/\#!Funeral-For-LocalControl/c93/5547d0140cf27313351493bb. Acesso em: 31/01/2016.

LUKE, Timothy W. On Environmentality: Geo-Power and Eco-Knowledge in the Discourses of Contemporary Environmentalism. Cultural Critique, No. 31, The Politicsof Systems and Environments, 1995, pp. 57-8. University of Minnesota Press Disponível em: http://www.jstor.org/stable/1354445 Acesso em: 06-03-2015.

LUKE, Timothy W. Generating green governmentality: A cultural critique of environmental studies as a power/knowledge formation. 1996. Disponível em: http://www.cddc.vt.edu/tim/tims/tim514a.pdf. Acesso em: 18/11/2015.

LUKE, Timothy W.Capitalism, democracy, and ecology: Departing from Marx. 1999a. Urbana, IL: University of Illinois Press.

LUKE, Timothy W. Environmentality as green governmentality. In E. Darier (Ed.),Discourses of the environment 1999b, pp. 121-151). Oxford, England: Blackwell.

LUNARDI, J. C. T. O campesinato tradicional e a indústria de biodiesel: integração subordinada no sul do Brasil 2003-2008. Tese de Doutorado. Programa de Pós-graduação em Educação. Universidade Federal do Paraná. Curitiba, 2011.

N.L.C. National League of Cities. Disponível em: http://www.nlc.org/about cities/cities 101/156.aspx . Acesso em: 27/01/2016. 
NORTH, D. Institutions, Institutional Change and Economic Performance.Cambridge:Cambridge University Press. Oxford, U.K. 1990.

MACLEOD, G; GOODWIN, M. Space, scale and state strategy: Rethinking urban and regional governance. Progress in Human Geography. Volume 23, nr 4, pp. 503-27, 1999.

MAIA, A. C. Sobre a analítica do poder de Foucault. Tempo Social; Revista de Sociologia da USP, S. Paulo, v.7, nr.1-2,pp.83-103, 1995.

MALEWITZ, J.Environmentalists Ask EPA to Strip Texas Authority.The Texas Tribune Digital News, January 12, 2016.2 Disponível em: http://www.texastribune.org/plus/water/vol-4/no-1/environmentalists-ask-epa-striptexas-authority/?mc cid=7071c05a2e\&mc eid=3fe457ae23Acesso em: 01/02/2016.

MALEWITZ, J. Porter Takes Over as Railroad Commission Chairman. The Texas Tibune. Digital News, June 9, 2015. Disponível em: http://www.texastribune.org/2015/06/09/porter-takes-over-railroad-commissionchairman/. Acesso em: 04/10/2015.

MALEWITZ, J. Lawmakers Move to Speed Permits, Limit Prostests. The Texas Tribune. Digital News. April 30, 2015). Disponível em: http://www.texastribune.org/2015/04/30/texas-lawmakers-move-limit-environmentalprotests/. Acesso em: 05/10/2015.

MAROUN, M. R.; LA ROVERE, E. L. Ethanol and food production by family smallholdings in rural Brazil: Economic and socio-environmental analysis of micro distilleries in the State of Rio Grande do Sul. Biomass and Bioenergy, v.63, p.140$155,2014$.

MARTINELLI, L.A.; Filoso S. Expansion of sugarcane ethanol productionin Brazil: environmental and social challenges. Ecological Applications, v.18, nr.4, p.885-98, 2008.

MARTINS, L. A. M.; PEIXOTO JUNIOR, C.A. Genealogia do biopoder.Psicologia e Sociedade, v. 21, nr.02, pp.157-165, 2009.

MARSHALL, E. In Wake of Scathing Review of Fracking Report, University of Texas Revises Conflic of Interest Policies. Science. December 7, 2012. Disponível em: http://www.sciencemag.org/news/2012/12/wake-scathing-review-fracking-reportuniversity-texas-revises-conflict-interest Acesso em: 13/02/2016.

MATHEUS, T. O fim do sonho. BiodieselBR, v.04, nr.42, p.30-33, 2014.

MATZ, Jacob; RENFREW,Daniel.Selling Fracking: Energy in Depth and the Marcellus Shale.Environmental Communication, Routledge, Londres p. 1-19, 2014.DOI: 10.1080/17524032.2014.

MCCARTHY, J. Neoliberalism and the politics of alternatives: Community forestry in British Columbia and the United States. Annals of the Association of American Geographers. Volume 96, number 1, 2006. pp. 84-104.

MCCARTHY, J.F. Processes of inclusion and adverse incorporation: oil palm and agrarian change in Sumatra, Indonesia. The Journal of Peasant Studies, 37(4), 82150, 2010. 
MCCARTHY, J., and S. PRUDHAM.Neoliberal nature and the nature of neoliberalism. Geoforum 5, 2004.pp.275-83.

MCGRATH, T. Taking the bad with the good, Eagle Ford Shale Magazine, v. 2, nr. 2, p. 22-23, 2014.

MEALER, B. "Y'all Smell That? That's the Smell of Money." Chasing the Boom in South Texas.Texas Montlhy, November 2013. Disponivel em: https://reedkath.files.wordpress.com/2014/10/do-yall-smell-that.pdf. Acesso em: 09/11/204.

MEHTA, L., LEACH, M. and SCOONES, I. Editorial: environmental governance in an uncertain world. IDS Bulletin, Volume 32, Issue 4. 2001 http://www.ids.ac.uk/UserFiles/File/publications/classics/mehta et al 32 4.pdf.

MELOSI, M.V. Houston: Energy Capitals, pp. 97-103.In: New Geographies 2: Landscapes of Energy. Harvard University Press, 2009.

MELO, M. A. Governance e reforma do Estado: o paradigm do agente x principal. Revista do Serviço Público, v.120, nr.01. pp.67-82, 1996.

MITCHELL, D. Work, struggle, death, and geographies of justice: the transformation of landscape in and beyond California's Imperial Valley, Landscape Research, 32(5), pp. 559-577, 2007.

MITCHEL, T. Carbon Democracy: Political power in the age of oil. 1. ed. New York and London. Verso, 2011.

MOL, A. P. J. Environmental authorities and biofuel controversies. EnvironmentalPolitics, v. 19, n. 1, pp. 61-79, 2010.

MOREIRA, V. S.; MEDEIROS, R. M. S. As novas configurações do espaço agrário no Rio Grande do Sul / Brasil: da pecuária tradicional ao complexo agroindustrial da soja. Confins, número 20, 2014.

MORRIS. J; SONG, L; HASEMYER, D. Fracking boom spews toxic air emissions on Texas residents. Pittsburg Post-Gazette, February 25, 2014. Disponível em: http://www.post-gazette.com/powersource/latest-oil-and-gas/2014/02/25/Frackingboom-spews-toxic-air-emissions-on-Texas-residents-1/stories/201402250141. Acesso em: 07/01/2014.

MORRIS. J; SONG, L; HASEMYER, D.Big Oil, Bad Air:Fracking the Eagle Ford Shale of South Texas. The Centre of Public Integrity, february 18, 2014. Disponivel em: http://eagleford.publicintegrity.org/. Acesso em: 01/02/2016.

MOULAERT, F., MARTINELLI, F. e SWYNGEDOUW, E. Social Innovation, Governance, and Community Building-SINGOCOM.Final Report Month 40, European Union Framework V, Key Action Improving Socio-economic Knowledge Base, Contract No. HPSE-CT2001-00070, Project No.SERD-2000-0028, Brussels, 2005.

MOULAERT, F., MARTINELLI, F. and SWYNGEDOUW, E. Social innovation and governance in European cities: between path dependency and radical innovation, Special Issue, Journal of European Urban and Regional Studies, 2006. 
NADAÏ, Alain; HORST, Dan van der. Introduction: Landscapes of Energies, Landscape Research, nr.35, v.02, pp.143-155, 2010.

NAVARRO Z. S., RIEDL, M., "Reforma agrária na região sul", In B.V. SCHMIDT, D.N.C. MARINHO, S.L.C. ROSA (Org.), Os assentamentos de reforma agrária no Brasil, Brasília, Ed. da UnB, p. 221-236, 1998.

NAVRUD, S.; READY, R. C.; MAGNUSSEN, K. \& BERGLAND, O. Valuing the social benefits of avoiding landscape degradation from overhead power transmission lines: do underground cables pass the benefitcost test?, Landscape Research, 33(3), pp. 281296, 2008;

NEUHAUSER, A. Oil and Gas Lobby Unveils 'Best Practices' for Talking Fracking. U.S.

News \& World Report. July 9, 2014. Disponível em: http://www.usnews.com/news/articles/2014/07/09/oil-and-gas-lobby-unveils-bestpractices-for-talking-fracking. Acesso em: 07/01/2016.

OECD, Participatory Development and Good Governance, Paris: OECD, 1995, p 14.

OLSON, Mancur.The Logic of Collective Action: Public Goods and the Theory of Groups (Revised ed.). Harvard University Press. (1971) [1965].

OPEN STATES. Texas Bill House, HB40.Relating to the exclusive jurisdiction of this state to regulate oil and gas operations in this state and the express preemption of local regulation of those operations.Disponivel em: http://openstates.org/tx/bills/84/HB40/ Acesso em: 01/04/2015.

OSAKA, M.; BATALHA, M. O. Produção de biodiesel e óleo vegetal no Brasil: realidade e desafio. Organizações Rurais e Agroindustriais, v. 13, n. 2, p. 227-242, 2011.

OSMANI, S. R. Participatory governance, people's empowerment and poverty reduction.Conference on Women (Beijing) and the World Summit for Social Development (Copenhagen).SEPED Conference Paper Series nr.07, 2000.Disponível em: http://www.chs.ubc.ca/lprv/PDF/lprv0478.pdf. Acesso em: 25/09/2015.

OSTROM, Elinor. A General Framework for Analyzing Sustainability of SocialEcological Systems.Science, vol. 325, p.419-421, 2009.

OSTROM, E. A diagnostic approach for going beyond panaceas.PNAS, vol. 104, nr.39, pp.15181-15187, 2007.

OSTROM, E. Governning the commons. The evolution of Institutions for Collective Action.1990. Cambridge University Press.

OSTROM, E.A diagnostic approach for going beyond panaceas.PNAS, v. 104, nr.39,pp.15181-15187. 2007.

OSTROM, E.A General Framework for Analyzing Sustainability of Social-Ecological Systems. Science, v. 325, pp.419-422, 2009.

OSTROM, E. Neither Market Nor State: Governance of Common-Pool Resource in the Twenty First Century. In: International Food Policy Research Institute. Washington, DC. IFPRI Lecture Series, pp.01-33, 1994. 
OSTROM, E. Understanding Institutional Diversity. Princeton University Press, 2005, 376pp. Understanding the Diversity of Structured Human Interactions. Chapter one, pp.01-31. Disponível em: http://press.princeton.edu/chapters/s8085.pdf Acesso em: 2308/2015.

OWEN, R. Developing the untapped wealth of Britain's 'Celtic Fringe': water engineering and the Welsh landscape, 1870 - 1960, Landscape Research, 31(2), pp. 121-133, 2006.

PADULA, A.D.; SANTOS, M. S.; FERREIRA, L.; Borenstein, D.The emergence of the biodiesel industry in Brazil: Current figures and future prospects. Energy Policy v. 44, p.395-405, 2012.

PANKE, M. RS é o estado que menos fez o Cadastro Ambiental Rural. Rádio Gaúcha. Disponível em: http://gaucha.clicrbs.com.br/rs/noticia-aberta/rs-e-o-estadoque-menos-fez-o-cadastro-ambiental-rural-140885.html. Acessso em: 12/10/2015.

PAROGI, Wong. Responses to Shale Gas Governance from a General Elicitation. In: STERN, Paul C. Risks and Risk Governance in Shale Gas Development. Summary of two workshops. The National Academy Press, Whasington, DC, 2014, pp. 16341662, 2014.

PASQUALETTI, M.J. Morality, space and the power of wind energy landscape, Geographical Review, nr. 90, v.03, pp. 381-394, 2000.

PEDROTI, P. M. Os desafios do desenvolvimento e da inclusão social: o caso do arranjo político-institucional do Programa Nacional de Produção e uso do Biodiesel. Texto para discussão $1858 /$ Instituto de Pesquisa EconômicaAplicada.2013. Rio de Janeiro ISSN 1415-4765.

PENNSYLVANIA. Department of Environmental Protection. Department of Oil and Gas. Permits Issued Reports. Issued Permits from 01/21/2015 to 02/08/2016.Disponível em: https://drive.google.com/file/d/0B8C719utCRLVW1iUEpwTU9GMG8/view. Acesso em: 23/01/2016.

PORTER, M. Clusters and the new economics competitions.Harvard Business Review, pp. 77-90, 1998.

PAINTER, J. Stateand governance. In: E. Sheppard and T.J.Barnes (Eds.) A companion to Economic Geography. Oxford University Press, Blackwell, pp.35-76., 2000.

PERREAULT, Custom and Contradiction: Rural Water Governance and the Politics of Usos y Costumbres in Bolivia Irrigators' Movement.Annals of the Association of American Geographers, Volume 98, number 4. pp. 834-854, 2008.

POLANYI K. (1944) The Great Transformation. New York: Farrar \& Rinehart.

PRUDHAM, S. Knock on Wood: Nature as Commodity in Douglas Fur Country. New York and London: Routledge , 2005.

QUIÑÓNEZ, ET.AL. Biofuel partnerships: from battleground to common ground? The effects of biofuel programs on smallholders' use of land and rights to land in four countries. Cordaid,

Belgium, 2012.

Disponível em: 
http://reporterbrasil.org.br/documentos/biofuelpartnerships.pdf. 16/08/2015).

RABE, Barry ET AL. Governance concerns and government capacity to shale gas. In: STERN, Paul C. Risks and Risk Governance in Shale Gas Development. Summary of two workshops. The National Academy Press, Whasington, DC, 2014, p.1663-1692.

RAMBO, A.G.; COSTA, G.C. Capital Social, Empoderamento e Governança na agricultura familiar: experiências de biocombustíveis enquanto sementes e brotos da transição para o desenvolvimento territorial? Projeto de pesquisa IPODE. Inovação, Poder e Desenvolvimento em Áreas Rurais do Brasil. Universidade Federal do Rio Grande do Sul. Porto Alegre, junho de 2010. Disponível em: http://www.ufrgs.br/pgdr/ipode/relatorios finais/Relatorio final Grupo Bioenergias 09 junho 2010.pdf. Acesso em: 01/02/13.

RAUF, D.S.Texas House OKs bill barring local officials from banning fracking.Houston Chronicle,April 17, 2015 Disponível em: http://www.chron.com/news/politics/texas legislature/article/House-OKs-fracking-bill6206286.php Acesso em: 28/01/2016.

REN21. Renewables Global Status Report, 2009.Update(Paris: REN21 Secretariat). Disponível em: http://www.ren21.net/Portals/0/documents/activities/gsr/RE GSR 2009 Update.pdf. Acesso em: 25/11/2014.

REN21. Renewables Global Status Report, 2015. Disponível em: http://www.ren21.net/wp-content/uploads/2015/07/GSR2015 KeyFindings lowres.pdf Acesso em: 02/03/2016.

RING, Peter Smith, \& VAN DE VEN, Andrew H. Developmental processes of cooperative interorganizational relationships. , 1994. Academy of Management Review, nr. 19, v.1, p. 90-118.

RIO GRANDE DO SUL. Decreto 42.676 de 25 de novembro de 2003. Programa Gaúcho de Biodiesel - PROBIODIESEL/RS. Assembleia Legislativa do Estado do Rio Grande do Sul. Disponível em: http://www.al.rs.gov.br/Legis/M010/M0100099.ASP?Hid Tipo=TEXTO\&Hid TodasNor mas=46998\&hTexto=\&Hid IDNorma=46998. Acesso em: 10/07/2015.

RIO GRANDE DO SUL. Política Industrial: Modelo de Desenvolvimento Industrial. 2012. Programa Setorial Biocombustíveis - Bioetanol e Biodiesel. 2012 - 2014. Disponível em: http://investimentos.mdic.gov.br/public/arquivo/arq1345148675.pdf. Acesso em: 09/10/14.

RIO GRANDE DO SUL. Programa Setorial Biocombustíveis - Bioetanol e Biodiesel 2012/2014. Modelo de desenvolvimento industrial do Rio Grande do Sul. Disponível em: http://investimentos.mdic.gov.br/public/arquivo/arq1345148675.pdf. Acesso em: 05/08/15.

RODRIGUES, F. Amazombio vê limitações no Selo Social. Disponível em: http://www.biodieselbr.com/noticias/agricultura/selo/amazonbio-limitacoes-selo-social060813.htm. Acesso em: 12/08/2015.

RODRIGUES, F. Com os pés no chão.BiodieselBR, v. 07, nr. 42, p. 09-11, 2014. 
RODRIGUES, F. Entressafra. BiodieselBR, v.06, nr.37. p.52-56, 2013.

RODRIGUES, F. Explosão em Iraquara. BiodieselBR, v.06, nr.37, p. 43, 2013.

RODRIGUES, F. Entidades representativas do biodiesel: Unidos? Venceremos? 2012. BiodieseBR, v.5, nr. [s/d] p.01-17. Disponível em: http://www.biodieselbr.com/revista/030/unidos-venceremos.htm. Acesso em: 26/07/2015.

RODRIGUES, F. Retorno Triunfal? BiodieselBR, v.07, nr.39, p.48-49, 2014b.

ROSENAU, J. Governance, order and change in world politics. In J. Rosenau and E. Czempiel (eds), Governance Without Government: Order and Change in World Politics. Cambridge University Press. Oxford, U.K.1991.

ROSENAU, J. Governance in the Twenty-first Century.Global Governance. 1995. Volume 1, number 1, pp. 13-43. Lynne Rienner Publishers Disponível em: www.jstor.org/stable/27800099

RHODES, R.A.W. The New Governance: Governing without Government. Political Studies XLIV.Political Studies Association, v. [?], pp. 652-67, 1996.

ROMERO, J.A.P.; LEITE, O.M.; EGUILUZ, K.I.B.; BANDA, G.R.S.; SILVA, D.P.; CAVALCANTI, E. B. Tratamentos dos efluentes gerados na produção de biodiesel. Química Nova, v.35, nr.02, pp. 367-378, 2012.

RRC. RailroadCommission of Texas. Railroad Commission. Eagle Ford Shale Task Force Report. Austin, 2013.2 Disponível em: http://www.rrc.state.tx.us/media/8051/eagle ford task force report-0313.pdf. Acesso em: 28/01/2016.

RRC. RailroadCommission of Texas. Railroad Commission Self Evaluation Report. 2009. Sunset Advisory Commmission. Disponível em: http://www.rrc.state.tx.us/media/30156/final-self-evaluation-report-2015.pdf. Acesso em: 05/10/2015.

RRC. RailroadCommission of Texas. RRC Mission Statement. 2015. Disponível em: http://www.rrc.state.tx.us/about-us/organization-activities/about-rrc/.

RUSSELL, B. The Independent Petroleum Association of America. Hydraulic fracturing under attack. IPAA. , 2009, June 5. Disponível em: http://www.ipaa.org/blog/. Acesso em: 21/01/2016.

SACHS, I. Desenvolvimento, includente, sustentável sustentado. Rio de Janeiro: Garamond, 2008.

SACHS, J. D.; WARNER, A.M. Natural Resource Abundance and Economic Growth.NBER Working Paper, 1995, nr. 5398.

SACHS, J. D.; WARNER, A. M.The Curse of the Natural Resources.European Economic Review, vol. 45, 2001, pp.827-838.

SANCHEZ, R.A. Governance, Trade, and the Environment in the Context of NAFTA.American Behavioral Scientistv.45, nr.09, pp.1369-133, 2002. 
SANTOS, G.R. Biocombustíveis no Brasil: Evolução da produção e uso do biodiesel de oleaginosas e interfaces com as políticas públicas.2010. Ipea Diretoria de estudos setoriais, inovação tecnológica e regulação. Disponível em: http://ipea.gov.br/agencia/images/stories/PDFs/100526 comunicaipea 53 apresentac ao biocombustiveis.pdf. Acesso em: 10/01/2015.

SANTOS, R. E. dos. Genealogia da Governamentalidade em Michel Foucault. Dissertação de Mestrado em Filosofia. Universidade Federal de Minas Gerais. 2010.

SCHAFELL, S.B. Em busca do eco-sócio eficiência no caso da agricultura familiar voltada para a produção de biodiesel no Brasil. Tese de Doutorado. Programa de Pós-graduação em Planejamento Energético, COPPE, Universidade Federal do Rio de Janeiro, UFRJ, Rio de Janeiro, 2010.

SCHUT, M.; SOARES, N. C.; VAN DE VEM, G.; SLINGERLAND, M. Multi-actor governance of sustainable biofuels in developing countries: The case of Mozambique.Energy Policy, número 65, 2014, pp. 631-643.

SESCOOP. Serviço Nacional de Aprendizagem do Cooperativismo. A Inserção das Cooperativas no Processo de Produção de Biodiesel. 2008. Série: Desenvolvimento em Cooperativa. Gerência de Apoio ao Desenvolvimento em Mercados (Germec). Disponível em: www.brasilcooperativo.coop.br. Acesso em 01/07/2015.

SEPTOFF, A. Fracking the Eagle Ford - TCQE's nondenial. Earthworksaction.org, September 30, 2013. Disponivel em: https://www.earthworksaction.org/earthblog/detail/fracking the eagle ford tcegs nond enial\#.Vq-Vf4-cHIV. Acesso em 01/02'2016.

SHOREMAN, E.E., HAENN, N. Regulation, conservation, and collaboration: ecological anthropology in the Mississippi Delta. Human Ecology: An Interdisciplinary Journal nr.37, v.01, pp. 95-107, 2009.

SILVA, A. C. A importância da soja para o agronegócio brasileiro: uma análise sob o enfoque da produção, emprego e exportação. Anais: Encontro de economia catarinense, $\quad$ APEC 2011. Disponível em: http://www.apec.unesc.net/V EEC/sessoes tematicas/Economia\%20rural\%20e\%20ag ricultura \%20familiar/A\%20IMPORT\%C3\%82NCIA\%20DA $\% 20$ SOJA $\% 20$ PARA $\% 200 \%$ 20AGRONEG\%C3\%93CIO\%20BRASILEIRO.pdf. Acesso em : 23/04/2015.

SIMON, HA. A behavioral model of rational choice. The Quarterly Journal of Economics, volume 69, number 1, p. 99-118, 1955.

SIMON, Pedro. A diáspora do povo gaúcho. Senado Federal, Brasília : 2009. 191 p. Disponível em: http://www.senado.leg.br/senadores/senador/psimon/livros/livro044.pdf. Acessoem: 24/04/2015.

SLAUGHTER, Anne-Marie."The Real New World Order".Foreign Affairs, v. 76, nr.05, pp. 183-197, 1997.

SMALL, Mitchell J. ET AL. Risks and Risk Governance in Unconventional Shale Gas Development.2014. Environmental Science \& Technology. 2014, Vol. 48, p.8289-8297. dx.doi.org/10.1021/es502111u | 
SMITH, A., STIRLING, A. \& BERKHOUT, F. The governance of sustainable sociotechnical transitions, Research Policy, nr. 34, pp. 1491-1510, 2005.

SOLANA, Javier; SAZ-CARRANZA, Ángel. "Governança Energética?". Valor Econômico. São Paulo, 25 de novembro de 2011.

SPAARGAREN, G., MOL, A. and BUTTEL, F. Governing Environmental Flows: Global Challenges to Social Theory. Cambridge, MA: MIT Press, 2006.

STAPLETON, S. Texas pushes forward with bill that would ban fracking ban. Reuters, April 18. Disponível em: https://www.rt.com/usa/250797-texas-bill-bans-frackingprohibition/. Acesso em: 28/01/2016.

STATTMAN, S.L.; MOL, A.P.J.; Social sustainability of Brazilian biodiesel: The role of agricultural cooperatives. Geoforum, v. 54, pp.282-294, 2014.

STATTMAN, S.L.; HOSPES, O.; MOL, A. P. J.; A comparison of ethanol and biodiesel policies. Energy Policy, v. 61, pp. 22-30, 2013

STEER. South Texas Energy and Economic Roundtable. 2015 Eagle Ford Excellence Awards. Disponível em: http://steer.com/efeal. Acesso em: 05/102015.

STEER. South Texas Energy and Economic Roundtable. 2014. The second annual Eagle Ford excellence awards. Disponivel em: http://steer.com/wpcontent/uploads/2014/11/STEER-EFE-Award-Winners-News-Release2014 FINAL.pdf

STRALOW, M. Oil self sufficiency. Eagle Ford Shale Magazine, v.1, nr.4, p. 11-12, 2013.

STRALOW, K. The Buzbee law firm: Championing the oilfield worker. Eagle Ford Shale Magazine v. 2, nr. 4, p.12-13, 2014.

SWYNGEDOUW, Erik. Authoritarian governance, power and the politics of rescaling, Environment and Planning D. Society and Space, v. 18, pp. 63-76, 2000.

SWYNGEDOUW, Erik. Governance Innovation and the Cititzen: The Janus Face of Governance-beyond-the-State. Urban Studies, Vol. 42, No. 11, pp. 1991-2006, 2005.

SWYNGEDOUW, E. Reconstructing citizenship, the re-scaling of the state and the new authoritarianism: closing the Belgian mines, Urban Studies, v. 33, nr.08, pp. 1499$1521,1996$.

TAVARES, J. Bomba Relógio. BiodieselBR, v.06, nr.40, p.52-55, 2014.

TAVARES, J. Descompasso na produção.BiodieselBR, v.38, nr.38, p.41-43, 2014.

TAYLOR, P.In the market but not of it: fair trade coffee and forest stewardship council certification as market-based social change. World Development, v.33, nr.01, pp. 129-47, 2005.

TAYLOR, P. A fair trade approach to community forest certification?A framework for discussion.Journal of Rural Studies, v.21, nr.[?],pp.433-47,2005.

TCEQ. Texas Commission on Environmental Quality. About Us. 2015. Disponível em: www. tceq.state.tx.us. Acesso em: 01/01/2015. 
TCEQ. Texas Commission on Environmental Quality. 2013 Strategic Plan, Fiscal Years 2013-2017. Disponível em:www.tecq.texas.gov/publications/sfr/035-13.htlm Acesso em:01/01/2015.

TENDLER, Judith. Good Government in the Tropics. The Johns Hopkins University Press. pp. 1-20. 1998. The Journal of Developing Areas, v. 32, nr. 03, pp. 411-413, 1998.

TEIXEIRA, E. C. O papel das políticas públicas no desenvolvimento local e na transformação da realidade. Política Públicas - $O$ Papel das Políticas Públicas. AATR, $2002 . \quad$ Disponível em: http://dhnet.org.br/dados/cursos/aatr2/a pdf/03 aatr pp papel.pdf. Acesso em: 02/10/2015.

TEXAS. General Appropriations Act for the 2012-13 biennium. $82^{\text {nd }}$ Texas Legislature, 2011.2 Disponivel em: http://www.lbb.state.tx.us/Documents/GAA/General_Appropriations_Act_2012-13.pdf

TEXAS. House Rules. 84 ${ }^{\text {th }}$ Legislature Austin, Texas 2015. Disponível em: http://www.house.state.tx.us/ media/pdf/hrrules.pdf. Acesso em: 29/01/2016.

TEXAS. Texas Legislature Online.Bill SB 709. Legislative Session 84R. Disponível em: $\quad$ http://www.legis.state.tx.us/BillLookup/Text.aspx?LegSess=84R\&Bill=SB709. Acesso em: 05/10/2015.

TEXAS. Railroad Commission of Texas. Self-Evaluation Report. Sunset Commission September 2009. Disponível em: http://s3.amazonaws.com/zanran storage/www.rrc.state.tx.us/ContentPages/69913783 .pdf Acesso em: 03/04/2015.

TEXAS. Witness List. SB1165. Senate Committee Report. Natural Resource and Economic Development. March 24, 2015. Disponível em: ftp://ftp.legis.state.tx.us/bills/84R/witlistbill/html/senate bills/SB01100 SB01199/SB011 65S.HTM. Acesso em: 01/04/2015.

TEXAS ALLIANCE.What is the Alliance?texasalliance.org. Disponível em: http://texasalliance.org/news/eyes-on-texas-and-washington/. Acesso em: 02/02/2016.

TEXAS ALLIANCE. Eyes on Texas and Washington.March 28, 2014. Disponível em:http://texasalliance.org/wp-content/uploads/2013/05/Eyes-on-TX-and-DC-3-28141.pdf Acesso em: 02/02/2016.

THE ECONOMIST. Sheiks vs Shale. Disponível em: http://www.economist.com/news/leaders/21635472-economics-oil-have-changedsome-businesses-will-go-bust-market-will-be Acesso em: 01/01/2015.

T.M.L. Texas Municipal League. Oil and Gas Regulation: H.B. 40 Updates. tml.org, 2016. Disponível em: http://www.tml.org/HB-40-updates. Acesso em: 01/02/2016.

TONATTO, N. Prefeito José Flávio e equipe participam de inauguração da BSBios em Passo Fundo. 2011. Clic Soledade Portal e Comunicação Ltda. Disponível em: http://www.clicsoledade.com.br/clicnews/?pg=ler\&id=5319. Acesso em: 27/07/2015. 
TUCKER, H.J.; LUTTBEG, N. Comparing the States and Communities: Politics, Government and Policy in the United States, 8th Edition. College Station, Texas, Texan Printing and Publishing, 2010,344p.

TUNSTALL, T. Eagle Ford and the State of Texas.In: HEFLEY, W.E.; YANG, Y. (Eds.) Economics of unconventional Shale Gas Development. Natural Resource Management and Policy. Springer International Publishing: Switzerland, p. 121- 148, 2015a.

TUNSTALL, T; OYAKAWA, J; MEDINA, C; GREEN, M; SANCHEHEZ, I; RIVERA, R; MORUA, D. Economic Impact of the Eagle Ford Shale, University of Texas at San Antonio.2014 Institute for Economic Development. Center for community and Business Research, Austin

TUNSTALL, T. Recent Economic and Community Impact of Unconventional Oil and Gas Exploration and Production on South Texas Counties in the Eagle Ford Shale Area. The Journal of Regional Analysis \& Policy, v.45, nr.01, pp.82-92, 2015b.

TUNSTALL, T. The multiplier effect in Texas. Eagle Ford Shale Magazine v. 2, n. 3, p. 50-1, 2014.

TXOGA. Texas Oil and Gas Association. About Us. Disponível em: www.txoga.or/about-us Acesso em: 01/01/16.

UBRABIO.União Brasileira do Biodiesel e Bioquerosene. Biodiesel: siga em frente, estrada sustentável.Biodiesel em Foco. Maio de 2011, edição nr.03. Disponível em: http://www.ubrabio.com.br/sites/1700/1729/00000327.pdf Acesso em: 01/03/2016.

UBRABIO. Informativo Ubrabio. 6 ${ }^{\mathbf{a}}$ Edição, janeiro de 2012. Disponível em: www.ubrabio.com.br. Acesso em: 25/07/2015.

UBRABIO. União Brasileira do Biodiesel e Bioquerosene. Quem somos. Disponível em: http://www.ubrabio.com.br/1891/textos/quemsomos 29614/. Acesso em: $16 / 082016$.

UNDP. United Nations Development Program. Governance for Sustainable Human Development, New York: UNDP, 1997, pp 2-3.

UNDP. United Nations Development Program.Decentralization: a sampling of definitions.UNDP role in decentralization and local governance. 1999. Disponível em: http://web.undp.org/evaluation/documents/decentralization working report.PDF.

Acesso em: 25/09/2012.

UNDP. United Nations Development Program.UNDP and Governance: Experiences and Lessons Learned,Management Development and Governance Division, Bureau for Development Policy, Lessons Learned Series No. 1, May 1999.

UNITED STATES. Energy Information Administration(E.I.A.).Review of emerging resources: U.S. Shale Gas and Shale Oil Plays.2011.Independent Statistics\&Analysis. U.S. Department of Energy, Washington, DC.Disponívelem: www.eia.gov. Acesso em: 01/02/15.

UNITED STATES. Bureau of the Census of Governments 2007. Disponível em: http:// www.census.gov/govs/www/cog2009.html. 
UNITED STATES. Federal Energy Regulatory Commission (FERC). Next Commission meeting.February, 2016. Disponível em: http://www.ferc.gov/. Acesso em: 31/01/2016.

UNITED STATES. Unconventional Resources Technology Advisory Committee (URTAC).December 18, 2013. Twenty-fifth meeting. Disponível em: http://energy.gov/sites/prod/files/2014/10/f18/Minutes\%20from\%20December\%2018\%2 C\%202013\%20URTAC\%20Meeting.pdf. Acesso em: 31/01/2016.

UREÑA, J. M. \& OLLERO, A. Fluvial landscapes, catchment administration and landuse planning: experience based on two rivers in Spain, Landscape Research, 26(3), pp. 225-243, 2001.

VACCARO, G.L.R.; POHLMANN, C.; LIMA, A.C.; SANTOS, M. S.; SOUZA, C.B.; AZEVEDO, D. Prospective scenarios for the biodiesel chain of a Brazilian state. Renewable and Sustainable Energy Reviews, v.14, p.1263-1272, 2010.

VALLE, A. Da revolução do gás não convencional nos EUA tendo como substrato uma interferência governamental persistente no estímulo a atividade econômica e no fomento as inovações tecnológicas. Dissertação de Mestrado. Escola Brasileira de Administração Pública e de Empresas, Centro de Formação Acadêmica e Pesquisa Fundação Getúlio Vargas. Rio de Janeiro, 2014.

VEDANA, M. A. Manter o selo Combustível Social é mesmo bom para o Brasil? BiodieselBR digital. 16 setembro de 2015. Disponível em: http://www.biodieselbr.com/noticias/agricultura/selo/manter-selo-combustivel-socialmesmo-bom-brasil-160915.htm?tmpl=component\&print=1. Acesso em: 01/10/2015.

VORLEY, B.; FEARNE, A.; RAY, D. Regoverning Markets: A Place form Small Producers in Modern Agrifood. International Institute for Environment and Development (IIED). 2006. pp.248. ISBN: 978-0-566-08730-1. Disponível em: www.gowerpublishing.com/isbn/9780566087301. Acesso em: 14/08/2015.

WILKINSON, J. and S. HERRERA.Biofuels in Brazil: debates and impacts. The Journal of Peasant Studies, 37(4), 749-68, 2010.

WHITE, B.; DASGUPTA, A. Agrofuels Capitalism: a View from Political Economy. Journal of Peasant Studies, 37, 4, pp. 593-607, 2010.

YAMAMOTO, M. CNPE? O quê?Blog Greenpeace Brasil. Nota endereçada ao ministro Edson Lobão. Disponível em: http://www.greenpeace.org/brasil/pt/Blog/cnpeo-qu/blog/47758/. Acesso em: 06/07/15.

XAVIER, F.L.S.; VIANNA, J. N. A atuação de grupos de pressão no cenário político e viabilidade de participação da agricultura familiar no Programa Nacional de Produção e Uso de Biodiesel. Revista Bahia Análise \& Dados, v.18, nr.04, p.699-720.

WOGAN, D. The Eagle Ford Shale Boom from Space. Scientific American. December 27, 2012. Disponível em: http://blogs.scientificamerican.com/plugged-in/theeagle-ford-shale-boom-from-space/ Acesso em: 01/04/2015.

WORLD BANK. Governance and Anti-Corruption. Ways to Enhance the World Bank's Impact. Independent Evaluation Group. Evaluation Brief 2, 2006. Washington, D.C. Disponível em: www.worldbank.org/ieg. Acesso em: 22/05/2015. 
WHITE, B.; DASGUPTA, A; Agrofuels capitalism: a view from political economy: BORRAS, S. J.R. et al. The politics of biofuels, land and agrarian change: editors' introduction. Journal of Peasant Studies, London, GB: Frank Cass, v.37, n.4, pp.593607, 2010.

WILLIAMSON, Abby, and ARCHON, F. Political Deliberation: Where We Are and Where We Can Go. National Civic Review, v.[s.i.], nr.[s.i.], pp.03-15, 2004.

WISSEMAN, Hannah. Evaluating and Enhancing the capacity of the States to Govern Unconventional Oil and Gas Development Risks. In: STERN, Paul C. Risks and Risk Governance in Shale Gas Development. Summary of two workshops. The National Academy Press, Whasington, DC, p.1750-1794, 2014.

ZAFIRRINI, J. Senator Judith Zaffirini hosts Oil and Gas Regulation Open House. Senator Judith Zaffirini blogspot.Disponível em: http://judithzaffirini.com/2014/11/ Acesso em: 23/02/2016.

ZARRILLI, S.The emerging biofuels market: regulatory, trade and development implications. New York: United Nations Conference on Trade and Development. 2006.

http://r0.unctad.org/ghg/events/biofuels/UNCTAD DITC TED 2006

4.Final.pdf; Acesso em: 01/03/15. 


\section{APÊNDICES}

\section{APÊNDICE A-Códigos e sua análise racional de definição a partir das entrevistas e materiais obitdos nos PG.}

\begin{tabular}{|c|c|c|c|}
\hline & Código & Análise racional & $\begin{array}{l}\text { Número } \\
\text { decitações }\end{array}$ \\
\hline 1) & Cooperação & $\begin{array}{l}\text { Expressam ações conjuntas, cooperaçâo e sinergia } \\
\text { na cadeia do produtiva do biodiesel e óleo vegetal. }\end{array}$ & 34 \\
\hline 2) & Bioenergia & $\begin{array}{l}\text { Ressaltam o papel da bioenergia como atividade } \\
\text { propulsora de "desenvolvimento"na dinâmica } \\
\text { agrícola e econômica do estado e do país. }\end{array}$ & 33 \\
\hline 3) & Inovação & $\begin{array}{l}\text { Citações } \quad \text { que } \\
\text { experiências,participações e/ou investimentos em } \\
\text { processos de inovação social e tecnológica. }\end{array}$ & 29 \\
\hline 4) & Participação & $\begin{array}{l}\text { Destacam situações em que a conjugação entre } \\
\text { políticas públicas e participação local em iniciativas e } \\
\text { decisões são fundamentais no processo de } \\
\text { desenvolvimento. }\end{array}$ & 28 \\
\hline 5) & Soja & $\begin{array}{l}\text { Citam a soja como ativdade agrícola que define o } \\
\text { regime de economias locais, a diversificação das } \\
\text { culturas, e os mercados de óleo e farelo. }\end{array}$ & 27 \\
\hline 6) & Logística & $\begin{array}{l}\text { Relacionado aos gargalos logísticos, como } \\
\text { obtenção de sementes e limites das estruturas de } \\
\text { mercado. }\end{array}$ & 26 \\
\hline 7) & $\begin{array}{l}\text { Limitações } \\
\text { Tecnológicas }\end{array}$ & $\begin{array}{l}\text { Especificamente citado como as dificuldades de } \\
\text { plantio, tratamento e colheita de novas culturas como } \\
\text { a canola. }\end{array}$ & 25 \\
\hline 8) & Reprovação & $\begin{array}{l}\text { Indicações de reprovação e censura aos } \\
\text { procedimentos adotados por outros atores sociais, } \\
\text { incluindo instituições, políticas e comportamentos. }\end{array}$ & 24 \\
\hline 9) & Segurança Alimentar & $\begin{array}{l}\text { Correlação indevida dos impactos dos } \\
\text { biocombustíveis sobre a segurança alimentar. }\end{array}$ & 22 \\
\hline 10) & Concorrência & $\begin{array}{l}\text { Casos de relações de concorrência entre as } \\
\text { cooperativas, cereal e indústrias de biodiesel no RS. }\end{array}$ & 22 \\
\hline 11) & Limitações Climáticas & $\begin{array}{l}\text { Geadas constantes e granizo para as culturas de } \\
\text { inverno como a canola. }\end{array}$ & 20 \\
\hline 12) & Parcerias & $\begin{array}{l}\text { Relatos de parcerias comerciais entre } \\
\text { cooperativas, empresas e indústrias feitas no } \\
\text { passado ou em vigor. }\end{array}$ & 20 \\
\hline 13) & Certificações & $\begin{array}{l}\text { Importância e relevância do Selo Combustível Social } \\
\text { e da DAP do ritmo e dinamismo do mercado de soja, } \\
\text { óleo e biodiesel. }\end{array}$ & 19 \\
\hline 14) & Rentabilidade & $\begin{array}{l}\text { Expressam que o núcleo fundamental para a } \\
\text { decisão para qualquer cultura passa sempre pela } \\
\text { perspectiva de rentabilidade financeira. }\end{array}$ & 19 \\
\hline 15) & $\begin{array}{l}\text { Proximidade } \\
\text { institucional }\end{array}$ & $\begin{array}{l}\text { Proximidade de instituições na cadeia produtiva do } \\
\text { agronegócio da soja e sementes de canola, óleo e } \\
\text { biodiesel em territórios do noroeste/ nordeste } \\
\text { gaúchos. }\end{array}$ & 18 \\
\hline 16) & Diversificação & $\begin{array}{l}\text { Quando a importância ea necessidade de } \\
\text { diversificação da produção agrícola e da matriz de } \\
\text { rotação de culturas, especialmente, é tratada como } \\
\text { estratégica para a emancipação socioeconômica dos } \\
\text { agricultores. }\end{array}$ & 17 \\
\hline 17) & Benefícios Edáficos & $\begin{array}{l}\text { Vantagens na estrutura do solo, nutrientes e } \\
\text { cobertura, no uso da canola no sistema de rotação. }\end{array}$ & 16 \\
\hline 18) & Desapontamento & $\begin{array}{l}\text { Decepção sobre as experiências e dificuldades } \\
\text { no plantio de Canola. }\end{array}$ & 16 \\
\hline
\end{tabular}




\begin{tabular}{|c|c|c|c|}
\hline 19) & Competição de culturas & $\begin{array}{l}\text { Exemplifica como a escolha na dinâmica de } \\
\text { culturas ocorre, especialmente o choque de Canola } \\
\text { com outras culturas de inverno. }\end{array}$ & 15 \\
\hline 20) & Conflitos & $\begin{array}{l}\text { Ocasiões de conflitos de interesse, entre grupos } \\
\text { de interesse, atores sociais ou instituições. }\end{array}$ & 15 \\
\hline 21) & Escala e Verticalização & $\begin{array}{l}\text { Importância de economias de escala e processo de } \\
\text { integração vertical para alcançar o sucesso } \\
\text { econômico para a indústria de biodiesel. }\end{array}$ & 13 \\
\hline 22) & Óleos nobres & $\begin{array}{l}\text { Opiniões sobre a viabilidadede a produção de } \\
\text { biodiesel a partir de óleos nobres. }\end{array}$ & 13 \\
\hline 23) & Expertise & $\begin{array}{l}\text { Referências e experiências industriais e agrícolas } \\
\text { relacionadas à indústria de biodiesel. }\end{array}$ & 13 \\
\hline 24) & Canola & $\begin{array}{l}\text { Credibilidade na viabilidade da Canola para os } \\
\text { agricultores familiares. }\end{array}$ & 13 \\
\hline 25) & $\mathrm{R}, \mathrm{V} \& \mathrm{I}$ & $\begin{array}{l}\text { Ênfase as questões de risco, vulnerabilidade e } \\
\text { incerteza nas culturas inovadoras. }\end{array}$ & 11 \\
\hline 26) & Ideologia & $\begin{array}{l}\text { O posicionamento político e ideológico altera os } \\
\text { resultados esperados. }\end{array}$ & 10 \\
\hline 27) & LUC & $\begin{array}{l}\text { Histórias e perspectivas relacionadas à mudança de } \\
\text { uso da terra causadas pela intensificação da } \\
\text { agricultura nas áreas visitadas. }\end{array}$ & 9 \\
\hline 28) & Otimismo & $\begin{array}{l}\text { Situações em que os atores sociais expressaram } \\
\text { otimismo no crescimento da cultura da canola, soja, } \\
\text { biodiesel, agricultura e economia agrícola em geral. }\end{array}$ & 9 \\
\hline 29) & Industrialismo & Credibilidade na expansão da indústria de biodiesel. & 8 \\
\hline 30) & Pertencimento & $\begin{array}{c}\text { Representação e responsabilidade social para a } \\
\text { agricultura familiar. }\end{array}$ & 8 \\
\hline 31) & $\begin{array}{l}\text { Viabilidade do biodiesel } \\
\text { de canola }\end{array}$ & Credibilidade no avanço do biodiesel de canola. & 8 \\
\hline 32) & Agregação de valor & $\begin{array}{l}\text { Projetos, desejos e benefícios da adição de valor e } \\
\text { tecnologia. }\end{array}$ & 7 \\
\hline 33) & Agroquímica & Uso intensivo de fertilizantes e agrotóxicos. & 7 \\
\hline 34) & Fisiocratismo & $\begin{array}{c}\text { Correlação da agricultura e o vigor econômico do } \\
\text { Estado e do país. }\end{array}$ & 6 \\
\hline 35) & Tecnocentrismo & $\begin{array}{l}\text { Fé na tecnologia como salvaguardas ambientais } \\
\text { suficientes. }\end{array}$ & 5 \\
\hline 36) & Credibilidade & $\begin{array}{l}\text { Situações em que os entrevistados mencionaram } \\
\text { credibilidade como elementar nas relações } \\
\text { institucionais. }\end{array}$ & 5 \\
\hline 37) & Farelo & $\begin{array}{l}\text { Destacam o farelo proteico como razão principal } \\
\text { para a produção de uma cultura particular, por } \\
\text { exemplo, farelo de soja, a principal razão para o seu } \\
\text { cultivo. }\end{array}$ & 5 \\
\hline 38) & $\begin{array}{l}\text { Esforços de } \\
\text { planejamento }\end{array}$ & $\begin{array}{l}\text { Relatos de tentativas de organização da cadeia de } \\
\text { produção de canola. }\end{array}$ & 3 \\
\hline 39) & Intimidação & $\begin{array}{l}\text { Relatos de sentimentos de intimidação nos fóruns } \\
\text { ou comitês. }\end{array}$ & 3 \\
\hline
\end{tabular}

\section{APÊNDICE B - Todas códigos e as respecitvas citações utilizadas pelas entrevistas obtidas nos PG.}

Hermeneutic Unity: PG

File: [C:IProgram Files (x86)|Scientific SoftwarelATLAStilProgramlHelp.hpr7]

Edited by: $\quad$ Super

Date/Time: $\quad$ 2015-08-02 14:00:06

PG2: - 2:1 [Você falou bem! Teoricamente!] (5:958-5:986)

Codes: [Segurança Alimentar]

Você falou bem! Teoricamente!

PG2: - 2:2 [Então assim ô, você é extensio..] (33:6-33:503)

Codes: [Cooperação] 
Então assim ô, você é extensionista, Emater, ou empresa de assistência, você simplesmente vai lá...ehhh....com esse equipamento aqui facilita todo processo! Daí assim, ao invés de você ir em cada propriedade regulando a máquina, você pode simplesmente dizer vamos trocar serviço!? Beleza Pura! Então Fulano aqui vai semear pra todos vocês aqui, entende!? Depois na hora da colheira, uma colheitadeira vai colher pra todos! Esse é o sistema que temos que fazer pra pequena propriedade!

PG2: 2:3 [Fazemos um curso, já a convite..] (36:476-36:652) (Super)

Codes: [Cooperação]

Fazemos um curso, já a convite do MDA fizemos muito de campo...a gente tem tentado envolver...há poucos dias chamamos o pessoal aí pra ver se a gente fazia um projeto conjunto

PG2: 2:4 [.mas na verdade assim, pra ser..] (36:663-36:800) (Super)

Codes: [Desapontamento]

.mas na verdade assim, pra ser bem sincero com você, não conseguimos fazer nem um projeto com eles...não é por falta de esforço nossa...

PG2: 2:5 [Foi um esforço muito grande de..] (36:804-36:966) (Super)

Codes: [Esforço de planejamento]

Foi um esforço muito grande deles e nosso! Houve ehhh...nós fizemos muitas reuniões em conjunto, em planejamento, tentando identificar as demandas deles e tal...

PG2: - 2:6 [Nenhuma dessas tentativas de d..] (2:222-2:667) (Super)

Codes: [Segurança Alimentar]

Nenhuma dessas tentativas de diversificação das matrizes de óleo acabam em biodiesel! E não vai acabar por muito tempo, por que os produtos são muito nobres, esses óleos são muito nobres para um uso menos nobre que têm...qualquer coisa que queima né... desde que não dê problema no motor não interessa se é um óleo de alto ou baixo valor. Todas as outras oportunidades são melhores que biodiesel...a ricinoquímica é um negócio fantástico!

\section{PG2: 2:7 [Que isso! Não, não, não! Na ve..] (6:892-6:1088) (Super)}

No codes

Que isso! Não, não, não! Na verdade nós somos bem pagos pra isso aí! Se você e seu pai estão com os impostos em dia, vocês são os nossos patrões! E o retorno merecido pelo investimento que faz!

PG2: 2:8 [Por que? Pra mim é....pela for..] (8:1263-8:1493) (Super)

Codes: [Desapontamento]

Por que? Pra mim é....pela formação que eu tenho é meio frustrante por que não é um negócio sofisticado, eu estudei isótopos estáveis, M15, teorias sofisticadíssimas, espectrômetro de massa e tal...agora que eu tô fazendo aqui!

PG2: - 2:9 [Sim, sim! Um banho de agua fri..] (9:1408-9:1555) (Super)

Codes: [Desapontamento]

Sim, sim! Um banho de agua fria muito grande só que assim né não tem outra alternativa...era o que eu acostumava a explicar pro pessoal no Canadá!

PG2: 2:10 [A situação nossa é minha altur..] (9:1557-9:2027) (Super)

Codes: [Clima]

A situação nossa é minha altura 1,80 metro por ano! 1773 pra ser preciso aqui! É normal! Lá no Canadá um

produtor de trigo e canola plantar é $30 \mathrm{~cm} / 380 \mathrm{~mm}$ sendo que a metade disso é gelo e neve, um tanto descongela, vai virar em $180 / 200 \mathrm{~mm}$ de água e o resto de chuva. Então isso aqui de 
chuva, de água comparado com minha altura! Então assim, o ambiente que nós temos, qualquer alternativa, não existe milagre! Qualquer alternativa aqui no inverno não é fácil!

PG2: 2:11 [Mas nós temos 2 milhoes, 2,5 m..] (12:1656-12:2170) (Super)

Codes: [Rentabilidade] [Tecnocentrismo]

Mas nós temos 2 milhoes, 2,5 milhões de canola no inverno sem afetar nada, na verdade só otimizando o que está ai. Estudo da década de 1970/80 aqui nós tínhamos quatorze toneladas de hectare por ano, medidas aqui, essas perdas diminuíram com plantio direto. $\mathrm{O}$ que que acontece, como esse solo fica descoberto, subutilizado no inverno, nós temos degradação ambiental....e uma concentração de custos.... safra de verão tem que pagar essas contas. $\mathrm{E}$ quando nós colocamos a canola isso muda nós geramos renda!

PG2: 2:12 [Então assim! A otimização de t..] (16:2450-16:2664) (Super)

Codes: [Ideologia]

Então assim! A otimização de tudo é uma coisa fantástica! Outra coisa assim que é muito chave oh...eu tentando ao máximo de abstrair a ideologia fora! Por que tem muito ideologia e política nesse negócio aqui!

PG2:- 2:14 [Que isso! Não, não, não! Na ve..] (6:892-6:1273) (Super) Codes: [Cooperação]

Que isso! Não, não, não! Na verdade nós somos bem pagos pra isso aí! Se você e seu pai estão com os impostos em dia, vocês são os nossos patrões! $\mathrm{E}$ o retorno merecido pelo investimento que faz! Na verdade estamos juntos! Na verdade quero agradecer sua vinda por que acho que é importante evitar a...assim saber até onde se chegou pra evoluir né!

PG2: 2:15 [Umas das coisas é que a canola..] (6:1277-6:1700) (Super)

Codes: [Diversificação produtiva]

Umas das coisas é que a canola é uma cultura de cadeia curta, então é...uma das coisas que ocorrem assim...até era uma teimosia minha ficar tocando um desenvolvimento de uma cultura que ninguém acreditava! Diversificação da matriz produtiva!

\section{PG2: 2:16 [E aqui...só pra colocar dentro..] (6:1704-6:2061) (Super)}

Codes: [Diversificação produtiva]

E aqui...só pra colocar dentro do contexto global...é...se descobriu junto com a escola canadense que nós não podemos produzir trigo sobre trigo...tem que variar a produção. Tem que fazer rotação com o quê? Daí tem aquele negócio bem teórico....faz rotação com leguminosa que interrompa o ciclo da doença....só que aí caía nas culturas de cobertura né!

\section{PG2: - 2:17 [As culturas de cobertura elas ..] (6:2065-7:1340) (Super)}

Codes: [Logística]

É bem claro que se não houver uma continuidade de pesquisa e essas coisas...suporte e essa parte estratégica..."ela" morre! A cultura do feijão no Rio Grande do Sul no final da década de 1980 tava quase terminando! Feijão preto! Tava se acabando por que não tinha pesquisa. Então assim ô, eu acredito muito na continuidade...desse...desse... processo e aí o que acontece, tem que organizar a cadeia produtiva!

PG2: 2:18 [Ótimo! Outra coisa, parte intr..] (8:777-8:1259) (Super) Codes: [Cooperação]

Ótimo! Outra coisa, parte introdutória...provavelmente todos os contatos...assim...é uma cadeia curta...o que que é curta... então a gente começou a abrir as alternativas...criamos a Abrascanola. Eu estou em contato com todos atores ligados à canola. Ou fui eu quem treinou a equipe deles ou ajudei a estruturar, entende? $\mathrm{Na}$ verdade, a gente procura fazer a parte técnica, científica, não só a parte técnica-científica mas a questão de estruturação da parte 
organizacional.

PG2: - 2:19 [Nós temos duas situações né! N..] (9:710-9:1352) (Super)

Codes: [Clima]

Nós temos duas situações né! No Paraná! Se você olha as estatísticas, vai ver assim...onde a gente (Embrapa/Tomm) teve oportunidade de fazer uma trabalho a área cresce! Paraná vem crescendo, é o último grande esforço a gente vem fazendo no Paraná, e a oportunidade é grande também! Mas a situação é a seguinte desde o Atlântico ali, Ponta Grossa até o Paraguai, o clima no inverno foi extremamente complicado! Veja o caso de Cascavel, maio e junho choveu $300 \mathrm{~mm}, 350 \mathrm{~mm}$ cada mês...praticamente não saiu o Sol! Então o trigo se acabou, caiu neve...geadas muito fortes...então assim, foi um tanto diferente do que normalmente ocorre!

PG2: - 2:20 [Sim, sim! Um banho de agua fri..] (9:1408-9:1890) (Super)

Codes: [Clima]

Sim, sim! Um banho de agua fria muito grande só que assim né não tem outra alternativa...era o que eu acostumava a explicar pro pessoal no Canadá! A situação nossa é minha altura 1,80 metro por ano! 1773 pra ser preciso aqui! É normal! Lá no Canadá um produtor de trigo e canola plantar é $30 \mathrm{~cm} / 380 \mathrm{~mm}$ sendo que a metade disso é gelo e neve, um tanto descongela, vai virar em 180/200mm de água e o resto de chuva. Então isso aqui de chuva, de água comparado com minha altura.

PG2: 2:21 [Sabe que isso aí é uma falácia..] (4:500-4:560) (Super)

Codes: [Segurança Alimentar, Ceticismo ambiental]

Sabe que isso aí é uma falácia! Isso aí do aquecimento global...

PG4: - 4:1 [Vai lá e pa pa pa! Se eu chega..] (3:589-3:896) (Super)

Codes: [Cooperação]

Vai lá e pa pa pa! Se eu chegar e dizer assim, pegar o telefone, e dizer ô Gilberto, seguinte cara...eu preciso que tu dê uma palestra amanhã de manhã lá em Francisco Beltrão no Paraná cara...nós te arrumamos a gasolina e pa pa pa...pá...Tu pode cara? ....Bah mas Bah!...não sei ô que vamos ver...VOU!

PG4: - 4:2 [Sabe....ele não tem...ele é um..] (3:900-3:1068) (Super)

Codes: [Conflitos]

Sabe....ele não tem...ele é um cara assim né...Não tem problema nenhum...mas tu sabe!...e essa questão...aí ele não respeita muito essa questão pública e coisa e tal..

PG4: - 4:3 [..só que os outros cara bah!! ..] (3:1068-3:1384) (Super)

Codes: [Conflitos]

..só que os outros

cara bah!! Aí tu vai conversar! Vai um dia que os caras vão tá bem humorado...não...por que o cara é isso...o cara é aquilo! Por que o Programa do Biodiesel atropelou a pesquisa da Canola, atropelou todo o coisa

assim...bá bá bá bá bá...e por que de tá tá tá...mas tu tem que..tu tem que...

PG4: 4:4 [É...e eles formaram, ele formo..] (3:1879-3:2035) (Super)

É...e eles formaram, ele formou uma parceria com a BSBios né! Por que rolou bastante dinheiro pra ele por ali né! Na importação de sementes! Coisa assim...

PG4: MDA_Coord Reg Bioc Roberto Terra.pdf - 4:5 [Mas pergunta pros agricultores..] (22:1180-22:1513) (Super)

Codes: [Segurança Alimentar]

Mas pergunta pros agricultores isso! Não é bem assim! 
PG4: 4:6 [E te garanto assim...ahh...com..] (20:1649-20:1859) (Super)

Codes: [Cooperação]

E te garanto assim....ahh...como é que é....ahhh...a Abrascanola e a própria BSBios tem insistido em projetos e tal com a gente né...e a gente sempre tem falado a mesma coisa! Nós apoiamos, tamos aí pra apoiar

PG4: 4:7 [.a Canola, que aspecto da Cano..] (20:1862-20:2046) (Super) Codes: [Canola]

.a Canola, que aspecto da Canola pode ser uma alternativa para a agricultura familiar... Entendeu? Dentro do Programa do Biodiesel, né!

PG4: MDA_Coord Reg Bioc Roberto Terra.pdf - 4:8 [E aí...e aí...entram alguns li..] (21:521:261) (Super)

Codes: [Competição de culturas]

E aí...e aí...entram alguns limites né! Uma questão, é essa questão da concorrência com oTrigo! Uma outra questão, e aí entra bastante a questão da agricultura familiar, ela também pode concorrer no inverno, com a questão das pastagens né! Com o leite!

PG4: MDA_Coord Reg Bioc Roberto Terra.pdf - 4:9 [E o leite é muito forte na agr..] (21:283-21:559) (Super)

Codes: [Competição de culturas]

E o leite é muito forte na agricultura familiar! Né! Nessa região aqui! É bastante forte né! Tem muito agricultor que utiliza as áreas de verão pra fazer pasto de Aveia e Azevém, faz um sistema de rotação ali né! No inverno né! Isso também é então...uma questão importante!

PG4: 4:10 [E outra questão bastante impor..] (21:564-21:862) (Super) Codes: [Limitações Tecnológicas]

E outra questão bastante importante também...ehhh...a Canola é bastante mecanizada, pro agricultor familiar nosso do sul é da metade norte, especialmente, ele é mecanizado! Né! Ele é mecanizado, ele tem o trator, não tem a colheitadeira né! Agora o limite dele é essa questão da plataforma né

PG4: 4:12 [Então os limites são esses né!..] (21:2381-22:332) (Super) Codes: [Limitações Tecnológicas]

Então os limites são esses né! Existem alguns limites técnicos a serem superados né! E a outra é isso né! Enquanto que o mercado também não consegue, mesmo se pagando, que se paga preço de soja né, mesmo preço de soja, ainda não é um preço convidativo pro pessoal...por que a produtividade que o pessoal tem tirado né! Em média né...daí talvez o Gilberto Tomm passe...por que eu fiquei dois anos afastado! 2011 e 2012 eu fiquei afastado! Não 2010 e 2011, e depois quando eu retomei, eu não acompanhei mais! Né! Eram outras pessoas que acompanhavam e aí não me passavam as informações!

Mas a produtividade em média fica em torno de $1200 \mathrm{~kg} / \mathrm{hectare}$. E aí não é convidativo!

\author{
PG4:4:13 [E agora tá fazendo concorrênci..] (19:5-19:226) (Super) \\ Codes: [Logística] \\ E agora tá fazendo concorrência com eles (cooperativas)! Compra deles e paga um preço! \\ $\mathrm{O}$ agricultor direto no contrato paga um preço maior!
}

PG4: 4:14 [Então o Orildo tá antes de mim..] (18:1712-18:1874) (Super)

No codes

Então o Orildo tá antes de mim, desde 2003 ele tá enfiado no biodiesel! Então ele é uma

referência aí do biodiesel. Ele vai te mostrar a avaliação do biodiesel 
PG4: - 4:15 [Ele vai fazer uma crítica à BS..] (18:1877-18:1959) (Super)

Codes: [Conflitos]

Ele vai fazer uma crítica à BSBios! Nessa região tu vai ver muita crítica a BSBios!

PG4: - 4:16 [E o X, depois, chegamos n..] (18:1597-18:1710) (Super)

No codes

E o Orildo, depois, chegamos no estudo de viabilidade que tinha que ser grande, que não podia ser pequena e tal!

PG4: - 4:17 [E o X, depois, chegamos n..] (18:1597-18:1875) (Super)

Codes: [Certificações]

E o X, depois, chegamos no estudo de viabilidade que tinha que ser grande, que não podia ser pequena e tal! Então o Orildo tá antes de mim, desde 2003 ele tá enfiado no biodiesel! Então ele é uma referência aí do biodiesel. Ele vai te mostrar a avaliação do biodiesel!

PG4: 4:18 [Eu acho que tu deveria, em Bra..] (1:94-1:1144) (Super)

Codes: [Certificações]

Eu acho que tu deveria, em Brasília, marcar com o André Machado nosso coordenador...aí tu conversa mais sobre o Projeto Polos né! Acho que a Ana Maria dá...dá... Mas tem outros aspectos que você pode me ajudar muito Roberto! Ehh...ehh...lá é um cara muito experiente! Daí tu teria que conversar com o Estefáno...ele é o cara que tocou tudo né! No início era o Estefáno e o Hermes...o Hermes saiu já faz uns cinco anos que saiu ele! Era o Estefáno e o Hermes no Nordeste, e eu no Centro-Sul. Os caras que iniciaram né

PG4: - 4:20 [SC é cooperativa, PR tem algum..] (1:1549-2:254) (Super)

Codes: [Certificações]

SC é cooperativa, PR tem alguma coisa...agora que a Cargill entrou lá! Caramuru entrou um pouco também! Eu vi que tu não botou o GO na Canola cara! ...o André que trabalhava com ele lá...que é o coordenador do Selo hoje! Eles não trabalham mais...

PG4: - 4:21 [E ali...ali é um...não sei se ..] (2:497-2:1508) (Super)

Codes: [Conflitos]

E ali...ali é um...não sei se tu já conversou com o pessoal da coordenação da Embrapa? Tem que conversar também! Por que daí é outra visão! Éhhh...tu vai ter que conversar com o... Tu vai ter que conversar com a chefia em geral, com a chefia de pesquisa de desenvolvimento...que eu acho que está o Osvaldo...ou tá o agrônomo aquele... ele é um doutor que veio lá da Embrapa Soja...Osvaldo e.....a pouquinho veio o nome...ehhh....tu vai conversar com ele... vai ver uma outra visão...uma visão da Embrapa Trigo que é responsável pela Canola...

PG4: - 4:22 [E ele é assim...a crítica dele..] (2:1633-3:581) (Super)

Codes: [Conflitos de interesse]

E ele é assim...a crítica deles...que eles vão te dizer é que ele navega sozinho! Ele tem a empresa dele! Ele navegou lá...navegou todo o Centro-Oeste, nem vou te detalhar né... Todo o Centro-Oeste ele navegou...é o cara da Canola! Se não fosse ele a Canola não estaria implantada dessa forma....mas caiu bastante dinheiro pessoalmente pra ele né! Pra empresa pública é complicado isso né! Nesse sentido, eles tem razão...mas eles ficam nessa questão...ehhh...a coisa não anda também, entende? Uhhh...ele é o desbravador da Canola! Se não fosse pelo Gilberto Tomm não existia Canola, entende? E ele é um cara assim...tu viu! Ele não esconde o jogo!

PG4: MDA_Coord Reg Bioc Roberto Terra.pdf - 4:23 [É...e eles formaram, ele formo..] (3:1879-4:744) (Super)

Codes: [Conflitos de interesse] 
É...e eles formaram, ele formou uma parceria com a BSBios né! Por que rolou bastante dinheiro pra ele por ali né! Na importação de sementes! Coisa assim... A firma dele...eles criaram uma empresa! Daí entrou esse novo... É...é eu não sei...por que a empresa dele, não é a mesma do $Y$ Eles tem um nome específico tá...a dele não é a importadora! A que é importadora é da BSBios! A dele só presta serviços! A dele é....não sei como é o nome! Ali ele pega os estagiários! Põe os estagiários pra trabalhar pra ele! Dentro do projeto tal...daí trabalha na empresa dele! Ele é...bastante...quem me contou essa história foi o X.

PG4: - 4:24 (4:754-4:1827) (Super)

Codes: [Expertise]

No memos

Fulano? se tu quiser falar sobre questões técnicas é com ele! Mas o cara depois do X é ele! Tá? O Fábio... se formou agrônomo e foi contratado pela BSBios! E a BSBios tava começando e...botaram ele junto com o X...é um cara que tecnicamentesabe muito de Canola! E o cara que mexia também com o Selo Combustível

Social! Aí o Jean saiu da Camera e veio tocar o Selo ele tá tocando outras questões da BSBios!

PG4: MDA_Coord Reg Bioc Roberto Terra.pdf - 4:25 [Hoje, a BSBios tem Selo Combus..] (5:5-5:883) (Super)

Codes: [Certificações]

Sim sim sim...todas as empresas de biodiesel, as novas que estão instaladas aqui... Todas estão com Selo! Senão, não sobrevive né! A Brasil Ecodiesel foi vendida né! Ela quebrou economicamente daí ela...foi vendida pra uma empresa e essa empresa vendeu pra Vanguarda, daí a Vanguarda vendeu...daqui foi vendida pra Camera ahh...da (unidade) de TO e da BA foi vendida pra Óleoplan! Daí a de TO foi vendida pra Granol! Na BA a Óleoplan continua tocando ela! Ehhh...é uma empresa que não existe mais! E a Camera agora tá tá desmanchou essa de Rosário do Sul pra instalar em Lajeado, mas tá num processo de liquidação também!

PG4: 4:27 [É...no MT, Cooperbio! Também n..] (6:339-6:1574) (Super)

Codes: [Escala e Verticalização]

No memos

É...no MT, Cooperbio! Também não era verticalizada...das cooperativas... A Cooperbio, por exemplo, essa era média! Ela foi vendida pro grupo Maggi, agora o grupo Maggi vai investir! A BioÓleo lá também...é...a BioÓleo era um filho de um fazendeiro lá...o cara também é da Cooperbio lá...o menino foi lá estudou...não tinha o que fazer, o pai dele deu lá um brinquedinho lá, pra ele montar uma indústria....do tamanho dessa cozinha! Pra fazer óleo lá....cara!!! Mas não dá! Não tem...! Não tem escala! É umas coisas que... não...é...uma questão que tu não tá verticalizado é...

\section{PG4: - 4:28 [Hoje ele é um mercado muito vo..] (6:1582-7:283) (Super)}

Codes: [Logística]

Hoje ele é um mercado muito volátil! O mercado de óleos, tu que tá estudando... ...vocês que fazem parte de um grupo...você viver só de um...entende? Não tem como viver só de um produto né ou dois! Com a Glicerina, mas a Glicerina ainda não tá né...não dá pra viver dentro de uma questão só...não tem como você acabar e apostando num processo desse! Então o que que acontece agora! Agora que você tá...tu tens um único mercado! Que é omercado interno! Né...tem duas ou três empresas todas elas verticalizadas...né...pegando exportação mas são escalas pequenas de exportação, né! $E$ aí tu tens um único mercado!

PG4: 4:29 [A - Elas são verticalizadas pr..] (7:287-7:1128) (Super)

Codes: [Escala e Verticalização]

É, o grão né? Isso! É...ehhh...e daí ela tem o farelo, tem todo o né, tem todo o né...e muitas delas já tem 
o agricultor fidelizado a ela! E dentro disso aí, tem o insumo que ela tá vendendo ou revendendo! Tem todo um processo de de...

PG4: 4:30 [E aí tu tens um único mercado!..] (7:254-7:283) (Super)

Codes: [Logística]

E aí tu tens um único mercado!

PG4: - 4:31 [ente de trabalhar com produçõe..] (7:1232-8:289) (Super)

Codes: [Logística]

Não é um processo de integração não! É...é, mas não é casado...até por que você tem Pronaf, você compra os insumos mas muitas vezes não financia né! $E$ se financia, você paga tudo em soja com aquilo alí...e depois o resto que te sobra....ahhh tu colheu 60 sacos, tá devendo pra empresa 27, certo? Aí os 27 tu paga, os outros tu vai vender pra quem te paga melhor! Entende?

PG4: - 4:33 [Sim, e alguém da diretoria...o..] (9:1167-9:1943) (Super)

Codes: [Conflitos]

Sim, e alguém da diretoria...o $\mathrm{X}$ andou me falando essa história de que...aí entrou a nova diretoria...esse pessoal continuou na outra chefia...o novo chefe exigiu que pra eles continuar nessa questão da importação aí teria que fechar um convênio com essa empresa exportadora né...aí eles ficaram um ano sem importar semente! $O$ ano passado foi plantado muito pouca Canola, em função de que eles não tinham sementes! $\mathrm{E}$ a gente achava realmente que eles não estavam conseguindo importar...não! Daí o Fábio me explicou, por que eles não conseguiram importar por que eles não tinham esse convênio com a

Embrapa! E aí foi trancado! E aí...era em função dessa briga! Por isso que eu estou te falando assim né!

\section{Comment:}

Aqui o entrevista dá a entender que houve um conflito de interesses dentro da Embrapa por conta de uma empresa de importação com suposta aproximação de membros da empresa pública e por isso ocorreu a suspensão da autorização de importação de sementes.

PG4: 4:34 [Um cara que...duas pessoas que..] (9:2038-10:1124) (Super) Codes:[decepção]

Um cara que...duas pessoas que tu...valeria tu...entrevistar sobre a Canola, lá no Ministério da Agricultura!Tá! No MAPA? É...um não tá mais...um é o Z! Que é lá...dá...ele tá responsável pela Câmera Temática do Biodiesel...tá...! Outro é o P! Eu tava vendo no meu computador o endereço dele! Ele sim! é o cara que batalhou muito pela Canola! No início da Abrascanola da associação aí...Ele é professor hoje em duas universidades em SP. Ele meio que se desgostou...

PG4:4:35 [E a sua percepção em relação a..] (10:1132-10:1445) (Super)

Codes: [Viabilidade da Canola pra biodiesel]

E a sua percepção em relação a Canola Roberto? O que você acha? Você acha que é uma cultura que pode se tornar viável assim logo ou a médio prazo, longo prazo...existe condição de crescer as áreas de produção e a produtividade para atender ambos os mercados: a indústria de biodiesel e a indústria alimentar?

PG4: - 4:36 [Difícil!] (10:1453-10:1460) (Super)

Codes: [Segurança Alimentar]

Difícil!

PG 4: - 4:37 [Eu sei que é um óleo nobre e q..] (10:1464-10:1586) (Super)

Codes: [Óleos Nobres] 
Eu sei que é um óleo nobre e que a função pra queimar não é nobre! Mas você houver...acha que se houver há possibilidade?

PG4: - 4:38 [Gilberto acredita que em médio..] (10:1592-10:1844) (Super)

Codes: [Viabilidade da Canola pra biodiesel]

Ele acredita que em médio prazo, longo prazo isso pode acontecer! Por que é uma cultura de entressafra né! Tem espaço ocioso, tem efeitos residuais positivos pras outras culturas...próximo cultivo, seja uma gramínea ou outra cultura qualquer...

PG4: - 4:39 [primeiro lugar! Essa questão de..] (10:2035-11:151) (Super)

Codes: [Segurança Alimentar]

Primeiro lugar! Essa questão de quê, esse mito de que é um óleo nobre...nehhh...não é bem assim! A questão de que ele é mais caro e de que ele está assim...eehhh...não, realmente ele tem as suas propriedades biomedicinas que é diferente mais...!!

PG4: - 4:40 [Mais ele é mais caro é por que..] (11:153-11:709) (Super)

Codes: [Logística]

Mais ele é mais caro é por queee...tem pouco no mercado! ...baixa escala...na época que ele tava sendo oferecido bastante ele tava com preço parecido com óleo de soja nehh...eu consumo óleo de Canola aqui...

PG 4: 4:41 [o por que que agora eles estão..] (11:712-11:1029) (Super)

Codes: [Industrialismo]

por que que agora eles estão com uma indústria né! Eles não tinham indústria! Essa indústria tá com dois anos né... Uma indústria super grande né!

PG 4: 4:42 [Cerealistas agora...nessa regi..] (11:1037-11:1105) (Super)

Codes: [Logística]

Cerealistas agora...nessa região de Lagoa! Pra cá já não muito...

PG4: MDA_Coord Reg Bioc Roberto Terra.pdf - 4:43 [Mas essa questão é o seguinte,..] (11:1182-11:2009) (Super)

Codes: [Farelo]

Mas essa questão é o seguinte, assim ô, por isso a questão da verticalização, a questão não tá no óleo da Canola pra tu...ahhh...pra tu....processar o óleo....pra tu ehh...está no farelo da Canola! Os consumidores de farelo dizem o seguinte, tu tem que ter uma certa escala! Se tu atinge uma certa escala de farelo, eu mudo uma das minhas plantas e começo a te comprar o farelo pra eu fazer o...ahhh...a ração! Entende! Então se tu vai conversar com o pessoal da indústria, por exemplo, tu tem que conversar com o pessoal da Óleoplan também que...o cara da Óleoplan dono da Óleoplan...é mais fácil conversar com ele do que com o Z.

PG4: - 4:44 [O $Z$ eu já senti que ele é..] (11:2018-12:285) (Super)

Codes: [Reprovação]

Ele é um pouco iná...difícil né!? O cara subiu rápido demais e... Com essa incorporação com a Petrobrás aí...sobrou um bom dinheiro pra ele...e ele botou em outros negócios né!

PG4: - 4:45 [ntão a chave está no farelo da..] (12:294-12:1981) (Super)

Codes: [Escala e Verticalização]

Claro! Não é que tá no farelo! Primeiro tu tem que ter um...não é no farelo tá! Tu tem que ter escala de produção! Aqui no RS, não sei o que o Gilberto Tomm te disse né! Mas nós estávamos com uma faixa de...na Região Sul de todo o Brasil...nós estávamos numa faixa de 15 mil hectares, hoje nós estamos com 30 mil hectares! 40 mil hectares! Basicamente o RS e o 
norte do PR! Éhhh...lá não tem regra né...aí os cara chegam lá e produzem da forma que querem! Éeeehhh...aumentou bastante a produção de 15 mil hectares foi pra 40 né! Em função do

programa de biodiesel! Mas tu precisa ter uma escala de produção pra ter uma escala de farelo! Né...então essa é uma segunda questão que...éhhh...te respondendo! Né! Então acho que

tem que ter...ter isso...

PG4: - 4:46 [É uma questão de jogada de mer..] (13:5-13:257) (Super) Codes: [Logística]

É uma questão de jogada de mercado da Europa também né! Eles dizem: não como é que o Brasil vai usar óleo de Canola e tal! Aí tu tem...

\section{PG4: - 4:47 [Aí tem uma outra também né! Te..] (13:265-13:758) (Super) Codes: [Clima]}

Aí tem uma outra também né! Tem a questão do fator de produção né! Basicamente, as questões de limites que tu tem no Brasil, né! Tu pode produzir no Cerrado mas você limite de produção de horas-frio né! $E$ aí então foi a partir daí das experiências que $\circ \mathrm{X}$ tirou principalmente em GO isso aí né! Dez anos atrás, dez, quinze anos atrás! O limite é altitudes acima de 650 metros! Por que daí tu tem a quantidade de frio necessário! Então esse é o limite no Cerrado!

PG4: 4:48 [Uhumm. R - E...outro limite é ..] (13:767-13:1832) (Super)

Codes: [Competição de culturas]

A mesma coisa...a mamona no RS produz mais do que no resto do Brasil! Mas o quê...é o mesmo ciclo da soja! E tem deficiência na colheita mecânica! Foi testado aqui! Principalmente pela Embrapa e outros, e ai junto com a BSBios e a Óleoplan, justamente nessa região norte aqui...conversei com agricultores, até o pai do Semar aqui produziu! Bah colhi muita mamona!... Vai plantar de novo ano que vem? Não! Por que não? Ahh por que a soja é mais fácil de colher e tal... Não vou me aventurar numa coisa nova, não! E a Canola de certa forma é isso! Né! O Trigo, por exemplo, o Trigo no Brasil, ele deu uma melhorada muito grande! Não só o preço né! Tu tinha o Trigo aí produzindo 30/40 sacos né...hoje o Trigo agora nos últimos cinco anos aí o Trigo tá produzindo 60 sacos por hectare!

\section{PG4: 4:50 [A - Pra fugir um pouco da gead..] (14:1096-14:1903) (Super)}

Codes: [Clima]

É...é...início de abril então...início de maio...pra colher em setembro! No ano passado não aconteceu isso, mas tu pega, tu pegou...os outros dois anos anteriores, tu pegou geada em agosto! Não né! Mas também né! Mas se tu pega -4 graus...aí foi né! Mas se tu tá na fase aqui...mas se tu tá na fase...tu ainda pode fazer o replante ainda! Se está na fase de germinação pode fazer o replante ainda! Aí, aí, tu salva! Mas se tu tá na fase da flor aí tu perdeu todo...perdeu três meses e pouco!

\section{PG4: 4:51 [Um cara que tá envolvido, que ...] (15:638-15:1110) (Super)}

Codes: [Certificações]

Um cara que tá envolvido, que se envolveu com a BSBios e um cara que tá com um projeto muito bom de Canola que tu pode conversar, é com o presidente da Coasa lá de Água Santa! Já que tu tá parando lá em Lagoa é bem fácil! Até se tu vai voltar hoje... Presidente da Cooperativa de Água Santa Coasa! Coopertativa de pequenos agricultores que começou em 2004. Ela até ia montar uma usina de biodiesel!

PG4: - 4:52 [É...eu acho que evoluiu bastan..] (14:160-14:869) (Super) Codes: [Limitações Tecnológicas]

É...eu acho que evoluiu bastante essa questão da colheita, evoluiu bastante! Essa questão dos 
equipamentos...que...que... Inclusive o produtor que eles fizeram, e um cara de Colorado! Município de Colorado que é um...da onde era o $X$ que é um amigo dele...até levaram o cara pra Austrália! Acho que pro Canadá, não sei se ele vai pro Canadá?!! Eles copiaram né! Eles copiaram os equipamentos, que funciona beleza! Só que a plataforma é muito cara né! É...e aí tu tem que plantar e produzir muito né! Então esse é um limite.

\section{PG4: - 4:53 [E aquelas máquinas que o Cored..] (14:1912-15:630) (Super)}

Codes: [Cooperação]

Parece que eles oferecem 9 máquinas pro pessoal trabalhar, pra incentivar a cultura né!

PG4: 4:54 [E terminando de responder aque..] (20:1421-20:1644) (Super) Codes: [Canola]

E terminando de responder aquela primeira pergunta! Eu te trago um novo eixo! Então aspecto do biodiesel nosso, tem que colocar o que é viável! A Canola né! Com diversificação! Com os aspectos da agricultura familiar né!

PG4: - 4:55 [Tu vai entrevistar inclusive, ..] (21:1593-21:1964) (Super)

Codes: [Cooperação]

Tu vai entrevistar inclusive, depois eu te passo, uma pessoa muito interessante de entrevistar! O presidente dos Trabalhadores Rurais de Passo Fundo, e ele vai te passar agricultores...inclusive ele é produtor de Canola! Produtores de Canola de Passo Fundo que produzem Canola há seis, sete anos!

PG4: - 4:56 [Não é o patronal! E aí tu vai ..] (21:1984-21:2359) (Super)

Codes: [Expertise]

Não é o patronal! E aí tu vai entrevistar agricultores que produzem a seis...sete anos! E assim é...o pessoal acha muito bom como modelo descompactador do solo né! Eles produzem soja e milho em cima (na sequência) da Canola. Tem gente que já plantou Canola em toda área! Cada dois, três anos faz uma rotação...a produtividade em cima da Canola é...aumenta muito assim!

PG4: - 4:57 [Mas no geral 1.200; 1.500; 1.6..] (22:718-22:919) (Super)

Codes: [Benefícios Edáficos]

Mas no geral $1.200 ; 1.500 ; 1.600$ !! Não compensa muito! Mas eu planto por que...acho que tem uma plataforma lá né! $E$ por que eu tô recuperando minha lavoura...e por que é bom para as outras culturas!

PG4: - 4:58 [Em 2004 eu entrei no MDA pra f..] (18:1213-18:1589) (Super)

Codes: [Agroindústrias Familiares]

Em 2004 eu entrei no MDA pra fazer um estudo de viabilidade, de levantamento de plantas pequenas pra essas duas cooperativas e mais uma que ia entrar com o álcool que é a Coopercana lá de... Porto Xavier! Que eles iam trabalhar com Etanol e usinas pequenas!

PG4: - 4:59 [É, Não-Me-Toque é a Cotrijal p..] (15:1784-16:155) (Super)

Codes: [Participação]

É, Não-Me-Toque é a Cotrijal por que, por que a Cotrijal plantou muito...só que a Cotrijal agora que entrou no programa do biodiesel na safra passada...por que nós aceitamos a habilitação com $60 \%$ ! E agora nessa semana ou na semana passada, ela conseguiu a certificação da DAP jurídica, que a DAP jurídica baixou pra $60 \%$ também...

PG4: - 4:60 [Não-Me-Toque! Tu pode conversa..] (16:664-16:991) (Super) 
Codes: [Reprovação]

! Tu pode conversar com o sindicato dos trabalhadores rurais ali que

acompanhou a BSBios e a Canola...sempre tá lá na colheita da Canola e...acompanhou...o

Nicolau! Presidente do Sindicato dos Trabalhadores Rurais! Ele se tu tirar um xerox do saco do

$\mathrm{X}$ aparece a boca dele lá!...(risos)Babando!

Comment:

Aqui o entrevistado destaca a proximidade e cooperação, porém, enfatiza a relação de bajulação que entende ocorrer entre uma cooperativa e a indústria de biodiesel BSBios.

PG4: - 4:63 [É...eu conversei com ele uma m..] (3:1392-3:1870) (Super)

Codes: [Reprovação]

É não...ele é entusiasta! Mas tu tem que ouvir o lado oficial lá!

PG4: - 4:65 [Não! Não é que...assim né...sã..] (5:2101-6:153) (Super)

Codes: [Escala e Verticalização] [Reprovação]

Não! Não é que...assim né...são empresas que criaram pequeninhas com aquela ilusão que tinha...muitos...esse cara lá de Dourados eu conheço desde o início do programa! O cara que queria entrar lá no programa...até veio chorar pra gente lá, que queria financiamento do Banco do Brasil que não tinha capital, não tinha investidor...

PG4: - 4:66 [BioÓleo lá também...é...a BioÓ..] (6:601-6:906) (Super)

Codes: [Reprovação]

BioÓleo lá também...é...a BioÓleo era um filho de um fazendeiro lá...o cara também é da Cooperbio lá...o menino foi lá estudou...não tinha o que fazer, o pai dele deu lá um brinquedinho lá, pra ele montar uma indústria....do tamanho dessa cozinha! Pra fazer óleo lá....cara!!! Mas não dá! Não tem...!

PG4: 4:67 [Sim, e alguém da diretoria...o..] (9:1167-9:1844) (Super)

Codes: [Conflitos]

Sim, e alguém da diretoria... andou me falando essa história de que...aí entrou a nova diretoria...esse pessoal continuou na outra chefia...esse Osvaldo e o...aí o novo chefe exigiu que pra eles continuar nessa questão da importação aí teria que fechar um convênio com essa empresa exportadora né...aí eles ficaram um ano sem importar semente! $O$ ano passado foi plantado muito pouca Canola, em função de que eles não tinham sementes! E a gente achava realmente que eles não estavam conseguindo importar...não! Daí o Fábio me explicou, por que eles não conseguiram importar por que eles não tinham esse convênio com a Embrapa! E aí foi trancado!

PG4:- 4:68 [E aí...era em função dessa bri..] (9:1868-9:1943) (Super) Codes: [Conflitos]

E aí...era em função dessa briga! Por isso que eu estou te falando assim né!

PG4: - 4:69 [Pronto! E tem deficiência na c..] (13:1025-13:1268) (Super)

Codes: [Cooperação]

Pronto! E tem deficiência na colheita mecânica! Foi testado aqui! Principalmente pela Embrapa e outros, e ai junto com a BSBios e a Óleoplan, justamente nessa região norte aqui...conversei com agricultores, até o pai do Semar aqui produziu!

PG 4: 4:70 [as é uma cooperativa modelo em..] (18:242-18:755) (Super) Codes: [Expertise]

...é uma cooperativa modelo em termos de biodiesel, em termos de atendimento, tu conversa com o pessoal assim....os armazéns são organizados! Se tu vai olhar o escritório dele, tu vai ver é dessa tamanhinho assim ô, mas o presidente atende no balcão...atende tudo junto assim! 0 
negócio assim...os caras...aí tu pode falar do programa do biodiesel como um todo! Da

PG5: - 5:3 [Com certeza! E a rotação com a..] (3:853-3:1216) (Super)

Codes: [Benefícios Edáficos]

Com certeza! E a rotação com a cultura da canola, pra rotação de cultura, ela é uma cultura bem interessante pra ter...pra que elimine algumas doenças da...da...do solo, não só as doenças mas também algumas ervas-daninhas que ela ajuda a controlar também!

PG5: - 5:5 [Nós como entidade, sindicato d..] (1:1177-1:1358) (Super)

Codes: [Inovação, cooperação]

Nós como entidade, sindicato dos produtores rurais de Passo Fundo...ehh...pode se dizer que na região aqui foi onde começou o trabalho...começou aqui dentro do sindicato!

PG5:- 5:6 [Foi com o trabalho...ahhh....q..] (1:1380-1:1738) (Super)

Codes: [Pertencimento]

Foi com o trabalho...ahhh....que começou com a Fetag né!

Né ligado ao biodiesel...e aí o pessoal...no começo ali foi meio que até...assimilar a ideia da cultura nova...e a gente representa a agricultura familiar, pequena produção, pequenos

agricultores...existe aquele risco de tu mudar pra uma coisa nova e não...não...se dar bem né.

PG5: - 5:7 [a gente representa a agricultu..] (1:1573-1:1613) (Super)

Codes: [Pertencimento, representatividade ]

a gente representa a agricultura familiar

PG5: - 5:8 [A - Sem dúvida! FT - E aí...co..] (1:1742-2:535) (Super)

Codes: [Cooperação]

E aí...começou...começou...começou...um pouco de pesquisa né através da Fetag né...e aí eles vieram no sindicato pra...buscar produtores e começar o trabalho no campo lá! Fazer algumas áreas de pesquisa!

O MDA teve mas quem iniciou foi a Fetag mesmo! Primeiro a Fetag...daí a federação nossa procurou o sindicato...onde começou....ahhh....o início do trabalho foi com a Fetag! E aí...a gente...veio um convite aí pros produtores né! $\mathrm{E}$ aí teve uma empresa daqui de Passo Fundo...até me fugiu o nome... BSBios! BSBios...ahh, veio conversar conosco e pra arrumar uns produtores...Aconteceu 2003, 2004...

Comment:

Aqui o entrevistado cita a importância do trabalho conjunto entre a Federação, o sindicato, local, os produtores e a indústria de biodiesel!

PG5: - 5:9 [veio um convite aí pros produt..] (1:2271-1:2307) (Super)

Codes: [Proximidade institucional]

veio um convite aí pros produtores né

PG5: - 5:10 [eles vieram no sindicato pra....] (1:1856-1:1903) (Super)

Codes: [Proximidade institucional]

eles vieram no sindicato pra...buscar produtores

PG5:- 5:11 [BSBios...ahh, veio conversar c..] (2:14-2:126) (Super)

Codes: [Proximidade institucional]

BSBios...ahh, veio conversar conosco e pra arrumar uns produtores pra fazer umas 
pequenas áreas de experimento!

PG5:- 5:12 [A gente mesmo encaminhou algun..] (2:798-2:1129) (Super)

Codes: [Credibilidade]

A gente mesmo encaminhou alguns produtores pra fazer experimento, mas não aprovou! Mas aí a canola começou a pegar espaço! Começou...o pessoal começou a acreditar mais! E a BSBios aqui teve um trabalho muito forte nessa questão! Da importância da soja/canola na região! E a questão de assistência técnica...eles davam assistência!

PG5: - 5:13 [.o pessoal começou a acreditar..] (2:933-2:967) (Super)

Codes: [Otimismo]

...o pessoal começou a acreditar mais

PG5:- 5:14 [E a questão de assistência téc..] (2:1070-2:1129) (Super)

Codes: [Cooperação]

E a questão de assistência técnica...eles davam assistência!

PG5: - 5:15 [E o senhor? O senhor já chegou..] (2:1138-2:1558) (Super)

Codes: [Competição de culturas]

No memos

Por que a gente ali...tradicionalmente produz trigo no inverno, então planta trigo...e a canola...Hoje...se for ver ela se equipara ao preço do soja né!...Então hoje ela te deixa uma renda um pouco maior que o trigo!

PG5: - 5:16 [Acha que hoje há uma boa atrat..] (2:1567-2:2053) (Super)

Codes: [Limitações Tecnológicas]

Hoje é! Hoje com certeza é! Devido ao melhoramento que teve nessa questão de variedades e de sementes... É, é, melhorou bastante! Então hoje...aqui na região...tem uma área boa...é não vou te adiantar aí...mas ela triplicou! Do início da implantação até hoje...e tem produtores fieis aí...todo ano planta!

PG5: - 5:17 [Você no seu caso, o que te lev..] (2:2061-3:184) (Super)

Codes: [Clima]

Na experiência que eu fiz, eu fui infeliz ali...por que eu peguei uma geada ali, fora de época! Ehhh....ai não...praticamente eu...

PG5: - 5:18 [Foi no processo de início tamb..] (3:192-3:797) (Super)

Codes: [cooperação]

Foi no processo de início. Então não tinha isso aí na....hoje tem sementes aí que elas resistem mais né! A questão de debulhar...ela é um padrão pra... Era o que eu ia comentar agora! Ela não tinha seguro né! Então quando tu perdia, tu perdia tudo! Hoje tá...ela tem um bom Proagro...que ela tem...

Comment:

Destaca a importância do seguro agrícola Proagro na evolução da cultura da canola!

PG5: - 5:21 [você apostaria novamente em pla..] (4:775-4:1154) (Super)

Codes: [R, V \& I]

você apostaria novamente em plantar a canola? Ou você não arriscaria trocar o certo pelo incerto? Não...não...hoje....ahhh....até esse ano, semana passada é...o pessoal da Óleoplan que tem aqui também, que trabalha com o biodiesel né! A gente é cliente deles lá...e eles foram lá...tão...tão trabalhando forte na canola!...Até tô pensando mesmo fazer um pouco de canola! 
PG5: - 5:22 [- E me diz uma coisa...a gente..] (4:1161-5:45) (Super)

Codes: [Viabilidade da Canola pra biodiesel]

...mais pelo farelo...jeu acredito que tem um mercado né! Hoje o produtor produz pro mercado né! Hoje em relação ao preço do soja tá um bom preço! E o custo né! Então a canola...ela não é...o custo do

hectare da canola ela não é muito diferente do hectare de soja!

PG5: - 5:23 [Não, não...é...o período é dif..] (5:6-5:666) (Super)

Codes: [Competição de culturas]

É! A nossa região aqui, é uma região que o pessoal tem a produção de leite né! Então é muito usado a pastagem, a aveia, o Azevém, e a própria Aveia pra forrageira né! A produção de leite aqui na nossa região ela é forte!

PG5: - 5:24 [- Por que vai ser de muita imp..] (6:773-6:2128) (Super)

Codes: [Cooperação]

Foi! Foi...a BSBios aqui e também a Óleoplan, que são as nossas empresas aqui em Passo Fundo...nós sempre fomos parceiros nessa questão aí...é uma questão de mais um incremento para a propriedade né!

Gerar uma renda pro produtor, a gente é parceiro! Eles que vieram procurar a gente no começo nós aqui!...justamente por isso! Tá mais próximo ahh do produtor né...então... Eles até nas primeiras lavouras que foram feitas ali, eles tinham uma parceria na questão de insumos, assistência...eles colocavam uma parte do insumo também! Mesmo porque a própria entidade (sindicato) ela tem uma credibilidade né! Com o associado, com o agricultor! E se tu vai com o nome dosindicato junto...

PG5:- 5:25 [Ahh, mas com certeza! Com cert..] (6:1904-6:2096) (Super)

Codes: [Credibilidade]

Ahh, mas com certeza! Com certeza! Mesmo por que a própria entidade (sindicato) ela tem uma credibilidade né! Com o associado, com o agricultor! E se tu vai com o nome do sindicato junto...

PG5: - 5:26 [foi uma questão de clima! Uns ..] (6:2305-6:2419) (Super)

Codes: [Clima]

foi uma questão de clima! Uns tiveram problema ali, meio que no começo e aí desacreditaram e não

quiseram mais!

PG5: - 5:27 [Eu não sei se é pela região aq..] (7:2041-7:2163) (Super)

Codes: [Cooperação]

Eu não sei se é pela região aqui! Mas quando o pessoal vai pro debate, debate mesmo! Eles não ficam muito escondidos não!

Comment:

Segundo a visão do entrevistado, ele próprio um agricultor, os produtores da região não costumam a ser intimidar nesse fóruns de discussão

PG5: - 5:28 [Às vezes a...mas existe hoje u..] (7:344-7:479) (Super)

Codes: [Industrialismo]

Às vezes a...mas existe hoje um trabalho da BSBios e da Óleoplan forte pra conseguir Incentivar, fazer o aumento da produção!

PG5: Sindicato Trab Rurais PF Airtom.pdf - 5:29 [E assim, que tem haver com iss..] 
(7:488-7:957) (Super)

Codes: [participação]

Eu participei de um...de um eu participei! Aí o pessoal trazia as experiências de cada localidade né! De cada região!

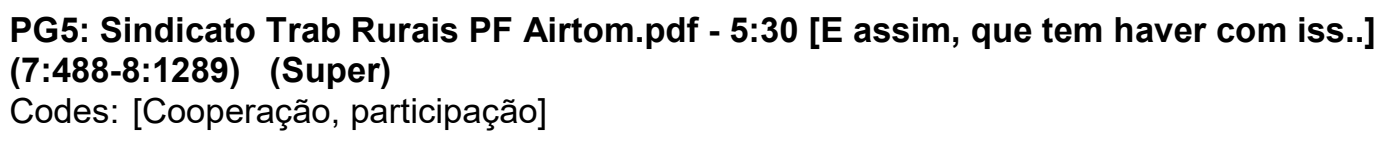

Eu participei de um...de um eu participei! Aí o pessoal trazia as experiências de cada localidade né! De cada região! As empresas, os produtores né, no caso, o MDA... É...éhh...eles que organizam, que puxavam né!

Olha! Nesse que eu participei acho que não tinha! Ele foi mais especifico pras empresas, pros produtores e aí...tinha as entidades, me lembro que a Fetag tava também, tinha representantes do sindicatos, eu não me lembro se...não eu acredito que não estava...essa que eu participei não! Mas aqui no interior teve um encontro que a Embrapa fez parte! Esperando, ouvindo coisa...ehh.. É, é...acho que é isso! Não importa se teja lá o Terra fazendo o debate ali...o produtor vai lá e troca ideia tranquilo! Normalmente! Pessoal das cooperativas e um pessoal bem acessível de conversar! Pelo que eu pude presenciar naquele dia no sindicato foi assim o...uma

troca de experiências de uma região pra outra né!

Comment:

Enfatizou o papel do sindicato rural de Passo Fundo como instituição chave no processo de participação dos atores sociais no Polos de Produção de biodiesel do MDA

\section{PG5: - 5:31 [Eles traziam lá...ô lá na minh..] (8:841-8:1125) (Super) Codes: [Expertise]}

Eles traziam lá...ô lá na minha região lá produziu tanto lá ahhh...o clima é diferente, mudou um pouco a época de plantio...Lá fizeram experiência que não deu certo! Lá numa outra já deu certo! Trazia assim experiências de uma região pra outra e assim se trocavam ideias!

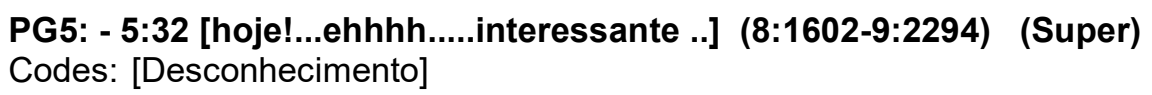

Não, não...não!

Não! Não! Cara....posso te assegurar, nós como entidade estamos envolvidos em vários segmentos aí fora...

Comment:

Nunca ouviu falar das políticas de desenvolvimento territoriais do MDA

PG5: - 5:33 [hh, mas com certeza! Pelo que ..] (10:1723-11:706) (Super)

Codes: [Bioenergia, participação]

Pelo que eu participei de uma encontro e depois comentando com o Presidente! E vendo os outros comentários dos outros encontros que aconteciam aqui! A gente via que se avançava...mudava a maneira de um enxergar a forma da produção! Ou a forma de como se trabalhar lá na empresa! Questão da assistência técnica, se discutia muito! Vendo assim a área rural né, foi um passo muito importante pro desenvolvimento da...da...área rural, dentro da pequena propriedade, da agricultura familiar, da área né...da categoria nossa...muito positivo o resultado!

\section{PG6: 6:1 [É! Eu diria que tem os pontos ..] (12:1461-12:1729) (Super) Codes: [Limitações Tecnológicas]}

É! Eu diria que tem os pontos críticos da própria cultura, são questões de produção, que é a questão da própria semeadura, uniformidade, né...a própria questão de colheita. Existe alguns problemas que questão do transcorrer desses três anos vem melhorando bastante! 
PG6: - 6:2 [Exatamente! Então, tem muitos ..] (7:179-7:811) (Super)

Codes: [Canola]

Exatamente! Então, tem muitos produtores que já entraram nisso! Outro detalhe em relação à expansão da cultura é que no início se quis trabalhar muito o pequeno produtor com a Canola... - Até pra difundir mais...pra trabalhar essa questão da agricultura familiar! Por que isso? Por que o pequeno produtor tem que ficar muitas vezes dependente de colheita de terceiros...muitas vezes até de plantadeira de terceiros...

PG6: Assoc Bras Prod de Canola_Gustavo Floss.pdf - 6:3 [Eu diria...ahhh...que sim, por..] (8:1800-8:2036) (Super)

Codes: [Logística]

Eu diria...ahhh...que sim, por que no ano passado nos tivemos um grande problema por causa disso! Nossa dependência da produção! Primeiro por que até no ano passado a gente tava dependendo de uma única empresa fornecedora de sementes

PG6: - 6:4 [Uma recuperação do ano passado..] (9:477-9:727) (Super)

Codes: [Otimismo]

Uma recuperação do ano passado, dessa demanda reprimida, e já o aumento consequente do cultivo! Eu vou te dizer uma coisa Arnoldo! Eu tenho na minha cabeça a algum tempo! Pra mim está muito claro! A Canola deve crescer em torno de 20 a $25 \%$ ao ano!

\section{PG6: - 6:5 [Na hora de colher! E tem um fa..] (13:678-13:1477) (Super) \\ Codes: [Logística]}

$\mathrm{Na}$ hora de colher! E tem um fator também que é bom você conhecer que é o seguinte, com essa ânsia de aumentar a área com essas empresas que fomentam chega um ano que eles tem que fazer uma importação muito prévia! Da semente! Então lá em Dezembro, pra início de Janeiro, no máximo tu já tem que estar definindo a quantidade que tu vai estar importando! Então vem uma quantidade $\mathrm{X}$, se o produtor não quiser plantar, vai sobrar! O que que muitas empresas fomentaram, mesmo no final de Maio,

inicio de Junho, eles fomentaram ainda essa cultura. E hoje Junho é um aumento ainda muito delicado!

PG6: - 6:6 [Então com a planta muito, muit..] (13:1588-13:2224) (Super)

Codes: [Clima]

Então com a planta muito, muito nova, é o maior potencial de estragar! Então as próprias fomentadoras tiveram um problema muito grande no passado no sentido de...da ânsia de aumentar a área! Avançaram no período de semeadura... Exatamente! Se nós pegarmos das Missões pra cá...vai ser mês de Abril até aproximadamente 15 de Maio! Aqui em Passo Fundo é o momento ideal! Daqui de Passo Fundo até a direção de Lagoa Vermelha, Vacaria, até o final de Maio tranquilo! Agora, iniciou Junho...já existe um potencial muito grande de geada..

\section{PG6:- 6:7 [xatamente! Então tem dois proc..] (17:1330-17:1686) (Super)}

Codes: [Bioenergia]

Exatamente! Então tem dois processos que aconteceram juntos! Se pegar a região de Passo Fundo que tá...talvez a região de Passo Fundo é a que tá melhor...tendo a melhor resposta pra isso tá... Por que além da questão de biodiesel, da formação de emprego, de novos...novas rendas! Hoje a BSBios é a número 1 em termos de geração de ICMS pro município!

PG6:- 6:8 [Eu te disse da escala, inclusi..] (7:929-7:1047) (Super)

Codes: [Escala e Verticalização]

Eu te disse da escala, inclusive a escala que é interessante pra Canola pra valer à pena fica em torno de 50 hectares 
PG6: - 6:9 [Pra nós aqui, nós temos um fat..] (8:222-8:559) (Super)

Codes: [Soja]

Pra nós aqui, nós temos um fator que quanto mais tarde for plantada a Soja, maior o problema de doenças, de pragas! Então essa antecipação pra primeira época de semeadura é interessante! Então hoje, o principal definidor da semeadura da Canola é a própria Canola, mas a semeadura da Soja...que é a principal cultura que nós temos...

\section{PG6: - 6:10 [Sem dúvida! Sem dúvida! Pelos ..] (8:1196-8:1401) (Super)} Codes: [Clima]

Sem dúvida! Sem dúvida! Pelos gargalos que se tem em termos de semeadura, né...pra ter uma uniformidade mais adequada...própria adubação adequada pra atividade, controle das daninhas, controle de pragas

PG6: - 6:11 [Advanta! Advanta! E a grande p..] (9:24-9:280) (Super) Codes: [Logística]

Advanta! Advanta! E a grande produção de sementes pra abastecer o Brasil estava na Argentina! Aqui tinha problema de produção, faltou semente pra nós! E houve uma redução da área...vamos dizer assim houve uma redução na...na....a demanda ficou reprimida!

PG6: - 6:12 [E justamente pensando no biodi..] (11:253-11:367) (Super)

Codes: [Óleos Nobres]

E justamente pensando no biodiesel! Só que como hoje o mercado da Canola não é o biodiesel, é o consumo humano...

PG 6:- 6:13 [então não tem uma penetração t..] (11:391-11:842) (Super)

Codes: [Inovação]

então não tem uma penetração tão forte! Mas ele já tá com um material que é Canola, esse ano ele deve fazer uns 2 mil hectares lá, pelo que ele tá falando! Ele tem compra garantida, acho que a Celena acertou com ele! De comprar...eh...então é uma forma de fomentar aquela região ali também né! E o Gilberto é um grande conhecedor dessas culturas de alto óleo aí, especialmente, o Girassol...então ele tem um grande conhecimento nessa área!

PG 6: - 6:14 [Acima de 120/ 130 mil hectares..] (11:1654-11:2526) (Super) Codes: [Viabilidade da Canola pra biodiesel]

Acima de 120/ 130 mil hectares nós teríamos que buscar novos mercados! E mais mercados seriam a: exportação, mas aí teria que ter uma logística pra isso também! Ou, o ponto mais fácil de acontecer é justamente ir pra produção de biodiesel! Então se nós pensarmos nos quatro, para os próximos cinco anos, a nossa estimativa é que possamos ter essa adequação! O que eu fiquei sabendo da própria BSBios é que tá faltando muito pouco pra eles conseguirem isso também! Pra ter essa condição de esmagamento e colocar ela no mercado! E tendo aumento das áreas, vai ter aumento da oferta no mercado! Tendo aumento na oferta, a indústria vai ter que possivelmente diminuir esse valor! O valor que é pago! Hoje, por exemplo, se tá num valor próximo da Soja, a tendência da Canola paga ao produtor é ter uma diminuição próxima talvez a $10 \%$ do preço que é hoje...

PG 6: pdf - 6:15 [Então eu acredito que nesse pe..] (12:150-12:431) (Super) Codes: [Otimismo]

Então eu acredito que nesse período aí de quatro, cinco anos, nós vamos ter que ter um fato novo! Nós vamos ter que ter um novo modelo de escoamento dessa produção, que não seja somente o consumo humano, e aí esse consumo humano, o preço tende a baixar! Tende a baixar também! 
PG 6: - 6:16 [Oferta e procura! E talvez sej..] (12:478-12:625) (Super)

Codes: [Logística]

Oferta e procura! E talvez seja esse o balizador! Hoje o que nós estamos pensando que o balizador seja em torno de 120, 130 mil hectares pra isso!

PG 6: - 6:17 [Acaba com tudo! Aí tu pode pla..] (12:2121-13:152) (Super)

Codes: [Clima]

Acaba com tudo! Aí tu pode plantar outra coisa. Né...então é o estágio mais delicado de todos! Depois tem estágios complicados principalmente no florescimento! Então se vier uma geada no florescimento, aquela camada de flor se perde! Ela é de ciclo indeterminado, então ela vai colocando flor e vai formando as síliquas durante quase trinta dias! Vinte e poucos dias! Então se vier uma geada, vai pegar essa camada aí...

PG 6: - 6:18 [Agora, por isso que veio a imp..] (14:129-14:238) (Super)

Codes: [políticas]

Agora, por isso que veio a importância de ter um Proagro! De ter um seguro pra minimizar esse tipo de risco!

PG 6: - 6:19 [Sim, sim, sim, sem dúvida! Peg..] (14:1384-14:1825) (Super) Codes: [LUC]

Sim, sim, sim, sem dúvida! Pega a própria região de Lagoa Vermelha, Vacaria, houve um incremento de área aí ao redor de 50 mil hectares! Esse período do final da década de 1990 até os últimos quinze anos...

Tranquilamente, entrou mais dentro do sistema uns 50 mil hectares! Então 50 mil hectares não é fazendo só Soja, e fazendo Soja e inverno (cultura de inverno)! É a principal região produtora de Trigo! E Milho!

PG 6: - 6:20 [Quando eu conheci minha esposa..] (15:1186-15:1390) (Super)

Codes: [LUC]

Quando eu conheci minha esposa em 1997, tinha muita área ali pra 'abrir', nesse período todo aí se abriu tudo, hoje tem pouca áreas de campo, muito poucas áreas! Então houve um crescimento muito forte!

PG 6:- 6:21 [Sem dúvida! Eu teria que busca..] (16:961-16:1293) (Super)

Codes: [Bioenergia] [Industrialismo]

Sem dúvida! Eu teria que buscar meus cadernos ali pra buscar uns números pra te dar, mas assim ô, hoje o Rio Grande do Sul tem uma capacidade instalada de esmagamento de soja praticamente...tá superior já à produção de Soja! Hoje o RS não é mais um produtor, ele é um importador de Soja pra poder sustentar essa indústria toda!

PG 6: - 6:22 [Agregar valor! E nesse caso, c..] (17:5-17:552) (Super)

Codes: [Bioenergia]

Agregar valor! E nesse caso, com o biodiesel está sendo agregado esse valor pra gerar isso...ehh...e pra onde está indo esse óleo? Existe um consumo local ehh...em termo de RS tem uma exportação desse óleo! Então se a gente analisar, antes do biodiesel e pra hoje o biodiesel, e nós formos ver o preço Chicago!

Quando a gente traz (o preço) de Chicago pra nós da Soja...quando a gente fazia isso lá atrás em comparação a hoje, nós estamos falando que o preço da Soja local é em termos de 1,50; 2,00 dólares a mais do que era no passado

PG 6: - 6:23 [Exato! Então 300 milhões de dó..] (18:542-18:961) (Super)

Codes: [Fisiocratismo]

Exato! Então 300 milhões de dólares numa economia aí...é um incremento muito grande! 300 
milhões de dólares pra gente comparar...vamos dizer que o Trigo hoje...o Trigo forneça 1 milhão de hectares...1 milhão de hectares...vezes, vamos botar uma média de 45 sacos! São 45 milhões de sacos vezes $30,32 .$. nós estamos falando que...2.3...éeéeéé'...nós estamos falando de 400 milhões de dólares o Trigo! Na economia.

PG 6: - 6:24 [Vamos dizer o seguinte, na cab..] (18:1256-18:1444) (Super) Codes: [Competição de culturas]

Vamos dizer o seguinte, na cabeça do produtor que pensa economicamente só! Existe uma concorrência! Mas se nós analisarmos do ponto de vista agronômico, elas são culturas complementares

PG 6: - 6:25 [Existe uma interrupção desse c..] (18:1628-18:1912) (Super) Codes: [Benefícios Edáficos]

Existe uma interrupção desse ciclo! Hoje nós temos um grande problema em termos de Trigo sobre Trigo! Problemas principalmente de manchas foliares! Então se nós colocarmos Trigo sobre Trigo aí nós temos uma perda, e tem trabalhos demonstrando, de vinte por cento na produtividade

PG 6:- 6:26 [hhh...concorrência com a Canol..] (19:482-19:762) (Super)

Codes: [Competição de culturas]

hhh...concorrência com a Canola não! Mas ela é concorrência do Trigo! Por que ela é a mesma época da semeadura, tem os mesmos tipos de doença, de pragas, e plantas daninhas...em termos de manejo! Então se a gente botar um ano Trigo e outro ano Cevada, não existe uma rotação!

PG 6: - 6:27 [Então você vai me perguntar o ..] (21:745-21:1724) (Super)

Codes: [Segurança Alimentar]

Então você vai me perguntar o seguinte, qual é a base da concorrência pra isso. Se o biodiesel, a base é a Soja! E a Soja está aumentando a produção no Brasil, se nós tirarmos biodiesel, a tendência da Soja é baixar! Qual que é o reflexo na cesta básica do óleo de Soja? Muito baixo! Esse, essa é a influência que vai existir no custo do alimento! É muito baixo! Não se faz biodiesel de Alface, de Milho, não tem....não tá entrando...de toda a cesta base (básica) nós não temos o uso em função disso! Então assim pra mim isso é uma verdadeira falta de conhecimento... Se nós realizarmos em relação aos americanos aí muda um pouquinho, e beneficia nós! Que aconteceu com os Estados Unidos? Os EUA são o maior produtor de Milho, o álcool pro biodiesel vem a partir do Milho, o álcool é a partir do Milho, diferente do nosso que é a partir da cana, que é muito mais energético...energeticamente muito mais.

PG 6: - 6:28 [..Só que, o percentual de álco..] (21:1955-21:2313) (Super) Codes: [Segurança Alimentar]

..Só que, o percentual de álcool é baixo! E a partir da produção de álcool sobra uma grande quantidade que não é um farelo! Eles tem um outro nome para aquela massa toda! Essa massa vai justamente pra criação de gado! Pros confinamentos americanos! Então existe uma produção de alimentos, de carne, muito grande! Mesmo a partir dessa produção de álcool!

PG 6: - 6:29 [Totalmente né! Vamos pegar um ..] (22:1635-22:2521) (Super)

Codes: [Fisiocratismo] [LUC] [Segurança Alimentar]

Totalmente né! Vamos pegar um outro...por que se fala nisso! Pelo aumento das áreas de cana que aconteceu no Cerrado! Né! Se nós analisarmos isso...é...se não tivesse havido o aumento das áreas no Cerrado, nós poderíamos ter até essa informação...ehh..ok! Por que teve aumento do preço de Milho e de Soja, área de Soja e Milho não tinha aumentado...nessas condições...só que aumentou as duas coisas! Aumentou a área de cana, mas muito maior foi o aumento das áreas de Soja e de Milho! Então ai nós não podemos estar dizendo que está 
havendo uma concorrência desleal! Por que existe o aumento de todos!

É diferente dos EUA onde se tu plantar uma cultura, outra vai diminuir! O Brasil está aumentando a área! Dessas culturas, então, pode chegar num ponto daqui há 20,30 anos de não ter mais área pra se abrir! Assim pode se estar pensando em alguma coisa diferente...

PG 6: pdf - 6:30 [O Brasil pode chegar...hoje o ..] (23:151-23:936) (Super)

Codes: [LUC]

Hoje a maioria, a maior parte de área de abertura é sobre área de pastagens! Pastagens degradadas!

Que já houve alteração da área! Vamos pegar o exemplo de MT. Mato Grosso já ultrapassou hoje os 25 milhões de hectares de pastagens! Em torno de 7,5; 8 de Soja! Tem 25 milhões de pastagem! Estimasse que desses 25 milhões, 18 milhões são de pastagem degradada! Então tem condições da Soja, só no MT, ocupa daqui há pouco mais 5 milhões de hectares de pastagens degradadas que não vai estar abrindo Cerrado novo!

PG 6: - 6:31 [Rio Grande do Sul! Ahh o RS nã..] (23:1519-23:2075) (Super) Codes: [LUC]

Rio Grande do Sul! Ahh o RS não tem mais área pra abrir! Hoje tem estimativa de abertura da metade sul (do estado) abrindo mais 2 milhões de hectares! Não vai ocupar área de arroz! Vai ocupar áreas de pastagens de gado! Ahh... vai diminuir o gado no RS!? O gado no RS já diminuiu! Nós tivemos problemas de seca aqui! E como o produtor é muito tradicional de gado, ele não tava conseguindo se manter! Não tava conseguindo se manter com a venda do terneiro! Começou a vender matrizes no passado

PG 6: - 6:32 [Sem dúvida! E aí tem a importâ..] (24:1099-24:1698) (Super) Codes: [Limitações Tecnológicas]

Sem dúvida! E aí tem a importância de trabalhar o custo energético dessas situações! Eu fiz uma análise energética! O meu mestrado eu trabalhei com sistemas de produção, aí na parte de produção agronômica, a gente também calculou a parte energética...então...eu estudei um pouquinho isso aí... É! Eu estudei um pouquinho isso aí, mas não com essa profundidade que tu tá tendo, em cima da cadeia, mas foi em cima do sistema produtivo! Mas eu acho que isso é fundamental pra poder ver a capacidade de produção de energia dentro de uma mesma área né!

PG 6: - 6:33 [Eu acredito que sim! Pras noss..] (25:408-25:571) (Super)

Codes: [Soja]

Eu acredito que sim! Pras nossas condições aqui, eu acredito muito forte nisso! Muito forte pra ser não uma adversária, mas um complementador de inverno...ehhh...

PG 6: Assoc Bras Prod de Canola_Gustavo Floss.pdf - 6:34 [Olha, um produtor que vale a p..] (26:1058-26:1140) (Super)

Codes: [Expertise]

Olha, um produtor que vale a pena conversar já que tu está em Lagoa é o Raul Basso

PG 6:- 6:35 [Que já houve alteração da área..] (23:519-23:936) (Super)

Codes: [LUC]

Que já houve alteração da área! Vamos pegar o exemplo de MT. Mato Grosso já ultrapassou hoje os 25 milhões de hectares de pastagens! Em torno de 7,5; 8 de Soja! Tem 25 milhões de pastage! Estimasse que desses 25 milhões, 18 milhões são de pastagem degradada! Então tem condições da Soja, só no MT, ocupa daqui há pouco mais 5 milhões de hectares de pastagens degradadas que não vai estar abrindo Cerrado novo!

PG 6: - 6:36 [Então, essa metade sul aí, a t..] (24:540-24:850) (Super)

Codes: [LUC] 
Então, essa metade sul aí, a tendência é ter esse incremento da área de Soja nessas áreas de pastagens degradadas, onde o gado já saiu, ou ele vai ter uma profissionalização! Ao invés de trabalhar a área toda com pasto, diminui a área, concentra, lota melhor essa área, e o resto fica disponível pra Soja!

PG 6: - 6:37 [Então, essa metade sul aí, a t..] (24:540-24:973) (Super)

Codes: [Soja]

No memos

Então, essa metade sul aí, a tendência é ter esse incremento da área de Soja nessas áreas de pastagens degradadas, onde o gado já saiu, ou ele vai ter uma profissionalização! Ao invés de trabalhar a área toda com pasto, diminui a área, concentra, lota melhor essa área, e o resto fica disponível pra Soja! Então nós temos aumento de disponibilidade pra Soja, pro Milho, especialmente pro CentroOeste, pra questão de safrinha!

\section{PG 7:- 7:2 [Então a Cooperativa a Colheita..] (3:995-3:1329) (Super)}

Codes: [Cooperação]

Então a Cooperativa a Colheita é uma cooperativa aqui de São José do Ouro, da qual eu sou sócio também né! Então a Colheita explora meu Silo em regime de arrendamento né! E eu entrego todo o meu produto aqui! Né!...Então é dessa forma que funciona, mas a propriedade, o plantio, a entrega do produto é tudo por minha conta né!...

\section{PG 7: pdf - 7:3 [Soja, Milho, Trigo e Canola! O..] (3:1886-4:463) (Super)}

Codes: [Soja]

Consigo, consigo pelo seguinte, por que na verdade é assim ô, o Soja é uma cultura de verão! Tu planta ele lá em Outubro, Novembro! O Milho também é uma cultura de verão. Tu planta ele em Setembro, Outubro...daí para pra plantar o Soja, planta Novembro Soja, depois volta plantar Milho ou Feijão, tanto faz né! Aí no inverno, geralmente tu começa a plantar Canola no mês de Abril

\section{PG 7: - 7:4 [Eu mudei bastante! Depois que ..] (8:131-8:263) (Super)}

Codes: [Inovação]

Eu mudei bastante! Depois que o pai...tipo assim faz uns quinze anos que o pai...ahh...passou o controle da propriedade pra mim né!

PG 7:- 7:6 [Tudo! Até por que se você para..] (9:749-9:1043) (Super)

Codes: [Inovação]

Tudo! Até por que se você para pra pensar daqui um ano não existir mais nem bloco de produtor (tipo de documento manuscrito) vai só existir Nota Eletrônica! Se tu é um produtor rural tu vai te quer ir nem que seja numa Lan-House lá e emitir uma Nota Eletrônica pra tu poder guiar o produto

\section{PG 7: - 7:7 [isso Passo Fundo pra Carazinho!..] (10:12-10:322) (Super) \\ Codes: [Inovação]}

Isso Passo Fundo pra Carazinho! Então essa empresa aqui, a Agrícola Ferrari através do Gilberto e do Vinicius, os dois sócios dela né! Eles como são amigos nossos, parceiros nossos, eles indicaram pra nós! Oh tem uma cultura alternativa aí, a Canola! Vocês querem começar a plantar? Bah! Queremos! Então tá

\section{PG 7:- 7:8 [Tá! Então, aí que a Celena ent..] (10:463-10:883) (Super) Codes: [Cooperação]}

Tá! Então, aí que a Celena entrou na jogada! Então a Celena vem aqui te visita, e te diz o seguinte: Leandro! Quantos hectares de Canola tu quer plantar esse ano? Ai tu diz. Ahh Wantuir, esse ano eu quero plantar 200 hectares de Canola! Tá bom! Qual é os materiais que 
tu tem? Ah eu tenho da Hyola lá...Hyola 61 (sementes), Hyola 433, Hyola 411, Hyola 76...Tá bom! Então...da LHT que mais do lado da Argentina lá.

PG 7:- 7:9 [lsso aí! Porque eu te falei da..] (11:1318-11:1417) (Super)

Codes: [Concorrência]

Isso aí! Porque eu te falei da BSBios? Por que a Celena compra Canola, mas a BSBios também compra!

PG 7:- 7:10 [É! É! Agora Canola é...BSBios ..] (12:692-12:867) (Super)

Codes: [Industrialismo]

É! É! Agora Canola é...BSBios eu já vendi Soja! Vendi Canola! A BSBios é uma empresa grande no mercado né! Ela tá comprando muitas unidades perto aqui né...tu pode ver que...

PG 7: - 7:11 [Cara, eu acho que a Canola val..] (15:1059-15:1187) (Super)

Codes: [Viabilidade da Canola pra biodiesel]

Cara, eu acho que a Canola vale à pena! Acho que vale! Que ela vai subir, acho que ela vai lá pra cima (centro do país) também!

PG 7:- 7:12 [O problema da Canola no meu po..] (15:1189-15:1264) (Super)

Codes: [Clima]

O problema da Canola no meu ponto de vista é a sensibilidade dela a geada!

PG 7: - 7:13 [Posso, eu posso te passar por ..] (19:612-19:829) (Super)

Codes: [Tecnocentrismo]

Posso, eu posso te passar por email! Mas eu vou te passar como regra geral! Porque o que acontece, como eu trabalho com agricultura de precisão, tem áreas que eu coloco uma coisa, tem áreas que eu coloco outra né!

PG 7:- 7:14 [O cara perdeu 1 tonelada e mei..] (24:1593-24:1650) (Super)

Codes: [Logística]

O cara perdeu 1 tonelada e meia de Canola daqui até Giruá!

PG 7: - 7:15 [- Mas a Canola como rotação de..] (25:271-25:562) (Super)

Codes: [Benefícios Edáficos]

Mas a Canola como rotação de cultura como sistema produtivo ela é muito boa! Por que geralmente o pessoal que planta inverno, planta gramínea! O Trigo é gramínea, a Aveia é gramínea, o Milho é gramínea, a Cevada é gramínea, o Azevém é gramínea né! E a Canola não

é gramínea! Entendeu!

PG 7: - 7:16 [Vem patinando! Mas tu sabe por..] (25:916-25:1122) (Super)

Codes: [Canola]

Vem patinando! Mas tu sabe por que ela tá patinando? Por três motivos! Básicos! Primeiro, ela é uma cultura que não é pra muitos e pra poucos! É para produtores técnicos que podem acompanhar a lavoura...

PG 7:- 7:17 [É...é...mas tu vê né Arnoldo, ..] (26:11-26:225) (Super)

Codes: [Soja]

É...é...mas tu vê né Arnoldo, que o preço da Canola baseado no preço da Soja é bom né! Pensa comigo, por que é que ela se torna atrativa? Lucrativa? Em função de que quando tu colhe Canola é entressafra de Soja!

PG 7: Agricultor Empresarial Leandro Loticci.pdf - 7:18 [É! No RS ela compete bastante 
..] (27:11-27:256) (Super)

Codes: [Competição de culturas]

É! No RS ela compete bastante com o Trigo né! O Trigo rouba muito a área dela né! Mas ela tá entrando justamente por ela não ser uma gramínea né! Então eu faço como te falei! Eu faço uma parte da minha área de Canola né, e outra parte Trigo!

PG 7:- 7:19 [É bom! É bom! É muito bom! E n..] (27:337-27:393) (Super) Codes: [Otimismo]

É bom! É bom! É muito bom! E no ano que eu faço Canola...

PG 7:- 7:20 [A Canola não! Se a Celena não ..] (27:813-27:977) (Super) Codes: [Concorrência]

A Canola não! Se a Celena não em comprar eu vendo pra BSBios! Se a BSBios não me comprar eu vendo pra Giovelli! Se a Giovelli não me comprar eu vendo pra Óleoplan!

PG 7: - 7:21 [Eu acho que sim, eu acho que s..] (29:607-29:806) (Super)

Codes: [Clima]

Eu acho que sim, eu acho que sim...o que falta pra melhorar um pouco mais, falta nós termos mais variedades adaptadas ao frio né! Esse problema da geada, que eu te falei, é um problema crônico né!

PG 7: - 7:22 [Estou sem semente! Essa varied..] (30:585-30:661) (Super)

Codes: [Logística]

Estou sem semente! Essa variedade que é resistente ao Pivot não chegou ainda!

PG 8: - 8:1 [Agrega valor! Desenvolveu...tu..] (9:412-9:475) (Super)

Codes: [Bioenergia]

Agrega valor! Desenvolveu...tu vê a nossa região aqui cresceu né

PG 8: - 8:2 [É por que estou com o pessoal ..] (1:306-1:422) (Super)

Codes: [Desapontamento]

É por que estou com o pessoal da extração num treinamento, né...o biodiesel nesse bimestre a gente não vendeu nada!

PG 8: - 8:3 [Sim, sim...temos Selo Social!] (1:546-1:574) (Super)

Codes: [Certificações]

Sim, sim...temos Selo Social!

PG 8: Indústria de biodiesel Bocchi Agrobios.pdf - 8:5 [Principalmente na pequena agri..] (2:493-2:547) (Super)

Codes: [Bioenergia]

Principalmente na pequena agricultura, criando fomento!

PG 8: Indústria de biodiesel Bocchi Agrobios.pdf - 8:6 [Um pouco depois da autorização..] (2:1679-2:1979) (Super)

Codes: [Certificações]

Um pouco depois da autorização da ANP né...por que tem a liberação, todos os procedimentos, a parte documental, parte de leis e coisa e tudo... a ANP veio fiscalizou, liberou e a gente reivindicou pra ter o Selo Combustível Social! Por que precisa superar todas as etapas pra ter tudo liberado...

PG 8: - 8:7 [Bem, essa parte de fomentação ..] (2:2154-2:2299) (Super)

Codes: [Bioenergia] 
Bem, essa parte de fomentação eu não saberia de cabeça! Só sei que é mais de duzentas e poucas famílias beneficiadas!

PG 8: - 8:8 [Sim. A extração do óleo de soj..] (3:68-3:219) (Super)

Codes: [Soja]

Sim. A extração do óleo de soja. No nosso caso é óleo de soja. Trabalhamos só com grão de soja, faz a extração e...vende o farelo normal no mercado...

PG 8: - 8:9 [Não, por que na parte de extra..] (3:543-3:640) (Super)

Codes: [Limitações Tecnológicas]

No memos

Não, por que na parte de extração tem que trocar alguns equipamentos, ajustes dos equipamento...

PG 8: - 8:10 [É o mesmo porte que o nosso, s..] (4:265-4:378) (Super)

Codes: [Parcerias]

É o mesmo porte que o nosso, só que a gente tem esse trabalho...com oleaginosas e sebo...então a gente troca né!

PG 8: Indústria de biodiesel Bocchi Agrobios.pdf - 8:11 [É só politicamente, acho! Por ..] (7:828-7:1137) (Super)

Codes: [Ideologia]

É só politicamente, acho! Por que tá deixando de desenvolver a agricultura familiar né....pessoal diminui a produção automaticamente não precisa correr atrás de fomentação pra ter o Selo Combustível Social pra ganhar um preço melhor né! Acabou o PIS e Confins né, o pessoal teve que correr atrás disso né!

PG 8: - 8:12 [Tanto é que fechou várias indú..] (7:1561-7:2282) (Super)

Codes: [Logística]

Algumas unidades estão fechando, outras estão com a capacidade ociosa muito grande né, tá sobrando óleo no mercado, as extrações de óleo também...tão fechando né...só aqui no Sul fechou duas, três unidades! A gente tá trabalhando com o mínimo de pessoal possível...pra tentar não parar

né! Tá todo mundo em treinamento né! Só pra você ter uma ideia, tô aproveitando e fazendo treinamento!

PG 8: - 8:13 [É uma desculpa...não...por que..] (8:547-8:685) (Super)

Codes: [Desapontamento]

É uma desculpa...não...por que você tá pagando o diesel lá fora mais caro pra trazer cá né! Do que estar comprando aqui, não tem sentido!

PG 8: - 8:14 [Com certeza! Todas as regiões...] (8:1256-9:376) (Super)

Codes: [Bioenergia]

Com certeza! Todas as regiões. Eu trabalhei não só aqui...eu trabalhei no Mato Grosso, eu vim do Mato Grosso.. Eu ajudei a montar a Feagril em Lucas do Rio Verde. Indústria de biodiesel também!

Principalmente Mato Grosso! Mato Grosso...quando eu cheguei lá praticamente em 2006, tava vendo os...as reportagens, que a gente começa a se inteirar nessa parte, Mato Grosso mandava soja pros portos $70 \%$ ! Ficava $20,30 \%$ de soja dentro de próprio estado, agora

2011 que eu estive lá praticamente 50\%, metade está sendo feita a extração dentro do próprio estado né! 
PG 8:- 8:15 [Mas em baixa escala, né] (9:1339-9:1361) (Super)

Codes: [Escala e Verticalização]

Mas em baixa escala, né

PG 8: - 8:16 [Lá no MT sim! Aqui no Sul não ..] (10:687-10:786) (Super)

Codes: [Certificações]

No memos

Lá no MT ...! Aqui no Sul não por que o pessoal é o pessoal mais perto nosso aqui é eu acho!

PG 8: - 8:17 [O Roberto Terra? GR - Isso. A ..] (10:794-10:970) (Super)

Codes: [Proximidade institucional]

Conheço, conheço da inauguração da unidade!

Ele esteve aqui né! Foi em 2011

PG 8: - 8:18 [e for pesquisar pra dar produt..] (11:1203-11:1546) (Super)

Codes: [Limitações Tecnológicas]

...pessoal não tá plantando muito por que não dá produtividade, apesar que ela deixa nitrogênio....deixa todas coisas pra próxima lavoura... É! Então ela precisa de ter mais um pouquinho de produtividade por hectare pra...um rendimento melhor pro pessoal que planta né!

PG 8: - 8:19 [Com isso tendo o grão...automa..] (11:1592-11:1818) (Super)

Codes: [Logística]

É...não tem como investir num equipamento se você não tem o grão né!

PG 9: - 9:1 [Eu assim né...eu mesmo que faç..] (11:541-11:665) (Super)

Codes: [Participação]

Eu assim né...eu mesmo que faço direto na firma...mas eu financio no banco pra fazer o Proagro né! Se dar algum problema...

PG 9:- 9:2 [isso! Por isso que eu limito a ..] (2:591-2:708) (Super)

Codes: [Diversificação produtiva]

Isso! Por isso que eu limito a quantidade por ano né! Se eu plantar trinta hectares, já limita pra fazer a rotação né

PG 9: Agricultor Familiar Edevaldo Lago.pdf - 9:3 [Faz mais, faz mais...de seis p..] (2:8352:877) (Super)

Codes: [Expertise]

Faz mais, faz mais...de seis pra sete anos!

PG 9: - 9:4 [Primeiro né...daí no outro ano..] (2:1230-2:1585) (Super)

Codes: [Inovação]

Primeiro né...daí no outro ano já veio a BSBios...ainda não tinham entrado em Passo

Fundo, eles tavam começando ainda...Daí precisava arrumar produtor pra começar plantar e ver como funcionava o negócio...e daí dali em diante nós começamos a plantar pra eles...daí eles já se instalaram em Passo Fundo e continuamos plantando...sempre com eles ali...

PG 9: - 9:5 [E o risco que tu tem também né..] (3:174-3:366) (Super)

Codes: [Clima]

E o risco que tu tem também né! Por ser uma cultura de inverno! Se ela pegar uma 
geada...ela pode prejudicar, se pegar uma tormenta de pedra ali quando tiver seca...ou muito vento também...

PG 9: - 9:6 [É, É...eu pego...até nos prime..] (3:513-3:859) (Super)

Codes: [Limitações Tecnológicas]

É, É...eu pego...até nos primeiros anos a gente enleirava, mas aí dava muito serviço...tinha que enleirar e daí...dava muito correria né! Daí a gente começou a passar o Finale! Que é...ele termina a planta né! No caso não é igual ao secante né! O secante ele mata...o Finale não! O Finale se tive o grão, meio grão, ele termina de fazer né!

PG 9: - 9:7 [Tenho até um vizinho né! De ve..] (3:2063-3:2173) (Super)

Codes: [Cooperação]

Tenho até um vizinho né! De vez em quando eu troco serviço com ele né! Quando ele pode ajudar...ele ajuda né!

PG 9: - 9:8 [Depois daquelas que iam nos tr..] (4:725-4:1068) (Super)

Codes: [Inovação]

Depois daquelas que iam nos tratores, veio uma pras colheitadeiras! $\mathrm{E}$ até dava certo na Massey (Ferguson) a colheitadeira que eu tinha! E quase ninguém tinha aqui! No caso, quem plantasse canola! Daí botaram na minha máquina e eu fiz serviço pra fora né! Eu enleirei bastante pra fora! Só que essa daí essa que eu peguei era da BSBios né!

PG 9: - 9:9 [ED - (Subindo no caminhão)...A...] (5:124-5:200) (Super)

Codes: [Cooperação]

Até veio pro vizinho e veio junto na mesma carga

PG 9:- 9:10 [E até era pra ele vir, só que ..] (7:1006-7:1121) (Super)

Codes: [Proximidade institucional]

E até era pra ele vir, só que ele hoje tem uma janta que eles vão dá ali na UPF...daí eles tão lá, organizando lá!

PG 9: - 9:11 [É, hoje tem até outras empresa..] (7:1372-7:2039) (Super)

Codes: [Concorrência]

É, hoje tem até outras empresas que tão...mas quem começou mesmo foi a BSBios...

Tem até no caso.... Cotrijal, eles queriam que eu plantasse com eles pra fazer com eles...só que eles só recebem e passam pra BSBios né! Humm...então eles só vão intermediar no caso né? E é claro que eles vão querer ganhar Sim...e que nem!...no caso o desconto de impurezas e umidade...daí vão te tirar...só que eles não fazem nada né! Eles não tem nem como trabalhar com a canola...Então eles só vão receber fazer o desconto e passar pra BSBios né

PG 9: - 9:12 [Soja sim, canola não!] (8:194-8:214) (Super)

Codes: [Soja]

Soja sim, canola não!

PG 9: - 9:13 [esse ano vou plantar dez hectar..] (8:659-8:809) (Super)

Codes: [Diversificação produtiva]

Esse ano vou plantar dez hectares de trigo! Por que daí o milho eu sempre colhia, agora comecei a lidar com vaca de leite...daí tô fazendo silagem né!

PG 9: - 9:14 [É uma corrente] (9:1919-9:1932) (Super)

Codes: [Proximidade institucional] 
É uma corrente

PG 9: - 9:15 [É, eu tava comentado com o Cel..] (10:1882-10:2141) (Super)

Codes: [Expertise]

É, eu tava comentado com o Celso Bicolo quando ele tava plantando...no que desce ali...plantando aquele pedaço ali...daí eu tava comentando do Alexandre que tava aproveitando semente que tinha deixado...e daí ainda tem dois anos que ele tem a semente né!

PG 9: - 9:16 [Olha! Até a gente já fez vário..] (12:861-12:923) (Super)

Codes: [Inovação]

Olha! Até a gente já fez vários cursos ali! Cursos da Sebrae...

PG 9:- 9:17 [É por que antes tava negociand..] (14:126-14:241) (Super)

Codes: [Concorrência]

É por que antes tava negociando com a Cotrijal também, mas já tô meio parando...tem uma nova aí...a Central Grãos!

PG 9: - 9:18 [Não tem como! Até antes, eu.....] (13:1617-13:1886) (Super)

Codes: [Logística]

Não tem como! Até antes, eu...acredito que eles me logravam, por que vinha um caminhão grande! Bem maior que esse aqui! Levavam cheio! 15 mil quilos...16 mil quilos...esse aqui se eu botar parelho na lata dá 10 mil quilos! Então né eu acho que os caras me logravam..

PG10-10:1 [É mais é soja!] (1:683-1:696) (Super)

Codes: [Soja]

É mais é soja!

PG10: - 10:2 [Sim, sim...dois anos! Ano pass..] (1:808-1:918) (Super)

Codes: [Concorrência]

Sim, sim...dois anos! Ano passado que nós paramos...a BSBios agora está aqui, anda direto aí com o produtor.

PG10: - 10:3 [nós fomos até...nós tivemos un..] (1:1388-1:1530) (Super)

Codes: [Certificações] [Proximidade institucional]

nós fomos até...nós tivemos uns vinte dias acho, ali em Passo Fundo que era todas as cooperativas, sindicatos e o MDA nós estávamos reunidos!

PG10: - 10:4 [Na verdade era mas uma coisa t..] (1:1857-1:2098) (Super)

Codes: [Certificações]

$\mathrm{Na}$ verdade era mas uma coisa técnica assim mesmo...mas como a gente tinha que fazer pra encaminhar de onde tu comprou!...tipo assim...como se chama ô...na verdade, quanto que foi comprado, quanto que foi vendido da agricultura familiar...

PG10: - 10:5 [Quanto pro biodiesel.] (1:2122-1:2142) (Super)

Codes: [Bioenergia]

Quanto pro biodiesel.

PG10: - 10:6 [A Óleoplan e os outros não né!..] (2:242-2:441) (Super)

Codes: [Concorrência] 
A Óleoplan e os outros não né! Mas a BSBios agora vai direto no produtor! A coisa veio correndo de nós aí...

PG10: - 10:7 [É as outras até que não, né! A..] (2:524-2:711) (Super)

Codes: [Cooperação]

É as outras até que não, né! A Óleoplan já cedeu armazéns aonde nós temos associados pra nós já...

PG10: - 10:8 [Mas com a BSBios hoje nós vemo..] (2:713-2:1230) (Super)

Codes: [Concorrência]

Mas com a BSBios hoje nós vemos como um concorrente nosso né! Eles adquiriram unidades (silos) aqui nas Duas Coxilhas!... E o pior ainda, eles pagam mais ainda ao produtor do que pagariam pra nós né... Nós tivemos que sugar toda nossa margem quase..

PG10: - 10:9 [Foi um concorrente eles, é um ..] (2:1615-2:1790) (Super)

Codes: [Desapontamento]

Foi um concorrente eles, é um concorrente, mas pra nós ajudou...por que o pessoal se revoltou com eles e...não entregaram mais!...Eles receberam bem menos do que esperavam...

PG10: - 10:10 [Também houve a entrado da linh..] (3:529-3:643) (Super)

Também houve a entrado da linha da Pronaf aí né...que paga uma real $(R \$ 1,00)$ / um real e vinte $(R \$ 1,20)$ a mais...

PG10: - 10:11 [Também houve a entrado da linh..] (3:529-3:928) (Super) Codes: [Participação]

Também houve a entrado da linha da Pronaf aí né...que paga uma real $(R \$ 1,00)$ / um real e vinte $(R \$ 1,20)$ a mais...

Pro produtor é...pra cooperativa praticamente...mm

PG10: - 10:12 [Pro agricultor melhorou!] (3:1019-3:1042) (Super)

Codes: [Bioenergia]

Pro agricultor melhorou!

PG10: - 10:13 [E hoje a gente vai ver...uma v..] (3:1294-3:1460) (Super)

Codes: [Bioenergia]

E hoje a gente vai ver...uma vez tu pegava um...agricultor grande assim e um pequeno...a tecnologia era bem diferente um do outro...hoje praticamente é a mesma coisa

PG10: - 10:14 [É pra nós também né! A gente t..] (4:6-4:307) (Super)

Codes: [Participação]

É pra nós também né! A gente tem...antes era 70 agora veio pra 60 dos agricultores que tenham...dos associados que estejam com DAP (referindo-se a percentagem), a gente consegue a DAP jurídica também né! Consegue tudo melhor aqui! Dos oitenta e pouco por cento dos nossos associados familiares...

PG10: - 10:15 [Até esse ano...nós pagamos um ..] (4:1016-4:1274) (Super)

Codes: [Desapontamento]

Até esse ano...nós pagamos um pouquinho a mais né...para incentivar! Por que pra nós também é melhor fazer operação com associado do que com terceiros né! Gera imposto... Mas não querem né! Por que o pai dele já foi associado da Copasa...quebrou a Copasa! 
PG10: - 10:16 [Contratavam gente que não tinh..] (4:1766-4:1864) (Super)

Codes: [Reprovação]

Contratavam gente que não tinha nada ver com o cooperativismo, pra ser presidente, ser diretor...

PG10: 10:17 [falta a licença ambiental pra ..] (5:549-5:799) (Super)

Codes: [Agroindústrias Familiares]

falta a licença ambiental pra nós iniciarmos a nova fábrica...fazemos uma bem...hoje nós atendemos a maioria dos associados e da agricultura familiar que a gente vende de ração...digamos que o cara queira queira aqui ô...paga com milho, o trigo...

PG10: - 10:18 [Soja, milho, trigo, cevada... ..] (5:1057-5:1332) (Super)

Codes: [Soja]

Soja, milho, trigo, cevada...

PG10: - 10:19 [Quatro ou cinco produtores que..] (5:1357-5:1522) (Super)

Codes: [Limitações Tecnológicas]

Quatro ou cinco produtores que plantavam e até foram mais ou menos, mas...depois

é....bem agora tem uma tecnologia diferente...antes se perdia muito pela debulha...

PG10: - 10:20 [em agora bom...agora o pessoal..] (5:1642-5:1721) (Super)

Codes: [Clima]

em agora bom...agora o pessoal...teve gente que plantou cedo deu uma geada aí...

PG10: Cooperativa Cotapel de Tapejara.pdf - 10:21 [Na colheita da soja...daí o pe...] (6:408-6:549) (Super)

Codes: [Competição de culturas]

$\mathrm{Na}$ colheita da soja...daí o pessoal prefere plantar milho! Tivemos aqui no ano passado uma média de trigo e cevada de 80 sacos por hectares!

PG10: Cooperativa Cotapel de Tapejara.pdf - 10:22 [É! E como você disse ele já te..] (6:705-6:773) (Super)

Codes: $[R, V \& I]$

É! E como você disse ele já tem conhecimento tudo o trigo e a cevada!

PG10: - 10:23 [Hoje, não tá sendo tá sendo usa..] (7:338-7:420) (Super)

Codes: [Óleos Nobres]

Hoje, não tá sendo tá sendo usado canola pra biodiesel né! São óleos mais nobres né!

PG10: - 10:24 [Éhh...por que não tem, não tem..] (7:470-7:523) (Super)

Codes: [Escala e Verticalização]

Éhh...por que não tem, não tem escala suficiente pra..

PG10: Cooperativa Cotapel de Tapejara.pdf - 10:25 [Hoje em dia com o soja, ele tá..] (7:801-7:898) (Super)

Codes: [Soja]

Hoje em dia com o soja, ele tá acostumado muito mal! Ganha por...o soja tá dando muito dinheiro! 
PG10: Cooperativa Cotapel de Tapejara.pdf - 10:26 [Sim! Se tivesse contrato també..] (7:1532-7:1654) (Super)

Codes: [Logística]

Sim! Se tivesse contrato também...cooperativa também...mas o pessoal não planta por que não tem uma rentabilidade boa né!

PG10: Cooperativa Cotapel de Tapejara.pdf - 10:27 [Outra coisa assim né...nós rec..] (7:1748-7:2024) (Super)

Codes: [Logística]

Outra coisa assim né...nós recebemos canola! Ela vem junto com o trigo e o milho...eu te dou uma guia

separada aqui...canola...ehh...tu não tem como secar em secadora! Tem que esperar o produtor tirar bem seca, senão fica aí... daí vamos esperar secar bem, perde a metade

PG10: Cooperativa Cotapel de Tapejara.pdf - 10:28 [Tenho certeza de que daria! Te..] (7:1674-7:1748) (Super)

Codes: [Canola]

Tenho certeza de que daria! Tem uma região aqui que já é forte em canola! O

PG10: Cooperativa Cotapel de Tapejara.pdf - 10:29 [Sim! Ele incentivou bastante e..] (8:323-8:410) (Super)

Codes: [Expertise]

Sim! Ele incentivou bastante esse ano! Ele também é agricultor, planta canola faz tempo!

PG10: - 10:30 [Ah com certeza! Pra parte prod..] (3:2040-3:2113) (Super)

Codes: [Bioenergia]

Ah com certeza! Pra parte produtiva e pra agricultura...pra nós também né!

PG10: Cooperativa Cotapel de Tapejara.pdf - 10:31 [ó que aqui é assim ô...faz par..]

(4:799-4:936) (Super)

Codes: [Segurança Alimentar]

ó que aqui é assim ô...faz parte de uma cultura diferente...aqui tem gente que trabalha $100 \%$ com a cooperativa e não quer ser associado!

PG11: 11:1 [Perfeito! A canola entrou numa ..] (1:594-1:677) (Super)

Codes: [Viabilidade da Canola pra biodiesel]

Perfeito! A canola entrou numa forma mais efetiva nas regiões por causa do biodiesel!

PG11: Indústria - 11:2 [Embora não seja utilizada para..] (1:681-1:723) (Super)

Codes: [Óleos Nobres]

Embora não seja utilizada para biodiesel né

PG11: - 11:3 [nossa empresa por exemplo para..] (1:728-1:836) (Super)

Codes: [Certificações]

nossa empresa por exemplo para ter o Selo

Social é exigido dela que faça a difusão de culturas alternativas

PG11: - 11:4 [O que traz de bom ao produtor?..] (1:2137-1:2574) (Super)

Codes: [Benefícios Edáficos]

O que traz de bom ao produtor? É uma cultura que agronomicamente recicla nutriente com uma facilidade muito grande, e uma cultura que estrutura o solo, e que tu percebes onde 
que você planta canola, na safra subsequente ele colhe um pouco mais! Tem exemplos aí de 3 ,

4 sacos a mais...inúmeros exemplos, né. A mais por hectare nas culturas subsequentes, né! Por conta da estruturação do solo, por conta da reciclagem de nutrientes!

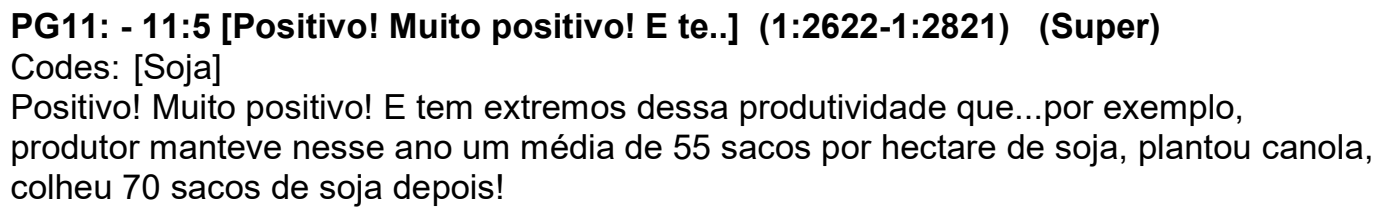

\section{PG11: - 11:6 [São todas propriedades pequena..] (1:2823-1:2989) (Super)} Codes: [Bioenergia]

São todas propriedades pequenas né! Nós estamos numa estrutura fundiária, na maior parte das regiões onde nós trabalhamos, onde mais de $80 \%$ são pequenos produtores

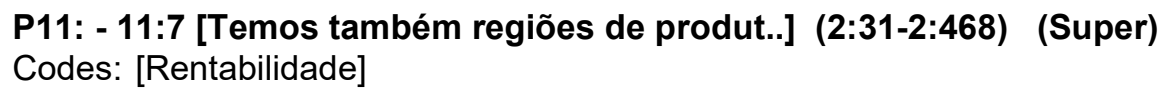

Temos também regiões de produtores maiores, mas a estrutura de produção para o biodiesel ela está calcada nas pequenas propriedades, né. Então a canola tem essas vantagens.

Temos dito ao produtor e ele tem percebido ahh...que a canola é uma cultura de melhoria da receita por unidade de área! Por que de melhoria? Por que o senhor colhe 65 sacos de soja por hectare e colhe 35 de canola, você tem 100 sacos! Vende tudo por soja...

\section{PG11: - 11:8 [A gente por não ter volume, po..] (2:1474-2:1577) (Super)}

Codes: [Escala e Verticalização]

A gente por não ter volume, por não ter escala, não industrializamos, nós produzimos e repassamos, né!

\section{PG11: - 11:9 [em zoneamento agroclimático! E..] (2:1141-2:1469) (Super) \\ Codes: [Bioenergia]}

...em zoneamento agroclimático! $\mathrm{E}$ tem a animosidade da indústria que percebeu que embora não seja uma cultura pra melhorar o faturamento da própria indústria mas ela traz ao produtor um agregado de melhoria do bem-estar social e econômico, que somada as demais culturas de diversificação, ela passa a ser muito importante, né!

\section{PG11: - 11:10 [Celena ou Giovelli dependendo ..] (2:1624-2:1981) (Super) Codes: [Proximidade institucional]}

Celena ou Giovelli dependendo da condição, nesse ano o trabalho tá sendo feito com a Celena, né! Então é uma cultura, principalmente pro nosso quadro técnico, é uma cultura que é muito bem-vinda! É uma cultura que demanda tecnicamente mais que o soja...por que tu conhece menos...então o técnico fica mais presente lá, mas é uma forma de aproximação...

\section{PG11: - 11:11 [lsso, isso! Por que se há um c..] (3:939-3:1539) (Super) Codes: [Bioenergia]}

Isso, isso! Por que se há um conjunto de produtores que está bem estruturado financeiramente, é um produtor que menos dependente da indústria, então tudo que se pode fazer pra ele, pra que ele melhore o bem-estar social e econômico dele, diminui a carga de responsabilidade da indústria de ter que estar suportando um ônus de custo com ele...então se ele tá bem, e se essa cultura nós dá essa indicação aqui...com uma cultura que pode fazer isso...ela compõe, ajuda compor a melhoria de receita da área, né! Onde ela foi introduzida ali e das melhoria agronômicas que a gente tem percebido 
PG11: Indústria de biodiesel Oleoplan.pdf - 11:12 [Com certeza! O biodiesel...ehh..] (3:1877-3:2110) (Super)

Codes: [Certificações]

Com certeza! O biodiesel...ehh...o principal produtor que a gente trabalha, que a empresa trabalha é o biodiesel!...produto principal...O programa nacional do biodiesel é um programa que foi montado de uma forma muito inteligente!

PG11: - 11:13 [Ele não que nem o programa do ..] (3:2132-3:2556) (Super)

Codes: [Certificações]

Ele não que nem o programa do Proálcool que acabou sendo conduzido, e a matériaprima produzida, por grandes empresas, por mega-investimentos, né! O programa do biodiesel, da forma que ele tá estruturado não vai sair da mão do pequeno produtor...que nós pra poder fazer a venda como indústria, pra fazer a venda do biodiesel ao leilão, nós temos que provar que aquele lote foi feito com $40 \%$ de soja da pequena produção.

PG11: - 11:14 [Isso aí! Isso aí! Isso justame..] (5:1201-5:1429) (Super)

Codes: [Otimismo]

Isso aí! Isso aí! Isso justamente por que o produtor não tem que estar comprando um conjunto e tal né! Depois de semear, depois de plantar adequadamente a canola, a lavoura dele é tão produtiva quanto uma lavoura empresarial!

PG11: - 11:15 [A produção de canola na nossa ..] (5:722-5:1078) (Super)

Codes: [Canola]

A produção de canola na nossa empresa, a base é familiar! Nós temos de 5 a 100 hectares. Tá, tá...o produtor familiar claro, aquele que é um pouco mais estruturado, ele faz o plantio mais independente em termos de mecanização. O pequeno produtor a gente tem até pequenos kit's de plantio que empresta pra ele...termina de plantar passa pro seguinte...

PG11: - 11:16 [Mais aí tu tem os bancos já fi..] (2:995-2:1089) (Super)

Codes: [Participação]

Mais aí tu tem os bancos já financiando a totalidade dos plantios, tem cobertura do Proagro..

PG11: - 11:17 [Fornecemos assistência! Desde ..] (2:2072-2:2172) (Super)

Codes: [Bioenergia]

Fornecemos assistência! Desde a escolha da área de plantio da propriedade até o dia do faturamento.

PG11: - 11:18 [De área cultivada né! Não quer..] (3:229-3:515) (Super)

Codes: [Desapontamento]

De área cultivada né! Não quer dizer que todos os produtores. Tem produtores que são habituais e todo ano planta um pouco né! Mas tem produtor que entra sai, depois entra de novo né! Tem também no ingresso dos produtores novos todo um cuidado pra que ela não frustre a produção...

PG11: - 11:19 [lsso, o Selo Combustível Socia..] (3:2598-3:2846) (Super)

Codes: [Bioenergia]

Isso, o Selo Combustível Social! Bom...O que isso tem trazido ao produtor? A gente vê o produtor entrar nos escritórios vendendo pequenos lotes de soja, ao preço que anteriormente só se pagava pra lotes maiores de cerealistas ou de cooperativas! 
PG11: - 11:20 [Por que nosso produtor produzi..] (4:937-4:1319) (Super)

Codes: [Tecnocentrismo]

Por que nosso produtor produziu $65 / 70$ sacos por hectare...o pequeno produtor!...Ele teve nos últimos anos, agregado a isso, um fator que a gente considera bastante importante: ele hoje, lá na propriedade dele, ele tem condições de mecanização adequada pra fazer plantio direto que nem faz a agricultura empresarial! Pequenos tratores, pequenas semeadoras seminovas ou novas..

PG11: - 11:21 [E o pequeno produtor...pode te..] (4:1506-4:1745) (Super)

Codes: [Pertencimento]

E o pequeno produtor...pode ter a tranquilidade de investir na sua pequena propriedade, que por muitos anos ele vai ter pra quem vender e vai ser muito assediado! Hoje ele é tão ou mais assediado pela indústria do que o grande produtor!

PG11: - 11:22 [Que podem, e ao longo tempo el..] (4:2361-4:2549) (Super)

Codes: [Canola]

Que podem, e ao longo tempo ele vai se tornar, por que tu vai perceber...como nós estamos comentando...que é uma cultura que traz pra ele uma melhoria de receita naquela área cultivada!

PG11: - 11:23 [Hoje somando soja e canola, pr..] (5:6-5:129) (Super)

Codes: [Soja]

Hoje somando soja e canola, pra crescer e ultrapassar 100 sacos por hectare é fácil! E isso é expressivo numa propriedade!

PG11:- 11:24 [E ocupando um espaço que é ocu..] (5:147-5:374) (Super)

Codes: [Competição de culturas]

E ocupando um espaço que é ocupado pela aveia, ou pela pastagem...e que a aveia como cobertura pra o plantio direto é ótima, mas não traz essa possibilidade de receita, apenas é um meio físico pro plantio que vem em seguida!

PG11: - 11:25 [É! Não é correto! É...Uma cult..] (5:2161-5:2298) (Super)

Codes: [Limitações Tecnológicas]

É! Não é correto! É...Uma cultura muito sensível a doenças! E as sementes são as maiores propagadoras. Então é interessante ele comprar.

PG11: - 11:26 [Totalmente, então no RS nós te..] (1:1100-1:1526) (Super)

Codes: [Pertencimento]

Totalmente, então no RS nós temos as áreas muito mecanizadas, mas ahh....nós temos um pacotinho tecnológico também pra mamona que a gente entende que é uma cultura de inclusão social, por que aquele produtor que pra nós deu certo e aquele que não tem mecanização nenhuma, que plantava feijão e milho nas encostas! Que usava uma carroça, um cavalo, esse é o cara que dá certo na mamona! É tem a mão-de-obra familiar dele

PG11: - 11:27 [.e a canola é diferente por qu..] (1:1792-1:1891) (Super)

Codes: [Canola]

E a canola é diferente por que? Por que ela utiliza

a mecanização existente das grandes culturas!

PG11: - 11:28 [Com pequenas adaptações. Então..] (1:1914-1:2114) (Super)

Codes: [Inovação] 
Com pequenas adaptações. Então isso tem facilitado! Nós temos levado nossa proposta ao produtor, garantindo um preço mínimo pra ele! E garantindo à ele o preço do soja no dia em que ele for faturar

PG11:- 11:29 [Celena ou Giovelli dependendo ..] (2:1624-2:1979) (Super)

Codes: [Óleos Nobres]

Celena ou Giovelli dependendo da condição, nesse ano o trabalho tá sendo feito com a Celena, né! Então é uma cultura, principalmente pro nosso quadro técnico, é uma cultura que é muito bem-vinda! É uma cultura que demanda tecnicamente mais que o soja...por que tu conhece menos...então o técnico fica mais presente lá, mas é uma forma de aproximação.

PG11: - 11:30 [..com uma cultura que pode faz..] (3:1355-3:1541) (Super)

Codes: [Benefícios Edáficos]

...com uma cultura que pode fazer isso...ela compõe, ajuda compor a melhoria de receita da área, né! Onde ela foi introduzida ali e das melhoria agronômicas que a gente tem percebido..

PG11: - 11:31 [nós temos que provar que aquel..] (3:2472-3:2556) (Super)

Codes: [Soja]

nós temos que provar que aquele lote foi feito com $40 \%$ de soja da pequena produção.

PG11: Indústria de biodiesel Oleoplan.pdf - 11:32 [Então o programa do biodiesel,..] (4:58-4:446) (Super)

Codes: [Bioenergia]

Então o programa do biodiesel, a gente percebeu que na forma que ele foi montado, ele trouxe essa possibilidade de melhoria...ele trouxe outra coisa que é muito importante! Quando a gente começou há alguns anos atrás, o pequeno produtor era menos assediado pela assistência técnica por que ele não gerava um volume de negócio que pudesse valer à pena pra ser atendido pelo tecnico!

PG11: Indústria de biodiesel Oleoplan.pdf - 11:33 [- Contribuiu muito pra isso, n..] (4:1369-4:1484) (Super)

Codes: [Otimismo]

Contribuiu muito pra isso, né!...Então a gente vê com bastante ânimo a fase em que está passando o segmento, né!

PG11: - 11:34 [O pequeno produtor a gente tem..] (5:953-5:1078) (Super) Codes: [Cooperação]

O pequeno produtor a gente tem até pequenos kit's de plantio que empresta pra ele...termina de plantar passa pro seguinte...

PG12: - 12:1 [Não eu acho que não! Na verdad..] (1:1010-1:1102) (Super)

Codes: [Canola]

Não eu acho que não! Na verdade hoje ela não é muito rentável! Ela é uma saída pro inverno!

PG12: - 12:2 [Daí o leite vai dar muito mais..] (1:1789-1:1953) (Super)

Codes: [Competição de culturas]

Daí o leite vai dar muito mais retorno se tu plantar uma área de pastagem do que se você plantar Canola! Mas no meu caso como eu só lido...é Soja, Milho e Trigo...

PG12: - 12:3 [E Canola! No caso, a Canola eu..] (2:49-2:125) (Super)

Codes: [Diversificação produtiva] 
E Canola! No caso, a Canola eu uso pra fazer uma rotação de cultura no Trigo!

PG12: - 12:4 [Digamos um ano passado naquela..] (2:280-2:430) (Super)

Codes: [Benefícios Edáficos]

Digamos um ano passado naquela área eu tinha...no ano retrasado eu tinha Canola, no ano passado eu plantei Trigo, nesse ano eu planto Canola de Novo!

PG12: - 12:5 [lsso...é...é! Hoje na parte eco..] (2:564-2:669) (Super)

Codes: [Logística]

Isso...é...é! Hoje na parte econômica se fosse avaliar, seria mais vantajoso plantar Trigo do que Canola!

PG12: - 12:6 [Só que a produtividade da Cano..] (2:1104-2:1145) (Super)

Codes: [Limitações Tecnológicas]

Só que a produtividade da Canola tá baixa!

PG12: - 12:7 [A minha Canola eu plantei até ..] (3:614-3:783) (Super)

Codes: [Bioenergia] [Cooperação]

A minha Canola eu plantei até com os caras que dão assistência até dos caras da BSBios! Saiu da minha semeadeira muito pouca semente! Daí ficou meio rala de Canola né!?

PG12: - 12:8 [É, é! Pra não debulhar, pra nã..] (6:58-6:114) (Super)

Codes: [Limitações Tecnológicas]

É, é! Pra não debulhar, pra não debulhar! Senão dá menos!

PG12: - 12:9 [É...o que eu escuto, e que tod..] (7:5-7:108) (Super)

Codes: [Soja]

É...o que eu escuto, e que todo mundo comenta, é que em relação à Soja...produz muito mais biodiesel!

PG12: - 12:10 [Atrai mais né! Por enquanto eu..] (7:730-7:806) (Super)

Codes: [Segurança Alimentar]

Atrai mais né! Por enquanto eu acho que ainda tem bastante coisa pra crescer!

PG12: - 12:11 [Eu acho que na nossa região aq..] (8:103-8:290) (Super)

Codes: [Concorrência]

Eu acho que na nossa região aqui tem duas! A BSBios e a Óleoplan! Mas eu acho que a mais forte é a BSBios! A Óleoplan eu não sei nem se eles estão recebendo nessa unidade que eles tem!

PG12: - 12:12 [Acho que é mais...não se tem t..] (8:312-8:386) (Super)

Codes: [Soja]

Acho que é mais...não se tem tanto...acho que é mais em cima da Soja mesmo!

PG12: - 12:13 [O fulano tem! Ele comprou! C..] (8:1025-8:1367) (Super)

Codes: [Cooperação]

O fulano tem! Ele comprou! Como ele planta sempre, ele comprou esse Kit pra ele né!

Daí pedi emprestado pra ele! Ele me emprestou pra mim plantar! É...aí eu tenho minha 
plantadeira...dá certo! É só tirar os bujão dele e botar na minha né

PG12: - 12:14 [Entre dessecação, plantio, dep..] (10:1282-10:1381) (Super)

Codes: [Agroquímica]

Entre dessecação, plantio, depois mais duas aplicações de algum inseticida, fungicida, e colheita!

PG12: - 12:15 [Claro! Sim! Uma alternativa a ..] (12:589-12:626) (Super)

Codes: [Bioenergia]

Claro! Sim! Uma alternativa a mais né!

PG12: - 12:16 [A cultura principal é a soja! ..] (12:1000-12:1118) (Super)

Codes: [Soja]

A cultura principal é a soja! No verão, a soja, e em torno de $20 \%$ de milho da área aí pra...fazer rotação de cultura!

PG12: - 12:17 [Quando dá no tempo ali...aí a ..] (12:1367-13:86) (Super)

Codes: [Cooperação] [Inovação] [Proximidade institucional]

Quando dá no tempo ali...aí a gente vai...

Tem da Embrapa, tem das empresas privadas que faz dia de campo né!

De Canola, até mais quem divulga é a Embrapa, eu fui numa da Embrapa que teve em parceria com a BSBios!

PG12: - 12:18 [Ele não vai plantar Canola. El..] (13:875-13:958) (Super)

Codes: [Desapontamento]

Ele não vai plantar Canola. Ele foi meio mal ano passado! Plantou daí não nasceu bem

PG12: - 12:19 [Não, não...daí esse ano ele nã..] (13:1004-13:1240) (Super)

Codes: [Clima]

Não, não...daí esse ano ele não plantou! Plantou Trigo! Por que o problema maior acho que é a geada! Quando dá no começo ali que ela germina...daí até ela pega um porte por que a geada prejudica ela...na nossa região a geada mata né!

PG12: - 12:20 [- Naquele caso, naquele ano qu..] (14:1237-14:1521) (Super)

Codes: [Parcerias]

Foi a BSBios! uando eu comprei a semente...eu peguei só a semente deles...o resto eu comprei

tudo em outras empresas né! E daí agora eu vou usar minhas próprias...

PG13: - 13:1 ["Tem que concentrar mais nos p..] (1:93-1:545) (Super)

Codes: [Agroquímica]

"Tem que concentrar mais nos produtos que temos que botar dentro de uma canola (referindo-se a herbicidas e dissecantes), por exemplo, seguindo o caminho do soja...pra tentar matar o azevém. Esses produtos foram desenvolvidos para matar o papuã e o milhã (gramíneas exóticas)...nas culturas de verão né! Parece que a Monsanto vai lançar um dissecante diferenciado desses que tem hoje no comércio. Mas tá patinando...precisa de uma coisa nova.

PG13: - 13:2 [a canola serve não apenas pra ..] (1:558-1:954) (Super)

Codes: [Benefícios Edáficos]

a canola serve não apenas pra fazer um monte de coisas mas também pra fazer a rotação de cultura, muito importante...se produz assim até 10 sacos mais de uma lavoura de 
trigo em cima (após) de uma cultura de canola. Se tu conduzir ela bem (plantação de canola) e conseguir matar as aveias e o azevém, folha estreita né... por causa das doenças não dá pra plantar sempre trigo sobre trigo..

PG13: - 13:3 [é o ponto favorável...e é uma ..] (1:1019-1:1093) (Super)

Codes: [Diversificação produtiva]

é o ponto favorável...e é uma cultura que entra na rotação no inverno né! P

PG13: - 13:4 ["Cotribá, mas uma vez plantei ..] (1:1444-1:1541) (Super)

Codes: [Concorrência] [Parcerias]

"Cotribá, mas uma vez plantei 300 hectares de canola e fiz 150 pra Cotriba e 150 pra

BSBios né!"

PG13: - 13:5 [“Tô fazendo só com a Cotribá....] (1:1597-1:1903) (Super)

Codes: [Clima]

"Tô fazendo só com a Cotribá....bem toda cultura tem seus problemas...então teria que superar o quê que é... a canola, o maior problema dela que diminui muito a colheita é que ela debulha, é uma planta alta, levizinha (muito leve), dá um vento ela debulha, tem que passar um óleo, eu nunca passei óleo.

PG13: - 13:6 [Isso uma cola...então se tento..] (1:1982-1:2672) (Super)

Codes: [Limitações Tecnológicas]

Isso uma cola...então se tentou colher em três etapas, plantar em três, quatro etapas, mas como plantava pouco não tinha...vai demorar muito quando vê está pronto a lavoura...mas esse ano vou plantar mais canola já não tenho canola nascida, tenho canola nascendo e tô plantando canola. As máquinas estão lá na lavoura esperando o pessoal liberar aquela lavoura...tô com pouca gente né! Daí então hoje de manhã tava muito úmido pra fazer as duas coisas, todo mundo parado...na propriedade pra fazer as duas não tem jeito...então ficou de eu levar o almoço agora as $11 \mathrm{~h} 30$ e daí levar um rapaz que vai plantar dois sacos...vai vir um guri que tá aí...não sei diz que já plantou...

PG13: - 13:7 [É. Seria assim que nem o milho..] (2:6-2:1284) (Super)

Codes: [Benefícios Edáficos] [Diversificação produtiva]

Então assim, a vantagem mesmo é essa diversificação de culturas com a rotaçã fecha toda a área plantada, toda a área plantada todos os anos! Aonde vai milho, vai milho e milho, onde vai soja, vai soja e soja, isso seria verão né, e onde que vai milho ainda planta nabo forrageiro pra ter aquele espaço entre a colheita de soja

e plantar o milho, tem o nabo né

PG13: 13:8 [“A canola tem outro problema q..] (4:279-4:398) (Super)

Codes: [Limitações Tecnológicas]

A canola tem outro problema que ela não acama! (Ficar homogênea). Todas as outras culturas acamam mas ela não acama!

PG13: - 13:9 [“Fui apostando!” Mas foi compl..] (4:516-4:696) (Super)

Codes: [R, V \& I]

No memos

"Fui apostando!" Mas foi complicado! Perdi muito em equipamento! Hoje a melhor opção é o enleiramento! Reduz o risco de perda por debulha. Mas uma plataforma custa 60 mil reais!

PG13: - 13:10 [“Háa!!! Acho que olha! Nos tem..] (4:1115-4:1209) (Super)

Codes: [Proximidade institucional] 
"Háa!!! Acho que olha! Nos temos que receber canola né! Então a empresa tá de novo apoiando!"

PG13: - 13:11 [Por causa da questão econômica..] (4:1328-4:1462) (Super) Codes: [Participação]

No memos

Por causa da questão econômica né! Não sobra né, que nem o óleo de soja. Eles pagam um pouco mais que o soja mais só um reais a mais!

PG13: - 13:12 [Acho que tinham que pagar mais..] (4:1464-4:1494) (Super)

Codes: [Reprovação]

Acho que tinham que pagar mais!

PG13: - 13:13 [É um óleo tão fino né por que ..] (4:1542-4:1601) (Super)

Codes: [Óleos Nobres]

É um óleo tão fino né por que não incentivar um pouco mais

PG13: - 13:14 [“Não, a própria plataforma é u..] (4:1808-4:2057) (Super)

Codes: [Desapontamento]

"Não, a própria plataforma é um risco, não funciona direito, quebra. A esteira estraga sempre! Qualquer coisinha e aquilo ali não funciona direito. Tinha que ser que nem o equipamento da soja que não estraga. Tinha que enleirar para os dois lados

PG13: - 13:15 [É, para enleirar! Pronto! O qu..] (3:397-3:843) (Super)

Codes: [Limitações Tecnológicas]

É, para enleirar! Pronto! O que que houve? O cara fez uma pra ele rústica e funcionava! Vendeu trinta, mas não tinha mais como fazer né...contratou uma equipe, com uso de solda Mig e tal e aconteceu! Atrás de um engenheiro que assinasse. Mas eles fizeram a parte da frente mais forte do que a parte de trás e daí ela não se movimentava e trincava tudo! Como eles fizeram uma parte de lata e outra de ferro, batia no chão e trincava tudo".

PG13: - 13:16 [Eu perdi trinta e cinco mil re..] (3:1571-3:1714) (Super)

Codes: [Desapontamento]

Eu perdi trinta e cinco mil reais" Colhi uma safra duas e quebrou a firma!" Mesmo assim fui numa feira e comprei outra (máquina colheitadeira)

PG13: - 13:17 [Tem uma empresa aqui em Colora..] (4:905-4:1066) (Super)

Codes: [Cooperação]

Tem uma empresa aqui em Colorado (município) que é um pouquinho melhor que a minha! Essa que a BSBios tava dando força!" Parece que voltou a dar força de novo!"

PG14: - 14:1 [lsso, do cooperativismo aqui $n .$.$] (8:27-8:507) (Super)$

Codes: [Bioenergia]

Isso, do cooperativismo aqui no RS...ehhh...o Polo acabou sendo absorvido por essa estrutura que já tinha...e é interessante por que muitas cooperativas já não operavam mais com a agricultura familiar, já não interessava mais esse público pra elas né! E em função disso começaram a resgatar, e resgatou esse público! Fizeram campanhas de associação, trouxeram o agricultor de volta! Acabaram inserindo esse produtor dentro da cooperativa como um elemento importante hoje! 
Comment:

Vale destacar o testemunho do entrevistado nessa passagem. Nota-se seu relato que a partir da entrada do setor do biodiesel e do Projeto Pólos houve o resgate do pequeno agricultor, da agricultura familiar pelas cooperativas

PG14: - 14:2 [Exatamente! É a DAP que é base..] (8:1030-8:1132) (Super)

Codes: [Participação]

Exatamente! É a DAP que é baseada em cima desses agricultores! Daí as cooperativas fizeram campanhas!

PG14: - 14:3 [A gente não..não sabe, coincid..] (8:1669-8:1907) (Super)

Codes: [Desconhecimento de política territorial]

A gente não..não sabe, coincidentemente eu acabei acompanhando até...uma reunião deles lá...ainda existem mas a gente não acompanha muito aí né...não tem muito acompanhamento né! As vezes acontecem né! Os Territórios estão funcionando!

PG14: - 14:4 [Visitados os Secretários de Ag..] (11:810-11:874) (Super)

Codes: [Proximidade institucional]

Visitados os Secretários de Agricultura dos Municípios! Emater...

PG14: MDA_pdf - 14:5 [Participavam né! Nesse sentido..] (11:1148-11:1280) (Super) Codes: [Cooperação]

Participavam né! Nesse sentido, eles participavam...eles não eram muito ativos assim nas ações, mas nas reuniões eles participavam!

PG14: pdf - 14:6 [Aí que tá! Viu Arnoldo! Aí que..] (12:64-12:198) (Super)

Codes: [Conflitos] [Reprovação] [Segurança Alimentar]

Aí que tá! Viu Arnoldo! Aí que tá a diferença! O Territórios é uma questão muito mais...tipo orçamento participativo...tipo de grana!

PG14: - 14:7 [Pega aqui ano passado! No ano ..] (12:1213-12:1883) (Super)

Codes: [Conflitos]

Pega aqui ano passado! No ano passado, tu vai ver essa discussão aqui que eu te falei! Que principalmente a entrada da BSBios na região Nordeste (RS), que tá...tem contrato com as cooperativas e tem contrato também com os agricultores individuais né! Por que está havendo uma concorrência! Se tu pega o coordenador, um dos assessores do Território da região Nordeste, que é um Território novo inclusive! É...é uma reunião lá na Expointer lá! Ele falou isso: Por que nós queremos chamar o pessoal do MDA, do Biodiesel, nos Territórios! Como é que um programa do governo...um programa do governo...deixa uma empresa fazer isso, acabar com nossas cooperativas!

PG14: - 14:8 [Daí eu falei né! Não...ok! Vam..] (12:1888-12:2008) (Super)

Codes: [Desapontamento]

Daí eu falei né! Não...ok! Vamos lá né! Fazemos questão de ir na reunião dos Territórios né! Até hoje não nós chamaram!

PG14:- 14:9 [Nós chegamos não só pela dific..] (12:2319-12:2744) (Super)

Codes: [Desapontamento]

Nós chegamos não só pela dificuldade, mas à conclusão aqui no Sul e no Centro-Oeste! Chegamos à conclusão assim, não tinha razão mais por que nós estarmos reunindo o pessoal assim...entende? Gastando bateria e....eu não falo pelo Nordeste (BR), pelo Nordeste e pelo Norte (BR), mas aqui no Sul e no Centro-Oeste (BR) que também a gente trabalhava...não tinha 
por que a gente tá gastando bateria... e por que também né?

PG14: - 14:10 [E por que por segmentos também..] (13:37-13:408) (Super)

Codes: [Intimidação]

E por que por segmentos também? Segmentos né! Por que hoje nós fazemos separado? Quando nós fazíamos todos juntos, que daí vinha inclusive a Emater, vinha o Sindicato, vinha tudo, o que que acontecia? E via a empresa...primeiro que o agricultor, o cara da cooperativa, e outro, tinha medo de falar na frente da empresa! A empresa passava a proposta que ela queria!

PG14: - 14:11 [Eles dialogam mais? Então, o q..] (14:1593-15:57) (Super)

Codes: [Bioenergia]

Eles dialogam mais os Polos funcionarem de uma forma que consiga aproximou podemos dizer que indiretamente os Polos promoveram um resultado muito positivo

Comment:

Essa é a resposta esperada, uma vez que, trata-se de pessoas responsáveis pelo projeto

PG14: - 14:12 [Mais como tu acabou de falar n..] (15:1278-15:1676) (Super)

Codes: [Intimidação]

Mais como tu acabou de falar né! Quando tu tava com as cooperativas, mais é uma questão de negócios com a empresa, não só a agricultura familiar mas também dos demais agricultores, numa relação de negócios, eles não se sentiam à vontade de questionar na frente no mesmo ambiente né! Com a empresa né! Por que temia sofrer retaliações ou qualquer coisa no processo de negociações deles e tal!

PG14: - 14:13 [Tu consegue avançar mais! Por ..] (15:2116-15:2196) (Super)

Codes: [Intimidação]

Tu consegue avançar mais! Por que assim todos os atores se sentem mais à vontade!

PG14: - 14:14 [Eu que peguei o biodiesel no i..] (16:300-16:1303) (Super)

Codes: [Cooperação] [Proximidade institucional] [Reprovação]

Eu que peguei o biodiesel no início do programa, a universidade entrou, primeiro assim ô: primeiro tocava o pau no programa! Tipo a Embrapa Trigo aqui! Por exemplo, a Embrapa Soja, A Embrapa de Pelotas, Clima Temperado, que nós fizemos...tivemos uma participação muito boa...de Pelotas até hoje nós temos parcerias e tal... Agora as outras, Santa Maria, tocava um pau desgraçado no governo...e eles também são governo...tocavam pau no programa sem ter a pesquisa na frente! Inclusive na própria transesterificação. Fizeram vários seminários aí e tal, 2004, 2005 e 2006, mas principalmente 2005. Faziam crítica! E segundo que eles vinham conversar com a gente que eles queriam aprovar os projetos deles né! E essa loucura né! Cada departamento tem seu projeto e seu convênio!

Nós conversávamos direto na UnB com o da Química lá...o...fez a transesterificação, ele fez as plantas pequenas, ele que fez o tratamento...que do petróleo se faz o combustível...leva a...

PG14: - 14:15 [E essa loucura né! Cada depart..] (16:1042-16:1109) (Super)

Codes: [Conflitos]

E essa loucura né! Cada departamento tem seu projeto e seu convênio!

PG15: - 15:3 [Nós...ehhh...os dois!! Diversi..] (1:1258-1:1340) (Super)

Codes: [Diversificação produtiva]

Nós...ehhh...os dois!! Diversificada né! Sempre trabalhando com rotação de cultura!

PG15: - 15:4 [Que produziria bem! Porém, o p..] (2:707-2:861) (Super)

Codes: [Logística] 
Que produziria bem! Porém, o pessoal teve dificuldade em adquirir o material né! O material vem de fora né!

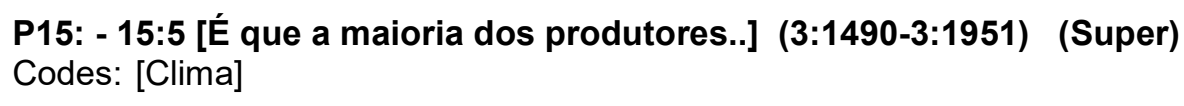

É que a maioria dos produtores na nossa região, na verdade não plantam bem no início do Zoneamento, porque tu acaba fugindo da geada mas aí tu tem problema na floração! Então tu acaba abortando bastante lá!

PG15: - 15:7 [Eu acho que...olha pra falar a..] (4:1132-4:1454) (Super)

Codes: [R, V \& I]

Eu acho que...olha pra falar a verdade acho que teria que experimentar mais esse ano assim né! Assim, a gente conhecendo mais o material, começando a se adaptar mais com o material, talvez seja assim, além de claro a rotação, tu já faz uma planta de inverno!...E tu consegue antecipar o Soja!...Seria rentável também!

P16: - 16:1 [Eu fui a Brasília agora, vária..] (3:256-3:358) (Super)

Codes: [Ideologia]

Eu fui a Brasília agora, várias vezes...conseguimos ter reunião com o ministro! Mas pouco adianta né!

PG16: - 16:2 [Eu sempre disse, você tem que ..] (2:1466-2:1731) (Super)

Codes: [Diversificação produtiva]

Eu sempre disse, você tem que criar uma estrutura que você não fica vulnerável...eu sempre brinco assim no caso do porco...o russo lá acordou mal da cara resolveu não comprar mais carne de porco e nós que temos que quebrar aqui dentro sabe! Isso não pode sabe!

PG16: - 16:3 [E isso te deixa relativamente ..] (2:1248-2:1463) (Super)

Codes: [Diversificação produtiva]

E isso te deixa relativamente vulnerável! Então no meio da agricultura, nós já começamos a introduzir o Canola, trabalhamos um pouco com o Girassol, trabalhamos um pouco com Linhaça...vários outros grãos, pra que

PG16: - 16:4 [Pra você entender a gente tem ..] (2:891-2:1224) (Super)

Codes: [Fisiocratismo]

Pra você entender a gente tem que ir um pouquinho mais pra trás...Nós trabalhávamos apenas com lavoura! Trabalhava só com agricultura, só com agricultura! Tá! E nesse período da

agricultura, ela tem muitos altos e baixos, ela tem interferência de clima, ela tem interferência de mercado, ela tem interferência de muita coisa né!

PG16: - 16:5 [Tu não podes ser tão vulneráve..] (2:1753-2:1868) (Super) Codes: [R, V \& I]

Tu não podes ser tão vulnerável! Então tu tens que fazer o seguinte, uma propriedade mais diversificada, entendeu?

P16: - 16:6 [Então nós começamos com a lavo..] (3:5-3:213) (Super)

Codes: [Diversificação produtiva]

Então nós começamos com a lavoura e depois nós vimos assim que pra completar aquilo era interessante alguém que consumisse esse grão...então o suíno se encaixa muito bem! Mas também tem seus ' $n$ ' problemas! 
PG16: - 16:7 [Não vai bem todo ela ali! Até ..] (3:1645-3:1862) (Super)

Codes: [R, V \& I]

Não vai bem todo ela ali! Até porque você não pode ficar tão vulnerável a um mercado! Volto aquilo de novo! Também tem que abrir um pouco mais! $\mathrm{E}$ a outra parte busca um mercado que normalmente está seguindo pra SP!

PG16: - 16:8 [É, nós começamos plantando com..] (8:68-8:269) (Super)

Codes: [Parcerias]

É, nós começamos plantando com a Camera na época! E a Celena foi uma parceria de um senhor com a Camera! Depois ele saiu fora da Camera! Que é o sr. Emílio Finger! Que é o proprietário da Celena né!

PG16: - 16:9 [Tá! E daí ela tem que ter...se..] (9:1521-9:1749) (Super)

Codes: [Rentabilidade]

Tá! E daí ela tem que ter...sempre separado, aquela cultura! Então ela tem que ter...ehh...uma contabilidade dela! E ela tem que responder economicamente! Se ela não me responder economicamente, eu não tenho porque continuar!

PG16: - 16:10 [Tá! Ele representa 50\% da minh..] (11:1002-11:1205) (Super)

Codes: [Diversificação produtiva]

Tá! Ele representa $50 \%$ da minha área total! Porque eu planto 50\% Trigo e 50\% Soja.

Então todo isso é pra construir uma estrutura boa de solo, de praga, controle de doenças e tudo, pra essas duas aqui!

PG16: - 16:12 [lsso! Entendeu! Por isso que e..] (17:760-17:926) (Super)

Codes: [Tecnocentrismo]

Isso! Entendeu! Por isso que eu te disse que a propriedade tem que trabalhar mais um pouco pra chegar naquela ideia! A ideia é tornar a propriedade auto-sustentável!

PG16: - 16:13 [Vale! E vou fazer! E outra coi..] (20:844-20:990) (Super)

Codes: [Segurança Alimentar]

Vale! E vou fazer! E outra coisa assim...Esse coisa de crédito de carbono e meio-ambiente é tudo muito bonito quando é nos olhos dos outros sabe!

PG16: - 16:14 [Os europeus com toda aquela ar..] (20:992-20:1050) (Super)

Codes: [Reprovação]

Os europeus com toda aquela arrogância deles e outros né!

PG16: - 16:15 [E mas daí esqueceu a questão d..] (20:1274-20:1377) (Super)

Codes: [Segurança Alimentar]

...Aquilo era um auê muito grande!

P16: 16:16 [Exatamente! E daí como eu esta..] (22:228-22:513) (Super)

Codes: [Tecnocentrismo]

Exatamente! E daí como eu estava dizendo antes assim, o dejeto, ele é uma fórmula de fertilizante! Fixa! Ela não muda! Se eu botar sempre a mesma coisa...e o que nós falamos muito hoje no momento, que é o oba oba da agricultura!? Que hoje o momento é o da agricultura de precisão! 
Comment:

Nessa caso ficou expresso durante a entrevista a fé na tecnologia, exemplificado pela agricultura de precisão, como elemento crucial a rentabilidade e a questão ambiental, nesse último aspecto, relacionado a manutenção do solo.

PG16: - 16:17 [pras culturas de Soja e Milho,..] (26:1532-26:1578) (Super)

Codes: [Soja]

pras culturas de Soja e Milho, as principais!

PG16: - 16:18 [Meia dúzia de plantadores no R..] (26:2058-26:2210) (Super)

Codes: [Ideologia]

Meia dúzia de plantadores no RS mais uma meia dúzia no PR...eles (governo?) não estão preocupados com nós! Eles estão preocupados com o custo do pão!

PG16: - 16:19 [Pode trocar governo, pode faze..] (27:5-27:286) (Super)

Codes: [Segurança Alimentar]

Pode trocar governo, pode fazer o que tu quiser! Trigo eles fazem qualquer tipo de negócio! E não é só Argentino, do Canadá agora compraram muito Trigo! Eles compram mais caro de fora do que o nosso! E é uma realidade! Certo ou errado, eu não sei! Cansei de brigar por isso né

PG16: - 16:20 [Ele é um modelo que...o sistem..] (1:1439-1:1645) (Super)

Codes: [Reprovação]

Ele é um modelo que...o sistema forçou e me levou todo criador, mas até porque o criador queria ou não! Bretou (forçou) o criador! Assim que ele hoje é um parceiro da agroindústria

Comment:

O entrevistado demonstra nesse trecho sua reprovação ao modelo de integração dos suinocultores as agroindustrias de grande porte, como Sadia, Perdigão e Seara.

PG16:- 16:21 [E uma parceria entre nós um ab..] (3:1524-3:1588) (Super)

Codes: [Parcerias]

No memos

E uma parceria entre nós um abatedorzinho, um supermercado, sabe?

PG16: - 16:22 [Isso aí! Esse seria assim ô, e..] (6:1662-6:2036) (Super)

Codes: [Agroindústrias Familiares]

Isso aí! Esse seria assim ô, essa Soja quando ela sai daí, ela tem uma logística, ela tem um armazém, tem uma indústria, essa indústria, ela recolhe impostos pro governo. Essa indústria, ela tem um passivo trabalhista, essa indústria tem uma lucratividade e de novo tem uma logística de volta pra cá! Se nós encurtar aquilo ali, eu acho que temos ganhos também sabe?

PG16: - 16:23 [Porque ele vai passar por dent..] (6:1105-6:1515) (Super)

Codes: [Farelo]

Porque ele vai passar por dentro de um suíno! Grande parte! E a outra parte. Já estou conversando com empresas, assim né! Não fiz ainda por uma questão de caixa, que tem que estruturar a propriedade primeiro, que é...Essa Soja! Eu ainda vendo ela! Ou troco ela! Por farelo de Soja! Eu tenho que sempre isso pra um comércio! $E$ tem hoje umas máquinas que desativam e tiram o óleo da Soja!

PG16: - 16:24 [Eu tenho uma programação de ro..] (8:1040-8:1729) (Super)

Codes: [Diversificação produtiva]

Eu tenho uma programação de rotação de culturas programadas oito anos pra frente! Nunca a Canola entra na mesma área! Quando eu falo 12,5\% não é exatamente! Nós temos uma média de 70 hectares! Foi 
dividida a propriedade em 8 partes! E cada uma, vamos supor, a Linhaça e a Canola, vão levar oito anos pra dar um giro!

PG16: - 16:25 [Essa...essa pergunta estava no..] (8:1848-9:297) (Super)

Codes: [Benefícios Edáficos]

Essa...essa pergunta estava no roteiro! Então na realidade a vantagem de plantar Canola, além do mercado garantido, seria também a vantagem agronômica né? Pra poder rotacionar? G - Isso! É! Também! E o Milho com a Soja é a mesma situação! Onde é quem tem Milho esse ano, entra a Soja, a próxima cultura, e só dali dois anos! E ainda vai se dividindo! Onde é que tenho $25 \%$ de Milho esse ano, no Agosto, vamos supor, dali dois anos, ele entra a Canola e a Linhaça! Entendeu?

PG16: - 16:26 [A que me dá o pior resultado f..] (11:461-11:521) (Super)

Codes: [Rentabilidade]

A que me dá o pior resultado financeiro é a Canola com Milho!

PG16: - 16:27 [E se tu já tens, já tem uma vi..] (16:1906-16:2111) (Super)

Codes: [Inovação]

E se tu já tens, já tem uma viabilidade de montar um equipamento de irrigação pra salvar tua lavoura com a estiagem eu vou viabilizar muito mais fácil! Por que esse mesmo equipamento vai levar o dejeto!

PG16: - 16:28 [.Eu fui a primeira granja do R..] (18:7-18:82) (Super)

Codes: [Inovação]

Eu fui a primeira granja do Rio Grande do Sul a receber crédito de carbono!

PG16: Agricultor - 16:29 [Isso! Eu não tinha recursos na..] (18:204-18:353) (Super) Codes: [R, V \& I]

Isso! Eu não tinha recursos na época, vieram com proposta, na primeira avaliação eu pensei: não tenha nada a perder! Eles fizeram esse investimento!

PG16: - 16:30 [Não é que ele recebe ordens, s..] (2:165-2:635) (Super)

Codes: [Reprovação]

Não é que ele recebe ordens, sempre ele não tem autonomia pra fazer nada diferente entendeu? E ele tá ali dentro de um sistema que ele recebe tudo! Um animal, uma ração, isso ou aquilo! Ele entra com o trabalho e com a estrutura física! Entendeu? E é remunerado até de uma forma que sempre dificulte! Esse sabe fazer o cálculo pra onde chegou, mas sempre é passado pronto pra ele!...Tá! Mas nós não queríamos fazer parte disso!

PG16: - 16:31 [Só que lá no computador de cas..] (11:8-11:190) (Super)

Codes: [Rentabilidade]

Só que lá no computador de casa que eu faço de noite! Bom então tá aqui...então eu tenho o resultado financeiro...O Trigo com a Soja tá aqui! Me dá o melhor resultado financeiro..

PG17: - 17:1 [Sim! Na verdade hoje nós traba..] (2:894-2:964) (Super)

Codes: [Cooperação]

Sim! Na verdade hoje nós trabalhamos de uma forma toda a lavoura junto!

PG17: - 17:4 [Bah! Eu não lembro...mas tem m..] (4:294-4:711) (Super)

Codes: [Clima] 
Bah! Eu não lembro...mas tem mais de dez anos né! Em torno de dez anos atrás, por aí! Mas aí assim, não foi uma quantidade enorme de granizo! Só que as pedras muito grossas! Dava pedra de $6 \mathrm{~mm}$ sabe!

E daí ela (chuva de pedra) quebrou um monte de galho da Canola! Deve ter sido em 2005...porque nós colhemos a nossa e fomos colher do Rogério também (outro vizinho de propriedade) naquele ano!

PG17: - 17:5 [Eles colheram foi uma loucura ..] (5:1336-5:1458) (Super)

Codes: [Rentabilidade]

Eles colheram foi uma loucura né! E uma coisa que tá levando esse ano nós a plantar a Canola, primeiro lugar, o preço né!

PG17: - 17:6 [Aí vai plantar Aveia pra fazer..] (5:1820-5:1919) (Super)

Codes: [Rentabilidade]

No memos

Aí vai plantar Aveia pra fazer cobertura não compensa! Preço de Canola ele tá atraindo o produtor!

PG17: - 17:7 [Um Trigo muito bom no ano pass..] (6:736-6:1094) (Super)

Codes: [Competição de culturas]

Um Trigo muito bom no ano passado! Um Trigo excelente! Né! Produção boa! Tudo, tudo perfeito! Daí nós paremos, nós paremos de plantar Canola, depois daquele ano lá em cima, nós

paremos de plantar Canola...

PG17: - 17:8 [Sim! Sim! Nós na verdade nós d..] (10:430-10:745) (Super)

Codes: [Agroquímica]

Sim! Sim! Nós na verdade nós dessecamos a resteva com Paraquat né! Gramoxona. É o princípio ativo Paraquat né...até não se consegue mais, só se consegue se vir uma liminar! É proibido né! Só que pra nós vai fazer muita falta se proibirem ele e tirarem do mercado! Por que o Azevém é resistente pra nós aqui né!

P17: - 17:9 [Aí claro! No momento de colher..] (2:988-2:1251) (Super)

Codes: [Participação]

Aí claro! No momento de colher a gente faz a divisão, por mais ou menos né...vamos dizer...pra não extrapolar DAP, dá problema com o leão lá, como se diz (imposto de renda)...daí a gente sempre tenta dividir pra não...! Uma, primeiro lugar não perder o DAP né!

PG17: - 17:10 [Pra conhecer a cultura! Pra ve..] (4:5-4:36) (Super)

Codes: [Inovação]

Pra conhecer a cultura! Pra ver!

PG17: - 17:12 [17 sacos! Aquele ano aqui em c..] (4:1596-4:1739) (Super)

Codes: [Limitações Tecnológicas]

17 sacos! Aquele ano aqui em casa nós conhemos mais! 19 sacos! Isso era começo, o cara não conhecia, não sabia nem o que a Canola exigia, nada

PG17: - 17:13 [É a Coasa que te dá assistênci..] (5:123-5:406) (Super)

Codes: [Cooperação]

Era...tinha...a BSBios por trás!

PG17: - 17:14 [L - É! E agora se sabe né!..Dá..] (7:1199-7:1678) (Super) 
Codes: [Limitações Tecnológicas]

É! E agora se sabe né!..Dá pra plantar Soja! É só dar um intervalo, na época o pessoal dizia que não dava pra plantar Soja em cima (na sequência) de Canola! Era no começo né, agora não, agora tá uma cultura mais conhecida! Mais estudada já!

\section{PG17: - 17:15 [Mas é claro que é! Claro que é..] (7:1787-7:2196) (Super) Codes: [Canola]}

Mas é claro que é! Claro que é! Assim ô, se fizer uma conta assim ô...ahh...claro não precisa colher como os caras colheram 40, 45 sacos por hectare! Mas tu colhendo 35 sacos por hectares que já é uma excelente produção! Trinta sacos por hectares que é uma produção boa!...Só que sem estudo, os caras já tão falando em 3.000 quilos, 50 sacos por hectare...né...que eu acho, eu acredito que chegue nisso

\section{PG17: - 17:16 [Só que sem estudo, os caras já..] (7:2066-8:123) (Super)}

Codes: [Otimismo]

Só que sem estudo, os caras já tão falando em 3.000 quilos, 50 sacos por hectare...né...que eu acho, eu acredito que chegue nisso...

A - Na Europa eles conseguem esses valores aí... $L$ - Eu acredito que chegua nisso né! Por que quando se começou a plantar Soja aqui os caras colhiam um miséria de Soja...

\section{PG17: - 17:17 [A Gramoxona cozinha tudo! Tu a..] (10:889-10:1018) (Super)} Codes: [Agroquímica]

A Gramoxona cozinha tudo! Tu aplicou ontem, hoje de manhã tem um cheiro de queimado no ar! Cheiro de queimado sabe! Ele cozinha!

\section{PG17: - 17:18 [Eu tô bem animado! Por que ass..] (10:2133-10:2477) (Super) Codes: [Otimismo]}

Eu tô bem animado! Por que assim ô, eu acho que esse ano não vai ser um ano tão frio assim, por que aqui teve casos antigos quando se começou a plantar Canola, há uns dez anos atrás, até um tio da Ana, ele plantou Canola aqui perto...e antigamente quando se começou a plantar Canola, eles mandavam plantar Canola mais ou menos nessa época!

\section{PG17: - 17:19 [O que nós temos agora é 15 de ..] (10:2482-11:161) (Super) Codes: [Clima]}

O que nós temos agora é 15 de maio! Né! Até fim de Maio...só que tem anos que dá geada muito forte né! $\mathrm{E}$ se a Canola tá recém saindo da terra não sobra nada! Extermina, extingue tudo! A - Uhumm.

...Né! E daí se descobriu depois que tem que se plantar antes né! E a geada tá maior! Pode dar geada que não mata! Problema ela tá pequeninha!

\footnotetext{
PG17: - 17:20 [lsso! Um ano atípico na verdad..] (12:1725-12:2171) (Super)

Codes: [Competição de culturas]

Isso! Um ano atípico na verdade! Se tu pegar produtor de Trigo e Canola no ano passado! E...ehh...Canola...vamos supor, se você tem um custo, vamos botar de 20 sacos, botando máquina e tudo! Né! Se você colher 25, você tem 5 sacos por hectare! Se colher 25 ! Tem 5 sacos por hectare a $\mathrm{R} \$ 70,00$ o saco! Entendeu só pra arredondar a conta: 7 × $5=35$ ! 350 reais

por hectare! Sabe...tu tem que colher dez sacos de Trigo por hectare pra empatar
}

\section{PG17: - 17:21 [Não tinha financiamento, não t..] (13:1636-13:1678) (Super)}

Codes: [Participação]

Não tinha financiamento, não tinha Proagro! 
PG18: - 18:1 [Nós aqui plantamos e trabalham..] (1:2764-1:3078) (Super)

Codes: [Soja]

Nós aqui plantamos e trabalhamos praticamente só com soja! Canola tá começando alguma coisinha, algum produtor aqui na nossa região. Parece que no ano passado, dois ou três produtores começaram...esse ano...aahhhh...uns quatro, cinco...então está começando...vamos ver conforme vai se desenvolver esse ano né!

PG18: - 18:2 [Hoje, temos assim uma concorren..] (2:437-2:517) (Super)

Codes: [Concorrência]

Hoje, temos assim uma concorrente nossa aqui é a BSBios, a indústria de biodiesel!

PG18: - 18:3 [E a gente nós também temos con..] (2:519-2:603) (Super)

Codes: [Parcerias]

E a gente nós também temos contrato lá...pra entregar produtos lá na BSBios também!

PG18: - 18:4 [É grande ehh digamos assim, el..] (2:1022-2:1407) (Super)

Codes: [Concorrência]

É grande ehh digamos assim, eles tem metas pra produzir, as unidades, então eles tem que correr atrás de produtor, vão atrás de meu associado também...um monte de coisas né! $\mathrm{E}$ eles trabalham bastante com contratos futuros né! Esse ano aqui contratos futuros de produto eles foram bem...então! Só que daí no disponível, no mercado disponível, eles estão meio que derrapando ali..

PG18: - 18:5 [Contratos futuros sim! Contrat..] (2:1761-2:2031) (Super)

Codes: [Reprovação]

No memos

Contratos futuros sim! Contrato do dia-a-dia não! Por enquanto não! Estão fazendo isso e esquecendo que o agricultor familiar ele não produz só soja né! O agricultor familiar produz trigo, produz milho, aqui em Ibiaça produz leite...leite também né! Tem tudo isso aí!

Comment:

Aqui o presidente da cooperativa faz uma crítica ao procedimento e postura da indústria de biodiesel em relação ao agricultor familiar

PG18: - 18:6 [Aqui sim! Daí eles esquecem de..] (2:2086-2:2218) (Super)

Codes: [Reprovação]

Aqui sim! Daí eles esquecem dessa parte e eles querem só...eles tão priorizando...digamos assim: da parte do boi só o Filet Mignon!

PG18: - 18:7 [a canola ahh...o ano passado a..] (3:8-3:75) (Super)

Codes: [Rentabilidade]

a canola ahh...o ano passado a rentabilidade da canola foi muito boa

PG18: - 18:8 [O clima foi excelente! Também ..] (3:78-3:398) (Super)

Codes: [Clima]

O clima foi excelente! Também trigo e canola ano passado foi muito bom né! Cada ano é um problema

que aqui é bastante climático né! O clima pra canola é...muitas vezes é prejudicial...uma geada, ano passado colheu mil maravilhas, produção excelente da canola né....e vamos ver esse ano né! Se der mais um ano de.

PG18: - 18:9 [A Giovelli troca em óleo de so..] (3:1686-3:1746) (Super)

Codes: [Parcerias] 
A Giovelli troca em óleo de soja pra entregar tudo na BSBios!

PG18: - 18:10 [É, essa questão de lavoura pra..] (4:1013-4:1338) (Super)

Codes: [Participação]

É, essa questão de lavoura pra biodiesel, me parece que eles estão trabalhando a um ano com - MDA! É que eles não tinham a quantidade de agricultores necessários pra ter a DAP jurídica deles....aí agora baixou pra sessenta...aí todo mundo...todo mundo não, ne'! ...mas uma boa parte...uma partizinha vai ficar fora né!...

PG18: - 18:11 [E dá uma boa aceitação...né.....] (5:622-5:1073) (Super)

Codes: [Rentabilidade]

E dá uma boa aceitação...né...mudou...hoje em relação ao preço quando nós começamos aqui, na época isso já faz um...se não me engano já faz uns cinco ou seis anos que a gente faz esse trabalho...o soja tava $R \$ 30,00 / R \$ 32,00$ a saca...um real a mais significava um bom percentual...hoje $\mathrm{R} \$ 60,00$ mas mesmo assim o pessoal dá um valor muito grande! (referindo a $\mathrm{R} \$ 1,00$ pago a mais por saca para os que possuem a DAP) Pra essa diferença do bônus

PG18: - 18:12 [Pra nós veio só a agregar. Dig..] (5:1483-5:1584) (Super) Codes: [Bioenergia]

Pra nós veio só a agregar. Digamos assim, tem mais gente comprando produtos da agricultura familiar!

PG18: - 18:13 [Nós temos, digamos assim, ganh..] (5:1586-5:1770) (Super)

Codes: [Bioenergia]

Nós temos, digamos assim, ganhado mais preços pela soja que é com DAP, nós se fossemos sem DAP nós não estaríamos nos níveis de preços desse patamar aqui! Então

teve mais corrida...

PG18: - 18:14 [Preço alto, o pessoal ficou ma..] (5:1794-5:1864) (Super)

Codes: [Rentabilidade]

Preço alto, o pessoal ficou mais agressivo no mercado...em função disso

PG18: - 18:15 [E nós da cooperativa conseguim..] (5:2159-5:2316) (Super)

Codes: [Participação]

E nós da cooperativa conseguimos um mercado bem mais fácil e com um resultado um pouquinho melhor financeiramente do que...muitas vezes o produto sem o DAP!

PG18: - 18:16 [Soja, milho e trigo! E temos v..] (6:192-6:239) (Super)

Codes: [Soja]

Soja, milho e trigo! E temos venda de insumos né

P18: Cooperativa Coofiume de Ibiaça.pdf - 18:17 [Não fomos convidados! Aqui que..] (4:510-4:583) (Super)

Codes: [Desconhecimento de política territorial]

No memos

Não fomos convidados! Aqui quem foi convidado e quem fez parte foi a Coasa

PG19: - 19:1 [Claro! Hoje eu faço a parte de..] (2:2078-2:2287) (Super)

Codes: [Soja]

No memos 
Claro! Hoje eu faço a parte de mesa de mercado né! Então é uma parte de compras de grãos da empresa né! Soja produzida por cooperativa de agricultura familiar ou de agricultor maior e também de cerealistas!

PG19: - 19:2 [Soja produzida por cooperativa..] (2:2184-2:2286) (Super)

Codes: [Parcerias]

Soja produzida por cooperativa de agricultura familiar ou de agricultor maior e também de cerealistas

PG19: - 19:3 [Isso, isso! Esse é meu trabalh..] (2:2383-2:2505) (Super)

Codes: [Soja]

Isso, isso! Esse é meu trabalho hoje né! A gente tem anos de mercado né, temos 10 anos de mercado nessa parte de Soja né!

PG19: pdf - 19:4 [A empresa inicialmente em 2006,..] (2:2527-2:2644) (Super)

Codes: [Cooperação]

A empresa inicialmente em 2006, 2009, a BSBios sempre só trabalhou até o ano passado né, com compras de cooperativas,

PG19: Indústria de biodiesel BSBios Passo Fundo.pdf - 19:5 [até o ano passado] (2:2646-2:2662) (Super)

Codes: [Concorrência]

até o ano passado

PG19: - 19:6 [O arranjo produtivo, vamos diz..] (2:2665-2:2893) (Super)

Codes: [Certificações] [Participação]

O arranjo produtivo, vamos dizer assim, pra se ter o volume necessário para se ter o Selo Combustível Social do MDA, uma norma pra você participar $100 \%$ do mercado do biodiesel, era comprada através de cooperativas com DAP né!

P19:- 19:7 [É! Unidade de Originação! Fili..] (3:221-3:333) (Super)

Codes: [Concorrência]

É! Unidade de Originação! Filiais! Unidades de Originação! Então, hoje a BSBios tem 16 unidades de originação!

PG19: - 19:8 [- Que trabalham diretamente co..] (3:674-3:1009) (Super)

Codes: [Bioenergia]

- Que trabalham diretamente com produtores! Uma amostra muito próxima de 2.000 agricultores mais ou menos! Hoje integrados né, com a BSBios no campo!

A - Entre familiares e não-familiares?

G - Exatamente! Desse número, a gente conseguiu acessar esse ano muito próximo de 1000 agricultores...890...870...agricultores familiares!

PG19: - 19:9 [A BSBios esse ano que passou f..] (3:1382-3:1442) (Super)

Codes: [Parcerias]

A BSBios esse ano que passou fez contrato com 7 cooperativas!

PG19: - 19:10 [O que eu posso te dizer mais d..] (4:113-4:428) (Super)

Codes: [Concorrência]

O que eu posso te dizer mais do arranjo...é muito importante, é inicial, é incipiente esse trabalho que a gente tem com o agricultor familiar, porque se a gente for olhar o espaço, a 
disponibilidade de mercado na região que a BSBios atua, nas unidades...tem a Olfar, a Óleoplan, Bianchini, e as cooperativas...

PG19: - 19:11 [Não são concorrentes porque a ..] (4:561-4:758) (Super)

Codes: [Parcerias]

Não são concorrentes porque a gente acaba vendendo óleo e farelo na mesma linha, um vende pro outro! Um compra do outro! Ou a Soja mesmo acontece isso, não é concorrente, são agentes do mercado!

PG19: - 19:12 [Claro tem uma concentração nas..] (4:1309-4:1460) (Super)

Codes: [Credibilidade]

Claro tem uma concentração nas cooperativas! Por que ali é onde os agricultores se

sentem mais em casa, é onde eles já têm vínculo há mais de 40 anos!

PG19: - 19:13 [Com certeza! Ela aumentou a re..] (5:672-5:1167) (Super)

Codes: [Bioenergia]

Com certeza! Ela aumentou a renda do agricultor! Não é que o agricultor ia plantar mais

Soja ou menos Soja! Na verdade quem ganhou foi o produtor né!

A - Uhumm. Eu escutei do pessoal da Óleoplan uma declaração interessante! Eles falaram que o agricultor familiar virou: Joia Rara!

$G$ - Exatamente!

A - Por que tudo mundo que tá ali, assediando ele agora!

$\mathrm{G}$ - Exatamente, exatamente! Então se tu pegar esse número de 25 mil agricultores, eu aposto contigo que $99 \%$ deles são acessados

PG19: pdf - 19:14 [A Canola...e aí fazendo um opi..] (6:1416-6:1721) (Super)

Codes: [Limitações Tecnológicas]

A Canola...e aí fazendo um opinião, não do jeito do pessoal que trabalha no fomento tá! Mas o dia-a-dia da Canola é o seguinte...hoje a Canola não é mais difundida porque falta pesquisa e desenvolvimento de produção, de maior produtividade, materiais vinculados a outros multiplicadores de sementes $\mathrm{n}$

PG19: - 19:15 [Outro dia pegamos a fundo! Lev..] (6:1745-6:1986) (Super)

Codes: [Logística]

Outro dia pegamos a fundo! Levamos pro Ministério da Agricultura isso aí! Eu estive pessoalmente com o Fábio pra falar sobre isso! Hoje nós temos a Advanta sementes né, que importa sementes da Austrália! Da Argentina que tem uma produção!

PG19: - 19:16 [Outro sentido assim, nós també..] (7:5-7:295) (Super)

Codes: [Agroquímica]

Outro sentido assim, nós também estamos atrasados na liberação de pesquisa de material de alteração genética da Canola né! Só no Brasil é plantado hoje com materiais que são convencionais, quando digo convencionais que não tem nenhuma tecnologia do tipo clear field ou Round Up Ready..

PG19: - 19:17 [Eu ia te recomendar no final, ..] (7:538-7:648) (Super)

Codes: [Proximidade institucional]

Eu ia te recomendar no final, fazendo um ensejo disso aqui né! Seria o seguinte, você procurar o doutor Tomm!

PG19: Indústria - 19:18 [Ela é uma mega oportunidade! P..] (7:1248-7:1360) (Super)

Codes: [Viabilidade da Canola pra biodiesel]

Ela é uma mega oportunidade! Por que? Porque no RS hoje nós temos uma área cultivável de 5 milhões de hectares! 
PG19: - 19:19 [Você te dizer mais! Porque! Is..] (8:522-8:723) (Super)

Codes: [Rentabilidade]

Você te dizer mais! Porque! Isso é um...eu vivi isso na pele, como filho de agricultor familiar! Por anos meu pai deixou de plantar Soja! Porque ela não era rentável! Plantava Milho ou não plantava!

PG19: - 19:20 [E tá crescendo a busca da Cano..] (8:1709-8:1962) (Super) Codes: [Benefícios Edáficos]

E tá crescendo a busca da Canola pelo produtor Baguara porque ela gera, por exemplo, se você pegar uma cultura de Trigo, onde você planta um ano Trigo e outro ano a Canola, outro ano você planta Trigo de novo, pô! Ele aumenta $20 \%$ a produção do Trigo!

PG19: Indústria de biodiesel BSBios Passo Fundo.pdf - 19:21 [Boa parte é feito um processam..] (9:1779-9:1892) (Super)

Codes: [Óleos Nobres]

Boa parte é feito um processamento de óleo e farelo no mercado ou é revertida pra indústria alimentícia...sim...

PG19: - 19:22 [É! Mas assim...tem que ter vol..] (10:331-10:539) (Super)

Codes: [Escala e Verticalização]

É! Mas assim...tem que ter volume né! Queria que ter mais ou menos assim 120 mil toneladas! Pra tu poder processar por dois meses óleo de Canola, mas mesmo assim o custo do óleo de Canola, ele é mais caro!

PG19: - 19:23 [Se você comprar ele no mercado..] (10:561-10:678) (Super)

Codes: [Segurança Alimentar]

Se você comprar ele no mercado interno e fazer dele biodiesel com o preço que o biodiesel tem hoje....bem complicado.

P19: - 19:24 [Então você vai perder $R \$$ 5,00!..] (10:2251-10:2320) (Super)

Codes: [Segurança Alimentar]

Então você vai perder $R \$ 5,00 !$ ! Você entende? Não existe matemática...

PG19: 19:25 [Na verdade é pra geração de re..] (11:1083-11:1199) (Super)

Codes: [Benefícios Edáficos] [Rentabilidade]

Na verdade é pra geração de renda, rotação de culturas, porque a gente tá vindo de uma situação assim...ano passado

PG19: - 19:26 [Trigo ano passado fui muito re..] (11:1235-11:1617) (Super)

Codes: [Fisiocratismo]

Trigo ano passado fui muito rentável! Quebrou $70 \%$ da safra do Paraná...Paraná diminuiu a área muito grande que tinha... também perdeu por geada...ahhh...lá fora em outros países, por exemplo, na Ucrânia por

problema de chuva perdeu um pouco do Trigo também, no RS plantou uma área menor também, colheu com boa qualidade...a Argentina produziu menos, o Uruguai produziu menos,

PG19: - 19:27 [! É! Exatamente! Gosto de conv..] (12:1507-12:1817) (Super)

Codes: [Proximidade institucional]

! É! Exatamente! Gosto de conversar com o Tomm pelo seguinte, se pegar o Trigo aqui no estado se plantava em 1949 e tal, e o pessoal colhia lá 900 quilos por hectare, 1000 quilos por hectare, 1200 quem era o papa! Se trouxe semente de fora dos EUA, da Austrália, do 
Canadá...o pessoal começou a pesquisar!

PG19: - 19:28 [Só que se o estado, não depend..] (13:5-13:106) (Super)

Codes: [Ideologia]

Só que se o estado, não dependesse de incentivar, mas só se não esbarrasse! Já fazia um bom serviço!

PG19: - 19:29 [Deixa pesquisar Clear Field, d..] (13:225-13:410) (Super)

Codes: [Agroquímica]

Deixa pesquisar Clear Field, deixa pesquisar Round-Up Ready, resistência a doença...pá...vai! Segurança alimentícia gente né! Por favor! Não é a indústria que vai ganhar, e o todo né

PG19: - 19:30 [Produtor que plantou Canola co..] (14:967-14:1264) (Super)

Codes: [Rentabilidade]

Produtor que plantou Canola com a BSBios nos últimos 3 anos, pode perguntar pra todos!

Tipo assim...quem perdeu dinheiro não perdeu! Por que fez seguro e tal! Mas quem conseguiu colher! Nossa! Claro não dá pra comparar com a safra de Trigo do ano passado! Mas o cara sempre manteve uma renda!

PG19: - 19:31 [Eu participei até numa reunião..] (14:1752-14:1865) (Super)

Codes: [Desconhecimento de política territorial]

Eu participei até numa reunião de grupo de trabalho que a gente fez do Ministério da Agricultura com João Abreu!

PG19 - 19:32 [É! Como DAP jurídica habilitad..] (3:5-3:177) (Super)

Codes: [Industrialismo]

É! Como DAP jurídica habilitada...cooperativas da agricultura familiar...esse é o conceito! A partir da aquisição de 16 unidades, que foi em 2013, ano passado, a BSBios...

PG19: - 19:33 [Agentes do mercado, noutro con..] (4:798-4:1149) (Super) Codes: [Participação]

Agentes do mercado, noutro conceito poderiam ser até concorrentes, mas a gente tem uma interação aí, que somos dez, que compram da agricultura familiar, e hoje no mercado disponível da BSBios da região de Passo Fundo, olhando o produtor né...a gente pode ter um número próximo ao de 25 mil agricultores com DAP! Que estariam habilitados a vender!

PG19: - 19:34 [..Números do MDA, e aí você po..] (4:1644-4:1815) (Super)

Codes: [Soja]

..Números do MDA, e aí você pode buscar através do MDA, aí a gente tem...número de agricultores hoje que plantam Soja da agricultura familiar são 225 mil aproximadamente!

PG19: - 19:35 [O mesmo produtor que vende pra..] (5:1384-5:1466) (Super) Codes: [Concorrência]

O mesmo produtor que vende pra cooperativa, vende pra Óleoplan, vende pra BSBios!

PG19: Indústria de biodiesel BSBios Passo Fundo.pdf - 19:36 [Você entende? Hoje o agriculto..] (8:1012-8:1479) (Super)

Codes: [Rentabilidade]

Você entende? Hoje o agricultor familiar voltou a plantar Soja! Se você mantiver produtividades menores com Canola, o produtor não vai plantar Canola! Mas se for atrativo pra ele plantar Canola, que dê produtividade e renda! Beleza...Qual é o produtor que tá 
plantando Canola hoje? Não é agricultor familiar! É o agricultor que tem um maior desenvolvimento técnico, tem um agrônomo que ajuda ele a cuidar da lavoura, tem solos padronizados...ahh...estáveis!

PG19: - 19:37 [É, migrou pra cá e pra região ..] (9:1357-9:1462) (Super) Codes: [LUC]

É, migrou pra cá e pra região sul pra região de Cachoeira do Sul, não sei se você já foi naquela região!

PG19: - 19:38 [.Você vai conversar com o pess..] (10:1483-10:1701) (Super)

Codes: [Proximidade institucional]

Você vai conversar com o pessoal da Celena com o Wantuir. A Celena deve importar 60

mil toneladas de Canola do Paraguai! Tudo por rodoviário. Aí atravessa o Rio Uruguai e vem para Guarani (das Missões) pra processar

PG19: - 19:39 [Eu não vejo isso viu! Teria si..] (10:1944-10:2196) (Super)

Codes: [Logística]

Eu não vejo isso viu! Teria sim claro! Um aumento de renda e tal...mas a Canola pra utilização de biodiesel é complicado! Vamos pegar um exemplo que a gente tem aqui! Óleo de Canola chega na gondola a $R \$ 7,00$; você vai vender o biodiesel a $R \$ 1,80$ !

PG19: - 19:40 [Eu acho que diversificação! Ro..] (11:826-11:892) (Super)

Codes: [Diversificação produtiva]

Eu acho que diversificação! Rotação de cultura, acho que é no ponto

PG19: - 19:41 [Hoje a Canola planta em Zoneam..] (12:487-12:697) (Super)

Codes: [Credibilidade]

Hoje a Canola planta em Zoneamento Agrícola, tem sementes certificadas, e tal...mas eu vejo que nós poderíamos...como eu comentei antes, dar uns passos a mais! Sabe? Começar a entrar um pouquinho mais forte!

PG19: - 19:42 [Ah é! O trauma impactou, e voc..] (13:1693-13:1855) (Super)

Codes: [R, V \& I]

Ah é! O trauma impactou, e você tem isso aí dentro do estado do RS, pode conversar numa pequena amostra, produtores que plantam bastante área, não plantam Trigo!

PG19: - 19:43 [Número de famílias então né! 2..] (4:1937-4:2150) (Super)

Codes: [Certificações]

Número de famílias então né! 225 mil né! Número que participaram até ano passado, 2013, foram 98 mil, próximo...o valor distribuído pela agricultura familiar no programa do Selo Social foi 2,8 bilhões de reais!

PG19: - 19:44 [G - É! Exato! Aí assim falando..] (6:105-6:195) (Super)

Codes: [Óleos Nobres]

G - É! Exato! Aí assim falando de Canola! Hoje a Canola não é usada pra produzir biodiesel!

PG20: - 20:1 [É diversificado! Vária de regi..] (4:1479-4:1597) (Super)

Codes: [Diversificação produtiva]

É diversificado! Vária de regiões pra regiões né! Lá em Santa Rosa a quantidade é bem maior de pequenos produtores...

PG20: - 20:2 [ se tu ver a dinâmica, ela é..] (5:1815-5:2020) (Super) 
Codes: [Escala e Verticalização]

... se tu ver a dinâmica, ela é verticalizada né! Por que ela (a indústria) atende o produtor de insumos até a assistência técnica né! Tanto é que hoje tem mais de 100 especialistas pra acompanhamento da

P20:- 20:3 [Mas claro com a entrada do DAP..] (6:338-6:502) (Super)

Codes: [Participação]

Mas claro com a entrada do DAP, isso ajudou a melhorar muito! A participação do agricultor né!

\section{PG20: - 20:4 [É! Em relação a outros concorr..] (6:1509-7:120) (Super)}

Codes: [Concorrência]

- ...O produtor estaria no meio deles, no meio dessa concorrência É, muito concorrido! O que ocorre na lá no Mato Grosso não tem...esse negócio de social né!

PG20: - 20:5 [A - E aumentando a renda, a ca..] (9:282-9:732) (Super)

Codes: [Bioenergia] [Fisiocratismo] [Rentabilidade]

...Então os produtores hoje estão investindo e comprando casa, comprando apartamento, comprando carro! Então isso vai girando a economia, desenvolvendo!

PG20: - 20:6 [Cacequi ali né! Agricultores q..] (9:1293-9:1384) (Super)

Codes: [LUC]

No memos

Cacequi ali né! Agricultores que plantavam arroz ou criavam gado tão migrando pro Soja né!

P20: - 20:7 [Até Cruz Alta que era uma das ..] (9:1435-9:1640) (Super)

Codes: [Soja]

Até Cruz Alta que era uma das maiores produtoras de Soja do Estado está perdendo hoje pra Cachoeira do Sul né! Que antes era tradicional no Arroz! O Arroz tá perdendo espaço e o Soja tá ganhando espaço!

PG20: - 20:8 [Justamente por causa do mercad..] (9:1645-9:1712) (Super)

Codes: [Industrialismo]

Justamente por causa do mercado do biodiesel, do mercado do Soja né!

PG20: - 20:9 [Ao invés de agregar valor aqui..] (10:394-10:566) (Super)

Codes: [Agroindústrias Familiares]

Ao invés de agregar valor aqui...o governo beneficia quem exporta, sem beneficiar o produto interno né! Ao invés de beneficiar a indústria que esmaga, separa e processa...

PG20: - 20:10 [O que eles comentam é essa que..] (11:316-11:1288) (Super) Codes: [Segurança Alimentar]

Não tem nada haver! Porque o óleo...!...o biodiesel é feito do óleo né! O consumo do óleo, ele não vai variar...ahh...porque hoje tem até vários tipos de óleo né... ...Óleo de Arroz, óleo de Canola, óleo de Milho né...e as pessoas também estão saindo muito do óleo pra fazer alimentação! Mas a base da alimentação não é o óleo!

PG20: - 20:11 [O impacto é favorável! Vai ter..] (11:1783-11:2052) (Super) Codes: [Farelo]

O impacto é favorável! Vai ter mais farelo! Tendo mais produção de óleo, tem mais produção 
de farelo, e tendo mais produção de farelo, tu vai baixar o preço do farelo no mercado que consequentemente vai baixar o preço da proteína e que vai baixar o preço da carne!

PG20: - 20:12 [hhh...O que interessa mesmo é ..] (12:219-12:498) (Super)

Codes: [Farelo]

hhh...O que interessa mesmo é o farelo né! O que dita o preço de mercado é o farelo! Não é o óleo! Pode ver que o preço do farelo tá cada vez mais tá subindo né! Mais o óleo se mantém nesse custo de patamar, não variou muito na bolsa de Chicago! Mais o que varia é o farelo!

PG20: - 20:13 [O que eu vejo assim é que a Ca..] (13:777-13:912) (Super)

Codes: [Soja]

O que eu vejo assim é que a Canola ela....ahh...e que o mercado tá voltado pro Soja! É mais Soja e Milho que investem em tecnologia né!

PG20: - 20:14 [Então as três esmagam. Aqui em..] (2:1818-2:1917) (Super)

Codes: [Óleos Nobres]

Então as três esmagam. Aqui em Santa Rosa, o óleo ele é voltado basicamente pra consumo humano né!

PG20: - 20:15 [É! Verticalizados! Camera forn..] (3:1363-3:1487) (Super)

Codes: [Escala e Verticalização]

É! Verticalizados! Camera fornece além das sementes e fertilizantes, até o diesel pra agricultor botar no trator e plantar!

PG20: 20:16 [lsso! Ou ele pode fazer no fin..] (4:345-4:555) (Super)

Codes: [Parcerias]

Isso! Ou ele pode fazer no financeiro...não, eu vou plantar! A empresa financia, por exemplo, pra safra do ano que vem! Financia né! Daí na época quando vem pagar a conta pego o Trigo, pega a Soja e paga né!

PG20: - 20:17 [Vem comprar das cooperativas....] (7:326-7:492) (Super)

Codes: [Reprovação]

No memos

Vem comprar das cooperativas...A cooperativa....ahh...tem os benefícios do governo lá! A cooperativa não precisa provar se vai fazer assistência técnica pro produtor!

PG20: - 20:18 [Isso aí é normal! A fiscalizaç..] (7:1030-7:1323) (Super) Codes: [Reprovação]

Isso aí é normal! A fiscalização do MDA vindo ou não vindo, a gente vai estar sempre acompanhando a lavoura dos produtores! Mas o que ocorre, por exemplo, é assim, tem regiões que a gente atende no qual o sindicato não dá a DAP! Porque o próprio sindicato dentro do sumo faz a negociação.

PG20: - 20:19 [Acontece! A gente briga! Quebr..] (7:1744-7:1794) (Super)

Codes: [Conflitos]

Acontece! A gente briga! Quebra um pau com o MDA...

PG20: - 20:20 [Se você olhar...ehh...o produt..] (8:847-8:918) (Super)

Codes: [Bioenergia] 
Se você olhar...ehh...o produtor hoje é assediado por tudo quanto é lado

PG20: Indústria de Óleo e Biodiesel Camera Energia e Alimentos.pdf - 20:21 [E outra! Você tem muito subsíd..] (8:1532-8:1778) (Super)

Codes: [Participação]

E outra! Você tem muito subsídio do governo federal! Tu tens esse (Programa) Mais Alimentos que compra máquina com 10 anos! E....ahh...toda parte de seguro...então tem muito benefício...e se o produtor não souber aproveitar esse momento bom né!

PG20: -20:22 [O Soja que está se produzindo ..] (10:21-10:136) (Super)

Codes: [Desapontamento]

O Soja que está se produzindo não está ficando no Brasil! Ele está sendo exportado e isso pra indústria não é bom!

PG20: - 20:23 [Não...não sei...o que eu posso..] (10:1385-10:1600) (Super)

Codes: [Ideologia]

Não...não sei...o que eu posso imaginar é por lobby das petroleiras! Por que o Brasil hoje importa bastante diesel! Então o B7 vai aumentar quase $50 \%$ do mercado de biodiesel né! Então isso vai baixar a importação

PG20: - 20:24 [Aí vocês vendem aqui pra Giove..] (12:982-12:1445) (Super) Codes: [Parcerias]

A gente manda pra outras indústrias que são especialistas nisso aí... Comercialização, depois vem pra nós envazar e a gente põe no mercado!

PG20:- 20:25 [Tu pode ver que tem os maiores..] (13:933-13:1250) (Super)

Codes: [Limitações Tecnológicas]

Tu pode ver que tem os maiores produtores nacionais trabalham na parte genética do Soja e do Milho! DuPont trabalha muito forte no Milho! Pionner trabalha muito forte no Milho! Daí vem a GalgoScience...Milho! Depois em Soja né! Depois vem Arroz! Só depois vem Canola, e na

Canola não existe essas multinacionais!

PG20: - 20:26 [Só ia te pedir assim...se você..] (15:2004-15:2133) (Super)

Codes: [Credibilidade]

Só ia te pedir assim...se você publicar algo com o nome da Camera ou meu nome né! Passar pra nós um e-mail pra passar pro meu...

PG22: pdf - 22:1 [Até fala um pouquinho primeiro..] (2:1246-2:1367) (Super)

Codes: [Proximidade institucional]

Até fala um pouquinho primeiro, até pra você entender o Canola como um todo você deve conversar com o pessoal da BSBios!

PG22: - 22:2 [Conheceu ele? Eu sou vice-pres..] (3:280-3:339) (Super)

Codes: [Proximidade institucional]

Conheceu ele? Eu sou vice-presidente técnico da Abrascanola!

PG22: - 22:3 [É, a gente tem uma aproximação..] (3:541-3:701) (Super)

Codes: [Proximidade institucional]

No memos 
É, a gente tem uma aproximação, inclusive com o Tomm também...com o Gustavo Floss, além de fazer esse trabalho, ele é o presidente, ele faz vários trabalhos...

PG22: - 22:4 [Com Canola...a equipe dele nós..] (3:725-3:1077) (Super) Codes: [Cooperação]

Com Canola...a equipe dele nós assessora no campo também! Então já tem...E tem essa ligação institucional com a BSBios apesar de que a gente é concorrente! BSBios, Celena e Giovelli cada um tem seu trabalho de campo, mas a gente tem assim, estamos tentando buscar esse consenso em algumas linhas de trabalho até pro crescimento da Canola em si né!

P22: - 22:5 [Mas tem as diferenças como tod..] (3:1574-3:1857) (Super)

Codes: [Cooperação]

Mas tem as diferenças como toda empresa! Cada um tem sua linha de trabalho e tal! Mas no contexto a gente tenta trocar algumas ideias pra o alinhamento da cultura né! Eles são bem necessários...ehh...o que a gente busca é o intuito comum é que a cultura em si no final ganhe né!

PG22: - 22:6 [Na época quando começou, se co..] (4:132-4:503) (Super)

Codes: [Parcerias]

Na época quando começou, se começou como uma empresa parceira da Camera

Agroalimentos! Não sei se tu já ouviu falar?

A - Eu fui lá na Camera também! Em ljuí né?

$W$ - É, que é uma grande empresa aí! E teve esse trabalho, na época que era parceiro. Em 2001, por aí, se criou a Celena Alimentos, coligada a Camera, que é percentual da Camera, e percentual da Celena!

PG22: - 22:7 [É, acho que o Paraguai deve ch..] (4:1598-4:2034) (Super)

Codes: [Óleos Nobres]

No memos

É, acho que o Paraguai deve chegar aos 70 mil hectares de Canola esse ano! Então assim, essa é a base do trabalho, daí nossa unidade de nossa matriz-sede é em Eldorado do Sul (MT) nós estamos lá em virtude da...lá é a matriz administrativa e financeira e tal...e estamos lá em função da indústria né! Porque estamos ao lado da Alvedra lá que produz todo o óleo pra nós! Óleo refinado! O produto final, então...hoje toda Canola...

PG22: - 22:8 [Parte marca própria, parte ref..] (5:174-5:285) (Super) Codes: [Parcerias]

Parte marca própria, parte refina pra terceiros...digamos assim! Cocamar é uma parceira...Cocamar ou Caramuru!

PG22: - 22:9 [Que hoje a Celena em si então ..] (5:726-5:843) (Super)

Codes: [Fisiocratismo]

Que hoje a Celena em si então usa os três pra Girassol, hoje a Celena é o maior produtor de Girassol do Brasil hoje!

PG22: - 22:10 [E no Canola a gente tem esse t..] (5:867-5:1022) (Super)

Codes: [Inovação]

E no Canola a gente tem esse trabalho todo de base, essas duas culturas principais a gente bota pra frente, faz todo um trabalho de campo e depois compra!

PG22: - 22:11 [Em termos de óleo, a Soja é o ..] (5:1899-5:2097) (Super)

Codes: [Soja] 
Em termos de óleo, a Soja é o carro chefe! Em termos de produção, produção própria é o Canola! Canola...vai ser ultrapassado pelo Girassol em função de volume, mas o Canola ainda é

o carro chefe!

PG22: - 22:12 [Hoje assim, se criou um trabal..] (6:81-6:303) (Super)

Codes: [Inovação]

Hoje assim, se criou um trabalho diferenciado, que nosso diretor assim, ele investiu muito na cultura que...Soja tudo mundo sabe, Soja todo mundo tem! É uma commoditie e tal! E eles queriam entrar num mercado diferente!

PG22: 22:13 [A Canola, eu vejo que ela cheg..] (6:666-6:902) (Super)

Codes: [Participação]

A Canola, eu vejo que ela chegou num momento que...aí que eu vejo o papel mais importante de algumas empresas...a própria Celena, a BSBios, tal...com essa facilidades do governo...bah...hoje se conseguiu o Zoneamento Agroclimático...

PG22: - 22:14 [É uma cultura que entrou num m..] (6:923-6:1306) (Super)

Codes: [Rentabilidade]

É uma cultura que entrou num momento interessante! Não é que como o Trigo, mas é uma alternativa de inverno bem interessante! Tem uma área muito grande ociosa...o pessoal tá buscando...e tem uma rentabilidade muito interessante!

Então ela tá crescendo...e até então o crescimento é sustentável! Acredito que já deveria ter crescido mais, mas está num crescimento sustentável!

PG22: pdf - 22:15 [Acho que...na hora que nós bat..] (6:1311-6:1449) (Super)

Codes: [Viabilidade da Canola pra biodiesel]

Acho que...na hora que nós bater num limite ' $x$ ' lá de produção, atendendo ao consumo humano, daí sim né...vai se partir pra biodiesel né!

PG22: Indústria de Óleo Vegetal Celena Alimentos.pdf - 22:16 [Acho que é bem por aí viu...pr...] (6:2119-6:2529) (Super)

Codes: [Óleos Nobres]

Acho que é bem por aí viu...primeiro ele vai ter que atender essa demanda, propriamente falar...ahh...o Brasil tem que plantar no mínimo 100, 120 mil hectares pra atender o mercado hoje! Nesse exato momento é um mercado crescente...ano a ano, mas é como você falou: é um óleo nobre! As pessoas estão melhorando a qualidade de vida também, isso eu vejo como um todo, claro cada classe tem sua situação...

PG22: - 22:17 [Isso é automático né! Eu vejo ..] (7:150-7:571) (Super)

Codes: [Escala e Verticalização]

Isso é automático né! Eu vejo que hoje...falando em 100 mil hectares de Canola...eu taria começando a atender o momento hoje, porque cada ano vai crescendo essa procura, então cada ano tem que crescer a produção! Ahh no momento que atingir um pico lá!...Agora sim vai se pensar ou em fazer exportação, tem muita gente que pode buscar exportação tal...ou pode propriamente, não vamos pensar o Canola como biodiesel!

P22: - 22:18 [Mato Grosso é uma outra realid..] (8:831-8:1161) (Super)

Codes: [Limitações Tecnológicas]

Mato Grosso é uma outra realidade que tem que resolver material (sementes) específico pra 
lá! São Paulo, Mato Grosso do Sul, Paraná tem! Eu acho que falta um pouco de trabalho! Alguns ajustes técnicos ainda tem que ser feitos...tem que fazer...mas é ainda um trabalho contínuo que tem que fazer! Empresas, pessoas...estar lá!

\section{PG22: - 22:19 [Investimento também! E algumas..] (8:1190-8:1603) (Super)}

Codes: [Competição de culturas]

Investimento também! E algumas empresas entenderem que não vai substituir o Trigo e a Cevada! Eles focam muito. Tem muitas áreas ociosas que dá pra trabalhar! Só pegar no RS! Se

falar só nesses 1 milhão e 200 mil hectares ociosos que vão ficar aí e tal, ou um pouco mais...tipo Trigo! Trigo vai plantar 1 milhão e 200 mil hectares no RS, tu tem pastagens, tem Cevada, tem Aveia...e o resto que fica ocioso?

\section{PG22: - 22:20 [Era só trabalhar essas áreas! ..] (8:1625-8:1984) (Super) \\ Codes: [Cooperação]}

Era só trabalhar essas áreas! Já seria suficiente! Sim! A cultura tem alguns ajustes técnicos e genéticos...tem que fazer, está se fazendo, tem...tipo o Tomm tem um papel bastante importante nisso, tipo o X está se aproximando mais da cultura em si mais...e realmente algumas empresas comprar esse trabalho né! 60 mil hectares é muito pouco ainda né!

\section{PG22: - 22:21 [É, eu acho que sim! Ano passad..] (8:2069-8:2454) (Super)}

Codes: [Desapontamento]

É, eu acho que sim! Ano passado a gente não cresceu por causa da problemá...do problema de semente né! Não teve semente suficiente! Esse ano a semente chegou suficientemente...mas acho que vai ter um crescimento assim que, eu vejo que é sustentável. Eu prefiro assim que a Canola cresça $30 \%$ ano ano, do que cresça $100 \%$ de um ano pro outro e

não seja sustentável né...não vai ser

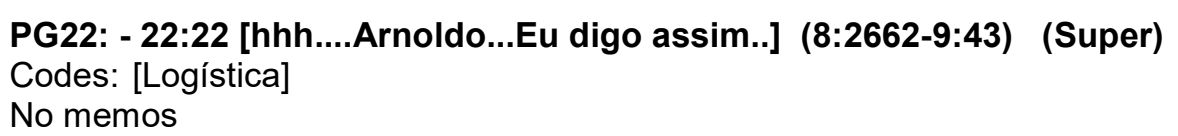

hhh....Arnoldo...Eu digo assim que em partes é! Por que tu ficas limitado a ter um fornecedor que ele produz, produzia numa região só e ano passado deu um problema ele já não conseguiu o tempo suficiente de importar dos EUA, importar da Austrália pra trazer pra nós com tempo hábil! Nós ficamos limitados!

\section{P22- 22:23 [O Grando é! O X...é...e...] (9:193-9:811) (Super) \\ Codes: [Inovação]}

...é...ele tem uma produção independente e tal, mas são outras empresas. Produção de híbridos e tal...Já tem, tá se fazendo né! $E$ vejo algumas empresas importantes entrando no processo. A própria Nuseed eu acho? Que comprou a Atlântica Sementes. A Nuseed é um grande trade de sementes no mundo né! Tem a Farmaco que é o braço químico e a Nuseed que é de sementes. Eles tão assim, eles vão...de repente pode demorar uns dois, três anos, mais eles tem uma genética interessante! Eles vão começar produzir no Brasil, então, eu acho que isso é saudável ter mais empresas fornecendo sabe!

\section{PG22: I - 22:24 [Eu diria assim falamos assim n..] (9:928-9:1215) (Super)}

Codes: [Otimismo]

Eu diria assim falamos assim num horizonte de três a cinco anos que vamos ter outra empresa que...o processo começa a ficar grande, aí eles vislumbram uma situação ahh...é possível numa imensidão dessa trabalhar culturas como da Canola. Algumas entraram no Brasil agora, acho que... 
PG22: - 22:25 [A gente faz uma pesquisa paral..] (9:1428-9:1747) (Super)

Codes: [Inovação]

A gente faz uma pesquisa paralela porque...eu vejo assim...tu deve ter falado com o Tomm...eles tem algumas restrições acho! Esse ano a gente acompanhou e tentou buscar um recurso do 8 milhões pro projeto Canola! Com alguns recursos que foram priorizados e se perdeu esse recurso...então se parou tudo de novo sabe

PG22: - 22:26 [Federal! Tinha um projeto muit..] (9:1852-9:2212) (Super)

Codes: [Ideologia]

Federal! Tinha um projeto muito grande lá! E...tava puxando a frente era via Embrapa né! Vários pesquisadores, viajamos até pro Mato Grosso! Eu fui com eles. A gente fez um trabalho de tentar ver a possibilidade de produção de Canola lá no MT...só que pá! Esbarrou! E priorizou outros projetos, o governo priorizou outros projetos! A Canola parou de novo!

PG22: - 22:27 [Então a gente, Celena, outras ..] (9:2217-9:2483) (Super)

Codes: [Inovação]

Então a gente, Celena, outras empresas, a gente faz um trabalho paralelo de algumas pesquisa, diz...ahh...tem outras sementeiras, a gente traz pra testar pra ver como é que vai, então...é...é um trabalho, daí é privado né! Não e trabalho público, é privado que...

PG22: - 22:28 [A Giovelli também tem...assim,..] (10:209-10:675) (Super) Codes: [Escala e Verticalização]

A Giovelli também tem...assim, até pra tu entender...tem várias indústrias aí que poderiam se fazer a extração de Canola! Só que tem um detalhe também....como o volume não é muito grande, algumas indústrias grandes tipo...ahh...vamos dizer tipo a Três Tentos montou uma ali em ljuí grande!....ahh...a Camera tem várias plantas!...como o volume é pequeno, tipo eles não vão parar uma indústria pra fazer tipo uma semana de Canola! E depois pra voltar pro Soja!

P22: - 22:29 [Na verdade eu também não sou! ..] (10:1029-10:1355) (Super)

Codes: [Limitações Tecnológicas]

Na verdade eu também não sou! Sou de um setor...mas máquina eu não entendo muito também...mas assim...ehh...Te dizer...a indústria foi feita com algumas adaptações! A Soja eu vou só esmagar no produto químico, no Hexano! Dissolvente, aquela coisa toda que eu não consigo extrair em prensa. Então tem que quebrar o grão...

\section{PG22:- 22:30 [Mas são óleos diferenciados qu..] (11:1216-11:1476) (Super)}

Codes: [Inovação]

Mas são óleos diferenciados que a gente atende o mercado...Ahh...o Girassol Altoleico que é uma nova

cultura aí...! Um Girassol, uma semente específica que gera um óleo especificamente pra indústria...a gente tá...tá bem avançado na frente pra isso aí né!

\footnotetext{
PG22: - 22:31 [Não sei se não foi bem isso.....] (12:254-12:730) (Super)
}

Codes: [Inovação]

Não sei se não foi bem isso...isso tudo começou de 2007 pra 2008...eu não entendi porque que era isso...o Girassol Altoleico chegou...quando viu nosso diretor falou: nós vamos produzir Girassol Altoleico! Mas como? Então nós vamos pra Argentina e vamos entender lá...e dar uma avançada, entende? Começamos aqui! O Girassol no RS tava perdendo muito espaço, não tem espaço aqui em função das culturas...ahh...Girassol safra normal se planta em Agosto e colhe Dezembro! 
PG22: - 22:32 [ai chocar com o Soja! Tava per..] (12:822-12:1139) (Super)

Codes: [Competição de culturas]

ai chocar com o Soja! Tava perdendo muito campo...daí se pensou...não, mas no MT dá pra reativar porque no MT é muito interessante! Planta o Soja e depois se planta o Girassol na safrinha...é fantástico! Tanto é que o Girassol hoje lá em cima (Norte) tá em fase de crescimento...daí que começou todo o trabalho.

PG22: - 22:33 [Pode! Então assim, esse é um t..] (12:1944-12:2164) (Super) Codes: [Parcerias]

Pode! Então assim, esse é um trabalho que está avançando bastante, e é claro as empresas também estão em parte começando um trabalho...ahh...Cargill! Hoje é nosso grande comprador é Cargill que revende pra Pepsico né!

PG22: - 22:34 [É! Essa é...porque a gente tá ..] (14:1332-14:1827) (Super) Codes: [Cooperação] [Parcerias]

É! Essa é...porque a gente tá aqui na verdade? Tu andou dez quilômetros em estrada de chão, fora da cidade...um negócio...A gente só tá aqui por causa da indústria! Uma indústria aqui que na época tava ociosa...!...ehhh...a gente fez uma bela parceria com a Warpol! Onde eles ajustaram a fábrica e tal. Eles fazem todos o recebimento pra nós, recebem, secam, limpam...e fazem todo o processo de industrialização e entregam o óleo e o farelo pronto! Né! Eu só faço o restante do trabalho

P22: - 22:35 [É, tu falou com as pessoas, nã..] (16:99-16:353) (Super)

Codes: [Expertise]

É, tu falou com as pessoas, não sei com que tu falo antes, mas o Edson Gross é uma referência! Esse é um cara que tá no processo desde o início! Quando foi retomada a Canola aqui em dois mil e pouquinho, ele já tava plantando a Canola e tendo sucesso!

PG22: - 22:36 [Ele é um farelo assim que vai...] (16:1111-16:1529) (Super)

Codes: [Farelo]

Ele é um farelo assim que vai...é, hoje ganhou um mercado interessante só que tão tem oferta ainda! Mas ele substitui bem o farelo de Soja! Um farelo que vale em torno de $70 \%$ do valor do farelo de Soja e tem uma proteína interessante eu algo de $36 \%$...nas dietas aí, o grande foco é (são) aves! E...agora sim um trabalho forte, que a gente que tem uma bacia leiteira muito grande! Pessoal tira muito pra...pra...

PG22: - 22:37 [Arnoldo, nós tamos assim...não..] (17:1511-17:1711) (Super) Codes: [R, V \& I]

Arnoldo, nós tamos assim...não é que pá!...queremos sair da mão...nós queremos resolver esse problema produtivo, nós queremos ver se realmente o que eles estão nós trazendo é o melhor que tem...né!

PG22: Indústria - 22:38 [Tô limitado! Na produção aí es..] (18:5-18:493) (Super) Codes: [Inovação]

Tô limitado! Na produção aí está tendo uns picos de produção. Tem uma estabilidade, mas ainda preciso ver se é o clima, ou verdadeiramente a semente! Então, nós buscamos muito isso né!

A gente pesquisa várias sementes de vários lugares do mundo! Eles nós mandam aí e tal...Procura o cara que sabe disso...eu vou te mostrar...Eu demorei um ano pra liberar isso aqui (mostrando um pacote)...Isso veio do Canadá pra mim! São oito variedades de Linhaça que eu vou pesquisar agora! 
PG23: - 23:1 [lsso vai ser muito difícil né] (1:2778-1:2806) (Super)

Codes: [Segurança Alimentar]

Isso vai ser muito difícil né

PG23: - 23:2 [Óleo de Canola é um óleo muito..] (2:18-2:67) (Super)

Codes: [Óleos Nobres]

Óleo de Canola é um óleo muito nobre hoje no país!

PG23: - 23:3 [Eu acho assim né! Hoje a Canol..] (3:1372-3:1599) (Super)

Codes: [Diversificação produtiva]

Eu acho assim né! Hoje a Canola...é que nem tu estás colocando aí né! De fato, o agricultor que produz grão, ela não compete...ahh...não compete com cultura de inverno, por que ela entra justamente pra rotacionar no inverno!

PG23: - 23:4 [Nós posicionamos ela em áreas ..] (3:1621-3:1873) (Super)

Codes: [Benefícios Edáficos]

Nós posicionamos ela em áreas que não dá...porque a cultura de inverno...em que predomina Trigo e Cevada né! Daí não dá pra tu plantar todo ano né! Porque começa a dar doença e tal! Então no máximo dois anos! Então tu vai ter sempre áreas que vão...

PG23: - 23:5 [Tá sendo...ahh...vão tá sendo ..] (3:1897-3:2051) (Super)

Codes: [Rentabilidade]

Tá sendo...ahh...vão tá sendo ocupada com produção, vamos dizer assim, utilização econômica né! Usar o potencial econômico também pra cultura de inverno!

PG23: - 23:6 [ai estar com Aveia pra desseca..] (3:2074-3:2418) (Super)

Codes: [Diversificação produtiva]

ai estar com Aveia pra dessecar, pra plantar, então...tu vai acabar de fato não tendo aproveitamento econômico naquele inverno! E aí que realmente, ela entra nessas áreas..! Nós entendemos ainda hoje que se tu comparar ela (Canola) com Trigo, é melhor Trigo, comparar com Cevada, é melhor Cevada! Mas...! Como a proposta não é monocultura!

\footnotetext{
PG23: - 23:7 [Nem a monocultura da Canola no..] (3:2440-4:129) (Super)

Codes: [Benefícios Edáficos]

Nem a monocultura da Canola no inverno! Nem a cultura do Trigo, e da Cevada, que são da mesma família! No caso de gramínea né! Então essa é...ela entra no esquema de rotação da

propriedade pra suprir no inverno...claro melhora a fertilização, melhora a estrutura de solo, e também como você bem colocou, principalmente pra cultura de inverno subsequente ou pra cultura da Soja que vêm em seguida dela!
}

PG23: - 23:8 [Justamente na entressafra do S..] (4:358-4:419) (Super) Codes: [Soja]

Justamente na entressafra do Soja que entra a safra da Canola.

P23: - 23:9 [Também é um potencial de preço..] (4:421-4:474) (Super)

Codes: [Rentabilidade]

Também é um potencial de preços pra melhorar a renda

PG23: - 23:10 [ntão depende da tua produtivid..] (4:478-4:676) (Super)

Codes: [Limitações Tecnológicas] 
ntão depende da tua produtividade! A questão hoje da cultura da Canola está muito ligada a questão da produtividade! Tem boas e ruins. Ainda não se conseguiu estabilizar uma linha de produção boa

PG23: - 23:11 [Então, eu acho assim ô, hoje c..] (4:844-4:1055) (Super) Codes: [Canola]

Então, eu acho assim ô, hoje com a agricultura familiar é uma...nós estamos incentivando muito a questão da Canola aqui. Esse ano vamos ter uma área considerável! Montamos um programa próprio, da cooperativa!

PG23: - 23:12 [Sim, já! Isso mesmo. Dois mil ..] (4:1211-4:1396) (Super) Codes: [Inovação]

Sim, já! Isso mesmo. Dois mil hectares e estamos projetando...a ideia é crescer mais ainda! Porque por todos esses fatores aí, acreditamos que demais da...então assim...é ver pra crer!

PG23: - 23:13 [Aquela caixa especial! Compram..] (4:1727-4:1958) (Super)

Codes: [Inovação]

Aquela caixa especial! Compramos várias né! Porque todo mundo que plantar no mesmo dia, então! Tem que ter várias...investimos, porque tem que dar estrutura pro pessoal plantar mesmo...ahh...a Canola! Então foi bem interessante!

P23: - 23:14 [A ideia nesse setor, nessa cul..] (4:1962-4:2356) (Super)

Codes: [Bioenergia] [Industrialismo]

A ideia nesse setor, nessa cultura, é crescer mais! Hoje nós temos nessa questão do biodiesel que...que...vamos dizer assim dá assim um incentivo maior pro agricultor familiar poder plantar, porque tem um bônus melhor, que a própria utilização da portaria do biodiesel consta! Se fazer óleo de Soja...se fazer com Soja...tem um peso...pra Selo Social! Se fizer com Canola é outro peso...

P23: - 23:15 [A ideia nesse setor, nessa cul..] (4:1962-4:2355) (Super)

Codes: [Canola]

A ideia nesse setor, nessa cultura, é crescer mais! Hoje nós temos nessa questão do biodiesel que...que...vamos dizer assim dá assim um incentivo maior pro agricultor familiar poder plantar, porque tem um bônus melhor, que a própria utilização da portaria do biodiesel consta! Se fazer óleo de Soja...se fazer com Soja...tem um peso...pra Selo Social! Se fizer com Canola é outro peso.

PG23: - 23:16 [Não, não...estou falando diret..] (5:300-5:535) (Super)

Codes: [Certificações]

No memos

Não, não...estou falando diretamente de Canola, nada haver! Eu estou falando ô seguinte ô...a cooperativa consegue, porque nós vamos vender esse Soja, essa Canola, direcionar o Selo

Social dessa Canola pra um indústria de biodiesel!

P23: - 23:17 [Vai buscar, está buscando parc..] (5:620-5:683) (Super) Codes: [Parcerias]

Vai buscar, está buscando parceria com a indústria de biodiesel!

PG23: - 23:18 [Não! Uma indústria que não con..] (5:714-5:769) (Super)

Codes: [Concorrência] 
Não! Uma indústria que não concorra com nós no campo né!

PG23: - 23:19 [Essa indústria concorre com nó..] (5:790-5:830) (Super)

Codes: [Concorrência]

Essa indústria concorre com nós no campo!

PG23: - 23:20 [Então não é, não é uma empresa..] (5:955-5:1058) (Super)

Codes: [Concorrência] [Reprovação]

Então não é, não é uma empresa parceira né! Empresa parceira é aquela que não vem competir contigo né!

PG23:- 23:21 [Mas tá nessa linha de biodiese..] (5:1462-5:1735) (Super)

Codes: [Rentabilidade]

Mas tá nessa linha de biodiesel, empresa de biodiesel...então como...eu quero dizer o seguinte ô, que hoje o bônus que nós vamos receber da indústria....ahh...pra fornecer Canola pra indústria de biodiesel é superior do que fosse fornecer Soja pra indústria de biodiesel!

PG23:- 23:22 [Entendeu? A indústria de biodi..] (5:1777-5:1905) (Super) Codes: [Certificações]

Entendeu? A indústria de biodiesel, ela consegue compensar muito mais a necessidade do Selo Social com Canola do que com Soja!

PG23: - 23:23 [Então, o bônus é melhor e poss..] (6:55-6:175) (Super)

Codes: [Participação]

Então, o bônus é melhor e posso passar esse valor pro produtor melhor também né! Produtor Dapiado (aquele que tem DAP).

PG23: - 23:24 [Nós faz tempo, faz alguns anos..] (6:260-6:404) (Super)

Codes: [Parcerias]

Nós faz tempo, faz alguns anos que estamos trabalhando com Canola, mas nós trabalhamos todos os outros anos sempre em parceria com a BSBios né!

PG23: - 23:25 [É! Então eu...a ideia é essa! ..] (7:608-7:686) (Super)

Codes: [Logística]

É! Então eu...a ideia é essa! Eles tem uma estrutura também pra manter e nós...

PG23: - 23:26 [É ano passado nós tínhamos pou..] (8:5-8:69) (Super)

Codes: [Logística]

É ano passado nós tínhamos pouca Canola porque não tinha semente!

PG23: - 23:27 [Precisa fazer DAP hoje! Porque..] (8:663-8:933) (Super)

Codes: [Participação]

Precisa fazer DAP hoje! Porque hoje o grande diferencial é vender a Soja com esse diferencial, com esse valor agregado né! Que ele te dá! Mas também linha de crédito né! Juros facilitados! Hoje pessoal vai no banco arrumar dinheiro numa facilidade...que tem crédito..

PG23: - 23:28 [Amanhã de manhã então, nós vem..] (9:550-9:639) (Super)

Codes: [Cooperação]

Amanhã de manhã então, nós vemos com nosso coordenador da área técnica pra te encaminhar 
PG23: - 23:29 [Eu faço parte de uma família q..] (9:1717-9:1928) (Super)

Codes: [Inovação]

Eu faço parte de uma família que 4...mais 3 irmãos né! Temos aviários né! Aviário de frango de corte e tem uma lavoura de 150 hectares de terra arrendada imprópria, mas daí seria em 4 né! Por isso que não dá!

PG23: - 23:30 [Então esse ano também tem uma ..] (10:94-10:216) (Super)

Codes: [Agroquímica]

Então esse ano também tem uma área um pouco menos justamente por que tivemos que passar Spyder num pedaço ai né, na Soja!

PG23: - 23:31 [Não dá pra plantar agora. Se n..] (10:253-10:538) (Super)

Codes: [R, V \& I]

Não dá pra plantar agora. Se não seria uma área maior. Tem 40...35 hectares de área! De canola! E assim, aquilo que falo pros produtores, eu só um que diz isso tranquilamente! Pra mim Canola é risco zero! Por que risco zero? Porque justamente numa área de inverno que só dá custo!

PG23: - 23:32 [É! Então tu tens todos os cust..] (10:728-10:967) (Super)

Codes: [Canola]

É! Então tu tens todos os custos dos tratos culturais pra instalar essa cultura, manter essa cultura, dessecar essa cultura! Tudo isso é custo! Sem retorno econômico, direto dela (Aveia)! Aí tu plantando a Canola, aproveitando essa área

PG23: - 23:33 [Então, você não vai ter risco ..] (10:970-10:1080) (Super)

Codes: [Participação]

Então, você não vai ter risco nenhum,

porque tudo que tu planta, como essa área é financiada, e é pelo Pronaf

PG23: - 23:34 [Aonde tem Proagro Mais aonde t..] (10:1083-10:1139) (Super)

Codes: [Participação]

Aonde tem Proagro

Mais aonde tiver problema de estiagem

PG23:- 23:35 [E corrigido! Sem custo! Por is..] (10:1483-10:1595) (Super)

Codes: [R, V \& I]

E corrigido! Sem custo! Por isso que eu falo. Cultura sem risco! Né! Tu corre risco de ganhar dinheiro! (risos)

PG23: - 23:36 [Resistentes. Mas isso tem, mui..] (10:1789-10:1889) (Super)

Codes: [Segurança Alimentar]

Resistentes. Mas isso tem, muita, muita resistência! Inclusive com técnicos, gente de dentro nosso!

PG23: - 23:37 [De um passado sem tecnologia, ..] (10:2075-10:2264) (Super)

Codes: [Desapontamento] [Limitações Tecnológicas]

De um passado sem tecnologia, de um passado com variedades que deixavam um residual de...de acho que era uma doença, Exiquitonia...não sei! Aquilo da haste! Tinha um problema de solo né!

PG23: - 23:38 [É! Tudo isso aí é algo assim q..] (11:525-11:910) (Super) 
Codes: [Inovação]

É! Tudo isso aí é algo assim que tem tudo haver e hoje é uma situação lenta...assim ô, nós encorajamos...nós compramos dois mil hectares de sementes! Trouxemos pra cá as sementes! É....pensamos várias vezes antes de trazer, queríamos trazer só a metade. Achamos que não ia fazer 2 mil hectares. Fizemos até parceria com a Cooperlate pra alguns hectares, uma outra cooperativa daí

PG23: - 23:39 [Fizemos até parceria com a Coo..] (11:825-11:911) (Super) Codes: [Parcerias]

Fizemos até parceria com a Cooperlate pra alguns hectares, uma outra cooperativa daí.

PG23: - 23:40 [Fizemos uma parceria com eles!..] (11:1032-11:1479) (Super) Codes: [Parcerias]

Fizemos uma parceria com eles! Nós e eles! Nós ajudamos, nós somos uma cooperativa que...ahh...nós convidamos também a Cotrisan pra participar do projeto. Nossa proposta seria assim ô, abrimos o guarda-chuva! Estávamos dispostos a ser o guarda-chuva! Uma central com

todos ligados a nós! Fica melhor né! Achamos que é melhor as cooperativas fazerem parceria conosco do que fazer com a indústria! E daí nós fazermos parceria com a indústria!

PG23: - 23:41 [Não, dificuldade não! Que nós ..] (11:1790-11:1971) (Super)

Codes: [Esforço de planejamento]

Não, dificuldade não! Que nós planejamos isso já tem muito tempo! Nós planejamos isso em...nós estamos em...? Nós estamos no mês de Abril, nós definimos a compra dela em Janeiro!

PG23: - 23:42 [Pra garantir a importação, não..] (11:2118-11:2418) (Super)

Codes: [Esforço de planejamento]

Pra garantir a importação, não foi de agora a decisão de plantar Canola! Mesma coisa agora, daqui um pouco mais tem que começar o planejamento do ano que vem! Em cima da colheita nós vamos definir o planejamento. Mas com certeza antes nós temos que definir o quanto de sementes pro anos que vem!

PG23: - 23:43 [Então esse é um papel nosso em..] (12:18-12:212) (Super)

Codes: [Inovação]

Então esse é um papel nosso em termos de chamar uns parceiros nossos pra participar do processo, mas principalmente mexer no nosso produtor! Então está bem interessante, esse ano virou muito!

PG23: - 23:44 [Tem potencial! Hoje se tu cons..] (12:481-12:814) (Super)

Codes: [Pertencimento]

Tem potencial! Hoje se tu considerar que mais ou menos $30 \%$ da área é aproveitada, outros $40 \%$ da área é...tem plantio de Trigo, por exemplo, de inverno tem Trigo e Cevada, nós podemos, você tendo 10 / 8 mil hectares de Trigo...Trigo e Cevada 10 mil hectares dá pra considerar que mais da metade disso dá pra trabalhar com Canola!

PG23:-23:45 [É, nós ano passado foi o prime..] (12:1078-12:1531) (Super)

Codes: [Expertise]

É, nós ano passado foi o primeiro ano que nós trabalhamos com Canola, nós secamos, beneficiamos...ano passado...nos outros anos nós recebíamos e passávamos pra BSBios. Bruta! 
Assim que recebia, passava. Não fazia processamento interno. Secagem, classificação...e ano passado como nós tínhamos pouca Canola, nós optamos digamos assim, esse ano nós vamos fazer todo o processo! Até pra conhecer a cultura no processo também né! De beneficiamento.

PG23: - 23:46 [Aí fizemos tudo! Até certo pra..] (12:1557-12:1870) (Super) Codes: [Conflitos]

Aí fizemos tudo! Até certo pra nós perder dinheiro né! Mas depois vimos que estamos pensando pequeno! Por que daí tu vê melhor as quebras que dá. $E$ de fato né, deu umas diferenças aí, mas não deu prejuízo! Mas deu umas diferenças, umas diferenças com a Giovelli, em relação ao medidor de aparelho de umidade.

PG23: - 23:47 [E também tem o seguinte, nós c..] (13:5-13:153) (Super) Codes: [Concorrência]

E também tem o seguinte, nós criamos uma oportunidade pra eles, porque também tem a Celena né, que pode ser também uma oportunidade pra cooperativa

PG23: Cooperativa Coasa de Água Sant.pdf - 23:48 [Hoje tu fala aqui assim em rel..] (13:477-13:628) (Super)

Codes: [Concorrência]

Hoje tu fala aqui assim em relação aqui a indústria... a BSBios tá com trabalha na nossa área de ação, porque é uma indústria que quer originar direto

PG23: - 23:49 [Essa é uma ligação que é uma g..] (13:631-13:933) (Super)

Codes: [Reprovação]

Essa é uma ligação que é uma grande crítica das cooperativas pra o Programa Nacional de Produção de Biodiesel é que o programa veio pra que? Pra ajudar na inserção da agricultura familiar no processo produtivo.

Então é essa a ideia! Aí evidente que é a agricultura familiar é suas organizações né!

PG23: - 23:50 [No início foi assim, hoje o pr..] (13:954-13:1113) (Super)

Codes: [Reprovação]

No início foi assim, hoje o processo nas indústrias indo diretos nos produtores está enfraquecendo as instituições, as organizações da agricultura familiar...

PG23: - 23:51 [Por que elas vem com um patama..] (13:1134-13:1277) (Super) Codes: [Pertencimento]

Por que elas vem com um patamar de indústria querendo o que? Querendo os melhores produtores. A indústria nunca vai focar no pequeno produtor!

PG23: - 23:52 [É! Mas não que ela vai intensi..] (13:1428-13:1626) (Super)

Codes: [Reprovação] [Segurança Alimentar]

É! Mas não que ela vai intensificar uma coisa pra trabalhar com o pequeno produtor! Ela quer volume! Ela não quer quantidade de produtor assistido! Ela quer volume de produção! Ela quer produção!

PG23: - 23:53 [O importante é o tanto de Soja..] (14:618-14:737) (Super)

Codes: [Participação] [Reprovação]

O importante é o tanto de Soja com DAP! Não é quantos produtores são assistidos! Ela quer saber quantos sacos de Soja! 
PG23: - 23:54 [lsso que dá dinheiro pra ela (..] (14:758-14:970) (Super)

Codes: [Certificações]

Isso que dá dinheiro pra ela (indústria)! Isso que dá retorno! Não é quantidade! Mesmo porque hoje a cooperativa pra ela ter Selo Social pra ela ter DAP (jurídica) ela precisa ter $60 \%$ do quadro social com DAP!

PG23: - 23:55 [A indústria não tem essa exigê...] (14:975-14:1326) (Super)

Codes: [Conflitos] [Reprovação]

A indústria não tem essa exigência de comprar $60 \%$ de agricultor com DAP! Ela compra de $10 \%$, passa tudo! Passa os $10 \%$ na indústria, ela não tem esse controle de quantidade...não interessa pra ela a quantidade de produtor, interessa o volume de produção! Isso é elitização! Isso está indo contra o Programa! Contra aquilo que o Programa foi criado!

PG23: - 23:56 [lsso aí! E nós dissemos isso c..] (14:1366-14:2146) (Super)

Codes: [Reprovação]

Isso aí! E nós dissemos isso claramente pro pessoal do Ministério! E o começo do fim do Programa! Pelo menos naquilo que eles desejam atingir! Não vai atingir...não vai ter inserção de ninguém nesse processo! Vai ter uma elitização do processo! Nessa lógica da indústria ir direto ao produtor e verticalizar! Ela verticaliza tudo! Insumos, tudo! E ela faz o que? Como é uma indústria e tem outros benefícios e bá bá bá...! Ela consegue competir com as cooperativas né...! Que trabalham assistência técnica pra produzir outras culturas, tem uma estrutura toda pra manter né, específica pra isso! Ela (indústria) consegue competir com as cooperativas, enfraquece economicamente as cooperativas, até o ponto de fazer que as cooperativas se inviabilizem economicamente!

PG23: - 23:57 [É, não é só o biodiesel! É tod..] (14:2222-14:2448) (Super) Codes: [Pertencimento]

É, não é só o biodiesel! É toda uma função social! Quer dizer! Nós vamos penalizar bastante se continuar essa política de verticalização das indústrias! Então nós estamos chamando muita atenção do governo em relação a isso!

PG23: - 23:58 [Porque não existe...eu acho as..] (15:572-15:720) (Super)

Codes: [Segurança Alimentar]

Porque não existe...eu acho assim, na minha opinião não tem como nós...mesmo com os Polos...! Conversa! Tchê! Essas indústrias elas querem mercado!

PG23:- 23:59 [Não adianta! Isso já foi conve..] (15:825-15:1417) (Super) Codes: [Concorrência]

Não adianta! Isso já foi conversado! Ah...nós somos concorrente aqui, mas nós vamos nós respeitar! Quando é que vão respeitar? Os caras tem uma estrutura aí que tem que se pagar né! Eles não têm, não têm um cliente! Vão ter que achar o cliente! Vão buscar de quem os clientes? Dos outros! Simples né! Eles vão tirar dos outros! Não tem! É assim que nós crescemos! Nós tivemos um faturamento menor, nós crescemos da onde? Crescemos conquistando clientes dos outros! Muito simples! A conta é essa! Não tem outra conta! Isso não é...o mercado é assim!

PG23: - 23:60 [E o biodiesel (setor) ajudou b..] (15:1421-15:1461) (Super) Codes: [Bioenergia]

E o biodiesel (setor) ajudou bastante né!

PG23: - 23:61 [Porque em 2005 nós tínhamos um..] (15:1906-15:2138) (Super)

Codes: [Agroindústrias Familiares] [Bioenergia] [Inovação] 
Porque em 2005 nós tínhamos uma planta (projeto) industrial do biodiesel né! Nós tínhamos a primeira....até o projeto era...o Biodiesel da Agricultura Familiar! Projeto que dominava era isso né! De ser uma indústria, uma planta...

PG23: - 23:62 [A minha, a minha avaliação é a..] (17:1038-17:1418) (Super) Codes: [Industrialismo]

A minha, a minha avaliação é a seguinte ô...logo em seguida nós desistimos do projeto, foi pra fase de desistência o projeto...e depois enterramos de vez quando saiu a notícia da BSBios em Passo Fundo! Nós eramos pra $45 \mathrm{mil} / \mathrm{dia}$ (capacidade de produção) e com não muito de investimento podia passar pra $90 \mathrm{mil} / \mathrm{dia}$ ! Eles (BSBios) anunciaram $300 \mathrm{mil} / \mathrm{dia}$ ! Aqui em Passo Fundo..

PG23: - 23:63 [Não tinha esse formato ainda n..] (17:1549-17:1705) (Super) Codes: [Inovação]

Não tinha esse formato ainda né! Nosso trabalho a gente tava pensando em vender pra frota de ônibus de Passo Fundo...inclusive pros nossos associados aqui!

\section{PG23: -23:64 [É! Eu penso que por causa diss..] (19:572-19:780) (Super)}

Codes: [Bioenergia]

É! Eu penso que por causa disso, o pessoal nós colocou ai...nós estamos num livro aí como protagonistas no desenvolvimento no RS pelo BRDES colocou isso...e...e...isso aí foi em função da entrada do BRDES!

\section{PG23: - 23:65 [Hoje a cooperativa cresceu mui..] (19:802-19:1126) (Super)}

Codes: [Agroindústrias Familiares] [Participação]

Hoje a cooperativa cresceu muito...por méritos próprios! Evidente né! Tem que ter os méritos próprios né! Mas hoje se tu não tens recursos financeiros e não está aliado a um banco estratégico né...e pela política do governo federal com os juros subsidiados! O Pronaf Agroindústria que nós acessamos aí foi fundamental!

\section{PG23: - 23:66 [Eu acho assim, que...ehh...é i..] (19:1988-19:2258) (Super)}

Codes: [Pertencimento]

Eu acho assim, que...ehh...é isso que, hoje o cooperativismo...tem que ter essa preocupação em sempre se puxar a orelha! O cooperativismo nunca enxergou a agricultura familiar como estratégica! Né! Quem prioriza a agricultura familiar nesse trabalho, não quebra né!

\section{PG23: - 23:67 [É! Por isso eu digo pra ti...E..] (19:2418-20:217) (Super) \\ Codes: [Ideologia]}

É! Por isso eu digo pra ti...Eu já sou filiado em partido, já fui...mas assim mas...esquerda né! Mas não me entusiasma muito! Hoje tá...só que eu acho, na minha avaliação, que conforme der a eleição tem que planejar algumas coisas pra fortalecer a ação! Se ganhar a Dilma, por exemplo, né! Nós temos que fortalecer ainda mais as ações relacionadas a agricultura familiar! A gente sabe que isso vai se fortalecer nos próximos governos né! Tu vai ter recursos aplicados! Nós temos ideia em relação a industrialização, em termos de utilização e alguma coisa assim...

\section{PG23: - 23:68 [É uma política de Governo, mas..] (20:333-20:760) (Super)}

Codes: [Ideologia]

É uma política de Governo, mas daí se ganhar, vão ser mais quatro anos! E existe uma chance maior de continuidade até depois inclusive né! Então se ganhar outra política, tem que ver também que é que ganha, pra avaliar essa situação aí! Porque hoje eu acho que a gente 
tem...nós temos uma agenda do pequeno produtor aqui, da agricultura familiar, e nós não estamos vendendo nada pra merenda escolar, essas coisas assim..

\section{PG23: - 23:69 [...tu pode vender mais então...] (20:1071-20:1371) (Super)}

Codes: [Ideologia]

...tu pode vender mais então. A ideia que a gente tá tendo aqui, nosso planejamento, que se...e uma coisa muito interna né!...porque outra coisa é quando se começa falar de política pra fora...pro associado...não dá pra misturar uma coisa com a outra né! Essa é uma estratégia interna mesmo né!

\section{PG23: - 23:70 [Eu acho que é um negócio que t..] (20:1396-20:1662) (Super)}

Codes: [Agroindústrias Familiares]

Eu acho que é um negócio que tem que ir atrás pra beneficiar, pra montar algumas indústrias aí (agroindústrias familiares) pra mandar pro mercado institucional (se refere aos $30 \%$ obrigatórios pelo PAA impostos as prefeituras para comprar da agricultura familiar).

PG23: - 23:71 [lsso aí, eu acho incompatível ..] (23:1304-23:1763) (Super)

Codes: [Óleos Nobres]

Isso aí, eu acho incompatível hoje! Na minha opinião a matemática tem que ser respeitada! Se o óleo de Soja vale $\mathrm{R} \$ 2,00$ e o de Mamona vale $\mathrm{R} \$ 2,10$, faz com o óleo de Soja!

E outra coisa, coloca esse óleo de Soja que não é comestível, não é comestível bem dizer né...eu comparo muito...Mamona até não sei dizer se é pra consumo humano...Eu sei que por exemplo, óleo de Canola, Girassol...o consumo desses óleos aí é muito melhor pro consumo humano...

PG23: - 23:72 [Nós fizemos um contrato com a ..] (23:2341-23:2419) (Super)

Codes: [Expertise]

Nós fizemos um contrato com a Petrobrás pra fornecimento de Soja pra biodiesel!

PG23: - 23:73 [Bah! A Petrobrás não é fácil! ..] (24:14-24:66) (Super)

Codes: [Reprovação]

Bah! A Petrobrás não é fácil! Difícil! Não é muito...

\section{APÊNDICE B - Interview Framework: Eagle Ford Shale Public Policies and Economic Development}

Interviews will begin after reading, signing, and discussing the Informed Consent Form. Question five in the consent form asks: What will I be asked to do in this study?Begin by following up on that question.

Respondent Code:

\section{A. Respondent Background}

What is/was your role in economic development, policy, or relations with oil and gas drilling in the Eagle Ford Shale?

[Allow for respondent to discuss this answer in his/her own terms]

Obtain professional credentials of respondent:

Elected or career official?

Expertise or credentials [degree; training; experience]?

How long in current position [years or months]? ... how long in this community [years or months]? 
Does your office have plans for expansion?

$\rightarrow$ be specific: workers, space, activities?

Is there a "culture" in this community regarding oil and gas development?

-Related to past oil production?

-Related to mineral rights ownership?

Who are/were the key figures involved in economic development, policy, or relations with oil and gas drilling in your city/town/county?[prompts: municipal officials; elected officials; industry representatives; prominent citizens; external figures]

\section{B. Municipal Ordinances}

Now we will ask specifically about municipal ordinances: Describe the municipal ordinances that regulate oil and gas development

whom

Year established by whom year revised by

Key aspects:

$\rightarrow$ setback distance, roads, aesthetics, noise, etc.

state?

Outside Consultants: Were outside consults involved in drilling in this region or in the

Objectives: Use these cards torank the importance of the following objectives as they were raised during the establishment ofpolicies regarding oil and gas:

Prevent noise complaints Preserve home property values( Protect public safety Protect public health( Encourage mineral production Reduce exposure to regulatory takings lawsuit $(\ldots ; \ldots)$ Other

Ordinance outcomes: litigation?

After the implementation of the ordinances, were there lawsuits, conflicts, or

Have there been complaints about drilling?

What was the nature of the complaints?

Were these before or after the adoption of the ordinances?

\section{Future of Eagle Ford Shale}

Describe your view of the future of oil and gas-related development in the Eagle Ford Shale

$\rightarrow$ whydoes respondent holds these views? How do they define "future"? How do they define "development"?

$\rightarrow$ which obstacles might impede future development?

D. Partnerships

Describe partnerships between your community, office or organization with oil and gas firms

$\rightarrow$ define "partnerships" as workforce training, housing, logistical, social, etc.

$\rightarrow$ ask for specific examples, for example, Have oil and gas companies provided any support (financial, volunteer, or otherwise) to the community?How closely do you work with the companies?

Which oil and gas companies are most prevalent in your community in terms of partnerships with public officials?

E. Economic Development 
List the 3-5 most important aspects of oil and gas-related economic development in the Eagle Ford Shale

1:

2:

3:

$\rightarrow$ ask for rationale

1:

2:

3:

F. Workforce

Do oil and gas firms (upstream and midstream) hire local or outside labor?

What types of education are desired or required for jobs in the EFS? workers?

Which part of oil and gas development presents the greatest challenges for obtaining

Are there locations/times that EFS management and workers in multiple firms share their experiences and discuss the happenings in their companies? (Perhaps at a conference or bar?)

Do EFS companies prefer to talk with you [city official] directly or is there a preference towards other communication mediums (i.e. phone, email, text, physical mail)?

Do workers move frequently between firms?Or between up and mid-stream sectors?

Where is most worker trainingcarried out? [job site, at a branch location on the EFS, or at other locations?]

Are local laborers still trained to old jobs [i.e. work on farms and manage livestock?]

G.Mineral rights

Do you have mineral interests in the Eagle Ford Shale?

Did most landowners in this community retain their mineral rights?

Are there particular individuals within the companies with whom you routinely communicate? Would you recommend us contacting them?

Apêndice D - Todas as citações e os códigos definidos pelas entrevistas de EFS.

Hermeneutic Unity: Eagle Ford Shale

File: [C:IUsersIUserlDocumentsIPH.D. ThesisICap_4_Rel Poder Est Soc Mer EFSIAtlasTI docs.hpr7]

Edited by: $\quad$ Super

Date/Time: $\quad$ 2015-08-26 09:19:42

EFS004 1:1 [And we try to get consensus be..] (1:528-1:668) (Super)

Codes: [Representativeness]

And we try to get consensus before we actually come out...speak about something...so...that why is tough. We're the voice of the local business.

\section{EFS004 1:2 [We go through a state legislat..] (1:669-1:1014) (Super)}

Codes: [Government \& Governance layout]

We go through a state legislated action plan, we go to federal legislative action plan, we survey the memberships, we do it two or three times, we collect it....we have a committee, we have a subcommittee...the 
subcommittee develops the plan, the subcommittee acted committed on each topic and its came back up and it is approved by the board

\section{EFS004 - 1:3 [And we can't go out; we can't ..] (1:1038-1:1103) (Super)}

Codes: [Representativeness]

And we can't go out; we can't say....anything that's in that document

EFS004 - 1:5 [and there's...fifty others membe..] (1:1402-1:1443) (Super)

Codes: [Conflits \& Interests]

and there's...fifty others members will hurt

EFS004 - 1:6 [l've been doing association wo..] (2:68-2:128) (Super)

Codes: [Government \& Governance layout]

I've been doing association work, lobbying, for thirty years.

EFS004 - 1:7 [Yeah! Always accepting new mem..] (2:283-2:418) (Super)

Codes: [Institutional approach]

Yeah! Always accepting new members and you know...depends on funding, and what chamber members want to do, as far as what programs...we do

EFS004 - 1:9 [We have a hundred plus events ..] (2:457-2:552) (Super) Codes: [Sociality]

We have a hundred plus events in the course of the year...that...you know...educate promote, connect

EFS004 - 1:10 [Yes! We have an economic outlo..] (2:751-2:940) (Super)

Codes: [Development as Economic]

Yes! We have an economic outlook briefing that we do every year......and this one was about oil and gas. And you can find that on our website and who those players were

EFS004 - 1:11 [And the goal that event was to..] (2:964-2:1151) (Super) Codes: [O\&G forthcoming \& structure]

And the goal that event was to bring to the forefront these background oil and gas

players who we see driving down the streets...We see at the distance with lights, we know they're here!

EFS004 - 1:12 [We heard they're here, the rev..] (2:1178-2:1286) (Super)

Codes: [Sale Taxes, Revenues \& Royalties]

We heard they're here, the revenue is showing up in the coffers but we just haven't done the chamber thing...

EFS004 - 1:13 [So, this was to do that. And t..] (2:1311-2:1384) (Super)

Codes: [O\&G forthcoming \& structure]

So, this was to do that. And than Apache oil came out, a land man came out

EFS004 - 1:14 [we built a panel that we creat..] (2:1386-2:1500) (Super)

Codes: [Community receptiveness]

we built

a panel that we created a public conversation about oil and gas. And the town was very receptive....ahhh... 
EFS004 - 1:15 [bviously a very pro-business o..] (2:1505-2:1569) (Super)

Codes: [Pro-business mentality]

bviously a very pro-business organization, it's pro-business town

EFS004 - 1:16 [you know...hotels...it generates m..] (2:1596-2:1686) (Super)

Codes: [Pro-business mentality]

you know...hotels...it generates money for the hotels, it generates money to the restaurants,

EFS004 - 1:17 [but the county is worried abou..] (2:1688-2:1729) (Super)

Codes: [Transportation (Traffic, Road impact \& Railroads)]

but the county is worried about the roads.

EFS004 - 1:18 [...there always sensitivities!] (2:1742-2:1771) (Super)

Codes: [Social Sensitives (population, genre, wage, accidents)]

...there always sensitivities!

EFS004 - 1:19 [it was the world economy, thing..] (3:431-3:501) (Super)

Codes: [World O\&G commodity prices]

it was the world economy, things that were going to make this...economic

EFS004 - 1:21 [and when the price comes up....w..] (4:26-4:205) (Super)

Codes: [O\&G and Technology]

and when the price comes up....we start to producing more, we started looking to alternative fuels, we started the create efficiency to our cars...but when the price comes down?!

EFS004 - 1:22 [Right to a point that they sta..] (4:231-4:387) (Super)

Codes: [O\&G procedures, strategies and investments]

Right to a point that they start to shut down striper wells, those that cost are the higher production wells and they shut they down....and then what happens?

EFS004 - 1:23 [They're going to flood the mar..] (4:956-4:1004) (Super)

Codes: [World O\&G commodity prices]

They're going to flood the market and get us out!

EFS004 - 1:24 [We are a facilitator, we hear ..] (4:1395-4:1444) (Super)

Codes: [Institutional approach]

We are a facilitator, we hear from our membership...

EFS004 - 1:25 [We had an event to try...you kno..] (5:983-5:1133) (Super)

Codes: [Institutional approach]

We had an event to try...you know... and highlight what they were doing, to create...you know...some faces...so if people have questions that they can do that...

EFS004 - 1:26 [They have to enjoy the Chamber..] (5:1137-5:1349) (Super)

Codes: [Pro-business mentality] 
They have to enjoy the Chamber to be part of the business community which connects them to the regular community and, as we are the voice of business, we love to be a collective voice and not just their voice...

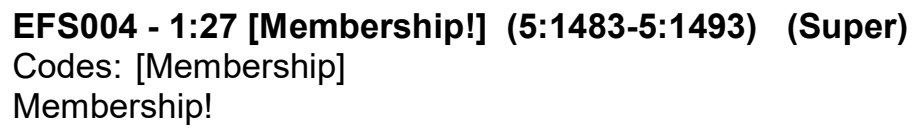

Yes is a system! Across the border there is no higher or lower...it is...you

know...everyone has one goal...

EF0S04 - 1:30 [with...membership! You know, our..] (5:1808-5:1952) (Super)

Codes: [Membership]

with...membership! You know, our membership is open to the public! So they can join just like everybody else and they can't join a hundred times...

EFS004 - 1:31 [Apache is getting an award for..] (6:111-6:167) (Super)

Codes: [Environmetal ceticism]

Apache is getting an award for environmental stewardship.

EFS004 - 1:32 [I think they have reached some..] (6:305-6:362) (Super)

Codes: [Transportation (Traffic, Road impact \& Railroads)]

I think they have reached some agreements about the roads...

EFS004 - 1:33 [They have bought...they have a w..] (6:190-6:302) (Super)

Codes: [Environmetal ceticism]

They have bought...they have a water contract with the city to buy gray water which has no value until it's bough

EFS004 - 1:34 [you also need to remember abou..] (6:367-6:525) (Super)

Codes: [O\&G Wealthy \& Benefits]

you also need to remember about the Raining Day Fund which is funding Prop 1, which is to fund the statewide transportation as the tax from the oil industry...

EFS004 - 1:35 [...so that is a relationship to ..] (6:531-6:680) (Super)

Codes: [Government \& Governance layout]

...so that is a relationship to the city...you know...state to local to driveway...you know, there is something there. I don't know how you present it, but...

EF004 - 1:36 [We are a rising tide for all s..] (6:1035-6:1218) (Super)

Codes: [Development as Economic]

We are a rising tide for all ships, you know, this isn't a social program, it's not about social legislation, it is about how do you have an impact on economic activity of your area...

EFS004 - 1:37 [Right, so by creating a job-an..] (6:1417-6:1588) (Super)

Codes: [Development as Economic]

Right, so by creating a job—an economic activity—our church thrive, our nonprofits thrive, our city through tax collection thrive, our schools thrive, our children thrive

EFS004 - 1:38 [And through job creation and e..] (6:1592-6:1792) (Super) 
Codes: [Development as Economic]

And through job creation and economic activity you create a beautiful place to live and work, which is what we call community... and not necessary Bryan or College Station, but to the Texas A\&M proper

EFS004 - 1:39 [Land Value, Job creation, and ..] (7:268-7:429) (Super)

Codes: [Development as Economic]

Land Value, Job creation, and Retail engagement and that would be hotel, restaurant, and retail other, and did I say Tax bases? And then it would be tax bases.

EFS004 - 1:40 [Because it does two things! An..] (7:452-7:726) (Super)

Codes: [Sale Taxes, Revenues \& Royalties]

Because it does two things! And generates from the well, there is the permits and there the royalties, believe they are in local or some source of that. And then by creating the sales activity, you have sale taxes and so that is refunding the services to all citizens.

EFS004 - 1:41 [ets re-start, that's my fault,..] (7:885-7:1083) (Super)

Codes: [Development as Economic]

ets re-start, that's my fault, I was presenting an cyclical idea...From the time someone buys the thing to the time they die, who sucks it out... sleeps in a hotel, I was doing a cyclical in my mind.

EFS004 - 1:42 [Oil and gas showed up fast. So..] (7:1616-7:1854) (Super)

Codes: [Educational Attainment]

Oil and gas showed up fast. So you know, we can't really create a community college or some type of course work in high-school...you know, so...will there be welders? Yeah, we've got high school and community college with welding programs...

EFS004 - 1:43 [Some people say that they up t..] (8:356-8:500) (Super)

Codes: [Social Sensitives (population, genre, wage, accidents)]

Some people say that they up the prices, because of those people go one day, we're still left with that infrastructure that we have to pay for!

EFS004 - 1:44 [I don't know it that's equitab..] (8:320-8:351) (Super)

Codes: [Equitable growth]

I don't know it that's equitable

EFS004 - 1:45 [you know, you gonna get people..] (8:165-8:317) (Super)

Codes: [Development as Economic]

you know, you gonna get people coming and reaching again! They buy houses, they buy cars, theirs kids goes to school, and it all feeds that same system

EFS004 - 1:46 [and a tech job that is suppose..] (8:1063-8:1287) (Super)

Codes: [Development as Economic] [Educational Attainment]

and a tech job that is supposed to high middle-level retail, government...type job.

And that's what this area or any area needs... is they need some higher paying jobs to have a multitude of impact on the economic development.

EFS004 - 1:48 [You know...people are getting jo..] (9:336-9:615) (Super)

Codes: [O\&G forthcoming \& structure] 
You know...people are getting jobs. They are high paying jobs and people are moving here because of those jobs. They are transferring here; they're accepting jobs...so...yeah! It's not migrant farm workers...you know... because there is a certain level of skill and therefore payment

EFS004 - 1:49 [Again, the Chamber is uniquely..] (9:1462-9:1553) (Super)

Codes: [Pro-business mentality]

Again, the Chamber is uniquely positioned as...you know... as a business to business engagement

EFS004 - 1:50 [We're not an environmental com..] (9:1556-9:1590) (Super)

Codes: [Environmetal ceticism]

We're not an environmental company,

EFS004 - 1:51 [That's where the buck stops. A..] (9:1934-9:2446) (Super)

Codes: [World O\&G commodity prices]

That's where the buck stops. And the question becomes: Can the U.S. create a price floor for domestic energy production? We are not the lowest cost oil producer on the planet. Therefore we will always be on a dollar-per-dollar basis unequal. The equality comes into the value of the oil by other countries with others values. And if they don't value their resources through their stock markets and their corporations, through their entities the way we have to value it, it's not a level playing field.

EFS004 - 1:52 [And that is based on a level p..] (10:8-10:497) (Super) Codes: [World O\&G commodity prices]

And that is based on a level playing field of some type of certainty...you know... because of the difference in cultures... and the value of these commodities, and the programs, and those countries that they live in are different. This is isn't about eggs. This isn't about trading cotton; this isn't about technology; this is about a commodity that many people own and that have different values, so...you know...how can we continue to invest in something that isn't an absolute crap shoot.

EFS004 - 1:53 [this isn't about technology;] (10:297-10:324) (Super)

Codes: [O\&G and Technology]

this isn't about technology;

EF004 - 1:54 [But, we don't do that! We are ..] (10:941-10:1126) (Super)

Codes: [O\&G and Technology]

But, we don't do that! We are now trying to control our destiny by investing in oil production and doing it in the U.S. and creating technology by making unrecoverable oil, recoverable

EFS004 - 1:55 [As long as the price of the wo..] (11:529-11:608) (Super)

Codes: [World O\&G commodity prices]

As long as the price of the world oil is one dollar above the cost of production

EFS005 - 2:1 [But right now I mean it's very..] (2:240-2:456) (Super)

Codes: [O\&G forthcoming \& structure]

But right now I mean it's very, very busy! So it is growing, growing... it kind of slows down towards the end of the year, first of the year, but it will be back...you know... within the next couple of weeks I would say. 
EFS005 -2:2 [Yeah! We promote new businesse..] (2:795-2:964) (Super)

Codes: [Pro-business mentality]

Yeah! We promote new businesses - through website, newspaper, email. We have ribbon cuttings...ahmm... for these new business if you join; try to keep everybody in the loop

EFS005 - 2:3 [we trying to bring tourism int..] (2:969-2:1381) (Super)

Codes: [Development as Economic]

we trying to bring tourism into Kenedy; we have several festivals; we have a wine festival, and...ahmm... just a regular festival just for kids. We have a parade...that sort of thing...ahmm...we're having a casino night, something new that we're doing so...try to keep....ah... keep bring people into Kenedy is what we are trying to do. Yeah, we have several events that we host. They're really big success so that's good!

EFS005 - 2:4 [Yeah, we do. Ah...They're great,..] (3:1119-3:1326) (Super)

Codes: [O\&G Donations and sponsorships]

Yeah, we do. Ah...They're great, they're big hope, they're sponsor. Some of them are sponsors like in many of our main events. Conoco has been a big partner, WoodGroup Duval has being a big partner as well.

EFS005 - 2:5 [Wood Group Duval. Our Presiden..] (3:1368-3:1421) (Super)

Codes: [Institutional approach]

Wood Group Duval. Our President used to work for them.

EFS005 - 2:6 [And I have somebody else on th..] (3:1447-3:1776) (Super)

Codes: [O\&G Donations and sponsorships]

And I have somebody else on the board that used to work to Conoco Select....they're a big help...for Thanksgiving... put on a Thanksgiving meal at City Hall from Conoco Philips for...you know...less fortunate families... ah....but I think that they've being really beneficial in supporting the schools, and supporting us...that sort of thing...

EF005 - 2:7 [It's made our roads a lot busi..] (3:1780-3:1826) (Super)

Codes: [Transportation (Traffic, Road impact \& Railroads)]

It's made our roads a lot busier and dangerous...

EFS005 - 2:8 [Yes. They do...ah...they do...Conoco..] (3:1994-3:2196) (Super)

Codes: [O\&G Community Volunteer actions]

Yes. They do...ah...they do...Conoco has a really good volunteer committee. We

have...ah.... B Blue Bonnet Festival two years ago and we need any help and they, at last

minute,

provide us like twenty volunteers..

EF005 - 2:9 [Yes. They're great! They're re..] (4:11-4:238) (Super)

Codes: [O\&G Wealthy \& Benefits]

Yes. They're great! They're really big help to us. Wood Group Duval, they have also done stuff. I guess I should mentioning these because they had an important number have worked for this community...this Oil field companies.

EFS005 - 2:10 [But, yeah! Ah...they're really r..] (4:493-4:1054) (Super)

Codes: [O\&G Community Volunteer actions]

But, yeah! Ah...they're really responsive if we need help...ah...they're very active. We have a 
second Friday community breakfast; Every second Friday a lot of them do go... a lot of representatives of each of these Oil and Gas companies go. And then they give a little overview of what they have going on in the community... ah...that sort of thing... And I know that...ah...they used to...I'm not sure if they still do...I think it was Conoco, Wood Group and there was another one...I'm not sure which one...they just have people picking up trash all day....around the community

EFS005 - 2:11 [Yes! Yeah, it's is great. You'..] (4:1094-4:1313) (Super) Codes: [O\&G Community Volunteer actions]

Yes! Yeah, it's is great. You'll see trash trucks just going by... and they just have people...you know...going up and down the road picking up trash on some of the major highways...that sort of thing...so it's been really good

EFS005 - 2:12 [Yeah, it's just awesome! They'..] (4:1464-4:1504) (Super)

Codes: [Sociality]

Yeah, it's just awesome! They're great...so

EFS005 - 2:13 [We don't but the housing aroun..] (4:1618-4:1766) (Super)

Codes: [Housing \& properties impact]

We don't but the housing around here is kind of a limited right now...ah...and it's expensive. Like one bedroom one bath is like two thousands dollars!

EFS005 - 2:14 [Yeah! And there's some apartme..] (4:1803-4:2063) (Super) Codes: [Housing \& properties impact]

Yeah! And there's some apartments that are right downtown here, and they're about just like two thousand dollars a month for one bed one bath. Ah... we don't have like a list or anything about available housing but I know just that it's limited right now...ah... Y

EFS005 - 2:15 [h. The hotels are packed thoug..] (4:2066-4:2171) (Super) Codes: [Infrastructure]

The hotels are packed though. So...Each hotel...is probably full and there's two more coming up on

$181 \ldots$

EFS005 - 2:16 [Everything is going to be in 1..] (5:1-5:100) (Super)

Codes: [Transportation (Traffic, Road impact \& Railroads)]

Everything is going to be in 181 or the main street we have on the $72 \ldots$ everything... mostly everything

EFS005 - 2:17 [We do! We get a percentage and..] (5:236-5:308) (Super)

Codes: [Sale Taxes, Revenues \& Royalties]

We do! We get a percentage and then city gets the rest... gets the majority

EFS005 - 2:18 [Pioneer, Marathon, yeah...they'r..] (5:450-5:568) (Super)

Codes: [Membership]

Pioneer, Marathon, yeah...they're ah...contributors as well...some are the larger oil field companies that are around town.

ESF005 - 2:19 [l think number one would be de..] (5:744-5:822) (Super)

Codes: [Pro-business mentality]

I think number one would be definitely bringing in a ton of new businesses that 
EFS005 - 2:20 [...you know...we never thought tha..] (5:823-5:995) (Super)

Codes: [Development as Economic]

...you know....we never thought that Kenedy would ever see! So, it's being good for the locals because...you know...we're getting this new things...and ahmm...different things to use

EFS005 2:21 [it's being good for the locals..] (5:884-5:913) (Super)

Codes: [O\&G Wealthy \& Benefits]

it's being good for the locals

EFS005 2:22 [Let me think what else...I guess..] (5:999-5:1199) (Super)

Codes: [Sale Taxes, Revenues \& Royalties]

Let me think what else...I guess also two for the city and us is the hotel-motel taxes that we are getting, cause it's allowing us to have a profit and we can use that on bringing people into Kenedy.

EFS005 - 2:23 [making Kenedy more known] (5:1226-5:1249) (Super)

Codes: [O\&G Wealthy \& Benefits]

making Kenedy more known

EFS005 - 2:24 [And I give all a lot people ca..] (6:1136-6:1615) (Super)

Codes: [Jobs opportunities and challenges]

And I give all a lot people came by here... wanting like a list of jobs, but we don't have that. They take care of that, so...but I think yeah! They're hiring a lot of the locals, giving locals jobs, but as well is a lot of this oil field companies are not just located in Kenedy. So they're having the people that work in their main offices coming down, train the people maybe from throughout, here in the area, and then they'll go back and they'll have it under control here.

\section{EFS005 Kenedy Chamber of Commerce.pdf - 2:25 [I would say. For a lot of them..] (7:54- 7:181) (Super) \\ Codes: [Educational Attainment]}

I would say. For a lot of them, you know, obviously not...bosses...and stuff like that. I would say mostly going to be high school

EFS005 Kenedy - 2:26 [Yeah. They have safety meeting..] (7:630-7:839) (Super)

Codes: [Safety \& bottlenecks]

Yeah. They have safety meetings, a lot of companies have them like every week...so....I feel like yeah...there are being safe and productive out there...but these guys know what their doing so they're being trained

EFS005 - 2:27 [Maybe...Yeah, more skills but I ..] (7:1035-7:1308) (Super)

Codes: [Educational Attainment]

Maybe...Yeah, more skills but I mean...I would say is easy to get a job... I mean is probably getting working outside; it's going to be doing something...but I think it will be pretty easy to find a job around here right now. For, you know, a guy that just once to start working

EFS005 Kenedy Chamber of Commerce.pdf - 2:28 [But, I mean yeah. I communicat..] (7:2012-7:2212) (Super)

Codes: [Community receptiveness]

But, I mean yeah. I communicate with them. My contacts...I pretty much have one for at least all 
of the major companies, so...yeah...they really do help out a lot...ah...I guess it's good having them around.

EFS005 - 2:29 [Yeah, it is. It's hard, I know..] (8:478-8:808) (Super)

Codes: [Jobs opportunities and challenges]

Yeah, it is. It's hard, I know we just got two new big restaurants here. They're having a hard time finding people for work because everybody is moving into the oil industry and going work to the oil firms. So it is a good time to start a business, I would say in Kenedy right now, but it would be hard to obtain the workers.

EFS005 - 2:30 [Yes. I think if starts like in..] (8:1135-8:1352) (Super)

Codes: [Jobs opportunities and challenges]

Yes. I think if starts like in the Subways like 10 dollars or something...It's like...It's Subway! But yeah! Definitely is what is happening here too!

EFS005 - 2:31 [Yeah. It's the Wood Group trai..] (9:174-9:300) (Super)

Codes: [Infrastructure]

Yeah. It's the Wood Group training facility...I think. But...I don't think it's just for

Wood Group; I think like anybody can go.

EFS005 - 2:32 [The reason why these people ar..] (9:1029-9:1237) (Super)

Codes: [Housing \& properties impact]

The reason why these people aren't brining their families here is because there is nowhere to house the family here. Or it is so expensive! And these guys they are making the money but it's just, you know...

EFS005 - 2:33 [a lot of people are working ou..] (9:882-9:1026) (Super)

Codes: [Jobs opportunities and challenges]

a lot of people are working out of town

and they came and they work and stay at the hotel for seven days and then they go home for seven days

EFS005 - 2:34 [Yeah. And a lot of people are ... (9:1303-9:1413) (Super)

Codes: [Social Sensitives (population, genre, wage, accidents)]

Yeah. And a lot of people are doing that. Like the guy-to-girl ratio out at restaurant; it's like ridiculous...

EFS005 - 2:35 [There just a whole bunch of gu..] (9:1441-9:1647) (Super)

Codes: [Social Sensitives (population, genre, wage, accidents)]

There just a whole bunch of guys and just like a few girls out but...ah...Yeah! A lot of these guys...You know...they're not from around here, they are from surrounds areas, some of them do drive back and forth.

EFS005 - 2:36 [Ah...they say it's gonna last at..] (10:909-10:1076) (Super)

Codes: [Future perspectives]

Ah...they say it's gonna last at least for the next ten years, maybe even longer. And I hope it is does because I don't what we're going to do with all these hotels if...

EFS005 - 2:37 [It's kind a be like a ghost to..] (10:1122-10:1387) (Super)

Codes: [Future perspectives] 
It's kind a be like a ghost town with all these hotels and nobody to stay in them...so I'm hoping that what they saying is right but I don't know how much research that y'all've done on the oil field, but they're on one layer and there's another layer below it so...

\section{EFS005 - 2:38 [Cause there's Eagle Ford and t..] (10:1579-10:1760) (Super)}

Codes: [Future perspectives]

Cause there's Eagle Ford and then I forget the one underneath it is called, but they haven't even tapped into that...so...I mean, more hoping that that one produced down here too so...

\section{EFS005 - 2:39 [Yeah. We owns some property ou..] (11:394-11:759) (Super)}

Codes: [Mineral Rights, Royalties \& Land Tenure]

No memos

Yeah. We owns some property out on 181 and we have the mineral rights to do it and then now we have the mineral rights right here too...ah....we getting some more wells that its running underneath this actual spot... EFS005 - So...yeah. They great for us and help us. It helps us out a lot...I guess we can make our events more elaborate with the royalties...

EFS005 - 2:40 [Not me personally, helpfully, ..] (11:787-11:936) (Super)

Codes: [Social Sensitives (population, genre, wage, accidents)]

Not me personally, helpfully, eventually, but my parents do also...and some of my friend do...so it's been good... a lot of people are really getting rich!

EFS005 - 2:41 [Yeah, it's crazy some of them.....] (11:1070-11:1234) (Super)

Codes: [Social Sensitives (population, genre, wage, accidents)]

Yeah, it's crazy some of them...like I know...they don't dress any different; it's like, "Spend some money!" But a lot of people are becoming millionaires around here.

EFS005 - 2:42 [I don't know, I mean it has sl..] (13:182-13:448) (Super)

Codes: [World O\&G commodity prices]

I don't know, I mean it has slowed down though. I do know that traffic, you know...I guess people at the restaurants, that sort of thing, I can just tell that it's been slow but I don't know if is because of the gas or oil prices or because it's the end of the year

\section{EFS005 - 2:43 [I don't know, I mean it has sl..] (13:182-13:638) (Super)}

Codes: [Future perspectives]

I don't know, I mean it has slowed down though. I do know that traffic, you know...I guess people at the restaurants, that sort of thing, I can just tell that it's been slow but I don't know if is because of the gas or oil prices or because it's the end of the year. They did it last year so l'm just assuming that but I don't know if there's any fear with it but...I hear everybody saying it is going to go back up, that sort of thing but I don't know...

\section{EFS006.pdf - 3:1 [t is! Yes, we having grown up ..] (2:11-2:124) (Super)}

Codes: [Development as Economic]

DATA SOURCE UNACCESSIBLE!: C:IUsersIUserlAppDatalRoaminglScientific Software\ATLAStilRepositorylManaged Files\EF006.atldoc

EFS006.pdf - 3:2 [Yeah...several of the major deve..] (2:1250-2:1423) (Super)

Codes: [O\&G procedures, strategies and investments]

No memos 
DATA SOURCE UNACCESSIBLE!: C:IUsersIUserlAppDatalRoamingIScientific Software\ATLAStilRepositorylManaged Files\EF006.atldoc

EFS006.pdf - 3:3 [but there has been a history a..] (2:627-2:1146) (Super) Codes: [O\&G forthcoming \& structure]

No memos

DATA SOURCE UNACCESSIBLE!: C:IUsersIUserlAppDatalRoaminglScientific Software\ATLAStilRepositorylManaged Files\EF006.atldoc

EFS006.pdf - 3:4 [They're have pretty impressive..] (2:1699-2:1742) (Super) Codes: [O\&G procedures, strategies and investments]

No memos

DATA SOURCE UNACCESSIBLE!: C:IUsersIUserlAppDatalRoaminglScientific Software\ATLAStilRepositorylManaged Files\EF006.atldoc

EF006.pdf - 3:5 [Policy and I guess the...ah...supp..] (3:202-3:289) (Super) Codes: [Community receptiveness]

No memos

DATA SOURCE UNACCESSIBLE!: C:IUsersIUserlAppDatalRoaminglScientific Software\ATLAStilRepositorylManaged Files\EF006.atldoc

EF006.pdf - 3:6 [people have been looking at th..] (3:338-3:528) (Super) Codes: [Development as Economic] [Jobs opportunities and challenges] No memos

DATA SOURCE UNACCESSIBLE!: C:IUsersIUserlAppDatalRoamingIScientific Software\ATLAStilRepositorylManaged Files\EF006.atldoc

EF006.pdf - 3:7 [you know, for instance, HEB gr..] (3:553-3:741) (Super) Codes: [Development as Economic]

DATA SOURCE UNACCESSIBLE!: C:IUsersIUserlAppDatalRoamingIScientific Software\ATLAStilRepositorylManaged Files\EF006.atldoc

EF006.pdf - 3:8 [the city has had to work with ..] (3:858-3:926) (Super) Codes: [Infrastructure]

DATA SOURCE UNACCESSIBLE!: C:IUsersIUserlAppDatalRoamingIScientific Software\ATLAStilRepositorylManaged Files\EF006.atldoc

EF006.pdf - 3:9 [And that...certainly the...ah...hote..] (3:764-3:983) (Super) Codes: [Housing \& properties impact]

DATA SOURCE UNACCESSIBLE!: C:IUsersIUserlAppDatalRoaminglScientific Software\ATLAStilRepositorylManaged FilesIEF006.atldoc

EF006.pdf - 3:10 [The mayor, the city council...] (3:1170-3:1197) (Super)

Codes: [Community receptiveness] 
DATA SOURCE UNACCESSIBLE!: C:IUsersIUserlAppDatalRoamingIScientific Software\ATLAStilRepositorylManaged Files\EF006.atldoc

EF006.pdf - 3:11 [Yeah. I have seen those....citie..] (3:2045-3:2176) (Super) Codes: [Ordinances: Why reinvent the wheel?]

DATA SOURCE UNACCESSIBLE!: C:IUsersIUserlAppDatalRoamingIScientific Software\ATLAStilRepositorylManaged Files\EF006.atldoc

EF006.pdf - 3:12 [Ah...and...especially more recentl..] (4:198-4:378) (Super) Codes: [Ordinances: Why reinvent the wheel?]

DATA SOURCE UNACCESSIBLE!: C:IUsersIUserlAppDatalRoaminglScientific Software\ATLAStilRepositorylManaged Files\EF006.atldoc

EF006.pdf - 3:13 [Primarily in-house with the in..] (4:1286-4:1488) (Super) Codes: [Conflits \& Interests]

DATA SOURCE UNACCESSIBLE!: C:IUsersIUserlAppDatalRoaminglScientific Software\ATLAStilRepositorylManaged Files\EF006.atldoc

EF006.pdf - 3:14 [And...ah...one of the other indivi..] (4:1584-4:1740) (Super) Codes: [Conflits \& Interests]

DATA SOURCE UNACCESSIBLE!: C:IUsersIUser|AppDatalRoaminglScientific SoftwarelATLAStilRepositorylManaged Files\EF006.atldoc

EF006.pdf - 3:15 [That and then preserve propert..] (5:1029-5:1074) (Super) Codes: [Housing \& properties impact]

DATA SOURCE UNACCESSIBLE!: C:IUsersIUserlAppDatalRoaminglScientific Software\ATLAStilRepositorylManaged FilesIEF006.atldoc

EF006.pdf - 3:16 [Noise, nuisance,] (5:861-5:878) (Super)

Codes: [Noise, nuisance, Flares]

DATA SOURCE UNACCESSIBLE!: C:IUsersIUserlAppDatalRoamingIScientific Software\ATLAStilRepositorylManaged Files\EF006.atldoc

EF006.pdf - 3:17 [Denton is it...ah...they're trying..] (5:1483-5:1586) (Super) Codes: [Development as Economic]

DATA SOURCE UNACCESSIBLE!: C:IUsersIUserlAppDatalRoamingIScientific Software\ATLAStilRepositorylManaged Files\EF006.atldoc

EF006.pdf - 3:18 [There has! You know, remember ..] (5:1825-5:2284) (Super) Codes: [Transportation (Traffic, Road impact \& Railroads)]

DATA SOURCE UNACCESSIBLE!: C:IUsersIUserlAppDatalRoaminglScientific Software\ATLAStilRepositorylManaged Files\EF006.atldoc

EF006.pdf - 3:19 [And I sympathize with this. We..] (6:25-6:106) (Super) Codes: [Transportation (Traffic, Road impact \& Railroads)]

DATA SOURCE UNACCESSIBLE!: C:IUsersIUserlAppDatalRoaminglScientific Software\ATLAStilRepositorylManaged Files\EF006.atldoc

EF006.pdf - 3:20 [It's ah...rental...rental rates, r..] (6:111-6:324) (Super) Codes: [Housing \& properties impact]

DATA SOURCE UNACCESSIBLE!: C:IUsersIUserlAppDatalRoamingIScientific 
Software\ATLAStilRepositorylManaged Files\EF006.atldoc

EF006.pdf - 3:21 [the number of people that rece..] (6:435-6:530) (Super) Codes: [Cristicism]

DATA SOURCE UNACCESSIBLE!: C:IUsersIUserlAppDataIRoamingIScientific Software\ATLAStilRepositorylManaged Files\EF006.atldoc

EF006.pdf - 3:22 [Ah...which bring another thing...a..] (6:328-6:434) (Super) Codes: [Jobs opportunities and challenges]

DATA SOURCE UNACCESSIBLE!: C:IUsersIUserlAppDatalRoaminglScientific Software\ATLAStilRepositorylManaged Files\EF006.atldoc

EF006.pdf - 3:23 [So...ah...is that I don't know...tha..] (6:556-6:1181) (Super) Codes: [Development as Economic]

DATA SOURCE UNACCESSIBLE!: C:IUsersIUserlAppDatalRoamingIScientific SoftwarelATLAStilRepositorylManaged Files\EF006.atldoc

EF006.pdf - 3:24 [most of companies in the area ..] (6:1806-6:2084) (Super) Codes: [O\&G Donations and sponsorships]

DATA SOURCE UNACCESSIBLE!: C:IUsersIUser|AppDatalRoaminglScientific Software\ATLAStilRepositorylManaged Files\EF006.atldoc

EF006.pdf - 3:25 [meone want...usually at the tabl..] (6:1637-6:1789) (Super) Codes: [Community receptiveness]

DATA SOURCE UNACCESSIBLE!: C:IUsersIUserlAppDatalRoaminglScientific Software\ATLAStilRepositorylManaged Files\EF006.atldoc

EF006.pdf - 3:26 [Certainly to accomplish it in ..] (6:2614-6:2687) (Super) Codes: [Environmetal ceticism]

DATA SOURCE UNACCESSIBLE!: C:IUsersIUser\AppDatalRoaminglScientific Software\ATLAStilRepositorylManaged Files\EF006.atldoc

EF006.pdf - 3:27 [- Taxes base it does. Now, I w..] (7:94-7:228) (Super) Codes: [Sale Taxes, Revenues \& Royalties]

DATA SOURCE UNACCESSIBLE!: C:IUsersIUserlAppDatalRoaminglScientific SoftwarelATLAStilRepositorylManaged Files\EF006.atldoc

EF006.pdf - 3:28 [ours has been in the millions,...] (7:1069-7:1454) (Super) Codes: [Mineral Rights, Royalties \& Land Tenure]

DATA SOURCE UNACCESSIBLE!: C:IUsersIUserlAppDatalRoaminglScientific Software\ATLAStilRepositorylManaged FilesIEF006.atldoc

P 3: EF006.pdf - 3:29 [Ah...I have mentioned this...for a..] (7:1460-7:1671) (Super) Codes: [Housing \& properties impact]

DATA SOURCE UNACCESSIBLE!: C:IUsersIUserlAppDatalRoaminglScientific Software\ATLAStilRepositorylManaged Files\EF006.atldoc

EF006.pdf - 3:30 [l know...one...maybe if the past t..] (7:1970-7:2127) (Super) Codes: [Sale Taxes, Revenues \& Royalties]

DATA SOURCE UNACCESSIBLE!: C:IUsersIUserlAppDatalRoaminglScientific 
Software\ATLAStilRepositorylManaged Files\EF006.atldoc

EF006.pdf - 3:31 [Ah...certainly the...persons who h..] (8:612-8:836) (Super)

Codes: [Educational Attainment]

DATA SOURCE UNACCESSIBLE!: C:IUsersIUserlAppDataIRoamingIScientific SoftwarelATLAStilRepositorylManaged Files\EF006.atldoc

EF006.pdf - 3:32 [another one is safety! There a..] (8:954-8:1241) (Super) Codes: [Safety \& bottlenecks]

DATA SOURCE UNACCESSIBLE!: C:IUsersIUserlAppDatalRoaminglScientific SoftwarelATLAStilRepositorylManaged Files\EF006.atldoc

EF006.pdf - 3:33 [Uh'mm. And...there, you know, th..] (8:1267-8:1401) (Super) Codes: [Educational Attainment]

DATA SOURCE UNACCESSIBLE!: C:IUsersIUserlAppDatalRoamingIScientific SoftwarelATLAStilRepositorylManaged Files\EF006.atldoc

EF006.pdf - 3:34 [No, I think there will be beca..] (9:178-9:295) (Super) Codes: [Future perspectives]

DATA SOURCE UNACCESSIBLE!: C:IUsersIUser\AppDatalRoaminglScientific Software\ATLAStilRepositorylManaged Files\EF006.atldoc

EF006 - 3:35 [o, I do think there would be u..] (9:299-9:696) (Super)

Codes: [Upward mobility]

DATA SOURCE UNACCESSIBLE!: C:IUsersIUser\AppDatalRoaminglScientific SoftwarelATLAStilRepositorylManaged Files\EF006.atldoc

EF006.pdf - 3:36 [Ah...ah...don't know...I know they d..] (9:1031-9:1459) (Super) Codes: [Safety \& bottlenecks]

DATA SOURCE UNACCESSIBLE!: C:IUsersIUser\AppDatalRoaminglScientific Software $A T L A S t i l R e p o s i t o r y l M a n a g e d ~ F i l e s \backslash E F 006 . a t l d o c$

P 3: EF006.pdf - 3:37 [h...but at least from what...l've ..] (9:1741-9:2165) (Super) Codes: [World O\&G commodity prices]

DATA SOURCE UNACCESSIBLE!: C:IUsersIUserlAppDatalRoaminglScientific Software $A T L A S t i l R e p o s i t o r y l M a n a g e d ~ F i l e s \backslash E F 006 . a t l d o c$

EFS007.pdf - 4:1 [And so, what I see in the diff..] (2:1244-2:1481) (Super) Codes: [Government \& Governance layout]

DATA SOURCE UNACCESSIBLE!: C:IUsersIUser|AppDatalRoaminglScientific SoftwarelATLAStilRepositorylManaged Files\EFS007.atldoc

EFS007.pdf - 4:2 [I told the major the other day..] (2:1665-2:1908) (Super) Codes: [Infrastructure]

DATA SOURCE UNACCESSIBLE!: C:IUsersIUser|AppDatalRoamingIScientific SoftwarelATLAStilRepositorylManaged FilesIEFS007.atldoc

EFS007.pdf - 4:3 [to look for an intern and mayb..] (2:2226-3:165) (Super) Codes: [Educational Attainment]

DATA SOURCE UNACCESSIBLE!: C:IUsersIUser|AppDatalRoaminglScientific SoftwarelATLAStilRepositorylManaged FilesIEFS007.atldoc 
EFS007.pdf - 4:4 [...just like they need doctors, ..] (3:411-3:616) (Super) Codes: [Educational Attainment]

DATA SOURCE UNACCESSIBLE!: C:IUsersIUser/AppDatalRoamingIScientific SoftwarelATLAStilRepositorylManaged FilesIEFS007.atldoc

EFS007.pdf - 4:5 [qualified to run the governmen..] (3:482-3:515) (Super) Codes: [Government \& Governance layout]

DATA SOURCE UNACCESSIBLE!: C:IUsersIUserlAppDatalRoamingIScientific SoftwarelATLAStilRepositorylManaged FilesIEFS007.atldoc

EFS007.pdf - 4:6 [And I think that is part of th..] (3:638-3:959) (Super)

Codes: [Government \& Governance layout]

DATA SOURCE UNACCESSIBLE!: C:IUsersIUserlAppDatalRoaminglScientific SoftwarelATLAStilRepositorylManaged FilesIEFS007.atldoc

EFS007.pdf - 4:7 [I want to say in the seventies..] (3:1320-3:1509) (Super) Codes: [O\&G forthcoming \& structure]

DATA SOURCE UNACCESSIBLE!: C:IUsersIUserlAppDatalRoaminglScientific SoftwarelATLAStilRepositorylManaged FilesIEFS007.atldoc

EFS007.pdf - 4:8 [And although there is some dim..] (3:1533-3:1708) (Super) Codes: [World O\&G commodity prices]

DATA SOURCE UNACCESSIBLE!: C:IUsersIUserlAppDatalRoaminglScientific SoftwarelATLAStilRepositorylManaged FilesIEFS007.atldoc

EFS007 - 4:9 [No, I thinking I'm the officia..] (3:1968-3:2046) (Super)

Codes: [Development as Economic]

DATA SOURCE UNACCESSIBLE!: C:IUsersIUserlAppDatalRoaminglScientific Software\ATLAStilRepositorylManaged FilesIEFS007.atldoc

P 4: EFS007.pdf - 4:10 [official sales man] (3:1991-3:2008) (Super)

Codes: [Pro-business mentality]

DATA SOURCE UNACCESSIBLE!: C:IUsersIUser\AppDatalRoaminglScientific SoftwarelATLAStilRepositorylManaged FilesIEFS007.atldoc

EFS007.pdf - 4:11 [If you do a backward look at h..] (3:2411-3:2697) (Super) Codes: [Development as Economic]

DATA SOURCE UNACCESSIBLE!: C:IUsersIUserlAppDatalRoamingIScientific SoftwarelATLAStilRepositorylManaged FilesIEFS007.atldoc

EFS007.pdf - 4:12 [more capabilities and more cap..] (3:2555-3:2619) (Super) Codes: [Educational Attainment]

DATA SOURCE UNACCESSIBLE!: C:IUsersIUserlAppDatalRoaminglScientific Software\ATLAStilRepositorylManaged FilesIEFS007.atldoc

EFS007.pdf - 4:13 [the fact is that...ah....all of the..] (4:676-4:791) (Super) Codes: [Government \& Governance layout]

DATA SOURCE UNACCESSIBLE!: C:IUsersIUserlAppDatalRoamingIScientific SoftwarelATLAStilRepositorylManaged FilesIEFS007.atldoc 
EFS007.pdf - 4:14 [And for that reason, you have ..] (4:1-4:112) (Super) Codes: [Social Sensitives (population, genre, wage, accidents)]

DATA SOURCE UNACCESSIBLE!: C:IUsersIUserlAppDatalRoamingIScientific SoftwarelATLAStilRepositorylManaged FilesIEFS007.atldoc

EFS007.pdf - 4:15 [And yet you have others like P..] (4:115-4:554) (Super) Codes: [Development as Economic]

DATA SOURCE UNACCESSIBLE!: C:IUsersIUserlAppDatalRoamingIScientific SoftwarelATLAStilRepositorylManaged FilesIEFS007.atldoc

EFS007.pdf - 4:16 [I don't think it's an error in..] (4:352-4:480) (Super) Codes: [Development as Economic]

DATA SOURCE UNACCESSIBLE!: C:IUsersIUserlAppDatalRoaminglScientific Software\ATLAStilRepositorylManaged Files\EFS007.atldoc

EFS007- 4:17 [And then they came in and talk..] (4:794-4:878) (Super) Codes: [Community receptiveness]

DATA SOURCE UNACCESSIBLE!: C:IUsersIUserlAppDatalRoaminglScientific Software\ATLAStilRepositorylManaged Files\EFS007.atldoc

EFS007.pdf - 4:18 [And I'm not saying that we're ..] (4:1304-4:1523) (Super) Codes: [Government \& Governance layout]

DATA SOURCE UNACCESSIBLE!: C:IUsersIUserlAppDatalRoamingIScientific Software\ATLAStilRepositorylManaged FilesIEFS007.atldoc

EFS007 - 4:19 [I'm saying that we are more sy..] (4:1355-4:1524) (Super) Codes: [Pro-business mentality]

DATA SOURCE UNACCESSIBLE!: C:IUsersIUser|AppDatalRoaminglScientific SoftwarelATLAStilRepositorylManaged FilesIEFS007.atldoc

EFS007 - 4:20 [I think one individual doesn't..] (4:1736-4:2276) (Super) Codes: [Community receptiveness]

DATA SOURCE UNACCESSIBLE!: C:IUsersIUserlAppDatalRoaminglScientific SoftwarelATLAStilRepositorylManaged FilesIEFS007.atldoc

EFS007 - 4:21 [t's a very general ordinances.....] (4:2433-4:2462) (Super) Codes: [Ordinances: Why reinvent the wheel?]

DATA SOURCE UNACCESSIBLE!: C:IUsersIUserlAppDatalRoamingIScientific SoftwarelATLAStilRepositorylManaged FilesIEFS007.atldoc

EFS007 - 4:22 [It's a very general ordinances..] (4:2432-4:2528) (Super)

Codes: [Pro-business mentality]

DATA SOURCE UNACCESSIBLE!: C:IUsersIUserlAppDatalRoaminglScientific SoftwarelATLAStilRepositorylManaged FilesIEFS007.atldoc

EFS007.pdf - 4:23 [more to do with protection of ..] (4:2544-4:2690) (Super) Codes: [Safety \& bottlenecks]

DATA SOURCE UNACCESSIBLE!: C:IUsersIUserlAppDatalRoamingIScientific SoftwarelATLAStilRepositorylManaged FilesIEFS007.atldoc 
EFS007.pdf - 4:24 [But usually there is a distanc..] (5:173-5:401) (Super)

Codes: [Ordinances: Why reinvent the wheel?]

DATA SOURCE UNACCESSIBLE!: C:IUsersIUserlAppDatalRoaminglScientific SoftwarelATLAStilRepositorylManaged FilesIEFS007.atldoc

EFS007.pdf - 4:25 [Ours is not as restrictive and..] (5:294-5:401) (Super) Codes: [Pro-business mentality]

DATA SOURCE UNACCESSIBLE!: C:IUsersIUserlAppDatalRoamingIScientific Software\ATLAStilRepositorylManaged Files\EFS007.atldoc

EFS007.pdf - 4:26 [No...we knew what we wanted to p..] (5:992-5:1279) (Super)

Codes: [Government \& Governance layout]

DATA SOURCE UNACCESSIBLE!: C:IUsersIUserlAppDatalRoaminglScientific SoftwarelATLAStilRepositorylManaged FilesIEFS007.atldoc

P 4: EFS007.pdf - 4:27 [Yeah. The Denton people have a..] (5:1375-5:1441) (Super) Codes: [Cristicism]

DATA SOURCE UNACCESSIBLE!: C:IUsersIUser|AppDatalRoaminglScientific Software\ATLAStilRepositorylManaged FilesIEFS007.atldoc

EFS007.pdf - 4:28 [The no drill thing and I think..] (5:1469-5:1548) (Super) Codes: [Government \& Governance layout]

DATA SOURCE UNACCESSIBLE!: C:IUsersIUser\AppDatalRoaminglScientific SoftwarelATLAStilRepositorylManaged FilesIEFS007.atldoc

EFS007.pdf - 4:29 [you know when city governments..] (5:1549-5:1937) (Super) Codes: [Conflits \& Interests]

DATA SOURCE UNACCESSIBLE!: C:IUsersIUser\AppDatalRoaminglScientific Software\ATLAStilRepositorylManaged FilesIEFS007.atldoc

EFS007 - 4:30 [And it's more in keeping with ..] (6:866-6:1036) (Super)

Codes: [Government \& Governance layout]

DATA SOURCE UNACCESSIBLE!: C:IUsersIUserlAppDatalRoaminglScientific SoftwarelATLAStilRepositorylManaged FilesIEFS007.atldoc

Comment:

Nessa passagem o entrevistado cita claramente como o banimento de certas atividades que entende como radicalização nas tomadas de decisões locais são passiveis de reinterpretações pelo legislativo estadual e pelo Governo Federal.

EFS007 - 4:31 [If I own a property and if I h..] (6:1392-6:1549) (Super)

Codes: [Conflits \& Interests]

DATA SOURCE UNACCESSIBLE!: C:IUsersIUserlAppDatalRoaminglScientific SoftwarelATLAStilRepositorylManaged FilesIEFS007.atldoc

EFS007.pdf - 4:32 [And this is what this guys are..] (6:2020-6:2185) (Super) Codes: [Cristicism]

DATA SOURCE UNACCESSIBLE!: C:IUsersIUserlAppDatalRoaminglScientific 
SoftwarelATLAStilRepositorylManaged FilesIEFS007.atldoc

EFS007.pdf - 4:33 [And I heard some presentations..] (6:2209-6:2447) (Super)

Codes: [Cristicism]

DATA SOURCE UNACCESSIBLE!: C:IUsersIUserlAppDataIRoamingIScientific Software\ATLAStilRepositorylManaged Files\EFS007.atldoc

EFS007.pdf - 4:34 [Yeah, I'm really not concerned..] (7:340-7:711) (Super) Codes: [Development as Economic]

DATA SOURCE UNACCESSIBLE!: C:IUsersIUserlAppDatalRoaminglScientific Software\ATLAStilRepositorylManaged FilesIEFS007.atldoc

EFS007.pdf - 4:35 [that you look at this you want..] (7:527-7:678) (Super) Codes: [Cristicism]

DATA SOURCE UNACCESSIBLE!: C:IUsersIUserlAppDataIRoamingIScientific SoftwarelATLAStilRepositorylManaged FilesIEFS007.atldoc

Comment:

O entrevistado acreditada que as pessoas que se opoem a atividade de exploração de gás e petróleo em Eagle Ford Shale são ingenuas ou exageradas em suas avaliações. Para ele, esses mesmos grupos no final serão benefíciados pelo processo e tomarão carona no desenvolvimento subsequente e diversificação que acompanhará o setor.

EFS007 - 4:36 [and so it brings, welcome reve..] (7:716-7:773) (Super) Codes: [Sale Taxes, Revenues \& Royalties]

DATA SOURCE UNACCESSIBLE!: C:IUsersIUser\AppDatalRoaminglScientific Software\ATLAStilRepositorylManaged Files\EFS007.atldoc

EFS007- 4:37 [You want it done in such way t..] (7:776-7:890) (Super) Codes: [Social Sensitives (population, genre, wage, accidents)]

DATA SOURCE UNACCESSIBLE!: C:IUsersIUser\AppDatalRoaminglScientific Software\ATLAStilRepositorylManaged Files\EFS007.atldoc

EFS007 - 4:38 [and preserving the home proper..] (7:895-7:934) (Super) Codes: [Housing \& properties impact]

DATA SOURCE UNACCESSIBLE!: C:IUsersIUserlAppDatalRoaminglScientific Software\ATLAStilRepositorylManaged Files\EFS007.atldoc

EFS007.pdf - 4:39 [Well, they wouldn't have to, b..] (7:1520-7:1600) (Super) Codes: [Pro-business mentality]

DATA SOURCE UNACCESSIBLE!: C:IUsersIUserlAppDatalRoaminglScientific Software\ATLAStilRepositorylManaged Files\EFS007.atldoc

EFS007.pdf - 4:40 [And, in fact, the city is a be..] (7:1633-7:2065) (Super) Codes: [O\&G Wealthy \& Benefits]

DATA SOURCE UNACCESSIBLE!: C:IUsersIUserlAppDatalRoaminglScientific SoftwarelATLAStilRepositorylManaged FilesIEFS007.atldoc

EFS007.pdf - 4:41 [the city is a beneficiary of s..] (7:1647-7:1707) (Super) Codes: [Sale Taxes, Revenues \& Royalties]

DATA SOURCE UNACCESSIBLE!: C:IUsersIUserlAppDatalRoamingIScientific 
Software\ATLAStilRepositorylManaged FilesIEFS007.atldoc

EFS007.pdf - 4:42 [production activity at the air..] (7:1722-7:1788) (Super) Codes: [Development as Economic]

DATA SOURCE UNACCESSIBLE!: C:IUsersIUserlAppDataIRoamingIScientific SoftwarelATLAStilRepositorylManaged FilesIEFS007.atldoc

EFS007.pdf - 4:43 [...we've been in a regulatory mo..] (7:2068-7:2332) (Super) Codes: [Government \& Governance layout]

DATA SOURCE UNACCESSIBLE!: C:IUsersIUserlAppDatalRoaminglScientific Software\ATLAStilRepositorylManaged FilesIEFS007.atldoc

EFS007.pdf - 4:44 [...I had a complaint from...ah...som..] (7:2411-7:2477) (Super) Codes: [Cristicism]

DATA SOURCE UNACCESSIBLE!: C:IUsersIUser|AppDatalRoaminglScientific Software\ATLAStilRepositorylManaged Files\EFS007.atldoc

EFS007.pdf - 4:45 [when they did the wells over t..] (8:25-8:382) (Super) Codes: [Lack of Jurisdiction]

DATA SOURCE UNACCESSIBLE!: C:IUsersIUserlAppDatalRoamingIScientific Software\ATLAStilRepositorylManaged FilesIEFS007.atldoc

EFS007.pdf - 4:46 [rrizo, and you got to gthe wat..] (@569-@499) (Super) Codes: [Environmetal ceticism]

DATA SOURCE UNACCESSIBLE!: C:IUsersIUserlAppDatalRoaminglScientific Software\ATLAStilRepositorylManaged Files\EFS007.atldoc

EFS007.pdf - 4:47 [they've made their positions v..] (8:1363-8:1635) (Super) Codes: [Cristicism] [Environmetal ceticism]

No memos

DATA SOURCE UNACCESSIBLE!: C:IUsersIUser\AppDatalRoaminglScientific SoftwarelATLAStilRepositorylManaged FilesIEFS007.atldoc

EFS007.pdf - 4:48 [So, I would call it 'greed'. T..] (8:1659-8:1784) (Super) Codes: [Cristicism]

DATA SOURCE UNACCESSIBLE!: C:IUsersIUser\AppDatalRoaminglScientific SoftwarelATLAStilRepositorylManaged Files\EFS007.atldoc

EFS007.pdf - 4:49 [h'mm. Are there any partnershi..] (8:1960-8:2217) (Super) Codes: [Parternships \& Participation] [Sale Taxes, Revenues \& Royalties]

DATA SOURCE UNACCESSIBLE!: C:IUsersIUserlAppDatalRoaminglScientific SoftwarelATLAStilRepositorylManaged FilesIEFS007.atldoc

EFS007.pdf - 4:50 [ah...to different groups, nonpro..] (8:2455-9:264) (Super) Codes: [O\&G Donations and sponsorships]

DATA SOURCE UNACCESSIBLE!: C:IUsersIUserlAppDatalRoaminglScientific SoftwarelATLAStilRepositorylManaged FilesIEFS007.atldoc

EFS007.pdf - 4:51 [BPH has been very strong in pa..] (8:2521-8:2595) (Super) Codes: [O\&G Community Volunteer actions] 
No memos

DATA SOURCE UNACCESSIBLE!: C:IUsersIUserlAppDatalRoamingIScientific Software\ATLAStilRepositorylManaged Files\EFS007.atldoc

EFS007.pdf - 4:52 [It's kind of unfortunate that ..] (9:410-9:757) (Super) Codes: [Community receptiveness]

DATA SOURCE UNACCESSIBLE!: C:IUsersIUser\AppDatalRoaminglScientific Software\ATLAStilRepositorylManaged Files\EFS007.atldoc

EFS007.pdf - 4:53 [And I think they've tried to b..] (9:760-9:863) (Super) Codes: [Parternships \& Participation]

DATA SOURCE UNACCESSIBLE!: C:IUsersIUser\AppDatalRoaminglScientific Software\ATLAStilRepositorylManaged Files\EFS007.atldoc

EFS007.pdf - 4:54 [BPH put...ah...their field office ..] (9:1013-9:1049) (Super) Codes: [O\&G forthcoming \& structure]

DATA SOURCE UNACCESSIBLE!: C:IUsersIUser\AppDatalRoaminglScientific Software\ATLAStilRepositorylManaged Files\EFS007.atldoc

EFS007.pdf - 4:55 [Anadarko has a...ah...very large i..] (9:1074-9:1220) (Super) Codes: [Pro-business mentality]

DATA SOURCE UNACCESSIBLE!: C:IUsersIUserlAppDatalRoamingIScientific Software\ATLAStilRepositorylManaged Files\EFS007.atldoc

EFS007.pdf - 4:56 [We have an industrial investme..] (9:1242-9:1538) (Super) Codes: [Development as Economic]

DATA SOURCE UNACCESSIBLE!: C:IUsersIUserlAppDatalRoamingIScientific SoftwarelATLAStilRepositorylManaged FilesIEFS007.atldoc

EFS007.pdf - 4:57 [If you draw a circle around th..] (9:1560-9:1791) (Super) Codes: [Development as Economic] [Pro-business mentality]

DATA SOURCE UNACCESSIBLE!: C:IUsersIUser\AppData|RoaminglScientific Software\ATLAStilRepositorylManaged Files\EFS007.atldoc

EFS007.pdf - 4:58 [And that's better than any gov..] (9:1793-9:1895) (Super) Codes: [Cristicism]

DATA SOURCE UNACCESSIBLE!: C:IUsersIUserlAppData|RoaminglScientific Software\ATLAStilRepositorylManaged Files\EFS007.atldoc

EFS007.pdf - 4:59 [hey paid for the roof! And so,..] (10:490-10:703) (Super) Codes: [O\&G Donations and sponsorships]

DATA SOURCE UNACCESSIBLE!: C:IUsersIUser\AppData|RoamingIScientific Software\ATLAStilRepositorylManaged Files\EFS007.atldoc

EFS007.pdf - 4:60 [The investments and the royalt..] (9:1922-9:2634) (Super) Codes: [Mineral Rights, Royalties \& Land Tenure]

DATA SOURCE UNACCESSIBLE!: C:IUsersIUserlAppData|RoaminglScientific Software\ATLAStilRepositorylManaged Files\EFS007.atldoc

EFS007.pdf - 4:61 [...ah...one of the great great-gra..] (9:2638-10:462) (Super) 
Codes: [O\&G Donations and sponsorships] [O\&G Wealthy \& Benefits]

DATA SOURCE UNACCESSIBLE!: C:IUsersIUserlAppDataIRoamingIScientific SoftwarelATLAStilRepositorylManaged FilesIEFS007.atldoc

EFS007.pdf - 4:62 [Probably, the most important o..] (10:838-10:974) (Super) Codes: [Mineral Rights, Royalties \& Land Tenure]

DATA SOURCE UNACCESSIBLE!: C:IUsersIUserlAppDatalRoaminglScientific SoftwarelATLAStilRepositorylManaged FilesIEFS007.atldoc

EFS007.pdf - 4:63 [ah....and I would think, the this..] (10:1093-10:1226) (Super) Codes: [Jobs opportunities and challenges]

DATA SOURCE UNACCESSIBLE!: C:IUsersIUserlAppDatalRoamingIScientific SoftwarelATLAStilRepositorylManaged FilesIEFS007.atldoc

P 4: EFS007.pdf - 4:64 [They hire anybody that pass in..] (10:1559-10:2454) (Super) Codes: [Jobs opportunities and challenges]

DATA SOURCE UNACCESSIBLE!: C:IUsersIUserlAppDataIRoaminglScientific SoftwarelATLAStilRepositorylManaged FilesIEFS007.atldoc

EFS007.pdf - 4:65 [And get them on the right path..] (11:1305-11:2218) (Super) Codes: [Educational Attainment]

DATA SOURCE UNACCESSIBLE!: C:IUsersIUserlAppDataIRoamingIScientific SoftwarelATLAStilRepositorylManaged FilesIEFS007.atldoc

EFS007.pdf - 4:66 [ah...the people who are...who are ..] (12:1239-12:1341) (Super) Codes: [Safety \& bottlenecks]

DATA SOURCE UNACCESSIBLE!: C:IUsersIUserlAppDatalRoaminglScientific SoftwarelATLAStilRepositorylManaged FilesIEFS007.atldoc

EFS007.pdf - 4:67 [On the drug test...so they only ..] (12:351-12:663) (Super) Codes: [Jobs opportunities and challenges]

DATA SOURCE UNACCESSIBLE!: C:IUsersIUserlAppDatalRoaminglScientific SoftwarelATLAStilRepositorylManaged FilesIEFS007.atldoc

EFS007.pdf - 4:68 [And I think that continuous to..] (12:1537-12:1877) (Super) Codes: [Safety \& bottlenecks] [Social Sensitives (population, genre, wage, accidents)]

DATA SOURCE UNACCESSIBLE!: C:IUsersIUserlAppDatalRoaminglScientific SoftwarelATLAStilRepositorylManaged FilesIEFS007.atldoc

EFS007.pdf - 4:69 [Yeah, and the worst part about..] (12:1926-12:2266) (Super) Codes: [Safety \& bottlenecks]

DATA SOURCE UNACCESSIBLE!: C:IUsersIUserlAppDatalRoaminglScientific Software\ATLAStilRepositorylManaged FilesIEFS007.atldoc

EFS007.pdf - 4:70 [And if you don't get there in ..] (12:2618-13:396) (Super)

Codes: [Infrastructure]

DATA SOURCE UNACCESSIBLE!: C:IUsersIUserlAppDatalRoaminglScientific SoftwarelATLAStilRepositorylManaged FilesIEFS007.atldoc

EFS007.pdf - 4:71 [Actually there is a bunch them..] (13:610-13:757) (Super) 
Codes: [Parternships \& Participation]

DATA SOURCE UNACCESSIBLE!: C:IUsersIUserlAppDataIRoamingIScientific SoftwarelATLAStilRepositorylManaged FilesIEFS007.atldoc

EFS007.pdf - 4:72 [...ah...last year I wanna say we h..] (13:782-13:1109) (Super) Codes: [Conflits \& Interests] [Parternships \& Participation]

DATA SOURCE UNACCESSIBLE!: C:IUsersIUserlAppDatalRoaminglScientific SoftwarelATLAStilRepositorylManaged FilesIEFS007.atldoc

Comment:

O entrevistado representara cidade e ao mesmo tempo é presidente de um conselho que agrega companhias de gás e petróleo e a área de engenharia do campus da universidade Texas A\&M em Kingsville

EFS007.pdf - 4:73 [You know...because they're just ..] (13:1494-13:2097) (Super) Codes: [O\&G procedures, strategies and investments]

DATA SOURCE UNACCESSIBLE!: C:IUsersIUserlAppDataIRoaminglScientific Software\ATLAStilRepositorylManaged FilesIEFS007.atldoc

EFS007.pdf - 4:74 [and he told me that at a meeti..] (13:2305-14:820) (Super) Codes: [Environmetal ceticism]

DATA SOURCE UNACCESSIBLE!: C:IUsersIUserlAppDataIRoamingIScientific SoftwarelATLAStilRepositorylManaged FilesIEFS007.atldoc

EFS007.pdf - 4:75 [You know, a told someone in Sa..] (14:1377-14:1796) (Super) Codes: [O\&G and Technology]

DATA SOURCE UNACCESSIBLE!: C:IUsersIUserlAppDatalRoaminglScientific SoftwarelATLAStilRepositorylManaged FilesIEFS007.atldoc

EFS007.pdf - 4:76 [And then sudden this battle, b..] (14:849-14:1004) (Super) Codes: [Conflits \& Interests]

DATA SOURCE UNACCESSIBLE!: C:IUsersIUser|AppDatalRoaminglScientific SoftwarelATLAStilRepositorylManaged FilesIEFS007.atldoc

EFS007.pdf - 4:77 [And of course, this thing abou..] (14:2269-14:2768) (Super) Codes: [Environmetal ceticism]

DATA SOURCE UNACCESSIBLE!: C:IUsersIUserlAppDatalRoamingIScientific SoftwarelATLAStilRepositorylManaged FilesIEFS007.atldoc

EFS007.pdf - 4:78 [I believe the slowdown is a te..] (15:1520-15:1932) (Super) Codes: [World O\&G commodity prices]

DATA SOURCE UNACCESSIBLE!: C:IUsersIUserlAppDatalRoaminglScientific Software\ATLAStilRepositorylManaged FilesIEFS007.atldoc

EFS007.pdf - 4:79 [Yeah, there probably is...ah...I w..] (15:110-15:1160) (Super) Codes: [Jobs opportunities and challenges]

DATA SOURCE UNACCESSIBLE!: C:IUsersIUserlAppDatalRoamingIScientific SoftwarelATLAStilRepositorylManaged FilesIEFS007.atldoc 
EFS007.pdf - 4:80 [And If...ah...the thing that Obama..] (15:2435-15:3513) (Super) Codes: [Government \& Governance layout]

DATA SOURCE UNACCESSIBLE!: C:IUsersIUserlAppDatalRoamingIScientific SoftwarelATLAStilRepositorylManaged FilesIEFS007.atldoc

EFS007.pdf - 4:81 [almost immediately after that ..] (16:2-16:723) (Super) Codes: [Gas exports opportunities]

DATA SOURCE UNACCESSIBLE!: C:IUsersIUserlAppDatalRoamingIScientific SoftwarelATLAStilRepositorylManaged FilesIEFS007.atldoc

EFS007.pdf - 4:82 [No, I don't think the...ah...the p..] (16:1228-16:1821) (Super) Codes: [Development as Economic]

DATA SOURCE UNACCESSIBLE!: C:IUsersIUserlAppDatalRoaminglScientific Software\ATLAStilRepositorylManaged FilesIEFS007.atldoc

EFS007.pdf - 4:83 [but...ah...the guy says: no, no, n..] (16:1852-16:2963) (Super) Codes: [Development as Economic]

DATA SOURCE UNACCESSIBLE!: C:IUsersIUserlAppDataIRoamingIScientific SoftwarelATLAStilRepositorylManaged FilesIEFS007.atldoc

EFS007.pdf - 4:84 [but I would think that Lewis i..] (15:1165-15:1514) (Super) Codes: [O\&G procedures, strategies and investments]

DATA SOURCE UNACCESSIBLE!: C:IUsersIUser|AppDatalRoaminglScientific Software\ATLAStilRepositorylManaged FilesIEFS007.atldoc

EFS007 - 4:85 [...and I think that, the railroa..] (17:327-17:649) (Super)

Codes: [Transportation (Traffic, Road impact \& Railroads)]

No memos

DATA SOURCE UNACCESSIBLE!: C:IUsersIUserlAppDatalRoamingIScientific SoftwarelATLAStilRepositorylManaged FilesIEFS007.atldoc

EFS007.pdf - 4:86 [...Oil and Gas continuous to be ..] (17:653-17:759) (Super) Codes: [Development as Economic] [Future perspectives]

DATA SOURCE UNACCESSIBLE!: C:IUsersIUserlAppDatalRoaminglScientific SoftwarelATLAStilRepositorylManaged FilesIEFS007.atldoc

EFS007.pdf - 4:87 [I think there is a combination...] (17:1338-17:1766) (Super) Codes: [Mineral Rights, Royalties \& Land Tenure]

DATA SOURCE UNACCESSIBLE!: C:IUsersIUserlAppDatalRoaminglScientific SoftwarelATLAStilRepositorylManaged FilesIEFS007.atldoc

EFS007.pdf - 4:88 [...so I think it's just got both..] (17:1794-17:2095) (Super) Codes: [Opportunism]

DATA SOURCE UNACCESSIBLE!: C:IUsersIUserlAppDatalRoaminglScientific SoftwarelATLAStilRepositorylManaged FilesIEFS007.atldoc

EFS007.pdf - 4:89 [l think the production side is..] (17:2260-17:3054) (Super) Codes: [Development as Economic] 
DATA SOURCE UNACCESSIBLE!: C:IUsersIUserlAppDatalRoamingIScientific SoftwarelATLAtilRepositorylManaged FilesIEFS007.atldoc

EFS007.pdf - 4:90 [So I think that what going to ..] (18:1-18:722) (Super) Codes: [Future perspectives]

DATA SOURCE UNACCESSIBLE!: C:IUsersIUserlAppDatalRoamingIScientific SoftwarelATLAStilRepositorylManaged FilesIEFS007.atldoc

EFS007.pdf - 4:91 [Plainsall American, which is j..] (18:744-18:1118) (Super) Codes: [Development as Economic]

DATA SOURCE UNACCESSIBLE!: C:IUsersIUserlAppDatalRoaminglScientific SoftwarelATLAStilRepositorylManaged FilesIEFS007.atldoc

EFS007.pdf - 4:92 [he biggest challenge to the co..] (18:1315-18:1791) (Super) Codes: [Future perspectives]

DATA SOURCE UNACCESSIBLE!: C:IUsersIUserlAppDataIRoamingIScientific SoftwarelATLAStilRepositorylManaged FilesIEFS007.atldoc

EFS008-9 - 5:1 [een a director with the board ..] (1:1294-1:1532) (Super) Codes: [Safety \& bottlenecks]

een a director with the board of the Chamber of Commerce for only a month now...two months...ah.... In my actual job, I'm actually the owner of Rooster Safety here in town. - Which is a safety company open up about a year ago

EFS008-9 - 5:2 [Well, We've gone from about on..] (1:1882-1:2000) (Super) Codes: [Membership]

Well, We've gone from about one hundred and ten members to about hundred and ninety! And that's just in the last year

EFS008-9 - 5:3 [And we're going to be doing ou..] (2:32-2:288) (Super)

Codes: [Membership] [Pro-business mentality]

And we're going to be doing our memberships drive again here shortly. It's time to start that, so hopefully will get $220 / 230$ [members]... Constantly getting new businesses in town. As they're coming into town, they're also adding us as members.

EFS008-9 - 5:4 [Yeah...ah...the big boom back was ..] (2:681-2:1070) (Super) Codes: [O\&G forthcoming \& structure]

Yeah...ah...the big boom back was in the late 80's and...a big boom then...that kind of died down...had a little residual...ah...maintaining the wells that were around the area... ....and then back in 2010 is whenever the Eagle Ford Shale started becoming popular... lot of companies started to moving into this area trying to...looking for fracking and...try the shale play [crack into the oil/gas reservoir

EFS008-9 - 5:5 [We haven't had a big role! No,..] (2:1685-2:1829) (Super)

Codes: [Membership]

We haven't had a big role! No, none at all.... we've worked hard to get members and get members to be involved...ah...the gas...it just came to town...

EFS008-9 - 5:6 [You know...for some reason they ..] (2:1864-2:2595) (Super) Codes: [Sense of Spatial Protagonism (SSP)]

You know...for some reason they picked Pleasanton be a kind of a hub or a focal point and I 
think it is because of I-37 being so close and the access out here. is a kind of the center of all the activity that is going within about a forty mile radius... You can get...ah...Pearsall in an hour, Cotulla is 45 minutes...1 hour, you get the Karnes City in an hour, you can get to Falls City in an hour...being right here in Pleasant town we really are centralized to where the operation are... out of the supermarkets...hotels...stuff like

that...it's definitely helped us drag more business to come to this area versus the smaller towns... HEB just made an improvement to their facilities... did you see it?

Comment:

Os atores sociais ligados as atividades comerciais e os gestores locais sempre demonstram um sentimento de protagonismo espacial, Sense of Spatial Protagonism, quanto ao crescimento econômico que Eagle Ford Shale tem causado as cidades inseridas em sua áreas. O discurso comum é que seus munícipios são o centro das atividades, o epicentro dos investimentos e que suas localizações privilegiadas thes garantem usufruir por um longo tempo das beneces do desenvolvimento subsequente causado pela exploração de gás e petróleo do xisto de EFS.

FS008-9 - 5:7 [ut of the supermarkets...hotels.....] (2:2380-2:2520) (Super)

Codes: [Pro-business mentality]

ut of the supermarkets...hotels...stuff like

that...it's definitely helped us drag more business to come to this area versus the smaller towns...

EFS008-9 - 5:8 [and, it's going be a big impro..] (3:78-3:405) (Super)

Codes: [Infrastructure] [Institutional approach] [O\&G Wealthy \& Benefits]

and, it's going be a big improvement to our community. And will keep a lot of people more doing their shopping locally. They've added a lot of different products and things to what they didn't have before [HEB] because they didn't have the space for it. But...ah...they have been a good business partners with the Chamber too...

EFS008-9 - 5:9 [Supporting us, sponsorships...ah..] (3:449-3:990) (Super)

Codes: [Community receptiveness] [Membership] [O\&G Donations and sponsorships]

Supporting us, sponsorships...ah...being on the board You know, things like that! Cindy: We do a lot with them as far as them supporting a project we have; if we need something.... if we do a crawfish boil, they furnish the crawfish...They do anything they can do...they're very supportive. They are large supporters. Atacoasa County Stock Show coming up, they betters on that [?]...ah...graduation comes up...they're definitely sponsoring for graduation...they've been a good support to the community. Just for years!

EFS008-9 - 5:10 [He's also a director here on t..] (3:1589-3:1913) (Super) Codes: [Parternships \& Participation]

He's also a director here on the board with us. You know, a lot of the city businesses have been promoting by the oil field business... you know, 'another person,' Wade McBee, he owns a local BBQ place in the town. You probably drove by it. They support Oilfield industry a lot and their business... and they go out and cater

EFS008-9 - 5:11 [a lot of the city businesses h..] (3:1647-3:1722) (Super) Codes: [O\&G Wealthy \& Benefits]

a lot of the city businesses have been promoting by the oil field business

EFS008-9 - 5:12 [lt does, it does...course if you..] (3:2002-3:2315) (Super)

Codes: [Development as Economic] 
It does, it does...course if you go look at the pharmacies are town, they're all busy...you know why? We have 5000 more people living here... used to 6 thousand...so, if you go to HEB or if you go to Walgreen's, you going to wait in the line cause they're just busy, because all of our retail establishments are busy.

EFS008-9 - 5:13 [...all the extra people we have ..] (3:2726-3:2768) (Super)

Codes: [Social Sensitives (population, genre, wage, accidents)]

...all the extra people we have here in town...

EFS008-9 - 5:14 [Greg deCaro is... definitely, se..] (4:393-4:475) (Super)

Codes: [Opportunism]

Greg deCaro is... definitely, seeing what is coming to town and, he's been building...

EFS008-9 - 5:15 [Greg deCaro he owns a lot of s..] (4:564-4:993) (Super)

Codes: [Housing \& properties impact]

Greg deCaro he owns a lot of storage units here in the town.....and...strip centers. Cindy: $\mathrm{He}$ had a few before this, but now he....Isn't that apartments that he's building over there. building a new apartment complex, which we haven't had apartments built since the 80's probably Cindy: They were probably built in the first oil boom. We're actually getting some very nice apartments that are coming to town

EFS008-9 - 5:16 [And there's a big need for the..] (4:1006-4:1220) (Super)

Codes: [Social Sensitives (population, genre, wage, accidents)]

And there's a big need for them too. You know these oilfield guys they get tired of living in those mobile units...they want something little more permanent. So, the apartments complexes are important to them too!

EFS008-9 - 5:17 [Yeah. I think that our town is..] (4:1397-4:1616) (Super)

Codes: [Future perspectives]

Yeah. I think that our town is growing with the Oilfield here but I'm hoping we will be able to sustain all the restaurants and hotels and everything like that once the... you know, twenty years down the road...you know...

EFS008-9 - 5:18 [That we'll be able to building..] (4:1651-4:1870) (Super)

Codes: [Quality of life]

That we'll be able to building the community up. I think that by having a bigger HEB, having more restaurants will drive more people to live in here...versus living in San Antonio with nonstop traffic all day long...so...

\section{EFS008-9 - 5:19 [I mean if haven't driven out a..] (5:14-5:213) (Super)}

Codes: [O\&G forthcoming \& structure]

I mean if haven't driven out all around Pleasanton... but they're just all scattered about this area all around 3, 4 miles, 10 miles, outside San Antonio, outside Pleasanton they're just everywhere!

\section{EFS008-9 - 5:20 [Well, actually they have. They..] (5:859-5:2019) (Super)}

Codes: [O\&G Donations and sponsorships]

Well, actually they have. They do sponsorships, things like that for events... -That we have...ah...

Cindy: I think that's a big thing. Sponsorships... We have big events and they sponsor our two main events. They have been a big sponsorships... [not enough voice reaching the microphone]. -Marathon Oil, MacAnier [Oil] either... [and others...] Office manager: ...They 
provide us with light towers and the things that we need. One of our largest events is The Cowboy Homecoming every year; we have that in October. We're going to have our Turn ' $n$ Burch event here in March....and last year we had a hundred and fifty barbequerers show up for that; this year we're hoping for two hundred; we'll wait and see. I don't know if we'll get there. We hope to...ah...that those are the two largest events that we put on as the Chamber, and the two largest events in the city! And they also I assume help out with other things, like the little league team or stuff like that? EFS008-Yeah. And they help out with the booster clubs; we've all been previous officers on booster clubs, and they were very helpful on that...

EFS008-9 - 5:21 [Sponsorships!] (6:774-6:786) (Super)

Codes: [O\&G Donations and sponsorships]

Sponsorships!

EFS008-9 - 5:22 [FracTech. They were one of the..] (6:1522-6:1656) (Super)

Codes: [O\&G forthcoming \& structure] [Opportunism]

FracTech. They were one of the first big ones to really open eyes that something's going on, that the town's fixing to start growing...

EFS008-9 - 5:23 [Number one...the tax bases of co..] (7:8-7:42) (Super)

Codes: [Sale Taxes, Revenues \& Royalties]

Number one...the tax bases of course!

EFS008-9 - 5:24 [Ah...the business they brought t..] (7:73-7:139) (Super)

Codes: [Pro-business mentality]

Ah...the business

they brought to town... just in motel, hotel taxes...

EFS008-9 - 5:25 [ah...Hotel, Motel taxes gone fro..] (7:311-7:388) (Super)

Codes: [Sale Taxes, Revenues \& Royalties]

ah...Hotel, Motel taxes gone from 100 thousand dollars to over a million dollars

EFS008-9 - 5:26 [And there's more hotels coming..] (7:663-7:843) (Super)

Codes: [Development as Economic]

And there's more hotels coming too.

EFS008-Yeah. Of course all these retail establishments, all this new business. It wouldn't be here if it wasn't for the Oilfield companies.

EFS008-9 - 5:27 [FS008-Because our growth would..] (7:862-7:1377) (Super)

Codes: [Social Sensitives (population, genre, wage, accidents)]

FS008-Because our growth wouldn't have been as fast. Ah..but, the schools haven't changed, the population of schools, the student attendants has grown very, very little, if it all. Which a lot of people find that strange and I do too in some ways, but it really hasn't.

Like I said earlier, the city, you know, four year ago was supporting about 8,500 homes and now it's about $13,500 \ldots$ so, you know, there hasn't been that much new home growth. It's still on the same pattern that it's always been on: $3-4 \%$

EFS008-9 - 5:28 [l guess I would say the jobs i..] (7:1676-7:2036) (Super)

Codes: [Jobs opportunities and challenges]

No memos

I guess I would say the jobs impact...ah....because, a lot of our local kids now...they can get 
employed locally. They can go work for the oilfields or related companies, our son being one.... He works for an electrical company right outside of town...that company wasn't here four years ago. But he's got a good job out there... a lot of theses kids are staying local...

\section{EFS008-9 - 5:29 [When the Oilfield came, I was ..] (7:2304-8:151) (Super)}

Codes: [Upward mobility]

When the Oilfield came, I was able to work my way up. At 22 years old I was a regional manager of a safety company and after that I had over 150 employees work for me in South Texas and allowed me to go open up in Wes Texas. The knowledge that I got was so fast and the owner and the vice president of the company trained me in management and a lot of it was crash course in how to deal with management...it has allowed me to have the knowledge that I have today! The real knowledge....not the book knowledge.

\section{EFS008-9 - 5:30 [How many jobs do you think we ..] (8:781-8:934) (Super) \\ Codes: [Jobs opportunities and challenges]}

How many jobs do you think we have in the O\&G in south Texas now? I mean, I couldn't put a number on that! Let's put a quick number and say 20 thousand!

\section{EFS008-9 - 5:31 [eah. There's 8.500 [people] be..] (8:1037-8:1248) (Super)}

Codes: [Jobs opportunities and challenges]

eah. There's 8.500 [people] before the Eagle Ford and they all had jobs, you know, a lot of those are student, kids not looking for jobs, living with the parents...now they have jobs! So there is a high demand!

\section{EFS008-9 - 5:32 [we have seen some teachers and..] (8:1260-8:1974) (Super)}

Codes: [Social Sensitives (population, genre, wage, accidents)]

we have seen some teachers and things like that go from the teaching side of it and go into the Oilfields, other people too in town, that's one example I can think of... we lost 3 or 4 coaches to Oilfield business...they pay better; it has helped to raise...ah...standard of living in town and the wage, and that's good Like the Village Inn trying to start a new business and hiring people....and...they're advertising 10 dollars an hour! Well, guess what? That's not even competitive anymore. EFS009- When I opened my office in West Texas, we were only hiring people at 14 dollars/hours...McDonalds had a sign and instead of saying " $\$ 0.99$ sausage biscuit," it said, "hiring at $\$ 15 / \mathrm{hr}$.

\section{EFS008-9 - 5:33 [And there's a lot of those job..] (9:885-9:1655) (Super)}

Codes: [Jobs opportunities and challenges]

And there's a lot of those jobs around too. If you really look probably...70\% of the jobs here...yeah, are high school. EFS009-When I did most of the hiring at my previous company, as long as they had a high school education...I had several guys that were ex-senior chiefs of the navy, pad masters that had engineering degrees and they're still working in the same position as long you have high school education. They didn't get paid more; they didn't get special treatment...the job was the job, except they like the pay, they like the position, like the hours, you know. It definitely made them qualified, but... or a little more qualified. I wouldn't have hired someone without a high school education. It all depends more on personality and responsibility than

EFS008-9 - 5:34 [70\% of the jobs here...yeah, are..] (9:957-9:1001) (Super) Codes: [Educational Attainment]

$70 \%$ of the jobs here...yeah, are high school.

EFS008-9 - 5:35 [l know one of the big obstacle..] (9:1811-9:2075) (Super)

Codes: [Social Sensitives (population, genre, wage, accidents)] 
I know one of the big obstacles for a lot of O\&G company here is related to the drugs testing T EFS008-It's a big problem. I don't know why... if it's the industry or what it attracts or what have you but it's a big thing.

EFS008-9 - 5:36 [Not in the community...we have s..] (9:2349-9:2572) (Super) Codes: [Institutional approach]

Not in the community...we have some conventions that we go to; there is a monthly safety meetings a lot of managements get together, work of couple fellowships up at church, there are some bigger conventions that... you know...

EFS008-9 - 5:37 [get involved in the community.....] (10:222-10:554) (Super)

Codes: [Community receptiveness]

No memos

get involved in the community... that's one thing that we're trying to do as a

chamber, we try to get more these oil companies. Most of thier home bases are around here, you know, they have satellite offices, satellite lots. You know...operations' lots....ah...now, a lot of them are supportive as far as donations and things like that...

EFS008-9 - 5:38 [now, a lot of them are support..] (10:478-10:553) (Super)

Codes: [O\&G Donations and sponsorships]

now, a lot of them are supportive as far as donations and things like that

EFS008-9 - 5:39 [Yes, cause they will jump for ..] (10:1017-10:1065) (Super)

Codes: [Jobs opportunities and challenges]

Yes, cause they will jump for fifty cents...[laughs

P 5: EFS008-9 - 5:40 [ou know, I can't give you exac..] (10:1139-10:1371) (Super)

Codes: [Transportation (Traffic, Road impact \& Railroads)]

ou know, I can't give you exact numbers but I do know that we have had a lot more accidents...not related to fracking and that's related to all truck traffic and all the traffic that's on the streets...you know....we didn't have before...

EFS008-9 - 5:41 [Because like he was saying, th..] (10:1714-10:1813) (Super)

Codes: [Cristicism]

Because like he was saying, the oilfield does not always bring the most honorable, the best people

P 5: EFS008-9 - 5:42 [o...when there is a job and ever..] (10:1825-10:2174) (Super)

Codes: [Social Sensitives (population, genre, wage, accidents)]

o...when there is a job and everybody can have a job...I think it kind of keeps some of the theft off of the streets. Back then, you know, people are stealing, because they couldn't afford something or they're lazy. You can get a job anywhere in this town; I mean in a heartbeat! You're not going to be bored if you find one job. That's my opinion.

EFS008-9 - 5:43 [I think the accidents... we have..] (11:9-11:633) (Super)

Codes: [Safety \& bottlenecks] [Transportation (Traffic, Road impact \& Railroads)]

No memos

I think the accidents... we have with tons drivers...we have a bunch of trucking [CDL]

companies....are common in... and will hire you...you know get you CDL...and then you have a guy that has been driving an eighteen wheeler for three months... who thinks he's been driving 
it for 30 years. And he's going 90 miles per hour down the highway with a full load...

T - That's a problem...

EFS009- That's a big problem! That's not just a big problem for him but it's a big problem for us...driving all through town and it's not just his life that he's putting on the life. It's everybody in this community that they're putting on the line

EFS008-9 - 5:44 [Oilfield tends to push to peop..] (11:639-11:1335) (Super)

Codes: [Social Sensitives (population, genre, wage, accidents)]

No memos

Oilfield tends to push to people work more than twelve hours a day! In this community, most of our citizens are not used to working 12 hours a day...before the oilfield came. They worked eight hours a day. So, you work twelve hours a day, seven days a week...it's putting a strain on someone's body! Now we've got these guys plus working the night shift and 7 day shift...so now we got 12 hours plus working night shift, and at 6 clock in the morning they're driving through town coming back home... you know... after a few days, who knows? It's very scary. I have a little girl on the way, and I'm kind of scared to see 15 years down the road...when she starts driving what it's going to be like.

EFS008-9 - 5:45 [We have lost some locals...ah...ve..] (11:1342-11:1842) (Super) Codes: [Transportation (Traffic, Road impact \& Railroads)] No memos

We have lost some locals...ah...very tragic accidents due to small vehicle accidents and again, we're not blaming oilfield for that. It's just more traffic on the road is going to cause more accidents! But... Oilfield does put a rush on things...so Oil companies put rush on the services companies, service companies putting rush on their employee...pushing them to where they probably are working themselves, working long hours, being exhausted, and pushing them to hurry up to get locations speeding...

EFS008-9 - 5:46 [l've seen several rollovers ju..] (11:3003-11:3337) (Super) Codes: [Transportation (Traffic, Road impact \& Railroads)] No memos

I've seen several rollovers just in the last few months in my company...we go out do ...ah...we are doing a safety consultant for a lot of companies, so anytime they have an accident, they'll call us out to do an accident investigation and one of my companies, they probably had one eighteen wheeler rollover every two to three weeks.

EFS008-9 - 5:47 [they probably had one eighteen..] (11:3263-11:3336) (Super) Codes: [Safety \& bottlenecks]

they probably had one eighteen wheeler rollover every two to three weeks

EFS008-9 - 5:48 [We're just trying to go throug..] (11:2234-11:2632) (Super)

Codes: [Transportation (Traffic, Road impact \& Railroads)]

We're just trying to go through that and they've been a long enough now our road are getting torn up... there's construction out here on 97 heading towards Jordanton and those improvements are getting more evident every day EFS009 - There's roads that we drive on to get to a location, a mile down the road going

$70 \mathrm{mph}$ there'll be a pothole that'll nearly throw you off the side of the road.

EFS008-9 - 5:49 [Well, that's one of the servic..] (12:931-12:1274) (Super)

Codes: [O\&G procedures, strategies and investments] 
Well, that's one of the services we offer. We do a lot of these safety training and other certain classes that are required to get on locations. There's my company and there are several other companies in town that also do the same thing. In Pleasanton, there's quite a bit of training between the 3 or 4 of us companies that do training...

EFS008-9 - 5:50 [A lot of the oil companies, th..] (12:1366-12:1880) (Super)

Codes: [O\&G procedures, strategies and investments]

A lot of the oil companies, they actually have a program ISNet World, which grades the employee...the company....If you want to work for Marathon...Let's say somebody wants to work for Marathon, then they're going to look at our insurance, they're going to look at all of our policies, procedures, they're going to want our OSHA compliance, they're going to look at all the accidents we've had, the lost time days, any incident and stuff like that! And they actually grade us. And then Marathon looks at it and...

\section{EFS008-9 5:51 [Some of the students go to loc..] (13:438-13:1128) (Super) \\ Codes: [Educational Attainment]}

Some of the students go to local colleges. A lot of them do that. There are courses that you can take for when you get out of high school and get some education. So, I know that something that...[indiscernible] and they're really involved in that. EFS008-It's a junior college town. But, it is a lot easier for our children-our kids to get jobs locally than it used to be. EFS009- They use to be "stay and work at McDonalds" or you know go to the college and find something...

EFS008-Unless your parents owned a business, they can get involved in the business, whether it is farming or ranching, private enterprise, such as EFS009's...but now there is a lot more jobs available

\section{EFS008-9 - 5:52 [A sore subject with oil at \$44..] (13:1993-13:2079) (Super) \\ Codes: [World O\&G commodity prices]}

A sore subject with oil at $\$ 44$. Going to have a bunch of vacant buildings here shortly.

\section{EFS008-9 - 5:53 [Well, I still think...ah...it's be..] (13:2091-14:87) (Super)}

Codes: [Development as Economic]

Well, I still think...ah...it's better for the consumer, if our gas and oil prices are lower! So, that is more affordable. Now they have more income, they can spend in other stuff. We all know that they turn over all their money ten times. Every dollar turns over ten times. They don't have to spend it on a necessity, which gasoline has become a necessity to go and back of work. It's a necessity. So, I do think our economy is better off! Now, does it help all companies? Not as much!

\section{EFS008-9 - 5:54 [Fortunately, west Texas and so..] (14:545-14:1131) (Super) Codes: [Future perspectives]}

Fortunately, west Texas and south Texas can produce oil cheaper than just about any other place in the United States on my understanding. My understanding is that west Texas and south Texas can produce it the cheapest. I don't see, even if this prices keep dropping, I don't see America, U.S. cutting the oil production. They will not going do it. They're going to do it where they think they can do it the cheapest. So I think the Bakken up in North Dakota, I think offshore, I think California, I think Oklahoma, I think a lot of stuff like that will cut down to a minimum...

\section{EFS008-9 - 5:55 [I mean, oil prices at 45 dolla..] (14:1168-14:1601) (Super)}

Codes: [World O\&G commodity prices]

I mean, oil prices at 45 dollars, I've had the month l've had all year. And the first two weeks have been great. I can't tell you what that means. I don't know if they opened their budgets back up or [if they will] spend a bunch of money this first month...I don't know... But I can tell you that as far as my personal business, we've done more in these first two weeks of January than we 
have in any month in the past 12 months!

EFS008-9 5:56 [But I can tell you that as far..] (14:1444-14:1601) (Super)

Codes: [Development as Economic]

But I can tell you that as far as my personal business, we've done more in these first two weeks of January than we have in any month in the past 12 months!

EFS008-9 - 5:57 [My understand is that a lot of..] (14:2247-14:2518) (Super) Codes: [Opportunism]

My understand is that a lot of companies out on the Bakken are already struggling. That's actually why I am going out there next week. We're trying to see how many assets we can purchase and bring them back down to this area. If oil goes down, it'll come right back up

\section{EFS008-9 - 5:58 [It may slow down this year, bu..] (14:2524-14:2668) (Super)}

Codes: [Booms cicles]

It may slow down this year, but it does that every eight years. Look at a historical trend, every 8 years, its go down and always comes back up

\section{EFS008-9 - 5:59 [FS009- 10-15 years. We have be..] (15:50-15:660) (Super) \\ Codes: [Future perspectives]}

FS009- 10-15 years. We have been going it a good 5 years right now...I think we will still [produce] have 12 years or more of it...there is the Pearsall Shale right below it! EFS009Pearsall Shale is twice the size! And is going to be...they're having a little trouble trying to produce the Pearsall, but once they get it that down and be able to...the viscosity of the oil is a lot thicker, and they're have having a little bit of trouble flowing it back on the oil wells...once they can get that figured out...south Texas going be the place to be! South Texas, west Texas... it is the place to be.

\section{EFS008-9 - 5:60 [ot peanut butter coming out of..] (15:1181-15:1549) (Super)}

Codes: [Future perspectives]

ot peanut butter coming out of the separator. Very high extras...so they called us out there to take a look at it and looking into it we figured out they were deeper than they thought they were. The EF had kind of risen in that area, and so they looked and started to do some seismic test and found that there's an even bigger shale that's twice the size of the EF!

EFS008-9 - 5:61 [So, in most cases the families..] (16:1-16:69) (Super)

Codes: [Mineral Rights, Royalties \& Land Tenure]

So, in most cases the families do retain at least a percentage of it.

\section{EFS008-9 - 5:62 [You know, some of these, like ..] (16:1051-16:1475) (Super) \\ Codes: [Booms cicles]}

You know, some of these, like Halliburton- they were here in the 80's. They've been here forever. They just down sized, they moved their equipment to other states, other locations and they downsized...I think that probably what we will see again when it starts deteriorating, starts dropping off. But [Lyonel] Bizzell moved to someplace else. Baker Hughes, Haliburton, those types of companies will still have presence!

\section{EFS008- - 5:63 [We have gas and oil there...I do..] (16:1488-16:1974) (Super)}

Codes: [Booms cicles]

We have gas and oil there...I don't see them moving away! They'll downsize I think due to price. They might cutback and not do as much as they did last year, but l'd say for the next 20 years I 
see this town as being an oil town. Every bit of 20 years. EFS008-And you still have to maintain this wells [the ones that were just drilled] EFS009- Exactly! There always going to be the workovers; there's always going to be maintaining the facilities. They've got to produce the oil.

EFS008-9 - 5:64 [There's a lot of farmers and r..] (16:2237-16:2502) (Super)

Codes: [O\&G Wealthy \& Benefits] [Sale Taxes, Revenues \& Royalties]

There's a lot of farmers and ranchers that were never wealthy people... ah...you know we've had farms and ranches passed on from father to father to their kids, but they never made a lot of money but now we see the impact of oil with a lot of these families...you know...

EFS008-9 - 5:65 [Yeah, a lot of upgrade opportu..] (16:2562-16:2757) (Super) Codes: [O\&G Wealthy \& Benefits]

Yeah, a lot of upgrade opportunities. Some of these guys drove the same pickup for 25 years; now they're driving around new diesel pickups and you see a lot of new diesel pick-ups on the road.

\title{
EFS008-9 - 5:66 [But it does have a big impact ..] (17:199-17:598) (Super) \\ Codes: [Development as Economic]
}

But it does have a big impact on us. All of our local dealerships are thriving...just the maintenance business that they get, besides the sales. But they all got double the cars on their lot that they used to have 4 years ago. EFS009- They used to have 10 cars in their lots. Now, they have to pull the car out for you to get on the inside to look at them; they're parked so close to each othe

\section{EFS014.pdf - 6:1 [It's not really the O\&G throug..] (1:427-1:556) (Super) \\ Codes: [O\&G Wealthy \& Benefits]}

It's not really the O\&G through the pipelines ... what it really is what the Appraisal District says that the oil and gas is worth.

\section{EFS014.pdf - 6:2 [ls where we get part of our mo..] (1:581-1:789) (Super) Codes: [O\&G Wealthy \& Benefits]}

Is where we get part of our money from. It all goes through the appraisal district office on what they say the value of it is... what the value of the mineral rights are...what the value of the oil and gas is.

\section{EFS014.pdf - 6:3 [o, they're all providing like ..] (1:1007-1:1165) (Super)} Codes: [Government \& Governance layout] [O\&G Wealthy \& Benefits] [Rules]

o, they're all providing like different kind of permits, fees and stuff. It's always...it's also coming...we get some of that, but state gets the majority of it...

EFS014.pdf - 6:4 [But far as budgeting, when I w..] (1:1189-1:1337) (Super) Codes: [Cristicism] [Sale Taxes, Revenues \& Royalties]

No memos

But far as budgeting, when I was talking about budgeting, we have to look past the oil and gas revenues to say "If it's not there, what do we do?".

\author{
EFS014.pdf - 6:5 [You know...It's great for us to ..] (1:1362-1:1518) (Super) \\ Codes: [Community receptiveness] \\ No memos
}

You know...It's great for us to have it! We're glad to have it but at the same time we have to look past it and ask when it is not there what we going to do? 
EFS014.pdf - 6:6 [Because the county keeps going..] (1:1547-1:1630) (Super)

Codes: [Sale Taxes, Revenues \& Royalties]

Because the county keeps going. We have to fund the county to keep this operational.

EFS014.pdf - 6:7 [- Yeah... a lot of that money, I..] (1:1636-1:2035) (Super)

Codes: [Sale Taxes, Revenues \& Royalties]

- Yeah... a lot of that money, I guess it goes to the rainy day fund of the Texas...

EFS014-It goes to a tax. Yeah, they use it, but we get our share of it through the appraisal district through what they think it's worth....but then you have a...you know...it's a....it's that big questionmark: Who is smart enough to tell you how much is under the ground and exactly how much it's worth to appraise it?

EFS014.pdf - 6:8 [Everybody has a different idea..] (2:9-2:256) (Super)

Codes: [Cristicism]

No memos

Everybody has a different idea! You know...it's always different in a...you have these wells coming in that are gang-busters [highly, highly profitable]... you know...but each month they go down....they drastically stop... not like the wells of south Texas

Comment:

gang busters podem ser comparados ao conceito de roving bandists destacados na obra de Ostrom (2011)

EFS014.pdf - 6:9 [The shale...down there...our wells..] (2:282-2:491) (Super)

Codes: [Opportunism]

No memos

The shale...down there...our wells here don't last like those do. They [the wells] come in gang-busters, but they gradually go down, now gradually is... real fast. In South Texas they'll keep going for a long time.

EFS014.pdf - 6:10 [You frack the oil here you do!..] (2:627-2:953) (Super)

Codes: [Future perspectives]

You frack the oil here you do! You're doing a thousand barrels, five hundred barrels a day...

$T$ - Exactly

EFS014-And then, three or four months later you're down to fifty to hundred barrels a day...

T - Wow...you just can't keep those cracks open I guess

EFS014- Yeah just ways the formations are here...from what I understand

EFS014.pdf - 6:11 [Yeah, they don't go anywhere f..] (3:1178-3:1313) (Super)

Codes: [Environment impacts]

No memos

Yeah, they don't go anywhere for a while...it's just local flood right now that flooding but it's just nothing compared to what's coming

EFS014.pdf - 6:12 [Back in eighties that was, but..] (4:49-4:748) (Super)

Codes: [History of Use]

Back in eighties that was, but it was all the small wells. You know, it's called the Woodbine back there and those wells that went... oh they weren't very deep wells...they were down-hole wells

T- mm'mm

EFS014- They weren't very deep and some of those wells still producing...they're producing like 
three or four barrels a day...you know... maybe really were good wells... maybe fifteen barrels a month maybe...

T - Uh'mm

EFS014- Most maybe but the new phase on what they call the 'shale' is the one with the horizontal

wells with the fracking process where they've been going down to get this oil and go to deeper depths...that's where the good oil is coming from, it's just not lasting very long.

\section{EFS014.pdf - 6:13 [You see these oil companies no..] (4:774-4:1476) (Super) \\ Codes: [Technology]}

You see these oil companies now.... in the old days you used to have a pad with one well on it, you know, every 600 acres or wherever you could lease one, and now l've seen some that have

four and five pumping jacks on one pad.

And, in South Texas I know there some wells that have eight...eight holes... what they do is they go

down different ways then move over about hundred foot and they start over with another four holes that's going different ways. So, it's saving oil companies a lot of money using the same pad,

and they're starting to do that here. Like right out here on [Highway] 974 you see four pump jacks or

five pump jacks on one pad site. A lot of that is starting to happen here.

EFS014.pdf - 6:14 [In gas they do a lot of that! ..] (4:1624-4:1906) (Super)

Codes: [Environment impacts] [History of Use] [Opportunism]

In gas they do a lot of that! Here we...ah...they're flaring a lot of gas here...there some pretty good gas wells, very first gas wells here were down in the bottom... what I call the bottom is

the cotton country, which Clayton Williams drilled...down in the Mumford [Texas] city (?) store...

\section{EFS014.pdf - 6:15 [Right. A lot of that gas they'..] (4:2254-4:2329) (Super)}

Codes: [Environment impacts]

Right. A lot of that gas they're flaring off is pretty hard to anything with

EFS014.pdf - 6:16 [No, is just not set-up for it ..] (4:2390-4:2500) (Super)

Codes: [Environmetal ceticism]

No, is just not set-up for it ...like I said, the way they handle the gas is completely different from the oil...

\section{EFS014.pdf - 6:17 [We interact with them tearing ..] (5:134-5:565) (Super)}

Codes: [Transportation (Traffic, Road impact \& Railroads)]

We interact with them tearing our roads up but...not really! We don't have a lot of interaction with them, you know. We have a little property here that the county has that we lease to

them, but that's about it. Most of our interaction with them is ah...our road situation. That's one thing that the oil industry has brought here is to getting our roads slapped up (?) and we only have

' $x$ ' number of dollars to put in our roads...

EFS014.pdf - 6:18 [Some of their roads were turn ..] (5:710-5:1233) (Super) Codes: [Cristicism] [Transportation (Traffic, Road impact \& Railroads)]

Some of their roads were turn back to gravel! They will pay it (?) or try to not do that with the few other paved roads they got. And I'm going to say that there are a few oil companies, very few, that have come to the plate and say, "Let us help you a little bit", especially when 
they're drilling a well right where they turn in off of a paved road going in or gravel or whatever. I mean they just tear the slab up. And there's a few oil companies, you know, will help us a little bit... but a majority of them, no.

EFS014.pdf - 6:19 [Yeah, you've got to figure tha..] (5:1278-5:1521) (Super)

Codes: [Transportation (Traffic, Road impact \& Railroads)]

Yeah, you've got to figure that... they say that...I don't know how true it is probably pretty much! The time they start a well until they finish is equivalent for... what it takes to do that well...truck wise is equivalent to ten million vehicles!

EFS014.pdf - 6:20 [Yeah, you do, you have some of..] (6:492-6:764) (Super)

Codes: [Sense of Spatial Protagonism (SSP)]

Yeah, you do, you have some of the major ones is here, Anadarko, Apache, Halcón. They're some of the bigger ones that are here...ah...you know... a lot of smaller companies seem to change

hands, you know, there's a lot of smaller companies here...but all the bigger ones is here

\title{
EFS014.pdf - 6:21 [They partner-up so much with t..] (6:980-6:1068) (Super)
}

Codes: [Big Companies]

They partner-up so much with the bigger companies too! And so you really don't know how

\author{
EFS014.pdf - 6:22 [No. This is the difference bet..] (6:1329-6:1729) (Super) \\ Codes: [Government \& Governance layout]
}

No. This is the difference between the counties and the cities. Us is a county. The only thing we can do is what legislator gives us...says that we can do! We're can't decide...or we don't like

the way this going to happen so we going make our ordinances against it...or we going do this or we

going do that! We can't do that! Whatever the legislator gives us the authority to do is always we can do

\section{EFS014.pdf - 6:23 [Yeah! We can't restrict O\&G in..] (6:1781-6:1901) (Super)}

Codes: [Noise, nuisance, Flares]

Yeah! We can't restrict O\&G industry. As people think that we can as noise and what else comes up but we can't do that!

EFS014.pdf - 6:24 [There's quite a bit of impact.....] (7:9-7:128) (Super)

Codes: [Transportation (Traffic, Road impact \& Railroads)]

There's quite a bit of impact....like I said the roads are an impact on us...personnel, you know, the more people that you

EFS014.pdf - 6:25 [we also get a very small perce..] (7:130-7:389) (Super)

Codes: [Sale Taxes, Revenues \& Royalties]

we also get a very small percentage of sales tax-so the more people that you have in here that are dealing with O\&G activities, the more things they're buying, the more groceries, the more gas, and the more of everything else...staying in the hotels in that...

EFS014.pdf - 6:26 [we also get a very small perce..] (7:130-7:803) (Super)

Codes: [Pro-business mentality]

No memos

we also get a very small percentage of sales tax-so the more people that you have in here that 
are dealing with $O \& G$ activities, the more things they're buying, the more groceries, the more gas, and the more of everything else...staying in the hotels in that......hotel, motel taxes...you know we get part of that to pay for the Expo Center, so they stay in hotels and motels. We're getting some of that. It goes in our Expo Center. Whatever money is generated-whether it's oil and gas or anything else-we're going to get a little piece of that some kind of way...that's good for us! General economy-it makes the economy better, keeps everybody is a little better mood!

EFS014.pdf - 6:27 [And of course the revenues. Th..] (7:831-7:1032) (Super) Codes: [Sale Taxes, Revenues \& Royalties]

And of course the revenues. The more O\&G that's being drilled, the more they're making....you know, the more the appraisal district...the more we'll get. ...Petromax is also here, Halcón, I said Anadarko...

\section{EFS014.pdf - 6:28 [They sure do! I can tell you t..] (7:1863-7:1980) (Super) Codes: [Conflits \& Interests]}

They sure do! I can tell you this because our road and bridge department...we've lost some people to the oil industry.

EFS014.pdf - 6:29 [And...I'm vice chairman of the b..] (7:2006-7:2253) (Super)

Codes: [Social Sensitives (population, genre, wage, accidents)]

And...l'm vice chairman of the board of a producer cooperative, which is the largest co-op in Texas that's member owned, and we lost a lot of people [to O\&G activities] We oil was at $\$ 110$ a

barrel... if you had a CDL and could breathe you got a job!

\section{EFS014.pdf - 6:30 [And it'd pay pretty good money..] (8:9-8:216) (Super)}

Codes: [Future perspectives]

And it'd pay pretty good money! Can't say how long it will last, but you know... whatever... They never said anything about anyone trying to better themselves, no matter what. [not sure what he means by that...]

\section{EFS014.pdf - 6:31 [Sure! If is somebody is making..] (8:618-8:781) (Super) Codes: [O\&G Wealthy \& Benefits]}

Sure! If is somebody is making, you know, U\$ 13.00; U\$ 14.00 per hour and go out there [O\&G activities] and going start at $\$ 19$ to $\$ 25 \ldots$ You're going to look at it.

\section{EFS014.pdf - 6:32 [Well, I think it depends of wh..] (8:1030-8:1465) (Super)}

Codes: [Educational Attainment] [Jobs opportunities and challenges]

Well, I think it depends of what they looking for...it depends...a lot for high school...main thing is...ah..., I think one of the main things they're looking for is the experience that you've got. Itreally doesn't matter kind of degree you got. What kind of experience you've got.... If you got a CDL, you got a clean record, you know, can you do this, can you do that... are you smart enough to pump a well! You know, these kinds of things!

\section{EFS014.pdf - 6:33 [Yeah, a lot of these guy's...you..] (8:2118-9:252) (Super)}

Codes: [Housing \& properties impact] [Social Sensitives (population, genre, wage, accidents)]

Yeah, a lot of these guy's...you've got to understand.... lot of these guy's are, you know...ah...'transient' is not the word but it really is because, they don't know how long they're going be here! You know, so they're not putting roots down here. Now, there are people in the oil business that are putting down roots, which you hope they're going to be here for a long time, but there're others that aren't. They're staying in these hotels and different things...they might go home once a week or twice a week. Or every two week or work out of this area! You know, depending on what company they're with and what they're drilling 
P 6: EFS014.pdf - 6:34 [You know, I really don't know ..] (9:803-9:966) (Super)

Codes: [Social Sensitives (population, genre, wage, accidents)]

You know, I really don't know the answer to that! But if I got take a guess...I would say that, you

know, where the highest paying job is where they're going to be!

EFS014.pdf - 6:35 [No. This is the difference bet..] (6:1329-6:1730) (Super)

Codes: [Rules]

No. This is the difference between the counties and the cities. Us is a county. The only thing we can do is what legislator gives us...says that we can do! We're can't decide...or we don't like the way this going to happen so we going make our ordinances against it...or we going do this or we going do that! We can't do that! Whatever the legislator gives us the authority to do is always we can do!

EFS014.pdf - 6:36 [And I can understand that! You..] (9:1211-9:1432) (Super)

Codes: [Future perspectives]

And I can understand that! You know, that it's only going to last so long and you need to try and make all the money you can make while it's there. And if you're good at what you do, you can probably get what you want.

EFS014.pdf - 6:37 [You know what...I just hear what..] (10:125-10:566) (Super)

Codes: [Future perspectives] [World O\&G commodity prices]

No memos

You know what...l just hear what people say...people say it's going to be here a few years...and other people say it's not! I think a lot of it has to do with the price of oil! They say, you know, you heard that $\$ 62-\$ 65$ is thebenchmark on breaking even for companies on drilling and oil, you know, I looked a while ago and it said $\$ 48, \$ 46-48 \ldots$ paper say's is going to be US20! I just read another article now that said will be the twenty

EFS014.pdf - 6:38 [Let me back up on that [revise..] (10:1267-10:1671) (Super)

Codes: [Conflits \& Interests] [History of Use] [Mineral Rights, Royalties \& Land Tenure]

Let me back up on that [revise that statement]: A lot of landowners did retain their mineral rights but the land was sold but they kept their mineral rights! There's a lot of land that's been bought and sold without the mineral rights in past, twenty, thirty years...twenty years anyways. If you own land and you had chance to keep the minerals and you didn't...you think about it right now every day...

EFS014.pdf - 6:39 [Well, you know, forty years ag..] (11:97-11:380) (Super)

Codes: [Mineral Rights, Royalties \& Land Tenure]

Well, you know, forty years ago, fifty years ago, who would have ever thought that minerals would be worth what they're worth now! They didn't even think about it at that time! Say they were selling the land and let's say the person buying the land didn't think about it either.

P 6: EFS014.pdf - 6:40 [Well, you know, forty years ag..] (11:97-11:446) (Super) Codes: [Mineral Rights, Royalties \& Land Tenure]

Well, you know, forty years ago, fifty years ago, who would have ever thought that minerals would be worth what they're worth now! They didn't even think about it at that time! Say they were selling the land and let's say the person buying the land didn't think about it either. EFS014- ...you know, mineral weren't big deal to them

EFS014.pdf - 6:41 [It is the same thing today wit..] (11:517-11:959) (Super)

Codes: [Conflits \& Interests] [Mineral Rights, Royalties \& Land Tenure] [Water Aspects]

It is the same thing today with what we're seeing with water rights. How many people today are 
concerned about their water rights? Which fifty years from now they will be kicking themself, you now, because people say that one day water rights are going to be worth as much as the mineral rights, and there will be more law suits and more lawyers fighting for water rights than mineral rights. You will probably see that in our lifetime

EFS014.pdf - 6:42 [You know, who can say what is ..] (11:988-11:1082) (Super) Codes: [Future perspectives]

You know, who can say what is going to happen down the road [what will happen in the future]?

EFS014.pdf - 6:43 [Unless they figure out how to ..] (11:1275-11:1406) (Super)

Codes: [Water Aspects]

Unless they figure out how to use that ocean water EFS014- That's the only choice when they look for water sources.

EFS014.pdf - 6:44 [I hope for a long time but, yo..] (11:1880-11:2225) (Super)

Codes: [Future perspectives] [Technology]

I hope for a long time but, you know, I can't answer that! I think a lot of it depends, as far as I know, a lot of it depends on the technology. You know, there's technology changing every day in the oil and gas business. And I think as the technology changes, they will figure out other ways to extract more O\&G very deeper, deeper depths.

EFS014.pdf - 6:45 [New kinds of ways to do it. Ne..] (11:2249-12:177) (Super)

Codes: [Future perspectives] [Technology]

New kinds of ways to do it. Newer technology, you know it could be here a while, and it might get too expensive... it depends on the price... if the price gets too low, it could be a little bit expensive to do it except for the companies that need that because they've spent so much money on their leases, to hold their leases, and to keep drilling. It's hard to say.

P 6: EFS014.pdf - 6:46 [So, in other countries are sti..] (12:1034-12:1253) (Super)

Codes: [Future perspectives]

So, in other countries are still producing oil every day; they've never stopped! In fact they're producing more! Just like we are. And there's no place to put it! You know, it all goes back to that supply and demand!

EFS014.pdf - 6:47 [Everybody says 'boy that's gre..] (12:1752-12:1902) (Super)

Codes: [Social Sensitives (population, genre, wage, accidents)]

Everybody says 'boy that's great', you know, gas got to dollar sixty, dollar seventy but let me tell you...It hurt a lot of people when that happens!

EFS014.pdf - 6:48 [eople that have gone to other ..] (13:24-13:253) (Super)

Codes: [Development as Economic]

eople that have gone to other places...some people that cut way back or slow down! You know had to lay-off the people....those people have to go some else to work! Hurts your home sells! Hurts the economy overall! Hurts everything.

\section{EFS010-013.pdf - 8:1 [It is one of those thing that ..] (1:508-1:664) (Super)}

Codes: [Infrastructure]

It is one of those thing that we knew it was coming but there is no way to prepare for it because you don't know what goods or services they're gonna need! 
EFS010-013.pdf - 8:2 [There also, and I don't mean t..] (1:688-1:988) (Super)

Codes: [Social Sensitives (population, genre, wage, accidents)]

There also, and I don't mean to say this in a negative way but they are pretty transient...they come in and work and then leave... so if a company is fracking, for instance, they come in and they bring their frack team...and they work and a lot work 12 or 24 hour shifts depending on how the frack is

EFS010-013.pdf - 8:3 [No! We haven't been but we als..] (1:1832-1:2118) (Super) Codes: [Future perspectives]

No! We haven't been but we also been reluctant to overbuilt...ah...because it does,you know, it's great while it lasts but when they all pull out and there's no end...you don't know... where end date is gonna be.... if they pull out and left you with 21 empties hotels it's not a good thing...

EFS010-013.pdf - 8:4 [This is nothing now...Of course ..] (2:1269-2:1355) (Super) Codes: [Infrastructure]

This is nothing now... Of course now we have folks like EFS012 and hotels to put them in

EFS010-013.pdf - 8:5 [People sleep on the parks, on ..] (2:1184-2:1255) (Super)

Codes: [Booms cicles]

People sleep on the parks, on the streets...EFS010 - Yeah, it was crazy!

P 8: EFS010-013.pdf - 8:6 [Now [EFS011] is a county commi..] (3:1488-3:1606) (Super) Codes: [Transportation (Traffic, Road impact \& Railroads)]

Now [EFS011] is a county commissioner and he takes cares of our roads and the oilfield its very detrimental to roads!

EFS010-013.pdf - 8:7 [I don't know what the next que..] (3:1741-3:2090) (Super)

Codes: [Transportation (Traffic, Road impact \& Railroads)]

I don't know what the next question gets in but no that's work, as a matter of fact on Monday we're going to be starting to tear up a road to redo where they did so many of these....ah ...new shale wells and hopefully I have some money in mind on TXDoT on the CTERS program and I hope to get a good chunk of change going from that to pay for this

EFS010-013.pdf - 8:8 [Right, right...and the problem i..] (3:2168-3:2386) (Super) Codes: [Booms cicles] [Infrastructure]

Right, right...and the problem is they're drilling so many wells that I cant get out there and work on it, because we either get runover or it wouldn't accomplish anything. And now we have seismograph crews everywhere

EFS010-013.pdf - 8:9 [I mean they are huge [the truc..] (4:50-4:307) (Super)

Codes: [Transportation (Traffic, Road impact \& Railroads)]

I mean they are huge [the trucks and equipment's] and is so wet here now, and they go along with these huge machines and they just tear the pavement up and everything else...going through farmers pastures and stuff but I mean... they are looking for more oil

\section{EFS010-013.pdf - 8:10 [They are looking at something ... (4:594-4:1084) (Super)} Codes: [Cristicism]

They are looking at something else now, obviously it is pretty good but...those guys are weird! Have ever seen this guys? They come alone and they strain cords like ah... EFS010- Electrical cords! EFS011- Electrical cords... and then they vibrate the ground and they have these cords 
for miles and miles and they have guys walking with the GPS and walking through the woods and when you drive in a country road and suddenly comes a guy out of woods...and... it'll scare the hell out of you!

\author{
EFS010-013.pdf - 8:11 [What hell are doing here? They..] (4:1131-4:1395) (Super) \\ Codes: [Conflits \& Interests]
}

What hell are doing here? They'll drop him off somewhere and he'll come out ten miles down the road through the woods. Cords everywhere...we were shredding (wheat/oats/alfalfa)...I kept telling them: "Put the cords further back." We eliminated some of their cords

\title{
EFS010-013.pdf - 8:12 [Well like the CETERS thing thr..] (4:1763-4:1847) (Super) Codes: [Transportation (Traffic, Road impact \& Railroads)]
}

Well like the CETERS thing through TEXDoT is the only thing that we have to deal with

\author{
EFS010-013.pdf - 8:13 [Yeah, they're local oil. They'..] (5:172-5:523) (Super) \\ Codes: [Transportation (Traffic, Road impact \& Railroads)]
}

Yeah, they're local oil. They've been very good to work with ...they'll own up to some of the stuff they tore up...yeah, they've been good, but you can't imagine how much they tore up... well if you've traveled to South Texas, you know what they done! Goodness, when they get on the road; it's just one...[??]...and...there aint much you can do

\section{EFS010-013.pdf - 8:14 [Yeah! And...ah...we've been, you k..] (5:989-5:1501) (Super)} Codes: [Booms cicles]

Yeah! And...ah...we've been, you know, pretty steady...you know...yeah we saw a lot when they started...started fracking and everything... then we saw an increase...ah...but we still

maintain our normal growth... we knew what the spike [in activity] was......it was...ah....anything abnormal. It was related to the O\&G but now... its kind...I guess that downturn right now because of the price! So, we're going back to the levels we were before [the boom]...so...we're not losing any business but we're not gaining any new one's right now...

\section{EFS010-013.pdf - 8:15 [ight now Venado is not doing a..] (5:1973-5:2189) (Super)}

Codes: [Booms cicles]

No memos

ight now Venado is not doing any activity! EFS011 - They drill some but they wont frack them EFS012 - They got them cased and drilled but they will not... EFS010 - Everything is in a holding pattern right now!

EFS010-013.pdf - 8:16 [Fracking that they were doing ..] (5:2203-5:2261) (Super)

Codes: [Social Sensitives (population, genre, wage, accidents)]

Fracking that they were doing at all bring a lot of people!

EFS010-013.pdf - 8:17 [You know, we are lucky that we..] (6:1574-6:1868) (Super)

Codes: [Community spirit]

You know, we are lucky that we got to stay here so long, but he made a choice to want to stay here.... because the kids were in school and things like that! They're out of school now...grown...we just love it here!

Loving Giddings, Giddings is a great place! Lots of...ah...community spirit! I think...

EFS010-013.pdf - 8:18 [That's part of the chamber pro..] (7:34-7:565) (Super)

Codes: [Community spirit] 
That's part of the chamber property, so we have three buildings that are depots, and that's why it's Giddings: "The Depot Capital of Texas." And then the silent movie theater which was built in 1918 or thereabouts...they were going to tear it down on another piece of property. And there was a group that thought it was worth saving, so they moved it over here on this property, so Calita's group-Friends of the Depot—have been doing some work over there in saving it. We hope to one day have an active silent movie theater.

\section{EFS010-013.pdf - 8:19 [But yes! Economic development ..] (7:1055-7:1126) (Super)}

Codes: [Development as Economic]

But yes! Economic development has a piece of the oilfield business side...

\section{EFS010-013.pdf - 8:20 [They have just recently bought..] (7:1151-7:1420) (Super)}

Codes: [Infrastructure]

They have just recently bought a 170 acres of non-developed business park out on the east side the town! Right on the corner of the county road 226 where the...I think... what's that? Oilfield company right there! Used to be Clayton Williams and now it is something else

EFS010-013.pdf - 8:21between 290 and 226...the Gidd..] (7:1494-7:1741) (Super)

Codes: [Sense of Spatial Protagonism (SSP)]

between 290 and 226...the Giddings Business Park. They will develop it for the customers, whatever the customer is looking for! And then it will be industrial based! We have road we have water and electrical access... it will be our business park!

EFS010-013.pdf - 8:22 [That's all right! It's interes..] (7:1949-7:2051) (Super)

Codes: [Community receptiveness] [Future perspectives]

That's all right! It's interesting to hear. So, the goal is to keep the Oil and Gas business to stay!

\section{EFS010-013.pdf - 8:23 [You need to talking with Alan ..] (8:583-8:679) (Super)}

Codes: [O\&G Wealthy \& Benefits]

You need to talking with Alan Robertson of PumpCo. He is an A\&M graduate and...big success story...

EFS010-013.pdf - 8:24 [You have to have! In the count..] (9:125-9:272) (Super)

Codes: [Ordinances: Why reinvent the wheel?]

You have to have! In the county we just come with...ah...Permits kind of thing! EFS011 - To make sure it's not located in the flood plain

\section{EFS010-013.pdf - 8:25 [I think everybody in Giddings ..] (9:777-9:1038) (Super)}

Codes: [O\&G Wealthy \& Benefits]

I think everybody in Giddings wants an Oil Well in their backyard and if they could attract that, then they would. And they believe they may actually have oil because when you go to buy housing here in Giddings....laughing.....it's so.... High because [they think]...

EFS010-013.pdf - 8:26 [The problem is that the shale ..] (9:1576-9:1683) (Super) Codes: [Noise, nuisance, Flares]

The problem is that the shale wells, none of them are hooked up to pipelines! And they're flaring all over

EFS010-013.pdf - 8:27 [...I have a lot more complaints ..] (10:439-10:878) (Super)

Codes: [Conflits \& Interests] 
...I have a lot more complaints about my roads from people that weren't leased to Venado because their wells are very productive and they're tearing the heck out of the roads! EFS011 .... [mimicking people who call in to office about torn up roads] you paying for this! You can tell who's leased to who. Cause the ones that lease to the wrong company, they're not getting oil wells and they're the ones causing the most hell

EFS010-013.pdf - 8:28 [It's a wiser more...big picture!..] (10:1198-10:1622) (Super) Codes: [Booms cicles] [Development as Economic] [Future perspectives] [Pro-business mentality]

It's a wiser more...big picture! The way they have look at it! Because everyone has decided... In the first boom, we missed a lot of things, because we didn't know what to expect and we didn't know what was going to happen!...And so in the second boom come along they've been a lot more cognizant of "what do we need to do to make sure these companies... if they all gonna be here...What can we do to make they stay longer?"

\section{EFS010-013.pdf - 8:29 [“What can we do to offer them"..] (10:1648-10:1812) (Super) Codes: [Future perspectives]}

"What can we do to offer them"...ah...incentives or benefits packages especially like...I think the county and the city on work on....ah...tax abatement or incentive program...

EFS010-013.pdf - 8:30 [...that's kind of been the thoug..] (11:10-11:365) (Super) Codes: [Government \& Governance layout] [Pro-business mentality] [Sale Taxes, Revenues \& Royalties]

...that's kind of been the thought process! They were...ah...we've been work on the tax incentives for about a year! Now city and county have come together and they are in the process of passing those packages through their boards......to the City Council to the County Commissioners Court. So that we don't miss any businesses that do want to come in here!

EFS010-013.pdf - 8:31 [So that has been...the thought p..] (11:391-11:565) (Super) Codes: [Community receptiveness] [Pro-business mentality]

So that has been...the thought process has been...what can we do to make beneficial for these companies and then...how do we go out and attract more of these kinds of companies?

EFS010-013.pdf - 8:32 [...Because we are centrally loca..] (11:570-11:943) (Super) Codes: [Sense of Spatial Protagonism (SSP)]

...Because we are centrally located! And we do have two really good highways! 77 and 290 that can take them wherever they need to go. We want to be the kind of central location! So if they central located here they can go to south Texas and come back, or go to east Texas and come back, go to west Texas and come back... ....we want all of the....ah...home offices to be here!

EFS010-013.pdf - 8:33 [The partnerships or the good r..] (12:1712-12:2007) (Super) Codes: [Parternships \& Participation]

The partnerships or the good relationships that we have are the oil field companies that have been here for a long time. We have a really relationship with PumpCo and Morgan Petroleum Testers and Fodale just joined the Chamber when they opened their new office. They wanted to get involved.

\section{EFS010-013.pdf - 8:34 [Casehold Solutions has never s..] (12:2151-12:2286) (Super)} Codes: [Cristicism]

Casehold Solutions has never shown any interest, but they're a multinational company, so they don't look at the communities that way 
EFS010-013.pdf - 8:35 [I guess it depends on who the ..] (12:2289-12:2724) (Super) Codes: [Parternships \& Participation]

I guess it depends on who the parent organization is and who the staff people are. Because the staff people drive the community participation. Fodale, they have local people working in the office and they're very local participation. They have young kids or whatever, so they're in the community. C\&J or Casehold Solutions is a multinational company and most of their people are not from here, so they don't participate locally.

EFS010-013.pdf - 8:36 [In the first boom there was mo..] (12:2736-12:2945) (Super) Codes: [Cristicism] [O\&G Donations and sponsorships]

In the first boom there was more...the companies took more interest in the community. Sponsored stuff...but now they don't have much interest. ... Youth programs and they'd say, "Well, how much money do you need?"

EFS010-013.pdf - 8:37 [And then...the group we have now..] (12:3460-12:3640) (Super) Codes: [Cristicism] [Parternships \& Participation]

And then...the group we have now is totally different. They really don't take to the interest. They do their jobs and then they leave. They stay in the hotel and then they're gone

EFS010-013.pdf - 8:38 [But I think it's different now..] (13:9-13:698) (Super)

Codes: [Booms cicles] [Cristicism]

But I think it's different now versus then is these companies versus then is that these companies now have stockholders that they are having to answer to. And in the old days; they didn't have that. It was different. Today, an oil company that has stockholders that they have to answer to, they're bottom line is affected by every dollar they give away. Whether it's a nonprofit Chamber or a little league team. But in the old days, and especially during the first boom, there were so many people and they moved here and they got involved because their kids were going to school and they were younger. Today, it's all about the dollar bill. It's a lot different in my opinion.

EFS010-013.pdf - 8:39 [Yeah, there were a bunch of th..] (13:1498-13:1665) (Super) Codes: [Community receptiveness]

Yeah, there were a bunch of them.... They were all part of the community...VFW and they all had a really good time... They're all gone now. They've moved back to West Texas.

EFS010-013.pdf - 8:40 [good relationship between city..] (13:2518-13:2885) (Super) Codes: [Community receptiveness] [Parternships \& Participation]

good relationship between city and oil and gas industry. Discusses industrial park. City speaking with oil and gas services. Oil and gas companies metrix of performance [relative to doling out incentives] is different. Metrix would be based on property tax or sales tax. Local players are helping formulate how oil and gas companies can be recruited to cities.]

EFS010-013.pdf - 8:41 [City and county has tax abatem..] (14:9-14:228) (Super) Codes: [Sale Taxes, Revenues \& Royalties]

City and county has tax abatements to oil and gas industry (and other industries). Fiber optic industry is in Giddings. Wants to attract downstream business services. Also looking at providing rebates for performance

EFS010-013.pdf - 8:42 [According to EFS013, EFS011/2 ..] (14:796-14:1125) (Super) Codes: [Development as Economic]

According to EFS013, EFS011/2 serve as ex-officio board members to advise the Economic 
Development of the county. This is a quasi-advisory board to the Economic Development organization. Other people serve on this board: mayor, city councilors, city managers, school super intendant and other members of the local government

EFS010-013.pdf - 8:43 [The oil and gas industry influ..] (14:2197-14:2477) (Super) Codes: [O\&G Wealthy \& Benefits]

The oil and gas industry influences Texas and the rest of the country so there is trickle down from that such as block grants and other resources. There are some downsides (trucks and traffic) and upsides (many people who have mineral rights and provide multiplier effects).

\section{EFS010-013.pdf - 8:44 [downsides (trucks and traffic] (14:2361-14:2392) (Super) \\ Codes: [Cristicism]}

downsides (trucks and traffic

EFS010-013.pdf - 8:45 [Most the people who live out i..] (15:77-15:1642) (Super) Codes: [Housing \& properties impact]

Most the people who live out in the country, in the county, if they have mineral rights and it's family property and they've had it for 100 years or 50 years or whatever; they're going to retain as much of their mineral rights as they possibly can. If they're trying to sell the property...say grandpa died and the kids don't want to live here...they will retain as much mineral rights as they can. So, anywhere from $25-50 \%$ when they're selling off the land. They will not give up the whole mineral rights unless they don't think there's nothing under it. But everybody here thinks there's an oil well under their property. I guarantee. They look next door and there's an oil well over there, and they're like, "There's an oil well under here too." No really...the property values in Lee County are substantially higher than say some of the other rural communities that are similar to ours, because of the oil. So, an acre of land here may go for anywhere from... depending on how much land is with the sale, the smaller the sale the bigger the price... an acre of land may go for $\$ 10,000$ or $\$ 25,000$ or whatever. I know of piece of property that's out on 141 which is between here and Dime Box. It's 96 acres. It's got a house that built in 1985 and hasn't been changed...not one bit since it was built. And it was built nice. It's an 8 bedroom home. And they want $\$ 845,000$ for it. For 96 acres and a house! So, property here is very high value. But...even between here and Roundtop...Round Top property is twice or three times the property value here.

\section{EFS010-013.pdf - 8:46 [There's going to be conflict w..] (15:2611-15:2691) (Super)} Codes: [Conflits \& Interests]

There's going to be conflict with oil and gas industry to protect some resources]

\section{EFS010-013.pdf - 8:47 [There's going to be conflict w..] (15:2611-15:2925) (Super)} Codes: [Water Aspects]

There's going to be conflict with oil and gas industry to protect some resources] EFS011-Luckily this year we've been very fortunate and have had an abundant rainfall and a lot of them [energy companies] are using that water from ponds and stuff to frack wells. They're not going to be using that resource or

\section{EFS010-013.pdf - 8:48 [So yeah... I think when we talk ..] (15:2938-15:3322) (Super) Codes: [Water Aspects]}

So yeah... I think when we talk about Lee County, the transportation issues because of the roads...that's the number 1 thing. Then we've got water. That's our precious commodity that we have available. Oil, which is our job driver here for the most part, unless you work in the teaching industry or state employee. Those are our things that we see as the top layer in 
our community

EFS010-013.pdf - 8:49 [And it impacts the county taxe..] (16:58-16:223) (Super) Codes: [Conflits \& Interests]

And it impacts the county taxes. The people who have their land in ag are going to want to keep their land in ag exempt. It really makes a difference on their taxes

EFS010-013.pdf - 8:50 [l think they're going to keep ..] (16:1103-16:1736) (Super) Codes: [Booms cicles] [Future perspectives]

I think they're going to keep on drilling. It's the price. The price is going to determine what's going to happen, but I think...Like I told you, the seismograph crews are running up and down. It's still going to happen. I don't know how big or whatever. It's not over. This isn't like the first boom. The first boom lasted 4 or 5 years. This one here is going to go on for l'd say 20 years probably. If y'all'd done interviews down in South Texas... I don't know...did y'all ever see the bumper sticker..what is it...? "God, please send us one more oil boom and I promise I won't piss this one off." I remember that sticker well.

P 8: EFS010-013.pdf - 8:51 [sustainability perspective]] (16:1772-16:1798) (Super) Codes: [Development as Economic]

Economic sustainability perspective to the development

EFS010-013.pdf - 8:52 [EFS013—says that Giddigs is we..] (16:2272-16:2385) (Super) Codes: [Sense of Spatial Protagonism (SSP)]

EFS013-says that Giddigs is well placed amongst the metropolitan areas. Leverage oil and gas when it's available

EFS010-013.pdf - 8:53 [Something else about it. I kno..] (16:2397-17:104) (Super) Codes: [Educational Attainment] [Jobs opportunities and challenges] [O\&G Wealthy \& Benefits]

Something else about it. I know we did some surveys with the Capitol Area County of Governments, I'm on the executive board there. We're in the CapCoG region and they did an economic development study for us and they said, "You're education line is just way down here, but at the same time, your earnings line is way up here. What was that about?" Well...you've got a truck drivers that never went to school that are making 70 to $\$ 80,000$ a year. They said, "That can't be right." I said, "Yup, that's right!" You've got ads in the newspaper for truck drivers and they're starting out at $\$ 5,000$ signing bonus....Someone says, "Well, where can I find a job." I tell them, "Go out to almond ranch. You're hired." They have any kind of job you want right now from construction to anything to planting plants to building roads...

EFS010-013.pdf - 8:54 [Yeah, we're dying for people. ..] (17:695-17:883) (Super) Codes: [Housing \& properties impact]

Yeah, we're dying for people. And then, on the other end... I'm going to tell you the bad news...nobody ever talks about the bad news. Our biggest weakness is that we don't have any housing

EFS010-013.pdf - 8:55 [We have the lowest unemploymen..] (17:183-17:656) (Super) Codes: [Jobs opportunities and challenges]

We have the lowest unemployment in the state! EFS011-2.9 is our unemployment rate. EFS010-We can't find enough people to do the jobs that we have here. We have a medical center, St. Marks Medical Center, has a little satellite office here. They have three job openings 
right now and they can't fill them. And that's an x-ray technician, and then staffing for their office. And then you've got the almond plants, then you've got...

P 8: EFS010-013.pdf - 8:56 [Yeah...affordable housing. Or a ..] (17:1171-17:1538) (Super) Codes: [Housing \& properties impact]

Yeah... affordable housing. Or a workforce housing. EFS010-That's our biggest weakness...if we have a weakness at all in our community, the lowest unemployment rate and no housing to go with that. For all the people who have higher education at the State School...hardly any of them live here. They come in from Phlugerville, or Hutto, or College Station or whatever

\section{EFS010-013.pdf - 8:57 [Giddings has 3-4 types of kids..] (19:827-19:1402) (Super) Codes: [Educational Attainment]}

Giddings has 3-4 types of kids. Kids that have no idea...they just do whatever their parents tell them to do. They were raised in the oil and gas industry so they just get an oil and gas industry job. 2) College bound higher achievers. Discusses intern from Bush School who came and worked with EFS013. 3) More people going into industry due to shifting education standards and goals of the state of Texas. 4) Some folks are really excited to leave town permanently. Giddings has more transients than most small towns due to proximity to Austin and the big highway.]

\section{EFS010-013.pdf - 8:58 [Because of the oil field, ther..] (19:1800-19:2077) (Super)}

Codes: [Jobs opportunities and challenges]

Because of the oil field, there's a lot of kids who leave here, go to A\&M to get into the petroleum industry. 2 of my children...well 3 of my children, girls' friends...Jackie has 3 that she graduated with that are petroleum engineers. Sarah has two that are petroleum engineers

\section{EFS010-013.pdf - 8:59 [With a silent auction and a li..] (21:17-21:215) (Super)}

Codes: [Community spirit]

With a silent auction and a live auction and the baked goods and the BBQ cookoff. They just did the whole thing. And so that's what we tell the story in Giddings is people take care of each other

\section{EFS010-013.pdf - 8:60 [Anyone who can sling a sledge ..] (21:2127-21:2224) (Super)}

Codes: [Jobs opportunities and challenges]

Anyone who can sling a sledge hammer can get a job making anywhere from $\$ 12-\$ 25 /$ hour. Literally...

\section{EFS010-013.pdf - 8:61 [Wants to know if anyone is tal..] (22:1681-22:1744) (Super)}

Codes: [Development as Economic]

Wants to know if anyone is talking about a sustainability plan?]

EFS015.pdf - 9:1 [lt's the extra work that has t..] (1:423-1:1272) (Super)

Codes: [Water Aspects]

It's the extra work that has to be done, because that are not in the floodplain. Those are fairly routine. We get up there; it doesn't take a whole lot of time to do that. And then the ones that are in the floodplain are much more detailed. We do have to do a lot more verification. We have to review them and go out there in the various phases of construction to make to make sure that they're being built...that the pad is being built above floodplain level, and then anything that's there has to be all strapped down. It's also required for the most part that it all be in a closed system. So, there's no retention pond or anything like that. If there are retention ponds, then they have to be covered and part of the closed system. So, there's a lot more to reviewing a floodplain application and making sure they're compliant 
EFS015.pdf - 9:2 [Everybody wants to be complian..] (1:1320-1:2308) (Super)

Codes: [Compliance]

Everybody wants to be compliant. We've not had any issues from any oil company not wanting to be. We have made some modifications. One in particular-and this is how we work with the oil companies to try and make this a....we want a business-friendly climate-so, with a lot of these new wells that are going in, they all use hydrofracking. Hydro-fracking, it is much better for the county if they build those hydrofrack ponds that are several acres big and 10-15 feet deep and then use pumps and waterline to move the water from that location to the well site that way it keeps those heavy water trucks off the roads. It reduces congestion as well as reduces stress on the infrastructure. But a lot of those retention ponds...or those fresh water frack ponds are in the floodplain. So, ok by strictest interpretation of the floodplain rules, everything has to be in a closed system, but the only water at peril, if a flood came along, would be water that they have stored

EFS015.pdf - 9:3 [we want a business-friendly cl..] (1:1546-1:1581) (Super)

Codes: [Pro-business mentality]

we want a business-friendly climate-

EFS015.pdf - 9:4 [Hydro-fracking, it is much bet..] (1:1665-1:1883) (Super)

Codes: [Water Aspects]

Hydro-fracking, it is much better for the county if they build those hydrofrack ponds that are several acres big and 10-15 feet deep and then use pumps and waterline to move the water from that location to the well

\section{EFS015.pdf - 9:5 [it keeps those heavy water tru..] (1:1901-1:2020) (Super)}

Codes: [Infrastructure]

it keeps those heavy water trucks off the roads. It reduces congestion as well as reduces stress on the infrastructure

\section{EFS015.pdf - 9:6 [We modified the rules to allow..] (1:2514-1:2806) (Super) \\ Codes: [Rules] [Water Aspects]}

We modified the rules to allow those frack tanks to be open in the floodplains, because it just made sense. There was no need to tell them that they have to put a cover over them and make them part of the closed-system, when the only water at peril was their water that they've collected

\section{EFS015.pdf - 9:7 [If a flood comes along, they'v..] (2:65-2:188) (Super)}

Codes: [Water Aspects]

If a flood comes along, they've got a big pond full of dirty water, which—quite frankly—-they can still use for fracking.

\footnotetext{
EFS015.pdf - 9:8 [It would have ended up in a co..] (2:1298-2:1555) (Super)

Codes: [Conflits \& Interests]
}

It would have ended up in a court battle. It had previously been determined that—over in Brazos County

about 20 years ago - there was a court case where Brazos County was trying to charge for road-use permits for trucks that already had the state permit.

\section{EFS015.pdf - 9:9 [Once they get the state permit..] (2:1589-2:1889) (Super) \\ Codes: [Rules]}

Once they get the state permit, you can't require anything else from them. We have two pronged one...for the other prong, is for the trucks that already have the state permits. Again, 
there's no charge for it or anything, but they do have to prove to us that they are registered in Burleson County

\section{EFS015.pdf - 9:10 [But it does present some probl..] (2:236-2:1015) (Super)}

Codes: [Infrastructure] [Transportation (Traffic, Road impact \& Railroads)]

But it does present some problems, because it is a little bit more corrosive and that kind of stuff. So, as we've gone through the process with these guys, we've had to... we've worked with them all along the way. Road-use permits are big point of contention with oil companies. They... a lot of your trucking companies are issued state permits, and state road-use permits allow them to run their heavy loads in whatever counties they're registered in. So, a lot of the big companies, register it in all 254 counties, and so that's fine and dandy. But when you look at the Transportation Code, it still gives us the clear right to designate the path that they use to protect load-limited bridges and some culvert crossings that aren't designed for that kind of a load.

\section{EFS015.pdf - 9:11 [Once they get the state permit..] (2:1589-2:1664) (Super)}

Codes: [Conflits \& Interests]

Once they get the state permit, you can't require anything else from them.

EFS015.pdf - 9:12 [Why we do that is because do w..] (2:2214-2:2609) (Super) Codes: [Transportation (Traffic, Road impact \& Railroads)]

Why we do that is because do want to...the county roads aren't built to sustain that kind of traffic or those kinds of loads. Basically, they're built to residential standards, because that's primarily who uses the county roads, and so putting these guys on the roads like has had a traumatic effect on our roads. They get torn up a lot, and then you dump a bunch of water on top of them.

\section{EFS015.pdf - 9:13 [But the...so, the routing and ev..] (2:2775-3:5) (Super) Codes: [O\&G Donations and sponsorships]}

But the...so, the routing and everything allows us to try and keep the trucks on the roads that they're already. The oil companies have been very good about working with the county for some material. We have come up with an option for the oil companies...that all oil companies, with the exception of Anadarko, have taken up. Basically they make a $\$ 8000$ donation towards the roads per well. It ain't much...

\section{EFS015.pdf - 9:14 [They're doing \$100,000 worth o..] (3:61-3:788) (Super) Codes: [Transportation (Traffic, Road impact \& Railroads)]}

They're doing $\$ 100,000$ worth of damage. Anyways, this was established in South Texas in DeWitt County. This activity got all, Judge Fowler and them, down there years before it came up here to us. And so, it's based off some of the compromises that were made down there, that we've worked those out up here. And so, the oil companies do the $\$ 8,000$ and that's just straight up cash. It is dedicated to the road and bridge side of the budget, so I can't pull it over to on the general side. It has to stay on the roads and bridges. And then they also, on top of that, donate material, because they buy a boatload of rock and they can't use it all. They actually get it at much better prices than even we can get it.

\section{EFS015.pdf - 9:15 [So anyways, that was the...very ..] (3:867-3:1780) (Super) Codes: [Rules]}

So anyways, that was the...very big point of contention for awhile. We did have some meetings with all the trucking industry, with the oil industry. We had... prior to actually putting the rules into effect, so that we could have their input on it. Once the rules went into effect, we've made some modifications to it to make it tailor and work a lot smoother both for our personnel and for the industry personnel. And that's where the $\$ 8,000$ contracts came up...er um....agreements came up out of those conversations. So, we've been evolving with the industry as they've gotten here as to how it works best for us to get the most benefit and to be able to protect the other drivers 
and other road-use people as well as making it accessible for the oil companies to go out there do the jobs they're trying to do. And so, we've struggled through it. At one point, I had-I don't know-20 lawyers in there.

EFS015.pdf - 9:16 [From Texas Oil and Gas Associa..] (3:1828-3:2604) (Super) Codes: [Compliance] [Conflits \& Interests] [Rules]

From Texas Oil and Gas Association, Texas Trucker's Association, Texas...blah, blah, blah, Petroleum and Producers Association. And it was....and all that was over the road use permitting stuff, because there are several places in the statutes that give clear authority to the county and then there are some other places in other statues that seem to be counter to this statute. And so, they [oil and gas] try to hang their hat over here [try to associate themselves with one particular set of rules], while I hang my hat over here [use a different set of rules], and nobody wants to go to court. Well, they didn't want to go, because we were doing - quite frankly and still in my opinion-everything complies completely with statute. So, I don't think they could win

\section{EFS015.pdf - 9:17 [Yeah, a meeting that was reque..] (4:98-4:476) (Super) Codes: [Conflits \& Interests]}

Yeah, a meeting that was requested, and so I made them come here. In fact, when we did that, I took them into the courtroom, to where I'm up on this side and they're up on that side. And it's my home turf...it's my little local Kyle Field over there. And...it's a very aggressive business, and so they're attorneys were very aggressive in they're arguments, as they should be

\section{EFS015.pdf - 9:18 [But those were the things that..] (4:479-4:779) (Super) Codes: [Cristicism]}

But those were the things that occurred for us to get to where we are now to where pretty much everyone is living in harmony. I don't think we're going to go out and sing Kumbaya [an American-spiritual friendship song]. Everybody's gotten used to it now, and gotten used to the way we do it.

\section{EFS015.pdf - 9:19 [And there's a big issue for th..] (4:779-4:1122) (Super) \\ Codes: [Conflits \& Interests] [Rules]}

And there's a big issue for the oil companies. In the state of Texas, you've got 254 counties. Each county has their own set of rules, so I can understand the frustration of an Anadarko or Apache-one of the bigger guys-that operates in 40 different counties. You've got 40 different sets of rules that they're going to try and follow

\section{EFS015.pdf - 9:20 [That's one reason why the stat..] (4:1122-4:1791) (Super) Codes: [Accountability]}

That's one reason why the state permitting came along back in the 70s and 80 s that allowed for them to be able to pull one permit. But.... what they don't everybody to think about or remember is that those permits

they pulled, they are bonding in that county...they do damage to the roads in that county, then that bond that they put up with the state comes to the county. So, it's our insurance that we're going to be able... and that's negligent damage. It doesn't...and there's no argument with anybody on that. If there was negligent

damage done, then yes, the oil company or trucking company or all of those parties...whoever we want to go after...are responsible

\section{EFS015.pdf - 9:21 [going over a load-limited brid..] (4:1925-4:2232) (Super)}

Codes: [Transportation (Traffic, Road impact \& Railroads)]

going over a load-limited bridge, when he knows he's over the load...loosing control on a little county road and everything like that and getting off on the side and taking out a 100 yards of 
fence and mailboxes. Those are the kinds of things... or coming over to the edge of the road and crushing culverts.

EFS015.pdf - 9:22 [Those are negligent issues. Th..] (4:2342-4:2787) (Super)

Codes: [Accountability] [Environment impacts] [Water Aspects]

Those are negligent issues. Those are things that because the truck driver erred through negligence, those occurred. And so, if they don't pony-up and come clean on those right away, then the only thing we have is the state bond to go after them on. Another goofy one that's occurred twice here in Burleson County

is truck drivers pulling away from sites in the fracking process and they have liquid sludge in the backs of their trucks...

\section{EFS015.pdf - 9:23 [They either have to hit their ..] (5:9-5:226) (Super)}

Codes: [Environment impacts]

They either have to hit their breaks a lot which makes it flow up and come out. If the tarp, and there is a tarp...and all it is is a tarp down...if the tarp doesn't hold then all of that material falls onto the roads.

\section{EFS015.pdf - 9:24 [nd it is a... We... Like I said, i..] (5:276-5:503) (Super) \\ Codes: [Environment impacts]}

nd it is a... We... Like I said, it's happened twice. I shut down interstate [Highway] 36 twice. One time, right in the middle of Summerville right at downtown where the guy just hit the brakes and everything like that. I guess...

\section{EFS015.pdf - 9:25 [Well, we had no clue, so there..] (5:1300-5:2367) (Super) \\ Codes: [Accountability] [Environment impacts] [Social Sensitives (population, genre, wage, accidents)] [Transportation (Traffic, Road impact \& Railroads)]}

Well, we had no clue, so therefore now it becomes a HAZMAT [hazardous materials] clean up issue. So then, we've got to call TXDOT in and everybody has to come in their HAZMAT stuff. As it turned out, there was no hazardous materials in it, but you don't know at that time what's in it. Once it becomes that kind of an issue, then the highway is shutdown a minimum of 8 hours. Whatever roadway it is, because it just takes that long to get a HAZMAT team together to come here and deal with it. And so, those are all the reasons that we want the truck numbers. Who's driving on the roads and the routes they're using and stuff like that. Now, once they get back out on state roads. That's all the state. We have no state on that. These events...those two flood events were on state roads, and so it took some extra investigation on our part to figure out exactly who they were. Then the company reimbursed...the company reimbursed the city of Summerville. The company reimbursed TXDOT. They took care of it, but if it had been left up to the driver

\section{EFS015.pdf - 9:26 [He received a citation: failur..] (5:2438-5:2644) (Super) Codes: [Cristicism]}

He received a citation: failure to stop at the scene of an accident. Those kinds of events have happened and so...that's the big thing about the roads. And for us locally, the roads about $50 \%$ of our budget

\section{EFS015.pdf - 9:27 [eah, they've gone through it. ..] (6:522-6:839) (Super) \\ Codes: [Conflits \& Interests]}

eah, they've gone through it. Right now, we've got a bill that's being introduced.... Right now, county right-of-way roads...those are part of leases. I mean they're pulling minerals out from underneath the road right-of-ways. There was a 1950, 60 AG [attorney general] opinion that all those monies go to the state?

\section{EFS015.pdf - 9:28 [So, we have bill being introdu..] (6:892-6:1071) (Super)}


Codes: [Conflits \& Interests]

So, we have bill being introduced and everything that, "no," those monies should stay with the county. We're talking about hundreds, if not thousands...I've got 666 miles of road

\title{
EFS015.pdf - 9:29 [l certainly try to use common ..] (6:2084-6:2471) (Super) Codes: [Cristicism]
}

I certainly try to use common sense when we can, in this case on the roads and everything like that, those are the guys that tearing it up. Roads are not built to that standard, and therefore, I think you could probably argue negligence if you really wanted to and everything. By running that heavy of a vehicle and that number of a heavy vehicles on a road like that is negligent

\author{
EFS015.pdf - 9:30 [Clarification, and they'll be ..] (6:1897-6:2081) (Super) \\ Codes: [Conflits \& Interests]
}

Clarification, and they'll be trying to get something that would reduce or limit of local governments to be able to regulate. As much as I don't like regulations and stuff like that

\section{EFS015.pdf - 9:31 [And so, right now I have a bil..] (6:1308-6:1623) (Super)}

Codes: [Conflits \& Interests] [Sale Taxes, Revenues \& Royalties]

And so, right now I have a bill being introduced primarily by Judge Fowler in DeWitt County and everything...he's really pushed it along, and the rest of us are getting our senators and reps representatives] to sign-off on it. But to allow those revenues... any revenues derived under that to stay with the county.

\section{EFS015.pdf - 9:32 [And if you didn't apply, you d..] (7:986-7:1578) (Super)}

Codes: [State Funds]

And if you didn't apply, you didn't get it. And if you missed the deadline, you didn't get it. And there were some counties that elected not to that had small amounts and everything and they didn't want to have to go through the paperwork. We decided it was worth it just in case there is a second round that could be of

more use to us, knowing that if there was a second round using more recent data that we would be much better off. So...those are all legislative things that we're watching for in the session.

Really after today it really gears up. Today is the last day to file

\section{EFS015.pdf - 9:33 [We are, for all intents and pu..] (7:1795-7:2330) (Super) \\ Codes: [Environment impacts] [Water Aspects]}

We are, for all intents and purposes, the Saudi Arabia of water for Texas. You're sitting right on top of it right now. We have deeper, more full. I don't know how you can have something more full than full. But, it's under intense pressure, so you keep squeezing more in there, acquires: the Carrizo-Wilcox and the State [?]. And while there's been a little press about the fact that some wells are...a small well field is going to be drilled and that water is going to be eventually moved to San Antonio, be sold down there.

\section{EFS015.pdf - 9:34 [Burleson County that have had ..] (8:38-8:478) (Super) Codes: [Conflits \& Interests] [Water Aspects]}

Burleson County that have had it's mineral rights leased, and it's water rights leased. And they are not leased to the same people. So, the mineral rights are leased to the Clayton-Williams and all of that-

everything like that. The water rights are leased to other companies. We've run into an issue now where you have a surface owner, who bought a piece of property, that has none of the minerals or water that goes with the dirt.

\footnotetext{
EFS015.pdf - 9:35 [Ok, but he's going to get all ..] (8:1642-8:1756) (Super)

Codes: [Noise, nuisance, Flares]
} 
Ok, but he's going to get all the noise, get any of the issue, all of the traffic, all of that that goes with it.

\author{
EFS015.pdf - 9:36 [And they are not leased to the..] (8:128-8:2318) (Super) \\ Codes: [Conflits \& Interests] [Mineral Rights, Royalties \& Land Tenure]
}

And they are not leased to the same people. So, the mineral rights are leased to the ClaytonWilliams and all of that-everything like that. The water rights are leased to other companies. We've run into an issue now where you have a surface owner, who bought a piece of property, that has none of the minerals or water that goes with the dirt. Basically, they're just buying the dirt....And when I say none of the water. Water for residential use and even for light cattle operations. Those are all upper acquires and everybody can get all of that that they want. No big deal! We're talking about the deep water, the 4-5,000 feet down good, thick water that is untapped, which is all the water you guys drink, over there. All y'all's water comes from groundwater in Bryan-College Station and A\&M to the tune of about 80,000 acre feet a year. And each acre foot is 350,000 gallons, and so you can do the math-a bunch of water. But, we have a

surface owner who has just the dirt. The property has been leased to an oil company. So, by the virtue of that lease, they have the dominant position where they can come in and they can drill. Now, they have to pay damages, typically the dirt owner is going to get a couple new roads and a good driveway into his place and stuff. Rock is cheap to them, so therefore, they give a lot of that stuff away. So,

they try to do some things like that. But that dirt owner gets none of the revenues that are going to be derived from the oil well. Ok, but he's going to get all the noise, get any of the issue, all of the traffic, all of that that goes with it. It's all going to be on them. And those are 24 hour operations once they get into business. And so...so anyways.... and so the oil company has a dominant position that's

thoroughly established in Texas law. And so, they commenced exploration. Whenever they were doing exploration, they have the right to draw all the water they need to do their exploration. Again, that's dominant position, well established in law, and so the law also defines exploration. Exploration is while the rig is in place. So, rig comes down and moves out. Frack teams come in

\author{
EFS015.pdf - 9:37 [And so, last thing you want is..] (8:2958-8:3206) (Super) \\ Codes: [Conflits \& Interests]
}

And so, last thing you want is some goofy-ass judge making a decision on this thing. So, it's much much better for the people in the business for us to figure it out. So anyways, as it turns out, the two sides were able to work out an agreement.

\title{
P 9: EFS015.pdf - 9:38 [I didn't even ask what the agr..] (9:1-9:839) (Super) Codes: [Environment impacts] [Water Aspects]
}

I didn't even ask what the agreement was. It really doesn't pertain to me, because it's a private agreement between two private companies, and therefore, I try to stay out of the way of that. They did end up having to work out something. I imagine that it involves paying something to Blue Water, the holder of those water leases, for the rights and use of that water. Where it does matter to us is that we have a groundwater conservation district, which that permits all commercial water wells and big agriculture wells. In fact they permit every well just for counting purposes, and the counting purposes are the big wells that we're looking at. And these are big wells. It takes about 35 acre-feet to frack the average hydro-frack well, each hole. And you can have 5 holes on each pad going out 5 different directions.

EFS015.pdf - 9:39 [And so, it adds up to a lot. N..] (9:893-9:2144) (Super)

Codes: [Conflits \& Interests] [Environment impacts] [Water Aspects] 
wells, 35 acre-feet per hole, and these do represent holes. So anyways, they worked out a deal where they would buy that. Our purpose... our deal is that we have to account for the water, because we have 'DFCs' or Desired Future Conditions that have been established for the aquifers, So, if you're using 35,000 acre-feet if you're going to do 1,000 wells, 35 [acre-feet of water] per well. 35,000 acre-feet, we have to account for that that that's part of this year's use. And so, the Post-Oak Savannah Water Conservation District must make that accounting, and so therefore, somebody has to pull a permit. And quite frankly, to all of us, the Post Oak Savanna or Burleson County, I don't care who pulls the permit, somebody's pulling it. I don't care if it's the oil company. I don't care if it's Blue Water. Blue Water says, "Hey, they've got the permit." "So then the oil company, you have to deal with Blue Water." And, so...again they were able to work something out. Those have been just the ongoing kinds of negotiations and the ongoing conversations that have to be had as this activity has spread and gone through the county

\title{
P 9: EFS015.pdf - 9:40 [We don't like regulations here..] (9:2870-9:3047) (Super) Codes: [Cristicism]
}

We don't like regulations here, and so we've given the attitude to the staff that does this permitting and everything to use common sense whenever you can interpret it a way.

\author{
EFS015.pdf - 9:41 [Well, um, yeah, um... the commis..] (9:2324-9:2636) (Super) \\ Codes: [Conflits \& Interests]
}

Well, um, yeah, um... the commissioners really talk with them a lot more. My staffer that does all of these permits and everything, he probably talks with them a lot more. These things do not come to me unless there is an issue unless l've got to have lawyers sitting around to try to figure out those things.

\section{EFS015.pdf - 9:42 [Most of the stuff they're able..] (9:2638-9:3046) (Super) Codes: [Rules]}

Most of the stuff they're able to get figured out with the guidance that the Commissioner's Court has given to them to the rules that we've established. And again, we're a small community. We're a very conservative community. We don't like regulations here, and so we've given the attitude to the staff that does this permitting and everything to use common sense whenever you can interpret it a way

\author{
EFS015.pdf - 9:43 [Land owner...I can remember some..] (9:3099-10:22) (Super) \\ Codes: [Conflits \& Interests]
}

Land owner...I can remember some of these cause like I said, I don't get too many of them. I don't have to deal with them until I get something that they don't want to deal with and they want me to make

the call. Landowner was pissed off because of lease terms with somebody. I don't know what oil company it was. And so then, the oil company was pulling the permit. And the land owner came up and said, "Don't give them a permit! They don't have a good lease. They don't have any right to be on my property and everything like that."

\section{EFS015.pdf - 9:44 [That is not a determination th..] (10:24-10:347) (Super) Codes: [Rules]}

That is not a determination that we make. If a company comes, and they present documentation, that we consider valid, we issue a permit, and now then, if you as a landowner got to fight, you with the oil company, get your lawyers. If it's a lease...I personally am in a big lawsuit with Apache over my family property.

\section{EFS015.pdf - 9:45 [personally am in a big lawsuit..] (10:279-10:1494) (Super)}


Codes: [Conflits \& Interests] [Cristicism] [Development as Economic] [O\&G procedures, strategies and investments] [Pro-business mentality]

personally am in a big lawsuit with Apache over my family property. That's just me personally, and I have to separate that from this stuff. In fact, I've used Apache whenever l've been asked to come and do some presentations on the oil and gas activities in Burleson County. I do depend on industry experts to help with those presentations, and Apache has a great presentation on fracking. They have a great video. The statistical data that they've put together over the years, and so, I don't care if I'm in a personal lawsuit with

Apache or not. If I'm having to explain fracking to somebody and everything, then I'Il bring Apache in and have them do that presentation for economic development groups or chambers of commerces or whoever it is. We've been asked to go and talk in front of them on a regional level, not just on a local level. And so, that's just a little personal side-not there on that stuff. There are those issues come up all the time in this business. You're going to have land owner disputes with oil companies. Period. Landowners want a better deal. Apache is saying they don't have to give me a better deal, and so ok. You've got your lawyers; I've got my lawyers.

\section{EFS015.pdf - 9:46 [We'll see what we can do. And ..] (10:1551-10:1881) (Super) Codes: [Rules] [Water Aspects]}

We'll see what we can do. And none of this is...somethings are very black and white and very easy to see in the law. Other things are not. It's those gray areas, and or the new areas. The areas where we're setting precedent: the surface owner, the water owner, the oil owner. You just don't have that situation in most places

\section{EFS015.pdf - 9:47 [And so, the land owner owns th..] (10:1947-10:2602) (Super) Codes: [Conflits \& Interests] [Rules]}

And so, the land owner owns the water. And so, therefore, even if this dirt owner, if he owned water, then he could get something out of it. He could say, "Hey Clayton, pay me for this water." And Clayton would say, "Yeah. If that's a way to make this guy happy, let's give him $\$ 10,000$. He gets something out of the deal." And so, we have a lot of acreage where that's not the situation, where developers...not developers....land speculators came in. They bought the land with all the rights, stripped all them rights from under it, and sold the dirt. It's a business model. Agree with it, don't agree with it. It doesn't matter. It's not illegal

\section{EFS015.pdf - 9:48 [It's simply the way that it is..] (10:2666-10:3092) (Super) Codes: [Conflits \& Interests]}

It's simply the way that it is. It is up to the buyer to understand what they're buying...that they're buying property that has all those things that have been stripped out from under them. And the only ones that have really come up to me and said, "This ain't fair. This ain't right. I didn't know." "Now, how can you not know?" I said, "Your realtor should have told you." "Well, we didn't want to use a realtor." So...

\section{EFS015.pdf - 9:49 [There it is. That 3\% was worth..] (11:48-11:155) (Super) Codes: [Cristicism]}

There it is. That $3 \%$ was worth so much to you...that you went in without representation. And now you're mad!

\section{EFS015.pdf - 9:50 [But those issues...those are the..] (11:216-11:441) (Super) \\ Codes: [Conflits \& Interests]}

But those issues...those are the issues that I deal with that this office deals with is trying to mediate, mitigate some of those things. And for the most part, we've been able to get them done, and keep stuff out of courts. 
EFS015.pdf - 9:51 [Have there been any benefits a..] (11:459-11:1144) (Super)

Codes: [Sale Taxes, Revenues \& Royalties]

Have there been any benefits associated with the oil and gas drilling? \#0:35:13.0\# EFS015-We haven't realized them yet. Ultimately, the ad valorem tax...the property tax on those wells will kick in, but typically, you're 2 years behind. \#0:35:29.0\# T- Why? \#0:35:29.0\# EFS015Because, while the well's being drilled, it doesn't count into the evaluation. \#0:35:33.5\# To- It doesn't count. \#0:35:33.5\# T- Oh! \#0:35:33.5\#

EFS015- Even as it's being completed, it's not done. Even if it's completed in December 2015, then it's January-December 2016 that the evaluation is calculated upon. So then it's 2017 that you actually would begin to see the revenues.

\section{P 9: EFS015.pdf - 9:52 [So there's always a lag, and t..] (11:1206-11:1861) (Super) Codes: [Cristicism] [Rules]}

So there's always a lag, and that's the way it's always been done. However, the damage is being done in the first two years that it's occurring. So, we're trying to deal with all of the extra expenses caused by the extra loads and everything, and yet the revenues won't be released for a couple more years. It's really hard to get people to...Now again, in public meetings we've had and all that, we've got out and we've explained that. The commissioners and myself, every time we speak in public on this, we explain the evaluation like system. That's just the way it is. That's what the law is in Texas. So we have no desire to change that law

\section{EFS015.pdf - 9:53 [And so, it's a...in anticipation..] (12:485-12:1113) (Super)}

Codes: [Sale Taxes, Revenues \& Royalties]

And so, it's a....in anticipation of using those funds, you want to be responsible with them. And so...that's one of the things we're doing with the capital project. Now. the bottom falls out of the bottom of oil and everything like that. So, we l've got to springboard the commissioners and the voters, assuring them that we...and that was one thing that we made sure of is that the revenue streams that we have today would cover the note for that, because it is being financed. And so, if revenues just stayed flat, then we were going to be able to cover that and not have to take money from anything else or any services.

\section{EFS015.pdf - 9:54 [So, those revenues will increa..] (12:1324-12:3251) (Super)}

Codes: [Rules] [Sale Taxes, Revenues \& Royalties]

So, those revenues will increase, and then we'll be able to pay that off quicker and everything like that. And so, it was case of money is extremely cheap right now. You could borrow it at extremely favorable rates, less than $3 \%$. And that we would have some additional revenues that we could use to cut it off. Now then, that brings a whole new issue to the local governments though. We're capped at $8 \%$ increase on our ad valorem taxes annually. If it's over $8 \%$, then your subject to a rollback election. So... when I first came into office-l've been doing this 12 years - the tax rate was $\$ 0.64$. Today, the tax rate here is $\$ 0.49$. So, over the 12 years, we've been able to...and it's a balancing act. As our economic development activities paid benefits and we started having more businesses locate here, because quite frankly, it's businesses that pay the ad valorem taxes. The crap that we pay on our houses is nothing. The $\$ 3,000$ check I have to write on mine seems like a lot, but it's the businesses that bear the brunt of it. In a rural county, even more, because

over $90 \%$ of our land is ag [agriculture] value. So, we get nothing off that. A penny on the dollar. So anyways, our economic development plan though has paid benefits. We've been able to drop the tax rate, and still increase the budget. It's a balance, but we got to $\$ .49$, which is where I wanted to get: less than $\$ .50$ back to the 1980 s values or tax rates. As this extra money comes in and everything, it will shoot the revenues up-way above $8 \%$. Then it is our job then to sell the public that we're going to keep it at $\$ 0.49$, even though we're going to have this extra money. We're going to use it to pay off our debt early. We're going to use it bolster...build our reserves up. We will be responsible with your money. In Burleson County, it would only take 50 people signing a petition to force a rollback election. \# 
EFS015.pdf - 9:55 [So, the job that we have to do..] (13:63-13:537) (Super)

Codes: [Sale Taxes, Revenues \& Royalties] [World O\&G commodity prices]

So, the job that we have to do is good enough that we don't...I have not 50 Tea Partiers-and I'm a Republican guy and...-people that are just anti-tax, no matter what. We've got some of those out there, and l've got my share of them here that I have to be able to convince them that what we are doing is the responsible thing to do, because if I drop that tax rate down to $\$ .30$ to keep me underneath the rollback rate and then oil goes down to $\$ 40$, you've got a problem

\section{EFS015.pdf - 9:56 [That means I fire cops, I fire..] (13:962-13:1797) (Super)}

Codes: [Cristicism] [Sale Taxes, Revenues \& Royalties]

That means I fire cops, I fire.... People start going. That [staff] are the expensive stuff. So, there's even a push this year... a piece of legislation that would take that down to $4 \%$ and automatic rollbacks with no petition, which was withdrawn by the senator...The senator then withdrew it the day before we were going to have testimony on it, because every city, county...everybody was there to testify against that. The city of Fort Worth estimated that it would cost them $\$ 11$ million. It would have cost us in the neighborhood of $\$ 1,000,000$ plus the expense of a rollback election, and each of those elections are about a minimum of $\$ 10,000$, so it's just [indicates a small amount of money]. But $\$ 10$ grand here, $\$ 10$ grand there, and all of a sudden you chip away pretty good. And our total budget here is only $\$ 8$ million.

\section{EFS015.pdf - 9:57 [Now then, the slow down has re..] (14:96-14:262) (Super)} Codes: [World O\&G commodity prices]

Now then, the slow down has really dragged the activity further out. It slowed it down considerably, although we still have 11 rigs working in Burleson County today.

EFS015.pdf - 9:58 [So, about \$4 million goes to r..] (13:2012-13:2101) (Super) Codes: [Transportation (Traffic, Road impact \& Railroads)]

So, about $\$ 4$ million goes to road-bridge and about 4 million goes to the general side. $S$

\section{EFS015.pdf - 9:59 [0, about \$4 million goes to ro..] (13:2013-14:261) (Super)} Codes: [Rules] [Sale Taxes, Revenues \& Royalties]

o, about $\$ 4$ million goes to road-bridge and about 4 million goes to the general side. So...we're very conservative in our budget and yet still providing the services at the level that most people...So anyways, the benefits that we were going to use them would be to do some capital projects like that that need to get done. Once those revenues start coming in, we would throw more of that money towards the roads and bridge side and...to be able to make up for this though kind of three years, while all this activity is going on. Now then, the slow down has really dragged the activity further out. It slowed it down considerably, although we still have 11 rigs working in Burleson County today

\section{EFS015.pdf - 9:60 [So, there's 10 more out there ..] (14:349-14:2321) (Super)}

Codes: [World O\&G commodity prices]

So, there's 10 more out there somewhere. And a half dozen wells or so that are in the completion phase. So, they're in the fracking phases right now. So, we still have activity here. We heard that from the industry that we would not... we saw a significant slow down, but that it would not hit us like it did Midland-Odessa or some of the places like that, because of some of the infrastructure around here. A lot of your workers are around here, so you don't have to house a lot of your workers; you don't have to move workers from place to place. So, you reduce some of those expenses. You want to keep your best workers working. You've got to keep them doing something, otherwise they'll move to other industries. They'll move back to the construction industry or something like that. A guy's got to have a paycheck. And so, we're seeing....we haven't seen the slowdown here. We're insulated 
somewhat by it though. It cannot be sustained at the $\$ 50$ level that long. We need to get back... and quite frankly, if you go back at the economic history of the

United States modern times, when oil-consider inflation rates and everything else-when oil's around $\$ 70-\$ 75 /$ barrel, this country hums. Everything works. The oil companies are making money. They're...not making like a $\$ 100 \ldots$ but they're making money. They're stockholders are very happy and everything. It keeps fuel costs at a rate that other businesses depend on and they're able to make money and they're able to do it. And then when it gets above that, that 's when you start seeing some problems. When were at $\$ 100$ and stuff like that you saw...inflation beginning to hit grocery stores and everything else

like that, because of transportation costs. So, it's a fine line for everybody. Whenever...if we get back to that \$70-75 level and just sit there for a while, I think everybody would be really, really, really happy. Additionally, it's happened over and over in the United States.

\section{EFS015.pdf - 9:61 [-This project over here is pro..] (14:2580-14:2827) (Super)}

Codes: [Social Sensitives (population, genre, wage, accidents)]

-This project over here is probably costing us $\$ 500,000$ more than it would have cost if companies would have full employment. Our drywall contract and everything: our guys are coming out of West Texas. We couldn't even find anybody around here.

EFS015.pdf - 9:62 [So, there's 10 more out there ..] (14:349-14:2317) (Super)

Codes: [Social Sensitives (population, genre, wage, accidents)]

So, there's 10 more out there somewhere. And a half dozen wells or so that are in the completion phase. So, they're in the fracking phases right now. So, we still have activity here. We heard that from the industry that we would not...we saw a significant slow down, but that it would not hit us like it did Midland-Odessa or some of the places like that, because of some of the infrastructure around here. A lot of your workers are around here, so you don't have to house a lot of your workers; you don't have to move workers from place to place. So, you reduce some of those expenses. You want to keep your best workers working. You've got to keep them doing something, otherwise they'll move to other industries. They'll move back to the construction industry or something like that. A guy's got to have a paycheck. And so, we're seeing....we haven't seen the slowdown here. We're insulated somewhat by it though. It cannot be sustained at the $\$ 50$ level that long. We need to get back... and quite frankly, if you go back at the economic history of the

United States modern times, when oil-consider inflation rates and everything else-when oil's around $\$ 70-\$ 75 /$ barrel, this country hums. Everything works. The oil companies are making money. They're...not making like a $\$ 100 \ldots$ but they're making money. They're stockholders are very happy and everything. It keeps fuel costs at a rate that other businesses depend on and they're able to make money and they're able to do it. And then when it gets above that, that 's when you start seeing some problems. When were at $\$ 100$ and stuff like that you saw...inflation beginning to hit grocery stores and everything else like that, because of transportation costs. So, it's a fine line for everybody. Whenever... if we get back to that $\$ 70-75$ level and just sit there for a while, I think everybody would be really, really, really happy. Additionally, it's happened over and over in the United Sta

EFS015.pdf - 9:63 [And a lot of it is because a l..] (14:2892-14:3272) (Super) Codes: [Infrastructure] [Social Sensitives (population, genre, wage, accidents)]

And a lot of it is because a lot of those guys went to the oil industry, because it paid so much better. Now then, with the downturn and some layoffs, stuff like that, you would expect that some of those open positions in construction filling on back up. Now we're complicated just a little bit more on a regional project and that's Kyle Field. They have hired everybody! \#

EFS015.pdf - 9:64 [So that...and it's a 24 hours a ..] (15:66-15:1043) (Super)

Codes: [Infrastructure] [Social Sensitives (population, genre, wage, accidents)]

So that... and it's a 24 hours a day operation that they have over there, and so a lot of contractors that we had that bid on stuff, because they have the big contracts over there and 
everything. Well, they bid on our project, but they bid $25 \%$ higher than what it would have otherwise been in a normal market. So, you have a small project over there that is very regional, but it just happens to be where I sit. And so, a couple of the oil industry taking employees from the construction industry, we've seen an increase in costs of that kind of activity...construction activities: cement, concrete, stuff like that. I mean you're two to three weeks out on trying to get jobs [?] ready to go just to be able to get the cement. So, you've seen the ripple effect in other industries of people going to the oil and gas industry. Blue collar workers come to oil and gas industry. Unskilled workers going other there that you've lost in some of these other industries.

EFS015.pdf - 9:65 [No. I haven't. I mean...I don't ..] (15:1164-15:1711) (Super)

Codes: [Social Sensitives (population, genre, wage, accidents)]

No. I haven't. I mean...I don't know what they're.... We lost 3-4 deputies to the oil industry, because it paid so much better. And so, when you only have 12 deputies, that's $25 \%$ of your law enforcement workforce. And again, I can't blame them. They're young guys and they're physically able to do that kind of work. They can always come back to law enforcement afterwards; go out there and get it while you can. And so....that's

some of the employment effects that we've seen here is that they've pulled a lot of people to work for them. \#0

EFS015.pdf - 9:66 [h...it's mixed. There's...the mine..] (15:1842-15:2199) (Super)

Codes: [Conflits \& Interests] [Mineral Rights, Royalties \& Land Tenure]

h...it's mixed. There's...the mineral rights that we're in the fight with Apache over. We don't own the dirt anymore. We simply own $50 \%$ of the minerals. We retained half of it when the property was sold. And so, it's mixed. There's some people....landowners that have the minerals still, and then there are others where

those minerals have been divided. So

EFS015.pdf - 9:67 [The big money would come with ..] (15:2713-15:2793) (Super)

Codes: [Conflits \& Interests] [Rules]

The big money would come with the roads if we can get that legislation changed.

EFS015.pdf - 9:68 [They have a huge Halliburton y..] (16:444-16:1738) (Super)

Codes: [Future perspectives]

They have a huge Halliburton yard here. They have +500 employees that are stationed out of Burleson County. They don't all necessarily live here. But the... which is a service industry and they only service after-the-fact wells that are being drilled when it comes to the fracking time and so....they're not drillers. And so, the...so for us, it is very important, we do have-when you talk about regular meetings-I meet about once a month with the Halliburton manager. "How's it going? What things are doing? How are we looking on stuff and everything?" And so, they've got contracts through the end of the year. They feel pretty good about the yard... where this yard is located. They also service western Louisiana. They go down to Central Texas towards South Texas and then all of this area of East Texas is serviced out of that yard. And so they have a pretty big area that they service out of, which has protected this yard from any big layoffs. Now, the acquisition of Baker-Hughes, how exactly that's going to play out...nobody really knows yet. And so....in the mean time, Baker Hughes guys are still doing their jobs and Halliburton guys are still doing their jobs. Let the big guys up there [referring to upper management] figure out all that's going to mesh together. So...

\section{EFS015.pdf - 9:69 [-Maybe 30+ years. The story go..] (16:1876-16:2091) (Super)}

Codes: [Community receptiveness]

-Maybe 30+ years. The story goes that a Mrs. Halliburton-and there are some Hallibrutons out there-that she came here. That she fell in love with Caldwell and told her husband that they needed to have a yard here 
EFS015.pdf - 9:70 [Quite that simple.. And that y..] (16:2144-16:2276) (Super)

Codes: [Future perspectives]

Quite that simple.. And that yard is built here and forever is supposed to be here, because whoever she is, I think is still around

EFS015.pdf - 9:71 [a coach...just as a competitor...l..] (17:828-17:1039) (Super) Codes: [Development as Economic]

a coach...just as a competitor...I couldn't much tolerate that. They'll either beat the hell out of me or I'm going to win it. So I ran again and was elected in 2002. Primarily on an economic development platform

EFS015.pdf - 9:72 [a coach...just as a competitor...l..] (17:828-17:1727) (Super) Codes: [Safety \& bottlenecks]

a coach...just as a competitor...I couldn't much tolerate that. They'll either beat the hell out of me or I'm going to win it. So I ran again and was elected in 2002. Primarily on an economic development platform, that we were really going to really ramp up our economic development activities. We had just lost a couple of plants here in Caldwell. There was a big, giant coat hanger plant out here that made coat hangers. There

was a ladder plant that made aluminum ladders and stuff like that, and it all closed up. And so a lot of people had lost jobs and stuff. They were ready for someone who could work the economic development side of it. So, we did. We came in and we've done a pretty good job. We've...that was my background. I don't have a law background. You don't have to be to be the constitutional county judge. You just have to have a general knowledge of the law, which...

\section{EFS015.pdf - 9:73 [We're very unique. I mean you ..] (17:2208-17:2544) (Super)}

Codes: [Cristicism] [Rules]

We're very unique. I mean you go to some places and there are horror stories, and even in commissioner's courts and offices within this place. In county government, we're fragmented on purpose. Everybody thinks I'm the county judge; I'm the boss. No! The sheriff is elected and the only thing I have over them is I make the budget.

\section{EFS015.pdf - 9:74 [And even the commissioners can..] (18:8-18:610) (Super)}

Codes: [Cristicism] [Rules]

And even the commissioners can vote that. So I have to get it past them. Once the budget becomes the sheriffs' though. I don't care if I've put in there for him to buy 4 new cars. If he only wants to buy 3 cars and do something else with some of the money; I can't stop it. He can do. Once it's his budget, it's his budget. And every office and county is like that. So, it's fragmented on purpose that there is no central figure at the top, which trust me, dictatorships are much easier to run than democracies. Much easier...like a benevolent dictator, but...nevertheless, they're a lot easier.

EFS015.pdf - 9:75 [Once it's his budget, it's his..] (18:299-18:527) (Super) Codes: [Government \& Governance layout]

Once it's his budget, it's his budget. And every office and county is like that. So, it's fragmented on purpose that there is no central figure at the top, which trust me, dictatorships are much easier to run than democracies

\section{EFS015.pdf - 9:76 [t because of that and everythi..] (18:618-18:1329) (Super)}

Codes: [Government \& Governance layout] [Representativeness] [Rules]

$t$ because of that and everything, it does foster-in me at least-a mindset of that authority and power are split amongst a bunch of different sources. And so, the...so the city of Caldwell, Summerville, and Snook. I have 3 towns here that have municipal governments. I understand the jurisdiction that each of those. I also understand the limitations that they have and/or the 
strengths that they have. And so, the...we've....whenever we had these early initial meetings with all the trucking industry and the oil industry and everything, we invited the city to every one of those. We knew it was going to affect them. It was going to affect them in lodging peoplestaying in motels and stuff like that.

\section{EFS015.pdf - 9:77 [And most of those are all in t..] (18:1331-18:1515) (Super) Codes: [Representativeness]}

And most of those are all in the incorporated areas, and so, we wanted them to be on board too and understand exactly what was going on timelines and timeframes that were happening.

\section{EFS015.pdf - 9:78 [And the economic development f..] (18:1517-18:2031) (Super)}

Codes: [Development as Economic] [Pro-business mentality]

And the economic development folks, which included the chamber of commerces was included in all of those talks in the beginning, because we needed everyone to understand what the plans were, how many wells there's going to be, the amount of time it was going to take get this done, the other things that were going to be needed in order to accommodate, and so in this...in sticking with the vein of oil and gas and energy industry development, the cities have been at the table every time with all of us.

\section{P 9: EFS015.pdf - 9:79 [So, when you're looking at us,..] (18:4037-18:4350) (Super)} Codes: [Government \& Governance layout]

So, when you're looking at us, it's not like you're in a Dallas or a Bryan-College Station-god bless Dwaine and all them over there-but it is staffers that handle all of that. Because we're not that big and we have taken a much more hands on approach to it. You're looking at the guys that make the decision.

\section{EFS015.pdf - 9:80 [ome back. And so, a large trac..] (18:2094-18:4350) (Super) Codes: [Development as Economic] [Rules]}

ome back. And so, a large tract of land that has been one of our economic failures. In 20 years the piece of property has been closed down that we've tried to get it back open has just been sold, and they are.....and have ordered the infrastructure from the city to be put back into the property. Ultimately this will... be a place where they will rail in frack sand and expand the rock operation that's there. Well, as soon as all of that started and everything like that, every meeting that occurred had me at it. had our economic development at it, and had the city manager at it of Caldwell. And so, it had all three of us, because all three played parts in that bit. Even though this is located outside the city, it's still well within the extra-territorial jurisdiction that they had. And all the utilities are suppliedby the city. So, the electrics, sewer, water, all come out there. And yet...the the ground transportation access to the property is in the county. And so, the property itself is in the county, and so it doesn't pay city taxes even though it does city utilities, which means then all law enforcement service fall upon the county to provide out there. So if they were going to be doing a bunch of stuff and doing things out there, we needed to be aware of it for

security purposes, then all of us have to be at the table together. And, like I said, I'm extremely fortunate in that all of us like each other and can work together. It's made it much, much easier for us whenever we have a business prospect, we can present a unified front to them of when they say, "Are we going to be able to do tax abatements or something like that?" You're looking at the 2 guys that make that decision: me and the city manager. If I come back and tell my commissioners, this is what we need to do for a good economic development project and he tells the city council that, then it's going to be done. So, when you're looking at us, it's not like you're in a Dallas or a Bryan-College Station-god bless Dwaine and all them over there-but it is staffers that handle all of that. Because we're not that big and we have taken a much more hands on approach to it. You're looking at the guys that make the decision.

EFS015.pdf - 9:81 [And so...it lends a certain peac..] (18:4352-19:770) (Super)

Codes: [Environment impacts] [Pro-business mentality] [Water Aspects] 
And so....it lends a certain peace of mind to the potential developers and everything that this is what it is. This is how it's going to happen. We've had another piece of property that has rail frontage, 400 acre tract, that's just been purchased. Currently, it's CalCaf operation, but it was purchased specifically to help support the energy industry, where they plan....it was going to be an energy industry distribution center, for lack of abetter term. Some pipe companies were going to come out there and be out there. There was going to be other frack sand companies that were going

to be able to store their product out there. Salt water disposal wells...there's not enough of them to support the other 750 of these wells once this comes back around. And so, getting those things in place right now is what a lot of those companies are doing. And so, we're still seeing some of that, but that's where we all work together on all that. Even the one that was way out in the country, I brought the city out there to them, because those people are going to have to say someplace.

\section{EFS015.pdf - 9:82 [The employees out there and ev..] (19:816-19:1059) (Super) Codes: [Community receptiveness]}

The employees out there and everything like that. More than likely they're going to come and stay in town, and/or use other town business services. So, that's the reason why we do it the way we do it here. It's worked extremely well for us.

\section{EFS015.pdf - 9:83 [I'm sure I provided some enter..] (20:1376-20:1764) (Super) Codes: [Cristicism] [Government \& Governance layout] [Rules]}

I'm sure I provided some entertainment to them for at least the next hour or so of that trip driving back. Even up there.....we have some...that has had some effect on us down here, because he's actually built a...he actually did a lot of work up there the money was so good, and the regulations-even though Texas is pretty easy on the regulations-the regulations up there were even less.

\section{EFS015.pdf - 9:84 [Each has benefits just like an..] (21:1043-21:1750) (Super) Codes: [Government \& Governance layout] [Rules]}

Each has benefits just like any job or any vocation or any cluster industry. Thereare... we....and...it presents problems for say like oil companies, because they have so many different regulation...I mean so many different local things that can happen to them in really a pretty small geographic area, because they just move over to Bryan and it's different than it is here. If you go up to Leon County, Robertson County, some of their local rules are different than they are here. And so, that's...the only way they can make that work is through an open communication. You've got to have everybody talking. And so, it's...so, it is what we've got....so...the dictatorship was just for me running the county.

\section{EFS015.pdf - 9:85 [This is the second round here ..] (21:2083-21:2554) (Super) Codes: [History of Use] [World O\&G commodity prices]}

This is the second round here and everything, because we did have the Austin Chalk back in the 70 s and 80 s. The chalk came through whenever they were able to have some good wells out of that. Really, that was about a 2 year, 3 year at the most phenomenon. So, it was very short lived and in the 70s, whenever that... whenever that happened and everything then you had some other...to some degree similar to this and everything... you had a lot of western world vs. OPEC

\section{EFS015.pdf - 9:86 [-It always does....that's the re..] (22:7-22:489) (Super) Codes: [Cristicism] [Future perspectives] [World O\&G commodity prices]}

-It always does....that's the reason why, these kinds of funds come in and everybody just has to know that they're temporary. This will not sustain the county, and if you put too much emphasis on it, or if you depend on it too heavily, you're just setting yourself up or you're just setting somebody else up for a real nasty fall. I mean I know I can always get out of office and say, 
"Psht, it was great while I was here." The decisions that I make can really jack somebody...

EFS015.pdf - 9:87 [Yeah... just not even really gen..] (22:553-22:796) (Super)

Codes: [Cristicism] [World O\&G commodity prices]

Yeah... just not even really generation. It can in the matter of a decade, much shortr of a time period. And some of the guys in South Texas are reaping that right now, because they went out and they hired a whole bunch of people and now....\#

EFS015- 9:88 [You fire them, lay them off, u..] (22:853-22:1387) (Super)

Codes: [Government \& Governance layout]

You fire them, lay them off, use whatever term you want to use, but out of a job is out of a job. And so that's the reason why the stuff that we will be using is what we will do in these types of projects that are capital projects and then we will grow our staff and we have over the years. This government's much bigger than when I came into office. I've been able to do some awfully conservative in lowering tax rates and things like that. At the same time, we've been adding people as the population demands more services. 